Historic, Archive Document

Do not assume content reflects current scientific knowledge, policies, or practices. 



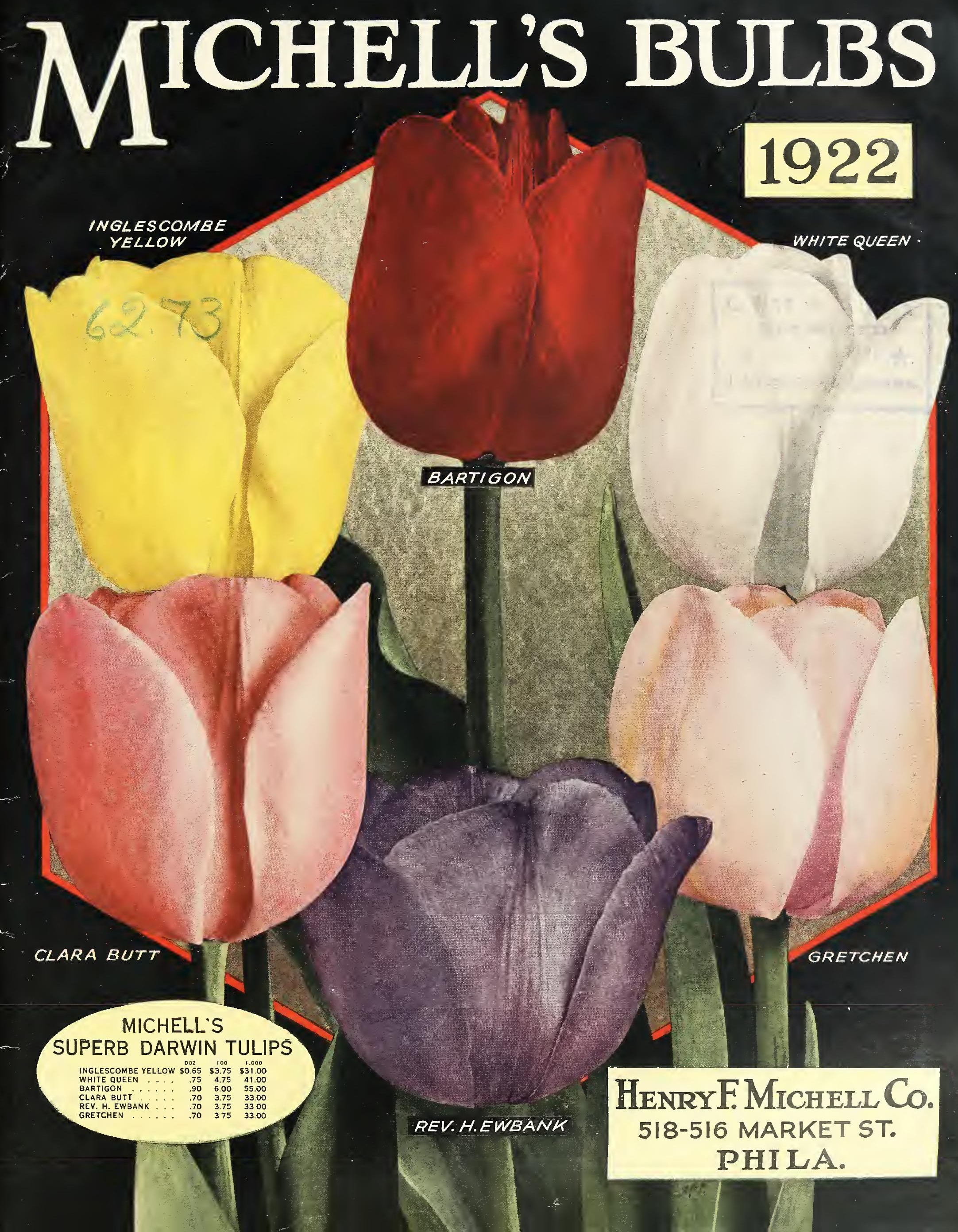


NOTICE TO CUSTOMERS OUTSIDE OF THE

UNITED STATES

In remitting for purchases at the time of ordering, or when paying accounts, by reason of the Exchange we ask that you please send $P$. O. TIoney order in U. S. Funds or a check or draft on a New York or Philadelphia Bank in par U. S. Funds.

\section{BUSINESS TERMS}

We especially invite Charge Accounts, which is more convenient than to remit for each order at the time it is sent us. When sending your first charge order, please send us the names and addresses of two or more business houses with whom you have had past or present credit relations.

\section{REGARDS C. O. D.} SHIPMENTS

Goods can be sent C. O. D. (with the exception of perishable items, which include plants and cold-storage bulbs; these cannot be sent C. O. D.). No C. O. D. shipments for any kind of goods can be made by express or freight out of town unless a partial remittance accompanies the order. No C. O. D. orders where the cept in the following zone in Philadelphia: Narket Street Ferry, to Sixteenth Street, Pine Street, to Vine Street. C. O. D. orders outside of this zone in our delivery limits must amount to $\$ 1.00$ or more. During April and May no tirety can be accepted.

SHIPPING INSTRUCTIONS-Always state by what method you want goods forwarded, otherwise we will ship according to our best judgment.

PACKING CHARGES-No charge is made for boxes, packing or bags, except for two-bushel seamless sacks, which are returnable for credit at the market price as charged.

PARCEL POST SHIPMENT AT OUR EXPENSE AS FOLLOWS-We pay postage charges on all orders for vegetable and flower seeds, provided the order calls for packets, ounces, quarter-pounds and pounds (beans, corn, peas and mixed orass seeds, bulbs, plants and sundries are not included). If these are wanted by mail, remit for postage according to rate of postage from Philadelphia to your post office.

Parcel Post weight limits are $70 \mathrm{lbs}$. in 1st, $2 \mathrm{~d}$ and $3 \mathrm{~d}$ zone; in all other zones $50 \mathrm{lbs}$.

\begin{abstract}
CONDITIONS OF SALES
All contracts, sales and acknowledgments of orders are contingent upon crop failures, partial deliveries by growers or manufacturers, strikes, or other unavoidable causes beyond our control; also unsatisfactory credit standing. All quotationsare subject to market changes and goods being unsold on receipt of order. Henry $F$. Michell Co. give no warranty, expressed or implied, as to the description, purity or productiveness of any seeds, plants or bulbs they send out. and theycannot be In any way responsible for the crop. If the customer does not accept the goods on these terms, they can be returned at once and no sale has been made.
\end{abstract}

HENRY F. MICHELL $\left\{\begin{array}{l}\text { PRESIDENT } \\ \text { SECRETARY }\end{array}\right.$

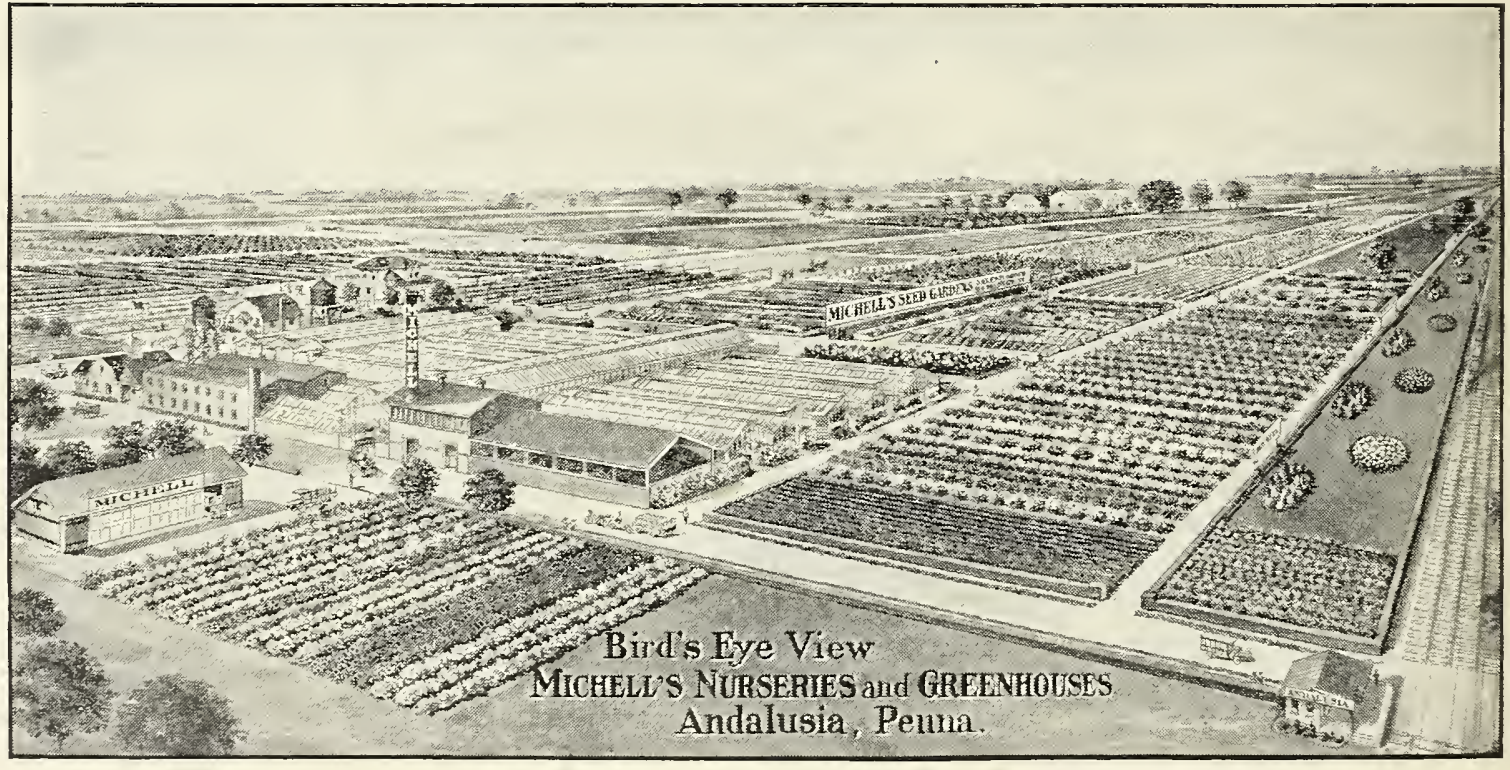

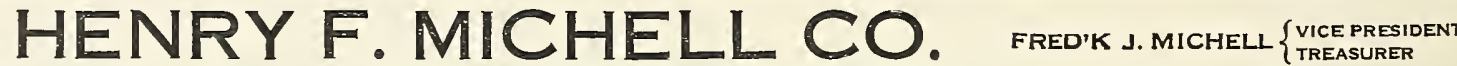
SEEDS BULBS, PLANTS, GARDEN SUPPLIES, FERTILIZERS INSECT DESTROYERS, POULTRY SUPPLIES, ETC.

518-516 MARKET ST., PHILA.

BELL AND KEYSTONE

WAREHOUSES $\left\{\begin{array}{l}509-11-13 \text { LUDLOW ST. } \\ \text { AMERICAN AND DAUPHIN STS, }\end{array}\right.$

NURSERIES AND PLANT HOUSES, ANDALUSIA, PA. TELEPHONES 


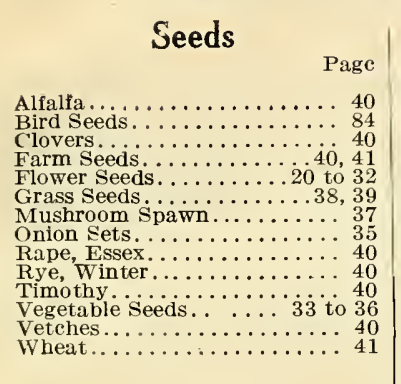

Bulbs, Roots, Etc.

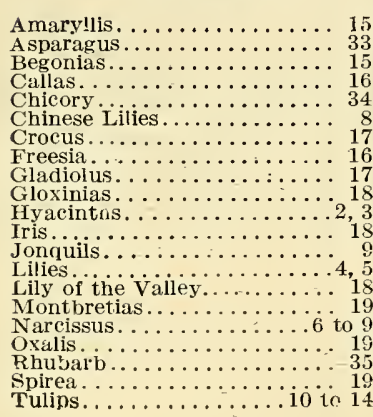

Plants, Etc.

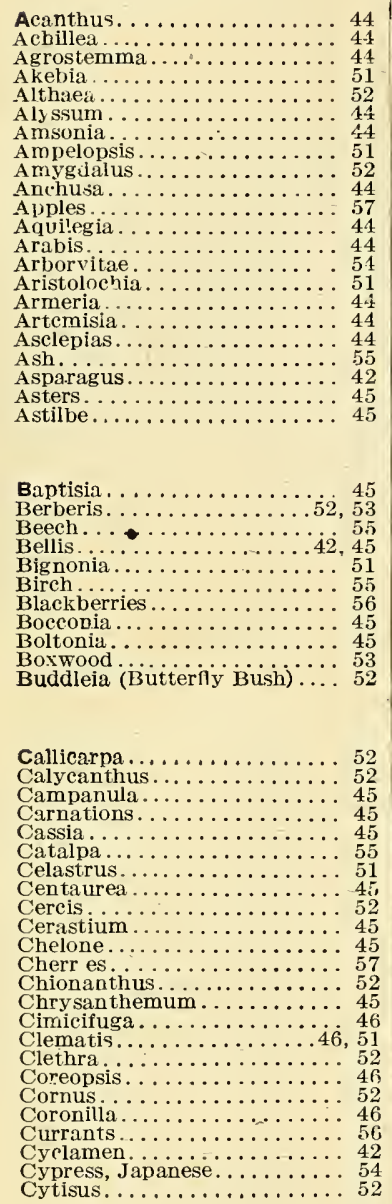

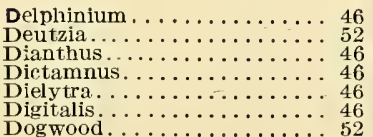

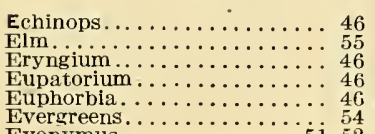

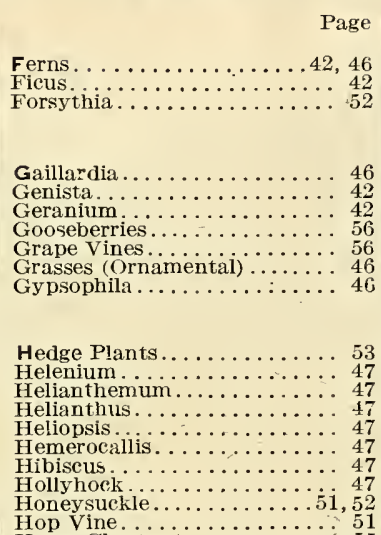

Horse Chestnut............

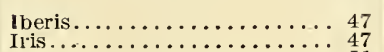

Jasminum

Kudzu Vine.

Larc

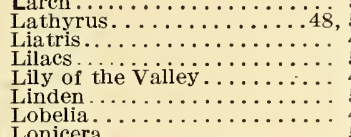

Lobelia

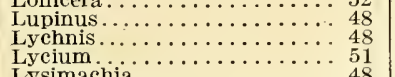

ysimachi

Lythrum.....

Magnolia

Maples.

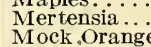

Monarda.

Mulberr

Oenothera

Pachysandra.

Paeonie

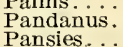

Pardanthus

Pears.

Pentstemon.

Philadelphus.
Phlox
Physali.............
Physostegia

Physo
Pine.
Pinks

Pinne

Platyeododon
Plumbago

Plums.t.

Poiygonum

Poppy:
Primula
Prit.

Privet........

Pyrethru....

Quinces.

Ranunculus

Raspb.

Roses..................

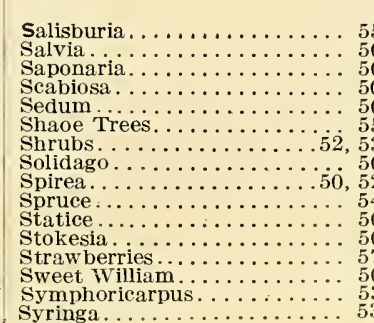

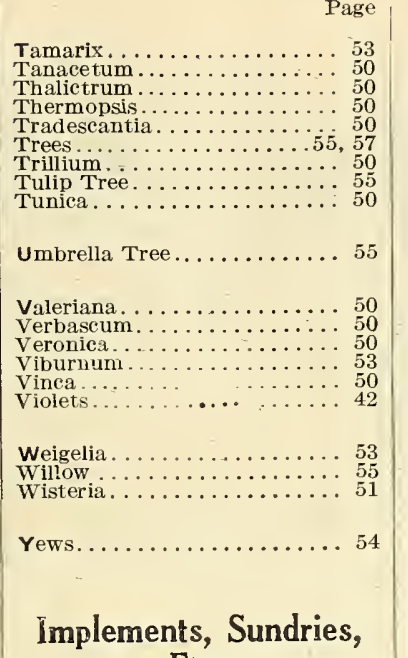

Etc.

Alphano Inoculant

Ant Exterminator.....

Aphine Punk

A prons. . o L Lead

Ashes.........

Axes....

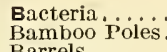

Barres T. Tricks

Baskets
Bellows.

Bellows.
Bill Hooks.

Bird Houses................

Black Leaf $(40)$
Blood (Dried)

Bon Arbor...............

Bone Flour
Bone Meal.

Books a i srenate.

Bordeaux Mixture

Boro Wax

Brooders

Brooms.
Brushes
B

Buck Saw
Bug Death

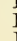

Bulb Fibre....
Bulb Pans
Buldog

Canning Apparatus.

Carbolineum..............

Carnation Clips.
Carnation Staple

Carnation Stapports.

Celery Bleachers

Celery Hiller

Celery Pape
Celery Tape

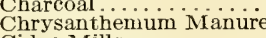

Cider Mills
Clay's Fertilizer

Colony Houses
Copper Solution

Corn Knife......
Corn Poppers

Corn Poppers
Corn Shellers.

Cotton Seed Mieal

Cow MInure.
Cot Flower Boxes

Cow Manure........... 78
Cut Flower Boxes.........
Cut Flower Vases......3rd cover
C

Dalmatian Powder.

Dibbles
Disinfectants.
Dried Blood
Dien

Dried Bloog
Dusters.

Egg Boses $\ldots \ldots$

Farmoger

Feeders...................... 81
Fencing

Fern Dish Liners...3rd cover page Fern Pans

Fertilizer Distributors

Fish Oil Soap ............... 78

Flower Scissor

Flyosan

Forks Ticiers

Fumigators

Getz There Soap

Glass Clamps
Glass Cleaner

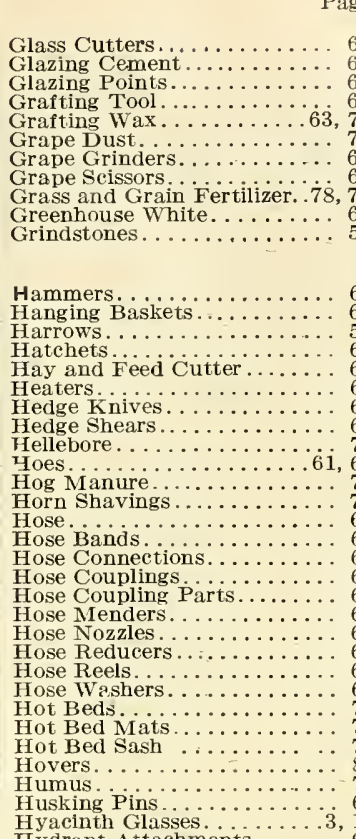

Hydrant Attachment

Incubators.

Insecticides.

Jardinieres.

Kainit

Kaylos . . Euision

Kerosene Emu.
Kirke Feeder.

Knives..

Labels.

Lawn Cleaners

Lawn Sand

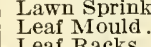

Leat Racks
Lemon Oil

Lemon Oil
Lime.
Iimestone

Limestone
Lime Sulphir
Limo

Limoid Liquid Manure Distributor

. 73

Mag-O-Tite

Manure

Manure Drags

Mastica iachine

Masticote.

Mattoeks.

Melon Net

Melrosine .............

Mole Trap

Moss.

Mosse Tra.
Mulford Germ

Mulford Germ.
Muriate of Potash

Muriate of Potash
Mushroom Spawn

Nails............

Nicotine Fumigator

Nicotine Sulphate

Nikoteen

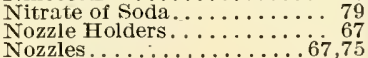

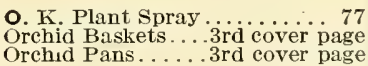

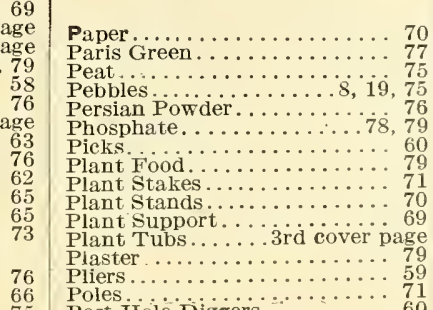

0

Wall Nails.

Weeders.

Wheat Fertilizet

Windmill

Wire and Tin șear

Wire Notking.
Worm Killer.
Wrenches.

Zementine

Salt Salt Bricki

Sash.

Saw Horse

Scalecide .............
Scale Destroyer

Scissors....

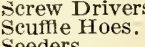

Shading Cioti

.

Sluevs shot

Snow Shove
Soap Spray

soot.

Sparrow Trap

Sprinklers...

take Fastener

stim-U-Plant

sulphate of A mmonia

sulphate of Copper

Sulphur

Sulphur Biowers.
Sulphur Coneses

Tankage.........

Thermostat Thompson's Manure

Thrip Juice...
Tinfoic
Tobacco Dust

Tobacco Soap

Toothpicks

Traes Bands

Tree Labels 0 .

Tree Paint
Tree seraper.
Tree Thangef

Trellises

Tubs.

Post Hole Diggers

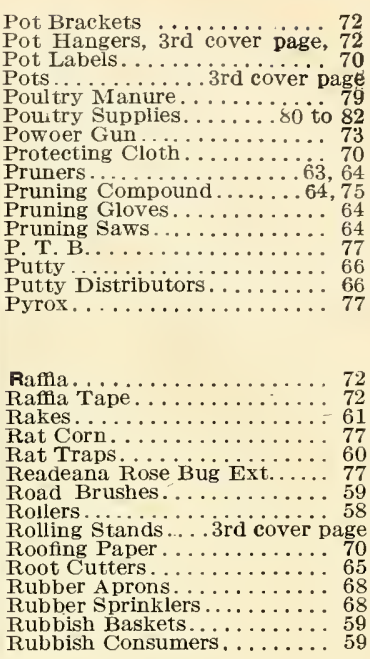

Pans .................. 6

….....6. 70

6i, 62

.51,52， Syringa 

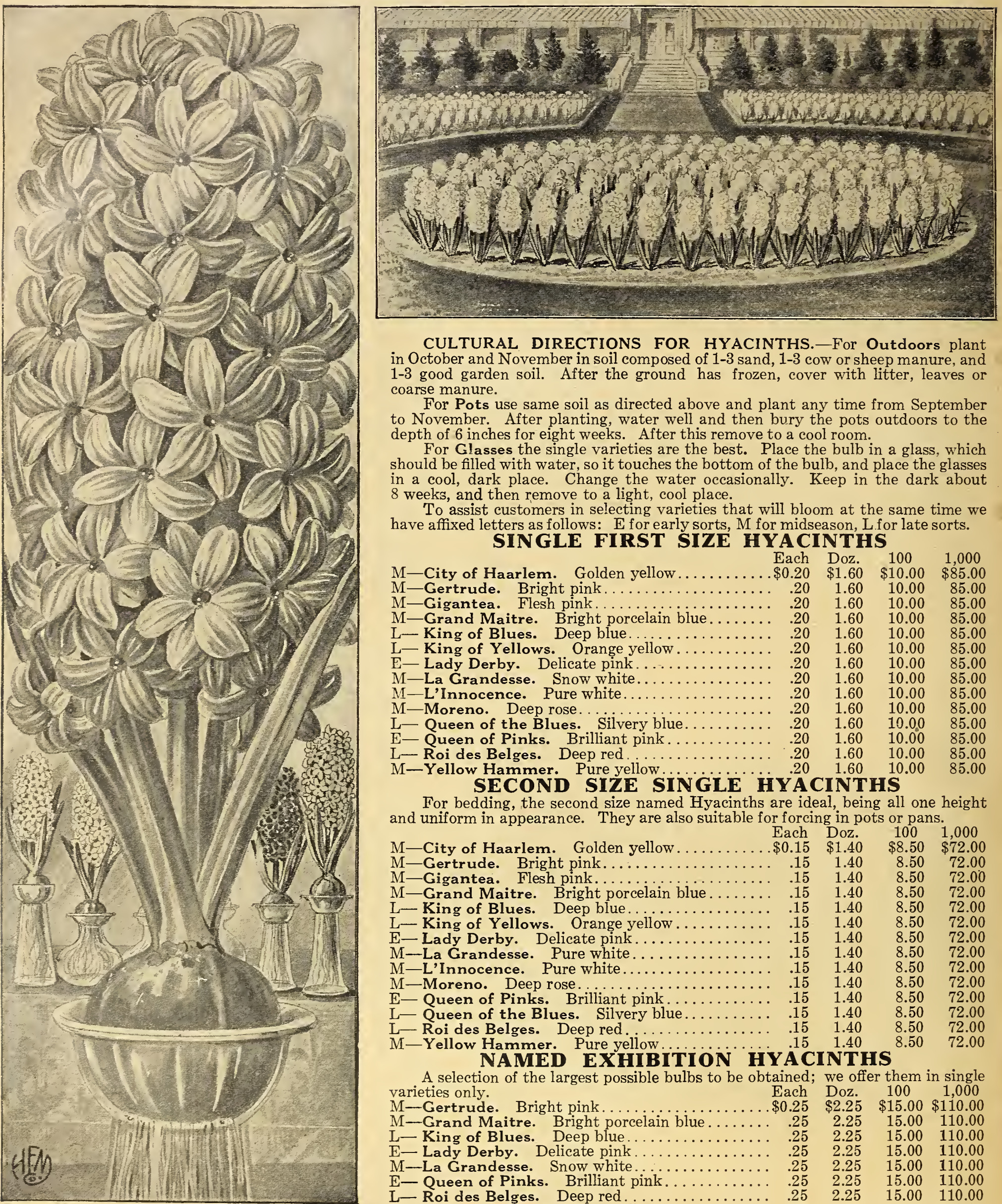

CULTURAL DIRECTIONS FOR HYACINTHS.-For Outdoors plant in October and November in soil composed of 1-3 sand, 1-3 cow or sheep manure, and 1-3 good garden soil. After the ground has frozen, cover with litter, leaves or coarse manure.

For Pots use same soil as directed above and plant any time from September to November. After planting, water well and then bury the pots outdoors to the depth of 6 inches for eight weeks. After this remove to a cool room.

For Glasses the single varieties are the best. Place the bulb in a glass, which should be filled with water, so it touches the bottom of the bulb, and place the glasses in a cool, dark place. Change the water occasionally. Keep in the dark about 8 weeks, and then remove to a light, cool place.

To assist customers in selecting varieties that will bloom at the same time we have affixed letters as follows: $E$ for early sorts, $M$ for midseason, L for late sorts. SINGLE FIRST SIZE HYACINTHS

Each Doz. $100 \quad 1,000$

- City of Haarlem. Golden yellow . . . . . . . . $\$ 0.20 \quad \$ 1.60 \quad \$ 10.00 \quad \$ 85.00$

M-Gertrude. Bright pink . . . . . . . . . . . . . .20 $1.60 \quad 10.00 \quad 85.00$

M-Gigantea. Flesh pink .................... $20 \quad 1.60 \quad 10.00 \quad 85.00$

$\begin{array}{llllll}\text { M-Grand Maitre. Bright porcelain blue........ } & .20 & 1.60 & 10.00 & 85.00\end{array}$

L- King of Blues. Deep blue................... $20 \quad 1.60 \quad 10.00 \quad 85.00$

L- King of Yellows. Orange yellow . . . . . . . . . . . $\quad .20 \quad 1.60 \quad 10.00 \quad 85.00$

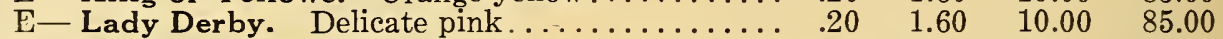

M-La Grandesse. Snow white..........................

M-L'Innocence. Pure white. ............... $20 \quad 1.60 \quad 10.00 \quad 85.00$

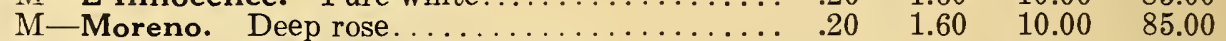

$\begin{array}{llllll}\text { L- Queen of the Blues. Silvery blue.......... } & .20 & 1.60 & 10.00 & 85.00\end{array}$

E-Queen of Pinks. Brilliant pink ............. $20 \quad 1.60 \quad 10.00 \quad 85.00$

L- Roi des Belges. Deep red . . . . . . . . . . . . .20 $1.60 \quad 10.00 \quad 85.00$

M-Yellow Hammer. Pure yellow... $\begin{array}{rrrr}20 & 1.60 & 10.00 & 85.00\end{array}$

SECOND SIZE SINGLE HYACINTHS

For bedding, the second size named Hyacinths are ideal, being all one height and uniform in appearance. They are also suitable for forcing in pots or pans.

Each Doz. $100 \quad 1,000$

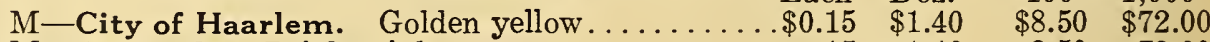

M-Gertrude. Bright pink. ................. $.15 \quad 1.40 \quad 8.50 \quad 72.00$

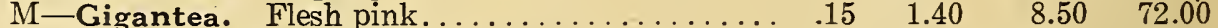

M-Grand Maitre. Bright porcelain blue...........

L- King of Blues. Deep blue .............. $.15 \quad 1.40 \quad 8.50 \quad 72.00$

L- King of Yellows. Orange yellow ........... $\quad .15 \quad 1.40 \quad 8.50 \quad 72.00$

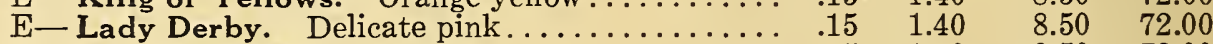

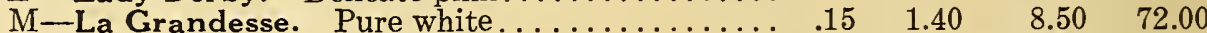

M-L'Innocence. Pure white......................... $15 \quad 1.40 \quad 8.50 \quad 72.00$

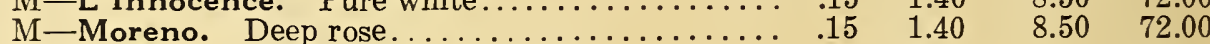

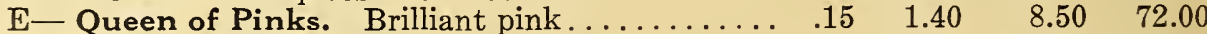

L- Queen of the Blues. Silvery blue............... $.15 \quad 1.40 \quad 8.50 \quad 72.00$

L- Roi des Belges. Deep red................. $.15 \quad 1.40 \quad 8.50 \quad 72.00$

M-Yellow Hammer. Pure yellow ............. NAMED EXHIBITION HYACINTHS

varieties only. $\quad$ Each Doz. $100 \quad 1,000$

M-Gertrude. Bright pink ...............\$0.25 $\$ 2.25 \quad \$ 15.00 \$ 110.00$

M-Grand Maitre. Bright porcelain blue ........... $\quad .25 \quad 2.25 \quad 15.00 \quad 110.00$

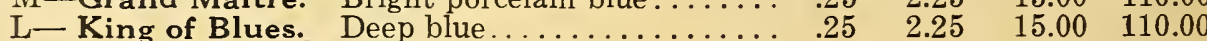

E- Lady Derby. Delicate pink ................. $25 \quad 2.25 \quad 15.00 \quad 110.00$

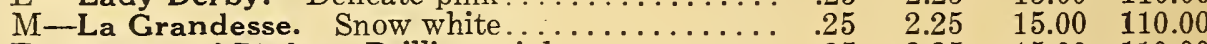

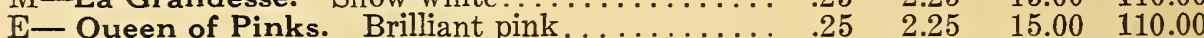

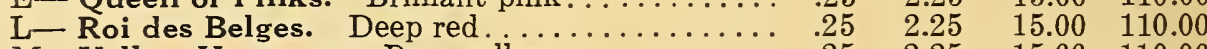

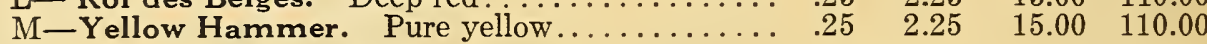




\section{MICHELL'S SUPERB HYACINTHS}

We have affixed the letters E, M and L, signifying: E, for early sorts; M, for midseason; L, for late sorts.

\section{DOUBLE FIRST SIZE HYACINTHS}

E- Blocksberg. Light blue....... \$0.20 $\$ 1.60 \$ 10.00 \$ 85.00$

M-Bouquet Tendre. Dark carmine. $\quad .20 \quad 1.60 \quad 10.00 \quad 85.00$

E- Delicata. Pale blue.............20 $\quad .201 .60 \quad 10.00 \quad 85.00$

E- Garrick. Blue, dark center ..... $\quad .20 \quad 1.60 \quad 10.00 \quad 85.00$

M-Lord Wellington. Rich pink ... $\quad .20 \quad 1.60 \quad 10.00 \quad 85.00$

M-Prince of Waterloo. Pure white.. $\quad .20 \quad 1.60 \quad 10.00 \quad 85.00$

M-Sunflower. Pure yellow........ $\quad .20 \quad 1.60 \quad 10.00 \quad 85.00$

CHOICE BEDDING HYACINTHS (Unnamed)

Michell's Bedding Hyacinths are larger than those put in ordinary mixtures. They will produce fine spikes and therefore can also be used for forcing purposes. Where bedding of Hyacinths is to be done in large quantity, we can particularly recommend them on account of their low cost, the length of time they remain in flower, and because of their handsome effect.

SINGLE AND DOUBLE FLOWERING

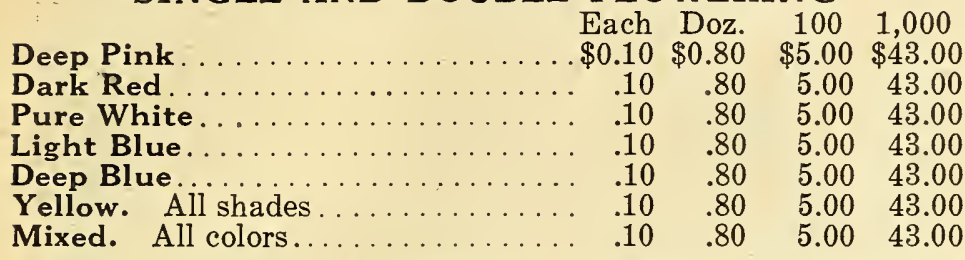

Walton, N. Y., April 3rd, 1922.

My Hyacinths have been wonderful this year, and I give your bulbs much of the credit. Many of them have borne two and some even three good blossom stalks, while the single stalks have been giants.

\section{FRENCH ROMAN HYACINTHS}

These afford a continuous supply of bloom from early winter until late in spring if planted in succession (two weeks apart) They are very fragrant; easily grown in pots or pans.

White. Extra selected bulbs

Each Doz. 100

1,000

Light Blue.

Light Pink.

$\$ 0.15 \$ 1.50 \$ 11.00 \$ 100.00$

White Italian

$\begin{array}{rrrr}.12 & 1.25 & 8.25 & 75.00 \\ 12 & 1.25 & 8.25 & 75.00\end{array}$

$\begin{array}{llll}.12 & 1.25 & 8.25 & 75.00\end{array}$

\section{HYACINTH GLASSES (Not Mailable)}

Hyacinths grow beautifully and look most decorative when grown in glasses with water.

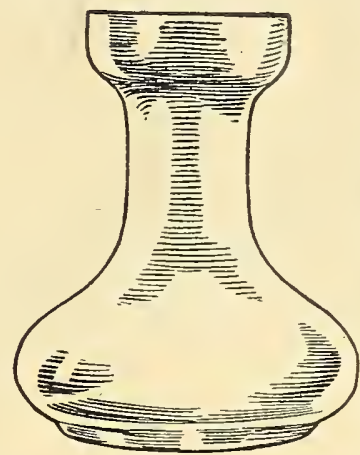

Tye or Low Pattern
These Hyacinth glasses are specially made for this purpose.

Belgian. In the following colors: Blue, green, white, 40c. each; per doz., $\$ 4.00$.

Tye or Low Pattern. Heavier than the above style, but in the same colors, 40c. each; doz., $\$ 4.00$.

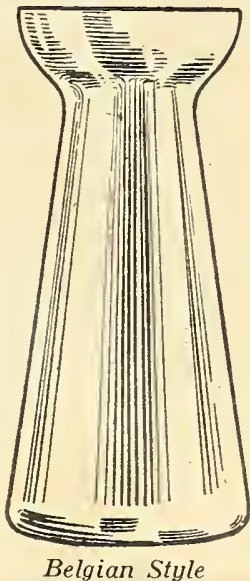

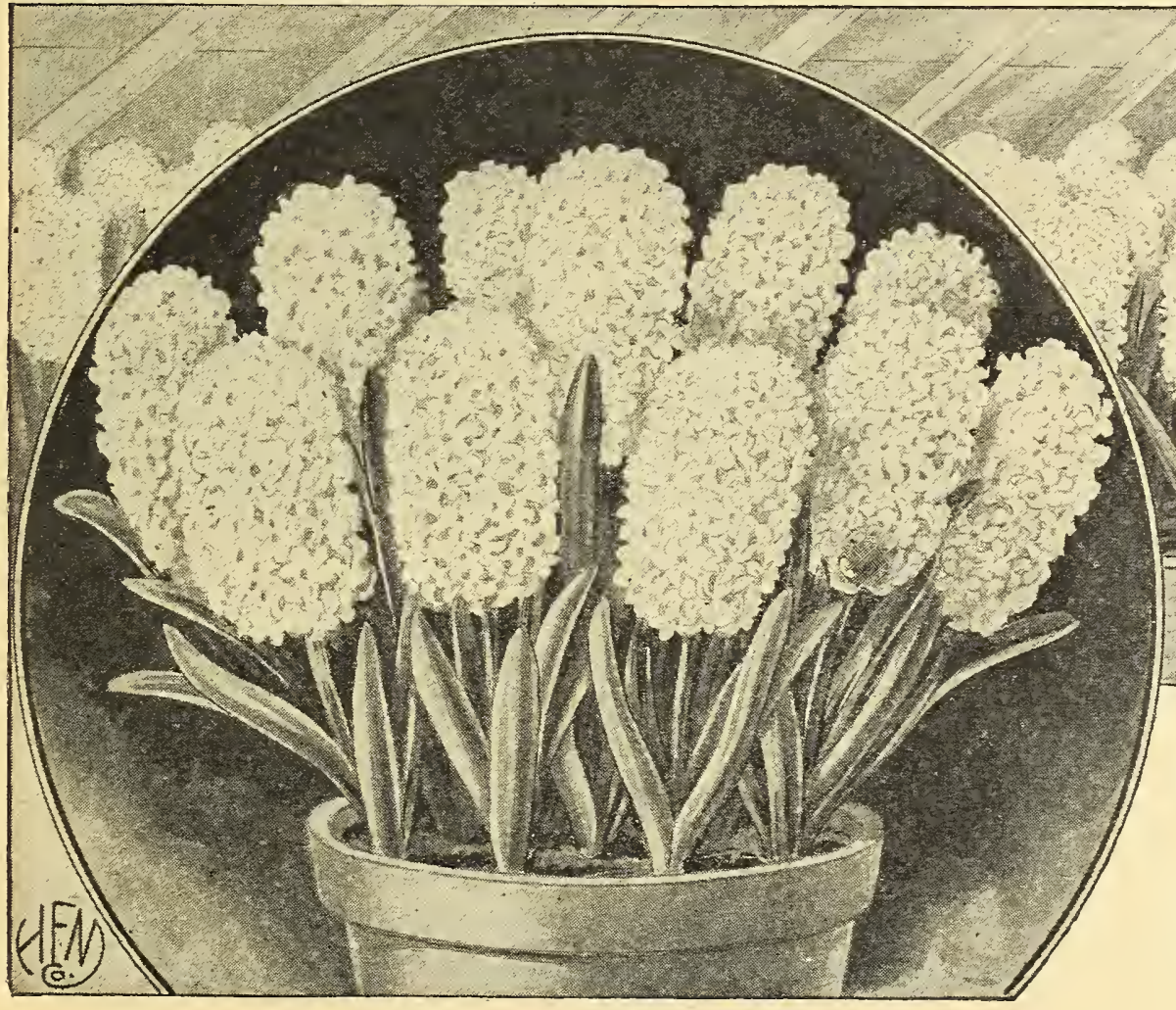

Miniature, or Dutch Roman Hyacinths

\section{CHRISTMAS FLOWERING DUTCH ROMAN HYACINTHS}

These specially prepared Hyacinths are peculiarly adapted for pot culture and early flowering. Can be made to bloom just at holiday season. We recommend every lover of flowers to try a few, as Hyacinths for Christmas are a most cheerful novelty.

Each Doz. $\quad 100 \quad 1,000$

Bismarck. Light sky blue .......... $\$ 0.15 \quad \$ 1.25 \quad \$ 6.75 \quad \$ 60.00$

L'Innocence. Pure white .......... $.15 \quad 1.25 \quad 6.75 \quad 60.00$

Moreno. Deep rose..............

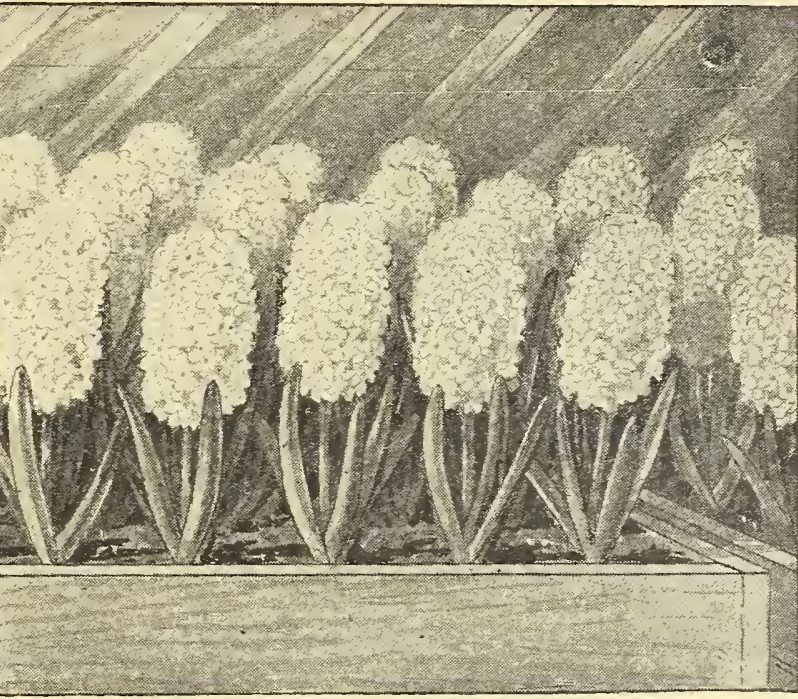

MINIATURE, OR DUTCH ROMAN HYACINTHS

We import fine, large bulbs of named varietie only, as these will be found far superior to the un named sorts offered at lower prices. Excellent for growing in pans, boxes or pots. The trusses are magnificent and almost as large as the regular hyacinths.

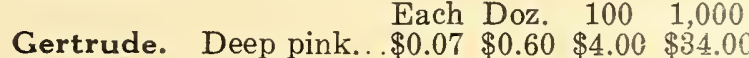
Gigantea. Light pink. . $.07 \quad .60 \quad 4.00$ Grand Maitre. Bright blue ........ $.07 \quad .60 \quad 4.00$ King of the Blues. Deep blue............ $\quad .07 \quad .60 \quad 4.00$ Lady Derby. Delicate pink. La Grandesse. Pure white. L'Innocence. Pure white.

Nimrod. Clear pink.

Roi des Belges. Fine deep crimson

Yellow Hammer. Pure yellow

If Bulbs are wanted by Parcel Post, add 10 per cent
order to points east of the Mississippi River, and 20 per ce

west of the Mississippi River. 


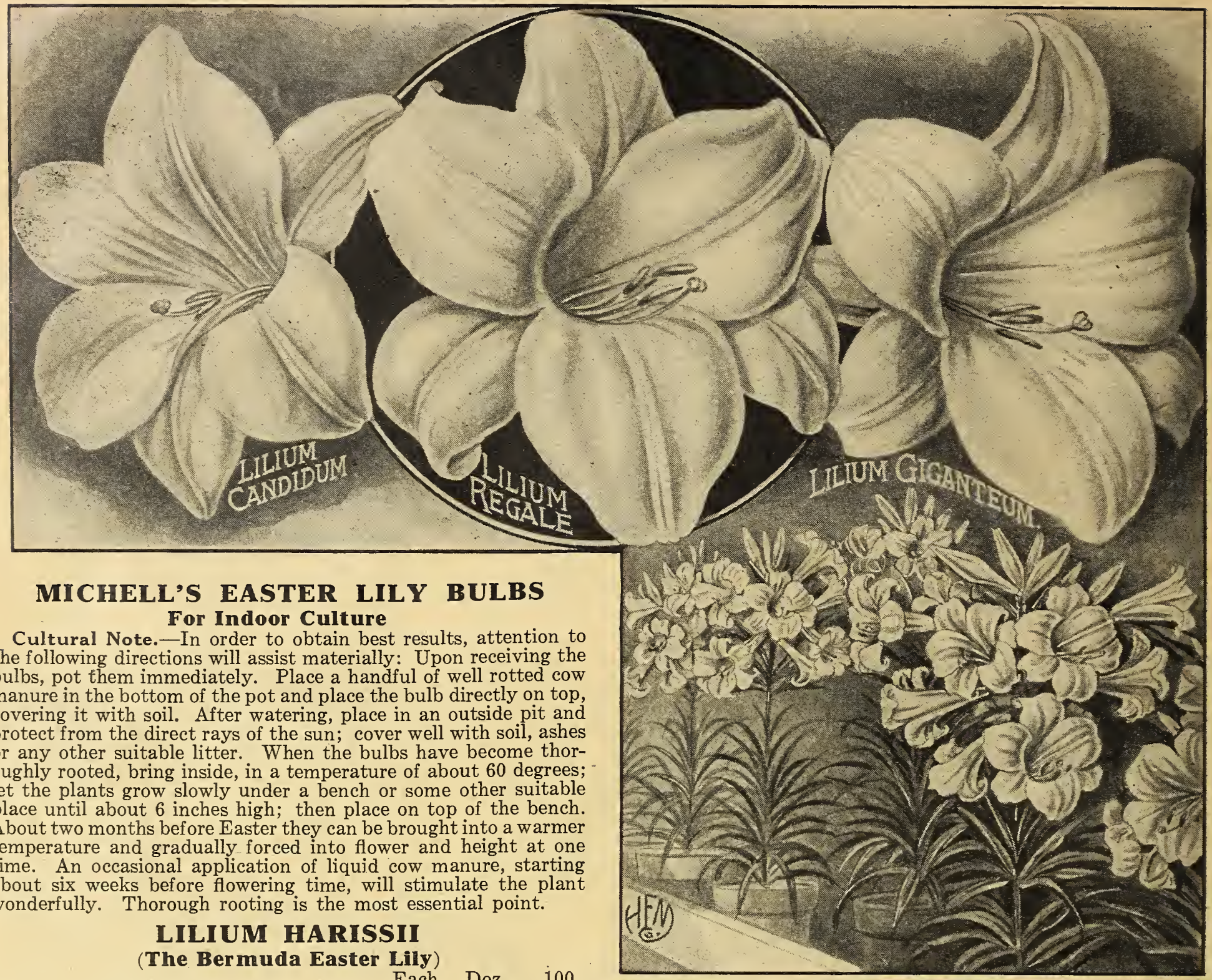

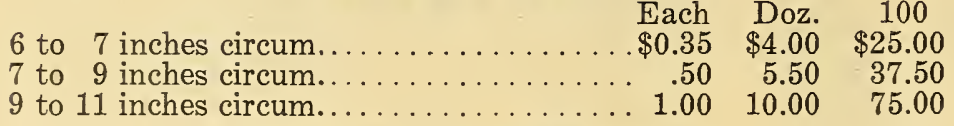

\section{LILIUM FORMOSUM \\ (The Formosa Easter Lily) Dark Stemmed Type}

Each Doz. 100

$\begin{array}{lllll}6 \text { to } 8 \text { inches circum } \ldots \ldots \ldots \ldots & \$ 0.45 & \$ 4.50 & \$ 32.50\end{array}$

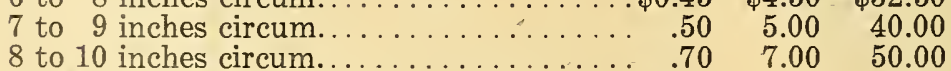

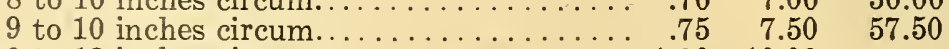

10 to 12 inches circum.

1.0010 .00

\section{LILIUM LONGIFLORUM MULTIFLORUM MICHELL'S SPECIAL BRAND}

This brand must not be compared with lower priced bulbs, as it is a distinct selection.

6 to 8 inches circum. .

7 to 9 inches circum.

8 to 10 inches circum.

Prices will be

9 to 10 inches circum. . established later.

\section{LILIUM CANDIDUM} (Madonna Lily)

This variety is sometimes called St. Joseph's, Madonna, or Annunciation Lily. One of the most popular and satisfactory of the American garden lilies. Pure waxy white flowers produced on straight stems bearing anywhere from 10 to 30 blooms of good size and substance; delightfully fragrant. Effective planting is the result of massing them in clumps or borders. Our bulbs are grown in Northern France, where they have a reputation of growing the finest in the world. To insure absolute success, plant the bulbs as early as possible-September preferred-6 inches deep, imbedded in sand and placed on their side; height, 4 feet; blooms in June.

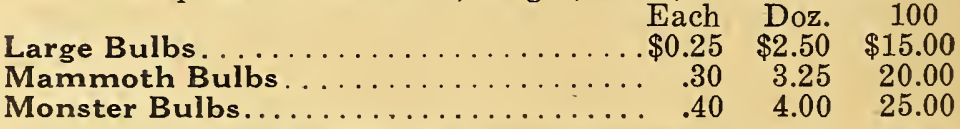

If Bulbs are wanted by Parcel Post, add 10 per cent. to value of order to points east of the Mississippi River, and 20 per cent. to points west of the Mississippi River. 


\section{MICHELL'S HARDY GARDEN LILIES}

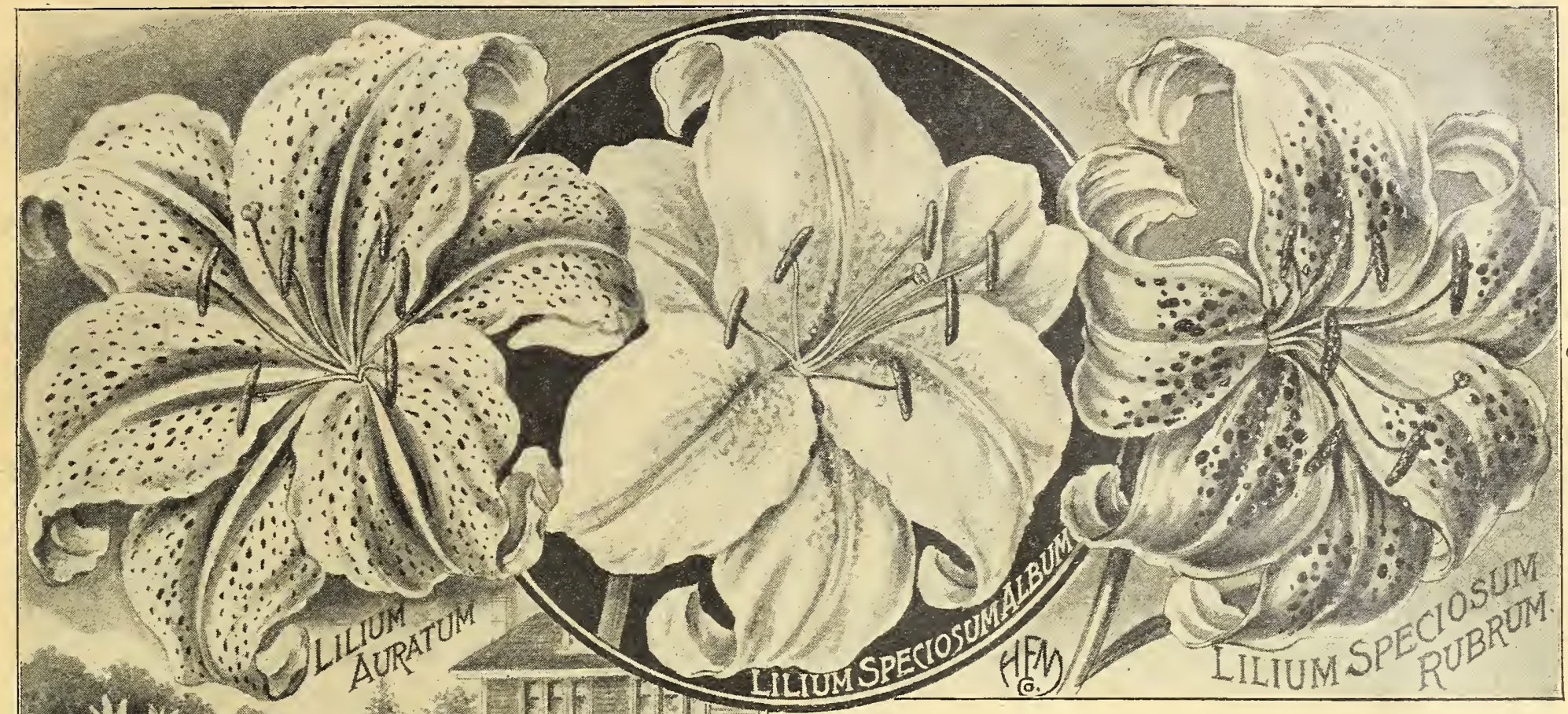

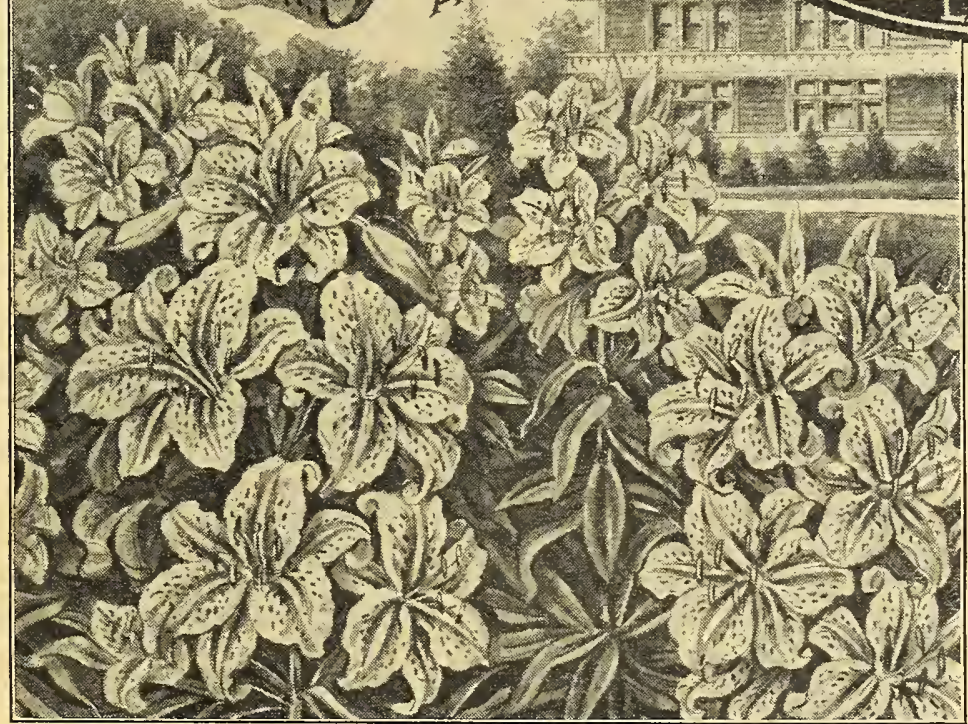

Cultural Directions.-All Hardy Lilies should be planted from 6 to 8 inches deep, the Japan varieties even 12 inches deep; the bulbs should be completely enveloped in sand; no manure should come in contact with the bulbs, but may be placed 4 to 6 inches underneath. All loose petaled bulbs should be planted on their side instead of upright. Hardy Lilies are sometimes grown in pots for indoor blooming, in which case they are handled much like the Bermuda Easter Lilies.

\section{JAPANESE LILIES}

Auratum (Golden Banded Lily). Enormous, measuring frequently 8 to 12 inches across; pure white, spotted crimson; each petal is marked in the center with a band of yellow. Flowers in August; delightfully fragrant.

$\begin{array}{lrrr} & \text { Each } & \text { Doz. } & 100 \\ \text { Large Bulbs, } 8 \text { to } 9 \text { inch circum.......... } \$ 0.30 & \$ 3.25 & \$ 22.50 \\ \text { Mammoth Bulbs, } 9 \text { to } 11 \text { inch circum... } & .45 & 4.75 & 35.00 \\ \text { Monster Bulbs, } 11 \text { to } 13 \text { inch circum..... } & .60 & 6.50 & 45.00\end{array}$

Speciosum Album. The best late flowering pure white hardy garden lily; of easy culture. The slender graceful stems and foliage are set off to wonderful advantage by the glistening pure white blooms.

$\begin{array}{lrrr}\text { Large Bulbs, } 8 \text { to } 9 \text { inch circum......... } \$ 0.30 & \$ 3.25 & \$ 22.50 \\ \text { Mammoth Bulbs, } 9 \text { to } 11 \text { inch circum... } & .45 & 4.75 & 35.00 \\ \text { Monster Bulbs, } 10 \text { to } 12 \text { inch circum.... } & .60 & 6.50 & 45.00\end{array}$

Speciosum Magnificum. An enormous flower; rich deep pink spotted crimson; height, 3 feet; flowers in August.

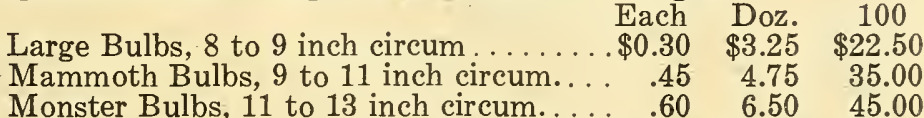
spotted red; one of the old garden favorites; height, 3 feet; flowers in August and September.

\section{Large Bulbs, 8 to 9 inch circum.}

Mammoth Bulbs, 9 to 11 inch circum.

$\begin{array}{rrr}\text { Each } & \text { Doz. } & 100 \\ \$ 0.30 & \$ 3.25 & \$ 22.50 \\ .45 & 4.75 & 35.00 \\ .60 & 6.50 & 45.00\end{array}$

Monster Bulbs, 11 to 13 inch circum......
Tigrinum Splendens (Tiger Lily). Orange, spotted black; double.

$30 \quad 3.00 \quad 22.50$

Tigrinum Splendens. Single ......... .25 2.50 MISCELLANEOUS JAPANESE LILIES

Each Doz.

Batemanni. Apricot colored; 3 feet; July.. $\$ 0.50 \$ 4.00$

Brownii. White inside, outside brown..... $\quad .75 \quad 7.50$

Hansoni. Often grows from 3 to 5 feet high; reddish orange, 8 to 12 in a cluster.

$\begin{array}{lll}75 & 7.50 & \$ 50.00\end{array}$

Henryi (Yellow SpeciosumLily). Tall grower, often 7 feet; produces flowers of a distinct orange yellow in great profusion ........ $\quad 75 \quad 7.50$

Krameri. Blush pink; 3 feet; August.... $\quad .50 \quad 4.00$

Macranthum. Giant Golden Banded Lily. $.60 \quad 6.50$

Wittei. Very fragrant; white, yellow band.. $1.00 \quad 11.00$

\section{AMERICAN OR NATIVE LILIES}

Canadense (Canadian Bellflower Lily). Bright yellow flowers, spotted black inside; June Each Doz. 100 and July; 2 feet $\$ 0.20 \$ 2.00$ $\$ 15.00$

Canadense Rubrum. Same type as above; crimson with black spots

Elegans, Leonard Joerg. Rich apricot pink $\begin{array}{lll}40 & 4.00 & 25.00\end{array}$

Superbum (Turk's Cap Lily). Grows from 3 to 6 feet high and produces from 15 to 25 orange red flowers on a stalk...

Tenuifolium (Coral Lily). Brilliant scarlet $\quad .35 \quad 3.50$ LILIUM REGALE (Myriophyllum)

Introduced from China; one of the most beautiful factory of all garden lilies. The stalk is slender, with grass-like leaves; it is absolutely hardy; also splendid fo
flowers are white suffused with pink, shaded canary-yell illustration on page 4.) $\$ 1.00$ each; doz., $\$ 10.00$

If Bulbs are wanted by Parcel Post, add 10

value of order to points east of the Mississippi rive

20 per cent. to points west of the Mississippi River. 
No garden is complete without the Narcissus or Daffodil, and they really deserve the foremost place among bulbous flowers. They are perfectly hardy and increase from year to year. As a house bulb in winter, they are indispensable and of the easiest culture.

Culture. Owing to the various sizes of the bulbs of different varieties, we cannot advisably give the exact depth to plant, but a good rule to follow is to cover the bulb one and one-half times its own depth. For house culture 3 or 4 bulbs can be put in a 5 inch of 6 inch pan or pot and given the same treatment as Hyacinths.

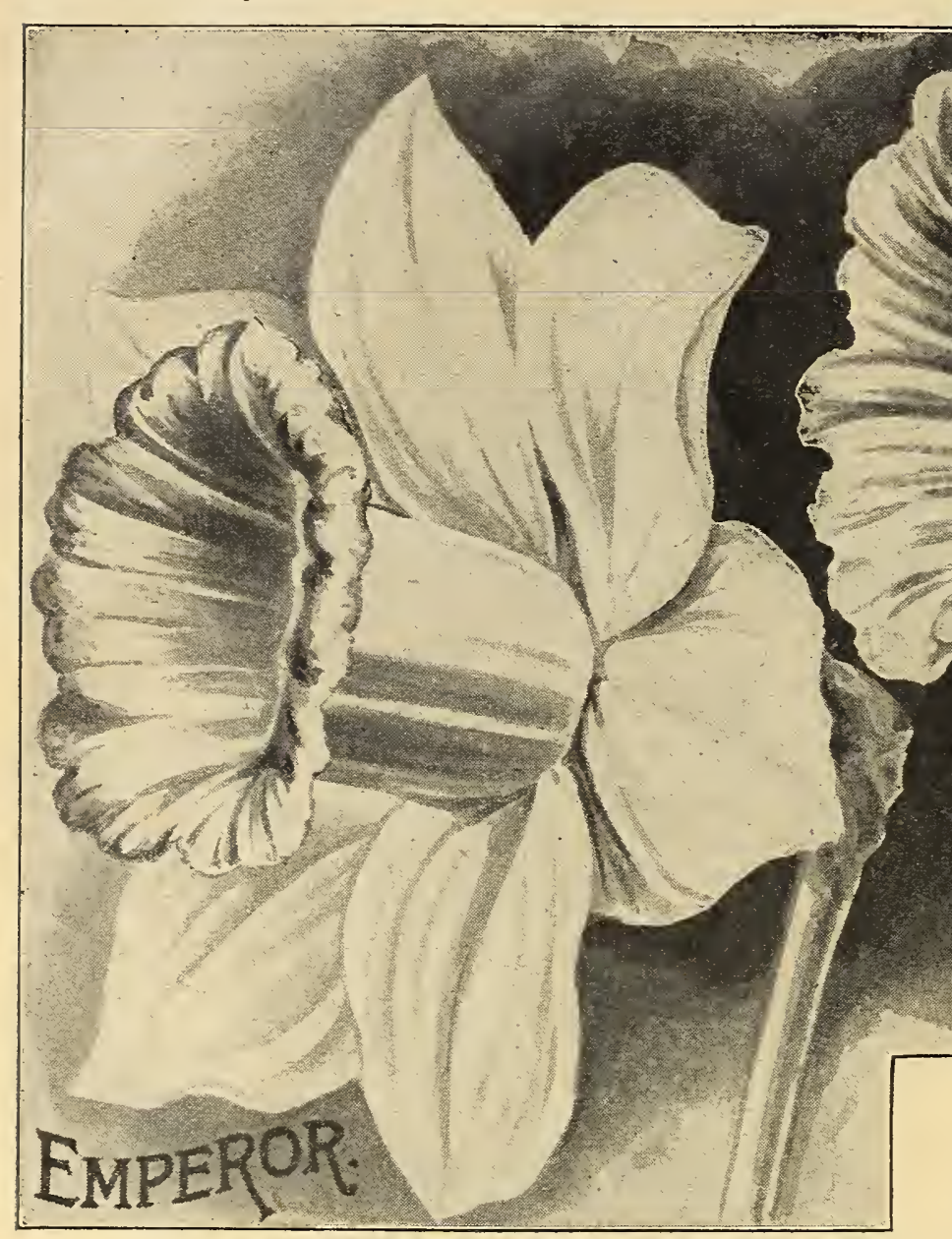

\section{GIANT TRUMPET VARIETIES}

The number prefixed before the variety denotes the height.

18 Bicolor Victoria. Trumpet golden yellow; perianth creamy white; early.

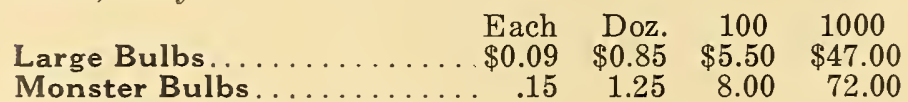

16 Cervantes. A fine variety; very

early; excellent for forcing; pale

yellow trumpet.

$\begin{array}{llll}.15 & 1.25 & 8.00 & 72.00\end{array}$

18 Emperor. One of the best Narcissus in cultivation, for either outdoor or indoor culture. Entire flower is pure golden yellow. Each Doz. 1001000 Large Bulbs ............... \$0.10 $\$ 0.90 \quad \$ 5.50 \quad \$ 48.00$

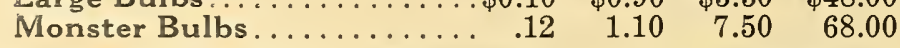

18 Empress. This variety tallies exactly with the foregoing sort, except that the perianth is pure white and the trumpet golden yellow, making the flower extremely attractive.

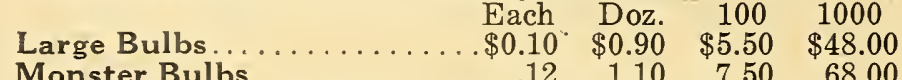

15 Giant Princeps. Extensively used for naturalizing; one of the best forcing sorts, being very early; perianth sulphur yellow, trumpet rich yellow. (Large double-nosed bulbs.) 8c. each; doz., 75c.; $\$ 4.75$ per 100 ; per 1000 , $\$ 39.00$.

14 Glory of Leiden. Immense flowers; long fluted trumpet, golden yellow; perianth petals very broad. Each, 10c.; $95 \mathrm{c}$. per doz.; per $100, \$ 5.75 ; \$ 54.00$ per 1000 .

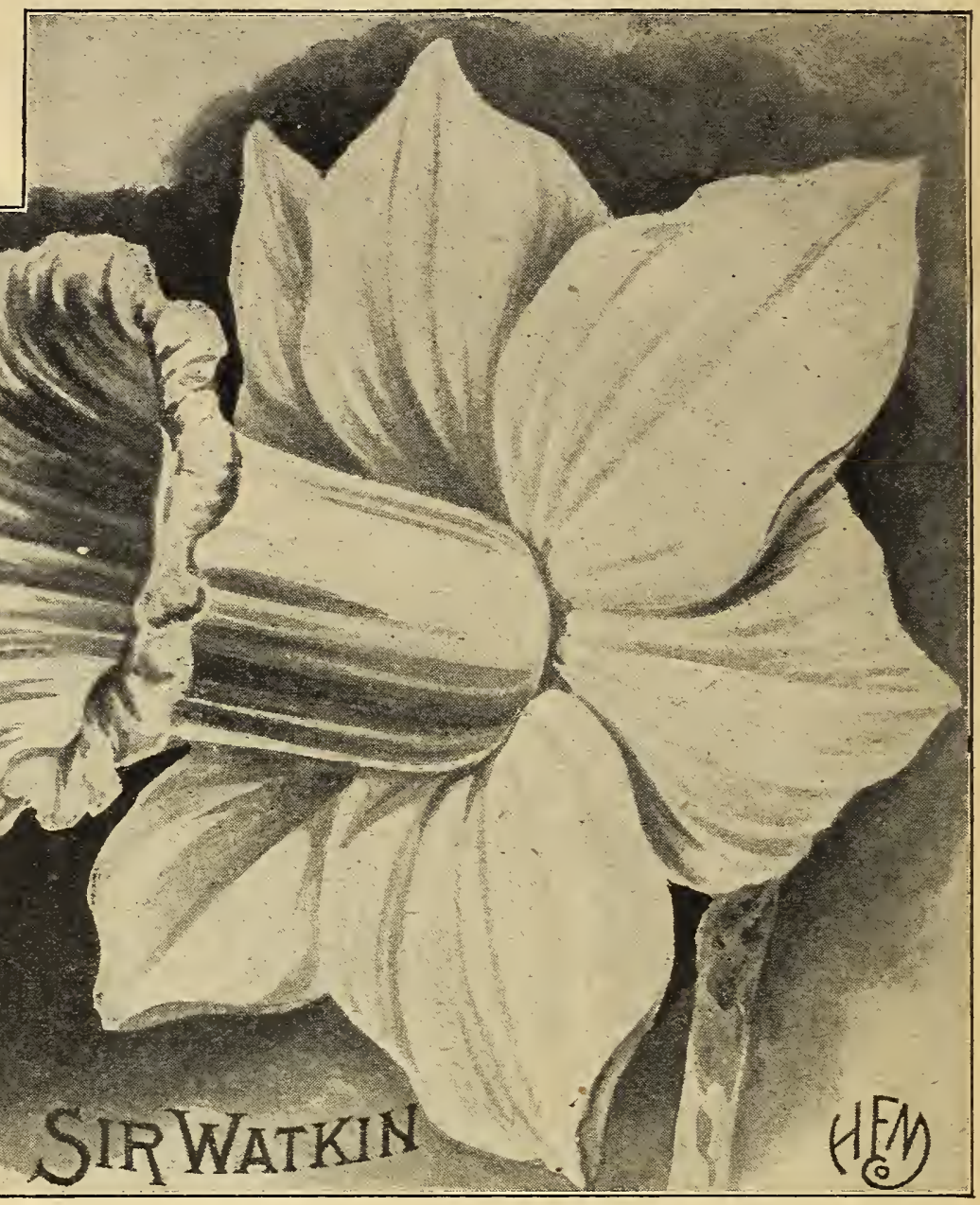

18 Golden Spur. A large striking variety of wonderful robust growth; unusually good for garden culture or forcing; very early and blooms freely; pure golden yellow.

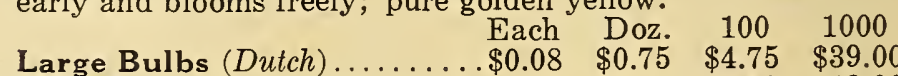

Monster Bulbs (Dutch) ....... $\quad .12 \quad \begin{array}{llr}1.10 & 7.50 & 68.00\end{array}$

Golden Spur (Extra Early Forcing $10 \quad 100 \quad 675 \quad 6000$

$\begin{array}{lllll}\text { Strain). Large Size Bulbs. } .10 & 1.00 & 6.75 & 60.00 \\ \text { ing Alfred. The gigantic flowers are of intense golden }\end{array}$

18 King Alfred. The gigantic flowers are of intense golden filled edge. 20c. each; doz., $\$ 1.80$; per $100, \$ 15.00$.

16 Madame de Graaff. The best pure white trumpet daffodil. When it first comes into flower it shows creamy white, changing to pure white as the flower matures. Each, 10c.; 90 c. per doz.; per $100, \$ 5.75 ; \$ 50.00$ per 1000 .

15 Sir Watkin (Giant Chalice Flower). The flower is probably the largest in its class; for moderate forcing as well as bedding on a large scale; perianth lemon yellow, cup or crown deep yellow; very early. 10c. each; doz., 95c.; $\$ 5.75$ per 100 ; per $1000, \$ 52.00$.

15 Trumpet Major. One of the best varieties; trumpet and perianth deep golden yellow; very early. Dutch-grown bulbs for outdoors and forcing. 7c. each; doz., 70c.; $\$ 4.50$ per 100; per $1000, \$ 37.00$.

15 Trumpet Major (Christmas Flowering). French-grown, for early forcing; medium-sized flowers with long stems.

$\begin{array}{rrrrr} & \text { Each } & \text { Doz. } & 100 & 1000 \\ \text { Mammoth Bulbs ........ } & \$ 0.07 & \$ 0.75 & \$ 5.25 & \$ 45.00\end{array}$

Van Waveren's Giant. Claimed to be the largest of all Narcissus; perianth soft primrose yellow, with large, bright yellow trumpet; either for growing in pots or in the garden. Each, $25 \mathrm{c}$; $\$ 2.50$ per doz.; per $100, \$ 16.00$.

If Bulbs are wanted by Parcel Post, add 10 per cent. to value of order to points east of the Mississippi River, and 20 per cent. to points west of the Mississippi River. 


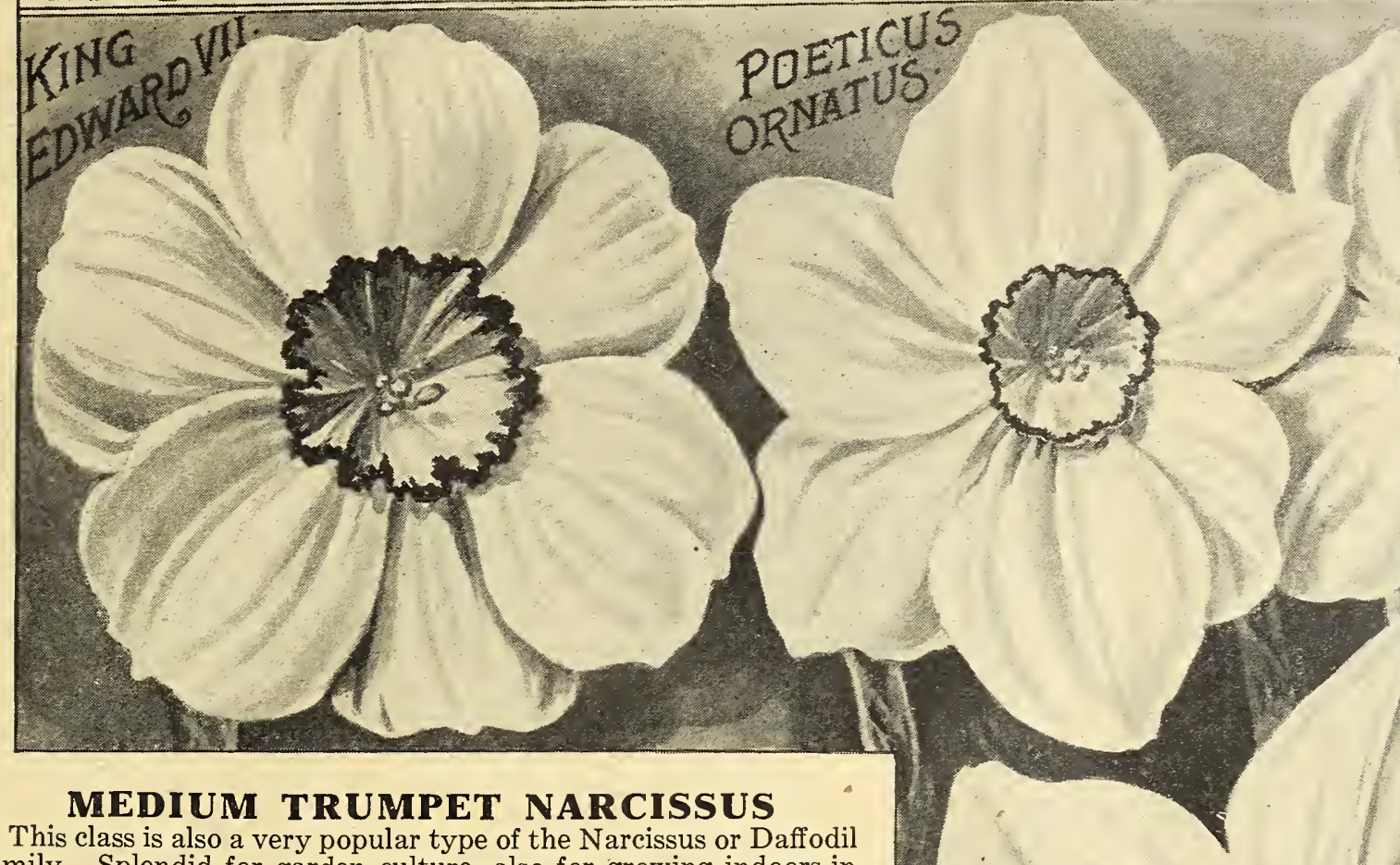

family. Splendid for y pop culture, of the for pots or pans. The number prefixed before the variety denotes the height.

20 Barrii Conspicuus. Broad, spreading perianth of pale yellow, darker yellow cup, edged scarlet; excellent for cutting. 7 c. each; doz., 70c.; $\$ 4.25$ per 100 ; per $1000, \$ 36.00$.

18 Incomparabilis, Lucifer. A very showy variety; perianth white, trumpet orange scarlet. Each, 9c.; 85c. per doz.; per $100, \$ 5.25 ; \$ 46.00$ per 1000 .

12 Leedsii, Mrs. Langtry. A very free flowering sort with pure white perianth and delicate primrose cup; good for pots; largely used for naturalizing. 6c. each; doz., 60c.; $\$ 4.00$ per 100; per 1000, $\$ 33.00$.

\section{THE OLD-FASHIONED POET'S NARCISSUS}

This class is noted for its hardiness and freedom of bloom. It is one of the most popular types, used extensively for wild gardening and naturalizing. They are quite fragrant and are splendid for cut flowers.

15 King Edward VII. An improved type, having magnificent large flowers with broad round petals of a glistening white; the yellow cup is edged deep red; a very early flowering variety. 11c.each; doz., $\$ 1.10 ; \$ 7.00$ per 100 ; per $1000, \$ 62.50$.

24 Poetaz Elvira. This remarkable novelty is the result of a cross between the Pheasant Eye and the Polyanthus Narcissus, combining hardiness with the cluster flowering effect. The blooms, which are pure white of remarkable substance with delicate yellow cup never come less than 3 to 4 to a long stem and from 2 to 3 stems are produced from a single bulb. The fragrance is distinct, resembling that of a Gardenia. It forces well and early. Each, 12c.; $\$ 1.10$ per doz.; per $100, \$ 4.50 ; \$ 39.00$ per 1000 .

12 Poeticus Ornatus. A much improved form of the ordinary Poeticus, producing larger flowers and blooming two weeks earlier; especially adapted for forcing; mid-season.

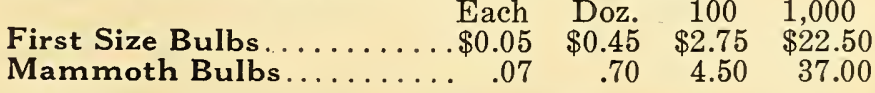

\section{HARDY NARCISSUS IN MIXTURE}

For massing in borders, fields, woods and, in fact, anywhere, they more than return their cost in the liberal manner in which they flower, producing a wide range of color and variety of bloom. We offer large size bulbs only, which can be depended upon for results the first season.

Single Varieties. Each, 6c.; 55c. per doz.; per 100, \$3.25; $\$ 28.50$ per 1000 .

Double Varieties. Each, 7c.; 70c. per doz.; per 100, \$4.25; $\$ 36.00$ per 1000 . 


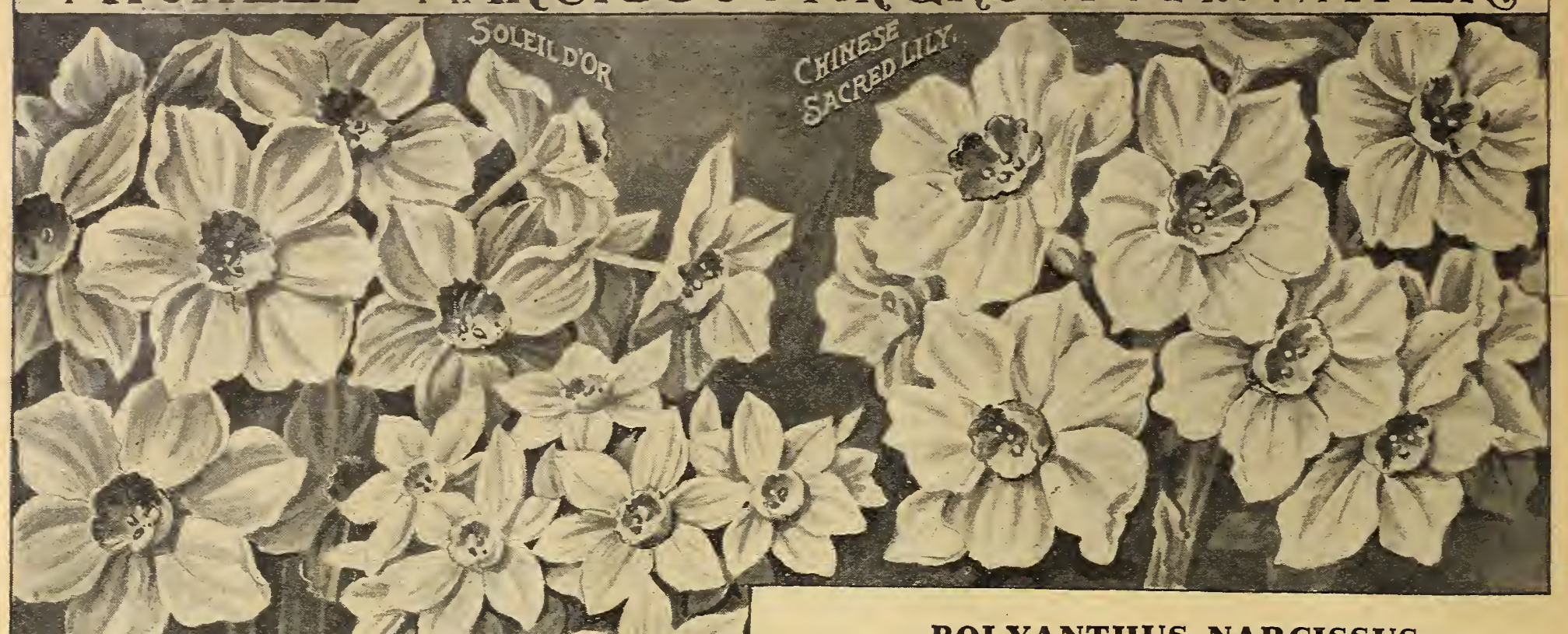

\section{POLYANTHUS NARCISSUS}

This class of Narcissus is a most interesting one. They may be grown in water and pebbles like Chinese lilies, but they are equally suited for growing in soil. The flowers are produced in clusters, like the illustration, and they are delightfully fragrant. Not suitable for outdr

Double Roman. White perianth, with an orange and yellow suffused cup; very free flowering and early. $7 \mathrm{c}$. each; per doz., 75 c.; $\$ 5.25$ per 100 ; per $1000, \$ 45.00$.

Gloriosa. White perianth and orange yellow cup; very pretty. 11 c. each; per doz., $\$ 1.10 ; \$ 7.00$ per 100; per $1000, \$ 62.50$.

Grand Monarque. Large, broad, white perianth with a primrose-yellow cup; a very striking flower. 6c. each; per doz., 65c.; $\$ 4.50$ per 100 ; per $1000, \$ 40.00$.

Grand Primo. Large white perianth with yellow cup. 6c. each; per doz., 65 c.; $\$ 4.50$ per 100 ; per $1000, \$ 40.00$.

Grand Soleil d'Or (often called "Yellow Paperwhite"). Rich yellow, with deep red cup. For cutting this is a fine variety. 15c. each; per doz., $\$ 1.75 ; \$ 12.00$ per 100 .

Paper White Grandiflora. This is quite a specialty with us; of it alone we import two million bulbs. It is a pure white flowering sort; used extensively for forcing, as it can be brought into bloom in 8 weeks' time. Each Doz. 1001000

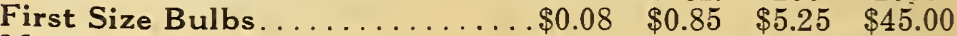
Mammoth Bulbs................ $\quad .10 \quad 1.00 \quad 6.75 \quad 60.00$

White Pearl. A large pure white; very exquisite. 11c. each; per

doz., $\$ 1.10 ; \$ 7.00$ per 100 ; per $1000, \$ 62.50$.

Polyanthus Narcissus, Mixed. All colors and varieties. 9c.

\section{MAMMOTH FLOWERING CHINESE \\ LILIES}

Place from 3 to 6 bulbs in a bowl on top of pebbles to the depth of 2 inches; place a piece of charcoal with the pebbles to keep the water sweet. Place more pebbles around the bulbs so they will not topple over and then fill the bowl with water to the top of pebbles. After being planted they should be stored for three weeks in a cool, dark corner and then brought forth to a light but cool place. They may also be grown in pots with soil or sand, bulb fibre and moss.

Basket of

Large Bulbs ..................... $\$ 0.15 \quad \begin{array}{r}\$ 1.65 \\ 2\end{array} \begin{array}{r}\$ 3.75 \\ 5.00\end{array}$

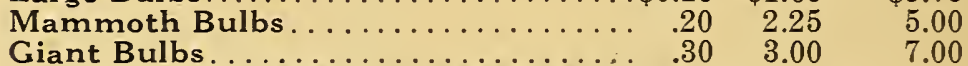

\section{GOLDEN CHINESE LILY}

A beautiful variety. The centre cup is deep yellow while the perianth is lighter. Treat exactly the same as the regular Chinese Lily. Very fragrant.

Large Bulbs, 15c. each; doz., $\$ 1.75$; per $100, \$ 12.00$.

Pebbles for Chinese Lilies. Carefully screened and selected. 10c. per qt.; 75 c. per peck; bushel, $\$ 2.00 ; \$ 4.00$ per barrel. (Pebbles cannot be mailed.)

If Bulbs are wanted by Parcel Post, add 10 per cent. to value of order to points east of the Mississippi River, and 20 per cent. to points west of the Mississippi River. 


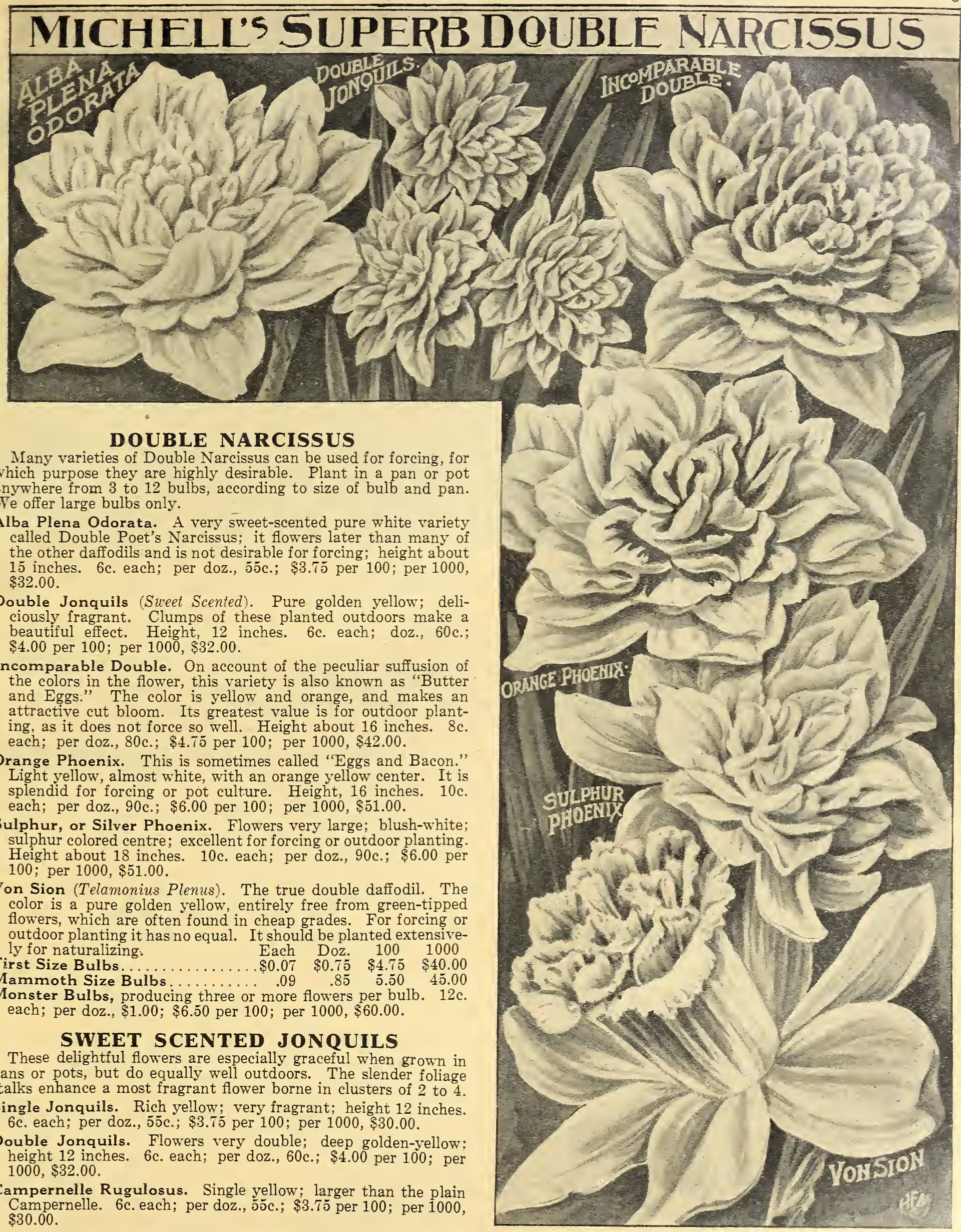

If Bulbs are wanted by Parcel Post, add 10 per cent. to value of order to points east of the Mississippi River, and 20 per cent. to points west of the Mississippi River. 


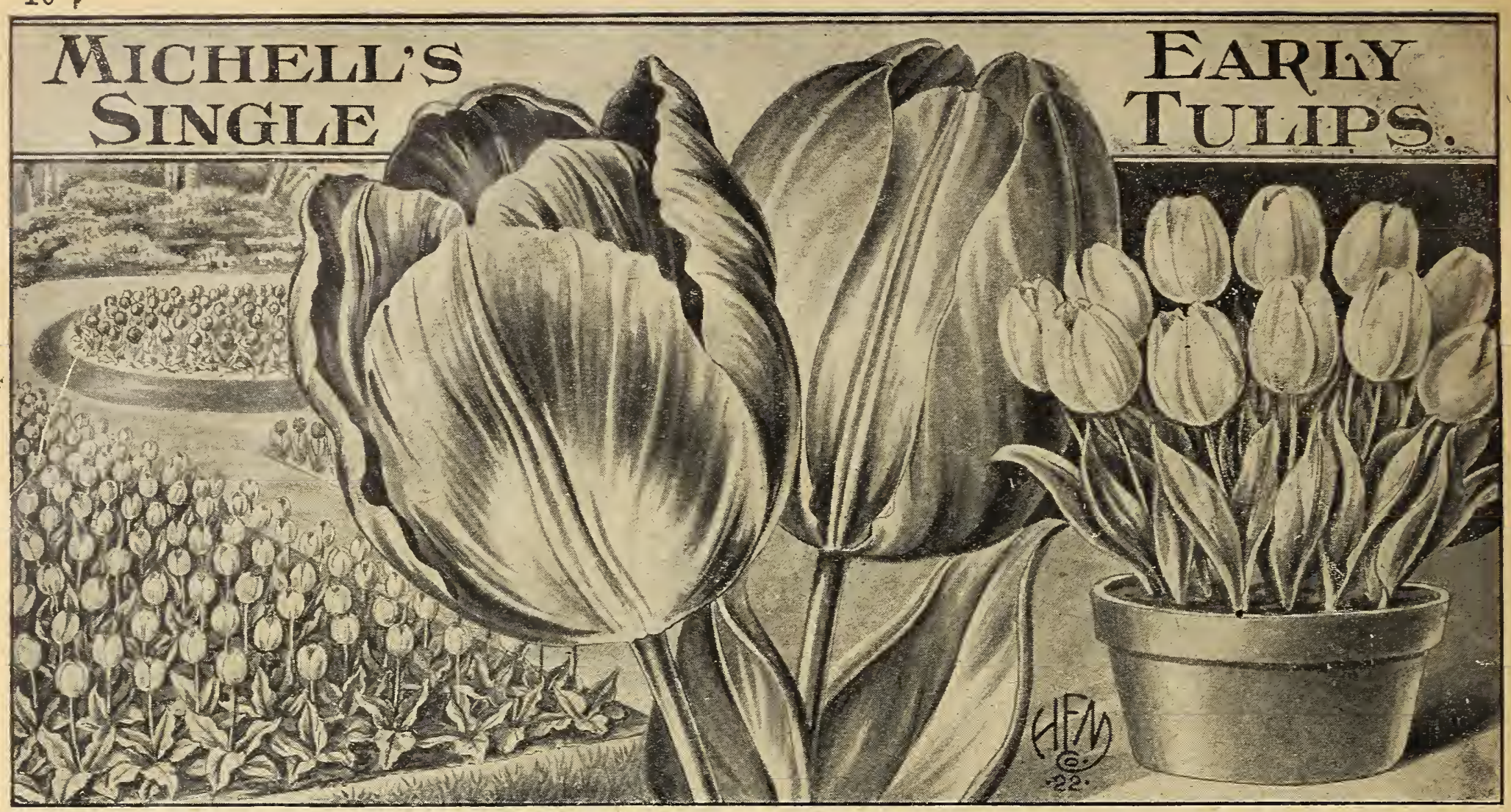

The Tulip is one of the most attractive and popular of spring blooming flowers for garden borders or for bedding. Most of the varieties being equally valuable for pot and pan culture indoors. The named varieties which we offer include some of the most beautiful and recently introduced sorts.

CULTURAL DIRECTIONS.-For Bedding Out: The bed should be formed of a compost similar to that recommended for Hyacinths. Plant the bulbs 4 inches apart and about 5 inches deep. They should be covered with litter before freezing weather.

For Pot or Pan Culture.-Plant about 4 bulbs in a 6-inch pot or 5 bulbs in a 6-inch pan, water thoroughly and then remove to the open ground or in a cold frame, covering with coal ashes; after they have rooted thoroughly they should be brought in a moderately cool room and gradually warmer; by bringing in a fresh supply every ten days, they can be had in bloom all winter.

We have affixed in front of the varieties figures denoting the approximate height; also letters to indicate the comparative blooming time. $\mathrm{V}$ means very early; $\mathrm{E}$ means early; $\mathrm{M}$ means midseason.

Inches PINK VARIETIES

High

8M Cottage Maid. Pink and white.... \$0.70 $\$ 4.25 \quad \$ 36.50$

$\begin{array}{lllll}12 \mathrm{E} & \text { Flamingo. Bright pink, shaded deeper } & .90 & 5.75 & 50.00\end{array}$

$12 \mathrm{E}$ Pink Beauty. Extra large; rich pink. . $\quad .90 \quad 6.00 \quad 53.00$

$8 \mathrm{E}$ Proserpine. Glossy pink; forces early; excellent for bedding ........... $.90 \quad 6.00 \quad 52.50$

8 E Prosperity. Rose pink.............65 $\quad 3.75 \quad 31.00$

10M Rose Luisante. Deep pink; large $\begin{array}{lll} & & \\ \end{array}$

\section{RED AND SCARLET VARIETIES}

$8 \mathrm{M}$ Artus. Bright scarlet; for bedding. . $.55 \quad 3.25$

8M Belle Alliance. Brilliant scarlet; for either forcing or bedding.

$\begin{array}{lll}.70 & 4.25 & 37.50\end{array}$

$12 \mathrm{E}$ Brilliant Star. Brilliant scarlet.... $1.10 \quad 7.00 \quad 64.00$

$10 \mathrm{M}$ Couleur de Cardinal. Bright scarlet; for forcing or bedding.

$10 \mathrm{M}$ Cramoise Brilliant. Scarlet; good for bedding or forcing.

$7 \mathrm{~V}$ Duc Van Thol. Cochineal. Rich vermilion; for forcing or bedding.

Duc Van Thol. Scarlet.

$.85 \quad 5.50 \quad 47.50$

$55 \quad 3.25 \quad 26.00$

$70 \quad 4.25 \quad 36.50$

$\begin{array}{lll}55 & 3.25 & 26.00\end{array}$

10M McKinley. Rose, shaded carmine.

12M Prince of Austria. Orange scarlet; for either forcing or bedding.

$10 \mathrm{M}$ Vermilion Brilliant. The richest scarlet; for forcing or bedding.

$\begin{array}{lll}.70 & 4.25 & 36.50\end{array}$

$\begin{array}{lll}70 & 3.75 & 33.00\end{array}$

$.90 \quad 5.75 \quad 50.00$
.

Inches VARIEGATED OR TWO COLOR VARIETIES

High $\quad$ Doz. $100 \quad 1000$

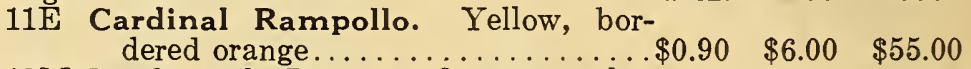

$12 \mathrm{M}$ Duchess de Parma. Orange scarlet, yellow border; for bedding ............ $\quad .65 \quad 3.75 \quad 31.50$

$\begin{array}{ccccc}12 \mathrm{M} \text { Keizerkroon. } & \begin{array}{c}\text { Brilliant red, gold } \\ \text { border; for forcing or bedding...... }\end{array} & .65 & 3.75 & 31.50\end{array}$ VIOLET OR BLUE VARIETIES

$9 \mathrm{M}$ Wouverman. Purple violet........65 $\quad .65 \quad 3.75 \quad 31.50$

\section{WHITE VARIETIES}

$9 \mathrm{E}$ Joost Van Vondel, White (Lady

Boreel). A real exhibition variety...
10M La Reine. White, at times showing a
delicate shade of pink............

$10 \mathrm{M}$ La Reine. White, at times showing a

$.75 \quad 4.75$

41.00

\section{YELLOW VARIETIES}

10M Chrysolora. Golden yellow.........
$10 \mathrm{M}$ Herman Schlegel (Primrose Queen). Pale yellow.

10M Mon Tresor. Golden yellow. .

8M Yellow Prince. Golden yellow.

$\begin{array}{lll}.65 & 3.75 & 31.50 \\ .50 & 3.00 & 23.50 \\ .65 & 3.75 & 32.00 \\ .55 & 3.25 & 26.50\end{array}$

SINGLE UNNAMED TULIPS (For Bedding Only)

These make a fine effect where a solid color is desired, and their cost is not so much as the named varieties.

Pink, in all shades

Doz. $\quad 100 \quad 1000$

Red and Scarlet, in all shades ........... $\quad .45 \quad 2.50 \quad 20.00$

White, in all shades.

$\begin{array}{ll}.45 & 2.50 \\ .45 & 2.50\end{array}$

20.00

SINGLE EARLY TULIPS IN MIXTURE

If Bulbs are wanted by Parcel Post, add 10 per cent. to value of order to points east of the Mississippi River, and 20 per cent. to points west of the Mississippi River.
Our mixtures of Tulips have long been noted for their brilliancy, proper blending and variety of colors. Doz. $100 \quad 1000$ Superfine Quality, all colors. $\begin{array}{lll}\$ 0.40 & \$ 2.40 \quad \$ 19.00\end{array}$ 


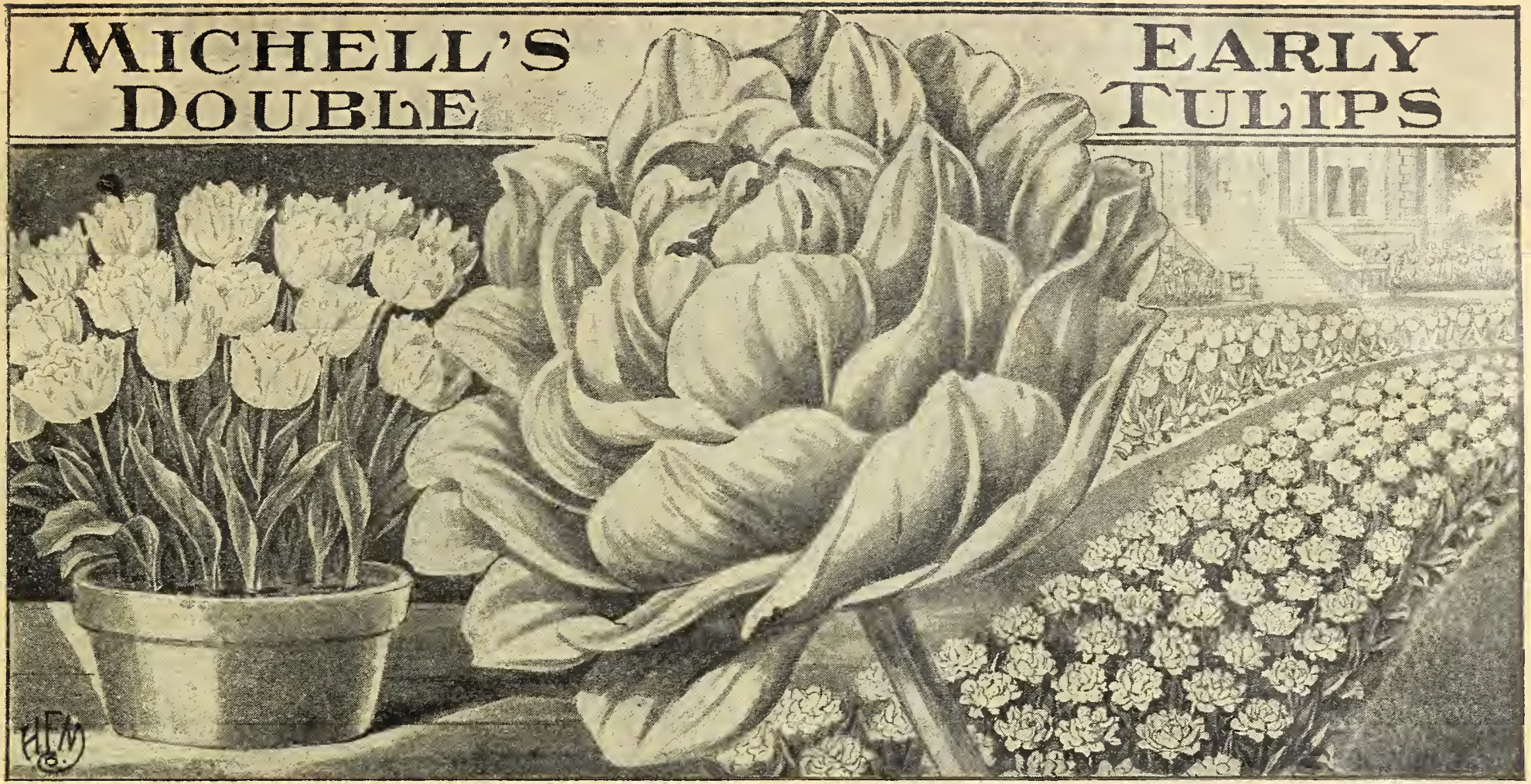

Double Tulips are used very extensively for forcing, but are equally valuable for bedding purposes. They remain in flower longer than do the single sorts on account of their substance, although they do not make quite as fine a show. They should not be planted in beds with single tulips, as they do not bloom as early as the single sorts. The number prefixed before the variety denotes the approximate height.

10 Boule de Neige. Large, pure white; resembles a Paeony in form; excellent for Doz. $\quad 100 \quad 1000$ bedding or forcing.............\$0.70 $\$ 4.25 \quad \$ 37.50$

12 Couronne d'Or. A handsome rich yellow variety; grand forcer.......... $\quad .75 \quad 4.75 \quad 41.00$

10 Imperator Rubrorum. Brilliant scarlet; especially adapted to forcing, also

12 Le Matador. Brilliant scarlet; splendid forcer or bedder. . . . . . . . . . . . . . .

7 Murillo. A very large pink sort, suffused with white; one of the best forcers....
ubra Maxima. Dazzling scarlet; good bedder and splendid early forcer......

10 Salvator Rosa. Beautiful deep rose; for forcing or bedding.

$.80 \quad 5.00 \quad 43.00$

$\begin{array}{lll}.75 & 4.60 \quad 40.00\end{array}$

$.45 \quad 2.75 \quad 20.00$

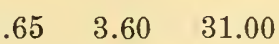

$\begin{array}{lll}.60 & 3.50 \quad 30.00\end{array}$

8 Toreador. A handsome rich orange; excellent for bedding or forcing........

8 Tournesol, Red and Yellow. For forcing and bedding.

\section{DOUBLE, UNNAMED TULIPS FOR BEDDING ONLY}

These are very valuable for solid color bedding where no particular design is to be carried, into effect and where expense is considered. At the low price offered anyone can afford them and thus avoid mixtures. They will bloom evenly and make a fine show.

Pink, in all shades ............... \$0.45 $\$ 2.50 \quad \$ 20.00$

Red and Scarlet, in all shades ........... . . . . $\quad 2.50 \quad 20.00$

White, in all shades............... .45 $2.50 \quad 20.00$

Yellow, in all shades.............. .45 $2.50 \quad 20.00$

If Bulbs are wanted by Parcel Post, add 10 per cent. to value of order to points east of the Mississippi River, and 20 per cent. to points west of the Mississippi River.

\section{MICHELL'S EARLY DOUBLE MIXED TULIPS}

\section{(For Bedding Only)}

These mixtures are carefully blended with the choicest varieties taken from the named sorts. The bulbs are selected for size, and the mixture will produce a grand array of colors. For planting between perennials they are unexcelled.

Superfine Quality, all colors

Doz. $\quad 100 \quad 1000$ $\$ 0.40 \quad \$ 2.50 \quad \$ 20.00$

\section{NUMBER OF BULBS REQUIRED FOR. PLANTING CIRCULAR BEDS AT DISTANCES NOTED BELOW}

Oval beds require very much the same number, although we will be glad to give the exact information whenever desired, also for other sized or shaped beds.

\section{DISTANCES FOR PLANTING APART}

\begin{tabular}{|c|c|c|c|c|c|c|c|}
\hline & Diam. of Bed & $\begin{array}{l}3 \mathrm{in}, \\
\text { apart }\end{array}$ & $\begin{array}{l}4 \text { in. } \\
\text { apart }\end{array}$ & $\begin{array}{l}6 \text { in. } \\
\text { apart }\end{array}$ & $\begin{array}{l}8 \mathrm{in} . \\
\text { apart }\end{array}$ & $10 \mathrm{in}$. & $\begin{array}{l}12 \text { in. } \\
\text { apart }\end{array}$ \\
\hline & feet. & 61 & 37 & 19 & & & \\
\hline 3 & & 127 & 95 & 37 & & & \\
\hline 4 & “ & 217 & 127 & 61 & 37 & 24 & 19 \\
\hline 5 & $\ldots \ldots$ & 331 & 225 & 91 & 69 & 37 & 25 \\
\hline 6 & 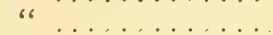 & 469 & 271 & 127 & 78 & 52 & 37 \\
\hline 7 & “ & 631 & 410 & 169 & 96 & 71 & 48 \\
\hline 8 & "“ & 817 & 469 & 217 & 127 & 85 & 61 \\
\hline 9 & $\ldots$ & 1027 & 650 & 271 & 156 & 110 & 74 \\
\hline 10 & $\ldots \ldots$ & 1261 & 721 & 331 & 19 & 127 & 91 \\
\hline 11 & $\ldots \ldots \ldots$ & 1519 & 940 & 397 & 240 & 150 & 110 \\
\hline 12 & " & 1801 & 1027 & 469 & 27 & 169 & 127 \\
\hline 13 & $" \ldots \ldots \ldots \ldots$ & 2107 & 1280 & 543 & 31 & 20 & 150 \\
\hline 14 & $\ldots$. & 2437 & 1387 & 631 & 36 & 240 & 169 \\
\hline 15 & $"$ & 2791 & 1670 & 721 & 420 & 271 & 200 \\
\hline 16 & $\ldots$ & 3169 & 1801 & 817 & 46 & 31 & 217 \\
\hline 17 & “ & 3571 & 2140 & 919 & 54 & 36 & 240 \\
\hline 18 & " & 4037 & 2269 & 1027 & 590 & 390 & 271 \\
\hline 19 & “" & 4187 & 2640 & 1141 & 63 & 420 & 318 \\
\hline 20 & “" & 4961 & 2791 & 1261 & 72 & 46 & 331 \\
\hline 21 & $" 6$ & 5459 & 3210 & 1387 & 785 & 54 & 360 \\
\hline $2 ?$ & $\ldots$ & 6981 & 3367 & 1519 & 817 & 590 & 397 \\
\hline 23 & " & 7527 & 3870 & 1659 & 945 & 62 & 420 \\
\hline 24 & $\ldots \ldots$ & 80 & 4037 & 18 & 10 & 67 & 469 \\
\hline 25 & $" \ldots \ldots \ldots$ & 8691 & 4325 & 1951 & 1165 & 721 & 590 \\
\hline
\end{tabular}




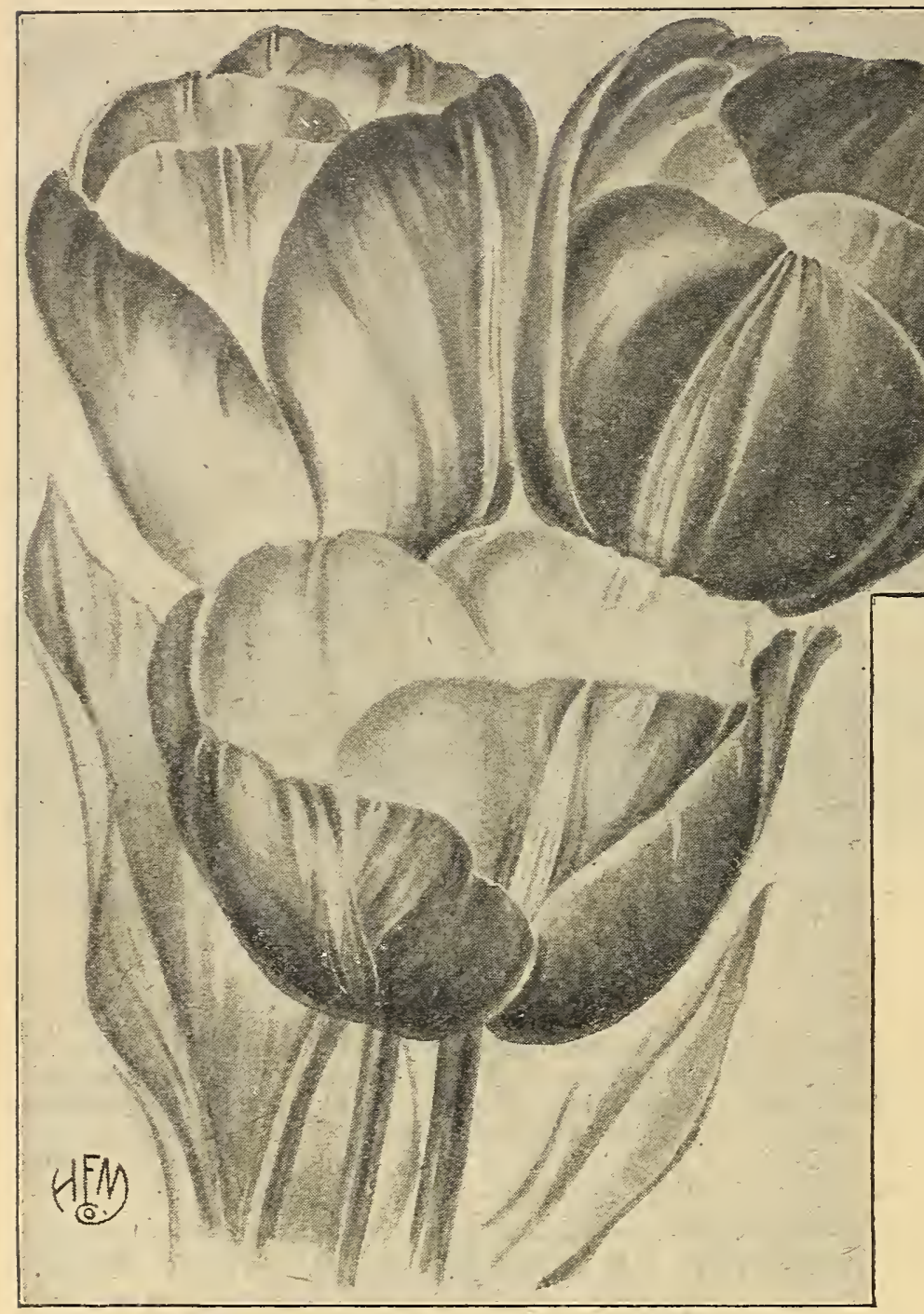

The color plate on the front cover of this catalog can give only a faint idea of the beauty of the Darwin Tulips. While they belong to the late blooming or May Flowering class, they are distinct in style of growth; the gigantic flower cups are borne on straight, stout stems which are far above a broad foliage. For massing, bedding or border planting the Darwins are hard to equal. For pot culture they are splendid and are just the ideal Tulip to grow for Easter; the varieties marked with an asterisk (*) are best adapted for the latter purpose. The number prefixed before the variety denotes the approximate height. Please note there is no yellow colored Darwins and for this the May-flowering Tulip, Inglescombe Yellow may be used.

28 Ariadne. Enormous bold, cup shaped flowers of fiery, scarlet red. $90 \mathrm{c}$. per doz.; per $100, \$ 6.00 ; \$ 51.00$ per 1000 .

*14 Bartigon. Fiery red color, with pure white base; a very showy variety, grand forcer. $90 \mathrm{c}$. per doz.; per $100, \$ 6,00$; $\$ 55.00$ per 1000 .

*20 Clara Butt. Delicate salmon pink. Its perfect shape and lovely color make it a real beauty. It is a good bedder and a splendid forcer. 70c. per doz.; per 100, $\$ 3.75$; $\$ 33.00$ per 1000 .

23 Glow. Scarlet, margined white, blue center, the flowers are of large size and very showy. $85 \mathrm{c}$. per doz.; per $100, \$ 5.50$; $\$ 48.00$ per 1000 .

If Bulbs are wanted by Parcel Post, add 10 per cent. to value of order to points east of the Mississippi River, and 20 per cent. to points west of the Mississippi River.
*18 Gretchen or Margaret. A most attractive variety of a soft salmon-rose color. Splendid for cutting. Good bedder and excellent forcer. 70c. per doz.; per $100, \$ 3.75$; $\$ 33.00$ per 1000 .

*26 La Tristresse. A very large flower of violet blue, with silver flush at margin; a very interesting color. $80 \mathrm{c}$. per doz.; per $100, \$ 4.75 ; \$ 42.00$ per 1000 .

25 La Tulipe Noire (The Black Tulip). The nearest color to black in Tulips; deep maroon black with a velvety sheen. Per doz., 75c.; $\$ 4.60$ per 100 ; per $1000, \$ 40.00$.

26 Madame Krelage. Bright lilac rose, margined pale silvery pink; inside is a soft rose pink; very large flower of beautiful form. A good forcing variety and excellent for the border. Per doz., 80c.; $\$ 4.75$ per 100; per $1000, \$ 42.00$.

20 May Queen. Soft rose; very large flower; splendid bedding variety. 75c. per doz.; per $100, \$ 4.60 ; \$ 40.00$ per 1000 .

*24 Mr. Farncombe Sanders. Brilliant scarlet, with a clear white base; giant flowering. One of the showiest of all Darwins; good forcer. 90c. per doz.; per 100, $\$ 5.75$; $\$ 50.00$ per 1000 .

28 Mrs. Potter Palmer. Rich glowing purple, a very distinct and striking color. Excellent for border planting. $70 \mathrm{c}$. per doz.; per $100, \$ 3.75 ; \$ 33.00$ per 1000 .

*28 Nauticus. A large handsome variety of rich, purplish rose. Excellent for outdoors and good for early or late forcing. 75 c. per doz.; per $100, \$ 4.25 ; \$ 37.50$ per 1000 .

*24 Phillippe de Commines. Rich, deep purple; one of the best dark sorts. 75c. per doz.; per 100, $\$ 4.25$; $\$ 38.50$ per 1000.

*24 Pride of Haarlem. Brilliant rosy carmine. This is one of the most popular varieties of Darwins. The size of the flowers is immense, having usually more than six petals, giving them the appearance of Double Tulips. A favorite for bedding and forcing. 70c. per doz.; per 100, $\$ 4.00$; $\$ 35.00$ per 1000 .

*26 Psyche. Large bold flowers; rosy pink outside; inside silvery rose, with pale blue base. 70c. per doz.; per $100, \$ 4.25$; $\$ 36.00$ per 1000 .

See next page for other varieties of Darwin Tulips

TESTIMONIAL
Grand Rapids, Mich., May 16, 1922.
Gentlemen:
Last fall I purchased $500 \mathrm{Mr}$. Farncombe Sanders Darwin
Tulips from you. They are so beautiful and have caused so
much comment by persons who notice them that I cannot resist
in letting you know that the stock that I received from you
was excellent and certainly produced the finest crop of large,
healthy tulips that I ever saw. These tulips are now in full
bloom and I receive compliments from all passers by. I live
next to one of our large City Parks and without any self praise,
I dare say that my tulips beat any that are in bloom in the
park.
Yours truly,
J.J.S. S.




\section{MICHELL'S SUPERB DARWIN TULIPS}

\section{(Continued)}

*20 Rev. H. Ewbank. Light heliotrope, shaded lavender. Rather dwarf variety; a splendid bedder. For forcing we recommend this variety very strongly, as it stands forcing splendidly and produces large flowers of a very pleasing color. 70c. per doz.; per 100, $\$ 3.75$; $\$ 33.00$ per 1000 .

20 Sultan. Very dark maroon, almost black. Undoubtedly the best of the dark varieties. The strong stems hold the flowers erect and make it an excellent bedder. 65c. per doz.; per $100, \$ 3.60 ; \$ 31.00$ per 1000 .

*25 Suzon. Large bold flowers of soft, salmon rose color, margined with white. A strong grower. $75 \mathrm{c}$. per doz.; per 100 , $\$ 4.25 ; \$ 38.50$ per 1000 .

24 Wally Moes. Large flowering; color, soft silvery heliotrope. $\$ 1.20$ per doz.; per $100, \$ 7.50 ; \$ 65.00$ per 1000 .

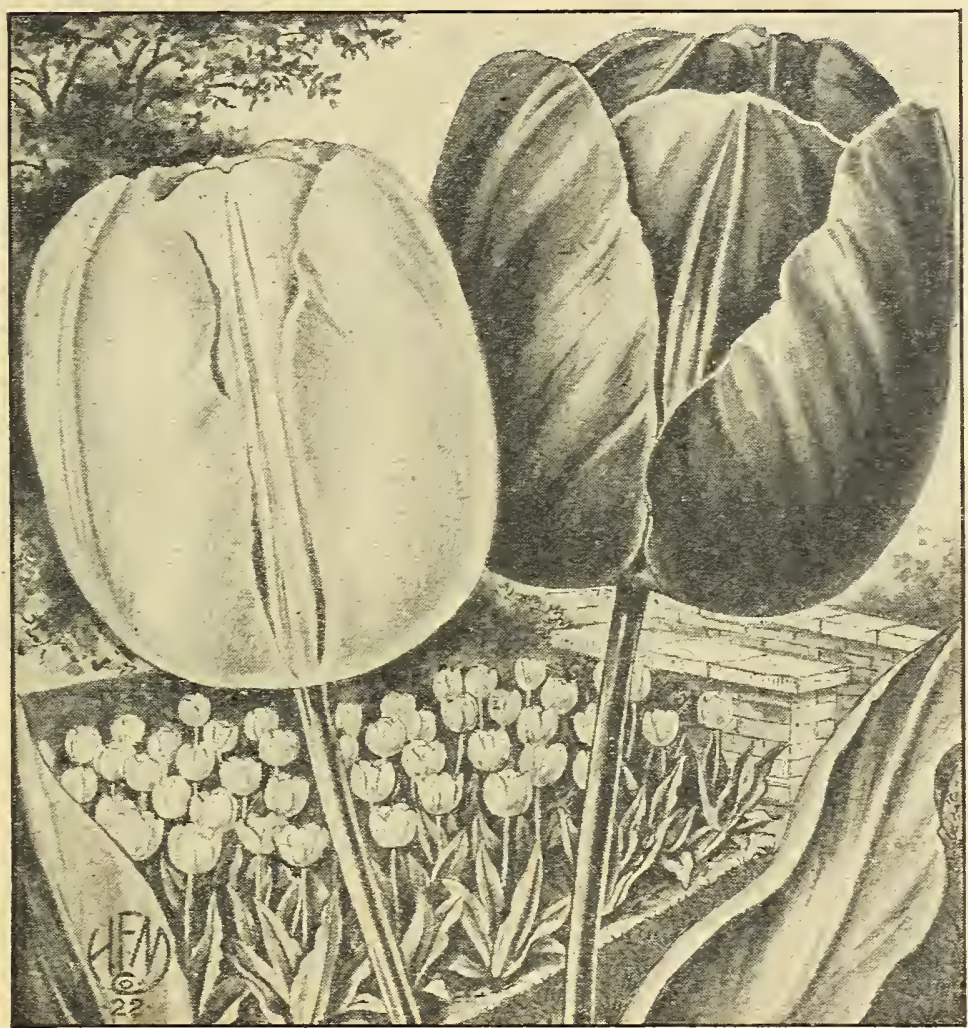

Breeder Tulips

\section{DUTCH BREEDER TULIPS}

This old fashioned type has come into prominence very much of late years. They are similar to the Darwins in their tall, strong growth. The flowers are extra large and run principally in purple, bronze, terra-cotta and orange brown shades. They make a fine effect in hardy borders and when used as a cut flower last a long while in water. Breeder tulips cannot be forced.

$\begin{array}{llll} & \text { Doz. } & 100 & 1,000\end{array}$

24 Aspasia. Wine red, shaded purple........ $90 \quad 6.00 \quad 55.00$

24 Bronze Queen. Soft buff, inside tinged

28 Cardinal Manning. Wine red, flushed rosy brown

25 General Ney. Olive and bronze......

24 Godet Parfait. Violet blue.......... dered................................

24 Prince of Orange. Golden orange....
24 Yellow Perfection. Light, bronze yel low.

$\begin{array}{ccc}.80 & 4.75 & 42.00 \\ .85 & 5.25 & 45.00 \\ .90 & 6.00 & 55.00 \\ 1.50 & 8.25 & 75.00 \\ & & \\ .85 & 5.25 & 45.00 \\ .90 & 6.00 & 55.00 \\ .80 & 4.75 & 42.00\end{array}$

*24 W. Copeland. One of the best early forcing varieties; color delicate lavender. 80c. per doz.; per 100, $\$ 5.25 ; \$ 46.00$ per 1000 .

22 White Queen. Can be called the only white Darwin. It opens rosy white, but passes off pure white. One of the most popular varieties. 75c. per doz.; per 100, $\$ 4.75$; $\$ 41.00$ per 1000 .

Darwin Mixed. A great variety of colors and shades. 55c. per doz.; per $100, \$ 3.25 ; \$ 28.00$ per 1000 .

The varieties marked with an asterisk (*), are the most adapted for forcing. The number prefixed before the variety denotes the approximate height.

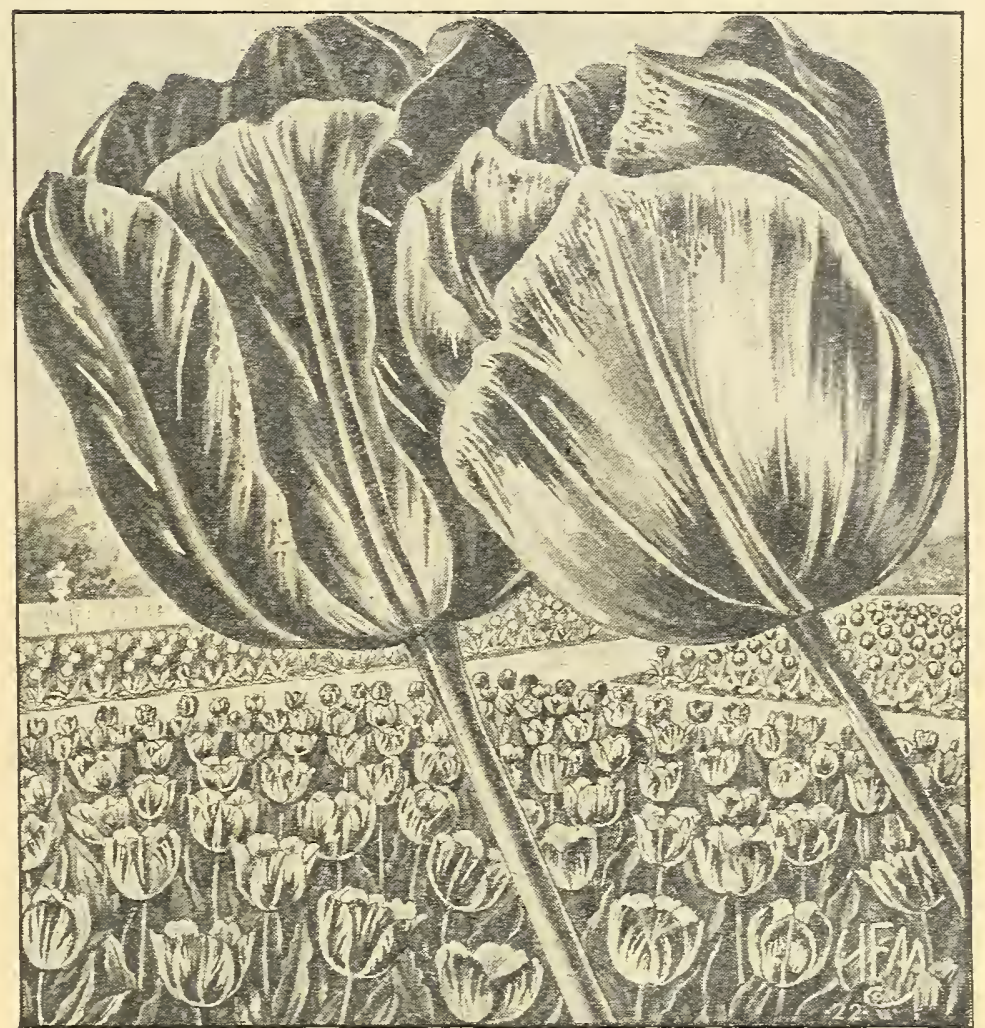

Rembrandt Tulips

\section{REMBRANDT TULIPS}

This type comprises a strain of variegated Darwin tulips frequently referred to as broken Darwin or Rembrandt varieties. They resemble the former with the exception of variation as to colors; they possess splendid decorative value. The stems average 18 to 22 inches in height. Rembrandt tulips cannot be forced.

$\begin{array}{ccccc}\text { Bougainville. Amaranth blue, striped } & 100 & 1000 \\ \text { white...................... } \$ 0.90 & \$ 6.00 & \$ 50.00\end{array}$

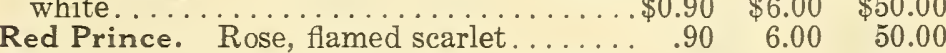
Salome. Carmine rose with white markings $\quad .90 \quad 6.00 \quad 50.00$ Semele. White, feathered rosy pink...... $\quad .90 \quad 6.00 \quad 50.00$

If Bulbs are wanted by Parcel Post, add 10 per cent. to value of order to points east of the Mississippi River, and 20 per cent. to points west of the Mississippi River.

TESTIMONIAL ON MICHELL'S BULBS

The bulbs received from you were excellent-could not have asked for anything better. As to your business methods, are certainly O. K

We have issued the above booklet, containing not only the most up-to-date cultural directions in general, but giving
concise detail to what use each variety is best put to and in addition describing very explicitly each and every bulb offered catalog. We want every bulb grower to have one; free on request. 
The number prefixed before the variety denotes the approximate height.

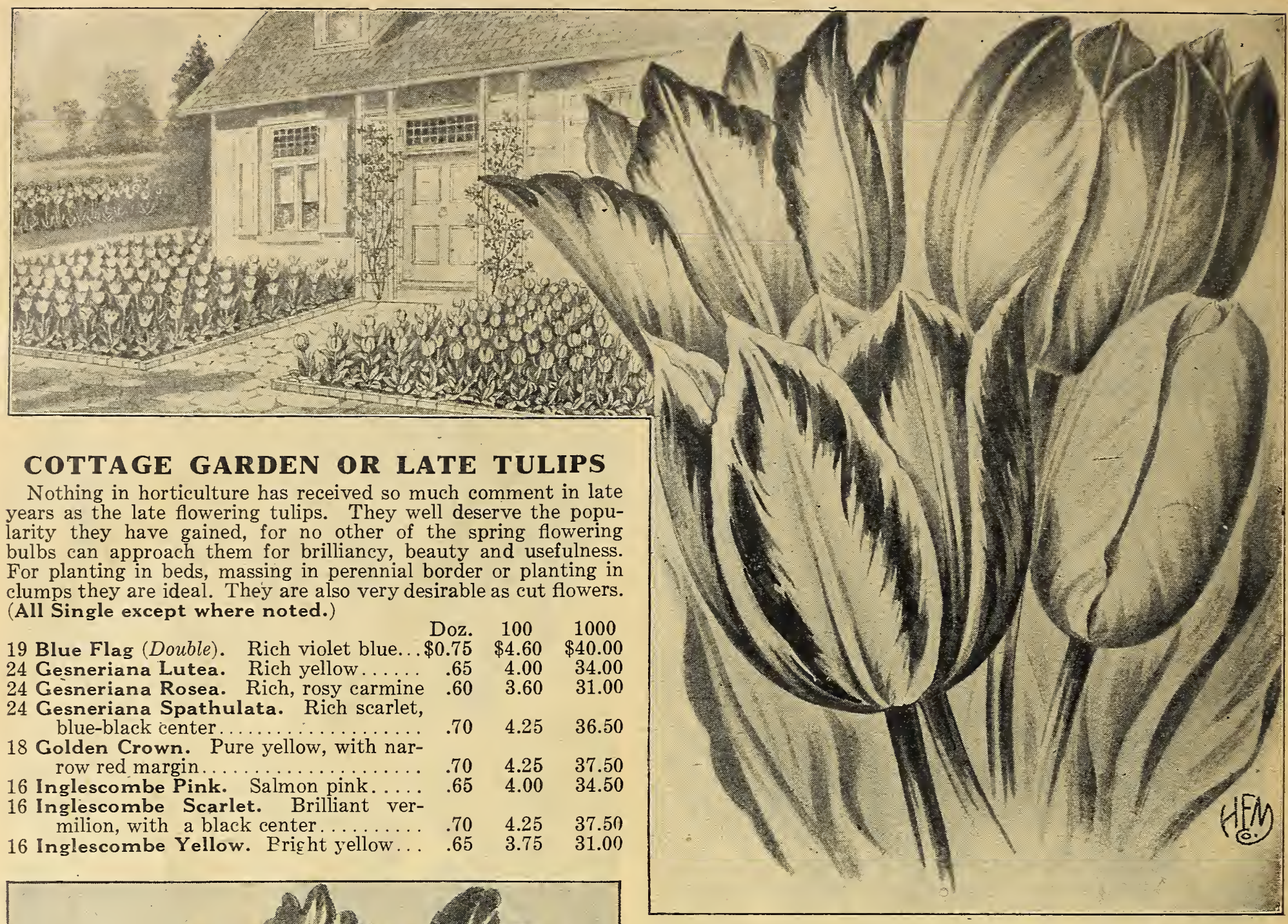
deserve the popularity they have gained, for no other of the spring flowering bulbs can approach them for brilliancy, beauty and usefulness. For planting in beds, massing in perennial border or planting in clumps they are ideal. They are also very desirable as cut flowers. (All Single except where noted.)

19 Blue Flag (Double). Rich violet blue...\$0.75 $\$ 4.60 \quad \$ 40.00$

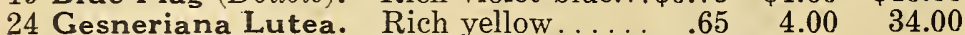
24 Gesneriana Rosea. Rich, rosy carmine $\quad .60 \quad 3.60 \quad 31.00$

24 Gesneriana Spathulata. Rich scarlet,

18 Golden Crown. Pure yellow, with nar-

16 Inglescombe Scarlet. Brilliant ver-

milion, with a black center........ $.70 \quad 4.25 \quad 37.50$

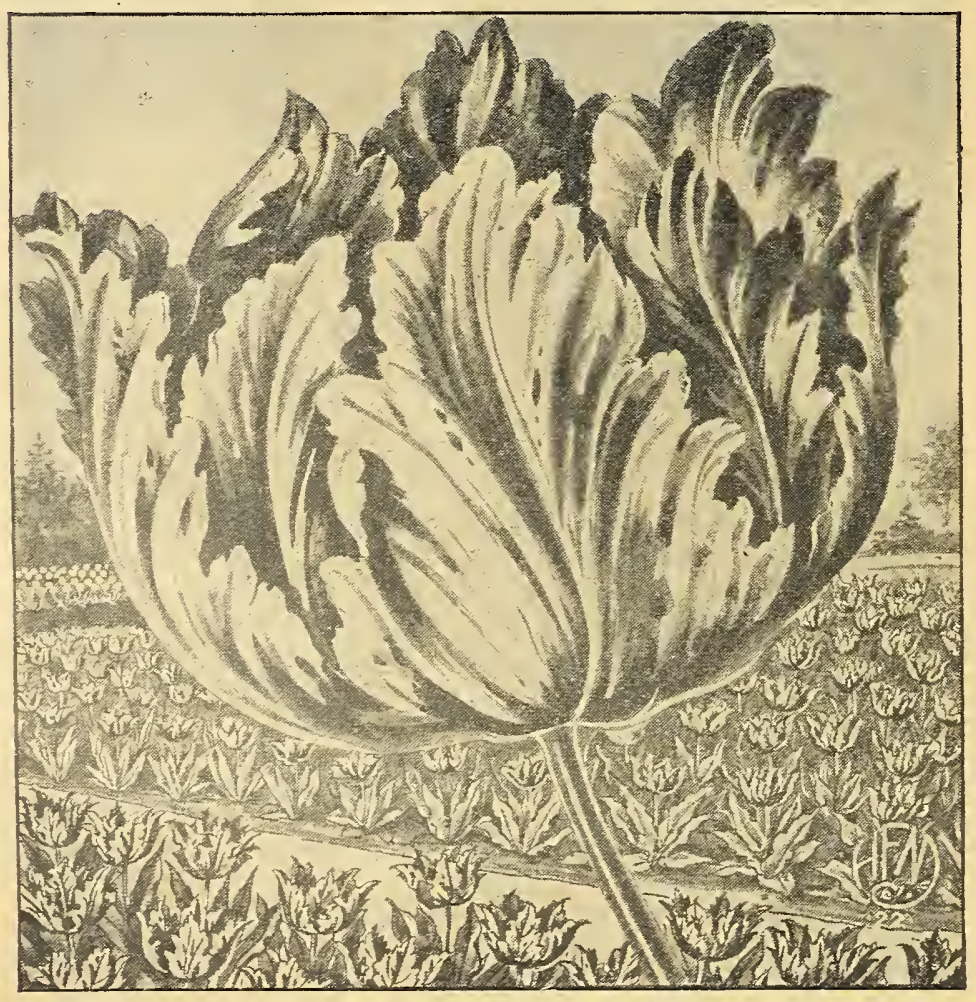

Cottage Garden Tulips

\section{COTTAGE GARDEN TULIPS-Con.}

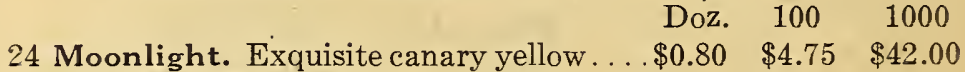
20 Picotee (Maiden's Blush). White, with distinct pink edged border .......... $.70 \quad 3.75 \quad 33.00$ 15 Royal White. Pure white; very fine... $\quad .90 \quad 6.00 \quad 55.00$ 12 Sara Bernhardt (Hobbema or Le Reve). $1.40 \quad 8.00 \quad 72.00$

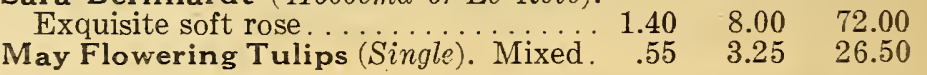

\section{PARROT OR DRAGON TULIPS}

These are curiously curled and crested. They are fine for bedding and border planting, also useful as a cut flower, keeping well for some time when placed in water.

$\begin{array}{llll} & \text { Doz. } & 100 & 1000\end{array}$

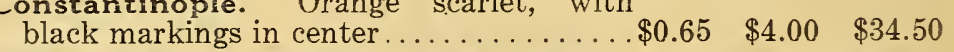

Lutea Major. Very large; bright yellow ... $\quad .65 \quad 4.00 \quad 34.50$

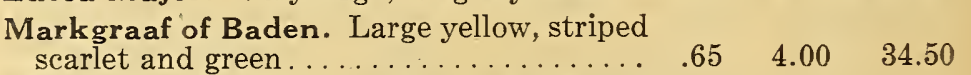

Mixed Colors. This mixture is carefully

blended and contains only the choicest sorts.

$.60 \quad 3.50 \quad 28.00$

If Bulbs are wanted by Parcel Post, add 10 per cent. to value of order to points east of the Mississippi River, and 20 per cent. to points west of the Mississippi River.

Fichell's Bulb Growing Guide, sent free on request. 


\section{MICHELL'S MISCELLANEOUS BULBS For Winter and}

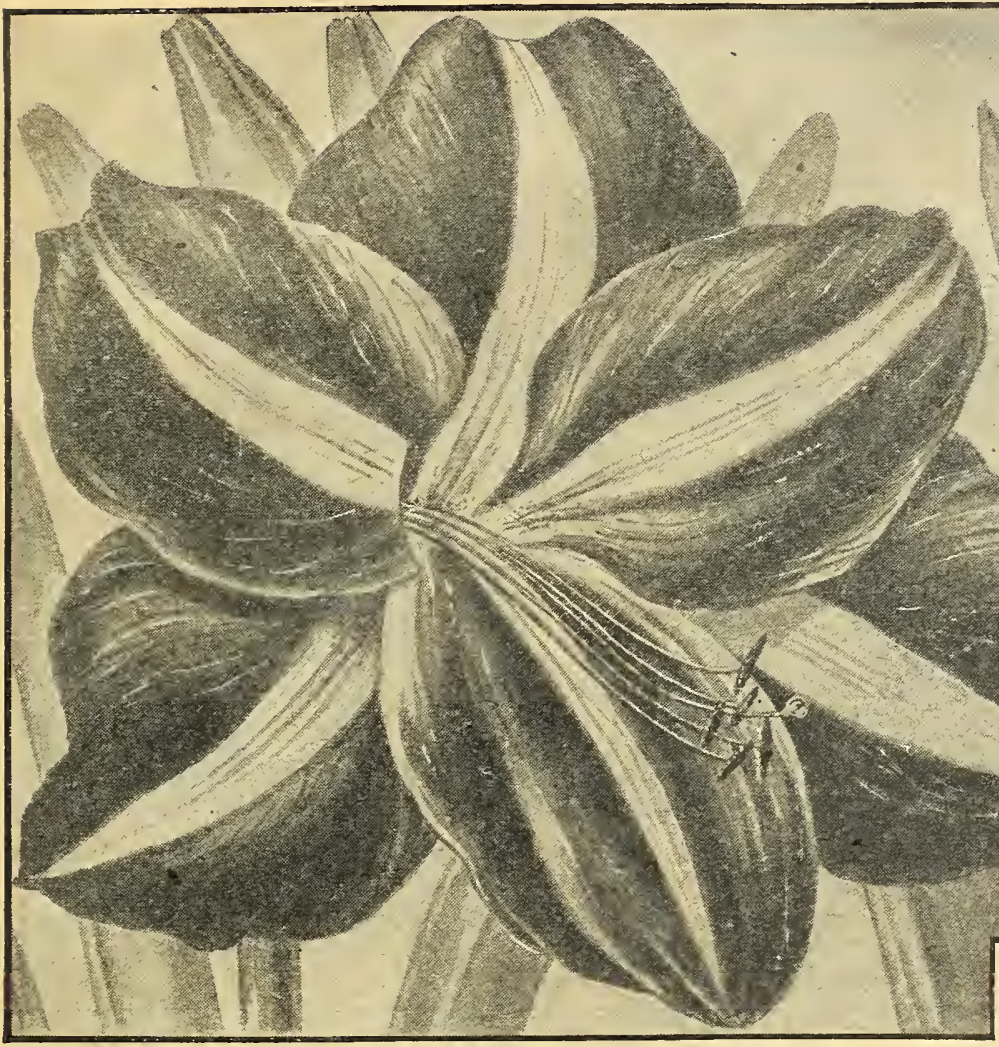

Amaryllis, Hybrids of Vittata

\section{AMARYLLIS}

(Ready in October)

One of the most gorgeous showy house plants, giving splendid satisfaction, not only because of their requiring little care, but also on account of their everlasting nature and tendency to increase.

Belladonna. A beautiful bright pink. 25c. each; doz., $\$ 2.50$; $\$ 17.50$ per 100 .

Hybrids of Vittata. The finest race of Amaryllis in cultivation, exceeding in the size and fine form of their flowers as well as in the diversity of colors and markings all former hybrids; flowers striped and flaked. $\$ 1.00$ each; per doz., $\$ 11.00$.

\section{BEGONIAS (Tuberous Rooted) \\ (Ready in January)}

Enormous wax-like flowers appear uninterruptedly from June until frost. Plant bulbs outdoors about May 1st or start indoors any time prior to then.

\section{SINGLE BEGONIAS}

\begin{tabular}{|c|c|c|c|c|c|}
\hline Each & Doz. & 100 & Each & Doz. & $\begin{array}{l}100 \\
\$ 20.00\end{array}$ \\
\hline $\mathbf{y} \$ 0.30$ & $\$ 3,00$ & $\$ 2000$ & $\begin{array}{l}\text { Salmon. . } \$ 0.30 \\
\text { Scarlet.. } .30\end{array}$ & $\begin{array}{r}\$ 0.00 \\
3.00\end{array}$ & $\begin{array}{r}\$ 20.00 \\
20.00\end{array}$ \\
\hline range. 30 & $\begin{array}{r}\$ 0.00 \\
3.00\end{array}$ & & White. 30 & 3.00 & 20.00 \\
\hline .30 & 3.00 & 2 & ow. & 3.00 & 20.00 \\
\hline .30 & 3.00 & 20.00 & Mixed. & 3.00 & 20.00 \\
\hline \multicolumn{6}{|c|}{ DOUBLE BEGONIAS } \\
\hline Each & Doz. & 100 & Each & Doz. & 100 \\
\hline $\mathrm{n} \$ 0.35$ & $\$ 3.50$ & $\$ 25.00$ & $\$ 0.35$ & $\$ 3.50$ & $\$ 25.00$ \\
\hline .35 & 3.50 & 25.00 & Yellow. & 3.50 & 25.00 \\
\hline non. & 350 & 5 & Mixed. & 3.50 & 25.00 \\
\hline \multicolumn{6}{|c|}{ BEGONIA, CRISPA } \\
\hline Each & Dor & 20 & $\mathrm{Ea}$ & Doz & 10 \\
\hline ge. $\$ 0.25$ & $\$ 2.50$ & $\$ 18.50$ & $\$ 0.25$ & $\$ 2.50$ & $\$ 18.50$ \\
\hline$\cdots \quad .25$ & $\begin{array}{l}2.50 \\
2.50\end{array}$ & 18.50 & Mixed. & 2.50 & \\
\hline
\end{tabular}

\section{BEGONIA, CRISTATA}

Beautifully crested single flowers.
Each Doz
100
Scarlet. $\$ 0.25$
Doz.
100
\begin{tabular}{lll|llll} 
Orange. $\$ 0.25$ & $\$ 2.50$ & $\$ 18.50$ & Scarlet..$\$ 0.25$ & $\$ 2.50$ & $\$ 18.50$
\end{tabular}

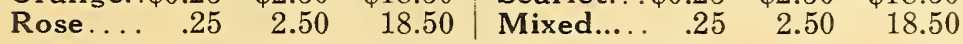

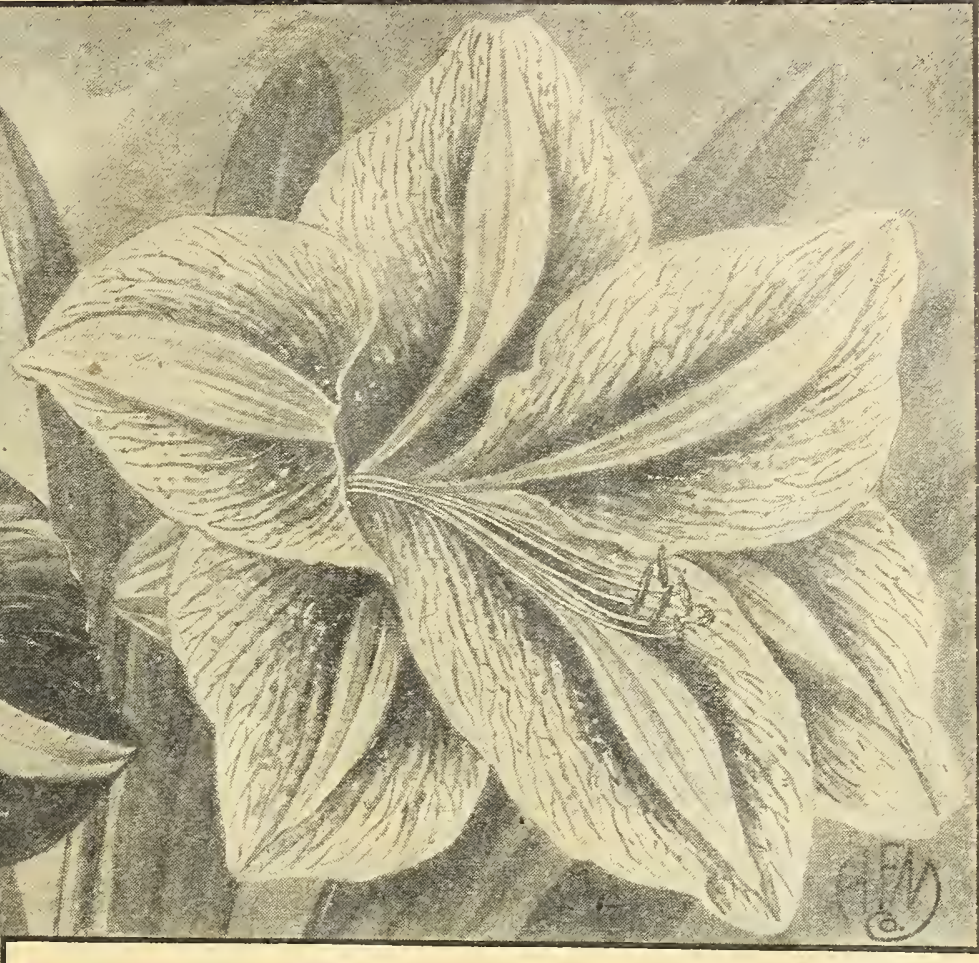

Cultural Directions for Amaryllis. Place bulbs in live moss, only moderately moist, near window of a warm room. When the first sign of growth appears through the top, pot them up in six inch pots; when the bulb is set, most of it should be above the soil. Water moderately at first, but increase as growth increases, then place in a warm, light room near the window.

If Bulbs are wanted by Parcel Post, add 10 per cent. to value of order to points east of the Mississippi River and 20 per cent. to points west of the Mississippi River.

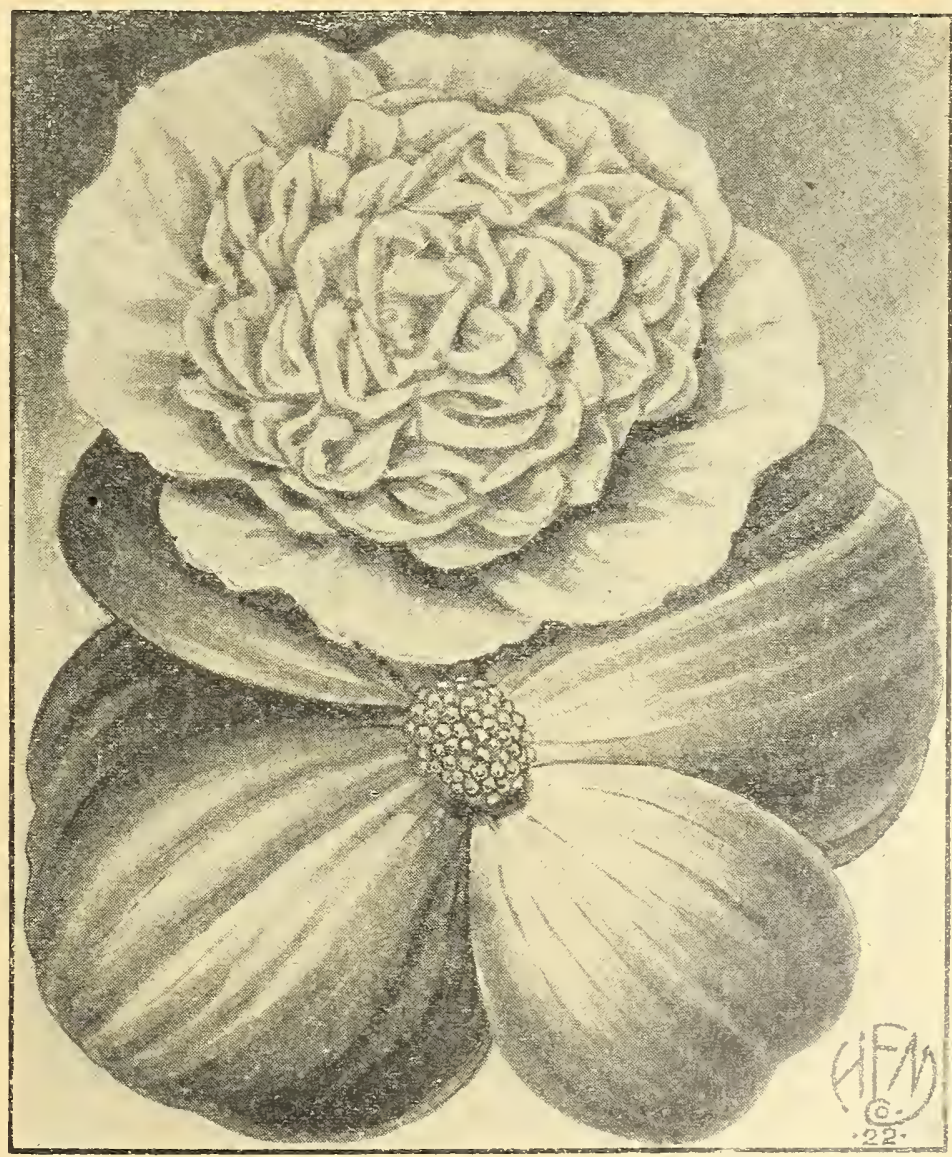




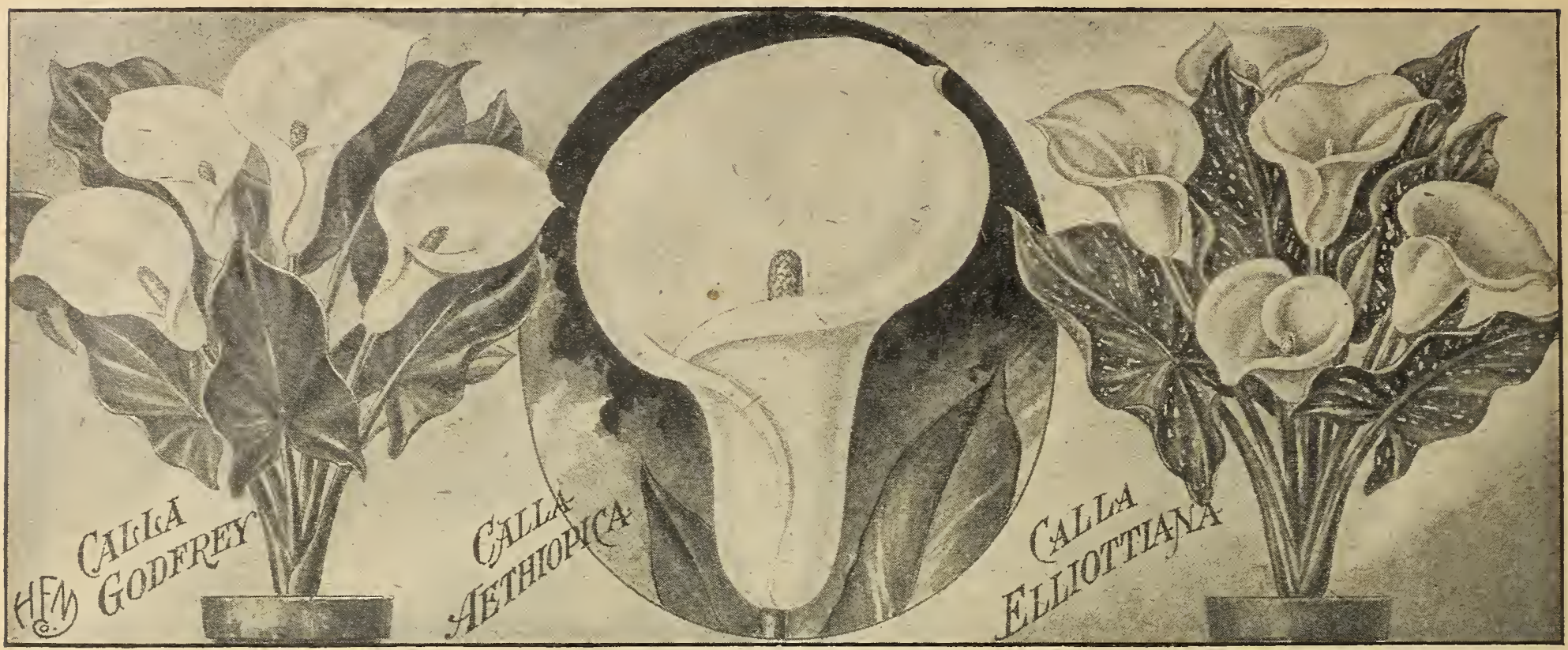

\section{CALLA LILY BULBS}

Callas require good, rich soil and plenty of warmth and water to make them thrive. Plant Callas indoors only.

\section{GODFREY DWARF EVERBLOOMING CALLA}

This comparatively new calla has proven an excellent one; its character is exactly like the Ethiopica or regular variety, except it is of much dwarfer habit and freer bloomer; very desirable as a pot plant. Large blooming size bulbs, 30c. each; doz., $\$ 3.00$; $\$ 20.00$ per 100 .

\section{CALLA AETHIOPICA}

Each Doz. 100

White, Monster Size, 2 to $21 / 2$ in. diam...\$0.60 $\$ 6.00 \quad \$ 37.50$

Mammoth Size, $13 / 4$ to 2 in. diam. $.40 \quad 3.50 \quad 24.00$

Medium Size, $11 / 2$ to $13 / 4$ in. diam. . $.30 \quad 3.00 \quad 17.50$

First Size, $1 \frac{1}{4}$ to $1 \frac{1}{2}$ in. diam.... . . 20 $1.75 \quad 12.50$

\section{YELEOW CALLA (Elliottiana)}

The rich, golden yellow flowers are large and massive.

Large Bulbs, ready in October, $45 \mathrm{c}$. each; doz., $\$ 4.00 ; \$ 27.50$ per 100

\section{SPOTTED CALLAS (Ready in October)}

Flowers white; foliage green spotted white. 40c. each; doz., $\$ 3.25 ; \$ 22.50$ per 100 .

\section{FREESIAS}

One of the most delightful house plants grown and well known for their delightful fragrance. Plant at intervals from August to October, six to twenty-five bulbs in a single pan, according to size. They should be put outside until the approach of frost, then taken inside to the conservatory or a light, airy window, where they will flower freely in January.

\section{MICHELL'S PURITY FREESIA}

The flowers are of extra large size, and of a pure glistening white; the stems are often 15 inches long and very wiry, rendering it a most valuable cut flower. Each bulb will produce 3 or 4 flower First Size Bulbs

Mammoth Size Bulbs

Monster Size Bulbs.

Jumbo Bulbs. .

$\begin{array}{rrrr}\text { Each } & \text { Doz. } & 100 & 1000 \\ \$ 0.04 & \$ 0.35 & \$ 2.25 & \$ 17.50 \\ .08 & .65 & 3.50 & 27.50 \\ .10 & .90 & 5.50 & 48.00 \\ .15 & 1.50 & 8.00 & 70.00\end{array}$

\section{FREESIA, FISCHERI}

An improvement over Purity Freesia, the originator claiming it to be the finest, largest, purest and most fragrant of any variety. 15 c. each; doz., $\$ 1.25$; $\$ 8.25$ per 100 ; per $1000, \$ 75.00$.

\section{NEW COLORED FREESIAS}

Equal in size to the "Purity." These colored Freesias produce flowers of excellent form and splendid texture.

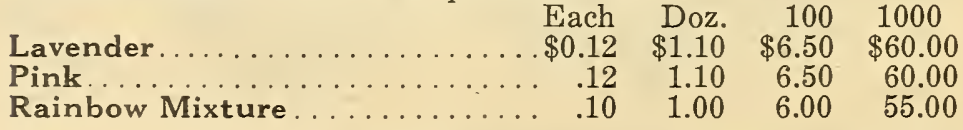

SPECIAL NOTICE.-Owing to the new Plant Qúarantine which took effect June 1,1919, prohibiting the importation of certain bulbs, our list of miscellaneous varieties is not as comprehensive as in former years.

\section{CHINESE LILIES (See Page 8) CROCUS (See next page)}

Shiremanstown, $\mathrm{Pa}$.

Bulbs I purchased from you did splendidly. I hope to order considerably more this year.

G. H. R.

If Bulbs are wanted by Parcel Post, add 10 per cent. to value of order to points east of the Mississippi River, and 20 per cent. to points west of the Mississippi River.

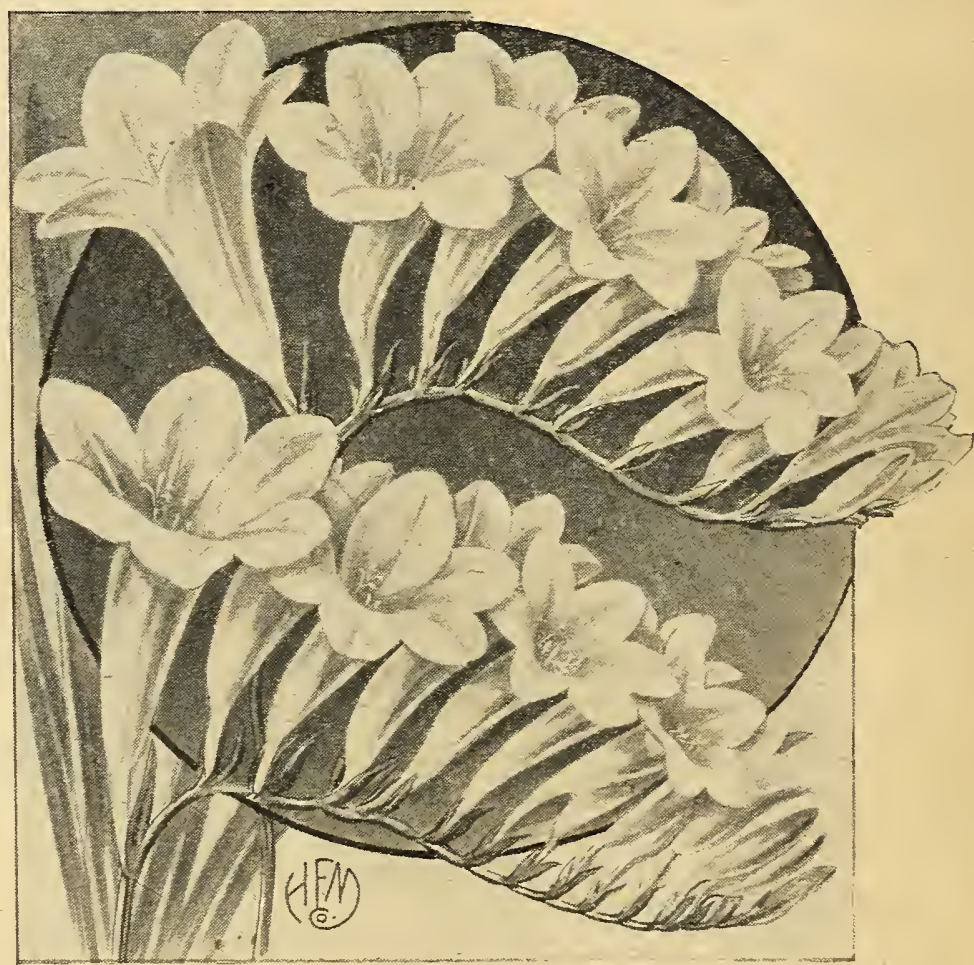

Purity Freesia 


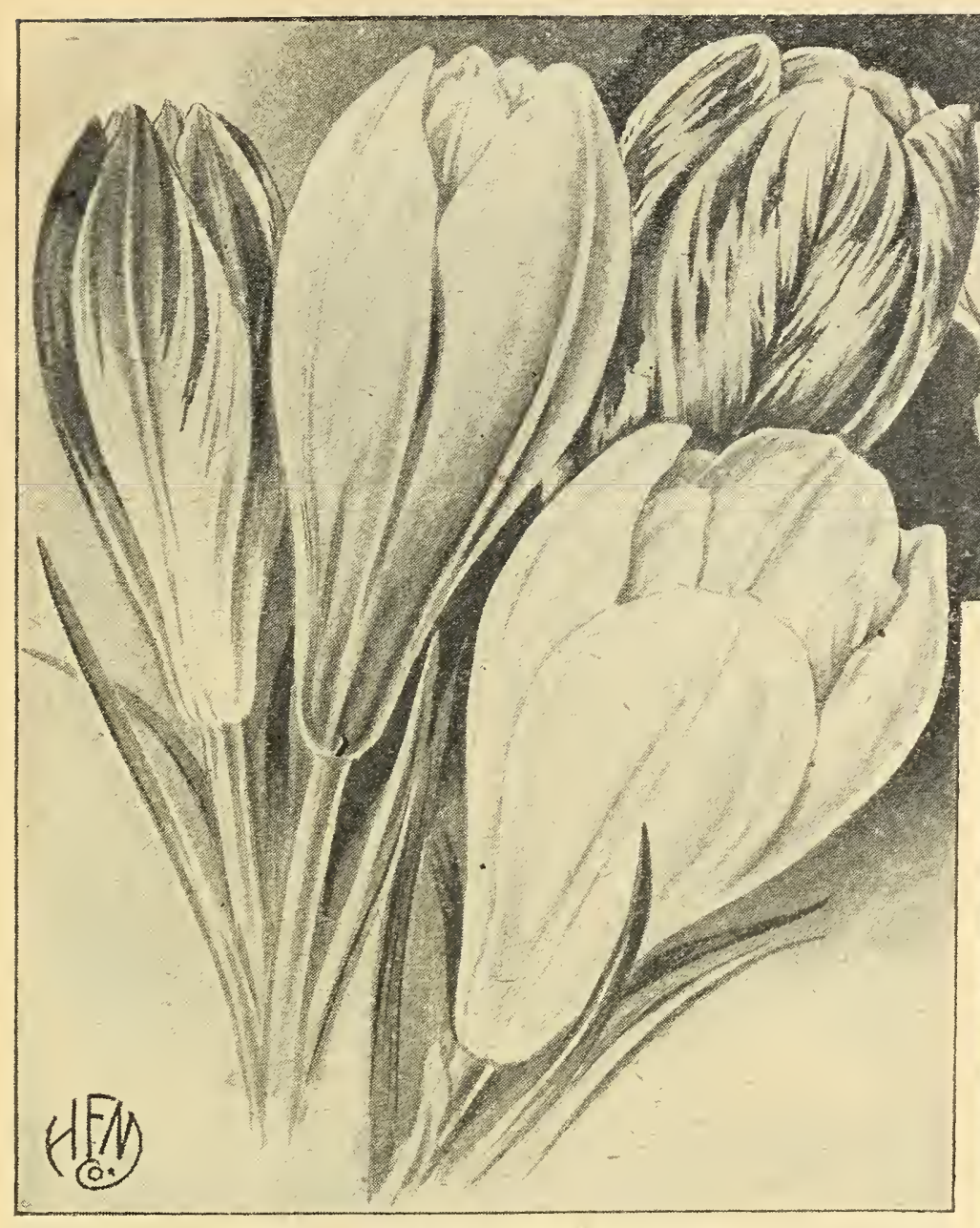

Michell's Giant Named Crocus

\section{CROCUS}

One of the earliest flowers to bloom in spring; most effective for borders or beds, also for planting in clumps amongst shrubbery. In lawns, planted in the grass the Crocus are extremely effective. The Giant Flowering varieties are also splendid for flowering in pots, but too severe forcing must not be attempted.

An effective method of planting is to scatter them over the lawn by digging up a small piece of sod here and there and placing one or two bulbs in each spot; this gives a very pretty effect.

\section{GIANT NAMED CROCUS}

The bulbs of these varieties are very large and each bulb is capable of producing several flowers of large size.

\begin{tabular}{|c|c|c|c|}
\hline $\begin{array}{l}\text { p blue.......... } \\
\text { ow, brown veins } \\
\text { hite, striped lilac } \\
\text { le................. }\end{array}$ & $\begin{array}{r}\text { Doz. } \\
\$ 0.25 \\
.35 \\
.35\end{array}$ & $\begin{array}{l}100 \\
\$ 1.40 \\
2.00 \\
2.00 \\
1.40 \\
1.40 \\
1.40 \\
1.50\end{array}$ & \\
\hline
\end{tabular}

\section{MIXED CROCUS IN SEPARATE COLORS}

Our bulbs of mixed Crocus are all of the largest size and should not be confounded with the cheap mixtures which are frequently offered.

Blue and Purple . . . . . . . . . . . . $\$$ \$0.20 $\$ 1.00 \quad \$ 7.50$

Striped ........................................... 20

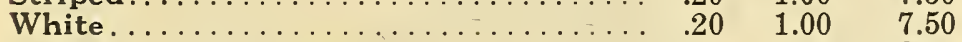

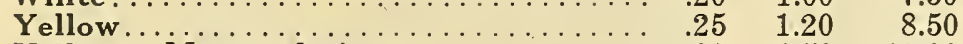

Yellow. Mammoth size ............ $30 \quad \begin{array}{lll}1.50 & 12.00\end{array}$

Yellow. Giant size................. . .50 $2.60 \quad 21.50$

Mixed. All colors .......................... $\quad .20 \quad 1.00 \quad 7.50$

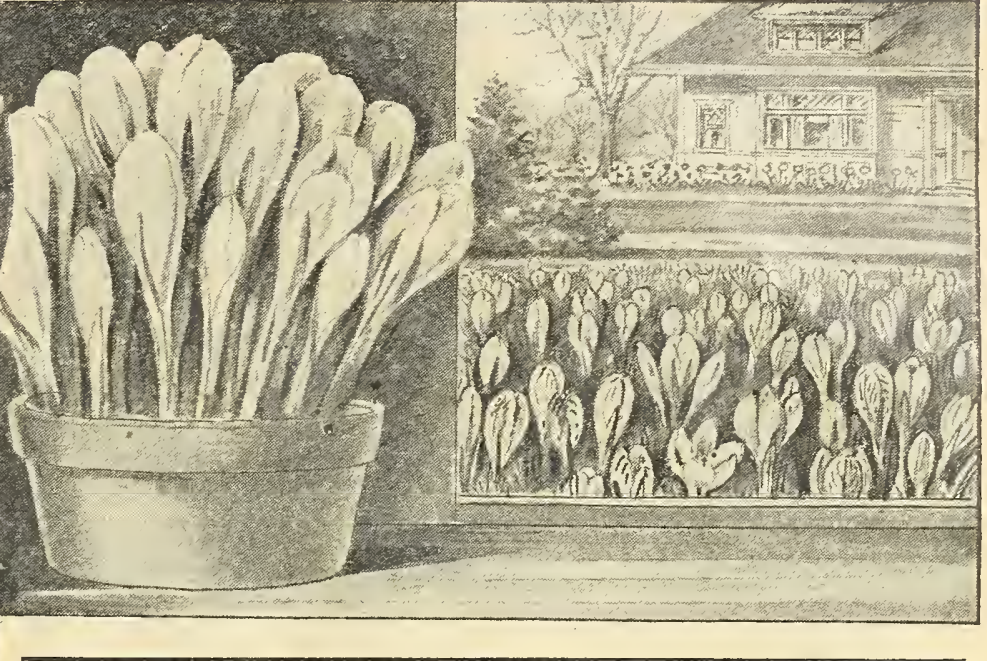

If Bulbs are wanted by Parcel Post, add 10 per cent. to value of order to points east of the Mississippi River, and 20 per cent. to points west of the Mississippi River.

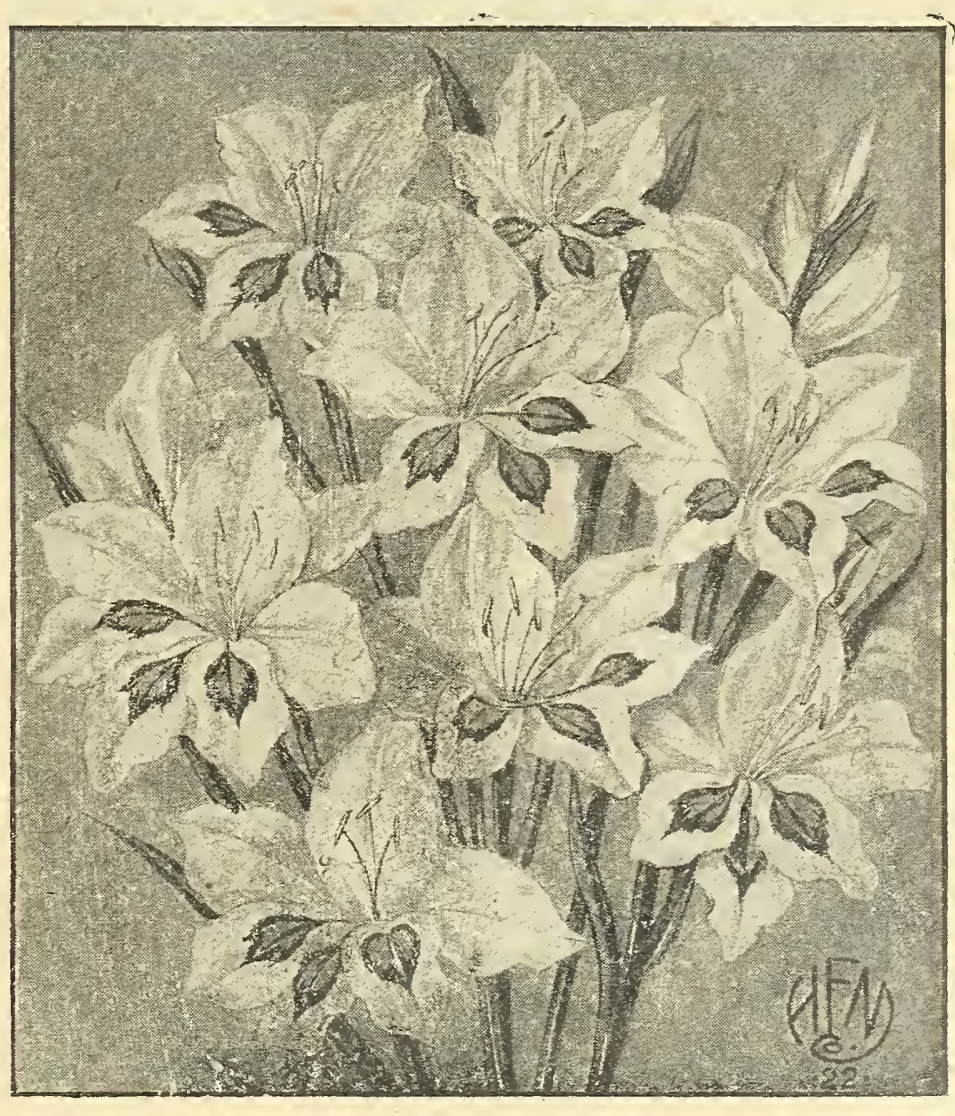

Gladiolus, Blushing Bride

\section{GLADIOLUS (For Forcing)}

COLVILLEI TYPE (Ready in October)

These are winter flowering strains of slender growth with beautiful orchid-like flowers, which are ideal for growing in the hot-house or conservatory.

As soon as received the bulbs should be planted in flats or pans and stored in a cold frame or other protected place. About February 1st they should be brought into gentle heat and light. They cannot stand quick forcing and should not be brought into bloom until April or May.

Ackermanni. Salmon, flaked carmine Doz, $100 \quad 1000$ violet eye........................... $\$ 1.00$

Blushing Bride. White, blotched crimson 1.00

Peach Blossom. Delicate pink......... 1.00
The Bride. Pure white............ 1.00 


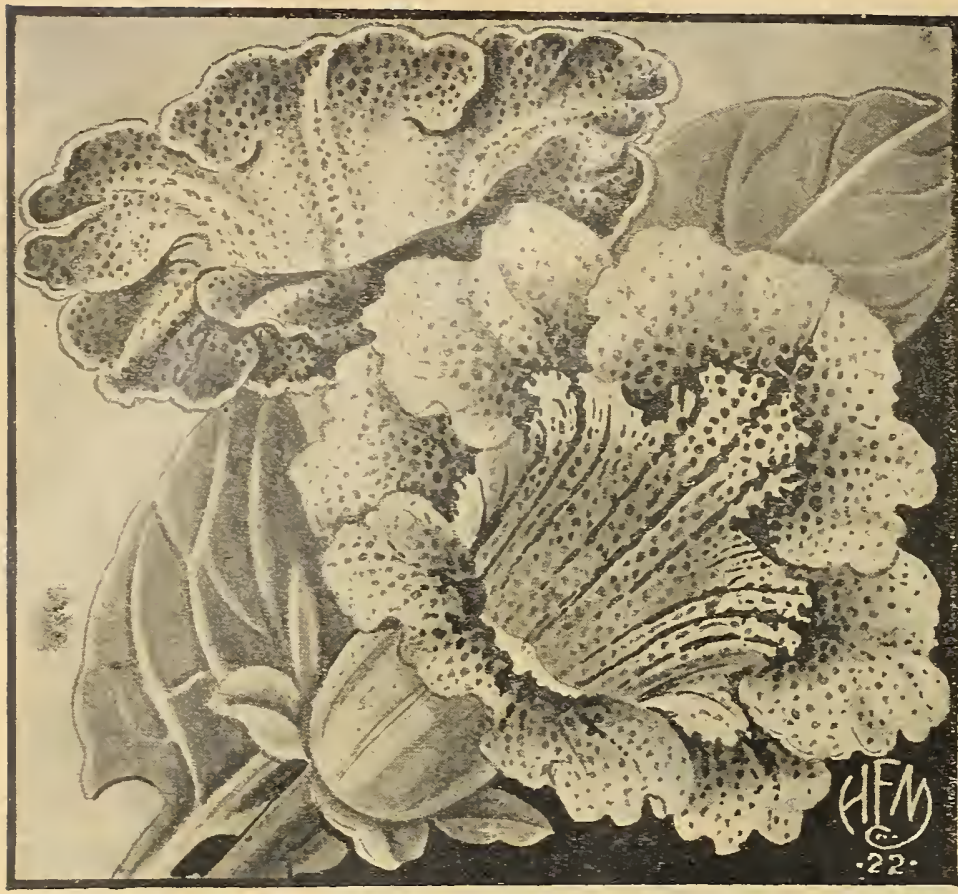

Gloxinias

\section{GLOXINIAS \\ (Ready in January)}

A gorgeous plant either for the conservatory or garden. They prefer a moist soil and a shady situation. Bulbs may be started as early as January, but should not be set outdoors until after May 15 th.

Purple

Red.

White

Mixed
Each Doz. -100 $\$ 0.35 \quad \$ 3.75 \quad \$ 25.00$

$\begin{array}{lll}.35 & 3.75 & 25.00\end{array}$

$\begin{array}{lll}.35 & 3.75 & 25.00\end{array}$

$35 \quad 3.75 \quad 25.00$

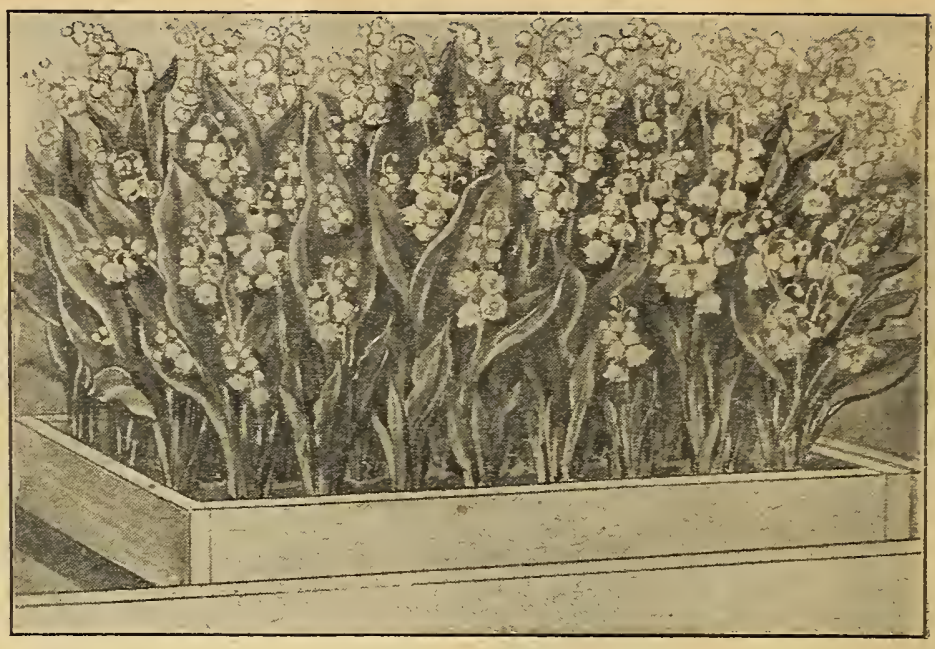

Lily of the Valley

\section{LILY OF THE VALLEY (Ready in December)}

A beautiful pure white flower; principally used for winter forcing. Very fragrant and produced in abundance. For indoor culture plant about 25 pips or roots in a 7 -inch pot or pan, place outside, where they should be left until they have been subjected to several nights' freezing, which brings them into flower more readily. When grown outdoors always plant in a shaded place, preferably moist.

Michell's Fancy Giant Flowering. The finest strain of Valley procurable. Per doz., $75 \mathrm{c}$.; $\$ 4.75$ per 100 ; per $1,000, \$ 40.00$.

Clumps. Ready in November. For outdoor planting only. 50 c. per clump; per doz., $\$ 5.00 ; \$ 35.00$ per 100 .

LILIES. See pages 4 and 5
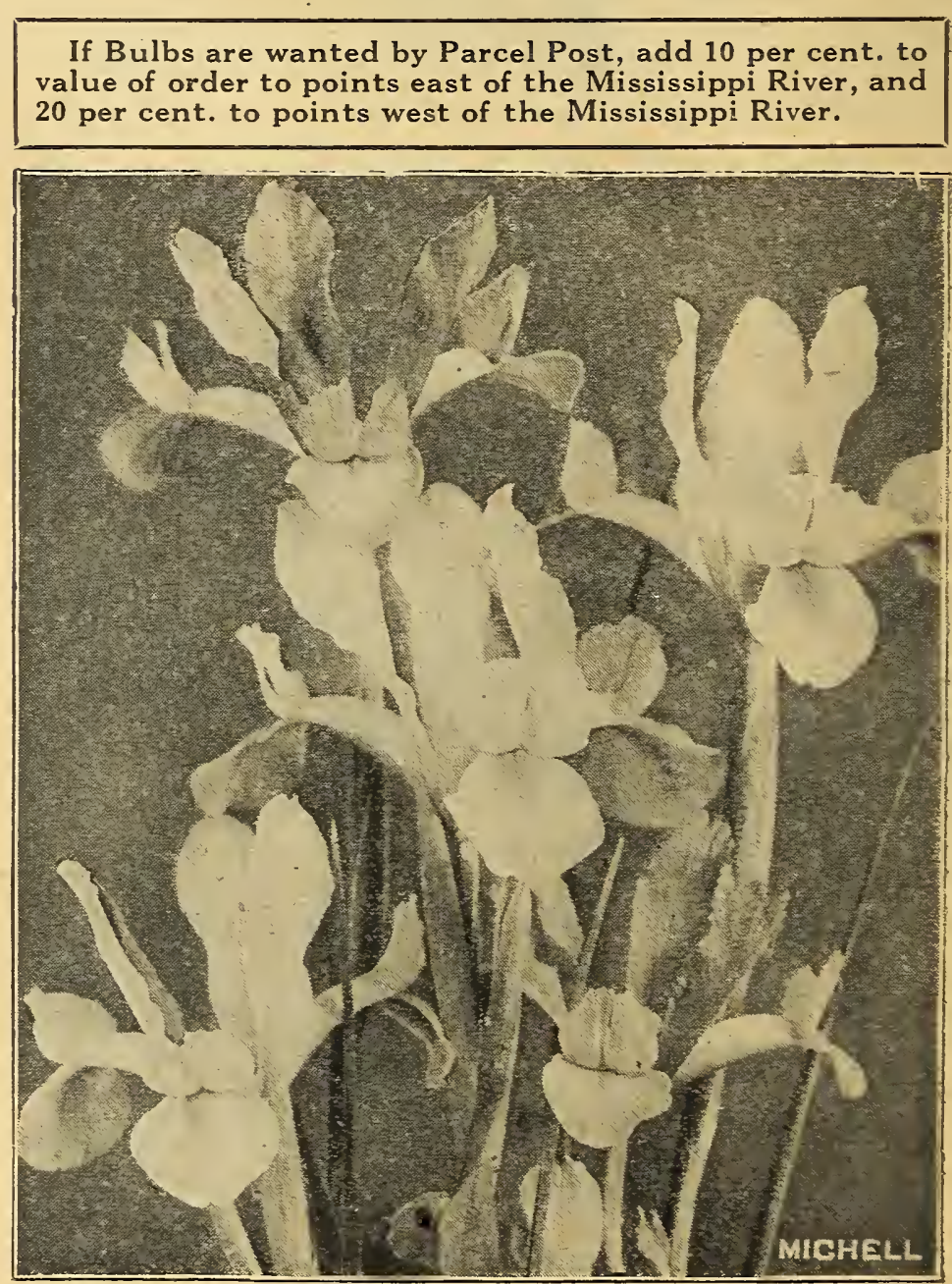

HYACINTHS. See pages 2 and 3

\section{SPANISH IRIS (Irish Hispanica)}

\section{Ready in October)}

Graceful, slender stems, with loose but beautiful flowers, the charming colors producing a combination not surpassed by an orchid. The finest effects are produced when planted in clumps in the perennial border; flowering period May and early June. They are also excellent for growing in pots indoors. Our list of Iris while small, contains the cream of the varieties.

Alex. Humboldt. Deep blue, with white blotches. $\$ 0.75 \$ 5.00$

Belle Chinoise. Deep yellow...

Darling. Deep azure blue; very early. . .

King of the Blues. Deep purplish blue.

Snowball. Pure white; the best of its color.

Mixed. Choice varieties

\section{DUTCH IRIS (Hollandia)}

These are best described as a giant strain of early flowering Iris Hispanica, blooming fully two weeks earlier; flowers very large.

Franz Hals. Standard pale blue, pale yellow falls Doz. $\quad 100$

with orange blotches; the best of the Dutch Irises. . \$0.85 $\$ \$ 5.25$

\section{IRIS TINGITANA}

A beautiful light blue; excellent for early forcing; can easily be had in bloom in December. 1.50

9.00

$75 \quad 5.00$

5.00

$75 \quad 5.00$

$75 \quad 5.00$
A Bunch of Spanish Iris 


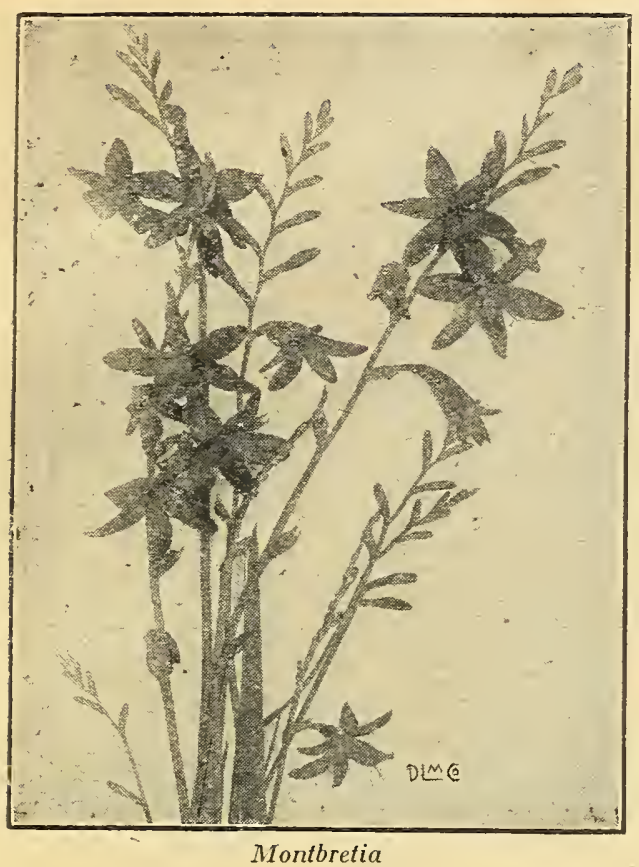

MONTBRETIAS (Ready in Becember)

A beautiful flowering bulb resembling a miniature Gladiolus; absolutely hardy and only effective when planted in masses of from 50 to 100 bulbs in a clump. The bulbs can be planted as long as the ground is open, about 3 inches deep; they can also be planted in the early spring.

Aurantiaca. Deep orange.

Fire King. Bright scarlet.

Doz. $100 \quad 1000$

Geo. Davison. Pure yellow

$\$ 1.25 \quad \$ 8.50 \quad \$ 75.00$

Gerbe d'Or. Golden yellow.

$\begin{array}{lll}1.25 & 8.50 \quad 75.00\end{array}$

$\begin{array}{lll}1.25 & 8.50 \quad 75.00\end{array}$

Germania. Brilliant scarlet.

$\begin{array}{lll}1.25 & 8.50 \quad 75.00\end{array}$

$\begin{array}{lll}1.25 & 8.50 \quad 75.00\end{array}$

NARCISSUS. See pages 6 to 9

If Bulbs are wanted by Parcel Post, add 10 per cent. to value of order to points east of the Mississippi River, and 20 per cent. to points west of the Mississippi River.

\section{OXALIS}

For conservatory, greenhouse and window garden culture the Oxalis is ideal. It succeeds anywhere and with any one, flowering often in 6 to 8 weeks after planting. Plant 4 to 6 bulbs in a pot or hanging basket.

Grand Duchess. Lavender.

$\begin{array}{lll}66 & \text { "6 } & \text { Pink .... } \\ 6 & \text { White... }\end{array}$

Bermuda Buttercup. Yellow, first size.

Bowei. Large flowering; rich pink

$\begin{array}{rrr}\text { Each } & \text { Doz. } & 100 \\ \$ 0.05 & \$ 0.45 & \$ 2.50 \\ .05 & .45 & 2.50 \\ .05 & .45 & 2.50 \\ .05 & .45 & 2.50 \\ .06 & .45 & 2.50 \\ .07 & .75 & 4.00 \\ .06 & .50 & 3.00\end{array}$

\section{SPIREA}

(Ready About December 1st)

This is a favorite Easter plant, rivaling with the lily. If wanted for indoor blooming, pot the roots on arrival, water well and place outdoors for about 6 to 8 weeks. They may be brought in and placed in a.moderately warm room, the cooler, without freezing, however, the better. They can be made to flower almost any time by putting in a warmer place.

Gladstone. This popular, large flowering variety is an improvement on all other white varieties. The immense trusses of flowers are snow white, borne on strong, erect stalks and are produced in great abundance. $\$ 1.00$ each; per doz., $\$ 10.00$.

Peach Blossom. A fine, new pink flowering variety; flower spikes are of a fine shade of pink and quite distinct. $\$ 1.00$ each; per doz., $\$ 10.00$.

Rubens. Rich, brilliant pink; in growth and habit it resembles Gladstone, but is much deeper than other pink varieties. $\$ 1.00$ each; per doz., $\$ 10.00$.

\section{MATERIAL FOR SUCCESSFUL HOUSE CULTURE OF BULBS}

Charcoal (Lump) Qt. 4 qts. Pk. Bu. Bbl. Bulb Fibre, Michell's Prepared.

Leaf Mould

Pebbles.

Potting Sand

Prepared Potting Soil

$0.10 \$ 0.35 \$ 0.60 \$ 2.00 \$ 3.00$

6-inch Bulb Pans

7-inch Bulb Pans

4-inch Pots

.20
.10
.10
.10
.10

\begin{tabular}{rrrr}
.45 & .75 & 2.00 & \\
.30 & .50 & 1.50 & 3.25 \\
.40 & .75 & 2.00 & 4.00 \\
.25 & .40 & 1.40 & 3.00 \\
.25 & .40 & 1.40 & 3.00 \\
\multicolumn{2}{c}{ Each } & Doz. & 100 \\
$\ldots$ & $\$ 0.09$ & $\$ 0.98$ & $\$ 7.29$ \\
$\ldots$ & .15 & 1.62 & 12.15 \\
$\ldots$ & .04 & .36 & 2.70 \\
. .40 & 4.00 &
\end{tabular}

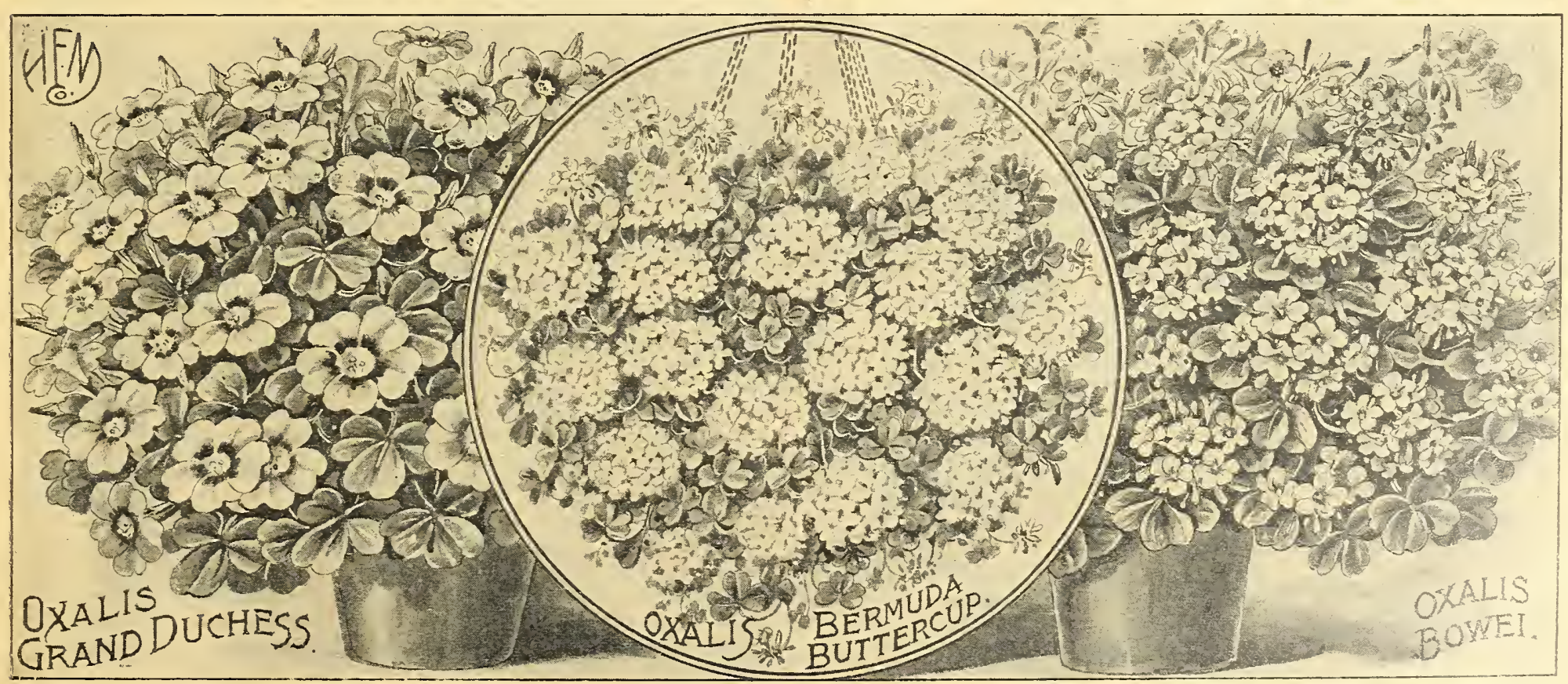




\section{FOR AUTUMN AND EARLY WINTER SOWING}

For Complete List of Flower Seeds, see Our General Catalogue for 1922

\section{ACHILLEA (Milfoil or Yarrow)}

Large pkt. Pkt. bearing its pure white double flowers in great profusion all summer; hardy perennial; $2 \mathrm{ft} . . . \ldots \$ 0.75 \quad \$ 0.10$ ACONITUM (Monk's Hood or Helmet Flower) Hardy perennial, thriving best in semi-shady situations; curious hood-shaped flowers in clusters; 4 feet; August-September.

Napellus. Blue.

\section{A GROSTEMMA}

Large pkt. Pkt.

Coronaria (Mullein Pink). Erect growing plants with silvery foliage and crimson flowers; hardy perennial; $21 / 2$ to 3 feet; June to August........

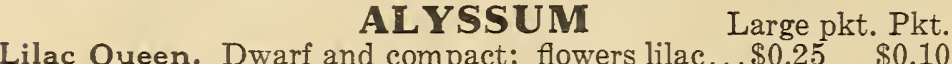

.25

.10

Little Dorritt. Extremely dwarf and compact, with miniature white flowers................ 90. 90.

Little Gem. Dwarf compact plants, densely covered with large pure white flowers; 4 inches... oz., $75 \mathrm{c}$.

Michell's Bouquet (New). Dwarf and compact; forms a perfect bouquet of miniature white flowers

Saxatile Compactum (Basket of Gold). Showy golden yellow flowers; hardy perennial; excellent for rock work or border; $1 \mathrm{ft}$...........oz., $90 \mathrm{c}$.

Sweet. The popular old-fashioned sort; of trailing habit, with pure white flowers; 6 inches..oz., $40 \mathrm{c} . \quad .25$

\section{AMPELOPSIS (Boston or Japanese Ivy)}

Veitchi. A hardy perennial climber with olive green leaves, which turn to scarlet in the autumn, oz., 40c. $\quad .25$

ANCHUSA (See Bugloss)

Italica "Dropmore." A hardy perennial plant, 4 feet high, with an abundance of beautiful flowers of a lovely gentian blue

\section{ANEMONE (Wind Flower)}

A dainty spring flower with bright cup-shaped blossoms; splendid for cutting; perennial.

Coronaria. Mixed colors; 1 foot.

St. Brigid, or Poppy. Flowers of large size; semidouble and double, in many colors; 1 foot. . . . . . .50

ANTHEMIS (Hardy Marguerite)

Tinctoria Kelwayi. A handsome hardy perennial; bearing all summer, daisy-like bright yellow flowers; excellent for cutting; 2 feet............ .30
AQUILE GIA OR COLUMBINE (See next page)
ARABIS (Rock Cress) ARABIS (Rock Cress)

Alpina. Early spring flowering perennial; especially adapted for edging and rockery; plants form a dense carpet completely covered with pure white blossoms; 6 inches.

\section{ASPARAGUS}

Plumosus Nanus. An excellent plant for house or conservatory decoration or cutting on account of its graceful, finely cut foliage........... $\$ 1.00$

Sprengeri. One of the best plants to grow in hanging baskets or window boxes for the greenhouse in winter or for outdoors in the summer.

\section{ASPERULA (Woodruff)}

Odorata. Dwarf spring flowering perennial, thriving in partial shade; flowers white; 1 foot; May....\$0.40 $\$ 0.10$ ASTER, PERENNIAL (Michaelmas Daisy)

Choice Mixed. One of the showiest of our late flowLarge pkt. Pkt. ering perennial plants; star-like, single flowers; 2 to 3 feet.

\section{AURICULA (Primula Auricula)}

Choice Mixed. These early flowering perennial plants resemble primroses; multi-colored flowers in great variety; for borders or pot culture; 6 inches.

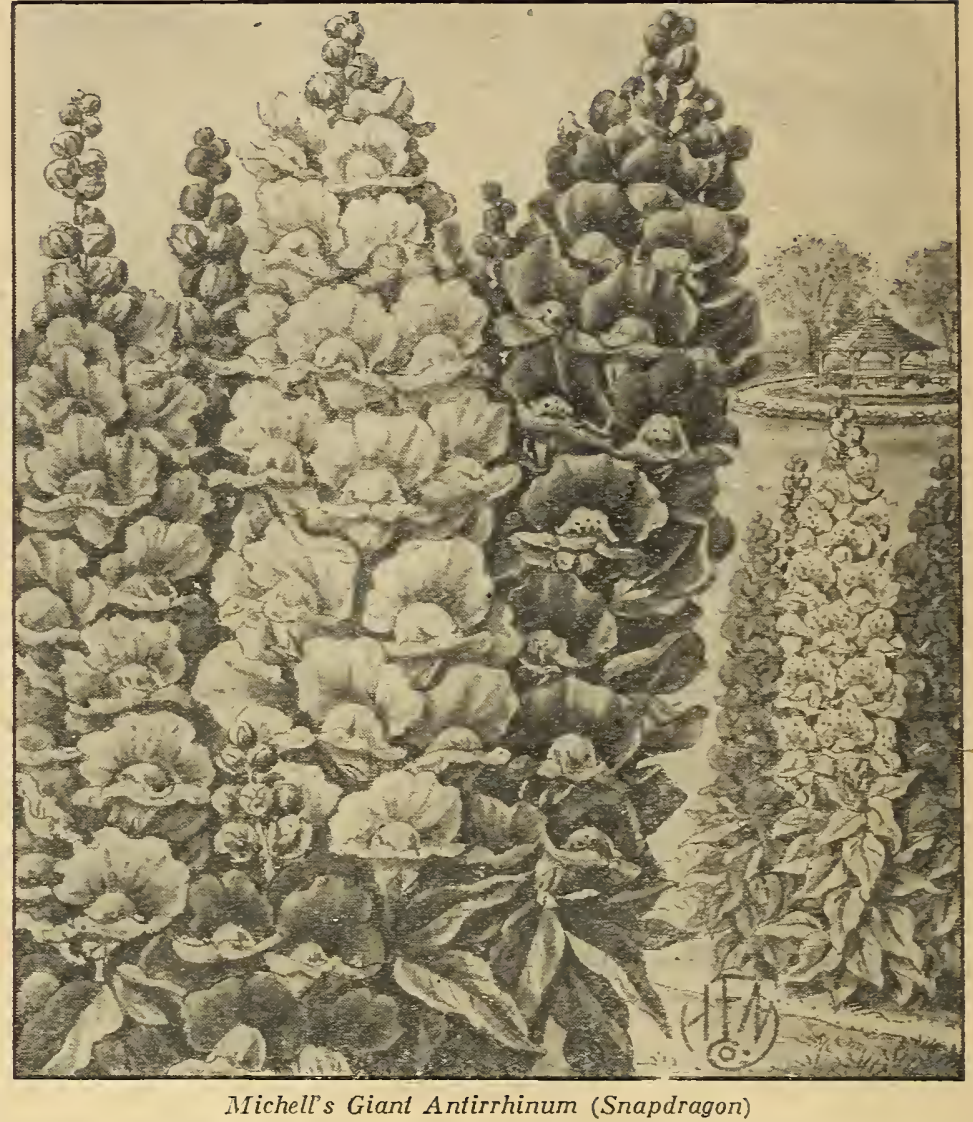

\section{ANTIRRHINUM (Snapdragon)}

A splendid plant for beds or borders and one of our choicest cut flowers; extensively forced under glass during the winter.

\section{MICHELL'S GIANT ANTIRRHINUMS}

Spikes, 2 to 3 feet in length, with giant flowers.

Michell's Giant Salmon Pink. Long spikes of

Large pkt. Pkt.

flowers of a delicate salmon pink color.

$\$ 0.60 \$ 0.15$

Keystone. Long spikes; color, rose pink ........ 1.25

Silver Pink ........................ 1.25

Golden Pink Queen $(N e w) . . \ldots \ldots \ldots \ldots \ldots \ldots \ldots . \ldots \ldots$

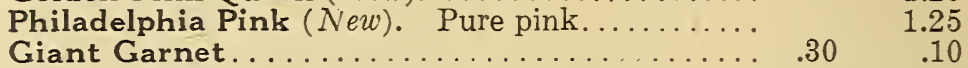

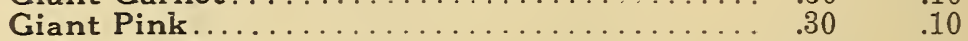

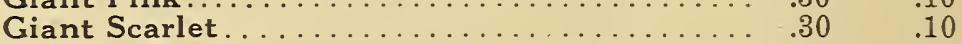

Giant Striped ................... . .30 .10

Giant Venus. Shell pink on white ground ..... . .50 $\quad .15$

Giant White............................... . $30 \quad .10$

Giant Yellow .......................... $30 \quad .10$

Collection, one packet each six colors, 50c.

Giant Mixed. All colors................ oz., 90c. .30 .10

\section{ANTIRRHINUMS-Various Sorts}

The Semi-Dwarf sorts grow about 18 inches high, with large flowers over most of the stem. Large pkt. Pkt. Semi-Dwarf. Bride. Pure white..........\$0.40 $\$ 0.10$

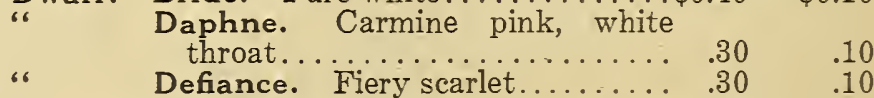
“ Firebrand. Rich deep red.......... $.30 \quad .10$ “ Golden Queen. Golden yellow..... $.30 \quad .10$ ، Mont Blanc. Pure white............. $.30 \quad .10$ “ Nelrose. Pink................... .60 .25 “ Rose Queen. Rich rose............ $.30 \quad .10$ " Mixed. All colors.......oz., $\$ 1.00 \quad .30 \quad .10$ Tall Mixed. Regular strain.............., 75c. .25 .05 Tom Thumb Mixed. All colors; 12 inches...... . . $30 \quad .10$ Ask for Cultural Leaflet No. 201 on the growing of Antirrhinums. 


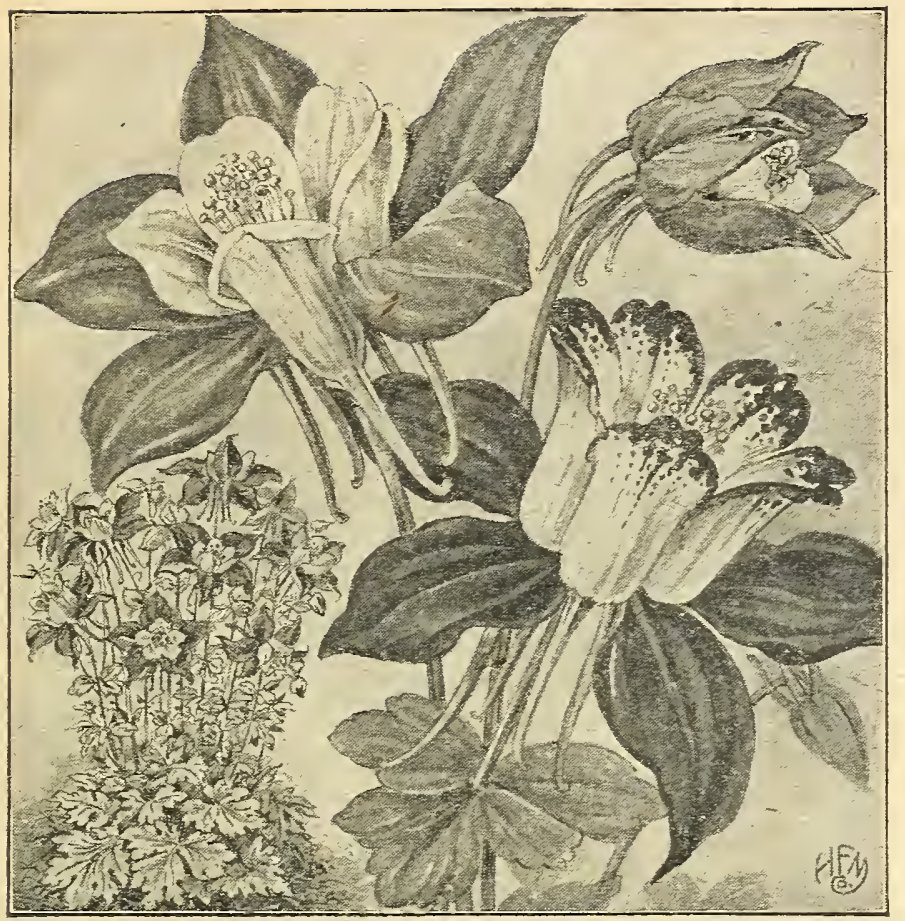

Aquilegia (Columbine)-Long Spurred (Large pkt. 50c.)

\section{AQUILEGIAS OR COLUMBINES}

A graceful spring flowering plant; exquisitely spurred flowers on stems 2 feet above the fern-like foliage. Large pkt. Pkt. Californica Hybrida. Mixed colors; long spurs . $\$ 0.50 \quad \$ 0.10$ Chrysantha (Golden Spurred). Bright golden yel-

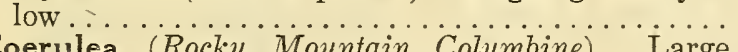

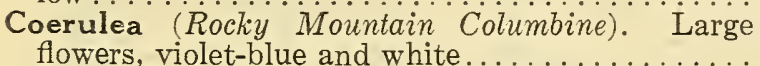
Long Spurred Hybrids. Flowers of many rich and varied colors, with long spurs................

Rose Queen. Pink, white centre, yellow anthers...

Double Mixed. All colors.............

Single Mixed. All colors. oz., $60 \mathrm{c}$. .25

$.60 \quad .10$ .50 .60

\section{BAPTISIA (False Indigo)}

Australis. A strong growing perennial plant about 2 feet high, with dark green, deeply cut foliage and spikes of dark blue flowers in June and July. .

BELLIS PERENNIS (See Daisy) BOCCONTA (Plume Poppy)

Cordata. A splendid hardy perennial, with glaucous green foliage and spikes 2 to 3 feet long of creamy white flowers; 5 feet.

\section{BROWALLIA}

Elegant free flowering plants; blooms finely in the winter if the plants are lifted and cut back; 18 inches.

Elata Coerulea. Sky-blue flowers

Large pkt. Pkt.

Speciosa Major. Large ultramarine blue flowers; desirable as a pot plant for winter and spring flowering...

\section{CALCEOLARIA}

Excellent plants for decorating the greenhouse or conservatory; produces a mass of pocket-like flowers.

Hybrida Grandiflora, Tall Mixed. Large, rich, self-colored flowers saved from a choice collection: 18 inches. . . . . . . . . . . . . . . $\$ 0.85$

Hybrid Grandiflora, Pumila Compacta. Of dwarf, compact growth; trusses - of large, self-

colored and spotted flowers; 1 foot...................
Rugosa (Shrubby). Mixed colors. Small flowering, for bedding . . . . . . .
CALIOPSIS (Coreopsis)

California Sunbeams. Large flowers beautifully formed; yellow and brown.............. $75 \mathrm{c}$.

Lanceolata Grandiflora. Single golden yellow flowers of graceful form; invaluable for cutting; blooms the entire summer.............. oz., $50 \mathrm{c}$.

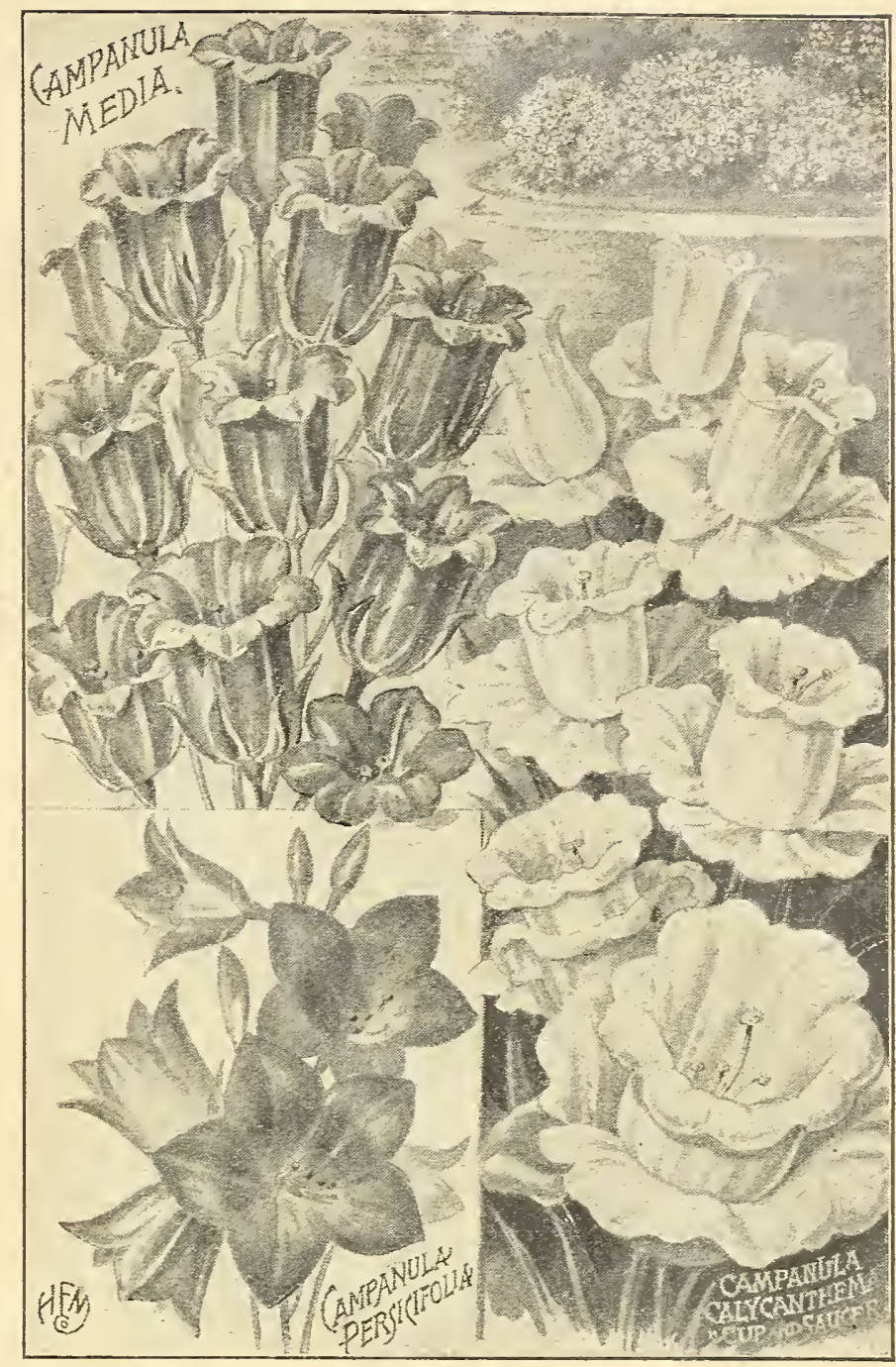

CAMPANULA MEDIA (Canterbury Bell)

Showy, hardy biennial, growing about 3 feet high, with large bell-shaped flowers. Sow from June 1st till September 1st; after frost has set in protect with leaves and straw.

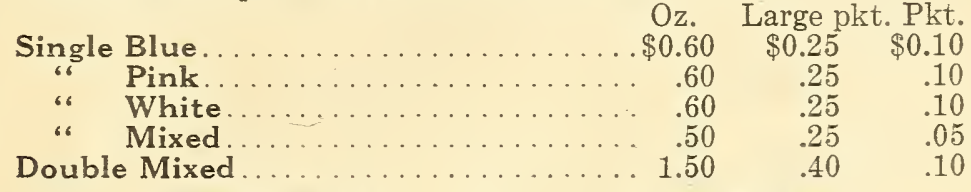

\section{CAMPANULA CALYCANTHEMA}

(CUP AND SAUCER, CANTERBURY BELLS)

These produce beautiful, large single flowers, resembling a cup and saucer; they require the same treatment as above.

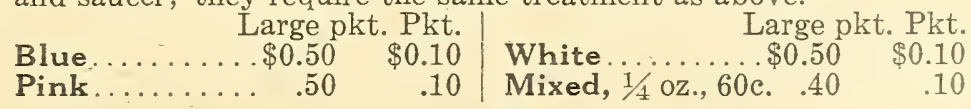

\section{CAMPANULAS OR BELLFLOWERS (PERENNIAL VARIETIES)}

These are among our best known hardy perennials; the tall varieties are fine for cutting while the dwarf sorts make excellent border plants; all have dainty bell-shaped flowers.

Carpatica (Carpathian Hare Bell). Compact tufts not exceeding 8 inches; flowers clear blue, held erect; blooms in June and July.

Persicifolia Grandiflora (Peach Bells). Blue; spikes 4 feet tall with bell-shaped flowers.

$.25 \quad .10$ Persicifolia Grandiflora, Alba. Pure white

Pyramidalis (Chimney Bell Flower). Perfect pyra-

mids 6 feet high crowded with large bell-shaped 


\section{CANDYTUFT (Iberis)}

Dwarf, profuse flowering garden annuals of easy culture; useful for bedding or borders; blooms within six weeks after sowing; excellent for cutting; height, 1 foot.

Carmine

Oz. Parge $\quad$ Pkt. Pkt.

$\$ 0.40 \quad \$ 0.25$

Empress. An excellent variety with long trusses of pure white flowers

Lavender

Little Prince. Very dwarf and compact, with pure white flowers; excellent for edging. .

Michell's Giant White. The largest and

finest white. From 10 to 12 immense spikes

resembling Hyacinths appear on a single plant; fine for forcing

Pink

$\begin{array}{lll}.40 & .25 & .10 \\ .40 & .25 & .10 \\ .40 & .25 & .10 \\ .50 & .25 & .10\end{array}$

$\begin{array}{lll}.60 & .25 & .10 \\ .50 & .25 & .10 \\ .40 & .25 & .10 \\ .25 & & .05 \\ & & .50\end{array}$

Choice Mixed All color.

Collection. One packet each, 6 colors

Sempervirens. Dwarf spring flowering perennial plants; ideal for the bulb border; flowers of glistening white; May; 1 foot

.60

\section{CARNATION}

These are general favorites for their richness of color and delightful fragrance; they are desirable for greenhouse culture in winter as well as for the garden in summer.

Chabaud's Everblooming, Mixed. Blooms in five

months after being sown, and continues to flower in

the greatest profusion indefinitely

$\$ 0.60 \$ 0.15$

Early Vienna. Large double flowers in mixture.

Choice Mixed. Double border varieties.

.50

.10

$60 \quad .10$

\section{MARGUERITE CARNATIONS}

These are the most satisfactory of the annual pinks, and will bloom in four months after sowing the seed. The flowers are large, fragrant and are produced continuously. If slightly protected they will survive an ordinary winter and bloom the following spring. Excelsior Mixed. Extra large flowers......... Large pkt. Pkt. $\$ 0.50$ \$0.15 Pink

Scarlet

White

Yellow

Choice Mixed

.50

.50
.50

oz., $\$ 1.50$

.30

Ask for Cultural Leaflet No. 213 on the growing of Carnations from seed.

\section{CERASTIUM (Snow in Summer)}

Tomentosum. Dwarf, white-leaved edging plant;

flowers white; perennial; 4 inches.

\section{CHRYSANTHEMUM (Perennial)}

Large pkt. Pkt.

King Edward VII. Flowers extra large; pure white; very free flowering

Shasta Daisy, "Alaska." Extra large flowers, of pure glistening white, with broad overlapping petals; a beautiful cut flower; 2 feet

\section{CINERARIA}

Most ornamental plants for conservatory or house decoration; seed may be sown from May to September for a succession. Our Grandiflora Prize Strain cannot be surpassed, immense trusses of large flowers, often measuring 4 inches across.

Grandifora Prize Dwarf. Mixed colors; plants Large pkt. Pkt. of dwarf habit.

Grandiflora Prize Medium Tall. Mixed colors;

desirable as a decorative plant.

Matador. Large flowering scarlet $\$ 0.85 \$ 0.35$

Stellata Hybrida. Of graceful habit; producing a

profusion of flowers; mixed colors

$.85 \quad .35$

$.85 \quad .35$ erarias.

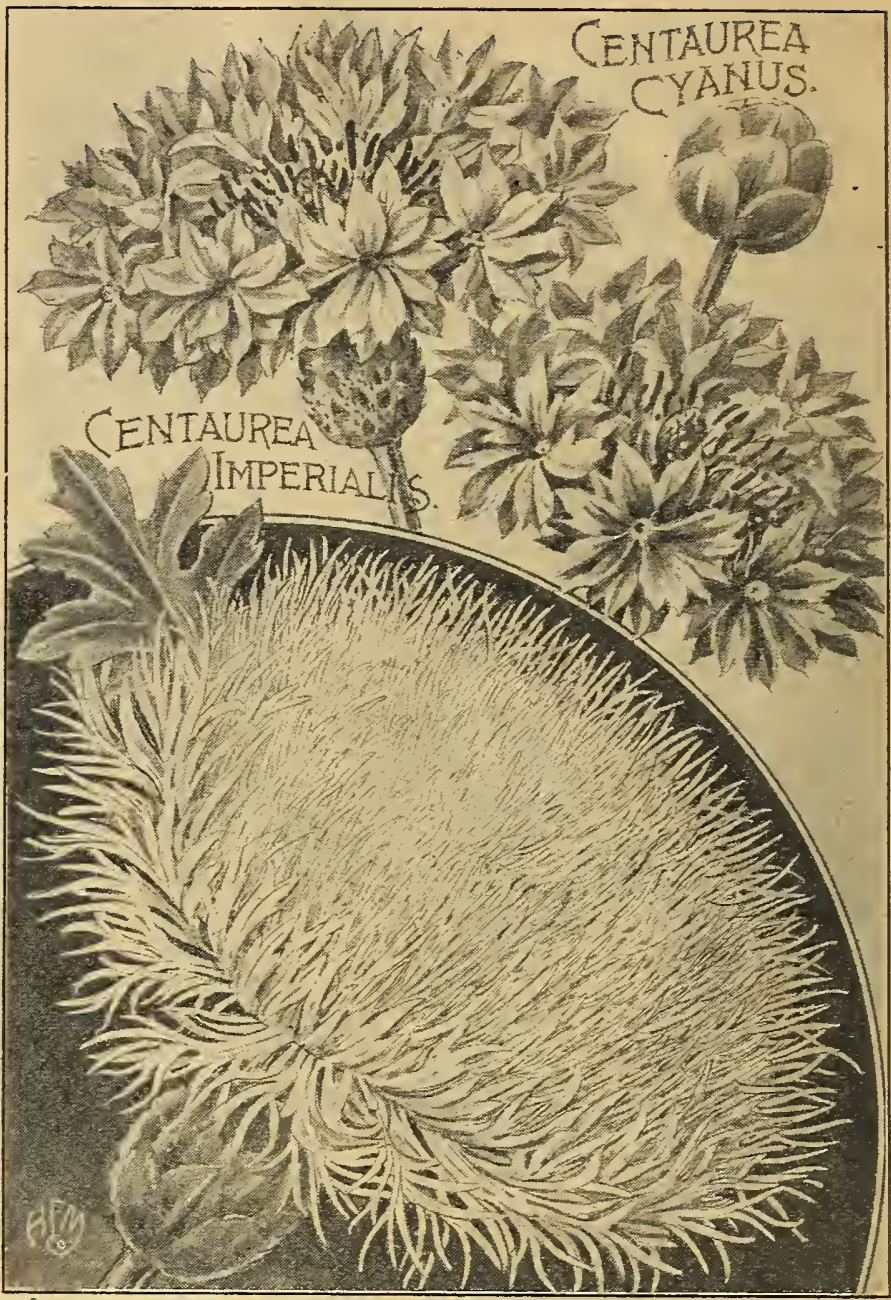

\section{CENTAUREAS CENTAUREA CYANUS}

(Cornfiower or Bachelor's Button)

Also known as Blue Bottle, Ragged Sailor, Bluet, etc.; frequently grown under glass for Christmas flowering; excellent for cutting; 2 feet.

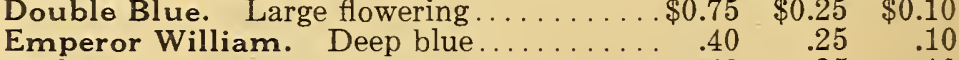

Pink

White

$\begin{array}{ll}.40 & .25 \\ .40 & .25\end{array}$

$.40 \quad .25$

$.40 \quad .25$

.10

Choice Mixed

.50

Double Mixed

\section{CENTAUREA IMPERIALIS}

\section{(Giant Cornflower, or Sweet Sultan)}

The finest of all Sweet Sultans for cut flower purposes; gigantic, beautiful, sweet-scented flowers borne on long stems. Splendid for forcing under glass. Height, 2 to 3 feet. Oz. Large pkt. Pkt. Deep Rose.

Lavender

$\$ 1.00 \quad \$ 0.30 \quad \$ 0.10$

Lilac

Brilliant Pink

1.00

1.00

Purple.

1.00
1.00

.30
.30
.30
.30
.30
.2

Choice Mixed

.75

.30
.30
.30
.30
.30
.25

.10

.10

Collection. One packet each above 6 colors..

\section{NEW GIANT FLOWERED CENTAUREA}

Magnificent flowers produced on long, stout stems; excellent for cutting.

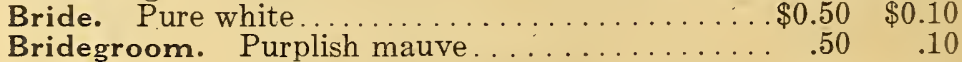
Large pkt. Pkt.

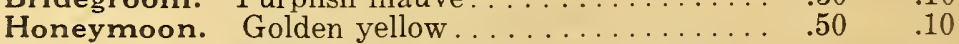

\section{CENTAUREA (Perennial)}

Large feathery flowers; splendid for cutting; blooms from July to September.

Montana. Blue; 18 inches.

Large pkt. Pkt. $\$ 0.40 \$ 0.10$ 


\section{MICHELL'S “DISTINCTIVE” FLOWER SEEDS}

\section{CLEMATIS}

Perennial climbers; fine for arbors, verandas, etc. Large pkt. Pkt. Flammula. Feathery white, fragrant flowers...... \$0.25 $\$ 0.10$

Paniculata (Japanese Virgin's Bower). The beautiful autumn-flowering variety, admired for its

fragrant, white, star-shaped flowers

COLUMBINE (See Aquilegia)

COREOPSIS (See Calliopsis)

CORNFLOWER (See Centaurea)

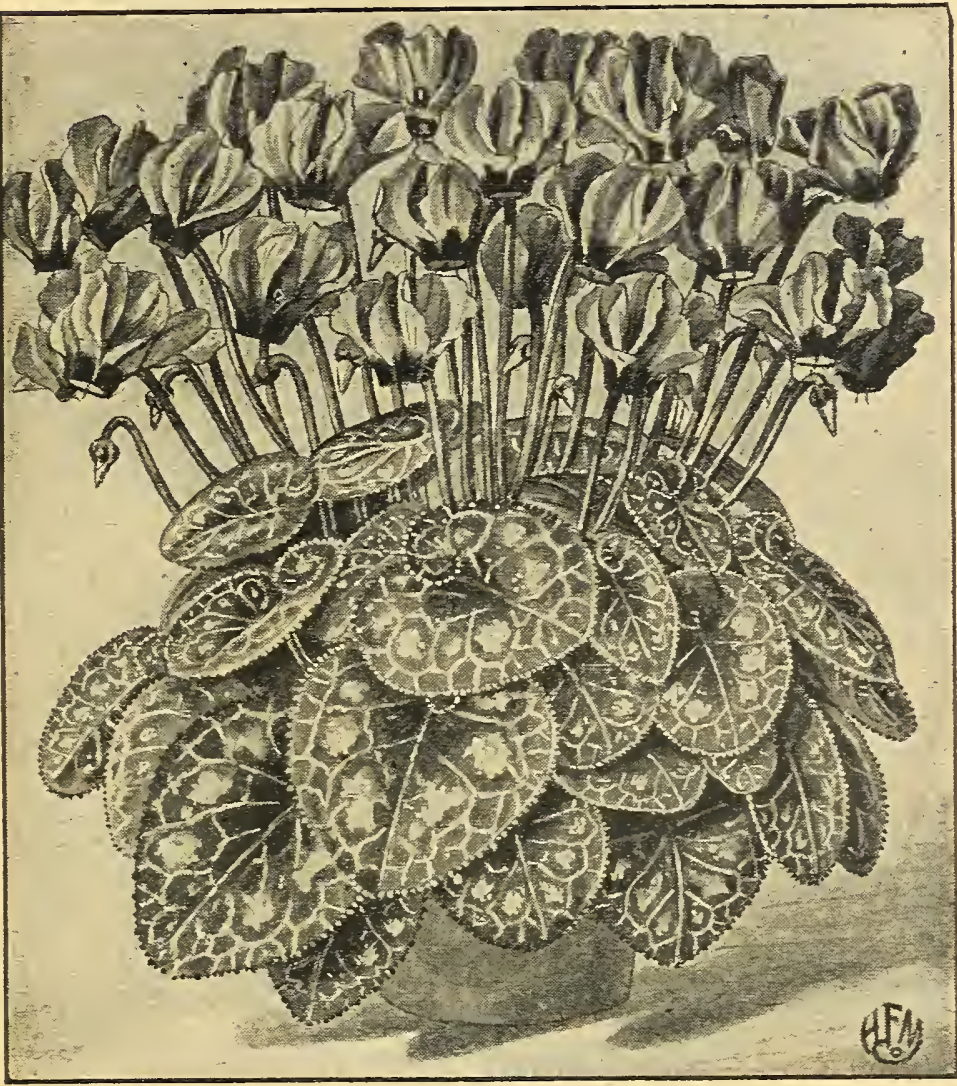

Michell's Giant Show Cyclamen

\section{CYCLAMEN}

Most beautiful winter and spring flowering plants for the window and greenhouse. Not only are the flowers of striking beauty, but the foliage is also highly ornamental.

\section{MICHELL'S GIANT SHOW}

Grown for us by a specialist who has received numerous first prizes for the large size and beautiful coloring of the flowers.

Bright Red

Dark Blood Red

Glory of Wandsbek. Salmon red

Perle of Zehlendorf. Salmon pink.

Pure White.

Rose of Marienthal. Bright pink

White with Carmine Eye.

Mixed. All colors.

Ask for Cultural Leaflet No. 215 on the growing of Cyclamen.

\section{DAST, ENGLISH DOUBLE (Bellis Perennis)}

These are favorite perennials; seed should be sown from June 1st till September, transplanted in the fall and they will flower the following spring; 4 inches.

Longfellow. Large double pink flowers.

Monstrosa, Pink. These surpass all strains of this

popular plant in strong, robust growth and in the

abundance of extra large, perfectly double flowers..

Monstrosa, White. .

Monstrosa, Mixed

Snowball. Purest white; large and double

Double Mixed. Extra fine.
Large pkt. Pkt.

$\$ 0.60 \$ 0.10$

100 Seeds Pkt.

2.50
2.50

$2.50-.50$

$2.50-50$

.50

(1)

$\begin{array}{ll}.75 & .25 \\ .75 & .25\end{array}$

$75 \quad 25$

$60 \quad .10$

$50 \quad .10$

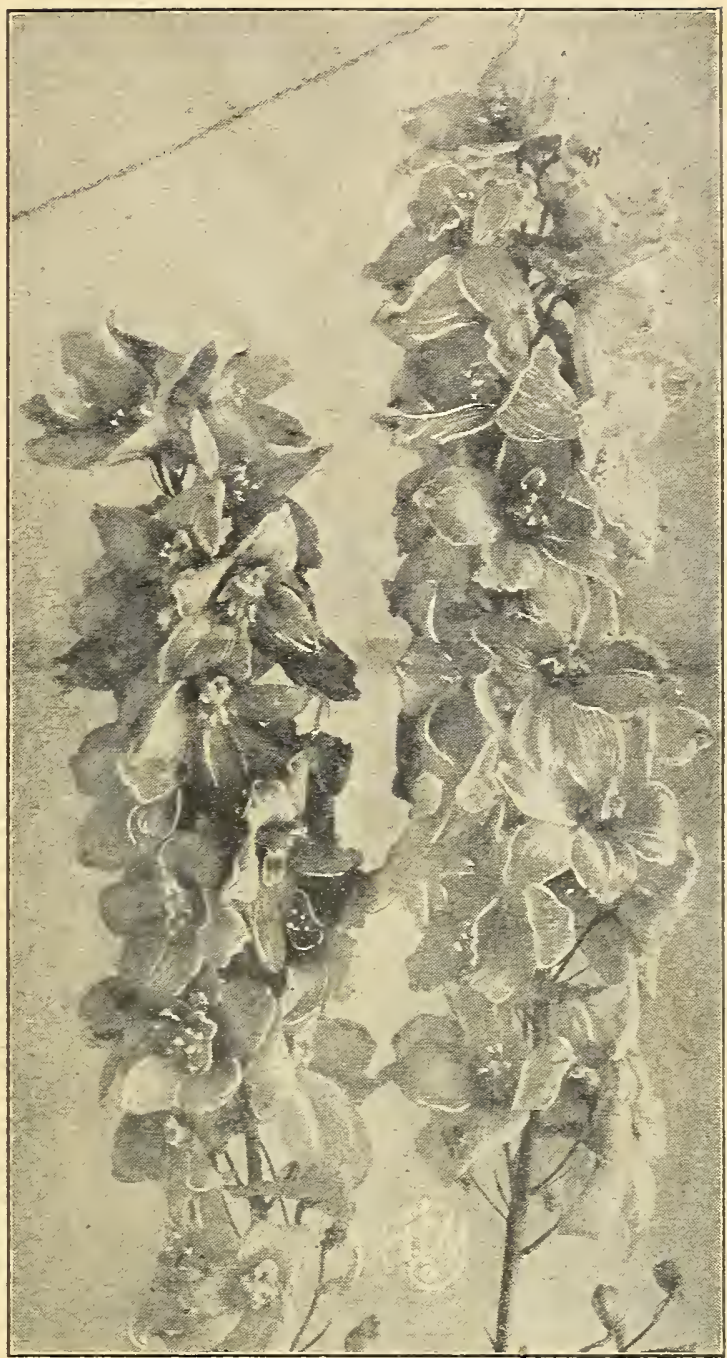

Delphinitim, Belladonna, (Larse plt. $75 \mathrm{c}$.)

\section{DELPHINIUM (Hardy Perennial Larkspur)}

One of the finest hardy perennials; very easily grown from seed. Very effective in beds, masses or borders. To prolong the season of bloom, cut the old flower stems off after they have faded, and new shoots will produce flower heads successfully.

Belladonna. One of the most continuous blooming Large pkt. Pkt

varieties: immense spikes of clear turquoise blue,

which cannot be excelled for beauty; 5 feet.....\$0.75 $\$ 0.25$

Bellamosum. A rich, deep blue form of the popular light blue Belladonna

$.75 \quad .25$

Chinense Grandiflorum. A dwarf strain with loose branches and sprays of bright blue flowers; 2 feet. . . . . . . . . . oz., 90.

Chinense Grandiflorum Album. Pure white flowers ...... oz. 90c.

Elatum (BeeLarkspur). Rich blue; 4 feet. oz.. $\$ 1.50$

Formosum. Deep blue; 3 feet........ oz., $1.75 \quad .40$

Formosum Coelestinum. Sky blue ........ . .60

Gold Medal Hybrids. Produces long spikes of large flowers, the lighter shades of blue predominating.

Kelway's Giant. An extra fine strain of strong, vigorous growth, with immense spikes of large flowers; many shades of blue; 5 to 7 feet

Rev. E. Lascelles. An extra fine variety; large double deep blue flowers with white centre.

Zalil. Sulphur yellow; 4 feet.

Hybridum Mixed. Very choice; 4 feet

\section{Gentlemen:}

Please send us the enclosed order. Thanking you and will state that we have been using your flower number of years with good results. 


\section{DIANTHUS (Hardy Garden Pinks)}

Elegant summer flowering border plants, producing a wealth of deliciously fragrant flowers.

Clove Scented. Double and semi-double varieties,

in beautiful colors; fragrant............ $\$ 0.50$

Double Scotch. Choice mixed colors ........... .50

Erfurt. Of dwarf, compact growth; blooms early;

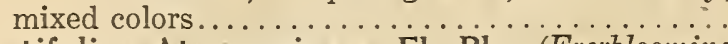

Latifolius Atrococcineus Fl. PI. (Everblooming Hybrid Sweet William). Double scarlet.........

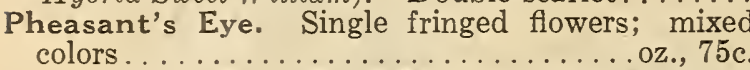

\section{DICTAMNUS (Gas Plant)}

Fraxinella. Showy, bushy plants $21 / 2$ feet high; purple red flowers; perennial; June and July...

$\$ 0.10$

$.60 \quad .10$

$.40 \quad .10$

$.25 \quad .10$

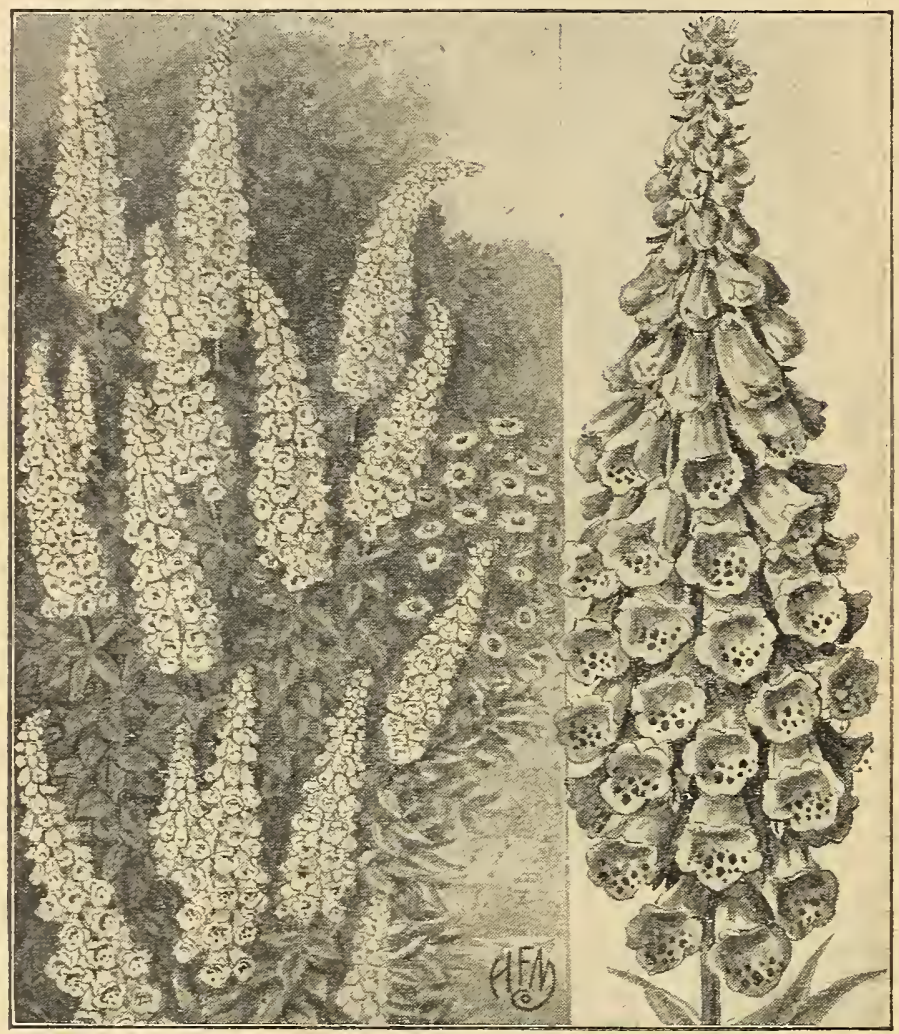

Digitalis (Foxglove) Gloxiniaeflora

\section{DIGITALIS (Foxglove)}

Ornamental hardy plants; long spikes of beautiful tubularshaped flowers; blooms during June and July; 4 to 5 feet.

\begin{tabular}{|c|c|c|c|c|}
\hline & & & arge & PK \\
\hline $\operatorname{iniaef}_{66}$ & Pink &.$\$ 1.00$ & $\$ 0.30$ & $\$ 0.10$ \\
\hline .6 & Purple & 1.00 & .30 & .10 \\
\hline 66 & Mixed. & $\begin{array}{l}1.00 \\
.75\end{array}$ & .30 & \\
\hline randiflora. & Yellow. & .90 & .25 & .10 \\
\hline
\end{tabular}

Monstrosa (Mammoth Foxglove). Long

spikes surmounted by one monstrous

flower; all colors mixed.

\section{DRACAENA}

Ornamental plants for vases or conservatory decoration.

Large pkt. Pkt.

Australis. Broad green leaves

Indivisa. Narrow green leaves

oz., $50 \mathrm{c} . \quad 25$

\section{EUPATORIUM}

Fraseri. A fine hardy perennial, thriving in almost any situation, excellent for cutting; 2 feet.

\section{FERNS}

Very desirable plants for ferneries.

Adiantum (Maiden Hair). Mixed.

Pteris Varieties. Mixed.

1.00

1.00

All Sorts Mixed. Choice collection .

1.00

$\mathrm{We}$ can also furnish all other good varieties of fern spores.

\section{FORGET-ME-NOT (See Myosotis) FOX GLOVE (See Digitalis)}

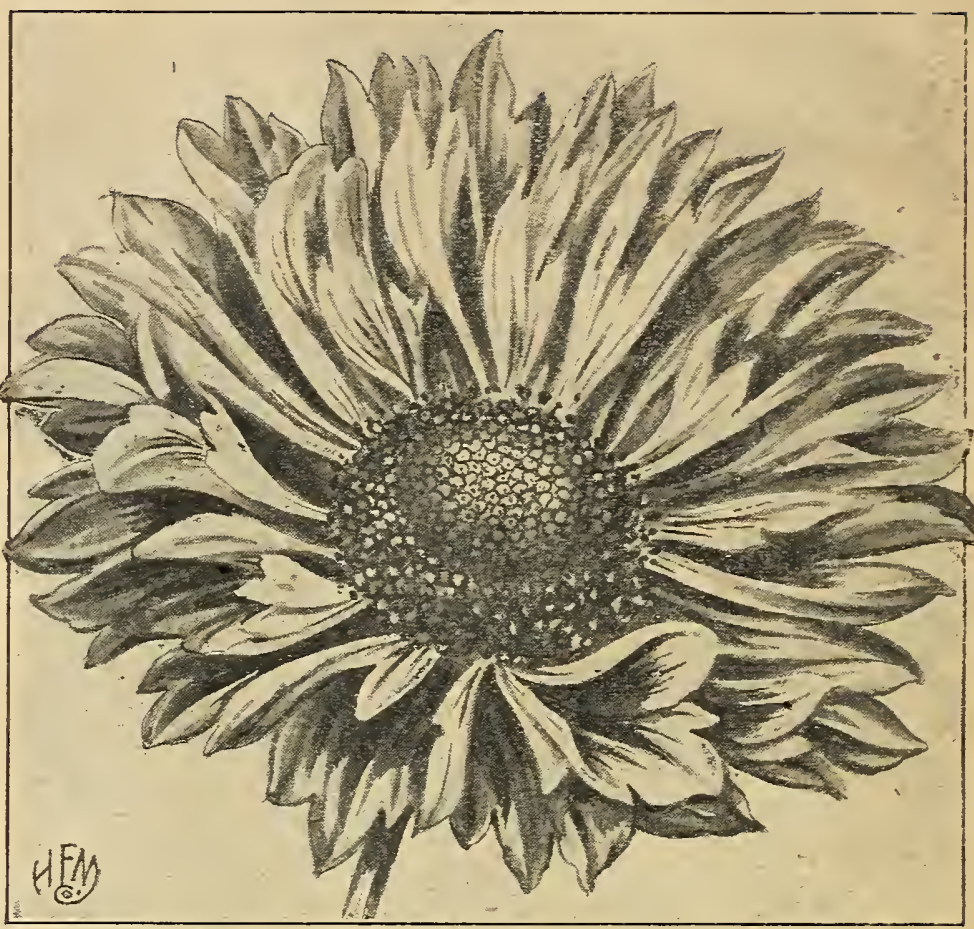

Gaillardia, Grandiflora Superba

\section{GAILLARDIA (Blanket Flower) PERENNIAL VARIETIES}

One of the most showy of hardy perennials; spikes of gorgeously colored flowers of immense size.

Grandiflora Compacta. A compact variety; choice

mixed colors; 12 to 15 inches............ oz., 75 c. $\$ 0.25 \quad \$ 0.10$

Grandiflora Sanguinea. Blood-red flowers; 2 ft. . $\quad .30 \quad .15$

Grandiflora Semi-Double. Mixed............ $.30 \quad .10$

Grandiflora Superba. Mixed; 2 feet........., $75 \mathrm{c}$. $\quad .25 \quad .10$

\section{GENTIANA (Blue Gentian)}

Large pkt. Pkt.

Acaulis. A dwarf hardy perennial; deep blue flow-

ers; suited to moist, shady situations.........\$0.40

$\$ 0.10$

\section{GERANIUM}

100 Seeds Pkt.

Apple Scented. Highly esteemed on account of its

fern-like, fragrant foliage; 1 foot...............

$\$ 0.40 \$ 0.10$

Pelargonium (Lady Washington). Seed saved from

the largest flowered show varieties........... $2.00 \quad .25$

Zonale Mixed. A superb strain of the largest Large pkt. Pkt. finest varieties; 1 to 2 feet..............\$0.60

$\$ 0.10$

\section{GERBERA (Transvaal Daisy)}

Splendid greenhouse perennials with large fine-leaved, daisylike flowers; splendid for pot plants or cutting. 100 Seeds Pkt.

Jamesoni Gigantea. Large flowers of bright scarlet....................... $\$ 1.25$

Jamesoni Hybrida. These hybrids include a wonderful range of brilliant colors and shades...... 1.00

\section{GEUM}

Atrosanguineum Fl. Pl. Hardy perennial, bear-

Large pkt. Pkt. ing large, showy, double, dark crimson flowers all

through the summer; fine for bouquets; $11 / 2 \mathrm{ft} . . . \$ 0.30$

Mrs. Bradshaw. Large, double brilliant scarlet flowers; blooms the entire summer.......... .50

\section{GLOXINIA}

Hybrida Grandiflora. An extra fine strain, embracing all the choicest self-colored and tigered and spotted flowers.

.85 .25 


\section{MICHELL'S “DISTINCTIVE” FLOWER SEEDS}

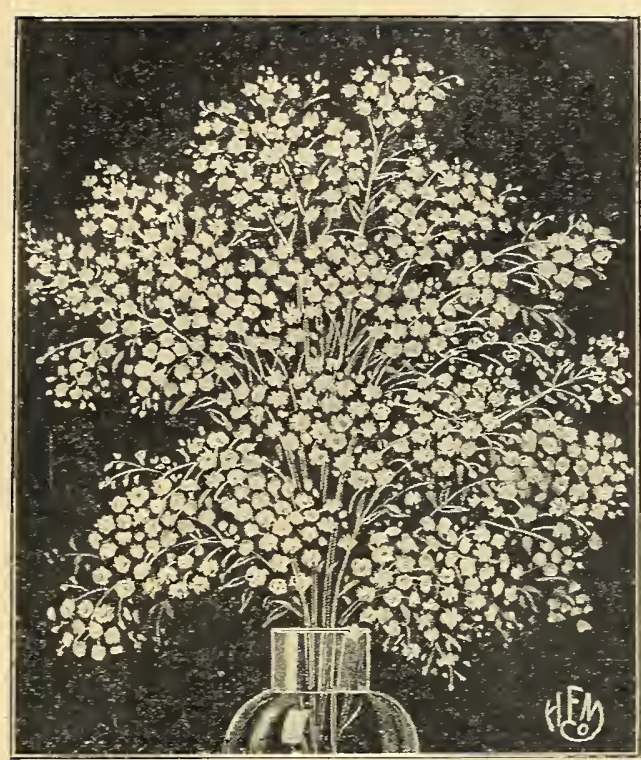

Gypsophila Paniculata Fl. Pl.

\section{GYPSOPHILA (Baby's'Breath)}

Paniculata. Hardy perennial; flowers in graceful sprays of white; 2 feet.............. oz., 60c.\$0.25 \$0.10

Paniculata, Fl. Pl. Double white............75

HELENIUM (Sneeze Wort)

Autumnale Superbum. Perennial; large heads of golden yellow flowers; 5 to 6 feet. . . . . . . . . .

\section{HELIOPSIS (Orange Sunflower)}

Pitcheriana. A handsome hardy perennial, producing an abundance of deep orange-yellow flowers the entire summer; excellent for cutting; 3 to 4 feet... . .2.

\section{HELIOTROPE}

A well-known and highly prized plant on account of the delightful fragrance of the flowers; excellent for pots, or for bedding; 18 inches.

Lemoine's Giant. Produces a profusion of flowers nearly double the size of the old sort; mixed colors $\$ 0.50$

Regal. Of dwarf compact growth; immense flowers; all shades...

Choice Mixed. Many varieties.

\section{HEUCHERA (Alum Root)}

Sanguinea. Hardy perennial; spikes of vivid crimson flowers; excellent for cutting; 1 foot.

$\$ 0.15$

$.60 \quad .15$

$.40 \quad .10$

\section{HIBISCUS (Marshmallow)}

Showy ornamental perennial plants for mixed beds or shrubbery borders, with beautifully colored flowers. Large pkt. Pkt.

Crimson Eye. Flowers large; color, pure white with velvety crimson centre, 4 feet..........\$0.30 $\$ 0.10$

Golden Bowl. Giant yellow, maroon centre....... $.30 \quad .10$

Moscheutos. Large, rosy pink flowers.......... .25 $\quad .10$

New Giant (Mallow Marvel). A greatly improved form; gigantic single flowers; many shades of red, pink, purple and white in mixture.

\section{IBERIS (See Candytuft)}

\section{IMPATIENS (Sultan's Balsam)}

A charming plant for house and conservatory decorations, flowering profusely and almost continuously. Large pkt. Pkt.

Holstii. Resembles Impatiens Sultani in leaf and shape of bloom, but flowers are larger; color, vermilion red.

Holstii, "New Hybrids."; The colors offered in these Hybrids are beautiful and of many shades. .

Sultani. Bright rose.......................... dark crimson

\section{IRIS (Flowering Flag)}

Kaempferi (Japanese Iris). Hardy perennial; very showy; blooms the second year from seed; mixed colors; 3 feet.

$\$ 0.20$

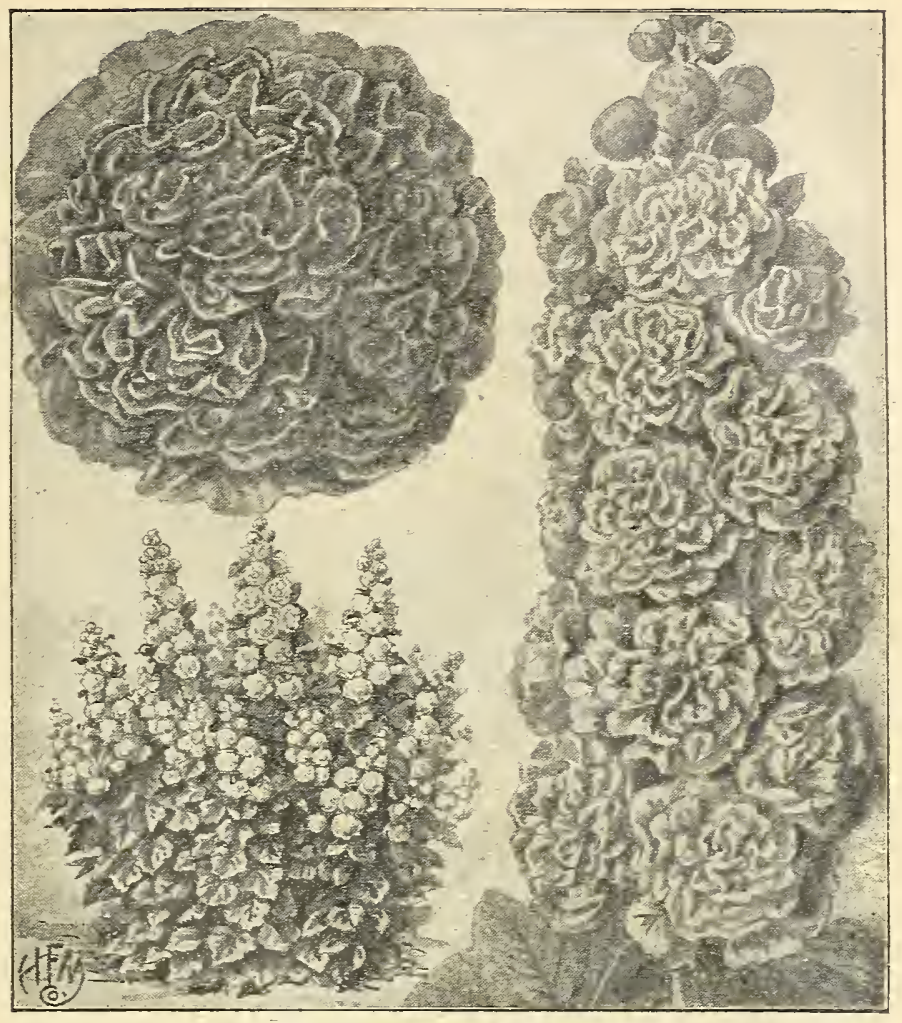

Hollyhock-Chater's Double

\section{HOLLYHOCK}

A popular and desirable hardy perennial plant; excellent for planting among shrubbery or forming a background for other flowers; 6 to 7 feet.

Allegheny. Semi-double; mammoth flow-

ers, edges fringed and laciniated; mixed..\$1.25 $\$ 0.30 \quad \$ 0.10$ Chater's Double Maroon.

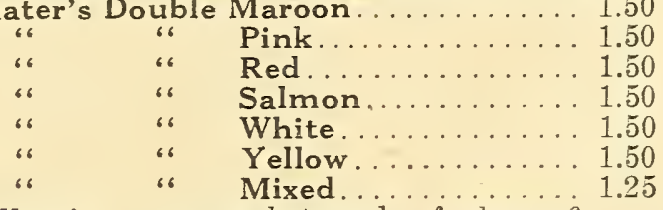

50
50 $\quad .30$

Collection, one packet each of above 6 colors, $50 \mathrm{c}$.

Double Ever-blooming Mixed

Single Ever-blooming Mixed

$\begin{array}{rrr}1.50 & .40 & .15 \\ .90 & .30 & .10 \\ .75 & .25 & .10\end{array}$

\section{KENILWORTH IVY (Linaria Cymbalaria)}

A charming, neat trailing plant, for baskets, vases, pots and rock work; flowers violet.

\section{KUDZU VINE (See Pueraria)}

\section{LARKSPUR, PERENNIAL (See Delphinium)}

\section{LATHYRUS LATIFOLIUS}

\section{(Everlasting or Perennial Pea)}

Showy hardy perennial climber; fine for covering walls, stumps, fences, etc. Free flowering, resembling Sweet Peas in growth, foliage and flowers; excellent for cutting; 6 to 8 feet.

Crimson. Brilliant

Pink Beauty. Bright rosy-pink Oz. Large pkt. Pkt.

White

Choice Mixed. All colors

$\$ 0.90 \$ 0.30$

$\begin{array}{rr}1.25 & .30 \\ 1.25 & .30\end{array}$

\section{LAVENDER (Lavendula Vera)}

Well-known perennial plant, bearing long spikes of fragrant blue flowers; 18 inches...... oz., $90 \mathrm{c}$.

\section{LOBELIA}

Cardinalis (Cardinal Flower). Hardy perennial; tall spikes of showy cardinal red flowers. 


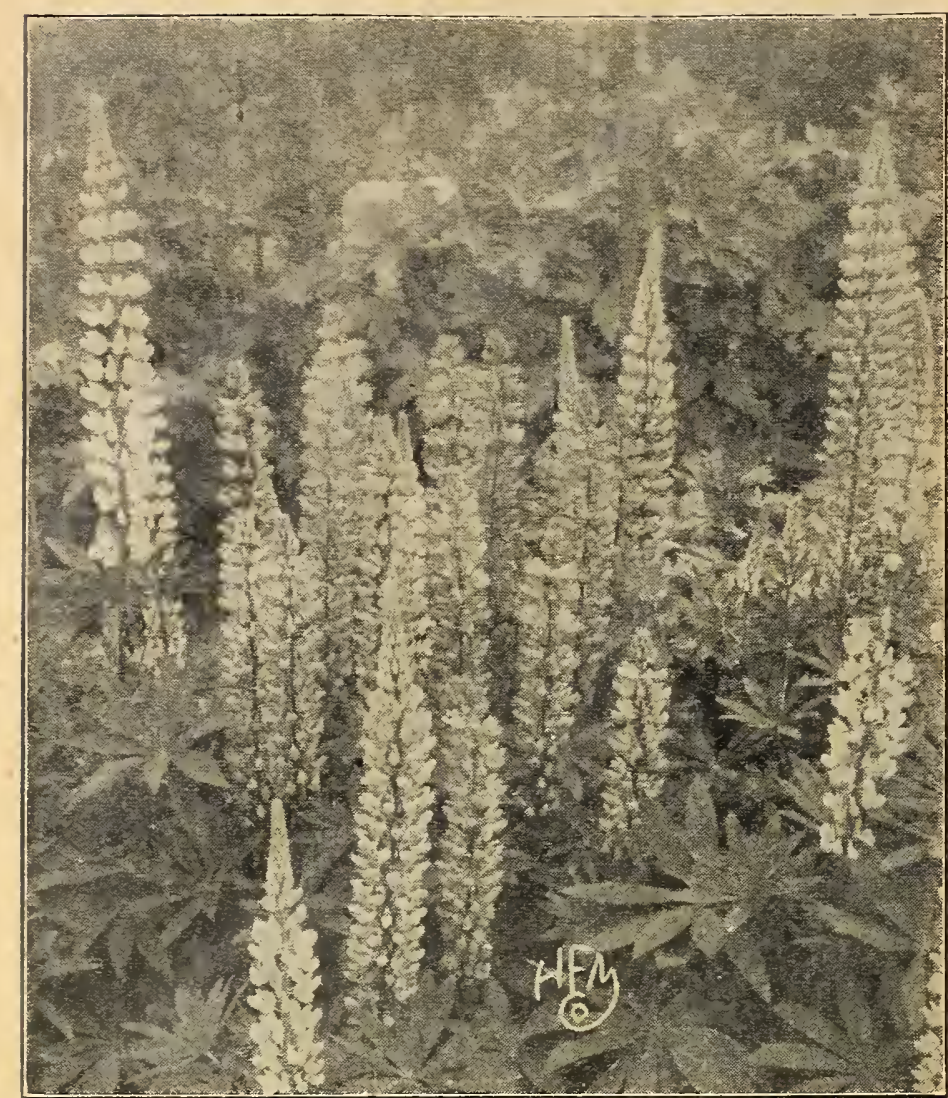

Lupinus

\section{LUPINUS (Lupins) Annual Varieties}

Seeds sown in greenhouse during the late summer and fall months will produce an abundance of bloom for winter.

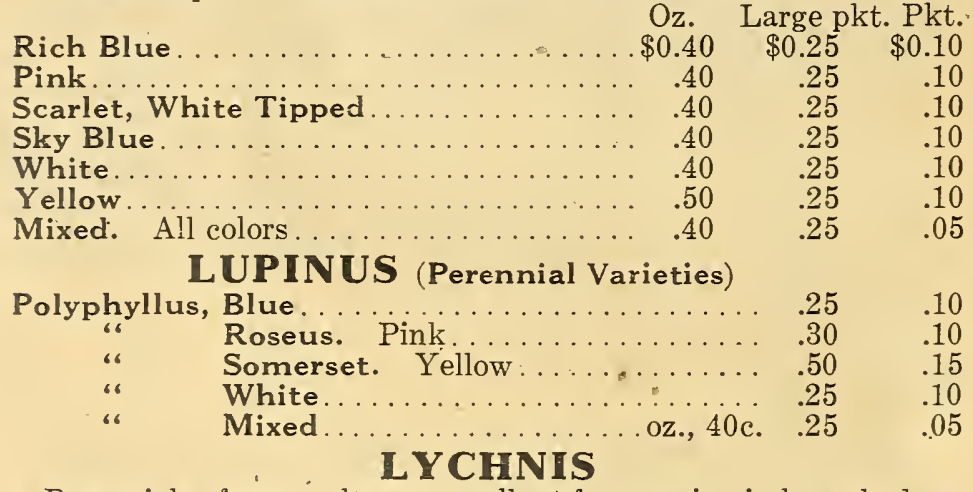

Perennials of easy culture; excellent for massing in large beds or borders; remarkable for the brilliancy of their flowers.

Large pkt. Pkt.

Chalcedonica (Rose Campion). Fine scarlet cross-

like flowers; 2 feet; July ............... oz., 50c. $\$ 0.25$

$\$ 0.10$

Haageana. Mixed colors; 1 foot; July.

$.60 \quad .10$

\section{MYOSOTIS (Forget-Me-Not)}

Beautiful, half hardy perennials, succeeding best in moist, shady situations. Very effective when grown in masses.

Alpestris Victoria. Of bushy habit; bearing large

Large pkt. Pkt.

bright blue flowers; very fine; 6 inches....... \$ \$0.40

$\$ 0.10$

Dissitiflora. Of dwarf, compact habit, deep green

foliage, and attractive deep blue flowers..........
Eliza Fanrobert. Of strong growth, with clusters of

作

$60 \quad .10$

Grandiflora Alba. Large white flowers; 8 inches.

$.40 \quad .10$

Grandiflora Rosea. Large pink flowers; 8 inches.

Palustris. The true Forget-Me-Not; bright blue.

Palustris Semperflorens. Dwarf; blooms the

entire season; deep blue.

40

40

60

Royal Blue. This variety belongs to the upright

(pillar-shaped section; large deep blue flowers.

Ruth Fischer. Flowers extra large, lovely sky blue.

Choice Mixed

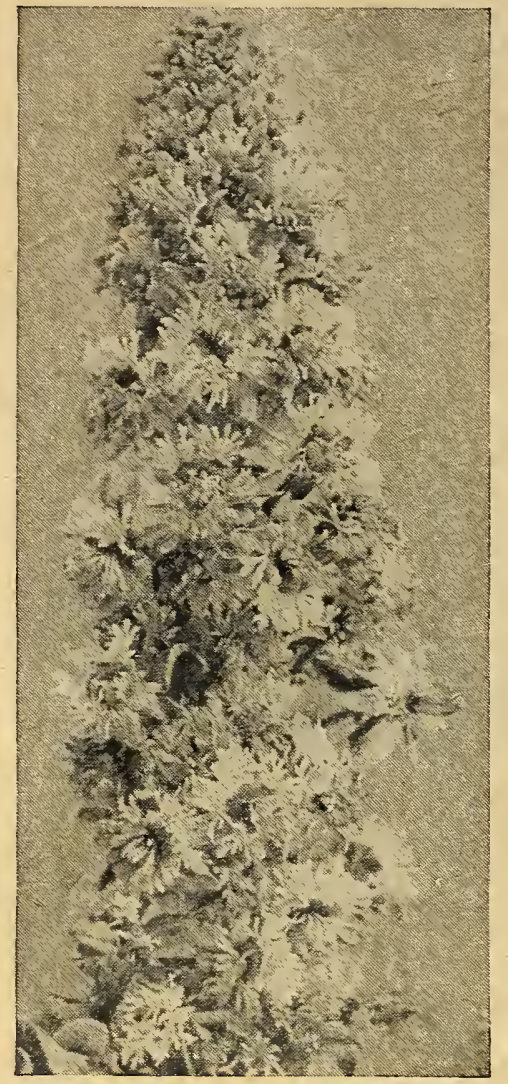

Mignonette, Michell's Colossal

\section{MIGNONETTE}

Valuable for cutting on account of its fragrance; sow in succession during the whole summer; can also be grown in pots for winter and early spring flowering. Large pkt. Pkt.

Allen's Defiance.

Spikes invariably

attain a height of

12 to 15 inches;

fragrant. oz., 60 c. $\$ 0.25 \$ 0.10$

Bismarck. Com-

pact plants of

strong growth,

with stout spikes of large flowers.

Golden oz., $\$ 1.25$

$.30 \quad .10$

Large golden yel-

low .....oz., 75c.

Goliath. Giant spikes of red flowers.... oz., $\$ 1.50$

Machet. Large reddish tinted, sweet scented flowers. oz., $75 \mathrm{c}$.

Michell's Colossal. Foliage, stalks and flowers are very robust. The flower-spikes often average 18 to 24 inches; extremely fragrant.......

Sweet Scented. The popular garden sort...oz., 25c. $\quad .15$

Collection. Six varieties, our selection

MUSA ENSETE (Abyssinian Banana)

A handsome tropical plant for planting individually or for the centre of beds; foliage broad and massive and very effective; 10 to 15 feet. Seeds should be started in hotbed or bottom heat in greenhouse. Per 10 seeds, 30c.; 65c. per 25 seeds.

\section{NEMESIA}

Large pkt. Pkt.

Strumosa Suttoni. A splendid annual, with large flowers varying in color from creamy white to deep orange and carmine; seeds sown in the autumn make excellent pot plants for early spring blooming; 18 inches

$\$ 0.60 \$ 0.15$

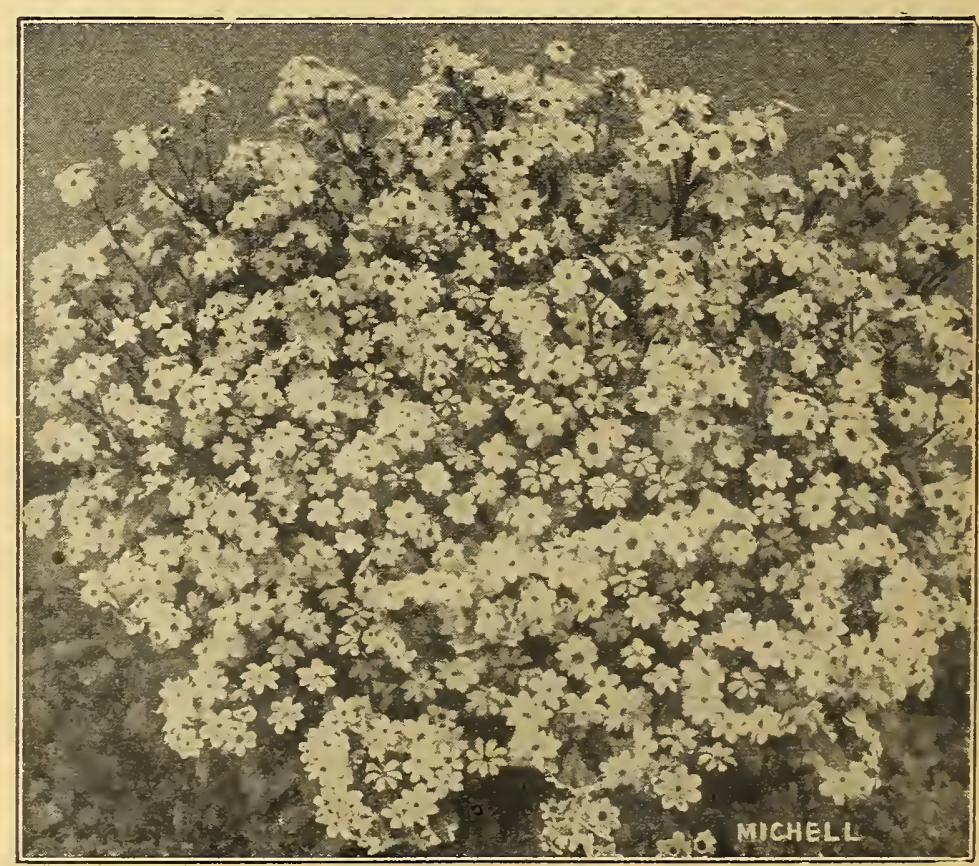

Myosotis-Alpestris Victoria. (Large pkt. 40c.) 


\section{MICHELL'S GIANT PANSIES}

Seed sown in frames during July and August and transplanted later gives us the main crop of flowers the following spring.

\section{PANSIES IN MIXTURE}

Michell's Giant Exhibition. A blending of our Large pkt. Pkt. own containing only the very choicest secured from the leading Pansy specialists; it can be relied upon to produce flowers of immense size, very heavy texture and of the most brilliant colors. Per oz., $\$ 10.00 ; \$ 3.00$ per $1 / 4$ oz.; per $1 / 8$ oz., $\$ 1.75 \ldots \$ 0.75$

Bugnot, Odier and Cassier. A superb mixture of giant blotched varieties . . . . . . . . 1/8 oz., $\$ 1.00$

Giant Trimardeau. Very large flowering; all colors, mixed ..................1/4 oz., $\$ 1.00$

Mad. Perret. Early flowering; fragrant; especially rich in red shades ..............1/4 oz., $\$ 1.25$

Masterpiece (Frilled Pansy). Beautiful rich colors; petals curled or waved............. I/8 oz., $\$ 1.00$

Odier or Blotched. Beautiful strain. 1/4 oz., $\$ 1.25$

Parisian Large Stained. Choicest colors.

$1 / 1$ oz. $\$ 1.25$

Triumph of the Giants Mixed. Immense flowers of great brilliancy and richness of colors, including many new and rare shades. Per oz., $\$ 11.00 ; \$ 3.25$ per $1 / 4$ oz.; per $1 / 8$ oz., $\$ 2.00$

Finest English Mixed . . . . . . . . . . . oz., $\$ 2.25$

Very Fine Mixed

oz., 1.75

.85

.40

.30

.75

$\$ 0.25$

.50

.75

.75

.75

.25

.15

.15

GIANT PANSIES (Separate Colors)

A strain secured from the leading pansy specialists, and not to be compared with the ordinary Giant Trimardeau, as the flowers are of much heavier texture.

Large

1/4 Oz. Pkt. Pkt.

Giant Prize, Azure Blue. Violet blue....\$1.50 $\$ 0.60 \quad \$ 0.15$

Giant Prize, Black Blue. Dark velvety... $1.50 \quad .60$

Giant Prize, Emperor William. Ultra-

marine blue........................ 1.50

Giant Prize, Hortensia Red. Scarlet... 1.50

Giant Prize, King of the Blacks ....... 1.50

Giant Prize, Lord Beaconsfield. Violet. . 1.50

Giant Prize, Peacock. Upper petals blue,

lower petals deep claret with white margin 1.50

Giant Prize, Snow Queen. Pure white... 1.50

Giant Prize, Striped and Mottled...... 1.50

Giant Prize, White, with dark eye..... 1.50

Giant Prize, Pure Yellow............. 1.50

Giant Prize, Yellow, with dark eye.... 1.50

.60

.60

.60

.60

.60

.60

.60

.60

.60

.60

.50

.10

.05

SPECIAL OFFER.-We will send 6 packets of any of the above varieties of Giant Pansies for $75 \mathrm{c}$.; or the entire 12 pkts. for $\$ 1.40$.

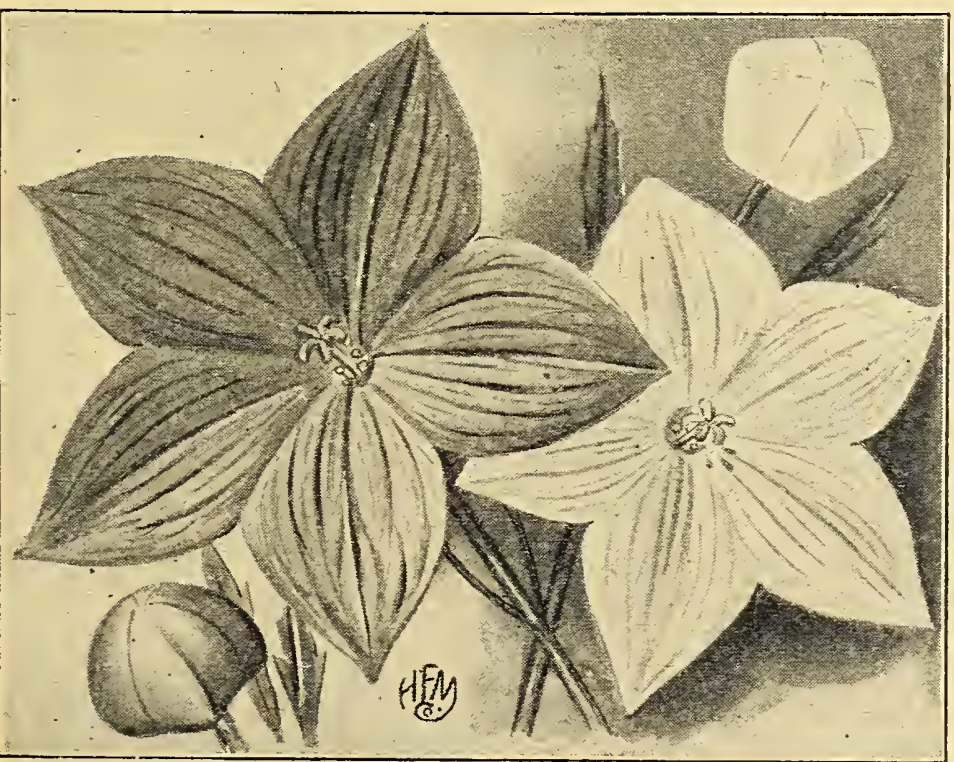

Platycodon Grandiflorum

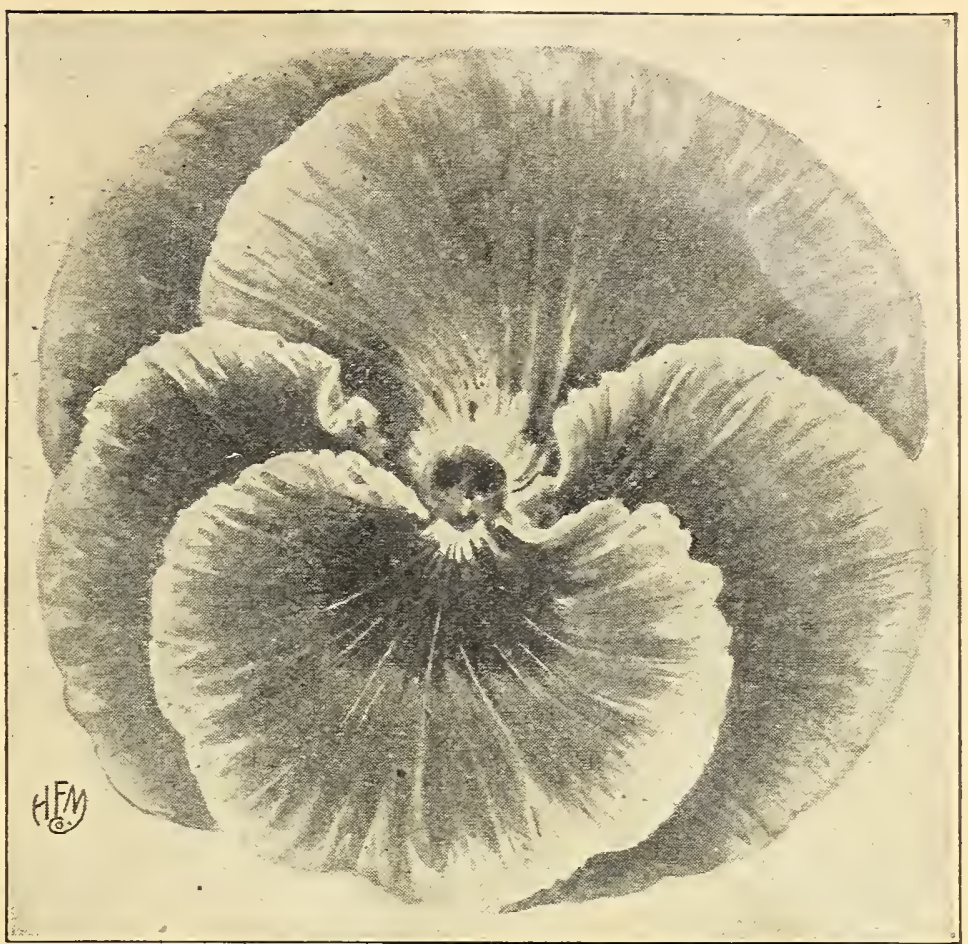

Michell's Giant Exhibition Pansy

PANSIES (Regular Sorts in Separate Colors)

Belgian Striped. Showy

Oz. Large pkt. Pkt.

$\begin{array}{rrr}2.75 & .40 & .10\end{array}$

Faust (King of the Blacks) . ......... 2.75 $\quad .40 \quad .10$

Gold Margined. Purple, golden edge... 2.75 . .40 $\quad .10$

Havana Brown. $\begin{array}{rrr}4.75 & .40 & .10\end{array}$

Lord Beaconsfield. Violet........... $2.75 \quad .40 \quad .10$

Mahogany Colored............ $2.75 \quad .40 \quad .10$

Silver Edged. Purple, silver edge..... . 2.75 $\quad .40 \quad .10$

Snow Queen. Pure white........... 2.75 $.40 \quad .10$

White, with dark eye.... $2.75 \quad .40 \quad .10$

Yellow Gem. Pure yellow.......... 2.75 $\quad .40 \quad .10$

Yellow, with dark eye.............. $2.75 \quad .40 \quad .10$

SPECIAL OFFER. - We will send 6 packets of any of the above varieties of regular sorts of Pansies for $50 \mathrm{c}$. ; or the entire 12 packets for $90 \mathrm{c}$.

Ask for Cultural Leaflet No. 209 on the Growing of Pansies.

\section{PENTSTEMON (Beard Tongue)}

A bejautiful perennial plant, producing freely large spikes of handsome tubular flowers.

Sensation. Large spikes of gloxinia-like flowers

of brilliant colors; 2 feet; requires protection....\$0.50 $\$ 0.15$

New Hybrids, Mixed. Produces large spikes of

handsome flowers; 3 feet

\section{PHLOX (Hardy)}

Decussata. Perennial plants 2 to 3 feet high; flow-

ers in all bright colors; sow seeds late in fall and

they will germinate in the spring .....1/1 oz, $75 \mathrm{c}, 50$

PHYSOSTEGIA (False Dragon Head)

A pretty hardy perennial, bearing freely, delicate tubular flow ers; 3 to 4 feet; July-August.

Virginica. Pink... White. Large pkt. Pkt $\$ 0.30 \quad \$ 0.10$

PINKS (See Carnation and Dianthus)

PLATYCODON (Chinese Bell Flower)

One of the best hardy perennials; large bell-shaped excellent for borders or among shrubbery; 2 to 3 feet.

Grandiflorum, Blue

Grandiflorum, White 


\section{POLYANTHUS (Primula Elatior)}

Beautiful spring flowering hardy perennials. Large pkt. Pkt. Gold Laced. Flowers of brilliant colors, with distinct yellow edge

Double Mixed. Beautiful colors $\ldots \ldots \ldots \ldots \ldots \ldots 0.60 \ldots 0.15$

English Mixed. All colors ................ .40 $\quad .10$

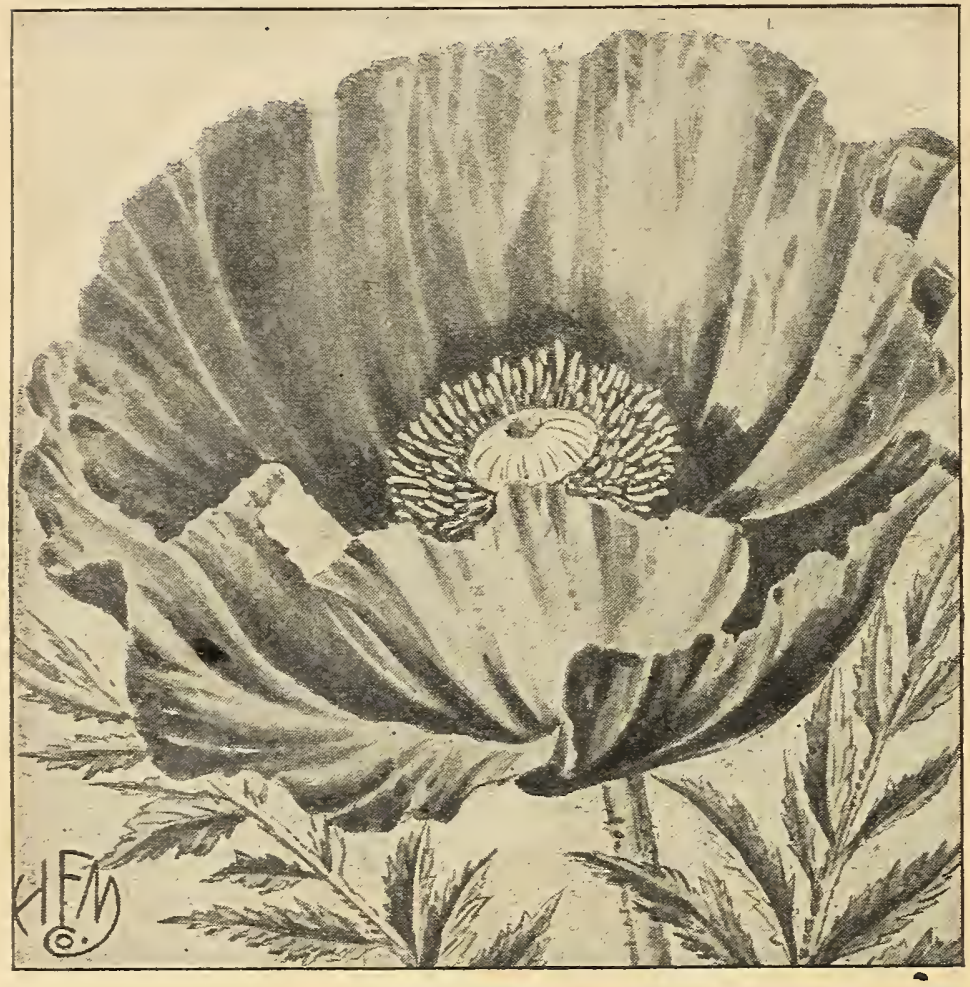

Oriental Poppy

\section{POPPY (Perennial)}

These brilliant hardy Poppies are unequalled for general effectiveness and brilliancy of display. Giant Scarlet (Bracteatum) Large flowers; 3 feet Large pkt. Pkt. Iceland (Nudicaule). White; 1 foot. "Yellow

" Single Mixed. A wide range of colors Orientale. Extra large flowers; deep scarlet. Mrs. Perry. Rich salmon pink. Hybrids. Beautiful flowers of large size; mixed colors........1/4 oz., $60 \mathrm{c}$.

0.25

.40

.40

.25

.25

.60

.40

\section{PRIMULA}

\section{FRINGED CHINESE PRIMROSE}

These are among our finest winter and spring blooming pot plants for decorations in the home or conservatory. Our seed has been grown for us by a Primula Specialist, and cannot be excelled for size and brilliancy of colors. Our strains have won many first prizes.

Large pkt. Pkt.

Alba Magnifica. Large pure white flowers . . . . \$0.85 $\$ 0.40$

Chiswick Red. Brilliant red............... .85

Duchess. Large; white with zone of rosy carmine,

Holborn Blue. A beautiful shade

Kermesina Splendens. Crimson

Rosy Morn. Delicate pink.

$.85 \quad .40$

Michell's Prize Mixture. This mixture contains only the finest sorts selected from the best strains.

Imported Collection. 8 varieties

\section{PRIMULA OBCONICA GIGANTEA}

$A$ beautiful and continuous blooming variety with handsome spikes of flowers and pretty foliage; elegant plants for greenhouse or light window of dwelling house.

Alba. White

Kermesina. Crimson

Lilacina. Pale lilac.

Rosea. Pink

Hybrida. Mixed
Large pkt.'Pkt. $\$ 0.75 \$ 0.20$ $\begin{array}{rr}.75 & .20 \\ .75 & .20\end{array}$ .75 .75 .75

\section{PRIMULA - Continued} PRIMULA OBCONICA GIGANTEA MONSTER STRAIN

An extra large flowering strain of this popular Primula. Seeds are grown for us by a specialist.

Apple Blossom. Soft pink. .

Large pkt. Pkt.

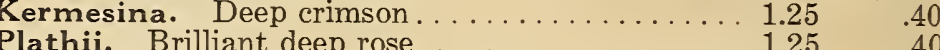

$1.25-.40$

Mixed Colors.

1.25

1.25

.40

PRIMULA OBCONICA GRANDIFLORA

Fimbriata. Flowers fringed; mixed colors .... L . $\$ 0.75$ pkt. Pkt.

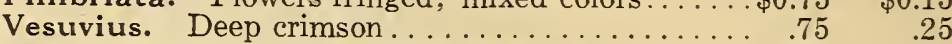

\section{VARIOUS SORTS}

Kewensis (Verbena Scented Yellow Primrose). Spikes each 12 to 18 inches long; color, soft yellow; very fragrant.............................. . . . Malacoides. Resembles Primula Forbesi, but the it will bloom in four to five months after sowing and continue for a long time; color, a pretty light lilac.............................. Malacoides Alba. Flowers pure white
Malacoides Alba Plena. A new variety with double white flowers

Malacoides Superba. Deep rosy pink; large....

\section{HARDY PRIMROSES}

Excellent early spring blooming plants; hardy, though in very cold localities they should have slight protection. Large pkt. Pkt. Veris (English Cowslip). Fragrant; flowers of vari-

ous colors; mixed; 6 inches.

Vulgaris (English Primrose). The common hardy

English variety; canary yellow..............60

$\$ 0.10$

\section{PUERARIA THUNBERGIANA (Kudzu Vine)}

One of the fastest growing hardy climbing plants; grows 8 to 10 feet the first year from seed; after the first year it will grow 30 to 50 feet in a season; rosy purple pea-shaped Large pkt. Pkt. blossoms toward the end of August.........\$0.25 $\$ 0.10$

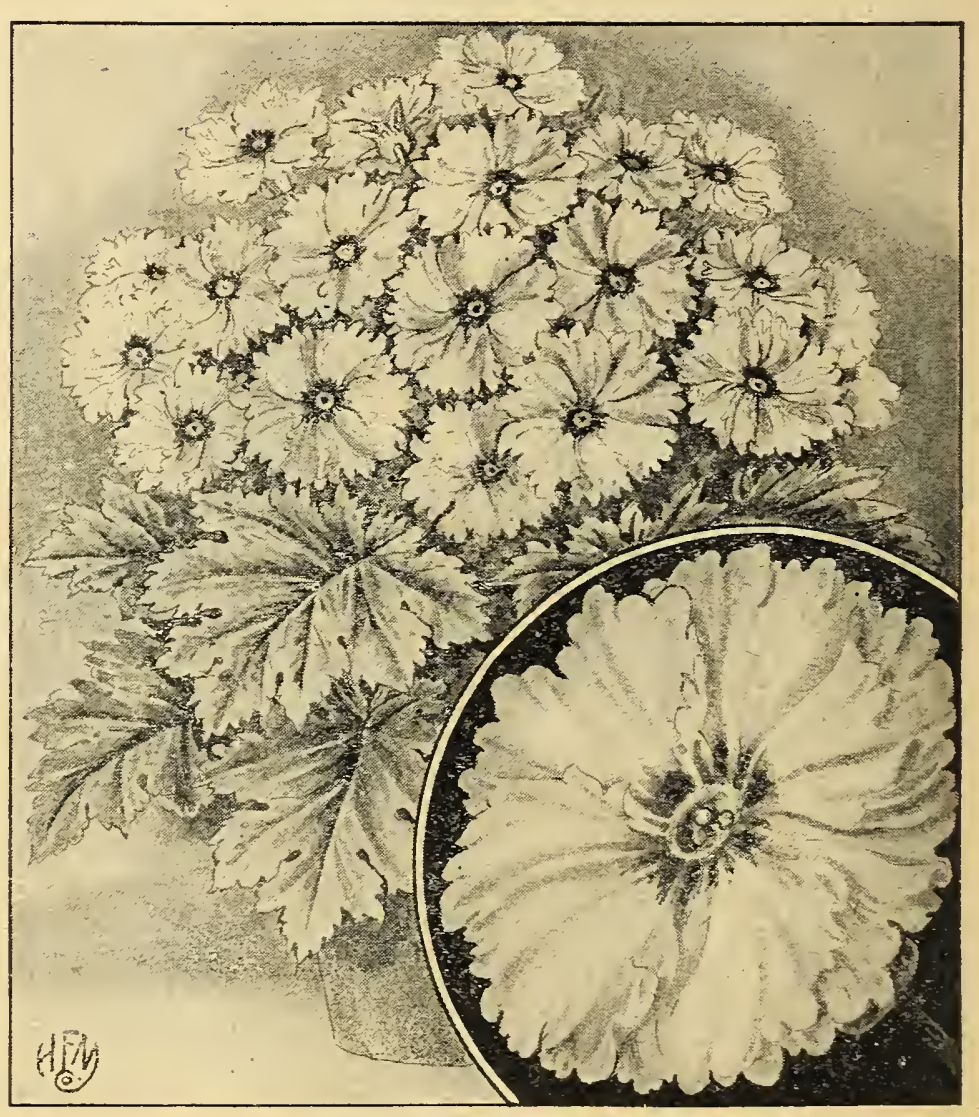

Michell's Prize Chinese Primula 


\section{MICHELL'S “DISTINCTIVE” FLOWER SEEDS}

\section{PYRETHRUM (Perennial)}

Handsome hardy perennial plants for the herbaceous border; flowers showy and excellent for cutting. Large pkt. Pkt.

Roseum. Flowers bright rose color; July; 2 feet. . $\$ 0.60 \quad \$ 0.10$

Uliginosum (Giant White Daisy). Large, single white flowers; September; 3 to $4 \mathrm{ft}$...........

$60 \quad .10$

Hybridum Single Mixed. Large flowers ranging in color from light pink to deep red, with bright yellow centers; July; 2 feet

Hybridum Double Mixed .

\section{RESEDA. See Mignonette} RUDBECKIA (Coneflower)

Newmani. Large yellow flowers with black centre; perennial; very showy; 3 feet.

Purpurea (Giant Purple Coneflower). Hardy perennial; reddish purple flowers, with dark brown disc; 3 feet.

\section{SALVIA}

Azurea Grandiflora. A hardy perennial variety producing during August and September spikes of pretty sky-blue flowers; 2 feet.

Farinacea. A perennial variety, but best treated as an annual; color, light blue; 2 feet...........

\section{SCABIOSA}

Handsome perennial border plants, flowering the entire season.

Caucasica. Soft blue; 3 feet............. Large pkt. Pkt.

Caucasica Alba. Pure white. . . . . . . . . . . $60 \quad \begin{array}{r}\$ 0.10 \\ .10\end{array}$

Japonica. Lavender blue................. $\quad .25 \quad .10$

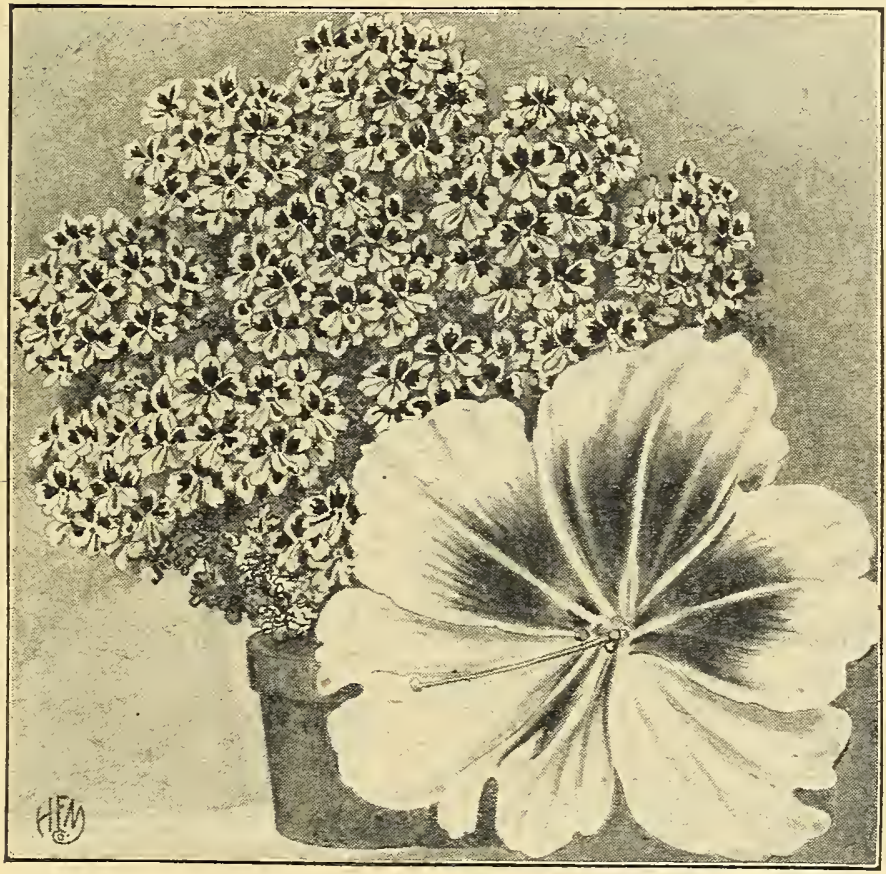

Schizanthus, Wisetonensis

\section{SCHIZANTHUS (Butterfiy Flower)}

One of our finest annuals, bearing a profusion of pretty butterflylike flowers of various colors; useful as pot plants for late winter and spring blooming; for this purpose sow in autumn.

Garraway's Hybrids. Flowers large, with handLarge pkt. Pkt. some markings on a white, buff, rose, blue or purple ground.

Hybridus Grandiflorus. Compact plants, with flowers of many shades and of orchid-like appearance; 12 inches.

$\$ 0.25$

Pink Beauty. A beautiful shade of rose pink....

Wisetonensis. A showy variety, largely used as a pot plant for the house or conservatory; flowers range from white with yellow centre to pink with brown centre, $11 / 2$ feet.

Mixed. Various colors.

$.30 \quad .10$

.50

\section{SHAMROCK}

Large pkt. Pkt.

Dainty little house plants, easily grown from seed.

True Irish. Small leaved variety.

$\$ 0.30$

SHASTA DAISY. See Chrysanthemum

SMILAX

A desirable greenhouse climber of great value for

floral decorations; seed should be soaked 24 hours

in. warm water before sowing.

oz., 50c.

SNAPDRAGON. See Antirrhinum

\section{STAT TE (See Lavender)}

Latifolia. Splendid hardy perennial, either for the border or rockery, producing all summer panicles of deep blue flowers, which can be dried and used for winter bouquets; 1 foot

\section{STEVIA}

Serrata. Free blooming plants for summer or winter, bearing a profusion of fragrant white flowers; excellent for cutting; 2 feet.

\section{STOCHS. See next page}

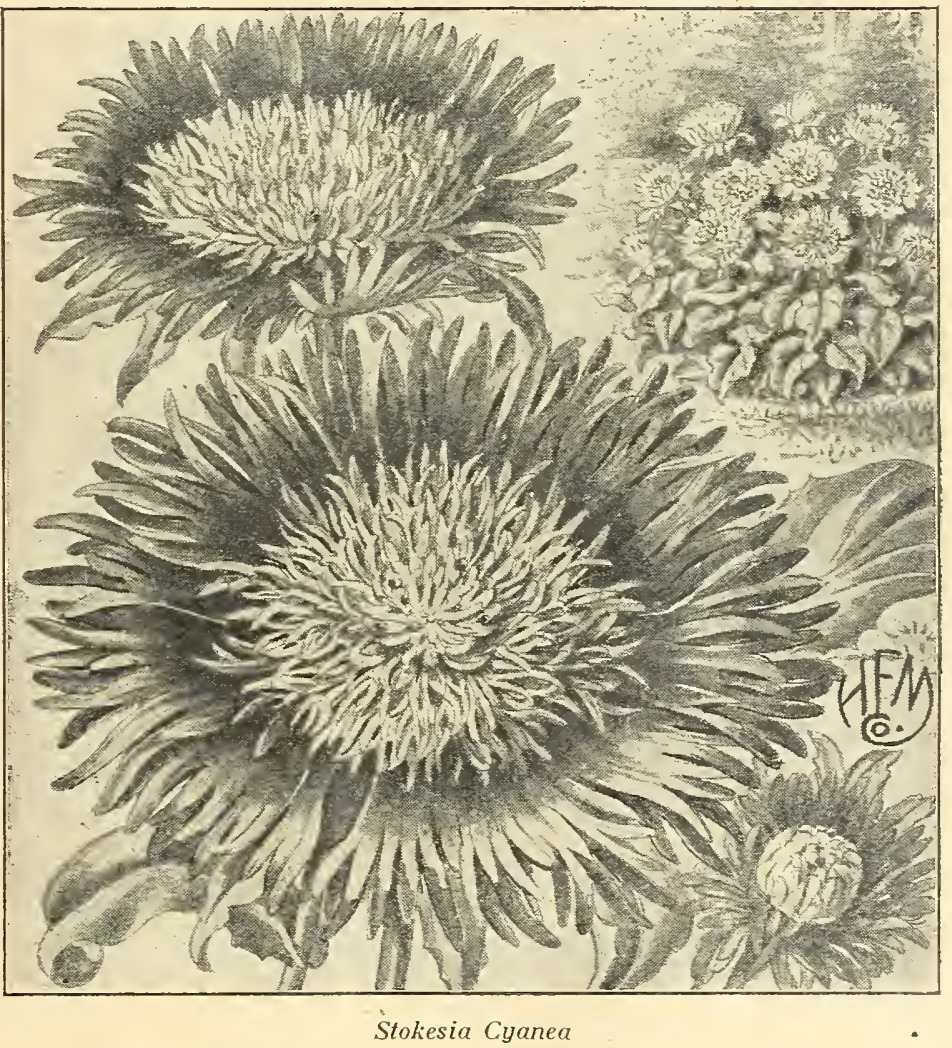

STOKESIA (Cornflower or Stokes'Aster)

A very desirable hardy perennial plant, bearing freely from July to October handsome Centaurea-like blossoms, each measuring from 4 to 5 inches across; excellent for cutting; $11 / 2$ to 2 feet.

Cyanea. Lavender blue Large pkt. Pkt. Alba. Pure white. $\$ 0.40 \$ \$ 0.10$

\section{SUNFLOWER (Helianthus)}

Showy garden flowers blooming all summer.

Choice Mixed. Contains the finest single flowering, hardy perennial sorts

.50

\section{Lowell, Mass.}

Enclosed find spring order for flower seeds and plan have had about 8 years success with your flower plants, so am sending you my 1922 order. 
The stock is one of the most popular and highly prized of our cultivated flowers, either for the garden or for pot culture. The charming colors, delightful fragrance and free blooming character, have made them favorite plants for both summer and winter cultivation. The seeds we offer are hand-saved from pot-grown specimens and will produce a large percentage of double flowers.

\section{MICHELL'S FLOWER MARKET STOCK}

This is the ideal stock for either garden, cutting or forcing under glass. Plants branch freely and produce from 10 to 15 heavy spikes of extra large perfect flowers; height, 2 feet.

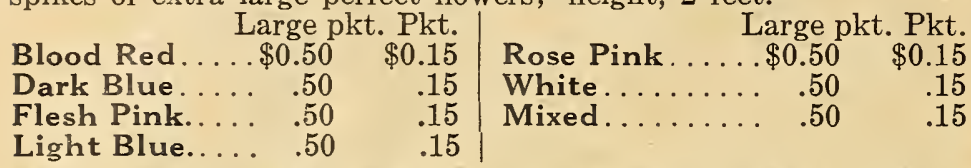

MICHELL'S EARLY FLOWERING "NICE"' STOCK

An early flowering strain of branching habit; remarkably free bloomer; large, double fragrant flowers; fine for garden bedding or cutting; especially desirable for use as a pot plant. For winter blooming, sow from July to September. Large pkt. Pkt. Abundance. Dwarf, spreading habit; carmine-rose. $\$ 0.50 \quad \$ 0.15$ Beauty of Nice. Charming delicate pink . . . . . . .50 $\quad .15$ Crimson King. Deep red.................... .50 .15 La Brilliante. Rich brilliant crimson ......... .50 Midsummer Night. Deep, dark violet.......... .50 Monte Carlo. Canary yellow ................5

Mont Blanc. Pure white................ .50

Old Rose. An extra fine variety ............ .50

Queen Alexandra. Delicate lavender........ .50

Choice Mixed. All colors.

.50

.15
.15
.15

.15

.15

.15

.15

.15

\section{LARGE FLOWERED DWARF TEN-WEEK STOCK}

This is the leading variety for bedding out, for summer blooming; also fine for pots.

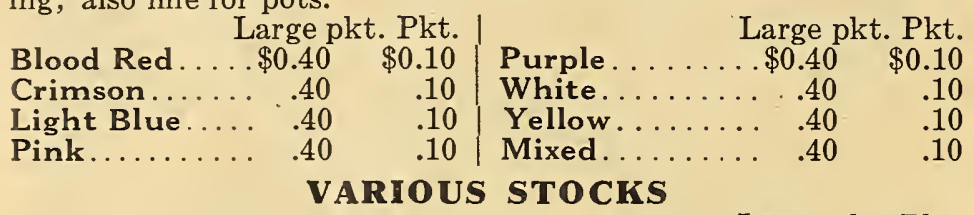

Brompton or Winter. Fine for forcing under glass or early summer flowering outdoors; mixed......\$0.50 $\$ 0.10$ Dresden Perpetual. A popular variety for cutting; large spikes; color, lustrous carmine......... $\quad .50$ Mammoth Ten Week, Snowdrift (New). Snow white; early blooming.

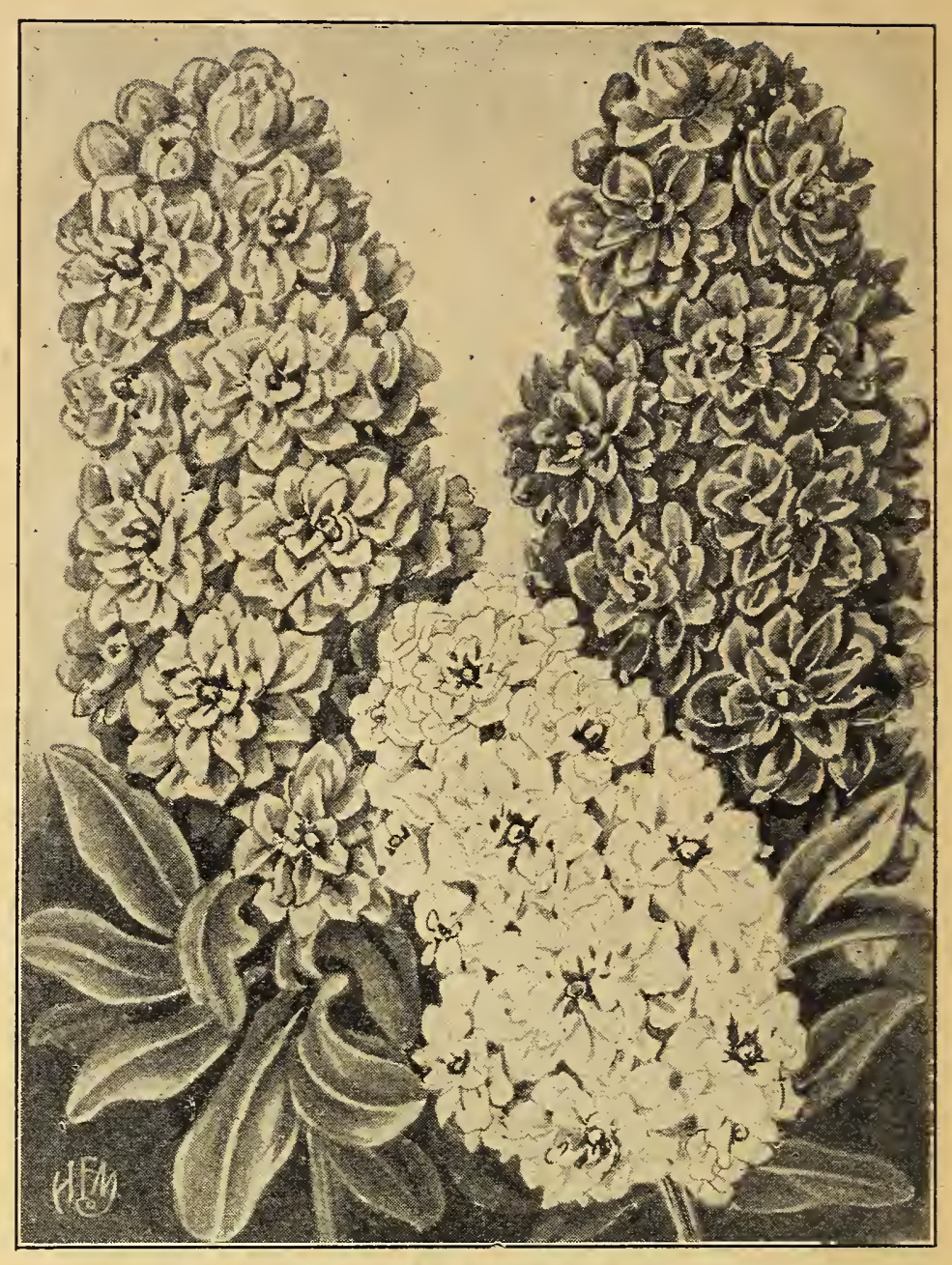

Stock, Michell's Flower Market

Large pkt. Pkt.

Princess Alice (Cut-and-Come-Again). Branching plants with double pure white flowers; fine for
cutting.
$\$ 0.50$
$\$ 0.10$

.50 Ask for Cultural Leaflet No. 211 on the growing of Stocks.

\section{MICHELL'S SWEET PEAS}

For early blooming out-doors we recommend sowing seed the latter part of November and covering with 2 or 3 inches of leaves or litter; these will bloom the following year much earlier than spring-sown seed.

\section{SPENCER OR ORCHID VARIETIES}

Apple Blossom Spencer. Standard light

rose; wings primrose flushed rose. .

. $\$ 0.25 \$ 0.40 \$ 1.25 \$ 4.50$

Blanche Ferry Spencer. Large flowers; pink and white.

Captain of the Blues Spencer. Standard purple; wings blue.

Constance Hinton. One of the largest varieties; flowers white; black seeded.

Countess Spencer. A lovely clear pink, shading deeper at the edge.

Fiery Cross. Intense orange scarlet.

Flora Norton Spencer. Beautiful azure, or pale blue

Florence Morse Spencer. Delicate blush, with deeper pink margin .......

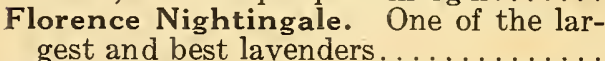

Helen Lewis. Orange pink; wings or-

Helen Pierce Spencer. White mottled light blue.
$1 / 2$ oz. Oz. $1 / 4 \mathrm{lb}$. Lb.

$\begin{array}{llll}.25 & .40 & 1.25 & 4.50\end{array}$

$\begin{array}{llll}.25 & .40 & 1.25 & 4.50\end{array}$

$\begin{array}{llll}.25 & .40 & 1.25 & 4.50\end{array}$

$.25 \quad .40 \quad 1.25 \quad 4.50$

$\begin{array}{llll}.25 & .40 & 1.25 & 4.50\end{array}$

$\begin{array}{llll}.25 & .40 & 1.25 & 4.50\end{array}$

$\begin{array}{llll}.25 & .40 & 1.25 & 4.50\end{array}$

$\begin{array}{llll}.25 & .40 & 1.25 & 4.50\end{array}$

$.25 \quad .40 \quad 1.25 \quad 4.50$

$.25 \quad .40 \quad 1.25 \quad 4.50$

$\begin{array}{llll}.30 & .50 & 1.75 & 6.00\end{array}$

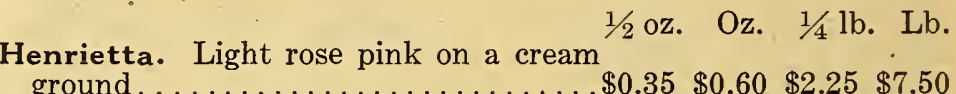

ground................... \$0.35 \$0.60 \$2.25 $\$ 7.50$

Hercules. Giant pure pink ......... $\quad .25 \quad .40 \quad 1.25 \quad 4.50$

Illuminator. Rich salmon pink............

King Edward Spencer. Crimson scarlet $\quad .25 \quad .40 \quad 1.25 \quad 4.50$

King Manoel. Rich maroon...........25 $\quad .40 \quad 1.25 \quad 4.50$

King White. Pure white........... $.25 \quad .40 \quad 1.25 \quad 4.50$

Margaret Atlee. Light salmon pink on

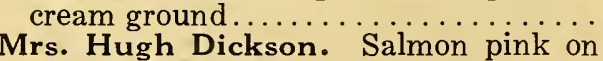

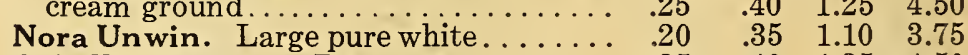

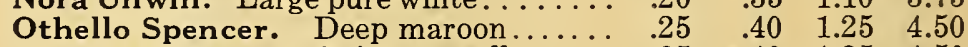

Primrose Spencer. Primrose yellow.... $\quad .25 \quad .40 \quad 1.25 \quad 4.50$

Royal Purple. Rich purple............ $.25 \quad .40 \quad 1.25 \quad 4.50$

Vermilion Brilliant. Intense scarlet... $\quad .25 \quad .40 \quad 1.25 \quad 4.50$

Wedgwood. A lovely self-blue....... $\quad .25 \quad .40 \quad 1.25 \quad 4.50$

$\begin{array}{lllll}\text { White Spencer. Pure white; large size. . } & .25 & .40 & 1.25 & 4.50\end{array}$

Price, any of the above varieties, 10c. per packet.

MICHELL'S SUPERB SPEN CER MIXTURE

Blended by ourselves from only the Giant Waved Spencer varieties in proper proportions of bright colors and including a number of new hybrids of exquisite colors and shades. Per pkt., 10c.; 25c. per oz.; $1 / 4$ lb., $75 \mathrm{c}$.; $\$ 2.50$ per lb. 


\section{GRANDIFLORA VARIETIES}

On account of the increased demand for the Spencer or Orchid Flowered varieties we have reduced our list of Grandifloras to a few of the very best sorts. $\quad \mathrm{Oz} .1 / 4 \mathrm{lb}$. Lb.

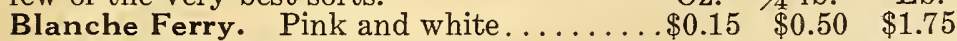

Dorothy Eckford. Large white.......... .15 $\quad .50 \quad 1.75$

Flor a Norton. Delicate lavender............... $.15 \quad .50 \quad 1.75$

Hon. Mrs. E. Kenyon. Primrose yellow... $.15 \quad .50 \quad 1.75$

King Edward VII. Crimson scarlet...... $.15 \quad .50 \quad 1.75$

Lady Grisel Hamilton. Pale lavender ... . $\quad .15 \quad .50 \quad 1.75$

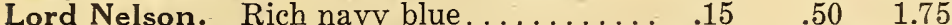

Lovely. Soft shell pink.............. $.15 \quad .50 \quad 1.75$

Miss Wilmott. Deep orange pink......... $.15 \quad .50 \quad 1.75$

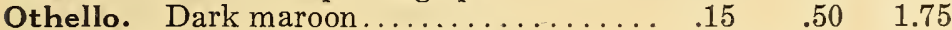

Prima Donna. Lovely soft pink........... $.15 \quad .50 \quad 1.75$

Price, any of the above varieties, $10 \mathrm{c}$. per packet.

\section{MICHELL'S GILT EDGE MIXTURE}

This mixture contains the Grandiflora varieties, and represents almost every color and shade in Sweet Peas.

Price: 5c. per pkt.; per oz., 15c.; 50c. per 1/4 lb.; per lb., $\$ 1.50$.

\section{EARLY OR WINTER FLOWERING SPENCER}

The following varieties are especially adapted for forcing under glass for winter and early spring blooming. Also excellent for sowing outdoors in the Southern States.

Asta Ohn. Rich lavender.

Pkt. 1/2 Oz. Oz.

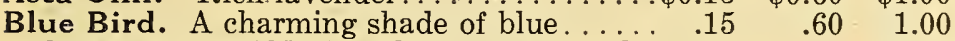

Bohemian Girl (New). Flowers large; color

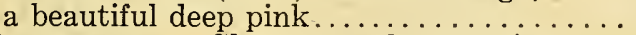

Cherry Ripe. Cherry or salmon cerise..........

Columbia $(N e w)$. Salmon color standard;

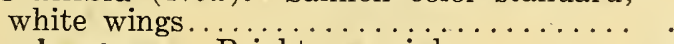

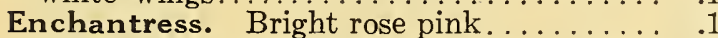

Fire King. Deep orange scarlet.............

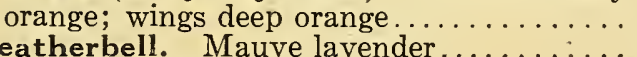

Heatherbell. Mauve lavender..........

Helen Lewis. Orange pink.................

Hercules. Soft rose pink............. .15

Illumination. Glowing salmon cerise..... . . .

Lavender King. Rich, deep lavender..... . .15

Mauve Beauty. Rosy mauve........... . .15

Meadow Lark. Rich cream ................. .15

Melody. Rose pink on white ground............ 15

Morning Star. Deep orange scarlet in standard, with rich, orange-pink wings........

Mrs. A. A. Skaach. Clear, light pink. . . . .

Mrs. M. Spanolin. Pure white.................

Mrs. William Sim. Salmon pink.............

Othello. Flowers large; a beautiful maroon ....

Pink and White....

Pink Beauty. Rose pink on white ground.

Primrose Beauty. Deep primrose, flushed rose......

Red Orchid. Bright cherry red............

Rose Queen. Flowers are borne freely on long stems, are of large size, and usually four flowers are produced on a stem. Color a most attractive shade of pink ..... 1/4 oz., $\$ 1.25$

Sankey. Large white; black seeded........

Snow Flake. Large pure white...........

Snowstorm. White; extra large............

Song Bird. Pale pink on white ground....

Songster. Rich lavender................

Spring Maid. Light pink on white ground....

True Blue $(N e w)$. A charming blue self; flowers large and well waved............

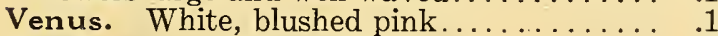

Warbler. Rich, mauve purple.............. 15

White Orchid. Pure white ..............

Yarrawa. Flowers exquisitely waved, and of large size, many of them being duplex or double. Color, a pleasing shade of bright rose pink with lighter wings..............

Zephyr. Pale blue or lavender.............

Zvolanek's Rose. Extra large; rose pink... $\quad .15$

Mixed Colors. Winter Flowering Spencer... . .10
$.60 \quad 1.00$

$.60 \quad 1.00$

$.60 \quad 1.00$

$60-1.00$

$.60 \quad 1.00$

$.60 \quad 1.00$

$.60 \quad 1.00$

$60 \quad 1.00$

$2.25 \quad 4.00$

$.60 \quad 1.00$

$.60 \quad 1.00$

$.60 \quad 1.00$

$.60 \quad 1.00$

$.60 \quad 1.00$

$.60 \quad 1.00$

$.75 \quad 1.25$

$60 \quad 1.00$

$.60 \quad 1.00$

$.60 \quad 1.00$

$.60 \quad 1.00$

$.75 \quad 1.25$

$.60 \quad 1.00$

$.60-1.00$

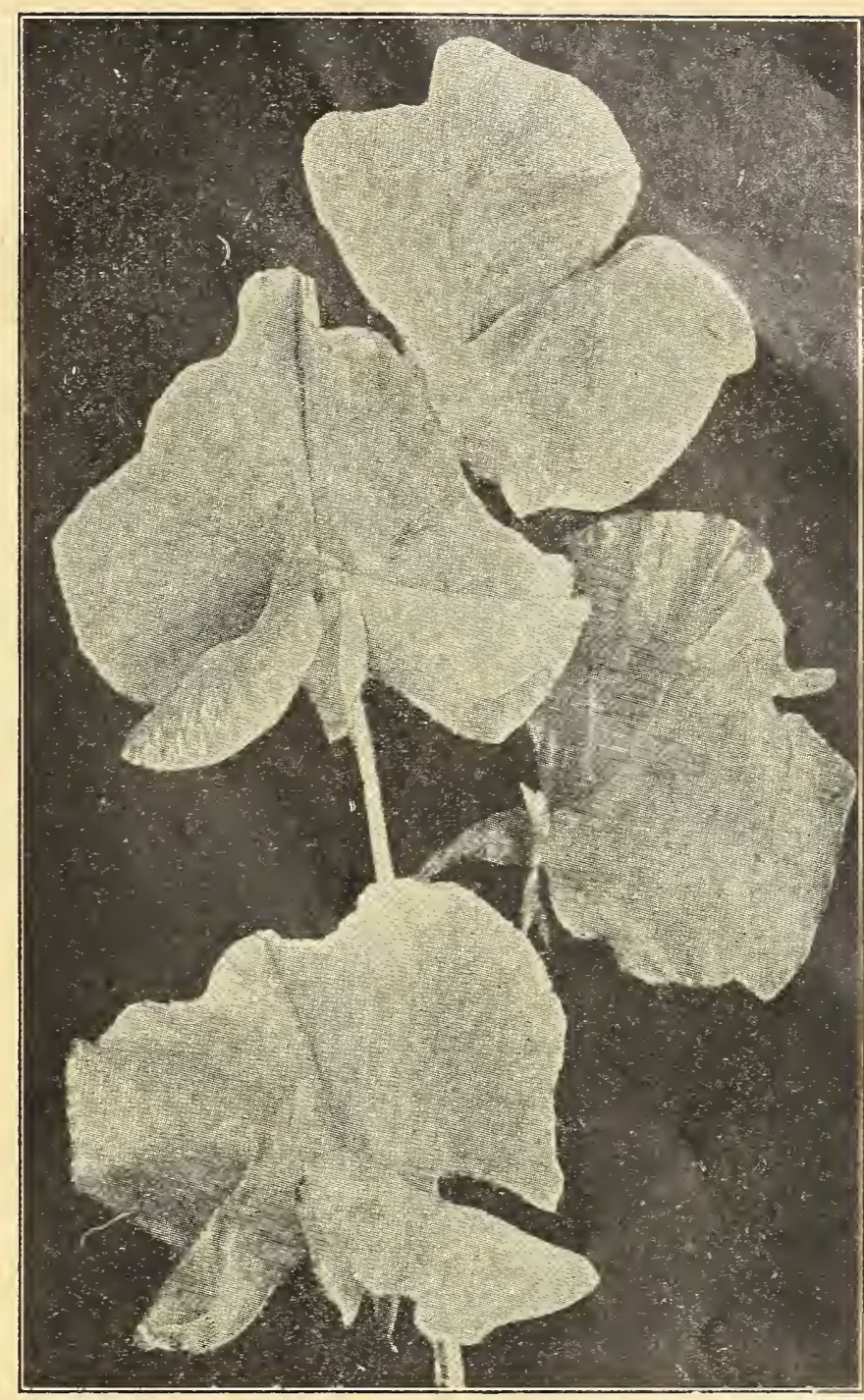

Winter Flowering Spencer or Orchid Sweet Pea

WINTER FLOWERING GRANDIFLORA

Christmas Pink. Pink and white.

Christmas White (Florence Denzer)

Earliest of All. Pink and white

Lavender Nora. A large flowering variety of

the Unwin type.

Mont Blanc. Pure white

Mrs. Alex. Wallace. Lavender

Mrs. F. J. Delansky. Daybreak pink

Mixed. Winter flowering grandiflora

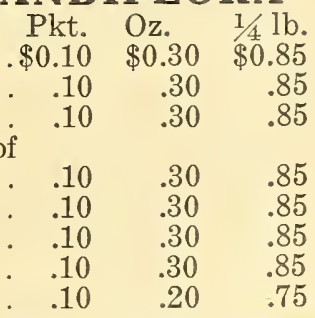

For Sweet Peas especially adapted for outdoor planting, see page 30 .

\section{NITROGEN-GATHERING BACTERIA}

An ideal preparation for treating Sweet Pea Seed when planting. Makes larger and more flowers, longer stems; proongs the blooming period.

Farmogerm. Trial size, 50c.

Mulford Culture. Trial size, $35 \mathrm{c}$

Standard Inoculating. Trial size, 25c.

\section{TESTIMONIAL}

Enclosed find money order for which please send me

Sweet Peas assorted. I purchased this variety last

they turned out to be the best and largest Sweet Peas

grew. 


\section{SWEET ROCKET (Hesperis)}

Excellent for naturalizing among shrubbery or for planting in a permanent border.

Mixed. Fragrant white and purple flowers; hardy Large pkt. Pkt. perennial; 2 to 3 feet oz., 50 c. $\$ 0.25$

$\$ 0.05$

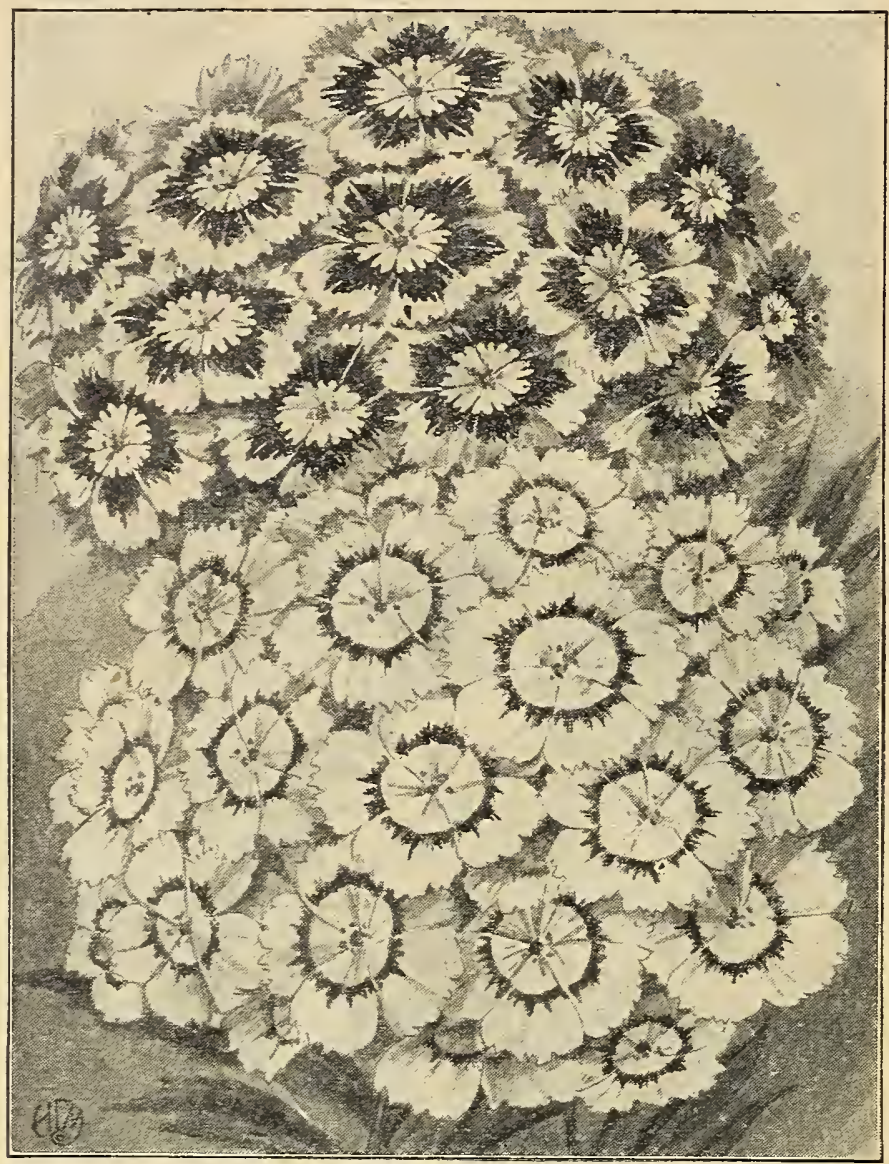

Single Sweet William

\section{SWEET WILLIAM (Dianthus Barbatus)}

One of the finest hardy garden plants; of easy culture, and lasting for years. The plants grow about $1 \frac{1}{2}$ feet high, and form fine clumps; produces fine effects in beds and shrubbery.

Large pkt. Pkt.

Auricula Flowered. A beautiful class of "eyed"

single varieties; all colors mixed. . ...... oz., 90c.\$0.25 $\$ 0.10$

Single Crimson....................... oz., 75c. $.25 \quad \begin{aligned} & .10 \\ & \text {. }\end{aligned}$

" Pink Beauty. Salmon pink

“ Scarlet Beauty. Deep scarlet. . $\quad .50 \quad .15$

“ Velvety Maroon ..................., 75c. $.25 \quad .10$

White........., 75c. $.25 \quad .10$

Mixed. All colors ................... oz., 60c. .25 .05

Double Mixed

\section{VIOLA CORNUTA (Tufted Pansies)}

These resemble pansies in shape and form, with the additional quality that they are of long stems, and appear uninterruptedly from early spring till snow flies.

Admiration. Dark blue................\$0.60 $\$ 0.10$

Mauve Queen. Lovely mauve color . . . . . . . . . . $\quad .60 \quad .60$

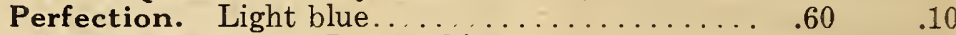

White Perfection. Large white . . . . . . . . . .60 .10

Mixed. All colors . ...................... 50

\section{VIOLA (Scotch Bedding Pansies)}

These are very free flowering and cannot be surpassed for bedding purposes; produce larger flowers than the Viola Cornuta.

Golden Gem. Yellow ................\$0.60 \$0.15 Lutea Splendens. Rich golden yellow . . . . . . . .60 $\quad .10$

Snowflake. Pure white ................. .60 $\quad .15$

Mixed. From the best named Scotch varieties . . .

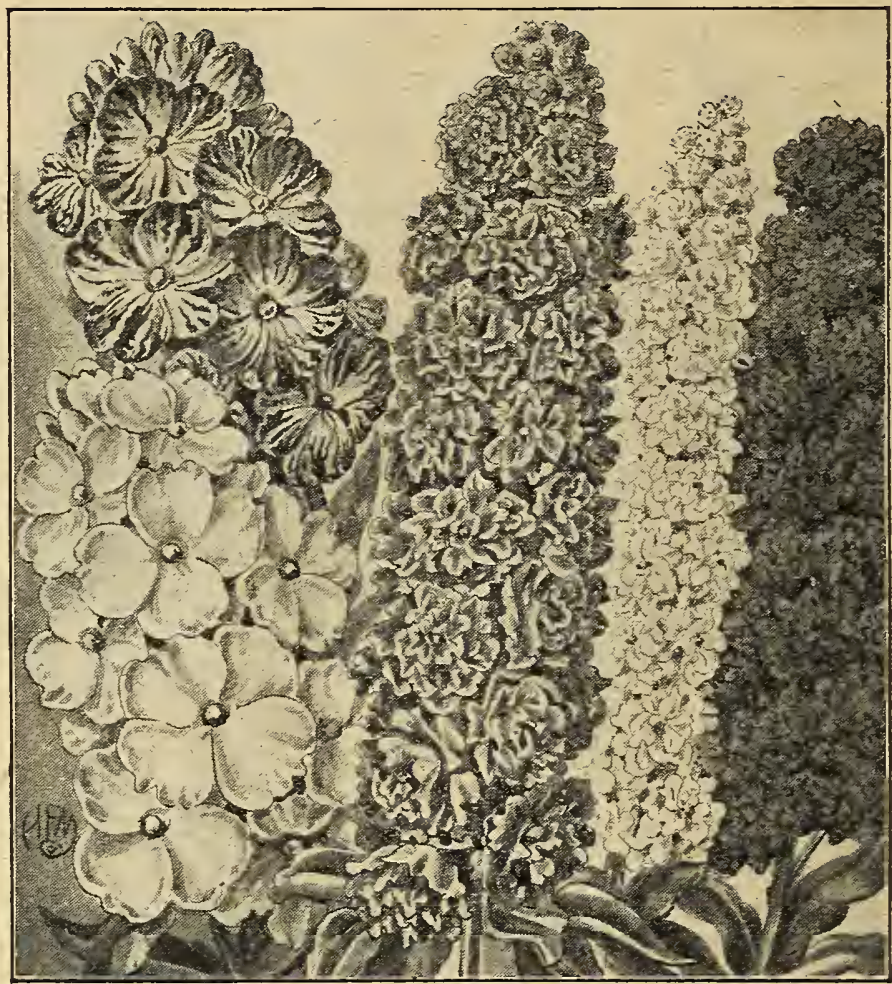

Wallflowers, Single and Double

\section{WALLFLOWER}

Half-hardy perennials of delicious fragrance. They should be protected in a cold frame in the winter and planted out in the spring; splendid for cutting; $1 \frac{1}{2}$ to 2 feet. Large pkt. Pkt.

Double Brown ..................... \$0.60 $\$ 0.10$

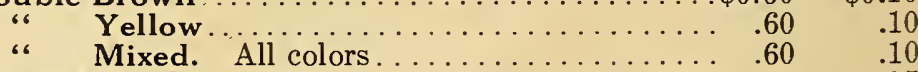

Single Mixed.

Imported Collection. 6 double varieties........

Imported Collection. 6 single varieties.......... $\quad .40$

Paris Extra Early. A single-flowering variety, which may be treated as an annual, flowering the first year from seed; $11 / 2$ feet.

\section{VALERIANA (Garden Heliotrope)}

Hardy perennial border plants; large fragrant flowers, the odor resembling that of the heliotrope; 2 to 3 feet.

Mixed Colors

Large pkt. Pkt. $\$ 0.25 \$ 0.10$

\section{VERONICA (Speedwell)}

An elegant hardy perennial plant of easy culture and freeflowering habit; of value as a cut flower or for garden effect. Plants grow bushy and produce long spikes of flowers.

Spicata. Large pkt. Pkt. picata. Long spikes of bright blue flowers; 18

$\$ 0.40 \$ 0.10$

Large pkt. Pkt.

Paris Extra Early Blood Red . . . . . . . . . . . \$0.25 \$0.10

$\begin{array}{llr}\text { Paris Extra Early Yellow . All colors . . . . oz., 60 6. } & .25 & .25\end{array}$

\section{PERENNIAL FLOWER GARDEN MIXTURE}

To create an old-fashioned wild garden or to naturalize along roads or woods we highly recommend this mixture, as it contains a large number of varieties of the choicest old-fashioned flowers. Pkt., 10c.; 40c. per oz.; per $1 / 4$ lb., $\$ 1.25$. 
A complete offering will be found in our General Catalog of Seeds that was issued in January; a copy may be had on request.

\section{WE PAY POSTAGE AND PACKING CHARGES}

(Except as noted)

on all orders for vegetable and flower seeds, provided the order calls for packets, ounces, quarter-pounds and pounds (beans, corn, peas and mixed grass seeds are not included), or such other seeds where mention is made in catalogue. If these seeds are wanted by mail, remit for postage. (Consult your post office for weight limits.)

\section{BEANS FOR FORCING}

Stringless Forcing. For culture under glass or for outdoor planting; the pods are long, slender, and round in shape; it grows dwarf and compact, and is a heavy yielder. Per pkt., 10c.; 40c. per lb.; 2 lbs., 75c.; $\$ 1.60$ per 5 lbs.; 10 lbs., $\$ 3.00$.

Triumph of the Frames. Splendid for forcing under glass, producing a narrow, tender pod of considerable length. Per pkt., 10c.; 60c. per lb.; 2 lbs., $\$ 1.10 ; \$ 2.50$ per 5 lbs.

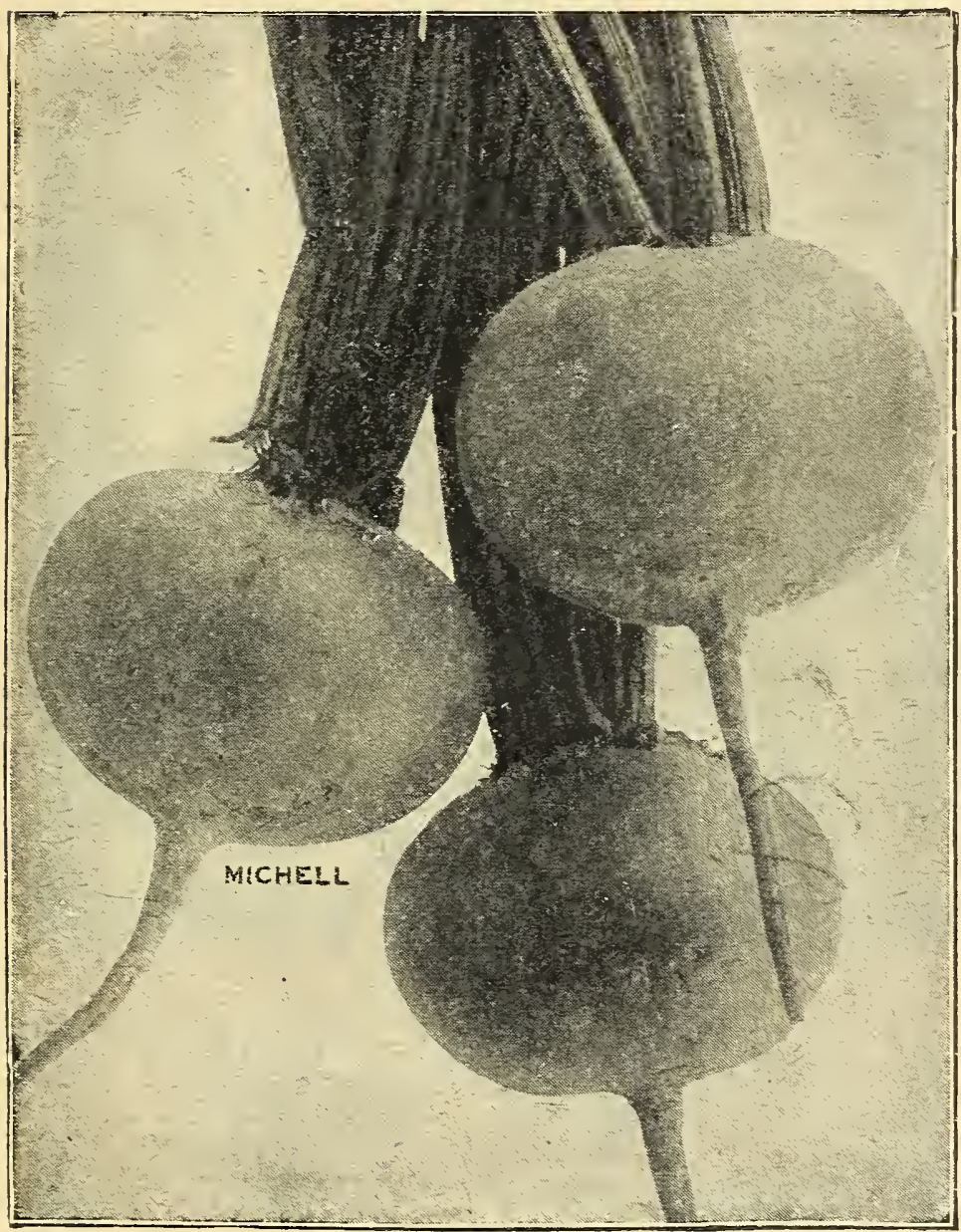

Beet, Crosby's Egyptian

\section{BEET (Table Varieties)}

Pkt. Oz. $1 / 4$ lb. Lb.

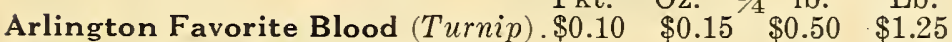
Bassano Extra Early (Turnip) ...... $.10 \quad \begin{array}{llll}.15 & .50 & 1.25\end{array}$

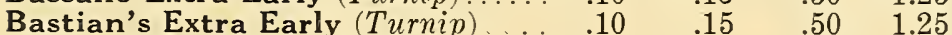
Bastian's Half Long Blood. $.10 \quad .15 \quad .50 \quad 1.25$ Crimson Globe (Michell's Improved). $\begin{array}{llll}.10 & .15 & .50 & 1.25\end{array}$ Crosby's Egyptian (Turnip) Detroit Dark Red (Turnip) Eclipse Extra Early (Round) Lentz Early Michell's Ideal Michell's Winter Keeper

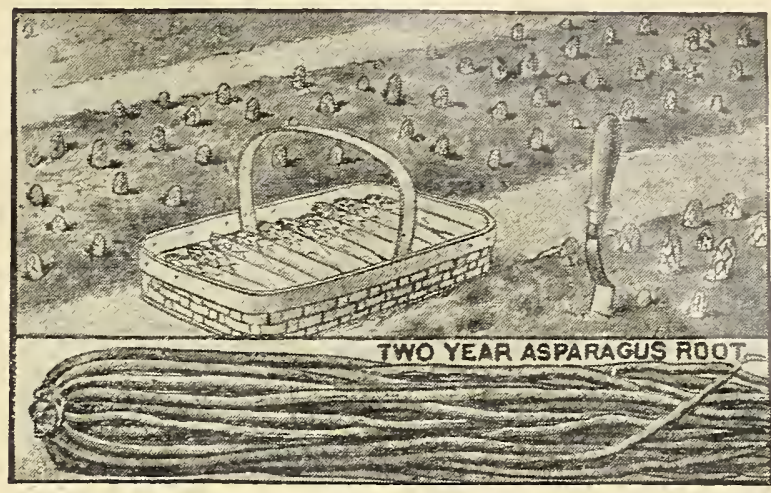

\section{ASPARAGUS ROOTS Ready after October 15th)}

4,000 to 6,000 roots required for an acre, according to the distance set apart.

Asparagus roots are planted quite extensively during the autumn and invariably give good results; we do not advise planting after the ground has been frozen at that season.

$$
\begin{array}{ll|lll}
\text { 2-Year-Old Roots } & 3 \text {-Year-Old Roots } \\
\text { Doz. } 100 & 1000 & \text { Doz. } 100 & 1000
\end{array}
$$

Barr's Mammoth ..... \$0.35 $\$ 2.00 \$ 12.50 \quad \$ 0.45 \$ 2.25 \quad \$ 17.50$

\begin{tabular}{llll|lll} 
Conover's Colossal.... & .35 & 2.00 & 12.50 & .45 & 2.25 & 17.50
\end{tabular}

$\begin{array}{llllllll}\text { Giant Argenteuil....... } & .35 & 2.00 & 12.50 & .45 & 2.25 & 17.50\end{array}$

$\begin{array}{lllllll}\text { Palmetto or Eclipse... } & .35 & 2.00 & 12.50 & .45 & 2.25 & 17.50\end{array}$

\section{FORCING CARROTS}

Early Half Long Scarlet. A very desirable pointed root variety of fine flavor and good color. Pkt., 10c.; 15c. per oz.; 40c. per $1 / 4 \mathrm{lb}$; per $1 \mathrm{~b} ., \$ 1.25$.

Oxheart or Guerande. An early forcing variety; small round roots, not much larger than a Radish. Pkt., 10c.; 15c. per oz.; $1 / 4$ lb., 35c.; $\$ 1.00$ per lb.

Rubicon Half Long. Of excellent shape and extremely well adapted for early forcing. Pkt., 10c.; 15c. per oz.; $1 / 4 \mathrm{lb}$., 35c.; $\$ 1.00$ per $\mathrm{lb}$.

Very Early Short Horn Scarlet or French Forcing. An early forcing variety; small round root, not much larger than a radish. It may be sown outdoors as well as under glass. Pkt., 10c.: 20c. per oz.; 1/4 lb., 40c.; $\$ 1.25$ per lb.

CAULIFLOWER (Varieties Suitable for Forcing

Michell's Earliest Snowstorm. Colossal heads of purest white averaging often 10 inches in diameter; being very long and compact, it gives enormous weight to the individual heads. Pkt., 25c.; 50c. per large pkt.; 1/4 oz., \$1.25; $\$ 2.25$ per 1/2 oz.; 1 oz. $\$ 4.00$.

Michell's Special Strain Selected Erfurt. One of the earliest in cultivation; small leaved; splendid forcer. Pkt., 25c.; 50c. per large packet; $1 / 4$ oz., $\$ 1.00 ; \$ 1.65$ per 1/2 oz.; oz., $\$ 3.00$.

Early Snowball. A splendid early variety, producing magnificent, medium size white heads. Pkt., 25c.; 50c. per large pkt.; $1 / 4$ oz., $\$ 1.00 ; \$ 1.65$ per $1 / 2$ oz.; per oz., $\$ 3.00$.

\section{CORN SALAD (Fetticus}

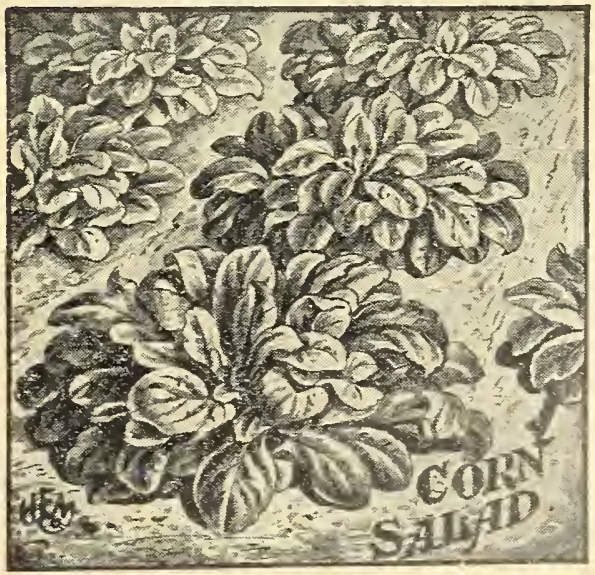

This is principally sown for a supply of greens during winter and early spring months. Sow in September broadcast; when cold weather approaches, cover with a litter of leaves or long manure or straw, and upon approach of spring the covering can be can also be gathered on mild days during winter. Large Leaved, Round Seeded.

large $p k$ 


\section{${ }^{34}$ MICHELL'S SEASONABLE VEGETABLE SEEDS, ETC.}

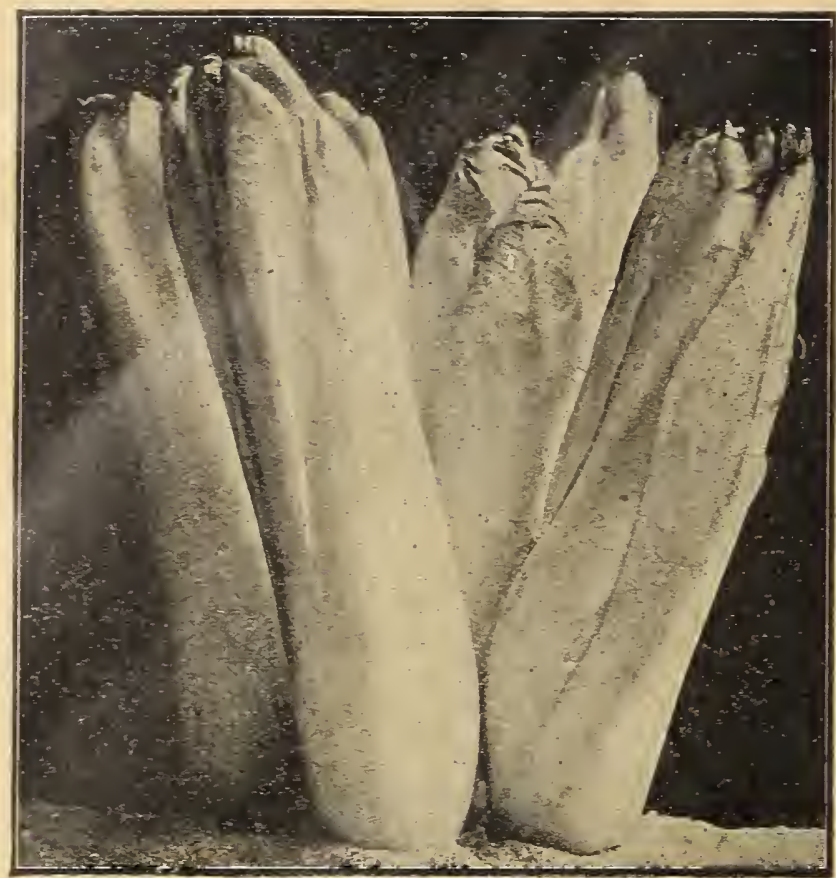

Witloof Chicory

WITLOOF CHICORY ROOTS

(Ready December 1st)

Used only as a winter vegetable, the top part only being edible. Plant under a bench in the greenhouse or dry, warm portion of a cellar in a bed of rich garden soil 12 inches deep; place close together and keep dark, so the tops will blanch, and not open or separate, and the top growth remains intact, as the illustration shows. It may be cut any time after 5 inches growth, before the heads begin to expand. Roots should be set in the soil six inches below the surface. A continuous supply of this delicious winter vegetable can be had from December 1st to April 1st. A cold frame makes also an ideal place for forcing them in the late winter or early spring months. Strong Roots, $75 \mathrm{c}$. per doz.; per 100 , $\$ 5.00$.

\section{WATER CRESS}

This may be grown on a greenhouse bench just as successfully as along a stream of water, and a continuous crop may thus be assured regardless of weather conditions. Nothing can compare for flavor with the delicious tenderness of young Water Cress.

True Erfurt.

10 c.; $25 \mathrm{c}$. per $1 / 2 \mathrm{oz}$. oz., 50c.; $\$ 1.50$ per $1 / 4$ lb.; - per lb., $\$ 5.00$.

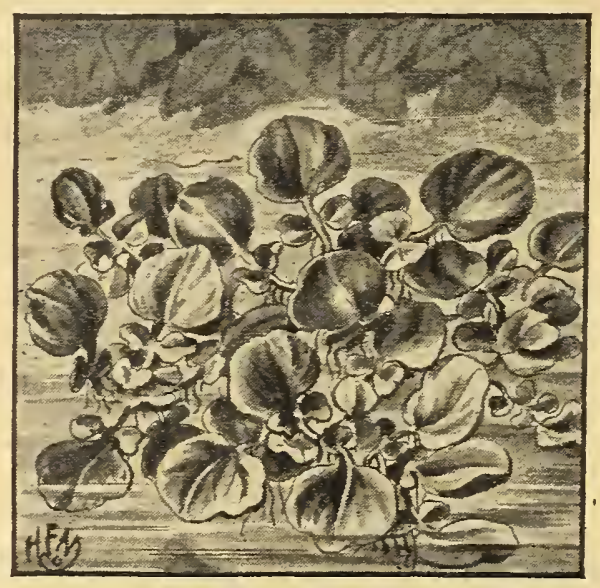

Water Cress

\section{KALE OR BORECOLE}

One ounce will sow a drill $150 \mathrm{ft}$. long; 3 lbs. will sow an acre.

For early use it may be sown in May; when desired for winter use, sow in September, broadcast or in rows $2 \mathrm{ft}$. apart. Cover for protection against severe freezing and snow. Do not handle while in a frozen condition. One of the finest nutritious greens for winter and early spring use.

Dwarf Green Curled. This variety is very compact growing, rarely attaining a height over six inches. The color is dark green, very curly. Pkt., 10c.; 15c. per oz.; 1/4.lb., 35c.; $\$ 1.10$ per lb.

Imperial Long Standing. The leaves are very crimpy and of a dark green color. It stands quite tall, and is an excellent producer. It is just as hardy as any of the other sorts, and will be found very profitable where quantity as well as quality is desired. Pkt., 5c.; 10c. per large pkt.; 0z., 15c.; 40c. per $1 / 4$ lb.; lb., $\$ 1.25$.

\section{ENGLISH CUCUMBERS}

These are splendid for growing in hotbed frames during the summer months, in preference to the open garden ground. They can thus be started earlier and protected during cool nights, as they are more tender

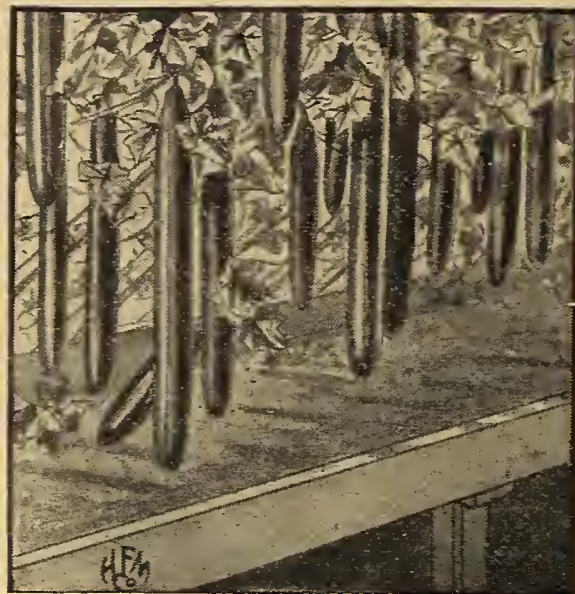

English Greenhouse Cucumbers than the regular outdoor varieties. They may also be grown under glass in greenhouses during the winter, producing enormous fruits, generally 18 to 24 inches long and 3 inches in diameter. They have a delicate flavor and possess very few seeds; for slicing, no other sorts can approach them.

Lockie's Perfection, Sion House, Telegraph, Tender and True. Per packet of 12 seeds of either of the 4 sorts above, 25c. per pkt.; 100 seeds, $\$ 1.75$.

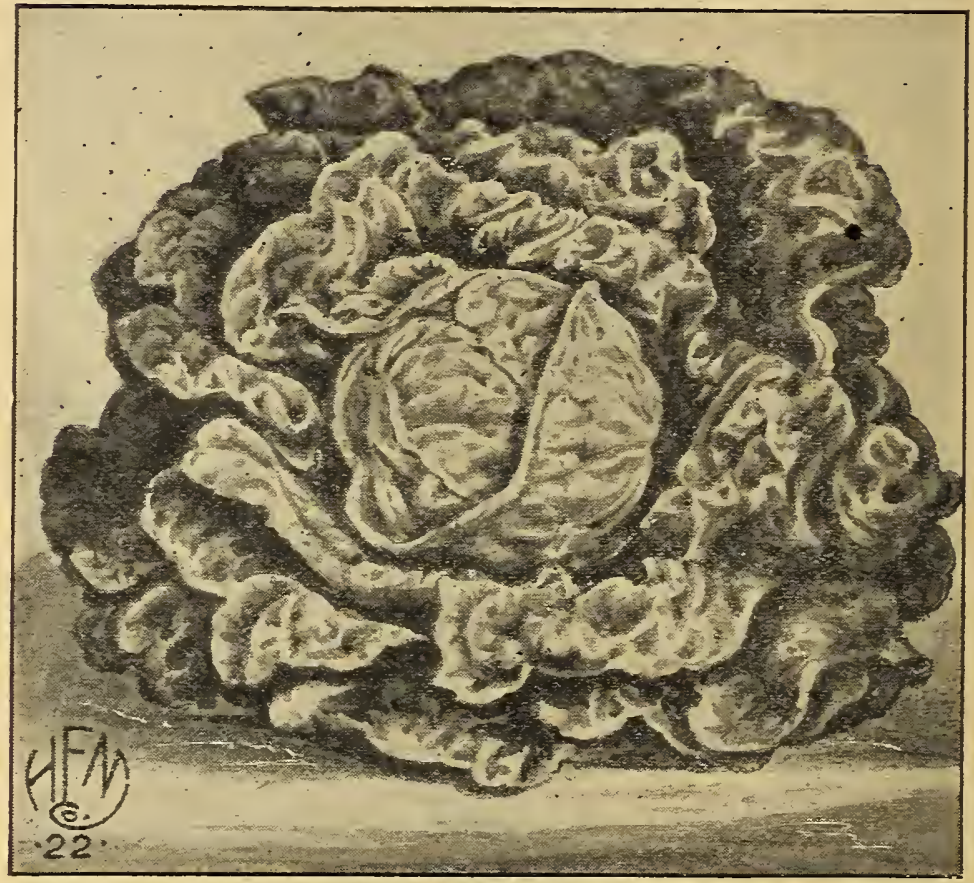

Lettuce, Boston Market

\section{LETTUCE (Heading Varieties)}

Pkt. Oz. $1 / 4$ lb. Lb.

All Right (Michell's) . . . . . . . . \$0.10 $\$ 0.25 \quad \$ 0.60 \quad \$ 2.00$

Big Boston.................. $.10 \quad .25 \quad .60 \quad 2.00$

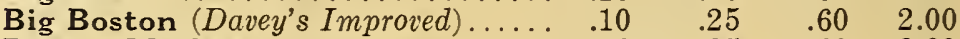

Boston Market............... . .10

Dutch Butter (Private Stock)......... .10

Hanson Improved . . . . . . . . . .

Kingsholm Cos or Romaine..... $\quad .10$

May King......................... 10

Michell's Number One . . . . . . . . 10

Prize Head .................. . . . . . . . . .

Way-a-head ................. 10

.250 .60

$.25 \quad .60$

$.25 \quad .60$

$.25 \quad .60$

$.25 \quad .60$

$.25 \quad .60$

$.25 \quad .60$

2.00

2.00

2.00

2.00

2.00

2.00
.60

$.60 \quad 2.00$

\section{LETTUCE (Loose Leaf Varieties)}

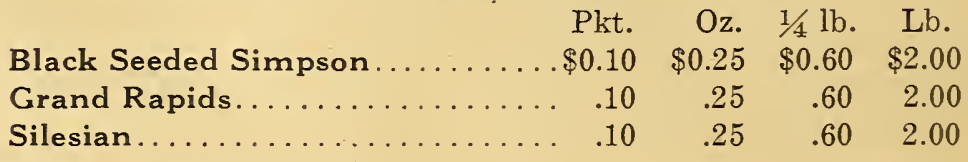




\section{MICHELL'S SEASONABLE VEGETABLE SEEDS, ETC. 35}

\section{FORCING MELONS (English Varieties)}

Forcing melons can be grown successfully outside in hotbeds. Sow seed in pots in March and transplant to hotbed when three leaves have developed; these will ripen fruit in June and July.

For indoor use treat same as forcing cucumbers.

Blenheim Orange. A handsome, scarlet fleshed variety of delicious flavor and beautifully netted. Sets well and is very prolific. Pkt., 25c.

Invincible Scarlet. Form globular; skin orange red when perfectly ripe; finely and evenly netted; thick, bright scarlet flesh of exquisite flavor. Pkt., 25c.

Sutton's A 1. Fruits large, globular and densely netted. Flesh thick, of a rich scarlet color and of a delicious flavor. Original pkt., $\$ 1.00$.

Windsor Castle. A green fleshed variety of excellent quality. Fruit oval in form, of large size and handsomely netted on a dark green ground; flesh thick and of a pale green color. Pkt., 25c.

MELON NETS. For supporting forcing melons in greenhouses; made very strong, will last for a number of crops. $\$ 2.25$ per doz.; per $100, \$ 15.00$.

\section{MUSTARD}

One ounce will sow a row 75 feet long. It makes a delicious green salad, pungent in taste, highly palatable and healthy. Sow every two weeks in rows the same as spinach. It must be used

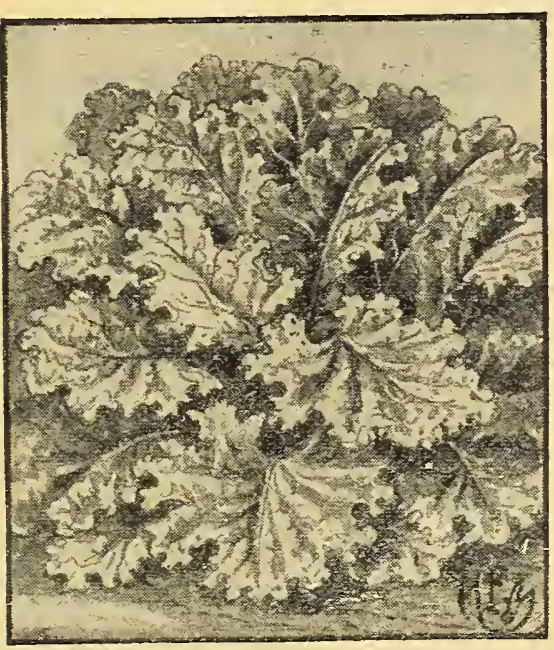

Mustard, Southern Giant Curled while young, as only then is it tender and mild. Fine winter greens if sown in a heated frame or greenhouse; also fine if served with lettuce for flavoring. The seed can be harvested if the plant is allowed to stand and used for other culinary purposes.

SouthernGiant Curled. The best of the curled mustards; of sweet flavor; matures very early and produces abundant foliage. Pkt., 10c.; $15 \mathrm{c}$. per oz.; 1/4 lb., 30c. $85 \mathrm{c}$. per $1 \mathrm{~b}$.

White or Yellow. Pkt. 5c.; 10c. per large pkt. oz., 15c.; 30c. per $1 / 4$ lb.; lb., $85 \mathrm{c}$.

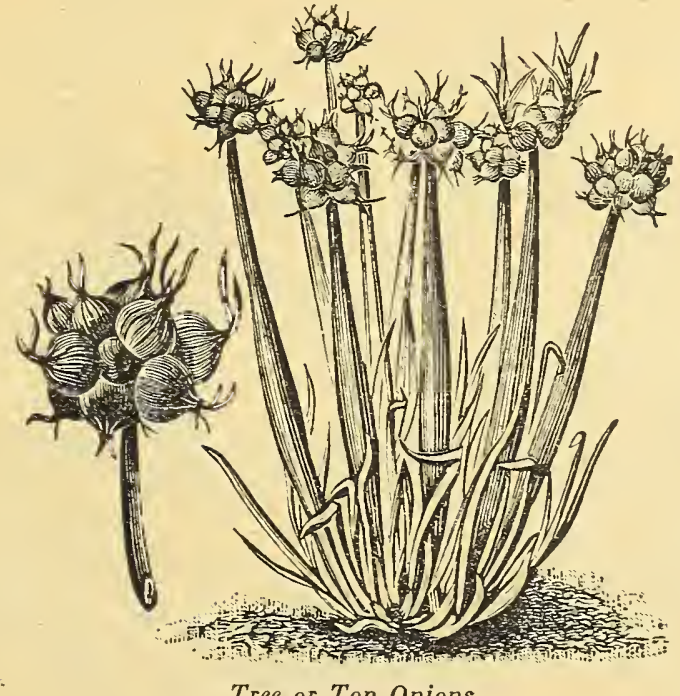

ONION SETS

Tree or Top. Should be planted in September for early spring use; they are perfectly hardy. 28 lbs. per bushel. Per qt., 20c.; 60 c. per 4 qts.; peck, $\$ 1.00 ; \$ 3.50$ per bushel.

White. $32 \mathrm{lbs}$. per bushel............. Prices will be quoted Yellow. 32 lbs. per bushel............ on application.

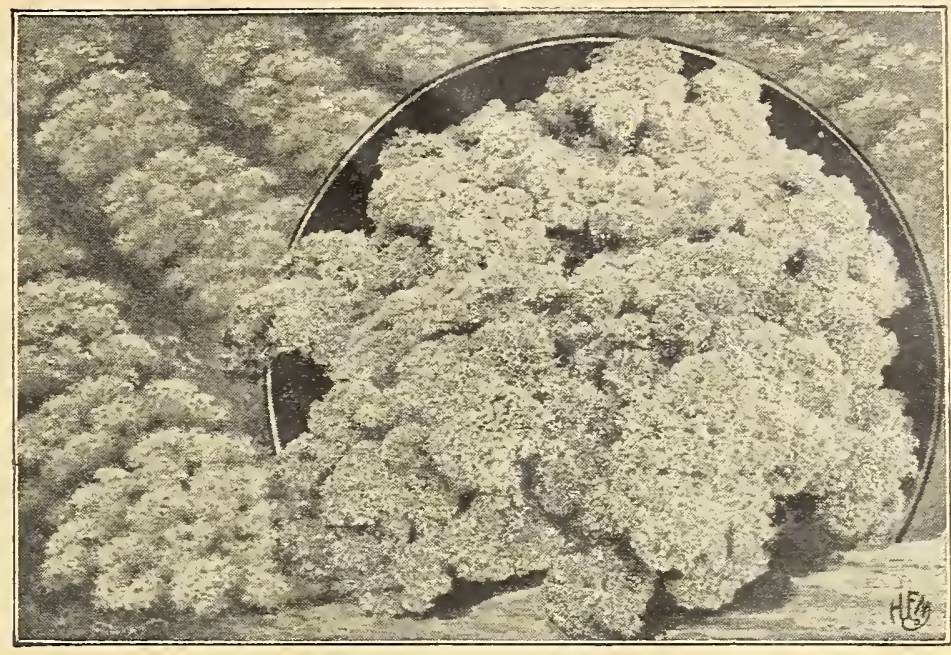

Double Curled Parsley

\section{PARSLEY}

One ounce will sow a row $100 \mathrm{ft}$. long.

After soaking the seed for a few hours in warm water, it should be sown in rows 18 inches apart, and when 2 inches high thinned out so the plants will stand 4 inches apart in the row. It takes parsley seed from 3 to 6 weeks ordinarily to germinate, so that a little patience in growing this is necessary. Parsley can be continued over winter, if given a heavy covering of long manure.

Champion Moss Curled. Beautifully crimped and curled. Pkt., 5c.; 10c. per large pkt.; oz., 15c.; 45c. per 1/4lb.; lb., $\$ 1.25$.

Double Curled or Covent Garden. A great improvement over all other varieties; a nicely curled leaf which has a tendency to retain its deep green color the entire season. Pkt., 10c.; 20 c. per oz.; $1 / 4$ lb., 60 c.; $\$ 1.50$ per lb.

Hamburg or Rooted. The fleshy roots are used for flavoring soups, stews, etc. Pkt. 10c.; oz., 15c.; 1/4 lb., 45c.; $\$ 1.25$ per lb.

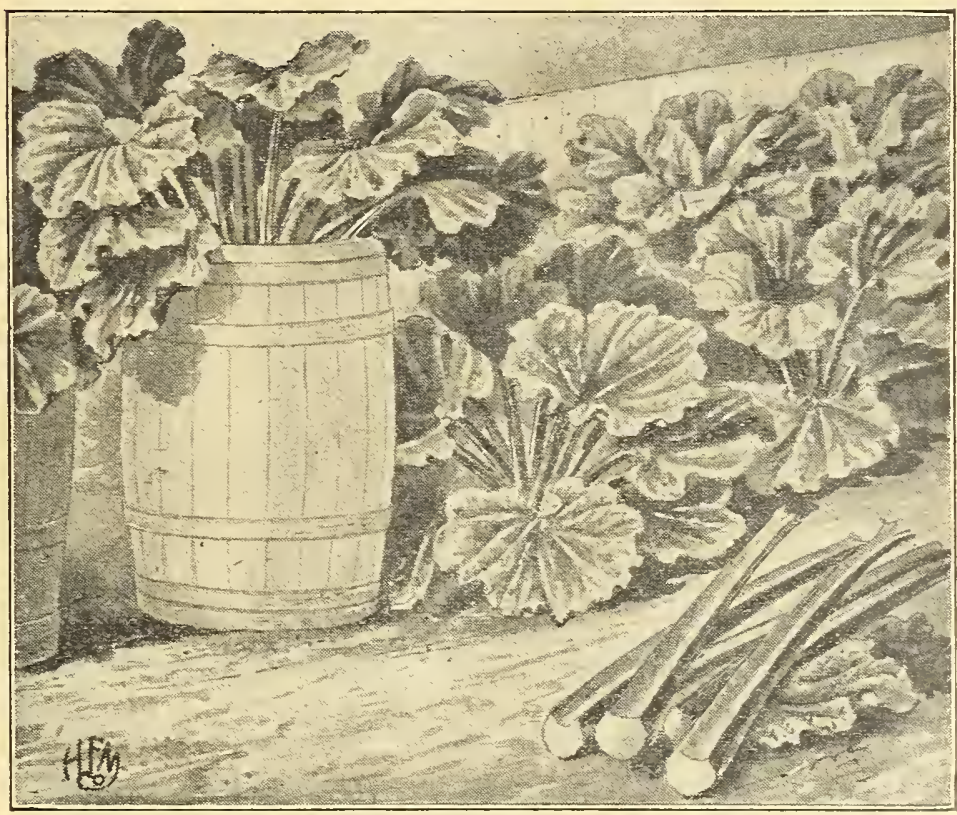

RHUBARB ROOTS (Ready in October

Rhubarb is as readily obtainable in winter as in spring. clumps, which should be at least four years old, should be planted in good garden soil in a cool cellar, preferably as dark as bottom, should be placed over each root to draw the to Does extra well under greenhouse benches. Place the close as possible. When spring approaches and rhubar able outdoors the clumps may be planted out for
season. The roots should always be subjected to before planting indoors.

Victoria, First Size Roots.

$\$ 1.50 ; \$ 10.00$ per 100 .

Victoria, Mammoth Roots. For forcing

$35 \mathrm{c}$. each (not mailable); doz., $\$ 3.50$ 


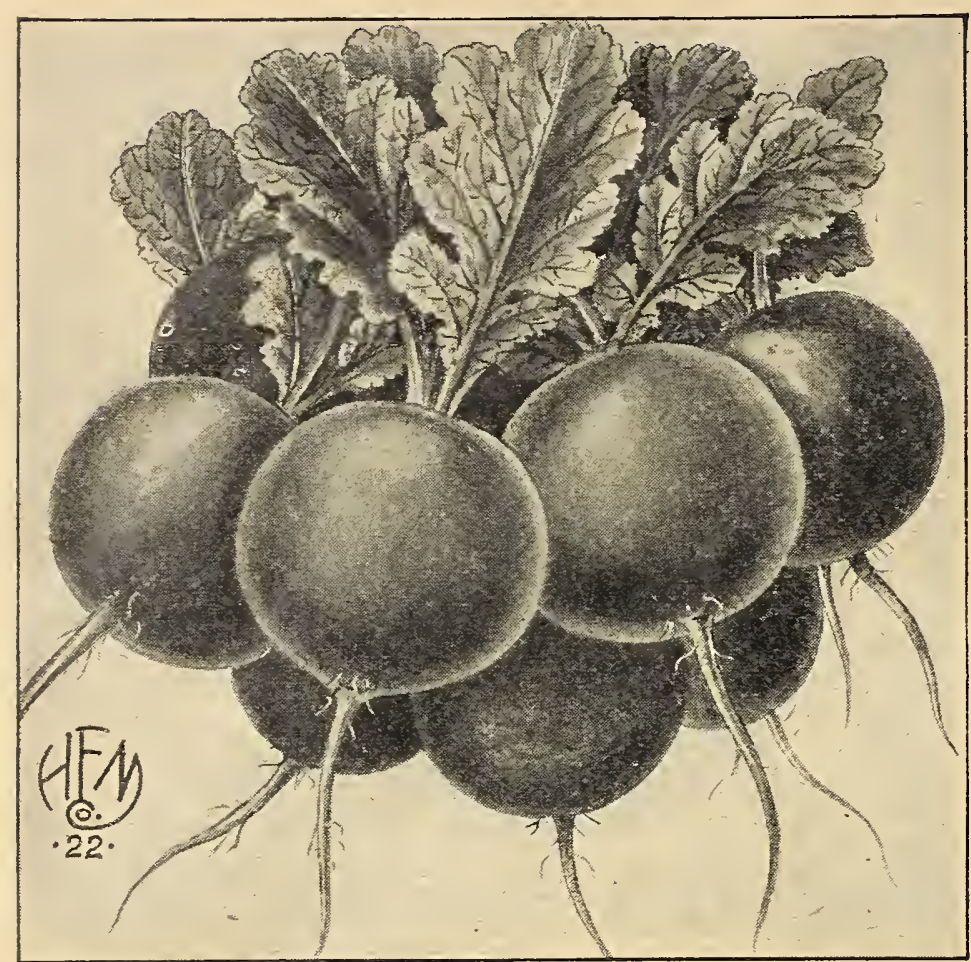

RADISH

EARLY VARIETIES

Cardinal Globe (Improved Strain). This popular radish will be welcomed readily in an improved form. The color and shape, a vivid scarlet oval form, are perfect. Pkt., 5c.; 10c. per large pkt.; oz., 20c.; 50c. per $1 / 4$ lb.; lb., $\$ 1.75$.

Early French Breakfast. Oblong shape; rapid grower; very mild and tender; of a beautiful scarlet color, tipped with white

Icicle (Improved Strain). A magnificent white variety of fine taste; grows $31 / 2$ to 4 in. long in 22 days. Also suitable for summer sowing.

Long Scarlet Short Top, or Salmon. A favorite variety; long, bright scarlet with small top.

Round Red Forcing, or Button. Very quick in maturing; splendid for hotbed or garden culture.

Scarlet Turnip, White Tipped. Fine early scarlet variety with white tip.

White Box, Felton's (Private Stock). A selection of the old reliable White Box radish; more perfect form, producing shorter tops, and does not have a tendency to grow long in shape. Pkt, 5c.

\section{SUMMER AND WINTER VARIETIES}

Celestial, or White Chinese. Large size. Pure white; excellent keeper.

China Rose. Bright rose color; flesh firm. One of the best for winter use. Half-long in shape with a scarlet blunt tip. Winter radishes should be cultivated more extensively than they are.

Half Long Black. A great improvement on the old Long Spanish Radish.

White Strasburg. Oblong; of a pure white color and mild flavor; a splendid variety for summer.

Prices.-Any variety of Radish offered on this page (except where noted) 10c. per pkt.; per oz., $15 \mathrm{c}$.; 45c. per $1 / 4 \mathrm{lb}$; per lb., $\$ 1.25$.

\section{SPINACH}

Bloomsdale Round Seeded Savoy (Improved Strain). The hardiest variety; curled and crimped, thick, fleshy leaves; the best for early spring and fall sowing. Per oz., 10c.; 15c. per $1 / 4$ lb.; lb., 50c.; $\$ 2.25$ for 5 lbs.

Long Season. A cross between the Bloomsdale and the Victoria Long Standing. It produces tremendously large plants and leaves which are strong and robust. It will resist heat better without shooting to seed than any variety yet introduced. The leaves are somewhat curled and are tender. Color, a beautiful dark green. Per oz., 10c.; 15c. per $1 / 4$ lb.; lb., 50c.; $\$ 2.25$ for 5 lbs.

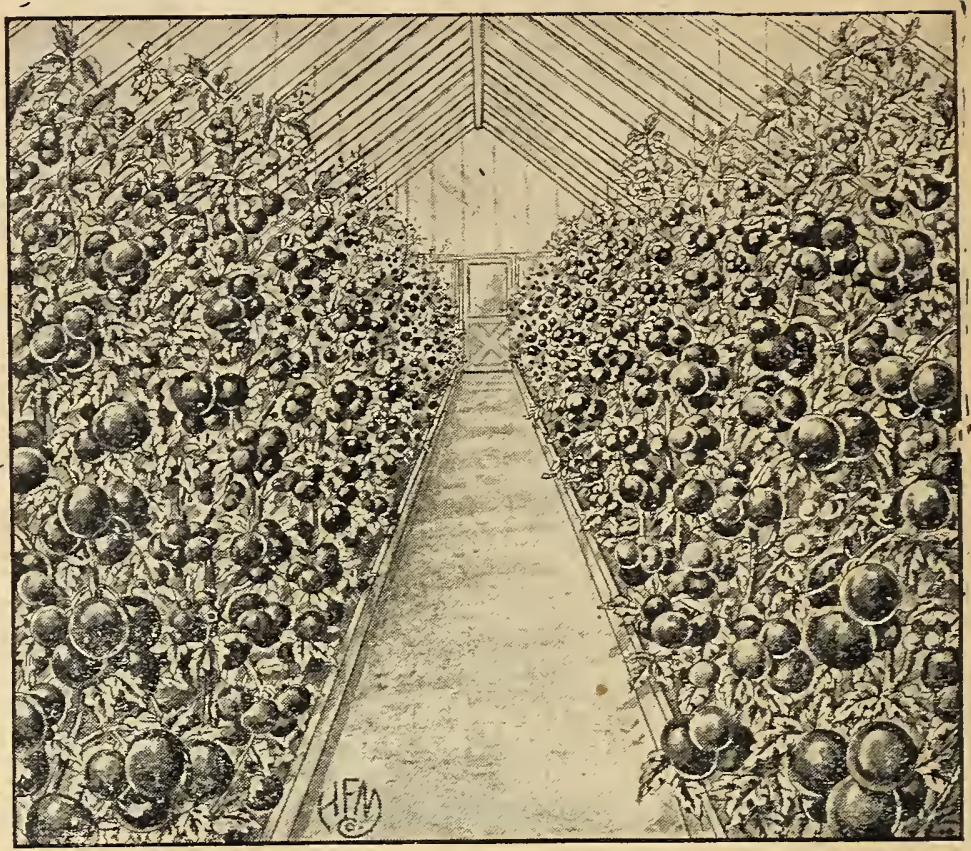

Tomatoes Growing in Greenhouse

TOMATOES (Adapted for Forcing)

Michell's Cracker Jack. One of the best for forcing. Fruits are of medium size and of a brilliant, rich scarlet color. Per pkt., 10c.; $1 / 2$ oz., 25c.; 45c. per oz.; $1 / 4$ lb., $\$ 1.50$.

Sutton's Best of All. The seed we offer is grown from Sutton's original stock. The fruit is medium sized, of an intense red color, and contains but few seeds. Pkt., 10c.; 25c. per $1 / 2$ oz.; oz., 50c.

Comet. A cluster averages 6 tomatoes of medium size of the brightest red, ripening up to the stem. Pkt., 10c.; 25c. per $1 / 2$ oz.; Oz., $45 \mathrm{c}$.

Sutton's Eclipse. A very smooth fruit, borne singly on plants which produce little foliage, a good point in a forcing tomato; vermilion red color; original packets, $\$ 1.25$.

\section{TURNIP AND RUTA BAGA}

Cow Horn Pkt. Oz. $1 / 4$ lb. Lb.

Early Purple Top, Flat $\$ 0.10 \$ 0.15 \$ 0.25 \$ 0.75$

White Globe (Private Stock)

Snowball

Southern Seven Top.

Yellow Aberdeen. Flat.

Yellow Globe, or Amber.

Ruta Baga, Yellow Purple Top (Private Stock)

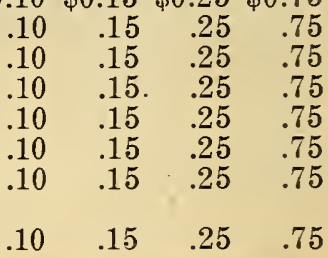

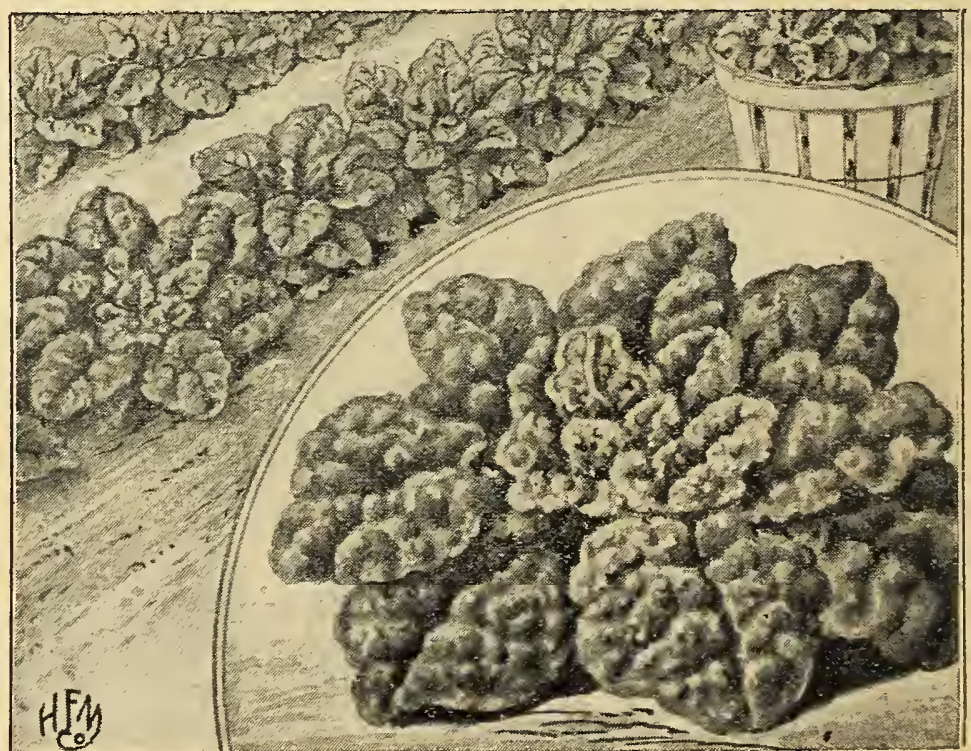

Spinach, Michell's Improved Strain Bloomsdale 


\section{MICHELL'S PURE “SPORE" CULTURE MUSHROOM SPAWN}

The growing of Mushrooms is rapidly increasing, and the demand for them has reached immense proportions. A fine crop of mushrooms can be secured with very little labor or expense, provided a suitable location can be obtained. Cellars, greenhouses and sheds can be used for their culture.

\section{SOMETHING NEW IN MUSHROOM SPAWN}

We are now prepared to offer our customers spawn that is made in quart milk jars under absolutely sterile conditions. The bottle and materials are sterilized under steam pressure of twelve lbs. so that every mould, weed seed or insect is destroyed and each bottle contains nothing but the pure spawn. Every particle is full run, covered with spawn grown direct from the spores. One carton of the spawn equals 5 bricks of ordinary spawn and is sufficient to spawn about 40 square feet. It is less expensive than brick

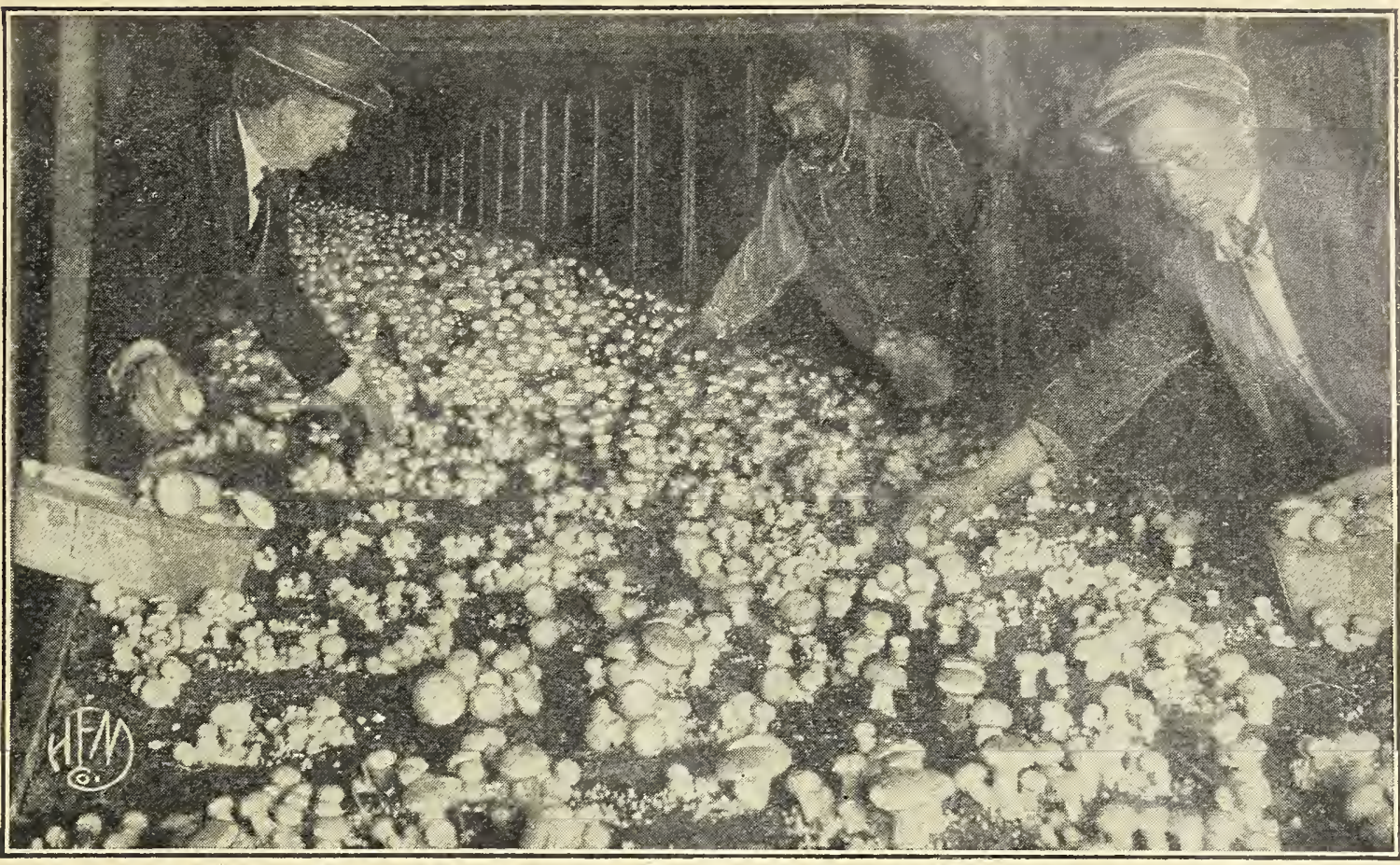
spawn and assures the amateur absolute success, always giving a crop if the beds are made properly. The sterile spawn is dried thoroughly and each piece wrapped in tissue paper, which contains full instructions, not only as to how the spawn should be used, but full particulars about growing mushrooms. Any one can order spawn and with it get the necessary knowledge to make growing entirely successful. PRICES

Per carton . . . . . . $\$ 1.00 \mid 25$ cartons.......... $\$ 22.50$ 12 cartons . . . . . . $10.75 \quad 60$ cartons............... 48.00

\section{Gentlemen: \\ TESTIMONIAL \\ Last fall I purchased spawn from you and I want to tell you} it is wonderful the way the mushrooms grew. I planted a bed about 5 by 9 feet and the bed was a solid mass of mushrooms.

\section{Yours truly,}

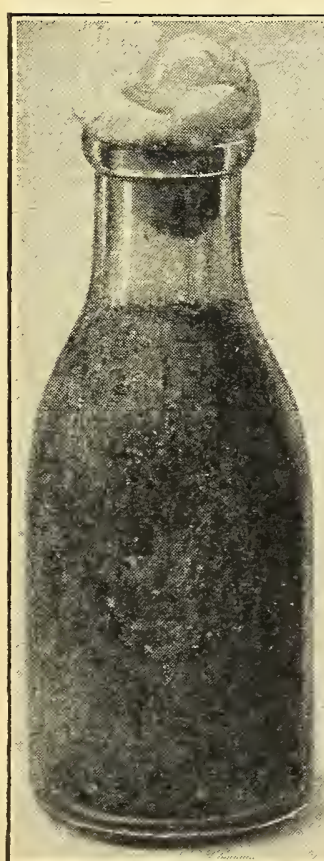

1. How the spawn is made and prepared for sterilizing.
E. J. B.

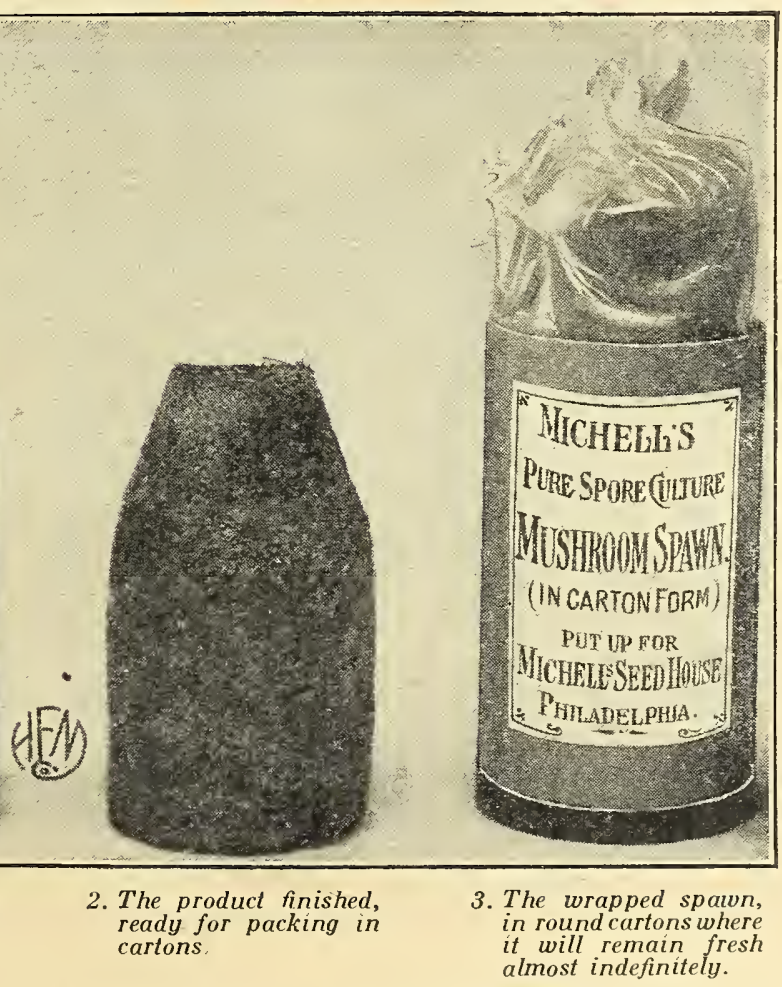

MICHELL'S "SUPERIOR" SPAWN (In Brick Form)

\section{If wanted by mail, allow for postage at rate of $10 \mathrm{c}$. per brick.}

Mushrooms are within the reach of anyone who has a greenhouse or a cellar. A crop is produced with good spawn, and a little care and patience in about 4 to 6 weeks, and continues bearing about two months. New beds can be started at intervals which will give a supply the entire season. The first planting can be made in July, the last in March. Summer spawned beds do not bear well. Ask for our Free Booklet on Mushroom Culture. 1 Brick will spawn 8 to $10 \mathrm{sq}$. ft.

\section{AMERICAN PURE CULTURE SPAWN}

This type produces larger mushrooms than the English, coming into bearing somewhat earlier, and continuing to crop for a long time. Pure culture bricks of spawn, when planted, produce mushrooms all of one type.

Direct No. 8. Cream White. For use from April to October.

Direct No. 9. Pure White. For use from October to April.

Per Brick

Per 5 Bricks

$\$ 0.35$ | Per 10 Bricks

Per 50 Bricks

$$
1.50 \mid \text { Per } 25 \text { Bricks }
$$

$-$

Rydal, Pa.

The last Mushroom Spawn I obtained from you is giving us the most delicious mushrooms I ever tasted. M. BAY ARD

BOOKS ON GROWING MUSHROOMS Pamphlet (Gratis for a postal card asking for it . Falconer's Book.

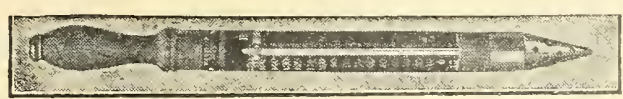

MUSHROOM OR HOTBED THERM ONETERS

\section{Heavy Galvanized Iron Point}

Brass Point Wood Case Paper Scale

Thermometers should, wherever possible

express. We do not guarantee safe arrival if $\mathrm{f}$

parcel post. 


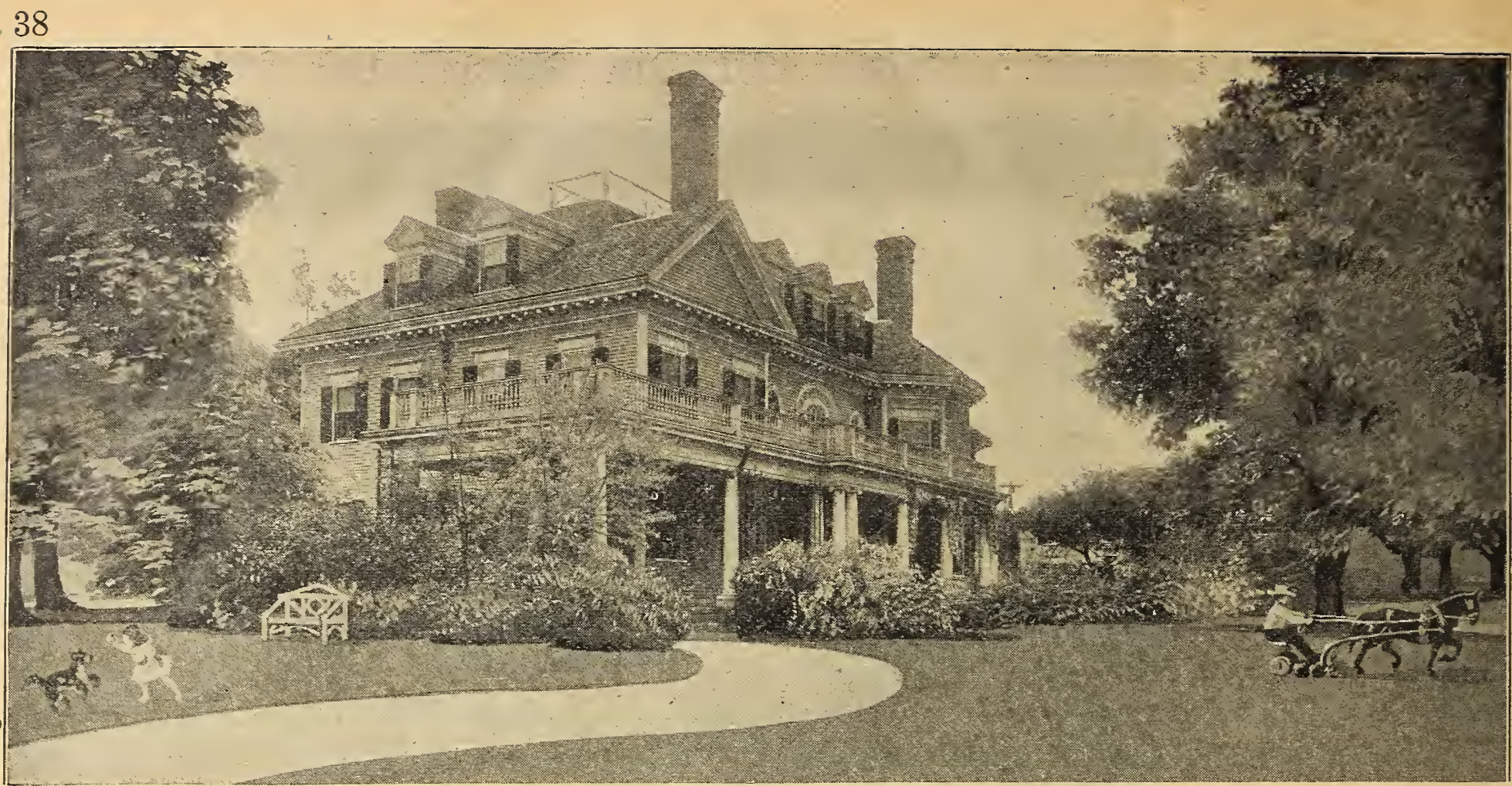

\section{MICHELL'S RELIABLE GRASS SEEDS}

\begin{tabular}{|c|}
\hline $\begin{array}{c}\text { All Prices Subject to } \\
\text { Market Changes }\end{array}$ \\
\hline
\end{tabular}

Our grass seeds are rigidly tested for purity and germination at the growing point, in the laboratories of the United States Department of Agriculture and by ourselves, and will be found of highest average. We make special formulas to suit various soils, climatic and local conditions.

Quantity to Sow for Lawns; you cannot sow too much, the more the better, it means a quicker, more satisfactory and more lasting results. On a small scale a quart will usually seed a space of $10 \times 10$ feet though twice that quantity is better; 6 to 8 or 10 bushels of $20 \mathrm{lbs}$. per bushel on new ground without grass, is the proper quantity per acre; 1 peck is needed for a space of 1000 square feet; $1 / 2$ bushel for a space 2000 square feet; 1 bushel for a space 4000 square feet or say 40 x 100 feet. For Putting Greens we advise 100 lbs. of seed for greens $100 \times 100$ feet. For Fairways, 8 to 10 bushels per acre. For Pasture and Hay Fields, 6 to 8 bushels per acre, based on a 20 pound bushel.

\section{MIXTURES FOR LAWNS}

Michell's "Top Notch" Lawn Grass Seed. The top notch of quality. A perfectly blended combination of quick growing, very compact, fine bladed grasses that will produce a perfect lasting turf in a few weeks. 25 lbs. per bu. 25c. per pt.; qt., 45 c.; 85 c. for 2 qts.; 4 qts., $\$ 1.50 ; \$ 2.75$ per pk.; bu., $\$ 10.00$; 100 lbs., $371 / 2$ c. per lb.

Michell's Green Velvet Lawn Grass Seed. Produces a perfect turf, composed of close growing, fine leaved hardy grasses. 20 lbs. per bu. 20c. per pt.; qt., 35c.; 65c. for 2 qts.; 4 qts., $\$ 1.25$; $\$ 2.25$ per pk.; bu., $\$ 8.00 ; 100$ lbs., 371/2c. per lb.

Michell's Evergreen Lawn Grass Seed. Composed of the finest native and foreign short growing and fine bladed grasses. 20 lbs. per bushel. 15c. per pt.; qt., 30c.; 55c. for 2 qts.; 4 qts., $\$ 1.00 ; \$ 1.75$ per pk.; bu., $\$ 6.50 ; 100$ lbs., 30c. per lb.

Michell's Clover Lawn Grass Seed. The increasing demand for a grass seed mixture, containing a larger proportion of White Lawn Clover induced us to offer this brand; mixed with a liberal quantity of the best recleaned White Clover, which is peculiarly suited to take firm hold and grow quickly on hard or worn-out spots which sun burn easily. Splendid for seashore lawns. 30 lbs. per bu. 30c. per pt.; qt., 50c.; 90c. for 2 qts.; 4 qts., $\$ 1.75$; $\$ 3.25$ per pk.; bu., $\$ 12.50 ; 100$ lbs., 40 c. per lb.

Michell's Seashore Lawn Grass Seed. Contains such grasses as thrive in salt air regions. 20 lbs. per bu. 20c. per pt.; qt., 35c.; 65c. per 2 qts.; 4 qts., $\$ 1.25$; $\$ 2.25$ per pk.; bu., $\$ 8.00$; $100 \mathrm{lbs}$., $371 / 2 \mathrm{c}$. per lb.

Michell's Shaded Lawn Grass Seed. Will produce a perfect sward in the most densely shaded places. 20 lbs. per bu. 20c. per pt.; qt., 35c.; 65c. per 2 qts.; 4 qts., $\$ 1.25$; $\$ 2.25$ per pk.; bu., $\$ 8.00 ; 100$ lbs., $371 / 2$ c. per lb.

Fairmount Park Lawn Seed. A mixture meeting the requirements of those desiring a moderately priced grass seed. 20 lbs. per bu. Pt., 15c.; 25c. per qt.; 2 qts., 45c.; 75c. for 4 qts.; pk., $\$ 1.50 ; \$ 5.50$ per bu.; 100 lbs. at 25 c. per lb.

Special Sod Grass Seed. Produces a heavy sod in a short time. 20 lbs. per bu. Pt., 15c.; 30c. per qt.; 2 qts., 55c.; $\$ 1.00$ for 4 qts.; pk., $\$ 1.75 ; \$ 6.50$ per bu.; 100 lbs. at 30 c. per lb.

\section{MIXTURES FOR LAWNS Continued)}

Michell's Terrace or Embankment Grass Seed. This mixture is composed of deep rooting varieties properly blended which will give very satisfactory results. 20 lbs. per bu. 20c. per pt.; qt., 35c.; 65c. for 2 qts.; 4 qts., $\$ 1.25$; $\$ 2.25$ per pk.; bu., $\$ 8.00$; 100 lbs. at $371 / 2$ c. per lb.

Southern States Evergreen Lawn Grass Seed. Made up especially for dry, hot localities; especially suited to the Southern States. 20 lbs. per bu. 15c. per pt.; qt., 30c.; 55c. for 2 qts.; 4 qts., $\$ 1.00$; $\$ 1.75$ per pk.; bu., $\$ 6.50 ; 100$ lbs. at 30 c. per lb.

\section{MIXTURES FOR PLEASURE GROUNDS}

Michell's Fair Ways (Golf Course) Mixture. Composed of shortgrowing, deep-rooted varieties that resist wear. Fairways to retain their permanency should receive additional sowings during the season. 20 lbs. per bu. 15c. per pt.; qt., 30c.; $55 \mathrm{c}$. for 2 qts.; 4 qts., $\$ 1.00$; $\$ 1.75$ per pk.; bu., $\$ 6.50 ; 100$ lbs. at $30 \mathrm{c}$. per lb.

Michell's Athletic Field Grass Seed. A special mixture of deep rooting, fine leaved grasses, especially suited for Baseball, Football and Cricket Grounds. Per qt., 30c.; 55c. per 2 qts.; 4 qts., $\$ 1.00 ; \$ 1.75$ per pk.; bu. (20 lbs.), $\$ 6.00 ; 100 \mathrm{lb}$. lots and over $281 / 2$ c. per lb.

Michell's Tennis Court Grass Seed Mixture. Our mixture will be found particularly adapted for the purpose as grass is coming more into favor on tennis courts. $20 \mathrm{lbs}$. per bu. 20c. per pt.; qt., 35c.; 65c. for 2 qts.; 4 qts., $\$ 1.25$; $\$ 2.25$ per pk.; bu., $\$ 8.00$; $100 \mathrm{lbs}$. at $371 / 2 \mathrm{c}$. per $1 \mathrm{~b}$.

Michell's Putting Greens Mixture. 'A mixture of quick-growing, short, fine-bladed grasses, over which the ball can roll without resistance. We do.not recommend less than $100 \mathrm{lbs}$. to a green, 100 feet square. 25 lbs. per bu.; 35c. per pt.; qt., 65 c.; $\$ 1.25$ for 2 qts.; 4 qts., $\$ 2.25 ; \$ 4.00$ per pk.; bu., $\$ 15.00$; 100 lbs. at 55c. per lb.

Michell's Teeing Grounds Mixture. Used on golf course tees or in other places where a tough resisting turf is wanted. 20 lbs. per bu. Pt., 20c.; 35c. per qt.; 2 qts., 65c.; $\$ 1.25$ per 4 qts.; pk., $\$ 2.25 ; \$ 8.00$ per bu.; 100 lbs. at $371 / 2$ c. per 1 . 


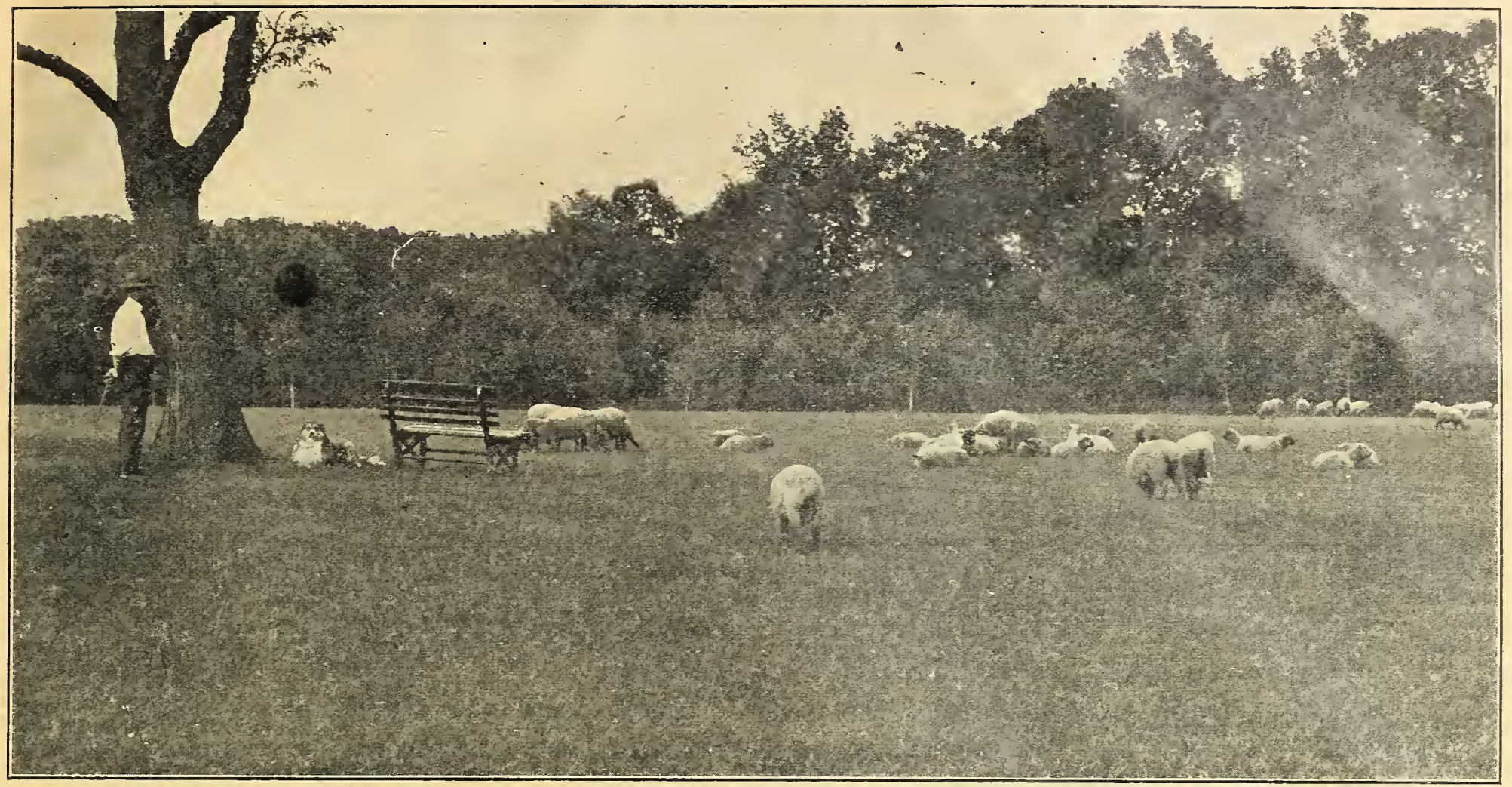

\section{MICHELL'S RECLEANED GRASS SEEDS}

\section{MISCELLANEOUS MIXTURES}

Michell's Permanent Pasture Grass Seed. This mixture is a combination of hardy grasses which are the most nutritious for stock feeding or grazing. One sowing will last many years, although we advise additional sowings each autumn, just previous to which a light harrowing is recommended to give the grass a quick hold. Sow 3 to $4 \mathrm{bu}$. per acre on new land or $2 \mathrm{bu}$. on established pastures. $20 \mathrm{lbs}$. per bu. Pt., 15c.; 25c. per qt.; 2 qts., 45 c.; 85c. for 4 qts.; pk., $\$ 1.50 ; \$ 5.50$ per bu.; 100 lbs. at 25 c. per $1 \mathrm{~b}$.

Michell's Permanent Hayfield Grass Seed. This mixture is gradually being adopted by the progressive farmer. Its main advantages are that certain grasses in this mixture will grow better in varying conditions of soil, thus giving a full crop of hay on land that otherwise might produce but a half crop of timothy and clover. Sow 3 to 4 bu. per acre on new lands or 2 bu. on established fields. 20 lbs. per bu. Pt., 15c.; 25c. per qt.; 2 qts., 45 c.; 85 c. for 4 qts.; peck, $\$ 1.50 ; \$ 5.50$ per bu.; 100 lbs. at $25 \mathrm{c}$. per $\mathrm{lb}$.

\section{GRASSES IN SEPARATE VARIETIES}

All Strictly Recleaned and Carefully Tested for Purity and Germination. Prices quoted on application.

We handle the best recleaned grass seeds in separate varieties. Some persons like to do their own mixing or prefer to sow only one kind of grass; we make no charge for mixing.

Bermuda Grass. For sowing as far North as Washington, D. C., above which latitude it is not hardy (35 lbs. per bu.).

Blue Grass. Fancy Kentucky (Poa Pratensis). Our stock of this is extra fine, thoroughly recleaned; sow 3 to $5 \mathrm{bu}$. per acre on lawns, $2 \frac{1}{2}$ to $3 \mathrm{bu}$. on pasture fields (14 lbs. per bu.).

Blue Grass, Canadian (Poa Compressa). Makes an ideal pasture, highly relished by cattle; excellent also for sowing on embankments; sow in same proportions as Kentucky Blue Grass Seed (14 lbs. per bu.).

Creeping Bent (Agrostis Stolonifera). Adapted admirably for lawns, also putting greens, tennis courts, etc.; sow 4 bu. per acre (20 lbs. per bu.).

Crested Dogstail (Cynosurus Cristatus). Excellent as a pasture and lawn grass. Sow $31 / 2$ to 4 bu. per acre (21 lbs. per bu.).

Fescue, Chewing's New Zealand (Festuca Chewing's). Especially recommended for putting greens and lawns (14 lbs. per bu.).

Fescue, Creeping (Festuca Rubra). Very valuable for sowing on sandy soil and in shaded places; also on putting greens (14 lbs. per bu.).

Fescue, Fine Leaved (Festuca Tenuifolia). This grass is especially valuable for dry soils. Sow $3 \mathrm{bu}$. per acre (14 lbs. per bu.).

\section{GRASSES IN SEPARATE VARIETIES (Continued)}

Fescue, Hard (Festuca Duriuscula). A splendid grass for golf links, tennis courts, etc.; will resist droughts. Sow 3 bu. per acre (12 lbs. per bu.).

Fescue, Meadow (Festuca Pratensis). Sow 40 to $50 \mathrm{lbs}$. per acre (22 lbs. per bu.)

Fescue, Red (Festuca Rubra). Valuable for putting greens; also for sowing on sandy soil and in shaded places (14 lbs. per bu.)

Fescue, Sheep's (Festuca Ovina). This makes an excellent grass for sowing on lawns, fields or pleasure grounds. Sow 40 lbs. per acre (12 lbs. per bu.).

Herd or Red Top, Fancy Recleaned. This is one of the best grasses for sowing for immediate effect. Our stock is free from chaff and is absolutely pure. Sow $25 \mathrm{lbs}$. per acre (32 lbs. per bu.).

Herd or Red Top, Unhulled (Agrostis Vulgaris). Sow 4 to 5 bu. per acre on lawns, or $3 \mathrm{bu}$. on pasture lands (10 lbs. per bu.)

Orchard Grass (Dactylis Glomerata). For early pasturing this is very desirable; also fine for sowing in shaded places. Sow $40 \mathrm{lbs}$. per acre (14 lbs. per bu.).

Rhode Island Bent. For sowing at seashore resorts, on putting greens, tennis courts, etc.; 40 lbs. per acre (14 lbs. per bu.

Rye Grass, English or Perennial (Lolium Perenne). (Pacey's Fancy Short Seeded.) This makes the quickest returns in growth of any grass; is deep rooted and is readily established. Sow 3 bu. per acre (24 lbs. per bu.).

Rye Grass, Italian (Lolium Italicum). Very desirable for pasture it comes to maturity the first season; the ideal seed for southern lawns in winter. Sow 50 lbs. per acre (18 lbs. per bu.)

Sudan Grass Seed (Annual). This belongs to the forage crops and is allied to the millets. Sow 16 to $24 \mathrm{lbs}$. per acre.

Sweet Vernal (Annual). 5 lbs. per acre with other grass.

Sweet Vernal (Perennial). 5 lbs. per acre with other grass.

Timothy (Phleum Pratense). Sow one-half bu. per acre alone (45 lbs. per bu.).

Wood Meadow (Poa Nemoralis). The best grass for sowing under trees where a lawn is desired. Sow $30 \mathrm{lbs}$. per acre (14 lbs. per bu.)

\section{WHITE DUTCH LAWN CLOVER}

Splendid for sowing among grass on lawns and where a thick, quick growth is desired; especially seashore lawns. Prices. 5c. per pkt.; oz., 10c; 20c. $1 / 2$ lb., 40 c.; 75 c. per lb.; 5 lbs., $\$ 3.50$;
bu., (60 lbs.) $\$ 39.00 ; \$ 65.00$ per 100 lbs. 


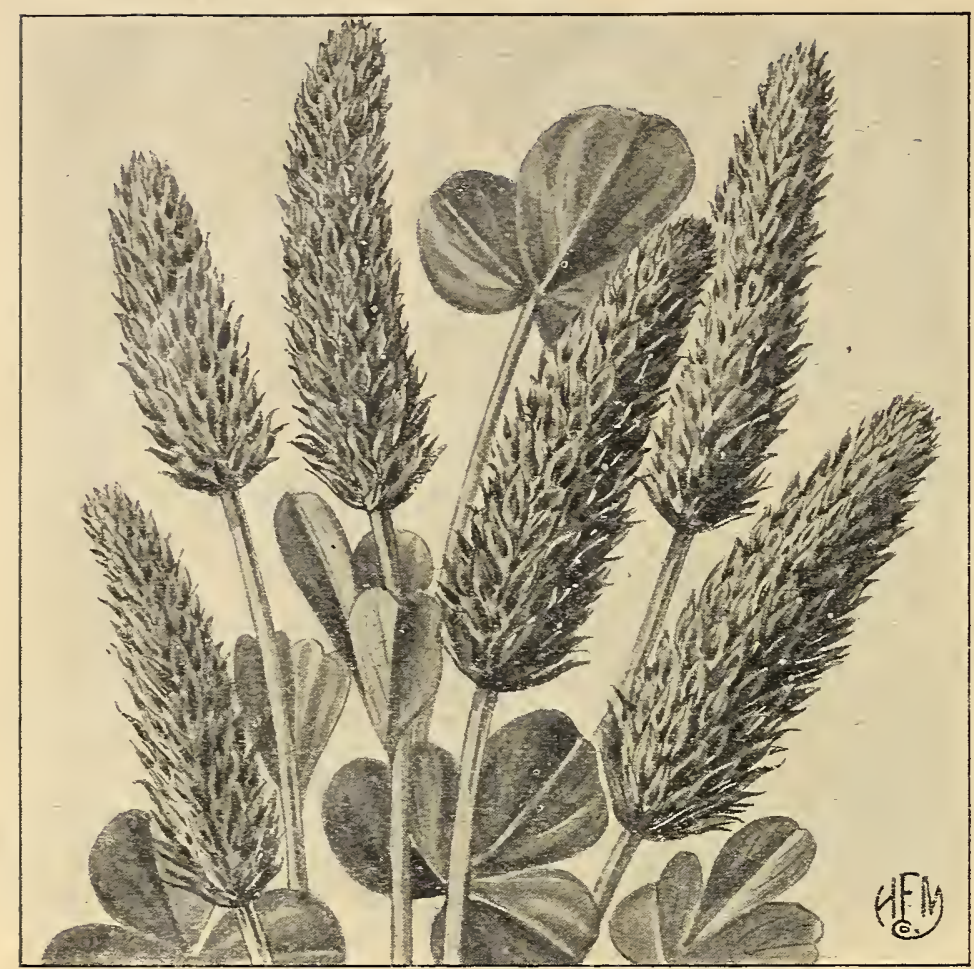

Crimson Clover

\section{CLOVERS}

Alfalfa or Lucerne (Medicago Sativa). This is sown during May, August and September. Careful preparation of the soil previous to sowing is the main thing. Our special Circular on Alfalfa explains this fully, and is free for the asking. Sow not less than $1 / 2$ bushel (30 lbs.) per acre preferably with no other crop. Our seed will give the best of results. Choice Non-Irrigated Western Grown Seed. Price on application.

Alfalfa (Grimm Strain). Claimed to be hardy in any and all regions; a heavy yielder and of deeper rooting ability than the àvove. It requires about $10 \mathrm{lbs}$. of Grimm Alfalfa to properly seed an acre on account of its great root system and spreading habit. Price on application.

Alsike or Swedish Clover (Trifolium Hybridum). One of the best for mixing with timothy; perfectly hardy in every climate or soil condition; grows from 1 to 2 feet high. Sown early in the spring or late summer and early autumn. It is as nutritious as red clover and is rapidly coming to the front as a valuable farm crop. Sow 10 to $15 \mathrm{lbs}$. per acre alone or $8 \mathrm{lbs}$. per acre with timothy. Price on application.

Bokhara or Sweet Clover (Melilotus Alba). Used either as a feed crop or as a fertilizer to plow under. Grows from 3 to 5 feet high, thriving on almost any kind of soil. If you have thin, rocky, hard or sour soil, which you wish to enrich, this is just the crop for you to grow. It will make two hay crops the first year. We handle only the true, white flowered variety. Sow $15 \mathrm{lbs}$. per acre in early spring alone, or $10 \mathrm{lbs}$. per acre with other crops. Price on application.

Crimson Clover (Trifolium Incarnatum). This is used principally for soiling or green manuring, for which purposes it is highly valuable. If desired for feed, cut it just before it flowers. When desired for green manure, it should be allowed to mature; its height is from 1 to 2 feet. Sow any time from April to October, the earlier the better, $20 \mathrm{lbs}$. to the acre. Price on application.

Mammoth Red Clover (Trifolium Pratense Perenne). Sometimes called Sapling or Pea Vine Clover and English Cow Grass. This differs from the "Medium," being of a ranker growth and yielding more hay per acre. It ripens somewhat later and is more hardy, lasting several seasons longer than the medium red clover. It also does well on poorer soils. The seed cannot be distinguished from the former. Our supply, however, is strictly reliable. Sow in early spring or in July and August, using 20 lbs. per acre alone or with other crops 10 lbs. per acre; flowers pink. It can be harvested several times in a season. Price on application.

\section{CLOVERS - Continued}

Red Clover, Medium (Trifolium Pratense). More widely known and used than any other; used principally for hay purposes. Height from 18 inches to $21 / 2$ feet. Sow early in the spring or in late summer-July and August; if alone, 20 lbs. per acre; if with other crops, 10 lbs. per acre. It is not hardy for a period of years, being usually resown every third season. Flowers pink. Price on application.

White Dutch or Lawn Clover (Trifolium Repens). This is valuable for pasturage as well as for lawns; it succeeds where other clovers and grasses fail, and it seldom dies out. It can be sown at all seasons, although early spring is best; flowers greenish white. Sow 10 to 12 lbs. per acre if alone or $5 \mathrm{lbs}$. if sown on old turf or with other crops. Pkt., 5c.; 10c. per oz.; $1 / 4$ lb., 20c.; 40c. per $1 / 2$ lb.; lb., 75 c.; $\$ 3.50$ per 5 lbs.; 10 lbs., $\$ 6.75 ; \$ 39.00$ per bush. (60 lbs.); 100 lbs., $\$ 65.00$. Prices on White Clover subject to change.

\section{DWARF ESSEX RAPE}

An excellent green food for pasturing sheep and hogs. Sow 6 lbs. per acre broadcast or in drills from April 1st to October 1st. Price on application.

\section{WINTER, RYE}

Pennsylvania Large White. Sow 1 to $1 \frac{1}{2}$ bushels per acre during fall. An excellent green food in spring, and may be used for turning under or harvesting. Winter rye will not mature if sown in spring. Price on application.

Rosen. A new strain; very long, stiff straw; large yielder, producing almost 50 per cent. more than ordinary rye. Price on application.

\section{RECLEANED TIMOTHY}

Our stock is of very best quality; for sowing among wheat as a second-year hay crop or for sowing alone for a first-year hay crop this is extensively used. Sow $1 / 2$ bu. per acre alone or 6 to 8 qts. with wheat. 45 lbs. per bushel. Samples and quotations on request.

\section{WINTER VETCH (Vicia Villosa)}

Our stock of this is the true type, which will absolutely live throughout the winter. There is also an English strain on the market which is not hardy in the Northern section of the United States, and buyers should beware when buying that they procure the right article, which is a small round black seed. It is far superior to Crimson Clover, as it never winter-kills. Sow from August 1st to October 1st, the earlier the better, broadcast, 1 bushel per acre, to which we suggest adding a bushel of winter rye or wheat. In the spring it can be plowed under as green manure, or when in flower, cut for hay. All stock relish it keenly. Price on application.

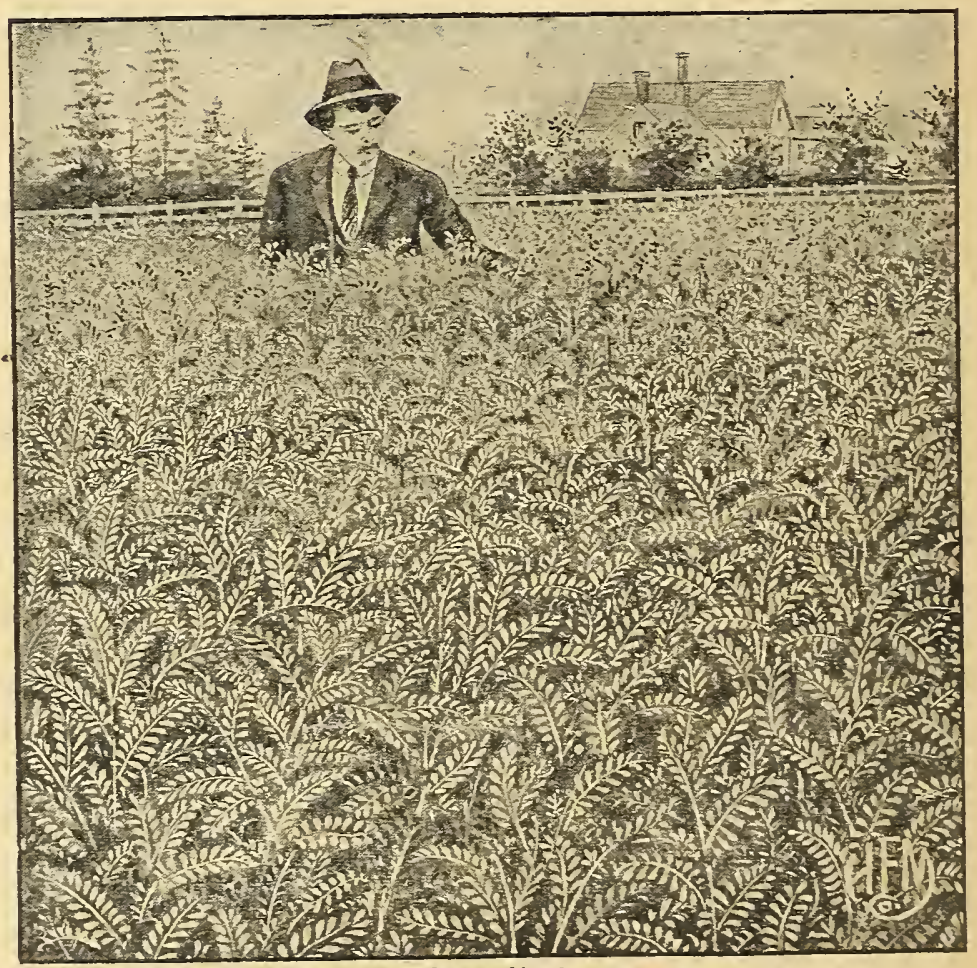




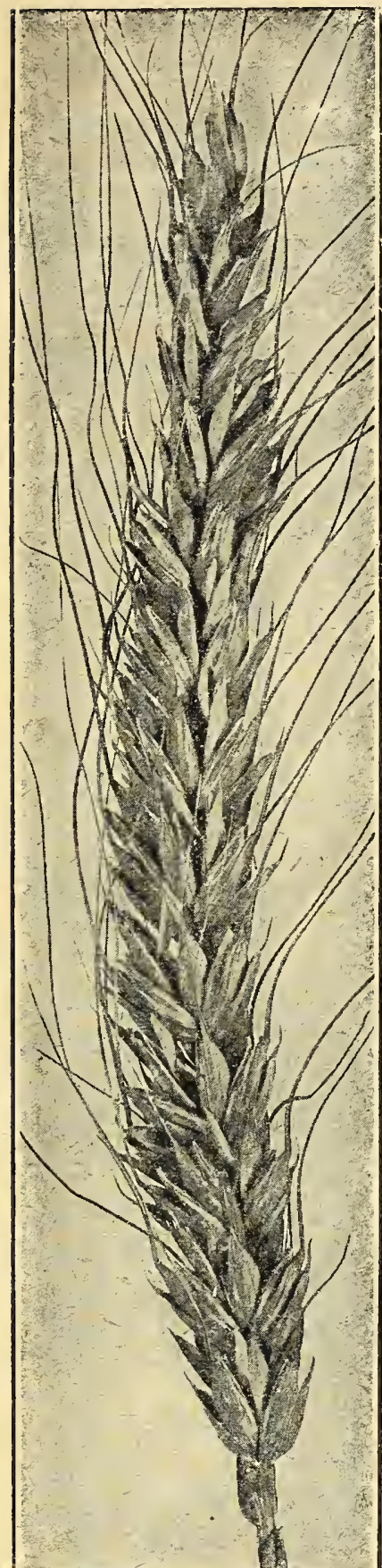

\section{FOUR-ROWED FULTZ (Beardless:}

Four-rowed Fultz has a tendency to produce spikelets composed of four grains of wheat arranged in a row close together. Although the heads are only of medium length, in most cases they contain more wheat than heads of other varieties that are much longer. Four-rowed Fultz is extremely early. The berry is of medium size, hard and red in color. Chaff is white. Straw is of medium length, strong and stiff. On rich soils, Four-rowed Fultz will give straw of great length; will stool out wonderfully, making a thick growth.

This variety has numerous records of yield of 40 bushels per acre on average land. On select land as much as 50 bushels per acre has been harvested. Sow $11 / 2$ to 2 bushels per acre.

\section{"FULTZO-MEDITERRANEAN" (Beardless)}

This is a cross of the "Fultz" and the old "Mediterranean" Wheats. The berry is short, plump and red. Chaff white and smooth. The heads are of medium length, very compact, well filled and inclined to widen at the top. For earliness or stiffness of straw it cannot be excelled. It stools well and $11 / 4$ to $1 \frac{1}{2}$ bushels per acre is sufficient to sow. It frequently produces over 40 bushels per acre.

\section{LANCASTER-FULCASTER (Bearded)}

A reselection from the old "Fulcaster" and one of the purest wheats now offered. There are few other varieties that will do quite as well on soils of average quality. Farmers who are not able to raise even fair crops on rather thin soils should sow "Lancaster-Fulcaster." Even under adverse conditions this variety will produce a satisfactory crop of straw and a surprising crop of grain. The grain is of finest quality, a genuine long berry, dark red and hard. The chaff is white and the straw is long and stiff. Lancaster-Fulcaster will carry through extreme winters; will also withstand attacks of insect pests and disease better than any other variety. Sow $1 \frac{1}{2}$ to 2 bushels per acre.

\section{LEAP'S PROLIFIC (Beardless)}

$\dot{A}$ most prolific variety indeed, and may be relied upon to give big crops. It stools out strongly and roots deeply. The grain is large, dark red and of the best milling qualities. The heads are large, the chaff is beautiful white and is without beards. "Leap's Prolific" is one of the earliest to ripen and we recommend it as an all around good variety. Sow $1 \frac{1}{2}$ bushels per acre.

\section{"MIRA CLE" (Bearded)}

This valuable Wheat was introduced by us in the vicinity of Philadelphia in 1911 . It produces a magnificent, heavy growth of straw, which is very stiff and erect. The head is bearded and contains well-shaped, red grains of a semi-hard nature of excellent milling qualities. It is a tremendous stooler, one grain producing as many as $\mathbf{2 5}$ stalks with of ten $\mathbf{4 5}$ grains to the head or stalk. It is readily seen that this wheat should produce on average conditions an enormous crop, its usual rating being anywhere from 40 to 50 bushels per acre under average conditions. The introducer impressed upon us very forcibly not to recommend the sowing of more than one half bushel per acre, as if seeded heavier it is liable to choke itself, on account of its free stooling habit. It is early to mature and produces straw often 5 feet high.

\section{PENNSYLVANIA 44 (Bearded)}

A new variety originating at the Pennsylvania Agricultural Experiment Station and developed from the Fulcaster. Grains red, purple straw, white chaff. It is a few inches taller than Fulcaster, and with stiffer straw. This variety has yielded an average of 35 bushels per acre for the last 8 years. Sow $1 \frac{1}{2}$ to 2 bushels per acre.

\section{PRICE'S WONDER (Bearded)}

It bears the longest heads of any wheat we know of and thrives under the roughest treatment. It may be sown very late in the fall under the most adverse conditions with every confidence of profitable crops to follow. Our grower says that everything about Price's Wonder is long, long in the berry, long in the straw, very long bearded heads and long in the yield. The grain is hard and dark red, while the chaff is white. The straw is long and stiff. $11 / 4$ to $11 / 2$ bushels per acre is all you need to sow.

Prices of Seed Wheat fluctuate constantly and will be quoted on application.

NITROGEN-GATHERING BACTERIA

The following crops are in season for sowing now and should be inoculated: ALFALFA, ALSIKE, CRIMSON CLOVER, RED CLOVER, VETCH

We can also furnish culture for all other legumes. Always specify on your order what crop you want to inoculate, as there is a different strain of bacteria for each legume.

\section{MULFORD CULTURES}

Legumes embrace all of the various types of clovers, peas, beans and such other plants that have blossoms similar in shape and form to the above named. This type of plant has the ability of taking from the air vast quantities of free nitrogen, which exists there, and which is not absorbed by other plants than those which belong to the legume family. This nitrogen is taken (breathed so to say) through the stems of the plant and deposited at the roots in little sacks or nodules, where it becomes immediately available as plant food in the form of nitrates. The application of bacteria to the seed of these legumes when planting practically trebles the nitrogen-gathering power.

Prices, trial size (supplied only for Garden Peas, Garden Beans, Lima Beans and Sweet Peas), 35c.; 75c. per $1 / 4$ acre size; 1-acre size, $\$ 1.50 ; \$ 5.00$ per 5 -acre size.

\section{STANDARD INOCULATING BACTERIA}

Like in most everything else there seems to be a demand for variety, even in "Legume Bacteria," which has induced us to add this brand to our offering. It is manufactured by a reputable concern, and from inquiries we have made, persons who have used same are enthusiastic in their endorsement of Standard Bacteria.

Prices, trial size (supplied only for Garden Beans, Garden Peas and Sweet Peas), 25c.; Garden Size, 50c.; 1 Acre Size, 2 Acre Size, $\$ 1.45 ; 4$ Acre Size, $\$ 2.25 ; 6$ Acre Size, $\$ 3.00$. postpaid on receipt of price.

\section{FARMOGERM}

An extensively advertised preparation for inoculating prior to sowing or planting. Because of the method bottle, it is claimed it will keep almost indefinitely.

Prices, trial size (for Beans, Peas and Sweet Peas), size, $\$ 1.00 ; 3$-acre size, $\$ 2.50 ; 12$-acre size, $\$ 9.00$. 
Our extensive trade, particularly with gentlemen's country estates, has made it necessary for us to give this department special attention. We have arranged with well-known specialists in this line to supply us extra well grown, clean stock. We also can procure any other plants not mentioned on this list. Kindly submit us a list of your requirements and we will be pleased to quote you.

\section{ASPARA GUS}

Plumosus Nanus (Asparagus Fern). Highly desirable for fern dishes, bouquet greens, garlands, etc. 3-inch pots, 25c. each; 4-inch pots, 50c. each.

Sprengeri. Adapted principally for hanging baskets. 3-inch pots, $25 \mathrm{c}$. each; 4 -inch pots, $50 \mathrm{c}$. each.

\section{CYCLAMEN PLANTS}

Splendid for blooming indoors during the winter, requiring a moderately cool temperature. 4-inch Pot Plants. . . . . . . . . . . . . . . . \$0.70 $\$ 7.00$

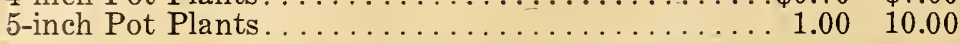

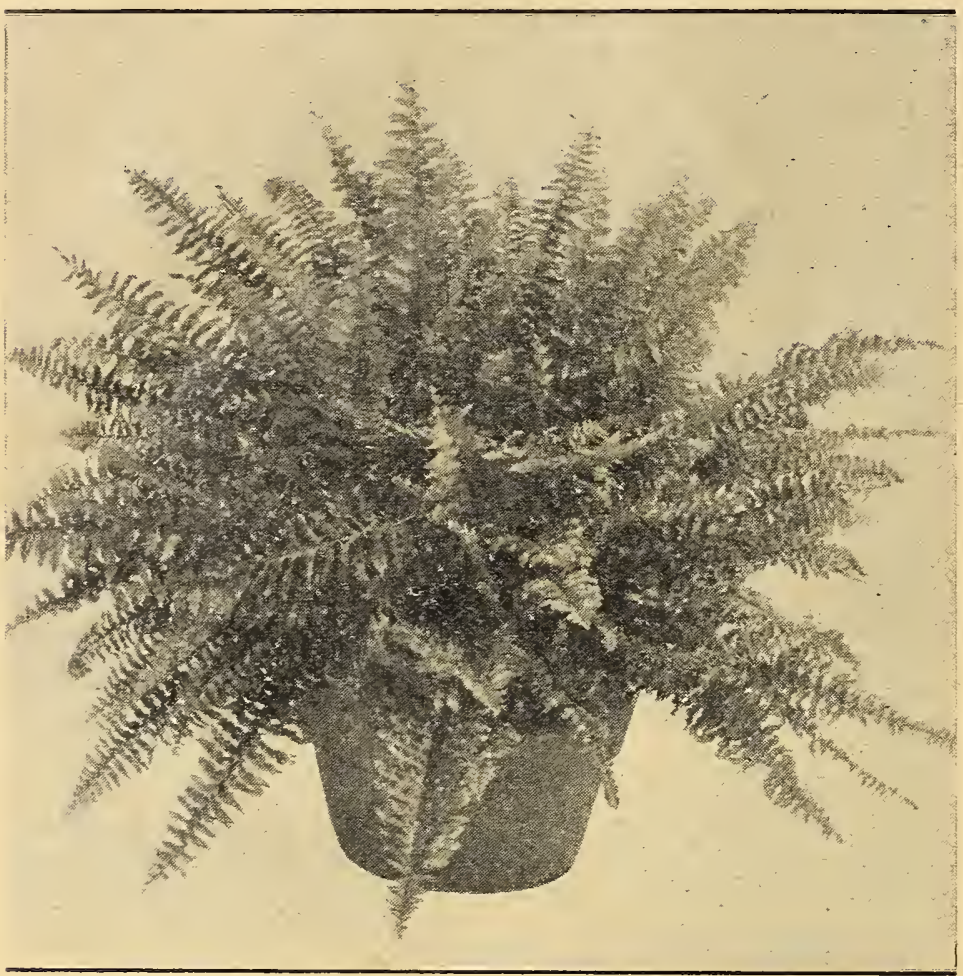

Nephrolepis, Teddy, Jr.

\section{FERNS}

The varieties we offer here are the best of their class and all are good house plants.

Nephrolepis, Scotti. An old favorite; dwarf and bushy.

very bushy.

Teddy, Jr. A dwarf form of the Roosevelt fern;

Nephrolepis, Verona. One of the lace ferns; the best of its type.

Either of above Ferns, 4 -inch pots, 75 c. each; 6 -inch pots, $\$ 2.00$ each; 8-inch pots, $\$ 4.00$ each.

\section{FERNS FOR FERN DISHES, Etc.}

We are always able to furnish a large selection of these in the leading varieties, in $2 \frac{1}{4}$-inch pots, $15 \mathrm{c}$. each; doz., $\$ 1.50 ; \$ 10.00$ per 100 .

\section{FICUS (Rubber Plant)}

Elastica. The old-fashioned variety. 4-inch pots, 75c. each; 6 -inch pots, $\$ 2.00$ each.

\section{GENISTA RACEMOSA}

A large stock of well-grown plants. 4-inch pots, $\$ 1.00$ each; 5 -inch pots, $\$ 1.50$ each.

\section{GERANIUM "HELEN MICHELL"}

Positively, without any exception, the best scarlet bedding geranium in cultivation. Orders booked now for delivery during December and the following months. Strong $21 / 4$-inch Pot Plants, $\$ 2.00$ per doz.; per $100, \$ 12.00$.

\section{MICHELL'S HYDRANGEAS (For Forcing)}

Private gardeners and others with greenhouses will find hydrangeas splendid as winter flowering pot plants, and for Easter. Plants of Hydrangeas placed in a moderate greenhouse temperature may be forced at will and are beautiful indeed. Our list embraces the best sorts. The Otaksa variety is planted outdoors extensively for summer bloom, but we do not recommend setting them out in the autumn.

Special Note.-Blue is a color that is not fixed in Hydrangeas. It is controlled sometimes by climatic, and other times by soil conditions. We cannot supply blue flowering Hydrangeas.

Baby Bimbinet. Silvery rose. Louis Moulliere. Deep rose. General de Vibraye. Bright pink. Otaksa. Rose pink.

La Perle. White fringed. Radiant. Rosy carmine. Trophee. Brilliant carmine.

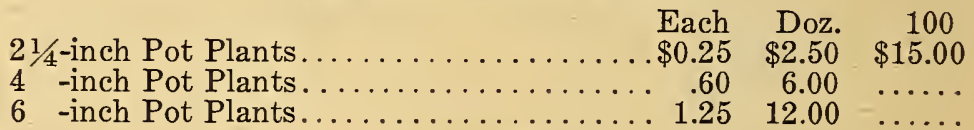

\section{PALMS}

Kentia Belmoreana. The hardiest palm in cultivation; of slow growth, and less affected by the dust and dry atmosphere of the house than any other.

Kentia Forsteriana. This splendid variety is very similar to $\mathrm{K}$. Belmoreana, but of stronger growth, with broader, heavier foliage.

Price, for either above Kentias.

4 -inch pots, $\$ 1.00$ each. $\quad 5$-inch pots, $\$ 2.00$ each.

6 -inch pots, 3.00 each. 6 -inch pots, heavy, $\$ 4.00$ each. 7-inch tubs, heavy, $\$ 10.00$ each.

\section{PANDANUS}

We highly recommend this plant where a good many varieties of other decorative plants will not do. They will thrive even in dark places such as reception halls, living rooms, etc.

Veitchi. Highly colored plants.

4 -inch pots, $\$ 1.50$ each. 6 -inch pots, $\$ 2.50$ each.
7 -inch pots, $\$ 5.00$ each.

\section{POINSETTIAS}

The true red variety. Stock of the highest quality.

3-inch pots, 50c. each. 4 -inch pots, 75 c. each.

\section{SEEDLINGS}

Many gardeners prefer to purchase their supply of these instead of growing them and for those we have produced a fine lot of the following:

Pansies. Michell's Giant Exhibition Strain.

Bellis. Monstrosa. Giant English Daisy, in pink and white, each separate.

Myosotis (Forget-me-not). Alpestris Victoria.

Any of the above can be supplied in not less than 100 of a kind. $\$ 1.50$ per 100 ; per $1000, \$ 10.00$.

\section{VIOLETS}

These extra fine plants will flower freely under glass in winter or in cold frames and outdoors in the early spring.

Lady Hume Campbell. Double, light blue.

Princess of Wales. Single blue.

Price for any of the above, extra large plants, 35c. each (by mail, 40c.); $\$ 3.50$ per doz.; per $100, \$ 22.50$.

\section{Testimonial}

Gentlemen:-

I am very much satisfied with the plants I received, but it would be impossible for them to do any better than the plants I received from you last year. 


\section{MICHELL'S DORMANT FIELD-GROWN ROSES \\ FOR FALL PLANTING}

Many of the most successful Rose growers prefer planting their Roses in the Autumn. We are now booking orders for strong, two year old Field-Grown budded plants, which will be ready for shipment just as soon as they are properly ripened by frost, which is usually late in October or early in November. Plants shipped in the dormant state take up but very little room and they may be safely shipped by parcel post. If there is danger of the ground freezing before the arrival of the plants, the space where you wish to plant them may be protected by a covering of leaves or other loose litter. When the plants arrive, plant them so that the bud is covered with at least one inch of soil; then make a mound of earth around the base of the plant about twelve inches high; by doing this all of the buds on the lower end of the branches are covered with soil; this covering protects them from the alternate freezing and thawing, which is so injurious. Early in the Spring, before growth starts-but after danger of severe frost is over, this covering of earth should be removed and the plants pruned.

\section{HARDY HYBRID TEA ROSES}

Betty. Color, coppery rose overspread with golden yellow. An excellent Autumn blooming variety.

Columbia. A most pleasing shade of rose-pink, delightfully fragrant.

Duchess of Wellington. Intense saffron yellow changing to coppery yellow.

Edward Mawley. A splendid rose, producing freely dark crimson flowers, which are very fragrant.

Etoile de France. Color, vivid crimson with darker shadings; very double, of good size and deliciously fragrant.

Gen. MacArthur. The blooms are large and very fragrant; color, rich crimson scarlet. For a bedding rose we recommend Gen. MacArthur.

Gruss an Teplitz. This is a rose for everybody, being the most profuse blooming crimson rose in existence. The color is of the richest scarlet, shading to a velvety crimson; very fragrant.

Hadley. Rich crimson, shading to velvety crimson; very fragrant.

Hoosier Beauty. Intense, rich, dazzling crimson-scarlet.

Jonkheer J. L. Mock. Bright cherry red on the outside of the petals and shining silvery white on the inside.

Kaiserin Augusta Victoria. Flowers large and very fragrant. Pearly white, tinted with lemon.

Killarney. The buds are long and pointed; color, sparkling brilliant pink, deliciously fragrant.

La France. One of the finest Hybrid Tea Roses. Color, bright pink on the outside of the petals and a lovely silvery pink on the inside.

Los Angeles. A luminous flame pink toned with coral and shaded with translucent gold at the base of the petals. In fragrance it is equal in intensity to the finest Marechal Neil. The buds are long, pointed and extend into a flower of mammoth proportions.

Mme. Caroline Testout. Bright satiny rose with brighter center; free flowering and fragrant.

Mme. Edouard Herriot. This is the celebrated "Daily Mail" rose. In color it is coral red, shaded with yellow and bright rosy scarlet, with yellow at the base.

Mme. Jules Grolez. A beautiful satiny china rose color, very bright and attractive. Very double and of fine form.

Mrs. Aaron Ward. The color is a distinct Indian yellow which under certain conditions becomes yellow tinted white. A favorite everywhere.

Mrs. Charles Russell. The flowers are large, globular and of fine form; color rosy carmine with rosy scarlet center.

Ophelia. The flowers held erect on long stems are of perfect form, and of a pleasing shade of light salmon flesh shading to pale yellow at the base of the petals.

Premier. A new variety which has proved to be a good forcer and promises to be an equally good bedder. The large full blooms are an exquisite pure rose pink and are borne singly on stiff, almost thornless stems. Very free flowering.

Radiance. A Rose of American origin and to our mind one of the very best varieties in cultivation today. It is an ideal bedder, producing large flowers throughout the Summer when many other varieties are out of bloom; color, a beautiful even shade of pink. This Rose should be in every garden.

Souv du President Carnot. Rosy flesh, shaded white; large pointed buds of superb form. Very free flowering, particularly fine in Autumn. This is indeed a splendid Rose and is a great favorite with those who are acquainted with its many excellent points.

Sunburst. Fair sized flowers of a rich yellow with orange yellow center.

White Killarney. A pure white sport of Killarney and equally as beautiful.

Price, any of the above, $\$ 1.00$ each; per $100, \$ 90.00$.

\section{HARDY HYBRID PERPETUAL ROSES}

Frau Karl Druschki. This is the queen of all white roses both in size and purity. The flower is very double and opens to a pure snow white.

Gen. Jacqueminot. The old favorite "Jack" rose is still popular. The blooms are large, full and globular; color, brilliant scarlet crimson, with deep veining toward the base of the petals.

Magna Charta. An old variety of great merit. The blooms are of large size; color, bright pink suffused with carmine.

Mrs. John Laing. Soft pink of beautiful form; exceedingly fragrant and remarkably free-flowering

Paul Neyron. Flowers of extra large size; color, clear pink shading to soft rose and having a delightful fragrance.

Ulrich Brunner. Extra large flowers of a bright cherry red. A strong grower and free bloomer.

Price, any of the above, $\$ 1.00$ each; per $100, \$ 90.00$.

\section{HARDY CLIMBING AND RAMBLER ROSES}

American Pillar. The large single flowers are a lovely shade of cherry pink, with a clear white eye surrounding numerous golden yellow stamens.

Aviateur Bleriot (The New Yellow Rambler). A strong grower with large clusters of flowers of a saffron yellow, almost golden yellow in the center.

Christine Wright. A beautiful rose of strong climbing habit producing large double flowers of a wild rose pink.

Climbing American Beauty. Bright self colored, medium pink flowers of moderate size. Splendid glossy foliage.

Dr. W. Van Fleet. One of the most important climbing roses, having perfectly formed buds, long and pointed, deep pink in color and very solid. Fragrant and fine for cutting.

Dorothy Perkins. Beautiful shell pink; fragrant and full, blooming in clusters in June. One of the most popular varieties.

Excelsa. Equally as free flowering as the Crimson Rambler, but without the unsatisfactory foliage. Really the best double red rambler.

Hiawatha. Brilliant ruby carmine with a clear white eye and a mass of golden stamens.

Pauls Scarlet Climber. No other rose in any class can compare with it for brilliancy of color, which is a vivid scarlet that is maintained without burning or bleaching until the petals fall The flowers are of medium size, semi-double, very freely produced in clusters of from three to six flowers each on much branched canes, the plants being literally covered with flowers from top to bottom. It is of strong climbing habit and perfectly hardy. $\$ 1.00$ each.

Silver Moon. Long, well shaped buds, opening into immense Clematis like flowers of a waxy whiteness.

Tausendschoen. The flowers are of a most elegant and graceíl form. Color, a most delicate shade of soft pink, changing to carmine on the reverse of the petals when fully expanded.

White Dorothy. A handsome pure white sport from the old favorite Dorothy Perkins and it has all of the finer qualities found in that charming variety.

Price. Strong plants of any of the above Climbing Rose (except where noted), 75c. each; per $100, \$ 60.00$

\section{Testimonial}

\section{Dear Sirs:-}

I received the Rose bushes all $\mathrm{O} . \mathrm{K}$. and was

pleased with them. They were a fine lot of bushes to have some nice roses from thein. 
Year by year these old fashioned hardy flowers are gaining favor and deservedly so, as there is not a time during the whole flowering season when some variety is not in bloom; they are especially valuable during the late Summer and Autumn, when there are but few shrubs in bloom. From early April they continue with constant changing variety throughout the Summer and Fall, when they are stopped only by severe freezing weather. Hardy Perennials appear year after year, and as each variety has a fixed time for blooming, a selection can be made that will give flowers to cut from early Spring until late Fall. The most satisfactory arrangement is to plant them in a border, which can be made in front of a hedge, fence or wall, or in the open garden; the soil should be dug to a depth of 18 inches or two feet, pulverizing it thoroughly and working in a liberal quantity of well decomposed stable manure or other fertilizer. The plants should be placed in groups of three or more of one variety together, the taller growing sorts at the back, the medium heights in the center and the dwarf varieties in front; they should also be placed so as to have some flowers in all parts of the border at all times. This can be easily arranged by referring to our descriptions as to the time of flowering. Our book on "Hardy Perennials" is an instructive publication, and it can be had free on request. We offer here only such varieties as can be planted in the autumn.

All plants are forwarded on receipt of order unless instructed to the contrary, and are sent by Express, purchaser paying charges. We can forward small plants or small numbers of plants by Parcel Post, and if wanted sent in this way add 10 per cent. to value of order for postage to points east of the Mississippi River, and 20 per cent. to points west of the Mississippi River.

\section{SPECIAL NOTICE ON GUARANTEE}

We spare no effort to supply plants of the best quality in first-class living condition. On account of the many causes beyond our control we regret we cannot guarantee this stock to live and establish itself, as that is usually entirely within the power of the buyer or planter. If customers desire us to guarantee plants and shrubs to live we will assume such guarantee at an advance of 25 per cent. over and above our usual prices, but not otherwise, and such guarantee will expire within 90 days from date of shipment.

\section{ACANTHUS (Bear's Breech)}

Mollis Latifolius. A handsome decorative plant of stately effect, with deeply-toothed, heart-shaped leaves, 2 feet long; excellent either for planting as single specimens on the lawn or in the border, or for grouping with other plants for sub-tropical effect, producing 3-feet high spikes of curious rose-colored flowers during August and September. 35c. each; doz., \$3.50.

\section{ACHILLEA Milfoil or Yarrow)}

Eupatorium (Fern-leaved Yarrow). Finely-cut foliage and brilliant yellow heads of flowers, lasting in full beauty all summer; 4 to 5 feet.

Millefolium Cerise Queen (Rosy Milfoil). Finely cut, deep green foliage; flowers cherry red in dense heads; 18 inches high.

Ptarmica Fl. Pl. "'The Pearl." Pure white flowers borne in the greatest profusion the entire summer on strong, erect stems, 2 feet high; as a summer cut flower it is of great value.

Ptarmica Boule de Neige (Ball of Snow). An improvement on The Pearl; the flowers, while not quite so large, are of more perfect form with fuller centres, which makes it appear purer in color.

Price, 30c. each; doz., $\$ 2.50 ; \$ 18.00$ per 100.

\section{AGROSTEMMA (Rose Campion)}

Stout, erect-growing plants with silvery foliage, which contrasts well with the showy flowers, which are produced during June and July.

Coronaria (Mullein Pink). Bright rosy crimson; $21 / 2$ to 3 feet. Coronaria Alba. A pure white variety.

Flos Jovis. Deep pink.

Price, 30c. each; doz., $\$ 2.50 ; \$ 15.00$ per 100 .

\section{ALYSSUM (Gold Dust or Basket of Gold)}

Saxatile Compactum. An excellent low spreading plant for rockery or border, growing about 10 inches high and producing in May masses of golden yellow flowers. 30c. each; doz., \$2.50; $\$ 18.00$ per 100 .

\section{AMSONIA}

Salicifolius. A stout, shrub-like plant, growing about 2 feet high, with terminal spikes of light steel-blue flowers; desirable to intersperse in clumps in front row of the shrubbery border. 35c. each; doz., $\$ 3.50$.

\section{ANCHUSA (Sea Bugloss)}

Italica. "Dropmore Variety." Plants grow 4 feet high in pyramidal shape, branch freely and are loaded with bright blue Forget-me-not-like flowers in June; very showy and valuable. 30c. each; doz., $\$ 3.00 ; \$ 17.50$ per 100

Opal. Pale blue; very large flowers. 35c. each; doz., $\$ 3.50$; $\$ 20.00$ per 100 .

\section{ARABIS (Rock Cress)}

Alpina. One of the most desirable of the very early springflowering plants that is especially adapted for edging and for the rock garden, but does equally well in the border, forming a dense carpet, completely covered with pure white flowers. Lasts for a long time in bloom. 30c. each; doz., $\$ 2.50 ; \$ 15.00$ per 100 .

\section{AQUILEGIA (Columbine)}

For spring blooming these are invaluable producing their graceful spurred flowers on stems rising 2 feet above their attractive foliage, during May and June. For rockery gardens, semi-shaded places, in hardy borders or in clumps, they are very effective.

Michell's Long-spurred Hybrids. This is the most admired type of Columbines. They have been produced from the strains of several famous hybridizers and are much superior to the usual grade. The plants are of strong, thrifty growth. The flowers of largest size vary in color through charming tones of cream, pink, lavender, blue, white, red, etc., hardly any two being exactly alike. We offer them in mixed colors only.

Canadensis (Common American Columbine). The native bright red and yellow variety and one of the brightest.

Chrysantha (Golden Columbine). Bright yellow, long-spurred flowers.

Coerulea (Rocky Mountain Columbine). Bright blue and white, long-spurred flowers.

Flabellata Nana Alba. A dwarf growing, pure white variety.

Helenae. Large blue flowers with white corrolla.

Rose Queen. A newer variety of a pleasing shade of delicate pink, long-spurred flowers.

Vulgaris (Common European Columbine). Violet blue.

Price of all Aquilegias, 30c. each; doz., $\$ 2.50 ; \$ 18.00$ per 100 .

\section{ARMERIA (Sea Pink or Thrift)}

Attractive dwarf plants that will succeed in any soil, forming evergreen tufts of bright green foliage, from which innumerable flowers appear in dense heads, on stiff, wiry stems, from 9 to 12 inches high. They flower more or less continuously from early spring until late in the fall. Very useful in the rockery.

Laucheana Rosea. Bright rose.

Laucheana Alba. White.

Price, 30c. each; per doz., $\$ 2.50 ; \$ 18.00$ per 100 .

\section{ARTEMISIA}

A most useful class of plants either for the border or for filling in within the shrubbery; highly ornamental foliage. The varieties we offer stand cutting down to 5 or 6 inches when used in carpet bedding.

Abrotanum (Old Man, or Southern-wood). Dark green, finely cut foliage, with pleasant aromatic odor; 2 feet.

Stelleriana (Old Woman). Deeply-cut silvery foliage; much used in carpet bedding; 18 inches.

Price, 30c. each; per doz., $\$ 3.00 ; \$ 18.00$ per 100 .

\section{ARTEMISIA LACTIFLORA}

A new variety of great merit; flowers white, in much branched panicles; very fragrant; $4 \mathrm{ft}$.; Aug., Sept. Should be planted in fertile, moist soil. 35c. each; doz., \$3.50; \$18.00 per 100 .

\section{ASCLEPIAS (Butterfly Weed)}

Tuberosa. Very showy native plants about 3 feet high, producing their flowers of brilliant orange-scarlet during July and August. 25c. each; doz., \$2.50; $\$ 15.00$ per 100 . 


\section{DWARF ALPINE ASTERS}

Alpinus. Indispensable for the rockery or edge of hardy borders; grows 6 to 10 inches high and bears large, showy bluish-purple flowers in May and June.

Alpinus Albus. Identical to the above, but with pure white flowers.

Price, 30c. each; doz., $\$ 2.50 ; \$ 18.00$ per 100 .

\section{HARDY ASTERS}

Tall-flowering, stately plants, which may be used with splendid effect in borders or in clumps as specimens on lawns, in large groups or beds. They form the basis of a color scheme in a perennial border during the months of September and October, and last well into November. They thrive equally well in sun or partial shade. For cutting they are invaluable.

\section{FALL FLOWERING VARIETIES}

Feltham Blue. One of the most decorative free-flowering varieties; color, a pretty shade of aniline blue; August and September; $21 / 2$ feet high.

Glory of Colwall. A splendid improvement on the variety Beauty of Colwall, with good-sized, nearly double, ageratumblue flowers; remarkably free flowering; $21 / 2$ feet, September and October.

Mrs. F. J. Raynor. Delicate lavender.

Novi Belgii Climax. Of strong, vigorous habit, 5 feet high; branched pyramidical-shaped flower stems; lavender-blue flowers. August-October.

Novi-Belgii, The Queen. A splendid variety; blush white; 4 to $5 \mathrm{ft}$. high.

Robert Parker. Pale heliotrope; height, $4 \mathrm{ft}$.

Snowflake. Very free bloomer; pure white; height, $2 \mathrm{ft}$

St. Egwin. Densely branched, producing beautiful pink flowers: 3 feet; September.

Summer Beauty. An exquisite shade of light blue; very large flowers, commencing to bloom in the late summer and continuing almost up to frost time; height, about 4 feet.

Tartaricus. Large bluish lilac, 6 feet.

Price, any of the above, $30 \mathrm{c}$. each; doz., $\$ 2.50 ; \$ 18.00$ per 100

\section{ASTILBE}

The varieties offered below are stately, hardy plants, and succeed best in rather heavy soil and where they will not suffer for lack of moisture.

Davidi. An important hardy plant. Its 5 to 6 feet high stems, which rise from a tuft of dark green foliage, are crowned with feathery plumes of deep rose-violet flowers during June and July.

Grandis. A grand species and a fine companion to A. Davidi, being of similar habit of growth; the panicles of white flowers are frequently 2 to $21 / 2$ feet long.

Either of the above, $50 \mathrm{c}$. each; per doz., $\$ 5.00$.

Hybrida Moerheimei. A strong growing hybrid of A. Davidi attaining a height of 5 or 6 feet and producing well branched spikes of flowers 2 feet in length and of a beautiful creamy white. $75 \mathrm{c}$. each.

Hybrida Salland. Another strong growing hybrid of A. Davidi attaining a height of 6 feet producing distinct red flowers, different from all others. $75 \mathrm{c}$. each.

\section{ASTILBE ARENDSI}

Plants are of vigorous growth, $2 \frac{1}{2}$ to $31 / 2$ feet high, producing their flowers in June and July.

Ceres. Delicate light rose-colored flowers, with peculiar silvery sheen.

Salmon Queen. Graceful panicles of a beautiful salmon pink. Price, 50c. each; doz., $\$ 5.00$.

\section{BAP TISIA (False Indigo)}

Australis. A strong-growing plant, about 2 feet high; suitable either for the border or wild garden, with dark green, deeplycut foliage and spikes of dark blue flowers in June.

Tinctoria. Spikes of bright yellow flowers in June; 2 to $21 / 2$ feet. Price, 30c. each; doz., \$2.50; $\$ 18.00$ per 100 .

\section{BELLIS PERENNIS (English Daisy)}

Improved double-flowering, white and pink, each separate.

20c. each; doz., $\$ 2.00 ; \$ 15.00$ per 100 .

\section{BOCCONIA}

Plume Poppy, or Tree Celandine)

Cordata. A noble, hardy perennial, beautiful in foliage and flower; admirably adapted for planting in the shrubbery borders, centre of beds and in bold groups in almost any position. It will grow in any soil or situation, attaining from 6 to 8 feet in height; flowers in terminal panicles, of a creamy-white color during July and August. 30c. each; doz., \$2.50; $\$ 18.00$ per 100 .

\section{BOLTONIA (False Chamomile)}

Among the showiest of our native hardy perennial plants, with large, single, Aster-like flowers. The plant is in bloom during the summer and autumn months, and with its thousands of flowers open at one time, produces a very showy effect.

Asteroides. Pure white; very effective; 5 to 7 feet.

Latisquama. Pink, slightly tinged with lavender, 4 to 6 feet. Price, 30c. each; doz., $\$ 2.50 ; \$ 18.00$ per 100

\section{CAMPANULA (Bell Flower)}

Showy perennial plants of special merit; some are tall, being suitable for borders; others are dwarf, for rockeries and edging, They delight in a good rich loam, preferring a semi-shaded place.

Calycanthema (Cup and Saucer). These are biennials, and last only one season, when planted in the autumn. Pink, white and blue, each color separate; height, 18 inches; June-July.

Media (Old-fashioned Canterbury Bells). This is a biennial type, like the Calycanthema, and will last only one season, when planted in the autumn. It flowers freely from June to August; 3 to 4 feet high. Blue, pink and white, in separate colors.

Carpatica (Carpathian Harebell). A pretty species, growing in compact tufts, not exceeding 8 inches high; flowers clear blue, held erect on wiry stems. It begins blooming in June, continuing until October. Fine for edging or the rockery.

Carpatica Alba. A white-flowered form of above.

Pyramidalis (Chimney Bell Flower). The most conspicuous of all Campanulas, forming a perfect pyramid 4 to 6 feet high of porcelain blue flowers in August.

Any of the above, 30c. each; doz., \$2.50; $\$ 18.00$ per 100 .

\section{HARDY BORDER CARNATIONS}

Choice mixed seedlings. We supply strong plants that will furnish an abundance of double flowers next season. $30 \mathrm{c}$. each: doz., $\$ 2.50 ; \$ 18.00$ per 100 .

\section{CASSIA (American Senna)}

The Cassias delight in a sunny exposure. They are shrubby perennials, attractive for the finely cut foliage and curious flowers.

Marilandica. Large panicles of yellow, pea-shaped flowers and attractive light green foliage. 3 to 4 feet. $30 \mathrm{c}$. each; doz., $\$ 2.50 ; \$ 18.00$ per 100 .

\section{CENTAUREA (Hardheads or Knapweed)}

Of easy culture, delighting in an open, sunny position, producing a wealth of bloom, which not only makes a fine display in the border, but is excellent for cutting.

Montana (Perennial Corn Flower). Grows 2 feet high, bearing large violet blue flowers from July to September.

Montana Alba. A large white variety of the above. Price, 30c. each; $\$ 2.50$ per doz.; per $100, \$ 18.00$.

\section{CERASTIUM (Snow in Summer)}

Tomentosum. A desirable low-growing plant with silvery foliage and white flowers in June; suitable for the rockery, or for carpeting dry, sunny spots, or for covering graves; can also be used with good effect in carpet bedding. 30c. each; doz., $\$ 3.00$; $\$ 18.00$ per 100 .

\section{CHELONE (Shell Flower)}

Glabra Alba. Terminal spikes of creamy white flowers.

Lyoni. Heads of showy purplish red flowers. Price, 30c. each; doz., $\$ 2.50 ; \$ 18.00$ per 100 .

\section{CHRYSANTHEMUM (Shasta Daisy)}

Arcticum (The Arctic Daisy). Among fall-flowering perennial this is a gem. In September multitudes of pure a ppear, from 2 to $21 / 2$ inches in diameter. These begin the last week in September, and continue in goo throughout October, and frequently into November

Shasta Daisy (Alaska). A decided improvement on the origina with blooms $4 \frac{1}{2}$ to 5 inches across, of pure glistening white. Very free-flowering and in bloom all summer and fall.

Price of the above, 30c. each; doz., $\$ 2.50$ 


\section{CIMICIFUGA (Snake Root)}

Racemosa. A handsome native species bearing in July and August spikes of pure white flowers; well suited for planting at the back of the border; 4 to 6 feet. 35c. each; doz., $\$ 3.50$.

\section{SHRUBBY CLEMATIS}

Recta. Grows 2 to 3 feet high and produces fragrant pure white flowers in large clusters during June and July.

Davidiana. A most desirable variety with fresh bright green foliage and bell-shaped, deep lavender blue flowers during August and September; very fragrant. 35c. each; doz., $\$ 3.50$.

\section{COREOPSIS}

Lanceolata Grandiflora. Flowers rich golden yellow and of graceful form; fine for cutting; dozens of flowers are produced on a single plant; June till October. 25c. each; doz., $\$ 2.50$; $\$ 15.00$ per 100 .

\section{CORONILLA (Crown Vetch)}

Vaira. A rampant creeper, with globular heads of bright pink and white Sweet Pea-shaped flowers; useful for covering rough banks or for the rockery. 30c. each; doz., $\$ 3.00$; $\$ 18.00$ per 100 .

\section{DELPHINIUMS OR HARDY LARKSPURS}

In order to keep Larkspurs in bloom continuously during the summer, cut the old flower stems off, after they have faded, and new shoots will produce flower heads in succession. To get the best out of hardy Larkspurs in the way of flowers, feed them occasionally during the growing season with an application of ground bone. A slight covering of long straw or leaves over the crowns of the plants during winter will prove a great benefit.

Belladonna. The freest and most continuous blooming of all, never being out of flower from the end of June until cut down by

hard frost. The clear turquoise-blue of its flowers is not equalled for delicacy and beauty by any other flower.

Bellamosum. A dark blue form of Belladonna with which it is identical excepting in color, which is a rich deep blue.

Chinense. A very pretty dwarf species, with fine feathery foliage and intense gentian-blue flowers in open panicles.

- Album. A pure white form of the above.

Formosum. The old favorite dark blue with white centre; 3 to 4 feet high. Very vigorous, and one of the best.

Michell's Gold Medal Hybrids. Unquestionably the finest strain of.mixed hybrids offered. The plants are of strong, vigorous habit, with large flowers on spikes two feet and over long, the majority running in the lighter shades of blue. We can supply them in mixture only 100.

Price. Any of the above, 30c. each; doz., $\$ 2.50 ; \$ 15.00$ per

\section{DIANTHUS (Garden Pinks)}

For edging hardy borders, garden walks, or planted in rock gardens, these fill an important place. They are at their height of bloom in June.

Deltoides (Maiden Pink). A continuous flowering variety with pink flowers. Especially suited for rock work.

Deltoides Alba. White flowers.

Latifolius Atrococcineus FI. Pl. (Ever-blooming Hybrid Sweet William). A splendid variety with brilliant crimson, double flowers.

Any of the above, 30c. each; doz., $\$ 2.50$; per $100, \$ 15.00$.

\section{DICTAMNUS (Gas Plant)}

A genus of very ornamental plants. The plant when rubbed emits a fine odor, something like that of lemon peel, which is strongest in the pedicels of the flowers. Valuable for cutting.

Fraxinella. Racemes of curious red flowers with decided balsamic scent. 2 to $21 / 2$ feet. May to July.

Fraxinella albus. Spikes of attractive pure white, sweetcented flowers, valuable for cutting. 2 feet. May to July. Price, 35c. each; doz., $\$ 3.50 ; \$ 18.00$ per 100.

\section{DIGITALIS (Foxglove)}

These will do well in semi-shaded spots; plants grow from 4 to 6 feet high; flower in June.

Gloxinaeflora. White, pink, purple, lilac, each separate. Grandiflora.

Lanata. A distinct species, producing dense spikes of curiouslooking flowers, the corolla being gray, the lips white.

Any of the above, 25c. each; doz., $\$ 2.50$; per $100, \$ 15.00$.

\section{DIELYTRA OR DICENTRA}

\section{Bleeding Heart or Seal Flower)}

Spectabilis. An old fashioned favorite, its long sprays of graceful heart shaped flowers are always attractive. A most satisfactory plant for the hardy border, especially when it can be planted in the shade. Strong clumps 50c. each; per doz., $\$ 5.00$.

\section{ECHINOPS (Globe Thistle)}

Ritro. Interesting thistle-like plants with globular heads of attractive, deep metallic blue flowers; 2 to 3 feet. $25 \mathrm{c}$. each; doz., $\$ 2.50$; $\$ 15.00$ per 100 .

\section{ERYNGIUM (Sea Holly)}

Amethystinum. The finely-cut, spiny foliage and the beautiful thistle-like heads are of glistening amethystine-blue. A most ornamental plant. 35c. each; doz., $\$ 3.50 ; \$ 18.00$ per 100 .

\section{EUPATORI UM}

Ageratoides (Thorough wort). A useful border plant of strong free growth, 3 to $31 / 2$ feet high, with minute white flowers in dense heads; splendid for cutting; August and September.

Coelestinum. A pretty hardy plant, with light blue flowers similar to the Ageratum. Blooms freely from August until frost; a splendid cut flower. 18 to 24 inches.

Price. 30c. each; doz., \$2.50; $\$ 15.00$ per 100 .

\section{EUPHORBIA (Milk Wort)}

Corollata (Flowering Spurge). A most showy and useful native plant, growing about 18 inches high and bearing from June to August umbels of pure white flowers, with a small green eye; desirable for cutting. 30c. each; doz., $\$ 2.50 ; \$ 18.00$ per 100 .

\section{HARDY FERNS}

The graceful plants grow on an average from 1 to 2 feet high, according to the variety, and the clumps increase in size and beauty each year. They die down in the winter and break forth again in May.

Adiantum Pedatum (Maidenhair Fern).

Aspidium Acrostichoides. Christmas Fern.

Asplenium Filix-Foemina (Lady Fern).

Cystopteris Bulbifera (Bulblet Bladder Fern).

Dicksonia Punctilobula (Gossamer Fern).

Onoclea Struthiopteris. Ostrich Fern.

-Sensibilis. Sensitive Fern.

Osmunda-Cinnamonea. Cinnamon Fern.

-Claytoniana.

Woodsia Illvensis. Excellent for rock-work, requiring little soil and thriving best in the sunniest corner.

Price, any of above, 30c. each; doz., \$2.50; $\$ 18.00$ per 100 .

\section{GAILLARDIA (Blanket Flower)}

Grandiflora. Dark brown centre, surrounded with a rich orange disc; petals on the outer edge are yellow. 25c. each; doz., $\$ 2.50$; $\$ 15.00$ per 100 .

\section{GRASSES (Hardy Ornamental)}

The generous beautiful effect produced by the hardy Grasses is hard to describe. Plantings must be seen to be appreciated. Elymus Glaucus (Blue Lime Grass). A graceful growing type with narrow, silvery blue foliage; a dwarf compact grower; height, 3 feet.

Erianthus Ravennae (Plume Grass or Hardy Pampas). Deep green, narrow foliage, growing about 10 feet high.

Eulalia Gracillima Univittata (Japan Rush). Graceful narrow foliage, growing 5 to 6 feet high. Green, with silvery rib.

Eulalia Japonica Variegata. An attractive variety with a variation of markings of white, green, sometimes light pink and yellow; 4 to 5 feet high.

Eulalia Japonica. Like the variegated variety, except that it is entirely green.

Eulalia Japonica Zebrina. Dark green foliage, crossmarked horizontally golden yellow. 4 to 5 feet.

Gynerium Argenteum (Pampas Grass). This variety in severe climates requires light protection in winter. The silvery flower plumes are indeed handsome. Height, 7 to 10 feet.

Phalaris Arundinacea Variegata (Variegated Ribbon Grass or Gardener's Garter). This sort is especially suited for edging taller varieties, as it grows somewhat dwarf. The foliage is somewhat broad, variegated white and green. 12 to 15 inches.

Pennisetum Japonicum (Hardy Fountain Grass). One of the most valuable hardy grasses, either for beds, mixed borders or as individual specimens. Height, 4 feet.

Price of Hardy Grasses, 35c. each; doz., \$3.50; $\$ 22.50$ per 100.

\section{GYPSOPHILA (Baby's Breath)}

During August and September this is a mass of delicate flowers. They keep for months without water.

Paniculata. Feathery sprays of white flowers; useful for effects in bouquets. 30c. each; doz., \$2.50; $\$ 15.00$ per 100 . 


\section{MICHELL'S HARDY PERENNIAL PLANTS}

\section{HELENIUM (Sneezewort)}

These desirable perennials succeed in almost any soil, in a sunny location. The flowers are splendid for cutting.

Autumnale Rubrum. Bright, terra-cotta red; 5 feet.

Autumnale Superbum. Massive spreading heads of deep golden yellow flowers; August-October; 5 feet.

Riverton Beauty. Rich lemon-yellow, with large purplish-black cone; August and September; 4 feet.

Price. 30c. each; doz., \$2.50; $\$ 18.00$ per 100.

\section{HELIANTHEMUM (Sun Rose)}

A very pretty family of evergreen plants; with flowers of the most brilliant colors. For dry, sunny situations.

Perry's Hybrids. Mixed varieties, all colors; June to August. Height, 12 inches. 35c. each; doz., $\$ 3.50 ; \$ 18.00$ per 100 .

\section{HELIANTHUS (Hardy Sunflower)}

Very effective in borders, among shrubbery or as clumps on the lawn, etc. Produce masses of flowers during the summer and autumn; splendid for cutting.

Maximiliana. The latest of all, blooming profusely in October; the fine golden yellow flowers appear in long graceful sprays; splendid for cutting; 5 to 7 feet.

Meteor. Large double orange-yellow flowers with bold yellow guard petals. 5 feet. August and September.

Multiflorus Fl. Pl. Large, double golden yellow; July-August; 4 feet.

Orgyalis (Willow Leaved or Skyrocket Sunflower). Long, graceful foliage, bright yellow flowers. 6 to 8 feet. October.

Rigidus Japonicus. One of the most desirable varieties, beginning to bloom early in July and continuing until fall; flowers golden-yellow, with dark centres; 5 feet.

Price, 30c. each; doz., $\$ 2.50 ; \$ 18.00$ per 100 .

\section{HELIOPSIS (Orange Sunfiower)}

This genus is very similar to the Helianthus. They are tallgrowing plants, well suited for the back of flower borders.

Pitcheriana. One of the best hardy plants for the perennial border; especially valuable for cutting. Daisy-shaped flowers of deep orange color; 2 to 3 feet.

Scabra Excelsa. Rich chrome-yellow flowers, turning to a bright yellow as they mature; these are almost double and are produced very profusely. The plant is of robust growth, about 3 feet high. Mid-July to the end of August.

Price, 30c. each; doz., $\$ 2.50 ; \$ 18.00$ per 100 .

\section{HEMEROCALLIS (Yellow Day Lily)}

Lily-like plants, flowering in great profusion during the summer, making a fine cut bloom.

Aurantiaca. Large, trumpet-shaped, orange yellow flowers; reverse of petals bright Indian yellow; sweet scented. $30 \mathrm{c}$. each; doz., $\$ 3.00 ; \$ 20.00$ per 100 .

Dr. Regel. Handsome, rich orange-yellow flowers in May; very fragrant and fine for cutting.

Dr. Sovereign. Chrome-yellow flowers during June and July.

Fulva (Tawny Day Lily). Trumpet shaped flowers; coppery orange shaded crimson; June and July.

Kwanso Flore Pleno (Double). Coppery red; July; 3 feet high.

Price, of above, except where noted, $30 \mathrm{c}$. each; doz., $\$ 2.50$; $\$ 15.00$ per 100 .

\section{HIBISCUS (Mallow)}

Giant Flowering. A wonderfully improved form of our greatly admired Marsh Mallows. They attain a height of 6 to 7 feet, have beautiful laciniated foliage and monstrous flowers, measuring from 6 to 8 inches in diameter. We offer these in mixed colors only. 35c. each; doz., $\$ 3.50 ; \$ 25.00$ per 100 .

\section{HOLLYHOCKS (Double)}

While perfectly hardy, we recommend protecting them slightly during the winter. Our strain of these is very fine, and we offer the following colors in double flowering only (each separate):

Yellow, Crimson, Pink, White. 30c. each; doz., $\$ 2.50 ; \$ 18.00$ per 100.

\section{IBERIS (Hardy Candytuft)}

Low-growing plants with evergreen foliage. In spring and early summer they are completely covered with dense heads of pure white flowers.

Snowflake. Pure white, of fine form and compact habit; blooms very early; height, 9 inches.

Sempervirens. Pure white flowers; 1 foot.

Price, 30c. each; doz., $\$ 2.50 ; \$ 18.00$ per 100 .

\section{IRIS GERMANICA (Fleur de Lis)}

No garden or perennial border is complete without a planting of Iris; they thrive most anywhere, being absolutely hardy under most all conditions.

Bridesmaid. White, shaded silvery lilac.

Dr. Bernice. Brown with purple falls.

Eugene Sue. Creamy white, spotted and striped purple.

Honorabilis. Golden yellow, shaded rich bronze.

Lohengrin. Lilac rose; very large flower.

Mad. Chereau. White, edged light blue.

Queen of May. Light pink; very early.

Rhein Nixe. Standards pure white, falls deep violet blue, margined white.

Price of any of the above, except where noted, 25c. each; doz., $\$ 2.00 ; \$ 12.00$ per 100 .

Mixed German Iris. 15c. each; doz., $\$ 1.50 ; \$ 10.00$ per 100 .

\section{IRIS KAEMPFERI (Japanese Iris)}

The King of all Iris and in popularity they can be classed with the Hardy Phlox and Paeonies, coming into flower about the middle of June, they continue for five or six weeks and are particularly welcome at this time. They succeed in almost any soil and like plenty of water when forming their flower buds. Valuable as cut flowers, but they should be cut in the bud state allowing the blooms to expand in water. If desired Japanese Iris may be ordered by the number prefixed to the variety.

1. Bandai-No-Nami. Clear white, with fringed center; double.

3. Kichi-Cohuo. White; single.

4. Ho-o-Jo. Rich velvety purple; double.

5. O-Sho-Kun. Dark tyrian blue; white veins; double.

6. Shippo. Rich tyrian blue, white lined, double.

8. Yudo-No-Komura. Deep rose pink.

10. En-U-No-Sora. Pink, reddish standards; single.

22. Suiren. Very light lavender; double.

34. Sassa-No-Koe. White, pink lined; single.

43. Summa-No-Ura. Light blue; darker spotted.

60. Uchiu. Light lavender; very double.

75. Yedo-Jiman. Dark violet, purple center; double.

Any of the above named sorts of Japanese Iris. 35c. each; doz., $\$ 3.50 ; \$ 25.00$ per 100 .

Mixed Japanese Iris. All colors and shades. 20c. each; doz., $\$ 2.00 ; \$ 15.00$ per 100

\section{IRIS INTERREGNA}

An entirely distinct type, being a cross between a German Iris and Iris Pumila. It is medium early to bloom, flowering in between Iris Pumila and Iris Germanica. Plants grow about 18 inches high and are surmounted with large flower heads, on spikes, which grow well above the foliage, appearing in May.

Ceres. Standards and fall pearl white, orange beard.

Walhalla. Standards light blue, violet blue falls, yellow beard. Fritjof. Purple shaded lavender; 20 inches high.

Price of the above, 30c. each; doz., $\$ 2.50 ; \$ 18.00$ per 100 .

\section{IRIS (Oriental and Siberian)}

The flowers resemble the Spanish and English Iris. These make a bright show in the garden and are also excellent for cutting. They can be cut when in bud and will fully develop in water. Blooms from latter part of May until end of June.

Blue King. Clear blue. Found by Mr. Peter Parr in Japan.

Sanguinea. Intensely brilliant blue flowers, the bud being inclosed in conspicuous crimson spathe valves.

Superba. Large, violet blue; handsome foliage, reaching almost to the flowers; 2 to 3 feet.

Iris Siberica. Purplish blue; 3 feet high; very desirable. June.

Iris Siberica Alba. Fine white. June.

Price, 30c. each; doz., $\$ 2.50 ; \$ 18.00$ per 100.

\section{IRIS PUMILA HYBRIDA}

The first of the Iris to bloom, resembling in appearan Germanica variety; the plants are about 6 inches high ideal when used as an edging for taller varieties or in rockeries; they delight in a fairly dry, high situation, planted will increase in numbers rapidly.

Cyanea. Rich royal purple with blackish shadings.

Excelsa. A splendid pale lemon yellow.

The Bride. A large showy pure white.

Price, 30c. each; doz., \$2.50; $\$ 18.00$ per 100. 
LATHYRUS (Everlasting or Perennial Sweet Pea)

The perennial pea is one of the hardiest and most easily cutlivated species, thriving almost anywhere. It is a good trellis plant, and is adapted as a cover to wild, rough places, where it scrambles over bushes and stones. Flowers July to September.

Latifolius. Large deep red flowers on long stems in constant succession. 6 feet.

-Pink Beauty. Clusters of large beautiful shell-pink flowers, like Blanche Ferry Sweet Peas.

Price, either of above, 30c. each; doz., $\$ 2.50$.

-White Pearl. Most beautiful of all everlasting peas, with pure white flowers, which are about double the size of the ordinary Lathyrus Latifolius albus. Price, 35c. each; doz., $\$ 3.50$.

\section{LIATRIS (Blazing Star, or Gay Feather)}

Pycnostachya. Showy and attractive native plants, succeeding anywhere, producing large spikes of light rosy-purple flowers in July and August; 5 feet. 30c. each; doz., \$2.50; $\$ 15.00$ per 100 .

\section{LILY OF THE VALLEY}

For outdoor planting in shaded places. Pure white flower bells appear on stems about 8 to 10 inches long in the latter part of May. Clumps, 50c. each; doz., $\$ 5.00 ; \$ 35.00$ per 100 .

\section{LOBELIA}

Handsome border plants thriving in any good garden soil but preferring a moist loam where they will not suffer from drought. Few plants are more effective at their season of bloom which extends from early August till late September.

Cardinalis (Cardinal Flower). Rich fiery cardinal flowers; strong plants often produce 10 to 18 spikes, 24 to 30 inches long. $30 \mathrm{c}$. each; doz., $\$ 2.50 ; \$ 15.00$ per 100 .

\section{LUPINUS (Lupins)}

These flower in May and June; are 3 to 4 feet high. In dry weather water liberally to prolong the bloom.

Polyphyllus. Blue, very showy.

Polyphyllus White.

Polyphyllus Pink.

Price, 35c. each; doz., $\$ 3.50 ; \$ 20.00$ per 100.

\section{LYCHNIS (Campion)}

All of the Lychnis are of the easiest culture, thriving in any soil, and this, in addition to their brightness, has brought them into high favor with lovers of hardy plants.

Chalcedonica. A most desirable plant; heads of brilliant orangescarlet in June and July. Grows 2 to 3 feet high.

Chalcedonica Alba. A white-flowered form of above.

Haageana Hybrids. Brilliant orange-scarlet flowers in May and June; 12 inches.

Viscaria. Forms a dense tuft of evergreen foliage, and in June sends up spikes of handsome, double, deep red, fragrant flowers; 1 foot.

Price, 30c. each; doz., $\$ 2.50$; per $100, \$ 18.00$.

\section{LYSIMA CHIA}

Ciliata (Fringed Loose-strife). Yellow flowers in July. 2 feet.

Clethroides (Loose-strife). A fine hardy variety about 2 feet high, with long, dense, recurved spikes of pure white flowers from July to September.

Nummularia (Creeping Jenny, or Money-wort). Valuable for planting under trees or shrubs where grass will not grow, where t quickly forms a dense carpet.

Price, 30c. each; doz., $\$ 2.50 ; \$ 18.00$ per 100 .

\section{LYTHRUM}

Roseum Superbum (Rose Loose-strife). A strong-growing plant, 3 to 4 feet high, thriving in almost any position, producing large spikes of rose-colored flowers from July to September. $30 \mathrm{c}$. each; doz., $\$ 2.50 ; \$ 18.00$ per 100 .

\section{MERTENSIA (BIue Bells)}

Virginica. An early spring flowering plant 1 to $11 / 2$ feet high, with drooping panicles of handsome light blue flowers fading to clear pink; one of the most interesting of our native spring flowers; May and June. 30c. each; doz., $\$ 2.50 ; \$ 15.00$ per 100 .

\section{MONARDA (Bergamot)}

Didyma Cambridge Scarlet (Oswego Tea). Crimson scarlet. Didyma Rosea (Bee Balm). Flowers of a rose color, and sweetly fragrant foliage. 18 inches. July to September.

Fistulosa Alba (Wild Bergamot). Pure white flowers in whorls. Leaves cordate and highly scented. 3 feet. June to September. Price, 30c. each; doz., \$2.50; $\$ 18.00$ per 100 .
MYOSOTIS (Forget-Me-Not)

These are most effective when intermingled with Pansies, English Daisies or amongst summer-flowering perennials. They bloom usually about the middle of April, and last well into the summer. Alpestris Victoria. A grand variety, with fine heads of clear azure blue flowers; bushy and compact; a fine edging plant.

Palustris Semperflorens (Perpetual Flowering Forget-me-not). Blue with yellow throat; thrives in damp places; spreads rapidly, 9 inches.

20c. each; doz., $\$ 2.00 ; \$ 15.00$ per 100 .

\section{OENOTHERA (Evening Primrose)}

The evening Primroses are elegant subjects for growing in an exposed sunny position, either in the border or on the rockery, blooming the greater part of the summer.

Missouriensis. Large golden-yellow. 1 foot. 30c. each; $\$ 2.50$ per doz.; per 100, $\$ 15.00$.

\section{PACHYSANDRA}

An evergreen trailing plant, with thick, glossy foliage forming a dense mat; one of the finest ground covers for either sunny or shaded locations.

Terminalis. Green; 6 to 8 inches high; small flower spikes of a grayish white, in May and June. 25c. each; doz., $\$ 2.50 ; \$ 15.00$ per 100 .

\section{PARDANTHUS (Blackberry Lily)}

Very pretty perennial with lily-like flowers of handsome appearance. Requires a rich soil and a sheltered situation in winter.

Chinensis. Flower orange-colored, spotted with purple-brown; 18 inches to 2 feet; flowers in June. 30c. each; doz., $\$ 3.00$; $\$ 20.00$ per 100 .

\section{PENTSTEMON (Beard Tongue)}

Most useful showy perennials, either for the border or rockery. They are perfectly hardy.

Digitalis. Large spikes of long, purple-white flowers with purple throats, during June and July; 2 to 3 feet. $30 \mathrm{c}$. each; doz., $\$ 3.00 ; \$ 18.00$ per 100 .

\section{PHYSALIS (Chinese Lantern Plant)}

Francheti. An ornamental variety of the Winter Cherry, forming dense bushes about 2 feet high and producing freely bright orange scarlet, lantern-like fruits; highly interesting. 30e. each; doz., $\$ 2.50$; $\$ 15.00$ per 100 .

\section{PHYSOSTEGIA (False Dragon-Head)}

One of the most beautiful of our midsummer flowering perennials, forming dense bushes 4 to 6 feet high, bearing spikes of delicate tubular flowers, not unlike a gigantic heather.

Virginica. Bright but soft pink.

-Alba. Pure white; very fine.

Price, 30c. each; doz., $\$ 2.50 ; \$ 18.00$ per 100 .

\section{PINKS, HARDY GARDEN (Double)}

These old-fashioned favorites, bearing their clove-scented flowers, during the spring and early summer, are splendid cut blooms. Elsie. Bright rose with maroon centre.

Essex Witch. Delicate pink, finely fringed.

White Reserve. An everblooming variety, very double and pure white.

Price, 30c. each; doz., $\$ 2.50 ; \$ 15.00$ per 100 .

\section{NEW PERPETUAL FLOWERING \\ HARDY PINKS (Dianthus Allwoodi)}

This is a most important addition to worth while perennials. They are perfectly hardy and flower continuously from early Spring until late in the Autumn. The flowers are much larger than the old type of Hardy Pinks and are borne on long stems suitable for cutting; deliciously clove scented.

Harold. Large double white, of symmetrical form.

Jean. Pure white with purple center.

Robert. Delicate shade of old rose with light maroon center. Good thrifty young plants of the above varieties. 50c. each; doz., $\$ 5.00$.

\section{PLATYCODON \\ (Balloon Flower or Japanese Bell Flower)}

The Platycodons are closely allied to the Campanulas, and form neat, branched bushes of upright habit.

Grandiflorum. Deep blue cupped, star-shaped flowers.

-Album. A white-flowered form of the above.

Price, 30c. each; doz., $\$ 2.50 ; \$ 15.00$ per 100 . 
Agida. Mid-season; showy red; very fine...... $\$ 0.60 \quad \$ 6.00$

Anemonaeflora Rubra. Mid-season; guard petals deep crimson, those of the center small.........

Duchesse de Nemours. Pure white, with a sulphurwhite centre; very early and extra fine.

Edulis Superba. Beautiful shaped flower of a bright mauve pink color, with narrow edges of lilac. One of the best early sorts.

Festiva Maxima. Beautifully shaped flower, 7 to 8 inches in diameter. Pure white, splashed red; late

Grandiflora Rosea. Full globe-shaped flower; light solferino red petal=, salmon centre. Mid-season. .

Humei. Late; bright, deep pink..............

L'Indispensable. Perfect shaped flower of a delicate

creamy color, shaded pink. Mid-season..........
Louis van Houtte. Rich dark crimson, developing a

slight silvery tip as the flowers age..............
Mme. Thouvenin. Brilliant rosy red, flushed carmine and lilac; a real beauty.

\section{$.50 \quad 5.00$}

$.50 \quad 5.00$

$60 \quad 6.00$

$.60 \quad 6.00$

$.50 \quad 5.00$

$\begin{array}{ll}.50 & 5.00\end{array}$

$\begin{array}{ll}.50 & 5.00\end{array}$

$\begin{array}{ll}.50 & 5.00\end{array}$

$.50 \quad 5.00$
Ne Plus Ultra. Fine bright pink; very free; an excellent cut flower variety............... \$0.50 \$5.00

Purpurea Superba. Midseason; bright purple;

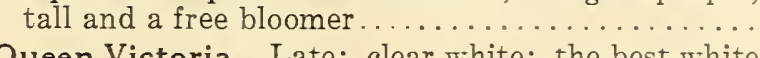

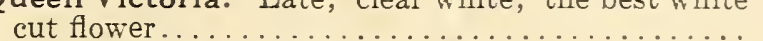

Reine des Fleurs. Clear pink............. . .50 5.00

Rose d'Amour. Hydrangea pink........... . .50 5.00

Solfatere. Guard petals snow white; centre sulphur yellow.......................... $60 \quad 6.00$

$\begin{array}{llll}\text { Van Dyck. Guards and center true enchantress pink } & .60 & 6.00\end{array}$

\section{PAEONIES TO COLOR}

Each Doz. 100

Double Pink.

$\$ 0.35 \quad \$ 3.50 \$ 25.00$

Double Red.

$\begin{array}{lll}.35 & 3.50 & 25.00\end{array}$

Double White

$.35 \quad 3.50 \quad 25.00$

\section{MICHELL'S SUPERB HARDY PHLOXES}

Among hardy herbaceous plants none are more easily grown than these. They are perfectly hardy, succeeding in any garden soil, and produce magnificent spikes of showy and lasting flowers year after year with comparatively little care. They are indispensable for brilliant, bold color effects in mass during the late summer and autumn as it would be difficult to maintain the display of dazzling color without them during July and August, at a time when there is hardly anything else in bloom that can be depended upon.

Baron von Dedem. Deep pink, suffused orange.

Eugene Danzanvilliers. Delicate lavender; a very attractive and decorative color; immense flowers. The peer of its color.

Europa. Blush white, with a large deep pink centre; the flower truss is very large, while the florets are also of gigantic size.

Frau Anton Buchner. Very large pure white flower truss, with gigantic individual florets; very dwarf.

Jules Sandeau. Dwarf; very large flowering; pure pink; extra fine variety and free bloomer.

Madame Paul Dutrie. Delicate soft pink; resembles a delicate orchid. The flower trusses are enormous.

Montagnard. Dark purple claret; large spikes and flowers.

Mrs. Jenkins. The best pure white.

Rheinlander. Deep salmon pink, with a distinct bright red eye. The trusses are of gigantic size and of fine form and substance. It is very early and lasts well into the season.

Rynnstrom. A splendid new phlox with gigantic flowers of a bright pink. Quite tall; flowers early and continues in bloom till frost; a grand variety.

Riverton Jewel. Mauve-rose with brilliant carmine-red eye.

Selma. Pale rose with cherry-red eye; one of the best.

Thor. Deep salmon pink, suffused with scarlet; a white halo surrounds the aniline red eye.

\section{PLUMBAGO (Lead-Wort)}

Larpentae. One of the most desirable border and rock plants; it is of dwarf, spreading habit, growing 6 to 8 inches high; covered with deep blue flowers during the summer and fall months. 30c. each; doz., \$2.50; \$15.00 per 100 .

\section{ORIENTAL POPPIES (Papaver Orientale)}

Goliath. One of the most effective; flowers of a rich scarlet; the largest flowered of this class.

Mrs. Perry. A soft shade of salmon rose; a beautiful large flower. This variety should be in every garden.

Perry's White. Pure satiny white with a bold crimson blotch at the base of each petal.

Orientalis (The Type). Brilliant scarlet with a black centre. Price, 35c. each; doz., \$3.00; $\$ 18.00$ per 100.

\section{ICELAND POPPIES (Papaver Nudicaule)}

The graceful foliage is surmounted with a mass of stems a foot high, which terminate in a beautiful cup-shaped flower. Flowers the entire summer.

Orange, Yellow, White; each color separate. Price, 30c. each; doz., $\$ 2.50 ; \$ 18.00$ per 100 .
Von Lassburg. The queen of all clear white phloxes; trusses and single flowers are immense in size; rather dwarf.

W. C. Egan. One of the prettiest in our entire collection, the color being a pale lilac with an intense solferino-red eye.

Price of any of the above Hardy Phloxes, extra strong roots which will flower next season, 30c. each; doz., \$2.50; $\$ 10.00$ per 100.

\section{PHLOX SUFFRUTICOSA, Miss Lingard}

This variety differs from the others, in that the foliage and stem are deep green and glossy, and they begin to blossom in June and remain in bloom until October. Its color is purest white. 30c. each; doz., $\$ 2.50 ; \$ 18.00$ per 100 .

MISCELLANEOUS VARIETIES OF PHLOX

Amoena. A beautiful plant, with soft rose-colored flowers; one of the best for rockeries or borders; 4 inches high; April-May.

Divaricata Canadensis. The large heads of fragrant lavender flowers appear the latter part of April and in May.

Subulata Rosea (Moss Pink). Moss evergreen-like foliage, tucking close to the ground and covered completely with pink star-like flowers in May.

Subulata Alba. The same as Rosea, with pure white flowers. Subulata Lilacina. A beautiful shade of lilac.

Price of any of the above Miscellaneous Phlox, 30c. each; doz., $\$ 2.50 ; \$ 10.00$ per 100 .

\section{PRIMULA Hardy Primrose}

One of the first of the early spring flowers. They delight in a rich soil, preferably in a semi-shaded location. Some of the varieties are richly colored, and are worthy of a place in every hardy garden. As a hardy border edging, as well as for rockery planting, it can be highly recommended.

Veris (English Cowstip). A mixture comprising the various shades of red and yellow; a splendid plant for the spring blooming garden.

Vulgaris (English Primrose). Beautiful light canary yellow; long flower stems with large trusses.

Price, 30c. each; doz., \$2.50; $\$ 15.00$ per 100.

\section{PYRETHRUM (Giant Daisy)}

Uliginosum. Grows 3 to 4 feet high and is covered with large white Daisy-like flowers, 3 inches in diameter, from July to September. 30c. each; doz., \$2.50; $\$ 18.00$ per 100 .

\section{RANUNCULUS Crowfoot Buttercup}

Acris FI. PI. A double flowered form of our common buttercup 2 feet; May and June.

Repens FI. PI. (Bachelor's Buttons). A pretty double flowering, bright golden buttercup, bearing masses of flowers durin
and June.

Price, 30c. each; doz., \$2.50; \$18.00 per 100. 


\section{RUDBECKIA (Cone-Flower)}

Indispensable plants for the hardy border; grow and thrive anywhere, giving a wealth of bloom; well suited for cutting.

Golden Glow. A well-known popular plant, attaining a height of 5 to 6 feet; produces masses of double, golden-yellow Cactus Dahlia-like flowers from July to September. .

Newmani. Dark orange-yellow flowers, with deep purple cone, borne on stiff, wiry stems 3 feet high; July to September.

Nitida "Autumn Sun." An attractive single-flowering variety, growing 5 to 6 feet high, with long, broad petals of bright primrose-yellow; August to October.

Purpurea (Giant Purple Cone-flower). Flowers about 4 inches across, of a peculiar reddish-purple with a remarkably large coneshaped centre of brown; forms bushy plants 3 feet high and blooms from July to October.

Price, 30c. each; doz., $\$ 2.50$; per 100 , $\$ 18.00$.

\section{SALVIA (Meadow Sage)}

Perennials with strikingly beautiful, orchid-like bloom, that make them welcome in the herbaceous border. Leaves are used in medicine and for the kitchen.

Azurea Grandiflora (Rocky Mountain Sage). Sky-blue flowers in greatest profusion; 6 feet.

Virgata Nemorosa. An interesting plant for the hardy border; flowers spikes bear many-flowered whorls of dark blue blossoms; the unexpanded buds are light violet blue, forming a pleasing color combination. It continues in flower for about six weeks during the early summer months; 18 inches.

Price, 30c. each; doz., $\$ 2.50 ; \$ 18.00$ per 100 .

\section{SAPONARIA (Soapwort)}

Very ornamental, dwarf-growing perennials; very attractive for the rockery or as an edging plant.

Caucasica (Bouncing Bet). White flowers. 6 to 9 inches.

Ocymoides splendens (Rock Soapwort). Dwarf creeping habit;

rosy crimson flowers; 6 to 9 inches.

Price, 30c. each; doz., $\$ 2.50 ; \$ 18.00$ per 100.

\section{SCABIOSA}

The flowers are gigantic, measuring frequently 3 inches and more in diameter. It delights in a sunny position, and is a cut flower few perennials can equal; it lasts a long while in water; the average height is about $21 / 2$ feet. Very free flowering.

Caucasica. A delicate shade of lavender blue, starting in flower in June and lasting well through the summer.

Caucasica Alba. White. Like the above, except the color.

Price, 30c. each; doz., $\$ 2.50 ; \$ 18.00$ per 100 .

\section{SEDUM (Stonecrop) \\ DWARF VARIETIES}

Suitable for the rockery and covering of graves, etc.

Acre (Golden Moss). Much used for covering graves; has green foliage and bright yellow flowers.

Album. Green foliage; white flowers.

Sieboldi. Round succulent glaucous foliage with bright pink flowers during August and September.

Stahli. A species with compact crimson foliage in the Autumn.

\section{ERECT GROWING VARIETIES}

Useful and pretty plants for the border, producing their interesting flowers during the late Summer and Fall.

Spectabile. One of the prettiest erect growing species, growing 18 inches high, with broad light green foliage and immense heads of showy rose colored flowers in September and October.

Spectabile "Brilliant." A rich colored form of the above, being a bright amaranth red.

Prices of any of the above varieties, 30c. each; doz., $\$ 2.50$; $\$ 18.00$ per 100

\section{SOLIDAGO (Golden Rod)}

Golden Wings. The finest of the Golden Rods; very showy; 5 feet high, with immense panicles of bright golden yellow flowers from July to September. 30c. each; doz., \$2.50; $\$ 15.00$ per 100.

\section{SPIRAEA (Goat's Beard, Meadow Sweet)}

Elegant border plants with feathery plumes of flowers and neat, attractive foliage; succeed best in a half-shaded location.

Filipendula (Dropwort). Numerous corymbs of white flowers on stems 15 inches high, during June and July; fern-like foliage.

Filipendula Fl. Pl. A double flowering form of the above.

Palmata (Crimson Meadow Sweet). The deep purple red of the stems and branches passes into the crimson purple of the broad corymbs of flowers; June and July; 3 feet.

Price, 35c. each; doz., $\$ 3.50 ; \$ 20.00$ per 100.

\section{STATICE (Sea Lavender)}

Latifolia (Great Sea Lavender). A handsome border plant with heads of dark blue flowers; invaluable for cutting, the flowers, when dried, lasting for months. 1 to 2 feet.

Eximia fl. alba (White Sea Lavender). Beautiful heads of light and graceful white flowers. Useful for table decoration. 1 foot. Price, 30c. each; doz., $\$ 2.50 ; \$ 18.00$ per 100 .

Cyanea. Very light blue.

STOKESIA (Cornflower Aster)

Cyanea Alba. Pure white.

Price of the above, 30c. each; doz., $\$ 2.50 ; \$ 15.00$ per 100 .

SWEET WILLIAM (Dianthus Barbatus)

Michell's Prize Mixture. In all colors.

Pink Beauty (Sometimes called Newport Pink). A splendid shade of salmon with immense flower trusses. When massed it is a striking feature of the perennial garden; extra fine novelty.

Price, 25c. each; doz., $\$ 2.50 ; \$ 15.00$ per 100 .

TANACETUM (Tansy; Costmary; Bible Leaf)

Vulgare (Tansy). Golden yellow flowers and beautiful sprays of fern-like foliage; 3 feet; June to August. 30c. each; doz., $\$ 2.50 ; \$ 18.00$ per 100 .

\section{THALICTRUM (Meadow Rue)}

Adiantifolium. A beautiful variety; foliage like the Maiden Hair Fern; miniature white flowers in June and July; $11 / 2$ to 2 feet.

Glaucum. Fine cut foliage; bronzy-yellow flowers; 2 feet. Price 30c. each; $\$ 2.50$ per doz.; $\$ 18.00$ per 100 .

\section{THERMOPSIS}

Caroliniana. A showy, tall-growing plant, attaining a height of 3 feet, producing long spikes of yellow flowers in June and July. 30 c. each; per doz., $\$ 2.50 ; \$ 18.00$ per 100 .

\section{TRADESCANTIA (Spider Wort)}

Virginica. Produces a succession of blue flowers all summer; $11 / 2$ to $21 / 2$ feet. 30 c. each; per doz., $\$ 2.50$.

\section{TRILLIUM (Wood Lily, or Wake Robin)}

Erectum. This is the Purple Wood flower; the earliest to bloom. Grandiflorum. The largest white; probably the handsomest. Price, 20c. each; per doz., $\$ 2.00 ; \$ 12.00$ per 100 .

\section{TUNICA}

Saxifraga. A pretty tufted plant with light pink flowers; pro duced all summer; useful either for the rockery or the border. 30 c. each; doz., $\$ 2.50 ; \$ 18.00$ per 100 .

\section{VALERIANA (Valerian)}

Coccinea. Heads of reddish flowers; June to October; 2 feet. - Alba. A white-flowered form.

Officinalis (Hardy Garden Heliotrope). Showy heads of rosetinted white flowers during June and July; 3 to 4 feet. Price, 30c. each; per doz., \$2.50; $\$ 15.00$ per 100 .

\section{VERBASCUM (Mullein)}

Phoeniceum. A distinct and valuable species, with purple and pink flowers. 2 feet. June and July. 30c. each; doz., $\$ 2.50$; $\$ 18.00$ per 100 .

\section{VERONICA (Speedwell; Cancerwort)}

Amethystina. Amethyst-blue flowers on short spikes; one of the best. 1 to 3 feet. May to June.

Incana. White, wooly plant, tufted, with pale blue flowers; useful in the rockery, border or geometrical garden; 1 to $11 / 2$ feet; July to August.

Longifolia Subsessilis (Japanese Speedwell). A strong grower and undoubtedly the finest of all the Veronicas; rich blue flowers on tall spikes. Fine for cutting; 3 feet; July and August.

Spicata. Long spikes of bright blue flowers; 2 feet; June to August.

Price, 30c. each; per doz., $\$ 2.50 ; \$ 18.00$ per 100 .

\section{VIN CA Periwinkle or Myrtle)}

Minor. Evergreen foliage and pretty lavender flowers, which appear in Spring and Fall. Extra strong plants. 20c. each; doz., $\$ 1.50 ; \$ 11.00$ per 100 .

\section{COLLECTIONS OF HARDY PERENNIALS}

We can offer these in distinct varieties as per our Spring 1922 Catalog. 


\section{MICHELL'S CLIMBING PLANTS AND VINES}

Vines play an important part in the landscape of the home. There are so many purposes they fill that we cannot recommend too highly their general use.

AKEBIA-Quinata. Quick growing vine; small, fine-lobed, half-evergreen leaves, and purplish brown or chocolate-colored flowers, which have a delicous odor. Desirable where a dense shade is not desired. Extra strong plants, 50c. each; doz., $\$ 5.00$.

AMPELOPSIS-Quinquefolia (Virginia Creeper). The large handsome, dark green leaves are deeply cut into five lobes. In the autumn the foliage turns a beautiful rich crimson; especially adapted to covering tree stumps and trunks. Extra strong plants, 40c. each; doz., $\$ 4.00$.

AMPELOPSIS-Veitchii (Boston Ivy). The popular climber for brick and stone buildings and walls. The leaves are a beautiful deep green, which in the autumn turn to a coppery red. Strong plants, 35c. each; doz., $\$ 3.50$; per $100, \$ 25.00$.

ARISTOLOCHIA-Sipho (Dutchman's Pipe). Handsome light green leaves, giving a quick, dense shade. The brown flowers are shaped like the bowl of a pipe. Large plants, $\$ 1.00$ each.

BIGNONIA (Trumpet Vine)-Radicans. These are strong-growing vines, with rich foliage and trumpet-shaped flowers. Free flowering; dark red, throat shaded orange. Strong plants, 50c. each.

CELASTRUS (Bittersweet or Waxwort)-Scandens. A vine of rapid growth. In the early summer it produces yellow flowers, which by autumn have turned to bright, orange-colored fruits, with red markings. Extra strong plants, 50c. each.

CLEMATIS. This family of Climbing Plants are probably more popular than any other. Some of the small flowering varieties are exceedingly fragrant. The large flowering types make a glorious effect on account of their gigantic blooms and striking appearance. All Clematis delight in plenty of sunlight, rich soil and plenty of water in dry weather.

Great care should be exercised in planting the large-flowering varieties; the stem is likely to get broken below the eye shoots, which would render the plant useless. In the winter put a covering of straw, long manure or leaves around the roots.

- Crispa. This variety bears sweet-scented, lavender flowers.

- Henryi. Creamy white, large single flowers, borne in great profusion.

—*Jackmanii. Violet-purple; gigantic flowers.

- ${ }^{*}$ Mme. Baron Veillard. Large flowering; reddish purple.

-*Mad. Edouard Andre. Velvety red; flowers are well formed and of great substance; the blooms are gigantic.

Any of above varieties of Clematis, 75c. each, doz., $\$ 7.50$.

- Paniculata (Japanese Virgin's Bower). A strong, luxuriant grower, with light green foliage. At the close of August innumerable star-like flowers cover the vine in a sheet of fragrant white. Strong plants, 30c. each; per doz., $\$ 3.00 ; \$ 18.00$ per 100 . Extra strong plants, 50c. each; per doz., $\$ 5.00 ; \$ 35.00$ per 100 .

\section{Non-Warranty on Clematis}

The large flowering types of Clematis those marked * are injured very easily often when being tied up, by annuals and otherwise. We ship these plants in perfect order, after which we must respectfully ask our customers to relieve us of any responsibility in the matter of them growing or thriving.

EVONYMOUS-Radicans Variegata. Self-clinging vine, suitable for covering walls, stumps or rockeries. Leaves are variegated. 30c. each; doz., \$2.50; $\$ 18.00$ per 100 .

- Evonymous Radicans. Deep green foliage, otherwise like the above variety; valuable for covering low walls. $30 \mathrm{c}$. each; doz., $\$ 2.50 ; \$ 18.00$ per 100 .

- Evonymous Vegeta. This plant is regarded far too little in importance as a strictly A-1 variety for climbing stone walls of buildings or otherwise; it ranks favorably with English Ivy, except that it is evergreen and does not winter kill or shed its foliage. The foliage is large and the plant produces an orangecolored berry, which remains on the plant the most part of the winter. 30c. each; doz., \$2.50; $\$ 18.00$ per 100 .

HONEYSUCKLE. This requires very little description, always yielding in their season a wealth of fragrant bloom.

- Chinese Evergreen. Yellow and white variegated flowers; very fragrant; blooms the entire season.

- Halliana (Hall's Honeysuckle). Pure white, turning to yellow; fragrant hardy evergreen; flowers from June until frost.

- Red Coral or Scarlet Trumpet. Bright red, trumpetshaped flowers. Blooms all summer. Extra strong plants only. 50c. each; doz., $\$ 5.00$.

- Variegated (Aurea Reticulata). Foliage beautifully mottled yellow and green; flowers white and yellow.

Price of any of the above Honeysuckles, except when noted, 4 in. pot-plants, 30 c. each; doz., $\$ 3.00 ; \$ 22.50$ per 100 . 6-in. potplants, 60c. each; doz., $\$ 6.00 ; \$ 45.00$ per 100 .

HOP VINE-Japanese. A rapid grower, with dark green foliage; bears a profusion of seed-pods, suitable for many domestic purposes. Strong pot-plants, 30c. each; doz., $\$ 2.50$.

IVY-English. This is an invaluable plant for covering brick and stone walls and buildings. It rarely ever dies out and needs no attention. 4 in. pot-plants, $35 \mathrm{c}$. each; per doz., $\$ 3.50 ; \$ 25.00$ per 100. 6 in. pot-plants, $\$ 1.00$ each; doz., $\$ 10.00$.

LATHYRUS ( Hardy Pea). This is a splendid plant for training on pillars, columns and-similar places; it flowers during the greater part of the summer, and is a really splendid cut flower, lasting well, and very effective.

- Latifolius, White Pearl. Pure white, giant flower trusses. 50c. each; doz., $\$ 5.00$.

- Latifolius, Pink Beauty. Beautiful rose pink. 30c. each; doz., $\$ 3.00$.

- Latifolius Crimson. Rich red. 30c. each; doz., \$3.00.

- Latifolius Albus. Pure white. 30c. each; doz., $\$ 3.00$.

LYCIUM (Matrimony Vine)-Barbarum. A dense growing climber, somewhat shrubby in nature. In late summer the small purple flowers are followed by a crop of red berries, which remain until late winter. 50c. each; doz., $\$ 5.00$

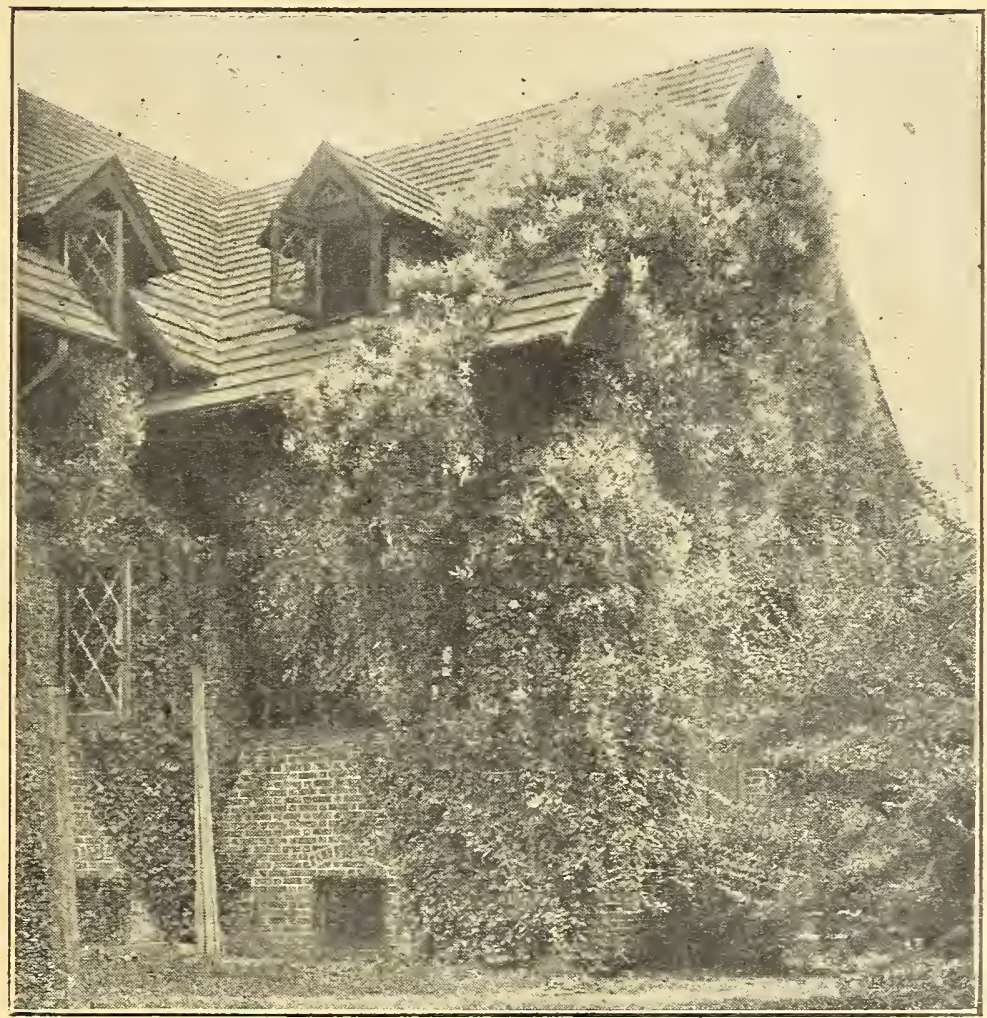

Polygonum Aubcrti

POLYGONUM-Auberti. For porches, fences, buildings, etc A useful vine which is perfectly hardy and free from disease or pests. It is quick growing, a small plant making twenty-five to thirty feet of growth the first summer, and produces clouds snowy white flowers, borne in long clusters, which turn rose color with age. The foliage is clean looking and attractive, and apart from its wonderful flower effect will please everyone pearance. It will not cling to the wall, but will ramble thing that will support it. Strong pot-grown plants, $\$ 1.00$ each

WISTARIA. This flowers in the latitude of Philadelphia during May. A strong developed vine produces hundreds panicles, while no foliage is visible until after the flo They thrive best in the sun, and with an application of nure once or twice a season they respond extra growth and an abundance of flowers.

- Chinensis (Chinese Wistaria). Pale blue

Extra strong plants, $\$ 1.00$ each

- Chinensis Alba. A beautiful white

above. Extra strong plants, $\$ 1.00$ each. 
SPECIAL NOTICE ON GUARANTEE

We spare no effort to supply decorative shrubs of the best quality in first-class living condition. On account of the many causes beyond our control we regret we cannot guarantee this stock to live and establish itself, as that is usually entirely within the power of the buyer or planter. If customers desire us to guarantee decorative shrubs to live we will assume such guarantee at an advance of 25 per cent. over and above our usual prices, but not otherwise, and such guarantee will expire within 90 days from date of shipping.

Shipping Seasons are usually from November 15 th until freezing weather, and from March 15th to May 1st.

ALTHEA (Rose of Sharon). These thrive almost anywhere, producing their bloom from July till September.

- Alba Plena. Pure white; double.

- Atropurpurea Plena. Double purple.

- Duchess de Brabant. Double; deep red.

- Lady Stanley. Semi-double; pale pink, splashed with carmine.

- Totus Albus. Single; pure white.

Plants, 2 to 3 feet high, 75 c. each; doz., $\$ 7.50$.

AMYGDALUS (Flowering Almond)-Alba Flore Pleno. Erect, slender branches, which are covered in May with small, very double, fragrant white flowers. Strong plants, 2 to 3 feet, $\$ 1.00$ each.

- Rosea Flore Pleno. Identical with the above, but bearing pink flowers. Strong plants 2 to 3 feet, $\$ 1.00$ each.

BERBERIS (Japanese Barberry)-Thunbergii. A good, hardy plant for lawn or border. The slender branches are prickly with small thorns, and tend to make a defensive hedge that few animals will attempt to penetrate. In autumn the foliage is a bright crimson; when it falls, a profusion of scarlet berries, which remain throughout the winter, are revealed on the branches.
Height
Each Doz.
100
$9-12$ inches
$\$ 0.35 \$ 3.50$
$\$ 22.50$
12 -18 inches
$.45 \quad 4.50$
32.50

BUDDLEIA (Butterfiy Bush)-Variabilis Magnifica. Flowers continuously all season. The flower racemes are composed of many little blossoms in the shape and color of lilacs. Pot plants, 30 c. each; doz., $\$ 3.00 ; \$ 20.00$ per 100 . 1 year old field grown plants, $\$ 1.00$ each.

CALLICARPA PURPUREA (Beauty Fruit). A beautiful shrub growing about 3 feet high, with graceful branches that are covered in August with tiny pink tinted flowers. These are followed in late September by violet purple berries born in clusters from the axil of every leaf. These remain on the plant until the middle of the Winter. 75c. each; doz., $\$ 7.50$.

CALYCANTHUS (Sweet Shrub)-Floridus. Chocolate-colored, double flowers, with a peculiar agreeable odor. Blooms in June. 3 to 4 feet, 75 c. each; doz., $\$ 7.50$.

CERCIS (Judas Tree or Red Bush)-Canadensis. A tall, slender growing shrub, developing eventually into a large tree. Very early in the spring the leafless branches are covered with delicate deep pink flowers. 4 to 6 feet plants, $\$ 1.00$ each.

CHIONANTHUS (White Fringe)-Virginica. In May and June the tree is covered with long, fluffy panicles of fine white bloom. Strong plants, 2 to $21 / 2$ feet, 75 c. each; doz., $\$ 7.50$.

CLETHRA (Sweet Pepper Bush)-Alnifolia. Of low and dense growth; has numerous spikes of small white fragrant flowers appearing in July; desirable for moist places or along water edges. One of the prettiest of our native shrubs. 2 to 3 feet, 75 c. each; doz., $\$ 7.50$

CORNUS (Dogwood) - This plant is so well known that it hardly needs description. The flowers appear before the foliage in May. In autumn it takes on a rich crimson shade.

Florida (White Flowered Dogwood). Strong plants; 4 to $5 \mathrm{ft}$., $\$ 2.00$ each; doz., $\$ 20.00$.

- Rubra (Pink:Flowered Dogwood). 3 to $4 \mathrm{ft}$., $\$ 3.00$ each.

- Elegantissima (Variegated Dogwood). A beautifully variegated shrub which should be planted more freely. Strong plants, 3 to 4 feet high, $\$ 1.50$ each; doz., $\$ 15.00$.

- Lutea (Golden-Twigged Dogwood). Bright yellow branches in Winter. Strong plants, 3 to 4 feet high, $\$ 1.50$ each; doz., $\$ 15.00$. - Sibirica (Siberian Dogwood). Branches a bright, coral red which are quite ornamental for Winter effects. Strong plants, 3 to 4 feet high, $\$ 1.50$ each; doz., $\$ 15.00$.

CYTISUS (Golden Chain).-Laburnum. A large shrub with shining green leaves and long drooping racemes of yellow flowers, which appear in early summer. $\$ 1.50$ each.
DEUTZIA.-The Deutzias are among the most useful of our summer flowering shrubs. For planting either individually or in masses they are very attractive.

- Candidissima Fl. pl. Abundant racemes of double, pure white flowers in June; luxuriant foliage, and fine habit. $3 \mathrm{ft}$. plants. - Crenata Rosea Fl. pl. Doubleflowering; whitetinged pink. $3 \mathrm{ft}$. - Gracilis. Of dwarf, bushy habit; white flowers. 18 inches. Price any of the above, $75 \mathrm{c}$. each; doz., $\$ 7.50$.

- Pride of Rochester. The flowers, borne in large panicles, are pinkish white, with under-side of the petals rose. June. $75 \mathrm{c}$. each; doz., $\$ 7.50$.

EVONYMUS ALATA (Ćork-barked Evonymus). Small delicate flowers in late Spring are followed by attractive red berries in the Fall. Curious corky bark, brilliant Autumnal foliage. Best for individual planting. 18 to 24 inches, $75 \mathrm{c}$. each; doz., $\$ 7.50$.

FORSYTHIA (Golden Bells). Bright golden yellow, star-shaped flowers burst into bloom just as winter is leaving and while the bush is otherwise bare.

- Fortunei. Erect growing with dark green foliage; strong plants, $4 \mathrm{ft}$., $75 \mathrm{c}$. each; doz., $\$ 7.50$.

- Intermedia. April. Vigorous grower with slender, erect or arching branches. Considered by many as the best of the family. $75 \mathrm{c}$. each; doz., $\$ 7.50$.

- Suspensa. Graceful, drooping tendency. Frequently planted on banks and slopes. Beautiful as specimens or in masses. 75 c. each; doz., $\$ 7.50$.

- Viridissima. Erect shoots, spreading branches and excellent foliage that assumes a rich Autumnal tint and persists until early Winter. 75c. each; doz., $\$ 7.50$.

HYDRANGEA-Arborescens Grandiflora Alba (Snowball $\mathrm{Hy}$ drangea). The snow-white blooms are of the largest size, coming into flower early in June and lasting until late in August. Is more hardy than any other sort and especially suited for shaded places. 2 to $21 / 2 \mathrm{ft}$., $75 \mathrm{c}$. each; doz., $\$ 7.50$.

- Paniculata Grandiflora. The large panicles of white flowers are at their best during August; later they take on a reddish cast. These plants look fine used as single specimens on the lawn or grouped in large beds. Strong bush form, $2 \mathrm{ft}$. plants, $75 \mathrm{c}$. each; per doz., $\$ 7.50$. Extra strong stock, $3 \mathrm{ft}$., $\$ 1.25$ each; per doz., $\$ 12.00$.

- Paniculata Grandiflora (Standard or Tree Shaped). These are fine, planted as individual specimens in the lawn or in the centre of beds, containing other plants. Stems 2 to $21 / 2$ feet long, with shapely heads, $\$ 1.50$ each.

Otaksa and French Varieties. See Page 42.

JASMINUM-Nudiforum. A fine shrub for sheltered positions, bearing fragrant yellow flowers very early in Spring. Hardy south of Philadelphia. 75c. each; doz., $\$ 7.50$.

LONICERA (Honeysuckle)-Fragrantissima. March and April. Delightfully fragrant white flowers that come with the first breath of Spring. A broad, many-branched shrub. 75c. each; doz., $\$ 7.50$.

- Morrowi. An open bush with irregular branches. The foliage is dark green with small white flowers, which appear during May. During the late summer and early autumn the plant is covered with bright red berries. Plants, 3 feet, $75 \mathrm{c}$. each; doz., $\$ 7.50$.

- Ruprechtiana. A free flowering variety producing pure white flowers during May and June, followed by red fruit. $75 \mathrm{c}$. each; doz., $\$ 7.50$.

MALUSS (Crab) -Bechtel's Double Flowering. Grows medium height, producing large double flowers of wonderful frag-

rance. 2 to $3 \mathrm{ft}$. high, $\$ 2.00$ each; 3 to $4 \mathrm{ft}$. high, $\$ 3.00$ each.
PHILADELPHUS (Mock Orange)Coronarius. Handsome foliage and beautiful fragrant white flowers in May and June. $2 \mathrm{ft}$. plants, 75c. each; doz., $\$ 7.50$.

PYRUS (Japan Quince)-Japonica. This shrub is a beautiful sight when covered in the early spring with cherry-red flowers, about the size of an apple blossom. After the flowers fall, many of them set fruit, which is edible, making the finest Quince Jelly or preserves. Extra strong plants, $2 \mathrm{ft} ., 75 \mathrm{c}$. each; doz., $\$ 7.50$.

RHUS-Typhina Laciniata (Dwarf Cut-leaved Sumac). Low growth and fern-like foliage make this variety distinctive. Foliage is brilliantly colored in the fall months. $75 \mathrm{c}$. each; doz., $\$ 7.50$.

SPIREA-Anthony Waterer. Of dwarf, dense habit, bearing a profusion of crimson flowers. 18 inches, $75 \mathrm{c}$. each; doz., $\$ 7.50$. - Prunifolia (Bridal Wreath). The pretty double white flowers are all along the almost leafless stem about May 1st, just as the leaves are budding. 3 feet, $75 \mathrm{c}$. each; per doz., $\$ 7.50$.

- Thunbergi. One of the prettiest of the dwarf shrubs with fine delicate foliage and a profusion of small white flowers in the early Spring. 12 to 18 inches, $75 \mathrm{c}$. each; per doz., $\$ 7.50$.

- Van Houttei. The most beautiful of all white Spireas, flowering in May when it is a complete fountain of white bloom. 3 to 4 feet, $75 \mathrm{c}$. each; per doz., $\$ 7.50$. 
SYMPHORICARPUS (Snowberry)-Racemosus. Small red flowers are succeeded by many white berries, remaining on the plant through half the winter. Strong plants, 75c. each; doz., $\$ 7.50$.

- Vulgaris (Red fruited or Indian Currant). This is a well known shrub, bearing pink flowers followed by bright red fruit. $75 \mathrm{c}$. each; doz., $\$ 7.50$.

SYRINGA (Lilac)-Japonica. A very desirable free flowering tree, bearing during June and July fragrant white flowers in large panicles. $75 \mathrm{c}$. each; doz., $\$ 7.50$.

- Vulgaris. Common purple, sweet-scented lilac. 75c. each; doz., $\$ 7.50$.

- Vulgaris Alba. Pure white type of the above, but more fragrant. $75 \mathrm{c}$. each; doz., $\$ 7.50$.

VIBURNUM (Snowball)-Plicatum (Japanese Snowball). A desirable shrub. Should be in every garden or on the lawn; perfectly hardy; blooms in June. Extra fine plants, 2 to 3 feet, 75 c. each; doz., $\$ 7.50$.

\section{MICHELL'S CHOICE CALIFORNIA PRIVET}

Unlike a fence, which needs painting, repainting, etc., and then never looks well, this hedge is no further expense after planted, and it adds dignity and charm to any home, and increases the value of real estate. Being absolutely hardy, it increases in beauty with each successive year. Privet is somewhat of an Evergreen nature and looks attractive until real winter sets in. Plants should be set 12 inches apart in double rows, in zig-zag fashion, so that the plants are diagonally opposite each other; this practically places them 6 inches apart, which is desirable to get a quick, dense growth. Plant from October 15th till the ground freezes, and from March 15th to May 15 th.

\section{Height}

1-yr.-old, 18 to $24 \mathrm{in.}$

Doz.

1000

2 -yr.-old, 24 to $30 \mathrm{in.}$

$\begin{array}{ll}1.50 & 8.00\end{array}$

$\$ 50.00$

2-yr.-old, 30 to 36 in.

$2.00 \quad 10.00$

70.00

90.00

NOTE-Our privet is especially fine and will give splendid satisfaction.

PLEASE NOTE.-All privet offered are of the height specified before shipping, but to save space in packing and transportation all privet will be shipped cut back to 18 inches. It is advisable to trim it after planting in any event to this height, if not lower.

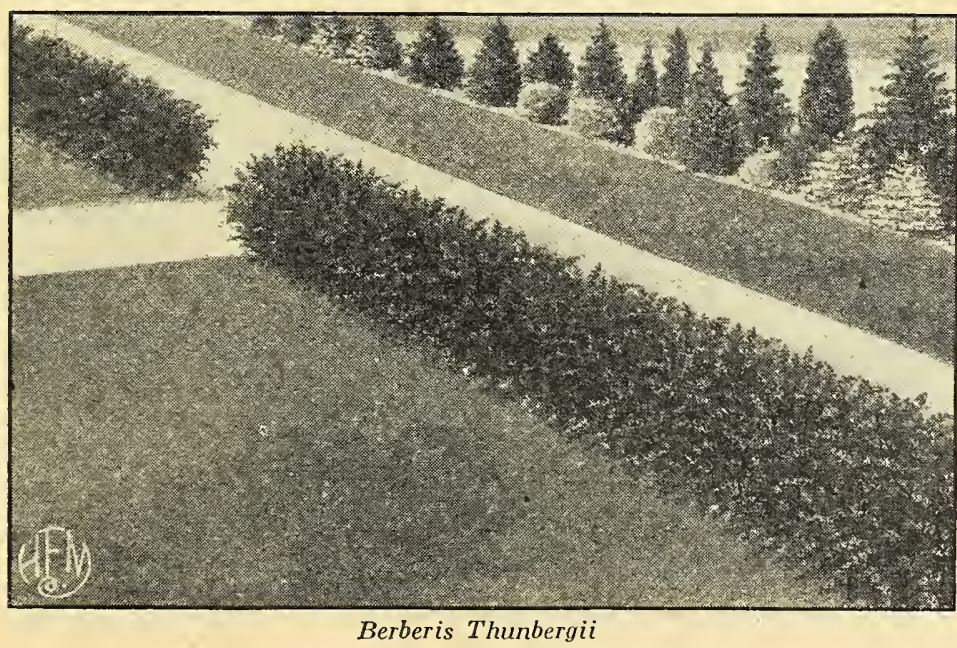

BOX WOOD (Bush Form) each. 12 to 15 inches high, $\$ 2.50$ each; 15 to 18 inches high, $\$ 3.00$
TAMARIX-Africana. Strong, slender, upright growth, with panicles of feathery pink flowers in May. 3 to 4 feet, $75 \mathrm{c}$. each; doz., $\$ 7.50$.

WEIGELIA - Candida. Flowers abundantly in June and July; additional bloom is also shown during the autumn months. The tube-shaped flowers are pure white; fine for cutting. Plants, 4 feet, 75 c. each; doz., $\$ 7.50$.

- Eva Rathke. Of erect form and vigorous habit. The deep carmine-red flowers are the best of the red-flowering sorts; 2 to 3 feet, $75 \mathrm{c}$. each; doz., $\$ 7.50$.

- Rosea. Remarkably showy flower; numerous spreading branches and dark green leaves. The rose-colored blooms are produced in great abundance. $75 \mathrm{c}$. each; doz., $\$ 7.50$.

- Rosea nana variegata. Silvery variegated leaves and pale pink flowers. 75c. each; doz., $\$ 7.50$.

Shipping season is usually from November 15 th until freezing weather, and from March 15th to May 1st.

\section{THRIFTY HEDGE PLANTS}

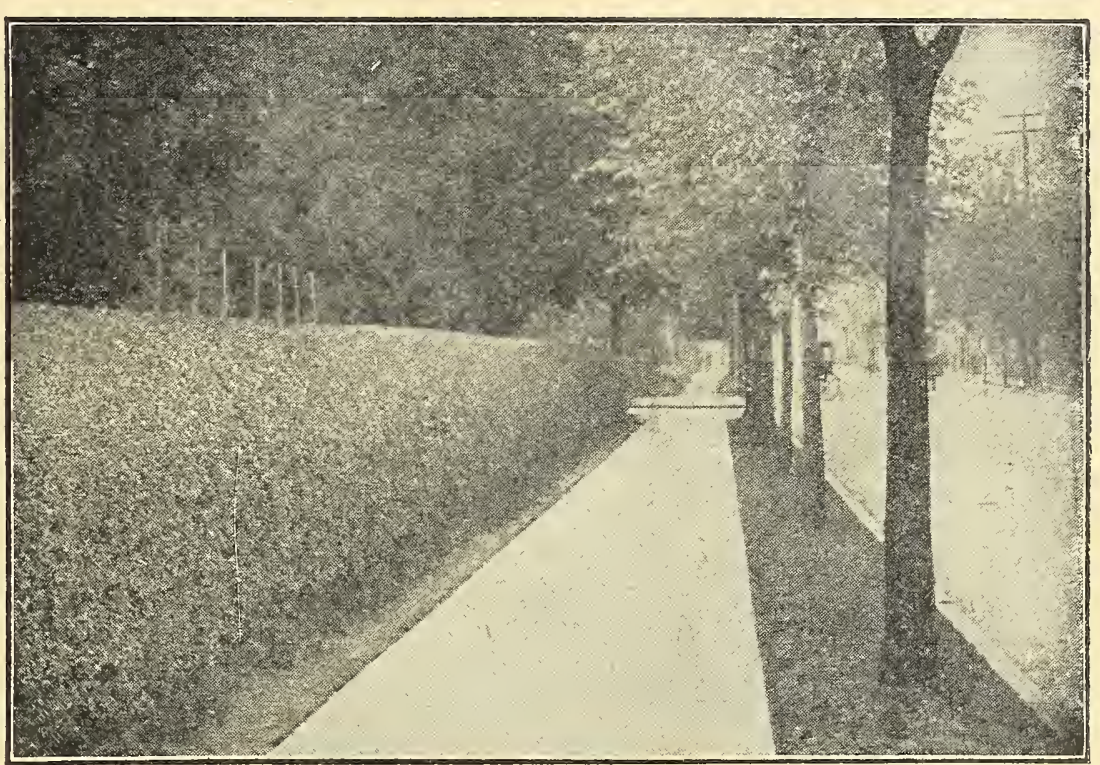

A Privet Hedge Is Much More Attractive Than The Best Fence

\section{BERBERIS THUNBERGII} (Japanese Barberry)

A good hardy plant of low dense growth. There is an air of grace and refinement to the Barberry Bush which is not embodied in any other hedge plant. It is a brilliant light green from early spring to winter. It has a manner of growth which does not give it the stiff, cold appearance which many other hedge plants have. It should really be regarded as a shrub, as it can be planted individually in lawn or border. The slender branches are prickly, with small thorns, and tend to make a defensive hedge that few animals will attempt to penetrate. In autumn the foliage is a bright crimson; when it falls a profusion of scarlet berries, which remain throughout the winter, are revealed on the branches.

Height

9 to 12 in. (plant 8 to $10 \mathrm{in.}$ apart)

12 to $18 \mathrm{in.} \mathrm{(plant} 10$ to $12 \mathrm{in.}$ apart)

BOXWOOD (Buxus Sufruticosa) In Europe the Boxwood edging plays a very conspicuous par in every garden. There is something about it which adds a home-like feeling to the surroundings. At times, especially in the morning or after a rain, it seems to permeate the air with a distinct, pleasant odor. A planting lasts a lifetime. Many Boxwood closures planted a hundred years ago are in existence today. grows rather bushy, instead of in height. It should be 4 inches apart and trimmed to shape according to its growt
2 to 4 in. high, $\$ 3.00$ per doz.; per $100 \ldots \$ 20.00$
4 to 6 in. high, 5.00 per doz.; per 100.35 .00 


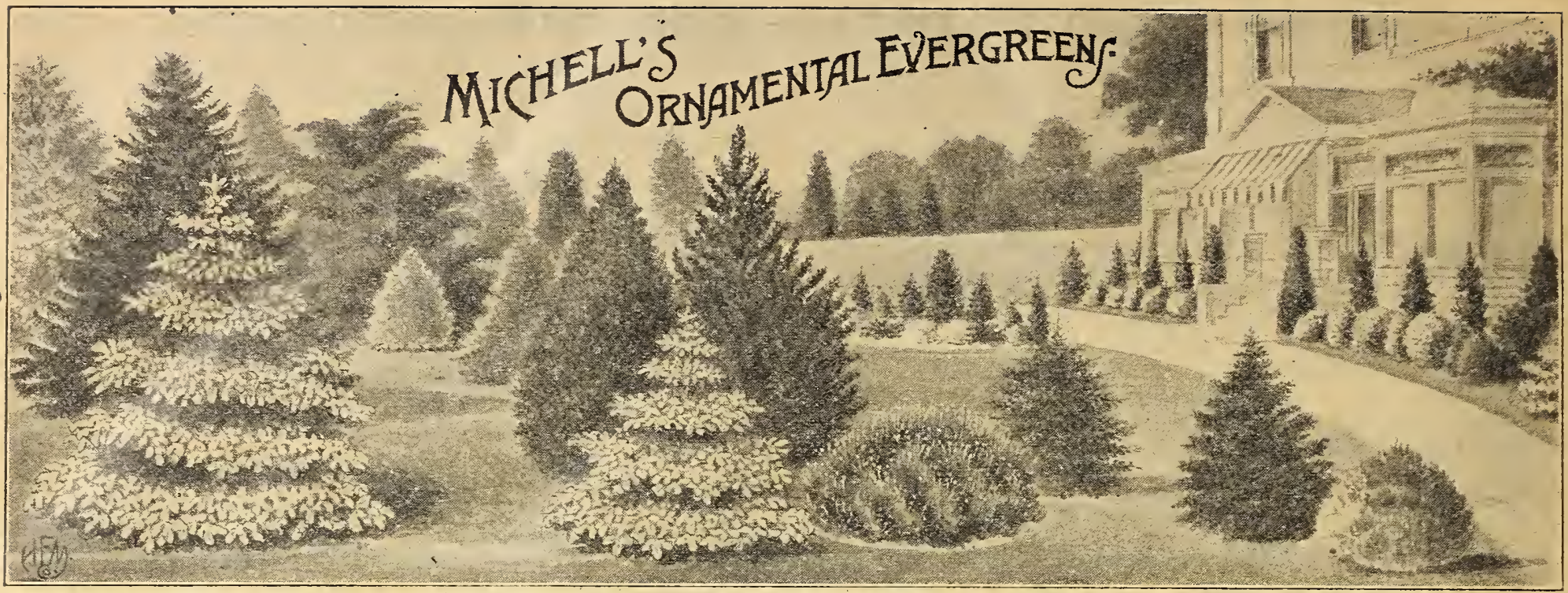

Evergreens offer a wide variety and brilliant diversity of color, every shade of green and blue foliage; then there are the rich, golden tints, the soft silvery grays and those varieties with the dainty white-tipped leaves.

Evergreens are much desired for specimen lawn trees; they are also extensively used for massing, shelter belts, screens and hedges. The taller varieties form perfect backgrounds for the showy flowering shrubs and trees of early spring, the berries of autumn. the bright bark and twigs of winter, or the light green, golden or silver-blue growth of smaller evergreens.

This list includes the varieties mostly in demand. We can furnish all other sorts.

\section{See Page 55 for Special Notice on Guarantee.}

ARBORVITAE (Thuya). These are chiefly of upright habit, not growing overly tall; exceedingly hardy; of a brilliant green all through the bleakest winter; splendid for backgrounds, windbreaks or garden fences.

- Aurea (Golden Arborvitae). Golden foliage retained well throughout the year. Attractive as a specimen, or to produce color contrasts in groups or beds. Not hardy north of New York. 18 inch, $\$ 3.75 ; 24$ inch, $\$ 4.50$.

- Globosa (Globe Arborvitae). Light green foliage of a grayish cast. The neat globular outline adapts this Arborvitae for formal plantings, tub and window box use, as well as in the foreground of Evergreen groups. 12 inch, $\$ 3.00 ; 15$ inch, $\$ 3.50$.

- Occidentalis (American Arborvitae). A well-known, popular evergreen for ornamental hedges; rapid growth. 2 to 3 feet, $\$ 2.25 ; 3$ to 4 feet, $\$ 4.50 ; 5$ to 6 feet, $\$ 7.50$.

- Occidentalis pyramidalis (Pyramidal Arborvitae). The most narrow, columnar-like evergreen; medium growth; very distinct light green, compact foliage. Very effective in landscape work. 2 to 3 feet, $\$ 4.50 ; 3$ to 4 feet, $\$ 7.50$.

CYPRESS, JAPANESE (Retinospora). The many varieties vary considerably in their general appearance and nature of growth; all of them can be clipped occasionally to keep them within growing boundary. The shades of colors are numerous, so that an assortment of them makes a handsome effect.

- Filifera (Thread Branched Retinospora). Broad and bushy, with pendulous, dark green foliage of a thread-like nature. A distinctive, valuable tree. $11 / 2$ to 2 feet, $\$ 4.50 ; 2$ to $21 / 2$ feet, $\$ 6.00$.

- Plumosa (Plume-like Cypress). A splendid bushy variety. with pyramidal outline, slender, graceful branches and light green leaves. $1 \frac{1}{2}$ to 2 feet, $\$ 3.75 ; 2$ to $21 / 2$ feet, $\$ 4.50$.

- Plumosa aurea. The most popular and generally useful of all the golden evergreens. Especially ornamental, and the soft, plume-like golden foliage is particularly bright in spring. A vigorous grower and unsurpassed for color effect. 12 to 18 inches, $\$ 2.25 ; 2$ to 3 feet, $\$ 5.00 ; 3$ to 4 feet, $\$ 6.25 ; 4$ to 5 feet, $\$ 9.50$.
JUNIPERS (Juniperus). These possess remarkable vigor and thrive in bleak situations, in poor, stony soils and barren lands, in low and damp places at the seashore, in fact, most anywhere.

- Excelsa Stricta (Greek Juniper). Close growing, pyramidal form, with gray green foliage. Excellent in the formal garden 12 to 15 inch, $\$ 2.75 ; 15$ to 18 inch, $\$ 3.50$.

- Hibernica (Irish Juniper). Very useful in formal planting. screenings for small yards and cemeteries. 1 to 2 feet, $\$ 2.25$; 2 to 3 feet, $\$ 4.50$.

- Pfitzeriana. A beautiful new form, with graceful dark green foliage. One of the most attractive of evergreens. $1 \frac{1}{2}$ to 2 feet, $\$ 4.50 ; 2$ to 3 feet, $\$ 6.00$.

PINE (Pinus). These will endure a wide range of climatic conditions, being native in the lowlands or the mountains, and will withstand cold, bleak winds. Useful on lawns and on public grounds. They are in variety so that a suitable sort may be selected for almost any purpose.

- Austriaca (Austrian Pine). Tall, massive, with spreading limbs and long, stiff needles. Thrives along the coast, inland, and under city conditions. Handsome for specimen or open group planting. We offer an especially fine lot of these desirable trees. 3 to 4 feet, $\$ 5.00$.

- Excelsa (Bhotan Pine). Somewhat like the White Pine, having graceful branches, silvery gray green in color; very suitable for massing. 3 to 4 feet, $\$ 5.00$.

- Mughus (Mugho Pine). A low growing, broad spreading tree; in fact it is more of a large pine bush than a tree, and is very ornamental. 1 to 2 feet, $\$ 5.00$.

SPRUCE (Picea). Probably better known and more largely planted than any of the other evergreens; they are hardy, tall and rapid growers; reliable in almost any locality, living for many years. Suitable for planting as specimens, while some varieties are used for hedges and windbreaks.

- Canadensis (Hemlock Spruce). A rapid grower; very hardy and not particular as to soil. If trimmed, it becomes dense and bushy, making beautiful hedges. 2 to 3 feet, $\$ 5.00 ; 3$ to 4 feet, $\$ 7.00$.

- Excelsa (Norway Spruce). Rapid grower; does well in most soils. It is highly valued for shelters, windbreaks or hedges. 2 to 3 feet, $\$ 3.00 ; 3$ to 4 feet, $\$ 4.00$.

YEWS (Taxus). These are a small growing evergreen, highly ornamental; effective in groups or bed plantings.

- Cuspidata (Japanese Yew). One of the hardiest of Yews. Upright, rather open growth, with rich green foliage. Makes a beautiful medium-sized specimen, and can be kept uniform and symmetrical by occasional shearing. 12 to 18 inch, $\$ 3.50$; 18 to 24 inch, $\$ 5.00$.

- Cuspidata brevifolia. The branches are spreading and the general aspect is less dense than the common Yew. Perfectly hardy. 12 to 15 inches, $\$ 3.75 ; 15$ to 18 inches, $\$ 4.50$. 


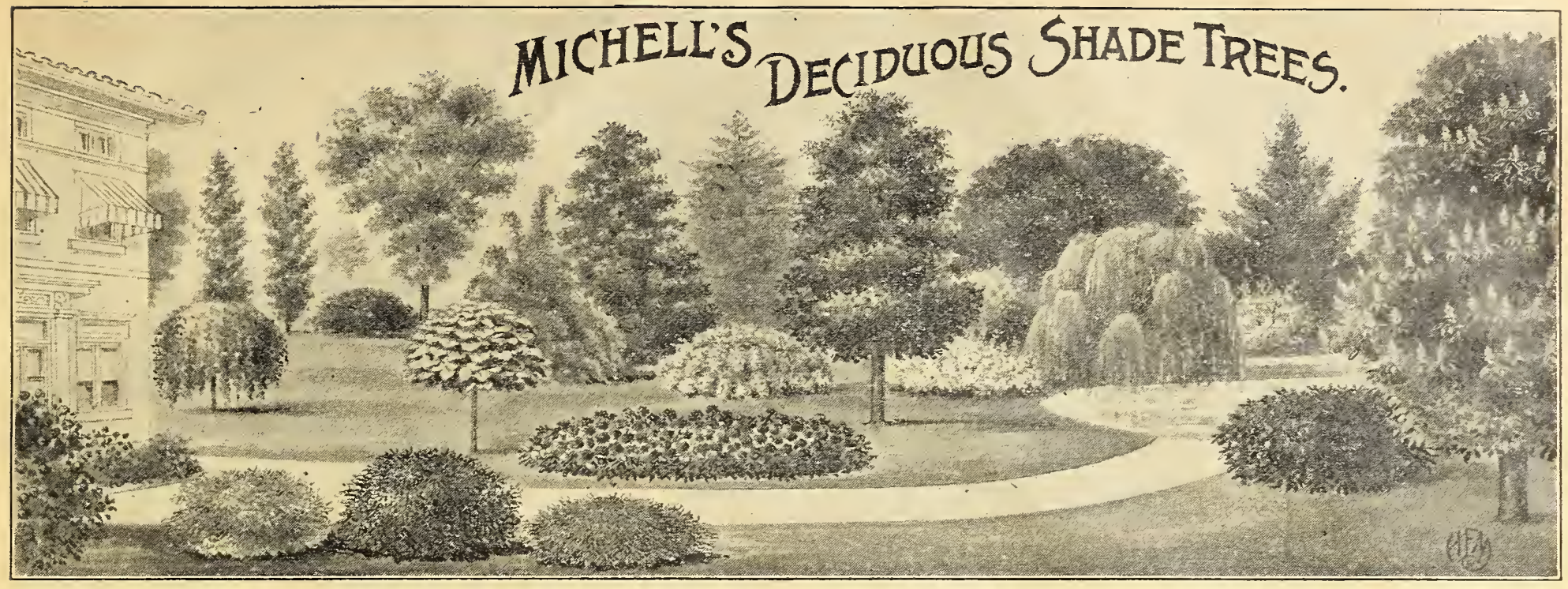

This list includes the varieties mostly in demand. We can furnish all other sorts.

Beech (Purple) F. sylvatica purpurea. The foliage in spring is a deep purple, changing later to green. Should be closely pruned when transplanted. 4 to 5 feet, $\$ 3.50$.

Birch (Cut-Leaved Weeping) Betula laba laciniata pendula. Tall, slender, with graceful drooping branches, silvery-white bark and delicately cut foliage. 4 to 6 feet, $\$ 2.00$.

Dogwood (Cornus). See Page 52.

Elm (American) Ulmus americana. One of the finest street shade trees in the world. 8 to 10 feet, $\$ 2.50$.

Horse Chestnut (Aesculus hippocastanum). The flowers are large, white, spotted with purple and produced in large, compact spikes. A fine shade tree. 4 to 6 feet, $\$ 3.00$.

Larch (European) Larix decidua. A conifer with deciduous needle-like leaves; bright green very early in spring, and clear yellow in autumn. 3 to 4 feet, $\$ 2.50$.

Linden (American) ${ }^{-}$T. Americana (Basswood). The largestgrowing Linden. Suitable for parks or streets. When in blossom, its yellow flowers are intensely fragrant. 8 to 9 feet, $\$ 3.00 ; 10$ to 11 feet, $\$ 5.00$.

Linden (European) Tilia europaea. Leaves smaller and darker than those of the American Linden; form a dense shade. 8 to 10 feet, $\$ 4.00 ; 10$ to 12 feet, $\$ 5.00$.

Magnolia Soulangeana. A low spreading tree, covered early in the spring before the leaves appear with large flowers, purple at the base and white in the upper half of the petals. 3 to 4 feet, $\$ 10.00$.

Malus Ioensis Bechtelii (Bechtel's Double-flowering Crab). The tree is of medium growth; the flowers of immense size and of a beautiful pink color; highly fragrant. Very double. 2 to 3 feet, $\$ 2.00 ; 3$ to 4 feet, $\$ 3.00$.

Malus, Parkmanii, (Parkman's Flowering Crab). Rose-colored buds open into little rosy-white flowers. These are succeeded by decorative fruits. The tree is of a rather spreading, irregular nature. 2 to 3 feet, $\$ 2.00 ; 3$ to 4 feet, $\$ 3.00$.

Maple (Norway) A. platanoides. One of the finest park, street or lawn shade trees in America; of rounded form, compact habit and stout, vigorous growth, 8 to 10 feet, $\$ 3.00 ; 10$ to 12 feet, $\$ 4.50 ; 12$ to 13 feet, $\$ 6.00$.

Maple (Sugar) A. saccharum. Its upright habit of growth, dense shade and adaptability to different soils have rendered it one of the most extensively used. The autumn effect of the foliage is particularly handsome. 8 to 10 feet, $\$ 3.50 ; 10$ to 12 feet, $\$ 4.00$.

Maple (Silver) Acer dasycarpum. Of rapid growth; extensively planted for ornament and shade. 8 to 10 feet, $\$ 2.50 ; 10$ to 12 feet, $\$ 2.75$.

Mountain Ash (Sorbus aucuparia). A handsome native tree. In autumn and early winter the tree is clothed with large clusters of red berries. 6 to 8 feet, $\$ 2.50$.
SPECIAL NOTICE ON GUARANTEE

We spare no effort to supply trees, plants and shrubs of the best quality in first-class living condition. On account of the many causes beyond our control we regret we cannot guarantee this stock to live and establish itself, as that is usually entirely within the power of the buyer or planter. If customers desire us to guarantee plants, trees and shrubs to live we will assume such guarantee at an advance of 25 per cent. over and above our usual prices, but not otherwise, and such guarantee will expire within 90 days from date of shipping.

Mulberry (Teas' Weeping) Morus alba pendula. Forms a perfect umbrella-shaped head, with slender, willowy branches, drooping to the ground. 1 year heads, $\$ 3.75 ; 2$ year heads, $\$ 5.00$.

Oak (Scarlet) Quercus coccinea. A large, well-shaped tree; in the fall the foliage changes to a brilliant scarlet. 6 to 8 feet, $\$ 3.75 ; 8$ to 10 feet, $\$ 5.00$.

Oak ( $P$ in) Q. palustris. Foliage deep green and finely divided. The leaves become a shade of scarlet and yellow in autumn. It thrives in almost any soil. 8 to 10 feet, $\$ 4.50$.

Plane (Oriental) Platanus orientalis (Buitonwood). A favorite tree for avenue and seashore planting; of large spreading habit and rapid growth; not affected by insects. Leaves large, smooth and handsome, affording abundant shade. 8 to 10 feet, $\$ 3.00$ 10 to 12 feet, $\$ 5.00 ; 12$ to 14 feet, $\$ 6.00$.

Poplar (Carolina) Populus caroliniana. Good in almost any location. 8 to 10 feet, $\$ 2.50$.

Poplar (Lombardy) P. nigro fastigiata var. Italica. Its tall form, sometimes reaching 120 feet, makes it indispensable in landscape effects for breaking monotony of outline. 6 to 8 feet, $\$ 2.00 ; 8$ to $10 \mathrm{ft}$., $\$ 2.50 ; 10$ to 12 feet, $\$ 3.50$.

Salisburia (Maiden Hair Tree). One of the oddest and most peculiar of all hardy exotic trees. Its leaves are deciduous, fan-shaped, broad and notched, resembling those of the Maiden Hair Fern. 6 to 8 feet, $\$ 2.50 ; 8$ to 10 feet, $\$ 3.00$.

Tulip Tree (Liriodendron tulipifera). A popular native deciduous tree, sometimes attaining a height of 75 to 100 feet. 6 to 8 feet, $\$ 3.00 ; 8$ to 10 feet, $\$ 5.00$.

Umbrella Tree (Catalpa bungei). For the lawn the Catalpa bungei is very effective. Has a dense, perfect, half-globular or umbrella-shaped head, high on a straight upright stem. the terraces when used in connection with the California Privet hedge the effect is most pleasing. Price, stems, 1-year heads, $\$ 3.75$ each; 5 to 6 feet stem heads, $\$ 6.25$ each; 6 to 7 feet stems, 4 -year heads, $\$ 9.50$

Weeping Willow (Salix babylonica). This is the well Weeping Willow, whose long pendulous branches gracefully, and sway to the slightest breeze. Grov wet or dry places. 6 to 8 feet, $\$ 2.00 ; 8$ to 10 feet

Weeping Willow (Salix Elegantissima). Similar to 


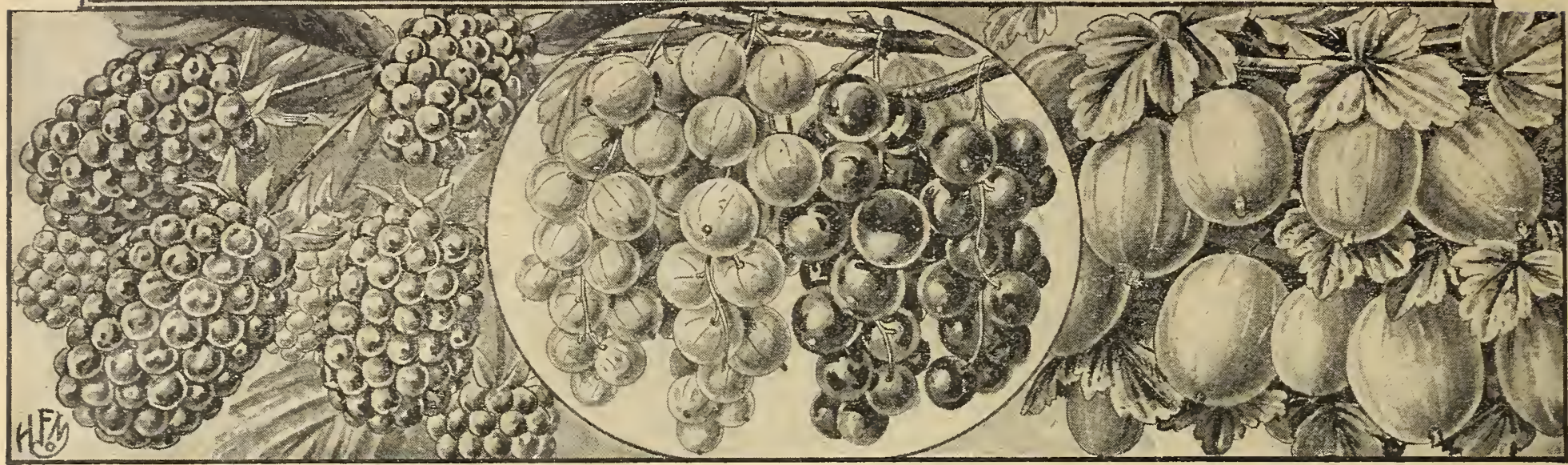

Blackberry, "Eldorado"

Currants

Gooseberries

Every garden should have some space reserved for small fruits. None bought in the market can compare with those picked fresh by yourself when you want them. Any surplus that cannot be consumed may be put up for winter use.

\section{TESTIMONIAL}

Orangeburg, S. C.

Enclosed find check to cover our account in full to date. Also order which you will kindly ship at once.

Allow us to say that we consider it a pleasure to deal with you, as everything that we have ever received from you has been absolutely satisfactory. JESSIE C. KELLY.

\section{BLACKBERRIES (Extra Strong Plants)}

Blackberries thrive most anywhere. The plants are subject at times to attacks of rust, particularly during prolonged wet spells in summer. A spraying, especially underneath the foliage, with copper solution, usually arrests this. However, if the disease spreads too much, it is best to dig up the bushes, burn them and plant new ones in another part of the garden. If they are sprayed before being affected it is the best plan.

Eldorado. A very vigorous grower, free from mildew or rust; enormously productive; fruit large, excellent quality and without core.

Mersereau. Remarkably strong grower. An enormous producer of extra size berries, which are brilliant black, and retain their color under all conditions; very sweet and without core. Unsurpassed as a shipper and keeper.

Ward. An extra strong grower; produces an enormous crop of extra large, glossy black berries, which are rich, sweet, and tender nd with no hard core.

Price of Blackberries, $\$ 1.00$ per doz.; per $100, \$ 7.00$.

Note-If Blackberries are desired by Parcel Post, allow 15c. per dozen for postage, as we send out only extra strong plants which generally bear some the first season.

\section{CURRANTS (Extra Strong Plants)}

Currants like good, rich soil. They are particularly susceptible to scale, and steps should be taken to keep them free from this by liberal spraying, when the bushes are dormant.

Red Dutch. An old and well-known standard variety; clusters average about three inches long; berries medium in size, dark red.

Price of Currants, strong 2-year old, 35c. each; per doz., $\$ 3.50 ; \$ 20.00$ per 100 .

Note-If Currants are desired by Parcel Post, add 20c. per doz. for postage, as we send out extra strong bushes.

\section{GOOSEBERRIES (Extra Strong Plants)}

Gooseberries should be cultivated during the growing season and fertilized with manure in the early spring or late fall. They will repay you for this trouble with an extra big crop.

Downing. Medium to large; whitish green; flesh soft and juicy. Red Jacket. Berries medium; color, pale red; tender and good.

A wonderful cropper, with clean, healthy foliage.

Price of Gooseberries, 30c. each; doz., $\$ 3.00 ; \$ 20.00$ per 100.

Note-If Gooseberries are wanted by Parcel Post, please add $25 \mathrm{c}$. per doz. for mailing charges.

PLEASE NOTE.--Some States forbid the shipment of Gooseberries into their boundary. Before ordering it might be well to ascertain if there is such a law in your State.

\begin{abstract}
SPECIAL NOTICE ON GUARANTEE
We spare no effort to supply "small fruit" bushes of the best quality in first-class living condition. On account of the many causes beyond our control we regret we cann ot guarantee this stock to live and establish itself, as that is usually entirely within the power of the buyer or grower. If customers desire us to guarantee these and trees and shrubs to live we will assume such guarantee at an advance of 25 per cent. over and above our usual prices, but not otherwise, and such guarantee will expire within 90 days from date of shipping.
\end{abstract}

NOTE-Owing to the peculiar laws of Florida and Mississippi concerning the shipping of nursery stock into these States, we regret WE ARE UNABLE TO ACCEPT ORDERS FOR NURSERY STOCK or SMALL FRUITS FOR SHIPMENT WITHIN THE STATES OF FLORIDA AND MISSISSIPPI.

\section{GRAPE VINES}

A few of these planted in the garden, after several years will yield abundant crops, and they last for years with little attention except pruning and spraying.

Caco. The most delicious of all Grapes and perfectly hardy; it has been pronounced by America's most expert grape growers to equal in high quality and melting texture the finest varieties grown under glass. When one considers the price of the greenhouse product and realizes that the wonderful Caco can be grown in the back yard, almost without attention, the force of the above statement is apparent. The large berry is winered. Bunch of good size, compact and of good form. Ripens in ten days to two weeks in advance of Concord; rich in sugar; excellent in flavor. Vine a very strong, vigorous grower, healthy and prolific. This is a very fine variety and is easily worth the slight advance in price over the older varieties. $\$ 1.00$ each; doz., $\$ 10.00$.

Campbell's Early. A valuable and delicious grape; vine very strong, hardy and vigorous, with thick, healthy foliage; berries large, black, with light purplish bloom; skin thin; few and small seeds; flavor rich and delicious.

Catawba. Delicious flavor; medium size, red berry.

Concord. The well-known standard purple variety; succeeds wherever grapes will grow.

Ives. One of the most prolific bearers; medium size; color, purplish black.

Moore's Diamond. A strong healthy grower; hardy and productive; color, white; berries large, flesh tender, juicy, but with little pulp; ripens before Concord.

Niagara. An unusually strong grower; bunches very large and compact; berries large, light greenish-white, semi-transparent; has very little pulp and is sweet to the center.

Prices-Any of the above excepting Caco, 2-year old vines, 50 c. each; doz., $\$ 5.00$. If Grape Vines are wanted by mail, add 5c. each for postage charges.

Please Note. - We have reduced the variety of Grape Vines offered, retaining the best in varieties which cover the different colors.

Shipping Seasons for small fruits are from October till freezing weather and from March 25th to May 15 th. 


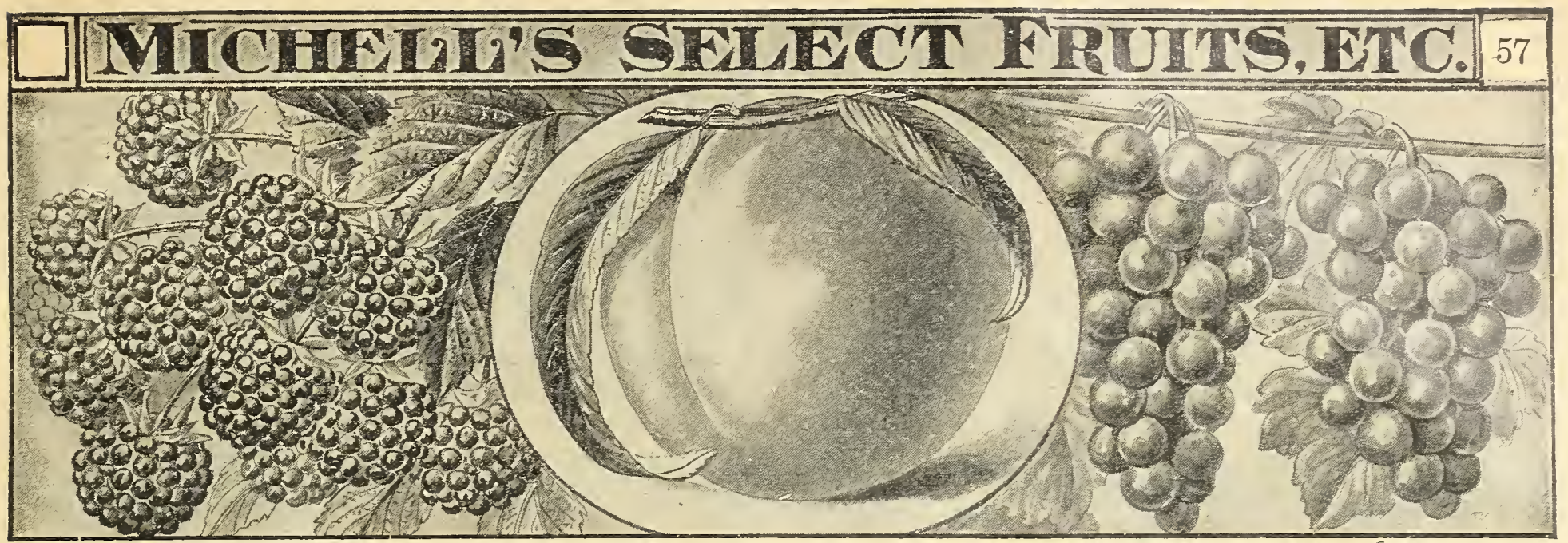

\section{RASPBERRIES (Extra Strong Plants}

Raspberries should be carefully staked, to get large crops. We also recommend that well-rotted manure or other suitable fertilizer be dug around the bushes, either in the fall or early spring.

Cumberland (Blackcap). The largest raspberry known. Selected specimens measure an inch in diameter; immensely productive.

Cuthbert. Berries very large, measuring 3 inches around; conical; rich crimson; one of the old-time favorites.

Golden Queen. Berries are large, of beautiful bright yellow and of excellent quality; medium to late; very sweet.

Ranere Everbearing. This yields its first crop of berries in June (the regular season), and yields an equally heavy crop the latter part of August and continues bearing right up to November.

It thrives equally well on sandy and heavy soil. The fruit is large, of a beautiful crimson color, very sweet and juicy and is borne in great abundance; does not seem to sunscald as easily as other sorts. A photo was made of a stalk which had by actual count 169 berries on one stem. This will give some idea of its free fruiting qualities.

Price, any of the above, $\$ 1.00$ per doz.; per $100, \$ 7.00$.

If Raspberries are wanted by mail, add 15c. per doz. for postage.

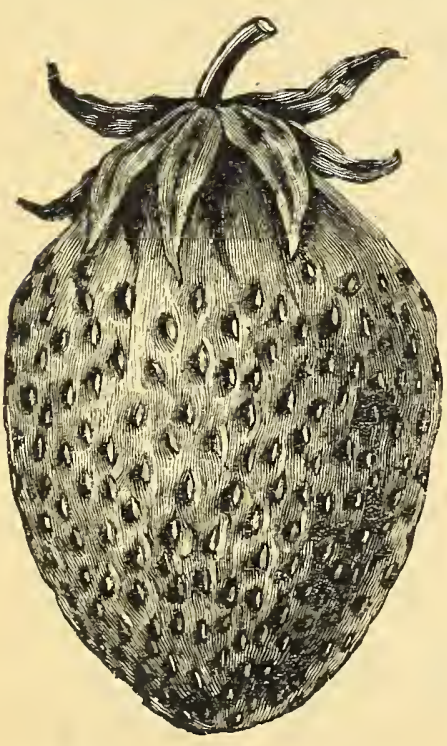

\section{STRAWBERRY} PLANTS

(Extra Strong Layers)

EARLY VARIETIES.--Early Jersey Giant, Premier, Senator Dunlap.

MID-SEASON VARIETIES.-

Big Joe, William Belt.

LATE SEASON VARIETIES.-

Gandy,Stevens' Late Champion.

Price of the above, 75c. per doz. 25 for $\$ 1.00 ; \$ 1.50$ for $50 ; \$ 2.00$ per 100 ; per $1000, \$ 17.50$.

We can also supply Pot-Grown plants of above varieties at $\$ 1.25$ per doz.; per $100, \$ 7.00 ; \$ 60.00$ per 1000 .

FALL FRUITING VARIETIES. Progressive. Price. 75c. per doz.; 25 for $\$ 1.00 ; \$ 1.50$ for 50 ; per $100, \$ 2.75 ; \$ 6.00$ for 250 ; per $1000, \$ 22.50$.

Pot-Grown plants of Progressive, $\$ 1.35$ per doz.; per 100 , $\$ 8.00 ; \$ 70.00$ per 1000 .

If layer Strawberry Plants are wanted by mail, add 5c. per doz. and $15 \mathrm{c}$. per 100 for mailing charges. Pot Grown Plants can best be shipped by express.

Shipping Seasons for small fruits are from October till freezing weather and from March 25th to May 15 th.

\section{CHOICE FRUIT TREES}

(Extra Strong Stock)

These can be shipped by express only.

\section{APPLES}

Baldwin. Large round, deep red, late variety.

Ben Davis. A late keeper; handsome striped fruit.

Fall Pippin. Large, yellow, rich and delicious. A good bearer when it reaches maturity. Likes a moist, well-drained soil; a good Autumn apple.

Grimes' Golden. Deep golden yellow; fine for Christmas.

Hyslop $(\mathrm{Crab})$. Deep crimson with blase bloom

Red Astrachan. An old popular variety; tart, juicy; flesh tinged with red; very early.

Stayman's Winesap. Fine variety; good keeper; deep red on a yellow ground.

Transcendent $(\mathrm{Crab})$. Yellow, striped red; good yielder.

Price of Apple Trees: 6 to 8 feet high, $\$ 1.75$ each; 6 for $\$ 9.00 ; \$ 15.00$ per dozen.

\section{CHERRIES}

Black Tartarian (Sweet). Large, purplish black; immense bearer.

Early Richmond (Sour). Dark red; medium size; splendid flavor.

Large Montmorency (Sour). Light red; very productive.

Schmidt's Bigarreau (Sweet). A good late variety. Fruit large; flesh dark red, very firm; sweet, rich and of good quality.

Napoleon (Royal Ann). The best and most profitable yellow sweet cherry. Flesh very firm, juicy and delicious.

Price of Cherry Trees: 5 to 7 feet, $\$ 2.00$ each; 6 for $\$ 9.00$; $\$ 15.00$ per dozen.

\section{PEACHES}

Belle of Georgia. Free-stone; rich creamy white, red cheek.

Carman. Early; pale yellow, red blush; very fine.

Champion. August. A magnificent white peach; extremely rich and juicy; very popular. Should be included in every home orchard. Free-stone.

Crawford's Late. Greenish yellow with dull red cheek; late.

Elberta. Medium; very large; yellow with red cheek.

Fox Seedling. Late September. Skin and flesh white. Freestone. Fruit large and of high quality.

Price of Peach Trees: 5 to 6 feet, $\$ 1.25$ each; 6 for $\$ 6.00$; $\$ 10.00$ per dozen.

\section{PEARS}

Bartlett. Yellow, shaded blush; very sweet and juicy; earl

Kieffer. A fine variety for late autumn, and for canning

Lawrence. Canary yellow; sweet and a splendid keeper.

Seckel. Small; yellowish brown; very sweet and juicy.

Price of Pear Trees: 5 to 7 feet, $\$ 2.00$ each; 6 for $\$ 10.50$ $\$ 17.50$ per dozen.

\section{PLUMS}

Abundance. Amber, turning to a rich, bright cherry color

Burbank. Orange yellow, overlaid red; rich and sugary.

Imperial Green Gage. Middle of August. A delicious, sized free-stone, sweet and juicy. Greenish in color.

Price of Plum Trees: 5 to 6 feet, $\$ 2.00$ each: 6

$\$ 17.50$ per dozen.

\section{OUINES}

\section{Champion. Very prolific bearer; large}

Orange. Round; golden yellow; fine for

Price of Quince Trees: 4 to 5 feet, $\$ 2.00$ each

$\$ 17.50$ per dozen.

NOTE - We can also supply all other varieties of $F$ 


\section{SCOTCH CHAIN HARROW}

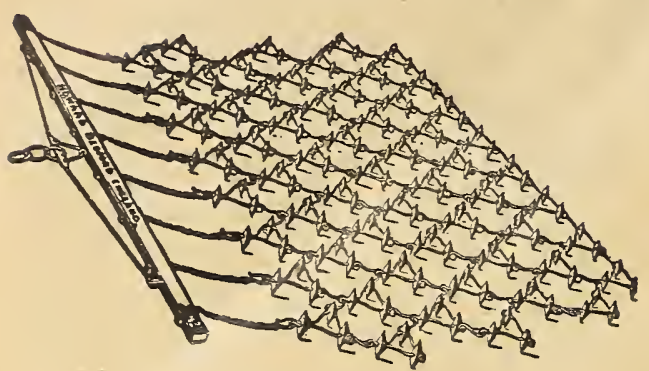

One of the best implements for pulverizing the surface soil, leveling and smoothing; also splendid for covering grass seed, etc. Used on driveways and race tracks, it smoothes the surface, eliminating ruts and footprints. Weight Price 126 lbs. $\$ 40.00$ $236 \mathrm{lbs} . \quad 55.00$

No. 1F. One-horse size, $5 \times 6$ feet

No. $2 \mathrm{~F}$. Medium two-horse, $6 \times 73 / 4$ feet

55.00
70.00

\section{The Stevens}

\section{Fertilizer}

\section{Distributor}

For distributing bone meal, wood ashes and other commercial fertilizers on fields, lawns, golf

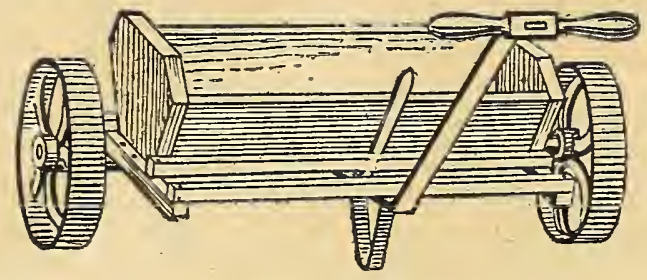

courses, etc., also for sanding putting greens. Insures perfect and even distribution and requiring less time than by the broadcast hand process.

Hand Machine. Holds about $13 / 4$ bu., covering area 3 feet wide. Nicely finished. Price, $\$ 22.50$.

Horse Machine. For use on large lawns, fields and golf grounds. It has a device for regulating the quantity that is to be sown; for either one or two horses, as may be desired. 5-ft. 10-in. spreading area, price, $\$ 62.50 ; 8$-ft. 3 -in. spreading area, price, $\$ 67.50$.

\section{PEN-VEL FERTILIZER SOWER}

A hand power fertilizer sower distributing evenly, accurately and any desired amount of all ized dry fertilizers. Sows equally well whether being pushed or pulled-that is backward or forward. The cultivator tivates the ground as the fertilizer is sown. Price, $\$ 5.00$.

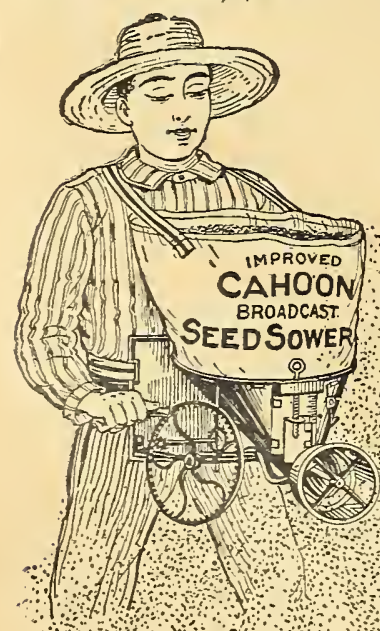

\section{BROADCAST SEED SOWERS}

For accurately sowing Timothy, Clovers, Millets and heavy seeds of grass and other farm crops. Can be regulated to sow any required quantity per acre. Cahoon, each. . . . \$6.50 Cyclone, each..... 3.00

\section{GARDEN AND} LAWN TOOLS

Our house makes a specialty of these, and carries probably the largest assortment in practical styles to be found anywhere; the quality is only the very best obtainable.

Dear Sirs:

Brooklyn, N. Y.

My order received in such fine condition that I will always remember Michell's Seed House for my future orders. O. E.

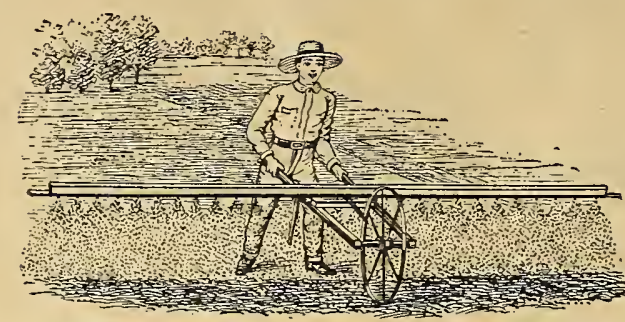

Wheelbarrow

Grass Seeder

The distributing box is very near the ground, which is an importantfeature, preventing the seed from blowing away and thus coming up unevenly.

Grass Seed), sows a width $14 \mathrm{ft} ., \$ 15.00$.

No. 9 (especially for

\section{LAWN AND PUTTING GREEN CLEANER}

The flexible rake bars are of wood, with steel springs and teeth; they rotate just like a lawn mower cylinder and clean up every particle of leaves, litter or rubbish, throwing it into a receptacle or bag in the rear, which is of large capacity.

Penn a. L a.w n Cleaner 24-in. rake, $\$ 30.00$.

Penna. Putting Greens Sweeper 24-in., $\$ 32.50$.

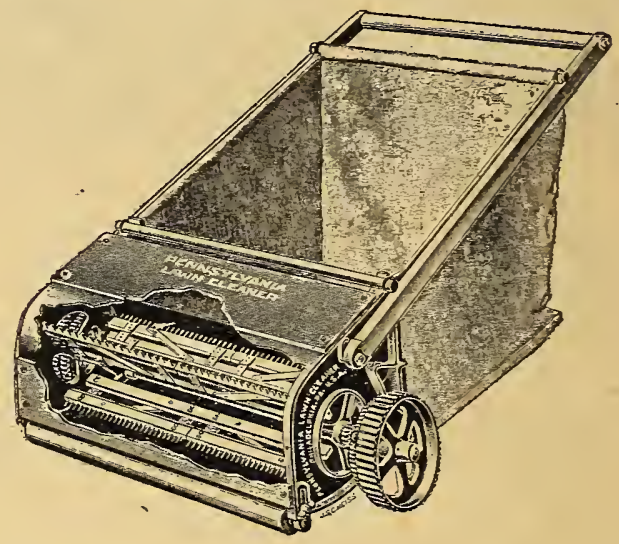

Sweeping Brushes. Can be readily attached to the Rake for sweeping lawns, putting greens, paths, etc. $\$ 8.00$ per set of three. We can also supply the Philadelphia Horse Lawn Sweeper. Price upon application.

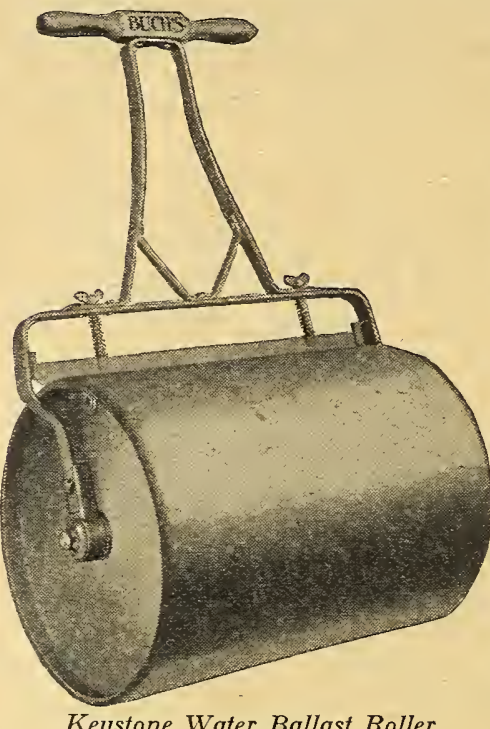

\section{PUTTING GREENS ROLLER}

Greens-keepers have found that a roller about 4 feet wide, weighing about 160 pounds, is right; evenly surfaced; will not leave a mark or ridge on the greens. Made of iron in 4 sections. $\$ 27.50$.

\section{KEYSTONE WATER-BALLAST ROLLERS}

Fill it with water, which will weight it up to any number of pounds desired, as shown below. Equipped with feature for balancing handles, which always keeps the handle in position ready for use; ball axle bearings.

\section{Keystone Water Ballast Roller}

Sec. Diam, Width Weight Weight

\begin{tabular}{|c|c|c|c|c|c|c|}
\hline & tions & In. & In. & Empty & water & Price \\
\hline & 1 & 14 & 24 & 60 & 250 & $\$ 16.65$ \\
\hline & 1 & 18 & 24 & 75 & 330 & 20.00 \\
\hline & 1 & 24 & 24 & 100 & 440 & 23.25 \\
\hline 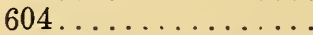 & 1 & 24 & 32 & 115 & 590 & 25.20 \\
\hline
\end{tabular}

KEYSTONE HAND LAWN ROLLERS

Drums are equipped with five spokes; the face is ground smooth and carefully finished. The steel roller bearings are mechanically constructed; the handle is made of steel and hard wood.

$\begin{array}{lccccc}\text { No. } & \begin{array}{c}\text { Diam. } \\ \text { In. }\end{array} & \begin{array}{c}\text { Length or } \\ \text { Width In. }\end{array} & \begin{array}{c}\text { No. of } \\ \text { Sects. }\end{array} & \begin{array}{c}\text { Weight } \\ \text { Lbs. }\end{array} & \text { Price } \\ 501 & 15 & 15 & 2 & 175 & \$ 16.00 \\ 502 & 15 & 22 & 3 & 250 & 19.00 \\ 504 & 20 & 20 & 2 & 250 & 21.00 \\ 507 & 20 & 24 & 2 & 300 & 25.00 \\ 508 & 20 & 30 & 3 & 350 & 29.00 \\ 509 & 24 & 20 & 2 & 400 & 34.00 \\ 511 & 24 & 24 & 3 & 450 & 37.00 \\ 512 & 24 & 30 & 3 & 500 & 42.00 \\ 514 & 28 & 24 & 3 & 500 & 42.00\end{array}$




\section{MICHELL'S LAWN AND GARDEN ACCESSORIES}

RUBBISH BASKETS

A basket for gathering up rubbish and itter. will be found a great convenience. This basket holds 3 bushels and can be carried or wheeled on a barrow. Price, with rope handles, $\$ 4.50$ each.
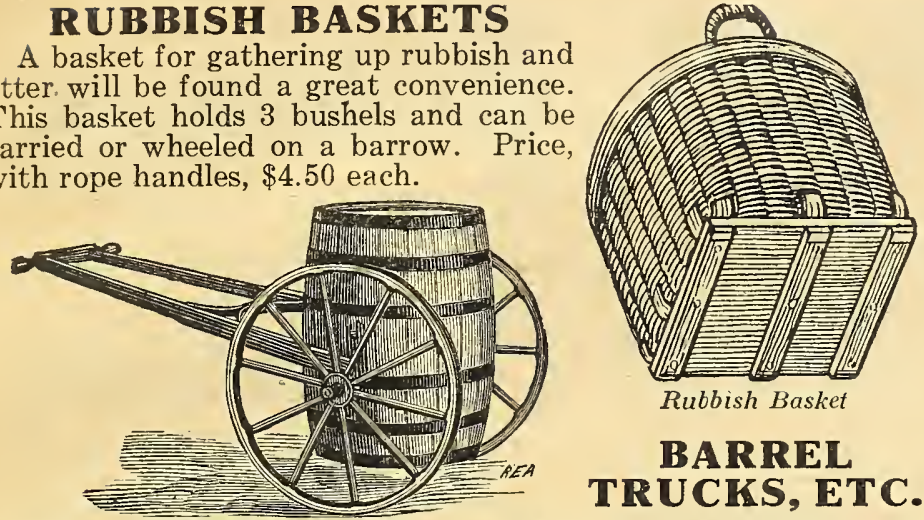

BARREL

TRUCKS, ETC.

The price below includes barrel and truck. The latter is constructed so that the barrel may be detached quickly and the leaf rack attached.

$21 / 2$-inch tire truck, all iron wheels, with barrel . . . . . . \$20.50 $31 / 2$-inch tire truck, all iron wheels, with barrel . . . . . . . 21.50 Extra Barrels, with trunnions, open head.

\section{KEYSTONE \\ LEAF RACKS}

This device can be used on wheelbarrows with removable sides. Convenient for gathering leaves, cut grass and rubbish. Has a capacity of 10 bushels; made of galvanized wire, bolted to a wooden base. Price, not including wheelbarrow, $\$ 7.50$.

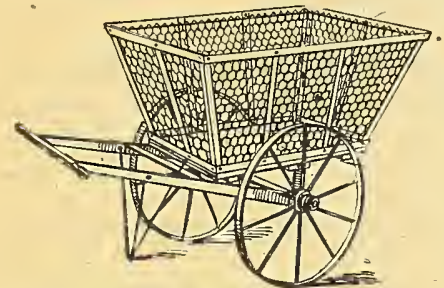

\section{WOOD LEAF RACKS}

Excellent for gathering leaves, litter, grass, etc. They can be attached to a water barrel truck, as shown above. While the illustration shows a wire rack, this style has been discontinued and wooden racks only are now supplied.

Leaf Rack only, no truck $\$ 8.00$

Leaf Rack with $21 / 2$-inch tire truck.

22.00

Leaf Rack with $31 / 2$-inch tire truck

23.00

Truck with $3 \frac{1}{2}$-inch tire wheels, no rack or barrel . . . . . . . 15.00

\section{RUBBISH CONSUMERS}

Made of galvanized wire; an indispensable arrangement for burning rubbish, paper, leaves, etc., without endangering property. Light Wire

No. $1,14 \times 20$ inches. . . . . . . . $\$ 1.50$

No. $2,15 \times 24$ inches.............. 1.75

No. $3,18 \times 30$ inches............... 2.50

No. 4, $20 \times 35$ inches ......... 3.00

Extra Heavy Construction

No. $10,16 \times 22$ inches......... $\$ 10.00$

No. $20,20 \times 30$ inches.

16.00

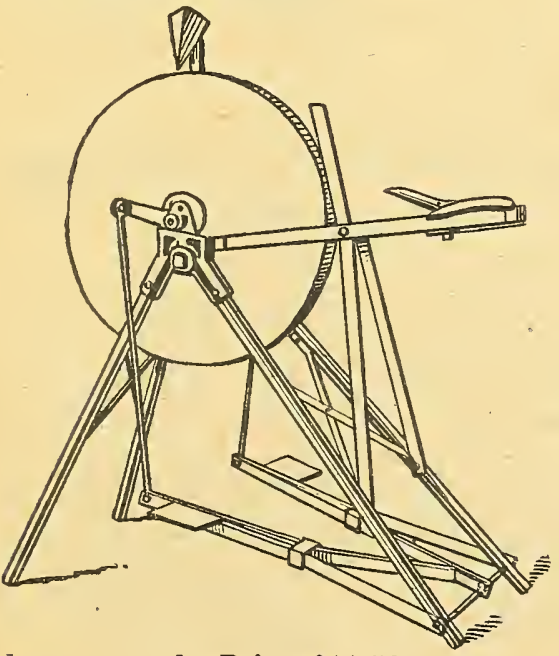

down, crated Price, $\$ 11.50$.

GRINDSTONE

heavy steel fram seat and double treadles: fitted with improved ball bearings, of the very best quality, encased so they will keep clean. Stone,19 to 22 inches diameter, $13 / 4$ to $21 / 4$ inches thick. Weight, $100 \mathrm{lbs}$.

Shipped knocked

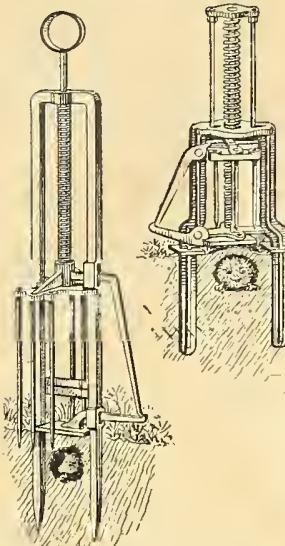

MOLE TRAPS

For catching moles that ruin lawns and damage the contents of hotbeds and cold frames. Moles move usually about 5 A. M. and 5 P. M., so that traps should be set for that period.

Olmsted.

$\$ 2.00$

Reddick.

1.25

P. P. Wt. of the above, 3 lbs.

Complete Booklet on the Habits of the Mole mailed free, or included with each Mole'Trap if asked for at time of ordering.

\section{BROOMSP ANDER B RSHES}

For sweeping paths, gutters, roads, etc.; all with handles.

\section{BROOMS}

No. 230. Japanese Fibre.

No. 8. Corn and

Rattan mixed

Golf Greens

(Birch)

No. 7. Plain Corn, extra quality

\section{ROAD BRUSHES}

(With Handles) No.'271. Rattan

Push, 14 in.... \$1.40 No. 0286. Bass or Cocoa Push, 14 in.
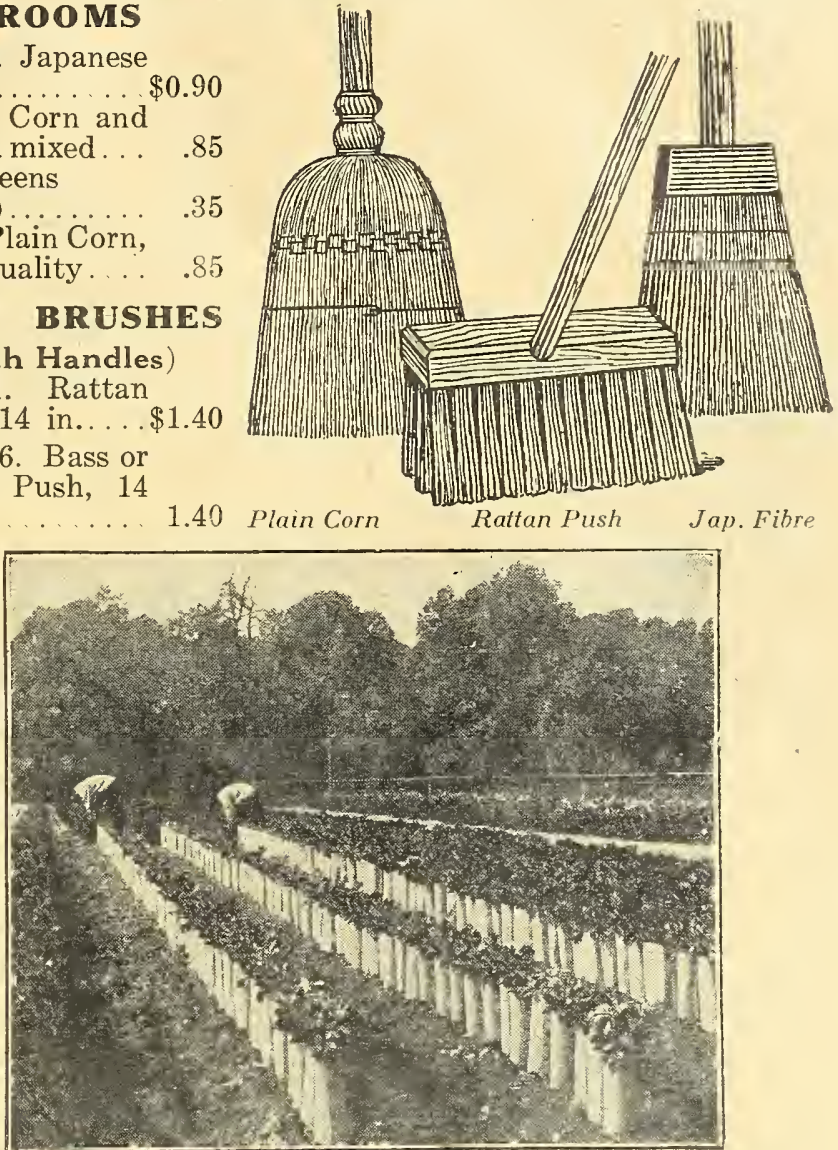

THE BALL CELERY BLEACHER

A practical, inexpensive device for bleaching celery early; made of stiff, heavy paper. If the tubes are to be left on the plants all winter and the soil drawn around them, you get celery clean and sweet. $\quad$ Per $50 \quad 1001000$ No. 1. 6 x 12 in. Wt. per 100,8 lbs.. $\$ 1.75 \quad \$ 3.25 \quad \$ 28.00$ No. 2. $6 \frac{1}{2} \times 13$ in. Wt. per $100,10 \mathrm{lbs} . .22 .25 \quad 4.00$ No. 3. 7 x 14 in. Wt. per 100, 14 lbs... 2.50 4.25

BALL CELERY HANDLER Brass, $\$ 4.50$ each.

Tin, $\$ 1.75$ each

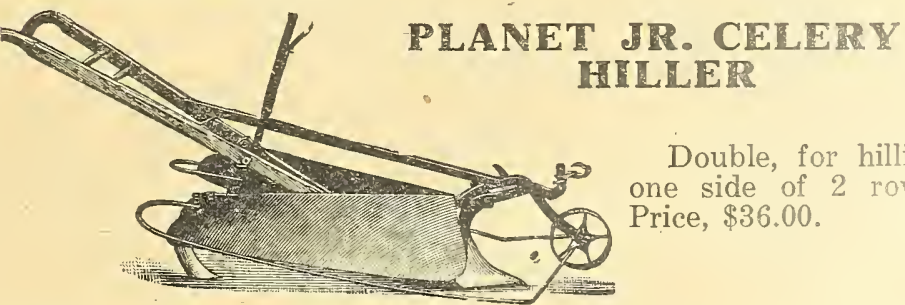




\section{WHEEL BARROWS}

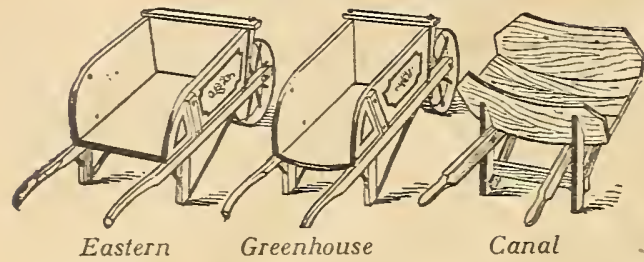

The measurements of barrows are understood, viz.: length, meaning inside length of body; depth, inside depth at front; width, outside width at handles.

Tire Lgth. Depth Width
in. in. in. in. Price

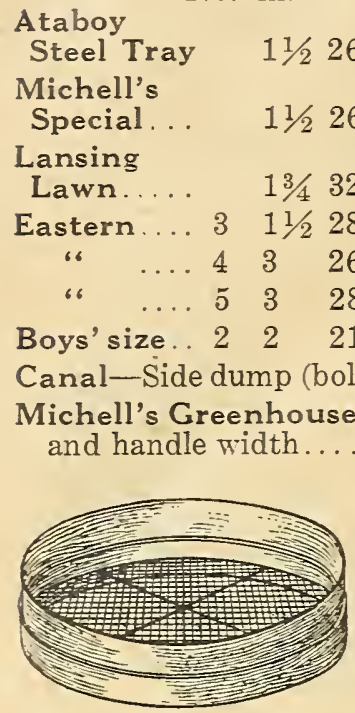

20-inch Steel (Heavy)

20 -inch Galvanized wire

18-inch Galvanized wire.
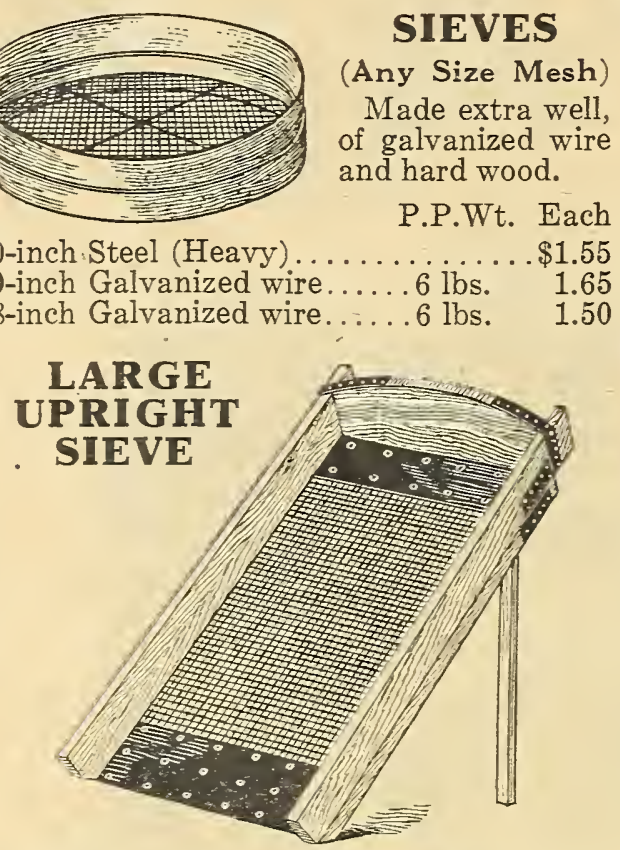

For soil, gravel, sand, etc. Made in any size mesh, of extra heavy grade foundry wire. $\$ 13.50$ each.

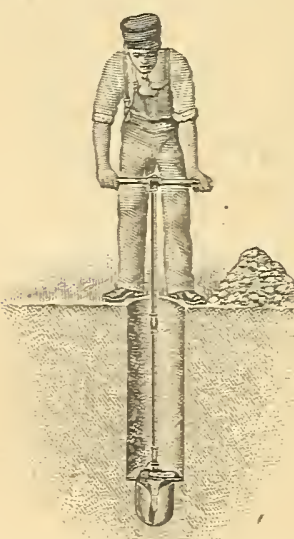

\section{POSTHOLE DIGGERS}

No. 8. (See Cut.)

This bores a hole $31 / 2 \mathrm{ft}$. deep and can be adjusted in diameter from 8 to 14 inches. It can be emptied instantly; made of the finest steel. \$5.50.

No. 15. Eureka, $\$ 2.75$.

Post Hole Spade point or tamper end, $\$ 2.00$.
All steel with either

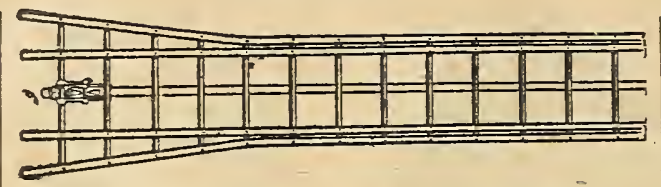

\section{EXTENSION LADDERS}

These are made in the best manner possible; are complete, being equipped with the necessary rope and pulleys.

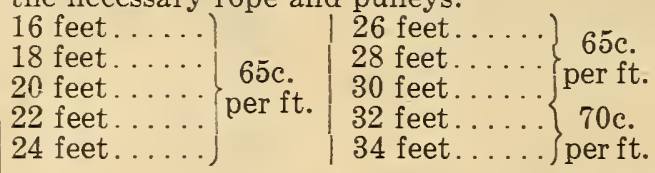

\section{SINGLE PLANK LADDERS}

Made of good hard wood, free from faulty knots and with perfect rounds.

10 feet......\$5.50 16 feet......\$8.80

12 feet.......6.6.60 18 feet........ 9.90

14 feet...... $7.70 \mid 20$ feet....... 13.00

\section{STEP LADDERS}

Gem. $4 \mathrm{ft}$. to $10 \mathrm{ft}$., $65 \mathrm{c}$. per foot.
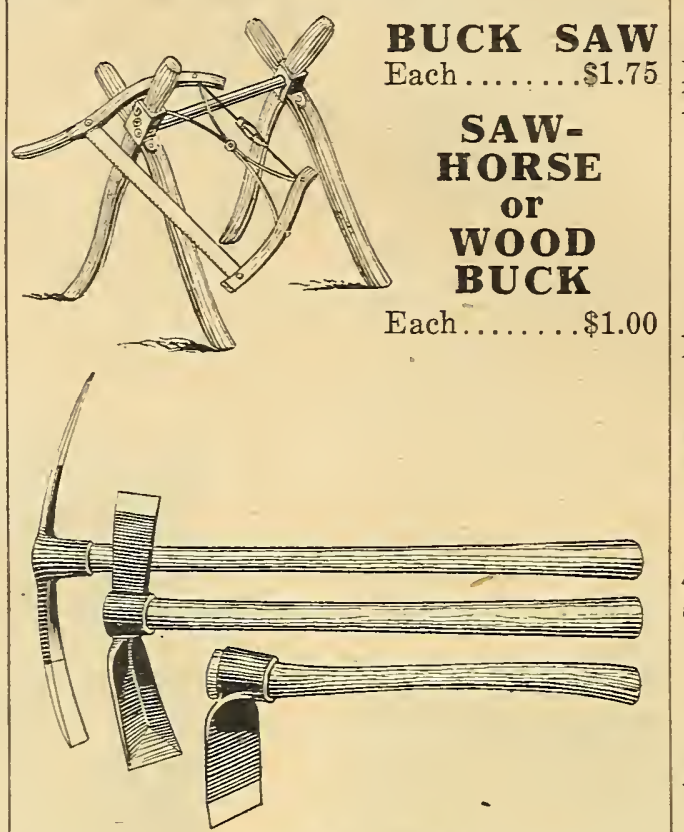

PICKS (Price includes Handle)

All steel. Double point, $\$ 1.35$; axe point, $\$ 1.35$.

\section{MATTOCKS (Price includes Handle)}

Axe, pointed.

Pick, pointed.

Half Mattocks or Grub Hoes
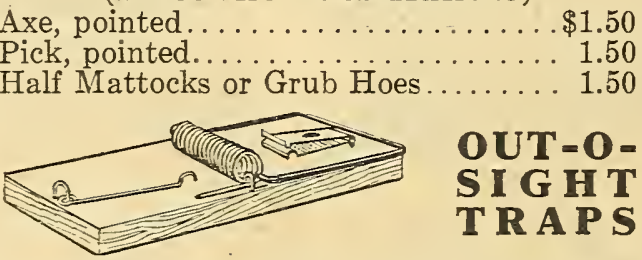

OUT $=0=$
SI G H T

The most satisfactory mouse and rat trap. Set off at the least vibration.

\section{Mouse.}

Rat.

P.P.Wt. Each

8 ozs. $\$ 0.10$

$1 \mathrm{lb}$.

Our Garden Tool and Sundries Department we believe to be the most fully equipped of any seed store in the United States. Most every article of real merit for horticultural work will be found here, and of the best quality.

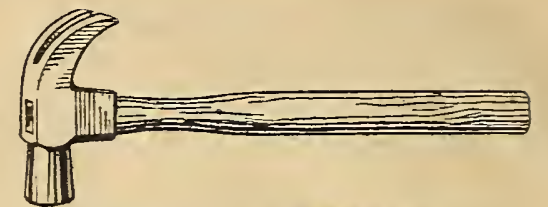

STEEL HAMMERS

No. $011 \frac{1}{2}$ Pexto. Price, $\$ 1.00$ each.

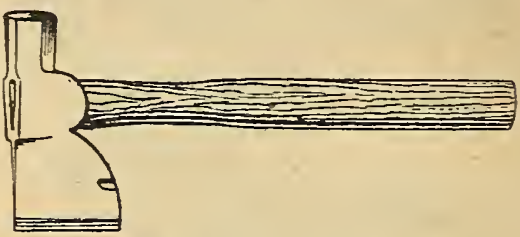

HAT CHETS

Made of the best quality tool steel, that will keep an edge.

Plumb.

$\$ 1.25$

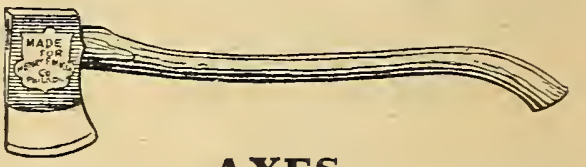

AXES

Plumb, medium, man's size...... \$2.50

Plumb, boys' size............... . 2.25

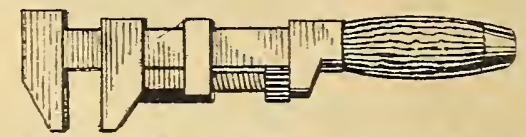

MONKEY WRENCHES

For machinery. Made of first quality hard steel; 8-inch, $\$ 1.00 ; 10$-inch, $\$ 1.25$.

Parcel Post Weight, $1 \mathrm{lb}$. each.

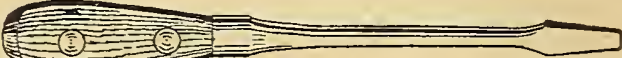

PEXTO SCREW DRIVERS

Parcel Post Weight, $1 \mathrm{lb}$. each.

4 -in. blade. . . \$0.50|7-in. blade . . \$0.80 5 -in. blade.... .65 10-in. blade... 1.00

\section{HUSKING PINS}

No. 15. Universal. All metal; adjustable to any size hand, $15 \mathrm{c}$.

No. 16. Combination; leather and metal, $25 \mathrm{c}$.

Parcel Post

Weight, 4 ounces each.
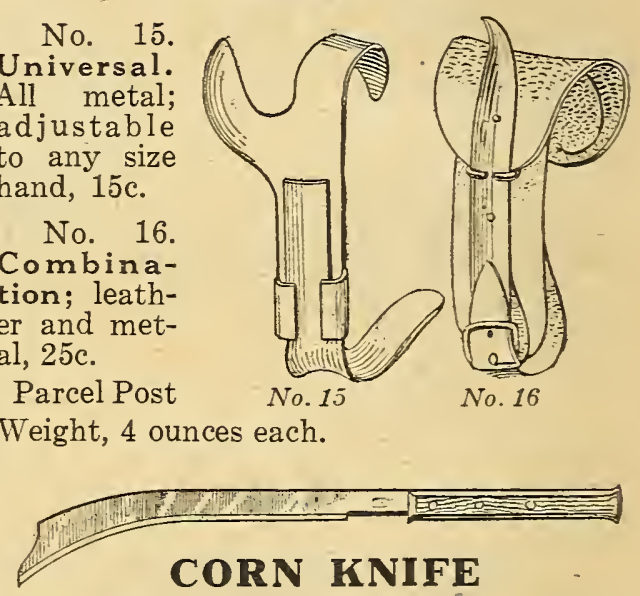

Eureka, bent blade. Weight, 2 lbs... . $\$ 1.00$

\section{CORN POPPERS}

Made of the best quality wire. Price includes handle and lid. 1 qt. size, $25 \mathrm{c}$. each; 2 qt. size, $35 \mathrm{c}$. each.

PARCEL POST SHIPMENTS

Where goods can be shipped in this manner, we have affixed the packed weight opposite. Where remittance accompanies order please include sufficient to cover mailing charges. 


\section{MICHELL'S LAWN AND GARDEN}

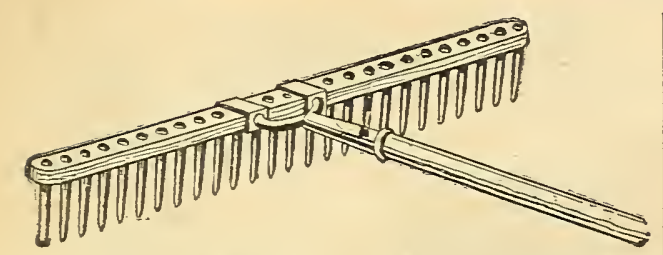

OLE OLSEN LAWN RAKE

Made of best hard wood, well braced; teeth set close together.

26-tooth, hickory wood. Price, \$1.25.

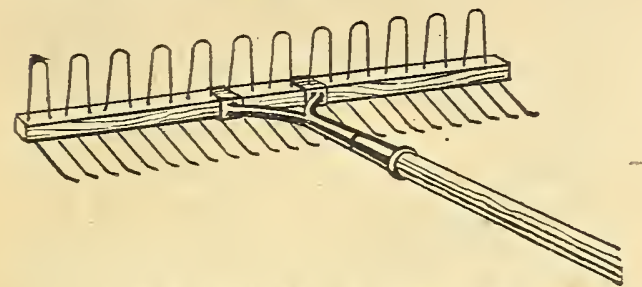

WIRE LAWN RAKE

Made of heavy tinned steel wire. The rake is reversible.

No. Tooth 1 No. Tooth 124R ...24 ..\$0.85 36LR ..36...\$1.25

No. $342 \ldots .42$-tooth . . . . . . $\$ 1.40$

No. $342 \mathrm{H}-42$-tooth, very close for cleaning off putting greens, $\$ 1.50$.

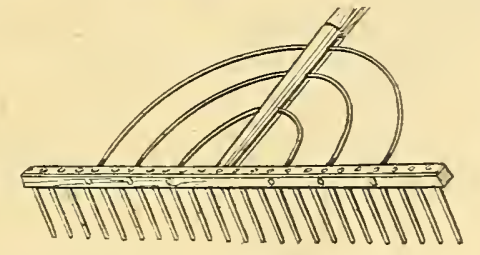

Ames, No. 37X Rake

WOODEN RAKES

Ames, No. 37X. 24-tooth, steel bows . \$1.40 Ames, No.30X. 14-tooth, hard wood.. 1.15 Wire Braced. 20-tooth, lawn...... .75

AUTOMATIC LAWN RAKE

A backward motion of the operator clears all the teeth at once.

26 -tooth, wood $\$ 1.50$ | 38-tooth, wood $\$ 1.75$ 26-tooth, wire $\$ 1.00$

\section{JAPANESE BROOM RAKE} Price, $\$ 1.50$.

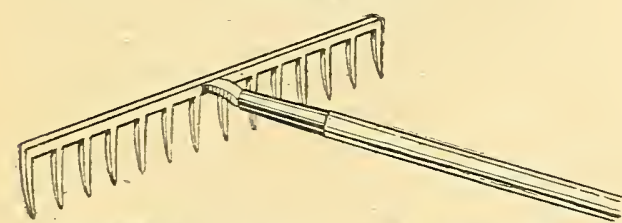

STEEL GRAVEL RAKES

No. Tooth

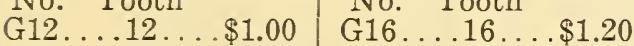

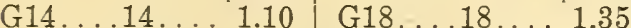

G20.....20-tooth..... \$1.45

STEEL BOW RAKES

Preferred by many to the regular garden rake, the teeth being slightly bent.

No. Tooth | No. Tooth

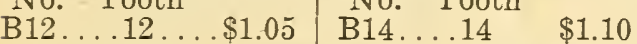

B16........16-tooth..... \$1.15

GEM DANDELION RAKE

The rake is self-cleaning; can also be used for leaves or grass.

No. 2, 24 inches wide.

$\$ 4.00$ each

No. 1, 16 inches wide.

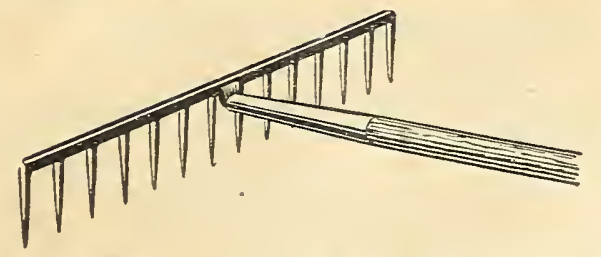

STEEL GARDEN RAKES

Made of best cast steel, with long teeth.

\begin{tabular}{l|l} 
No. Tooth & No. Tooth
\end{tabular}

$6 \ldots \ldots 6 \ldots \$ 0.80 \quad 14 \ldots \ldots 14 \ldots \$ 1.00$

$8 \ldots \ldots 8 \ldots 8.85 \quad 16 \ldots \ldots 16 \ldots 1.05$

$10 \ldots \ldots 10 \ldots .90 \quad 18 \ldots \ldots 18 \ldots 1.10$

$12 \ldots 12 \ldots, .95$

HOE AND RAKE

(Combined)

An excellent tool for ladies, combining simplicity and utility. Made of the very best steel,

which will outlast several

cheaper tools of the same

class.

No. 4P. 4-prong. . $\$ 1.00$

No. 6P. 6-prong. 1.10
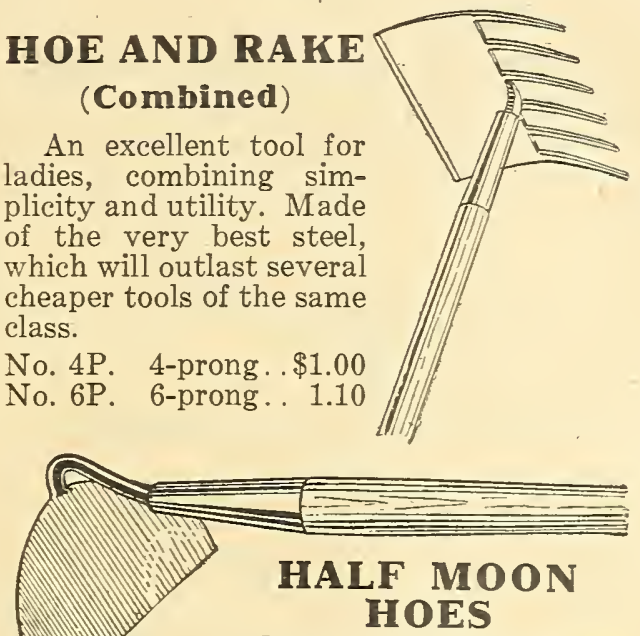

Best steel, solid sockets, which will not pull out.

No. HM3. 3-inch.

No. HM4. 4-inch.

No. HM5. 5-inch

No. HM6. 6-inch

No. HM7. 7-inch.

No. HM8. 8-inch

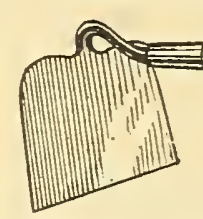

No. G06.

SQUARE HOES

7-inch, solid shank

8-inch, solid shank.

No. 010

10-inch, for celery

$\$ 1.00$

TWO-PRONG ONTON HOE

Will be found very valuable for weeding in narrow rows. (See cut below.)

No. 2P. Price................\$0.65

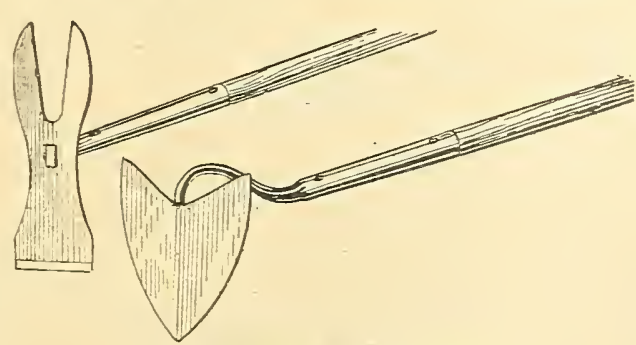

WARREN HOES

Excellent for making drills preparatory to sowing of seed. (See cut above.)

No. W7...... \$1.10 | No. W71/2... \$1.20 Baby Warren Hoe No. BW41/2. Short Handle, 50c. each.

Special Steel Weeding Hoe No. 3W. Short Handle, 55́c. each.
ACCESSORIES

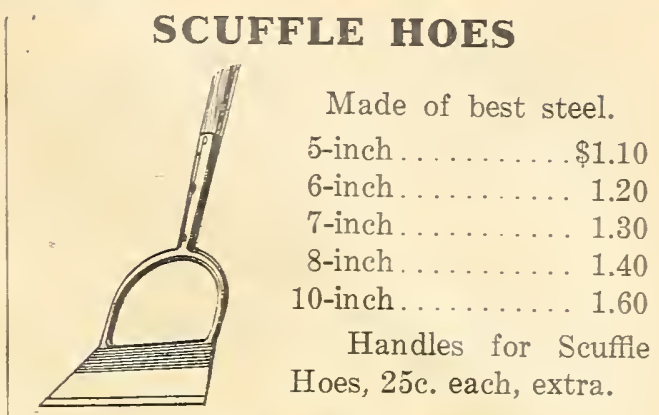

\section{SHOVELS \\ Long Handle}

Ames, round point

$\$ 2.25$

Maynard, round point.

2.75

Maynard, square point

2.75

Red Edge, round point

2.50

Portage City; round point

1.50

Portage City, square point

1.50

Ames, round point

$\$ 2.25$

Ames, square point

2.25

Maynard, round point

2.50

Maynard, square point

Red Edge, round point

2.50

Red Edge, square point.

2.25

Portage City, round point

1.50

Portage City, square point.

1.50

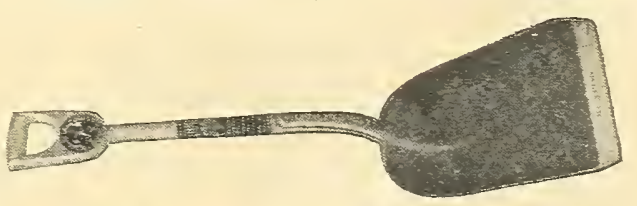

\section{STEEL SCOOP SHOVELS}

Strapped shanks, wood D or short handles.

No. 1. 9 -inch mouth......... \$1.25

No. 2. 10 -inch mouth........... 1.35

No. 3. 11 -inch mouth.......... 1.50

No. 4. 111/2-inch mouth........... 1.55

No. 5. 12 -inch mouth.......... 1.60

No. 6. 13 -inch mouth.......... 1.75

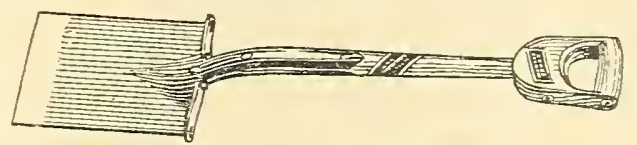

\section{STEEL SPADES}

Ames, short handle.

$\$ 2.25$

.

Michell's Special, short handle.

1.75

Red Edge, short handle.

2.50

Nursery (Ames), short handle.

Portage City, short handle.

3.50

Boys'.

1.50

\section{SNOW SHOVELS}

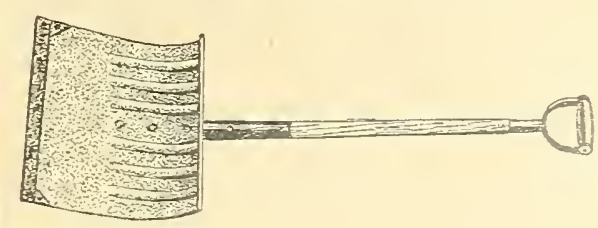

Adams, wood (see cut), D handle

Phillips, wood, long handle.

Owosso, galvanized, style like Adam. 


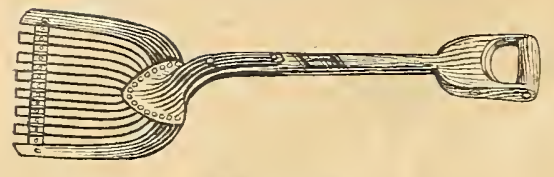

\section{WIRE \\ SCOOP SHOVEL}

For handling potatoes, turnips and root crops without bruising or cutting. Made of heavy steel wire. . . . . . . . . . \$3.00

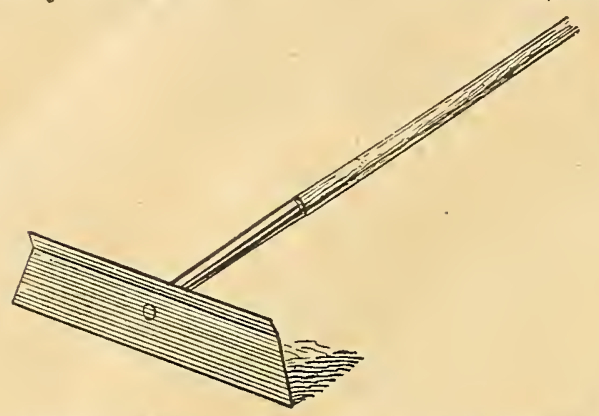

MEHLER HANDY SCRAPER

This was originally designed as a dropping-board scraper in poultry and pigeon houses. It gets in the corners easily. It is also suited for a variety of other work around the farm or garden. Price, $\$ 1.50$.
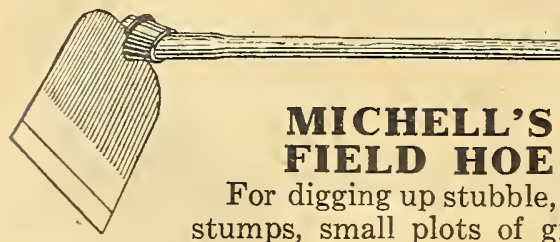

For digging up stubble, small for planting purposes, etc.

51/2-inch blade, each

$\$ 1.00$

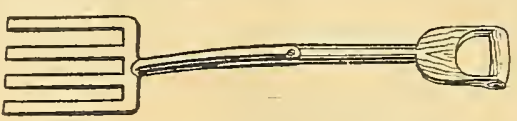

\section{SPADING FORKS}

Strapped shanks, short or D-wood handle. Made of best quality steel.

No. OHW. Men's 4-tine..........\$2.00

No. O5HW. Men's 5-tine......... 2.25

No. B4D. 'Boys' or Ladies 4-tine.... 1.00

\section{ENGLISH DIGGING FORK, No. EB4}

Though made in America, it is made exactly after the pattern of garden forks such as are made and used in England. The prongs are solid steel, with square instead of round edges, which adapts it especially for digging in heavy soil, in which it works with ease. Every gardener should add one of these to his collection of tools, as we known it will give him splendid satisfaction. $\$ 2.25$ each.

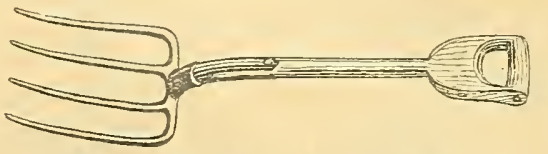

MANURE FORKS Strapped Shanks.

$04 \mathrm{~W}-4$ tine, light, short handle.

163 -4 tine, heavy, short handle.

$06 \mathrm{~W}-6$ tine, medium, short handle.

$0441 / 2-4$ tine, long handle.

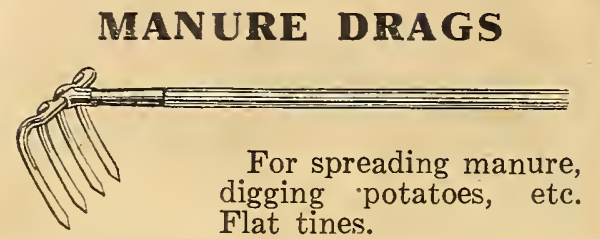

No. 4 BHFM, 4 tine

$\$ 1.35$

No. $6 \mathrm{BOH}, 6$ tine

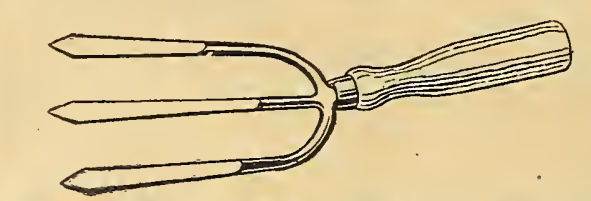

EUREKA WEEDING FORK

No. G. Made of best flexible steel; splendid for loosening soil in the garden, in hotbeds, etc., 50c. Parcel Post Weight, 2 lbs.

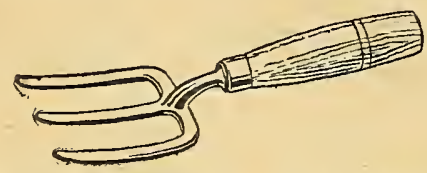

\section{EXCELSIOR WEEDING FORK}

No. 300. Made of malleable steel, finished in tin, 15c. Parcel Post Weight, 1 lk.

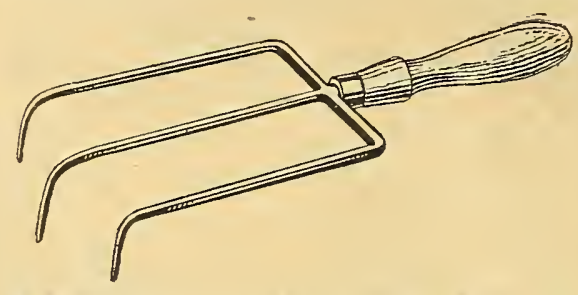

EUREKA WEEDER No. E

Made of flexible steel; very light; an ideal tool for market gardeners, florists and amateurs, 50c. Parcel Post Weight, 2 lbs.

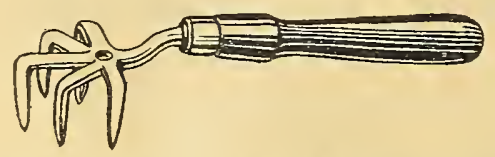

\section{EXCELSIOR WEEDER}

Made of malleable iron, finished in tin, 15c. Parcel Post Weight, $1 \mathrm{lb}$.

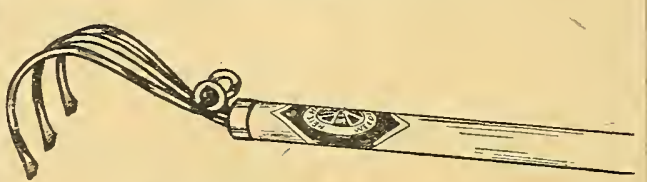

\section{MA GIC W WEDER}

Made of heavy galvanized flexible wire, with flattened prongs or ends.

No. A. Short Handle, Small. . . . . . \$0.25 No. B. Short Handle, Medium...... . . . 35 No. H. Long Handle, Large....... 1.25

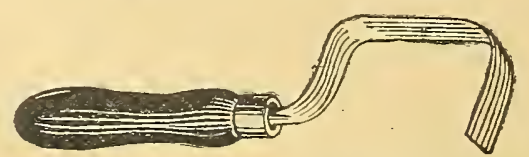

No. Bw1, 50c. Parcel Post Weight, 1 lb.

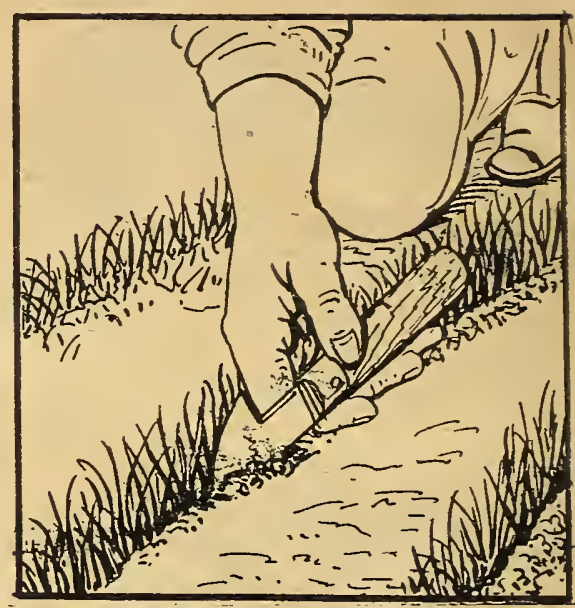

MAKEFIELD WEEDER

A splendid little tool for weeding in the garden seed bed, greenhouse or hotbed; made of fine tool steel; it can be sharpened easily and does not become dull readily; with it you can work closer to seedlings in a row than with any other tool we know of. $50 \mathrm{c}$. each.

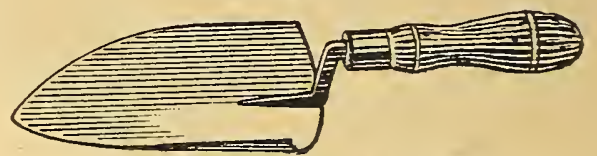

JOHNSON STEEL

TROWELS, No. 211

These are made of one piece steel blade and shank, equal to the imported trowels. P.P.Wt. 5 in.... 1 lb. $\$ 0.80 \quad 7$ in.... 1 lb. $\$ 0.90$ 6 in.... 1 lb. $\quad .85$

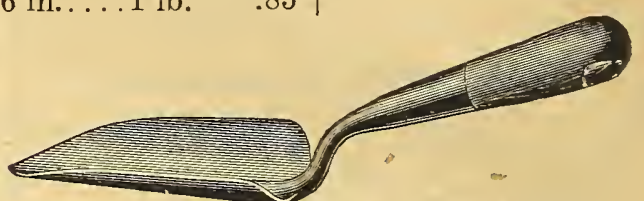

\section{S. T. STEEL SHANK} TROWEL

These are somewhat long in blade and handle, making a very practical tool. Will last a lifetime. 6-in. blade. 85c. each.

Parcel Post Weight, $1 \frac{1}{2}$ lbs.

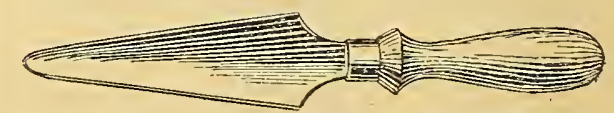

\section{CLEVES' ANGLE TROWEL, No. 217}

For getting dandelion, plantain and other weeds out of the lawn, and transplanting.

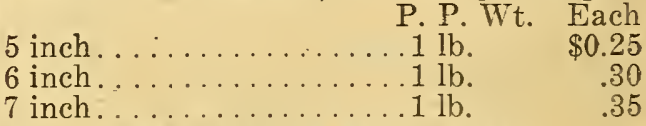

\section{MISCELLANEOUS TROWELS} P. P. Wt. Each

No. 213-5 inch....... $1 / 2$ lb. $\$ 0.20$

No. $213-6$ inch ......... $\quad .25$

Neverbreak - 6 inch, heavy steel, $1 \mathrm{lb}$. .25

\section{DIBBLES}

For Planting Bulbs, Etc. Equipped with wooden handles. No. 2180. Brass point, $\$ 1.00$.

No. 218. Iron point, $70 \mathrm{c}$.

Parcel Post Weight, $1 \mathrm{lb}$. 


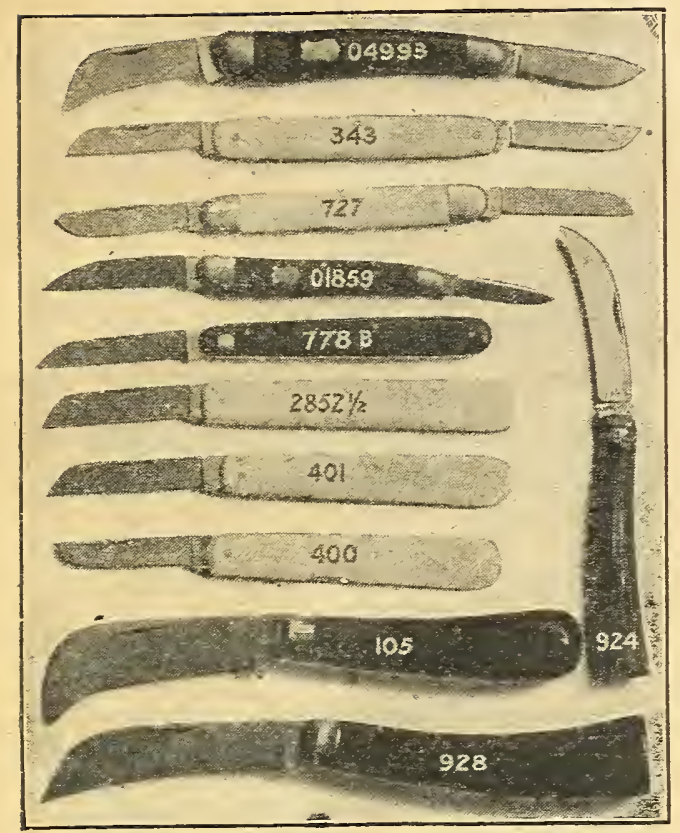

HORTICULTURAL KNIVES

A good knife is an essential to every gardener and florist. Our stock consists of such styles that are practical and in demand. They are all of the best steel. Every one is guaranteed to be perfect.

No. Blades Style Handle

Each 3432 Saynor, brass lined, ivory . . .\$3.75 $727 \mathrm{~W} 2$ Brass lined, white......... 1.75

049932 Steel lined, ebony . . . . . . . . . 1.75

4001 Saynor, not lined, ivory..... 3.75

4011 Saynor, not lined, ivory

$28521 / 21$ Not lined, bone.........

9281 English, steel lined, stag .

9241 English, steel lined, stag

778B 1 Brass lined, ebony.

105 1 Heavy, steel lined, cocoa

3032 Saynor, Pruning, stag.

3.50
1.25

2.75

2.50

.85

1.25

2.50

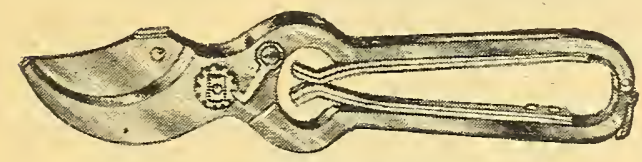

Pexto Pruning Shear

\section{PRUNING SHEARS}

Our pruning shears are procured from the most reliable makers and all are fully guaranteed.

No.

P.P.Wt. Each

110 Perfection, 8 in....... 11/2 lbs. $\$ 3.25$

50 Pexto, 8 in............ 2 lbs.

R 50 Pexto, 9 in.......... 2 lbs.

55 Pexto, 9 in........... 2 Ibs.

R 95 Pexto, 10 inch .......... 2 lbs.

110 Pexto, 8 in........... 2 lbs.

109 Wiss, 8 in............ 2 lbs.

65 Pexto American, 9 in... 2 lbs.

R 165 Pexto American, 9 in. 2 lbs.

R 70 Pexto American, 9 in... 2 lbs.

23 Henckel, 41/2 in....... $1 \mathrm{lb}$.

23 Henckel, $61 / 2$ in........ 1 lb.

14 Nickeled, $6 \frac{1 / 2}{2}$ in. . . . . . . 1 1 $1 / 2$ lbs.

0 Pexto

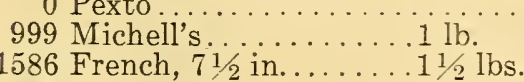

1586 French, $81 / 2$ in.......2 lbs.

1.10

1.25

1.75

4.50

3.25

4.00

1.75

2.25

1.75

2.00

2.25

1.40

.60

3.25

3.25

3.25

Spiral Springs for any of the above Pruning

Shears. 15c. each; per doz., $\$ 1.50$.

Parcel post weight, per doz., $1 / 2$ lb.

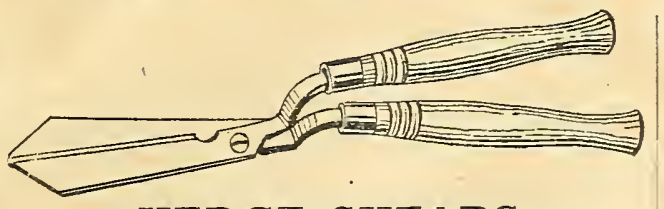

\section{HEDGE SHEARS}

No. P.P.Wt. Amer. Eng

101. 61/2-inch Ladies' 4 lbs. $\$ 1.50$

101. 8-inch.......4 lbs. $2.50 \quad \$ 3.25$

101. 9-inch .......5 lbs. $3.00 \quad 3.50$

101. 10 -inch ......... . los. $3.25 \quad 4.00$

101. 12-inch .......6 lbs. $4.00 \quad 4.50$

Bolts and Nuts for hedge shears, $25 \mathrm{c}$.

Handles for Hedge Shears, 75c. per pair.

Neverslip Hedge Shears

\begin{tabular}{|l|l|l}
8 -inch . . . . . \$2.50 & 10 -inch . . . . . \$3.00 \\
9 -inch . . . . 2.75 & 12 -inch . . . . 3.50
\end{tabular}

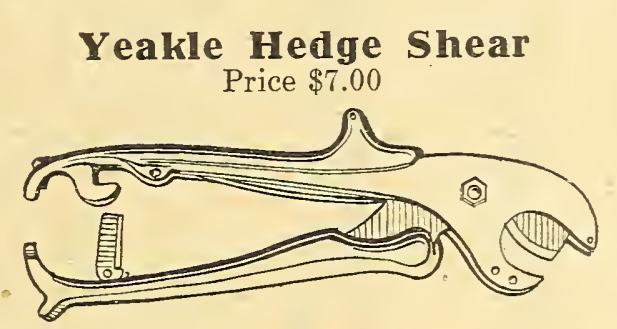

LEVIN PRUNER No. 23

The handle of these shears affords a great deal of leverage, which makes very easy cutting possible. Price, $\$ 1.00$. Weight, 2 lbs.

\section{LOPPING SHEARS}

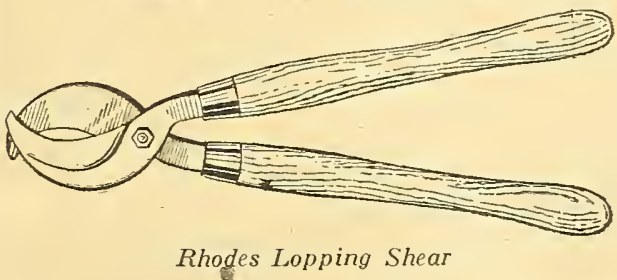

Rhodes Lopping Shears. Makes an absolutely clean, perfect cut; the blades are concaved at the cutting edge, producing with the handles an enormous leverage. They are the easiest operating Lopping Shears ever made or sold. 24-inch and 28-inch handles. Price, $\$ 5.00$. Weight, 5 lbs.

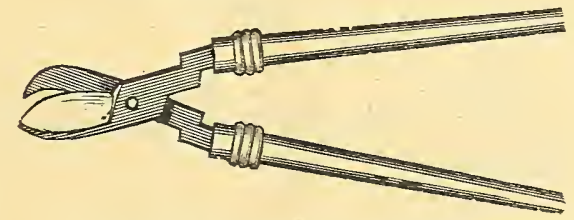

No. 109 English Lopping Shears. 4-inch cut; made of the finest English steel; has great cutting power; will sever heavy branches readily (see cut). Price, $\$ 6.00$.

No. 5400 Clyde Lopping Shears. 24-inch handles; a splendid, medium-priced tool; weight, $5 \mathrm{lbs}$.; 11/2-inch jaw. Price, $\$ 3.50$.

No. 5400 Clyde Lopping Shears. 30-inch handles. Weight, 5 lbs. This shear has a straight jaw so that it will handle a limb up to at least $2 \frac{1}{2}$ inches in diameter; fitted with an adjusting nut to keep it tight. Price, $\$ 3.75$.

No. 5406 Rockdale Lopping Shear. 26inch handle, $\$ 2.25$.

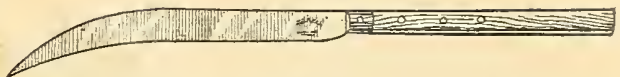

STEEL HEDGE KNIFE

For cutting heavy brush, shrubbery, hedges, etc. Made of the finest steel with a slight hook on blade. Each, $\$ 1.25$.

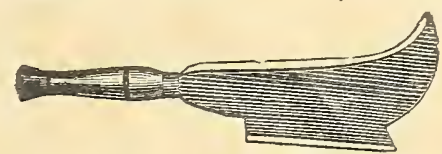

ENGLISH BILL HOOKS

For trimming heavy shrubbery, trees etc. P. P. Weight, 4 lbs.

Short Handle.

$\$ 3.50$ 5.00

No. 1
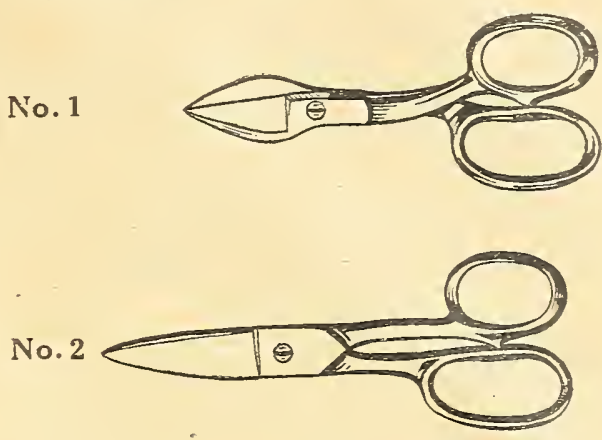

No. 3

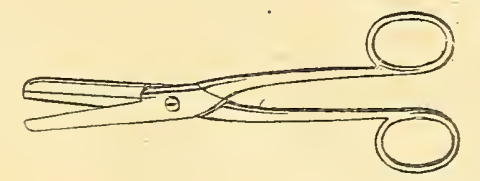

Key to illustrations: No. 1, Wire and Tin Shears: No. 2, Grape Scissors; No. 3, Flower Scissors.

WIRE AND TIN SHEARS

No. 833. $7 \frac{1}{2}$ inch, used for cut flower

wire, etc. .............. \$1.25

No. 832. 8 inch, used for cut flower

wire, etc.

Parcel Post Weight, $1 \mathrm{lb}$.

No. 12. 8-inch for heavy wire and tin 1.50 No. 10. 10-inch for heavy wire and tin 1.85 Parcel Post Weight, 2 lbs.

\section{GRAPE SCISSORS}

For thinning out bunches of grapes, and not disturbing the berries that are to remain for development.

No. 6148,6 inch, P. P. Wt., 8 ozs.... $\$ 2.00$

\section{FLOWER SCISSORS}

No. 1922. Cuts flower and holds the stem. Price

Parcel Post Weight, 4 oz.

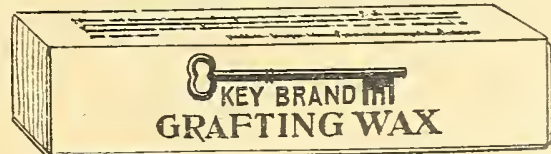

GRAFTING WAX

$1 / 4$ lb., 15c.; 25c. per $1 / 2$ lb.; 1 lb.,

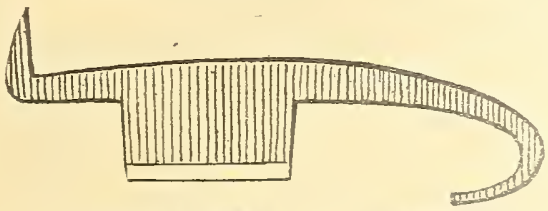

GRAFTING TOOL

Made of the best steel. For

trees, etc.

All steel. P. P. Weight, $1 \mathrm{lb}$ 


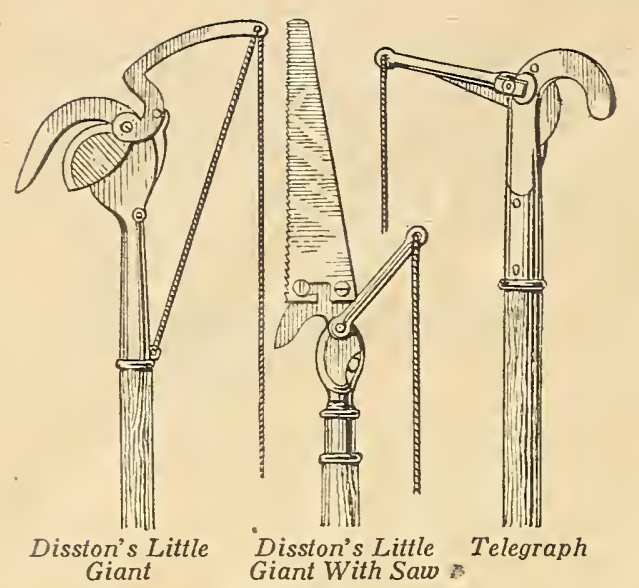

TREE PRUNERS

Disston's Little Giant. Pruner. . . \$ $\$ 2.00$ Parcel Post Weight, $31 / 2$ lbs.

Disston's Little Giant. With saw attachment.

Parcel Post Weight, 4 lbs.

Prices are for Pruner without rope or pole.

TELEGRAPH TREE

\section{PRUNERS}

Removable blade, which.can be renewed when worn out for 25c. Price, plain, without pole, $\$ 2.00$. Parcel Post Weight, 2 lbs.

\section{WATERS TREE PRUNERS}

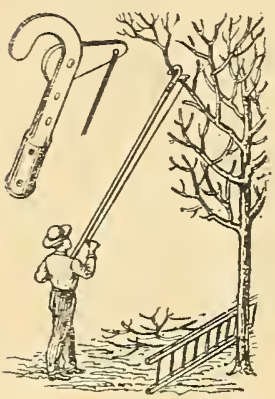

With removable cutting blade and pole complete.

4 feet.

6 feet

8 feet.

10 feet

12 feet.

Extra Blades for Waters Pruners, 35c. each.

The Waters Tree Pruners are equipped with poles.

Waters Pruners are not mailable.

12 feet long

Poles for Tree Pruners

14 feet long

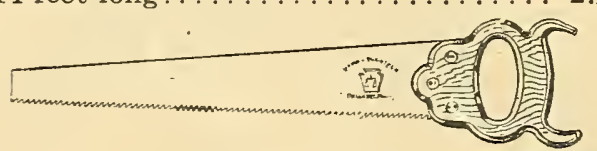

$\$ 2.00$

th

No. 40, 18-inch. Avery double

P.P.Wt. Each

edge.................2 lbs. $\$ 1.10$

No.40. 20-inch. Avery double

edge............... lbs. 1.25

No. 7. 16-inch. Single edge..2 lbs. 1.50

No. 7. 18-inch. Single edge. . 2 lbs. 1.60

No. 7. 20-inch. Single edge. .2 lbs. 1.70

No. 7. 22-inch. Single edge. . 2 lbs. 1.80

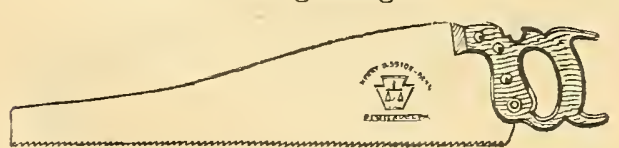

CARPENTER SAWS

State if rip or cross-cut is wanted.

Disston No. 8D. 26-inch blade..... \$3.00

Disston No. 8D. 28-inch blade.
No. 1. Cuts limb up to 1 inch in diam.; weight 2 lbs.; 23 inches long, $\$ 4.50$.

No. 2. Cuts limb up to $11 / 2$ inch in diam.; weight 5 lbs.; 30 inches long, $\$ 6.50$.

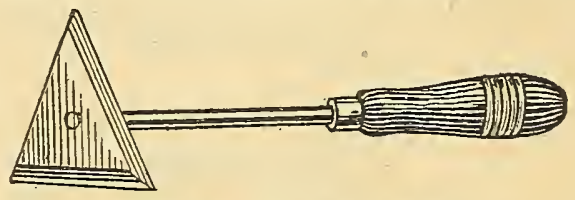

\section{TREE SCRAPER}

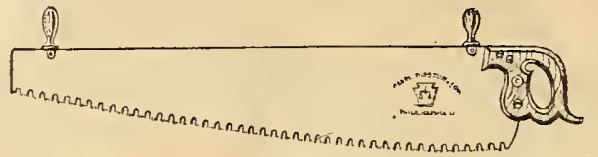

\section{CROSS CUT LOG SAWS}

Disston Make.

Keystone No. 3, one-man, $31 / 2 \mathrm{ft}$. blade. $\$ 3.50$

Gt. American, two-man, $5 \mathrm{ft}$. blade... 5.50

MCKENNEY TREE PRUNER AND LOPPING SHEAR

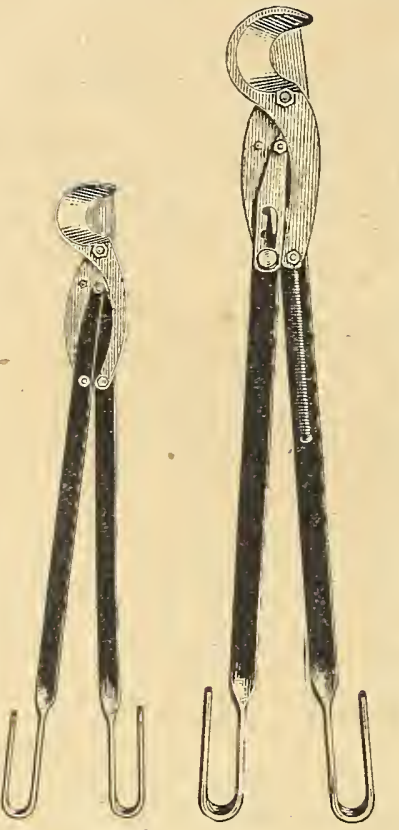

Designed and built to meet ments requireprofessional rruit growers of America. They in installed features that go make up a fect pruning rs the "McKeneasiest cutng pruner in world; the perfect cutthe pruner in that does not any way, as both blades edges; the only pruner that will cut seasoned limbs $11 / 2$ in. in diameter; the lightest pruners on the steel throughout; nothing about them to reak. The blades are dropped forged from the bar steel and therefore are as strong as they can possibly be made. The handles are

moving loose bark from trees prior

to spraying. Steel blade may be detached and sharpened: No. 5, short handle, 60c. Parcel Post Weight, $1 \mathrm{lb}$.

\section{TREE OR BARK BRUSHES}

For brushing down trees for removing insects, borers, etc. Made of steel. Price, 81/2-inch, 60c.

See pages 74 and 75 for complete line of Sprayers and 76 and 77 for Spraying Material. ney" Pruner,

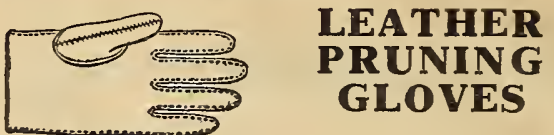

Parcel Post Weight, 1 lb. per pair No. 216. Horsehide, with gauntlets, lined............... $\$ 2.00$ No. 66. Horsehide, with gauntlets, not lined.....................-2.00 No. 62. Buckskin, with gauntlets, not lined...

\section{PRUNING COMPOUND}

Used for painting the wounds of trees after pruning.

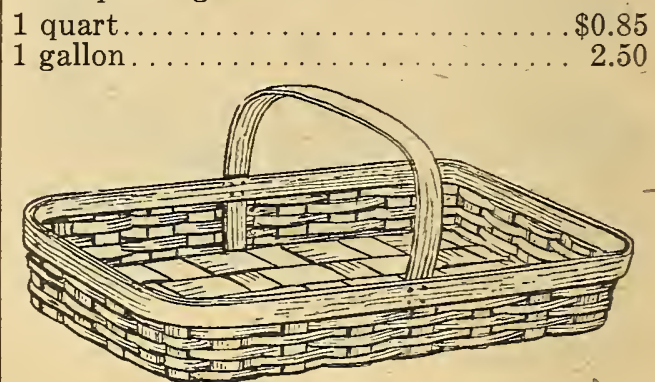

GATHERING BASKET

Very convenient for carrying berry boxes, asparagus and other vegetables. Made of oak, with double collapsible handles; 12 in. wide, 23 in. long, 4 in. deep. Price, $\$ 1.25$.

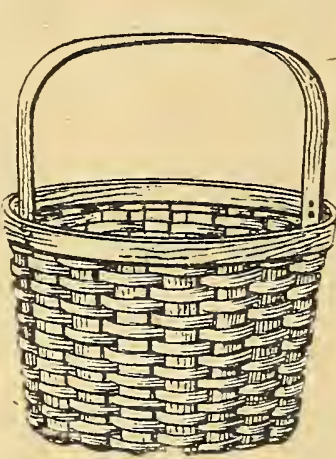

GARDEN BASKETS

No. 2, Stiff Handle

$1 / 2 \mathrm{Bu} . \ldots$. Each

No. 3, Drop Handle

$1 / 2 \mathrm{Bu} . \ldots . \$ \$ 1.00$

No. 4, Without Handle

Each

$1 / 2 \mathrm{Bu} . \ldots \ldots \$ 1.00$

$1 \mathrm{Bu} . \ldots . .1 .2$ อ

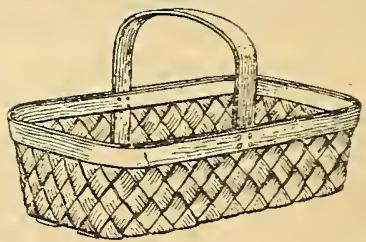

SPLIT OR CHIP BASKETS

Without Handles | With Handles Each Doz. $1 / 4$ bu.... $\$ 0.15 \$ 1.50$

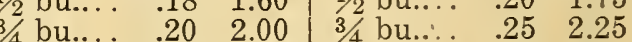
\begin{tabular}{ccc|ccc}
1 bu... & .35 & 3.75 & 1 bu... & .40 & 4.00
\end{tabular} Please note our present supply of handled splint baskets are double, drop style.

\section{WOOD MEASURES}

$1 / 4$ peck . . . . . $\$ 0.75$

$1 / 2$ peck ....... . 80

1 peck....... 1.10

$1 / 2$ bushel...... 1.75

1 bushel..... 3.00

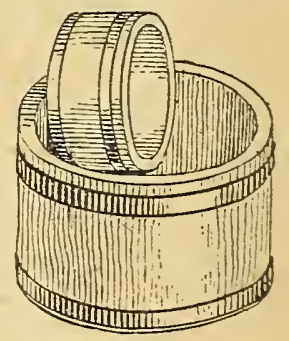




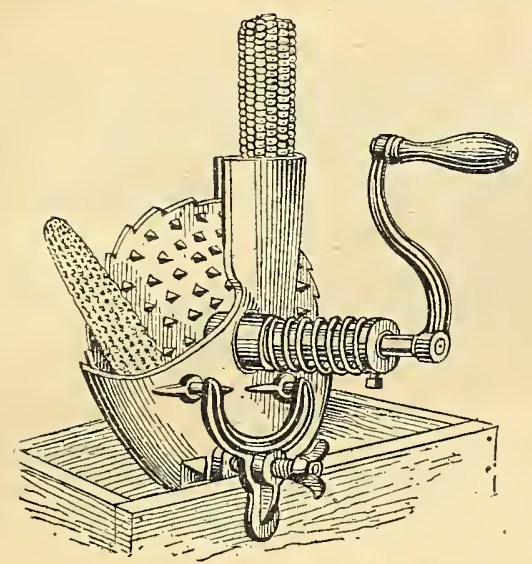

\section{BLACK HAWK CORN SHELLER}

Excellent for small poultry farms, etc. Ball-bearing; suitable for fastening to a bench, box, etc., for shelling small quantities of corn. $\$ 4.00$ each.

\section{PENNA. CORN SHELLER, No. 3}

Useful on every farm and private estate. Separates the corn from the cob, throwing the cob to one side and allowing the corn to pass out another, $\$ 16.00$.
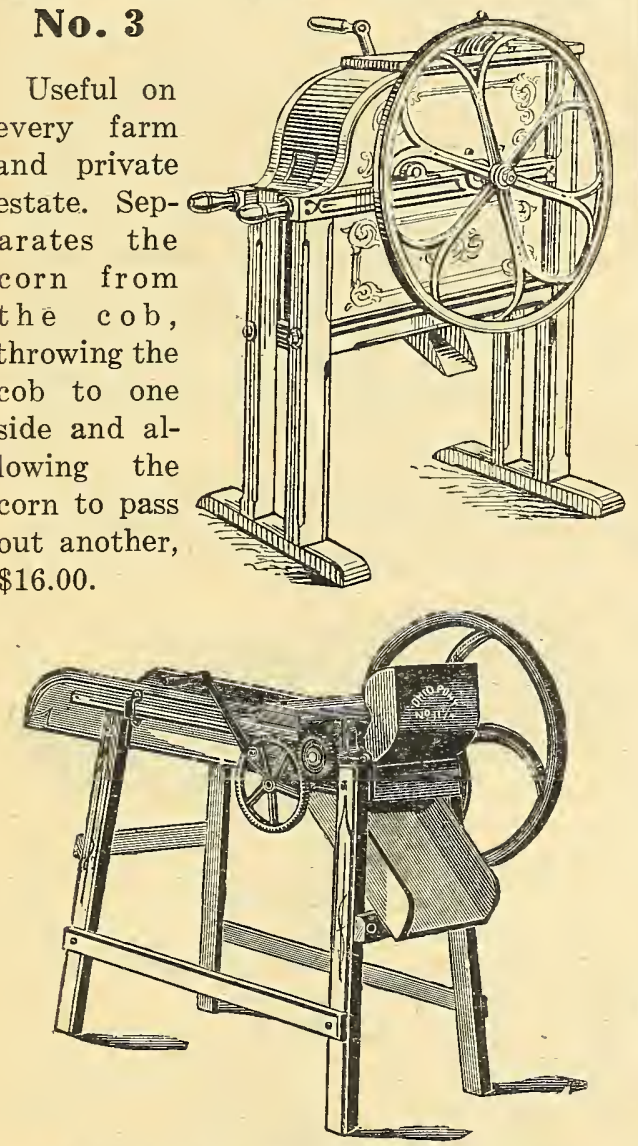

HAY AND FEED, CUTTER

For cutting hay, ensilage, etc.

No. 111/4, Ohio. Single knife.... \$32.50

Triumph. Double knife........ 30.00

\section{PRESTO FRUIT PRESS}

Used for extracting juices from Fruits, Berries, etc. Made entirely of iron and steel; all parts heavily tinned.

No. 1. 3 quart size ...........\$6.00

No. 2. 6 quart size.

10.00

No. 3. 9 quart size.

12.00

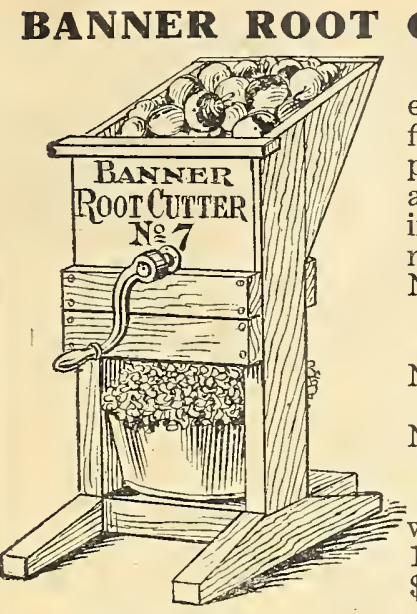

CUTTER

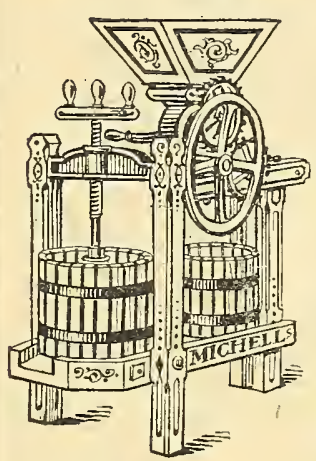

CIDER MILLS nior.....\$30.00 ity wood, carefully Medium .... 32.50 bolted and finished Senior.... 45.00 No. 1 ..... . \$8.00 Bantam....2 20.00 No. 2
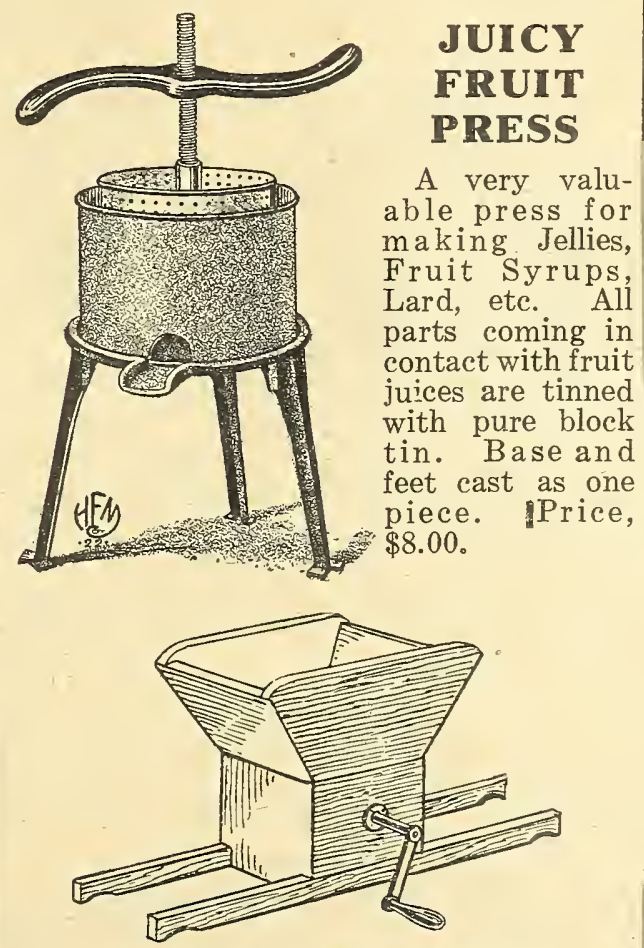

GRAPE GRINDER

Suitable for crushing berries, grapes and similar soft fruit.

No. 5 . .

No. $10 \ldots$

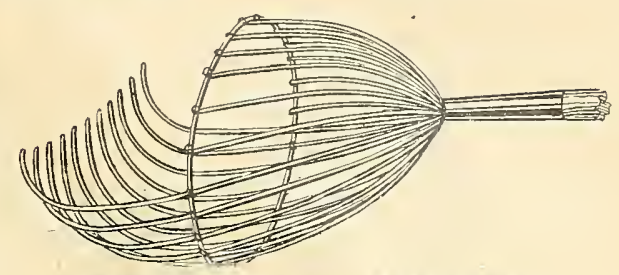

BOSS FRUIT PICKER

Made substantially of galvanized wire. Can easily be attached to a pole of any length. Price, 40c. P. P. Weight, 2 lbs.

\section{MASTERS FRUIT PICRER}

Equipped with an attachment for a pole and holding bag; a very desirable type, that will not bruise the fruit. Price, $\$ 1.50$.

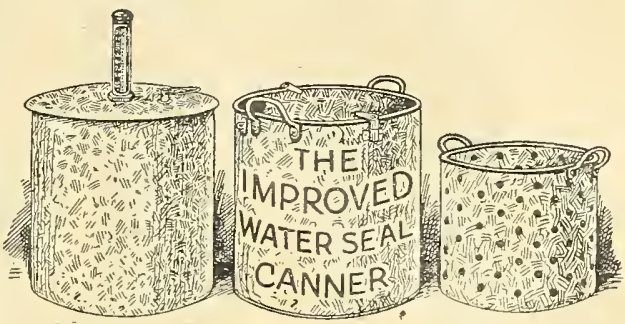

\section{MPR OVED}

WATER SEAL CANNER

Put up your own Vegetables and Fruits with an Improved Water Seal Canner. It gives the necessary rapid application of heat, and maintains it uniformly as long as required. Therefore it insures canned fruits and vegetables that retain their natural color, delicious flavor, rich food value and firmness. Strongly built of galvanized iron, with brass fittings. The Water Seal Canner is portable and adapted to kitchen stove, gas range or open fireplace.

No. 1, capacity 13 one-quart glass jars, or 17 three-pound cans, $\$ 12.50$ each.

No. 7 , capacity seven one-quart glass jars or 10 one-pint glass jars, $\$ 7.00$ each.

\section{MAN O' WAR WINDMILL}

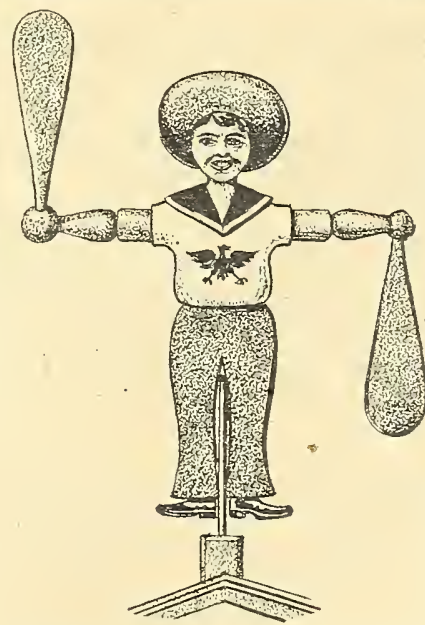

An interesting feature for the children's garden, although they are equally practicable for the grown-ups. They revolve with theleast puff of wind, and on account of their looks they serve as a scarecrow for undesir able birds or animals. They can be fastened to any tree, post, house or wash line pole. P. P. W., 3 lbs. Height, 15 in., $\$ 1.40$ each.

Our Garden Tool and Sundries De-partment we believe to be the most fully equipped of any seed store in the United States. Most every article of real meric for horticultural work will be foun and of the best quality. 


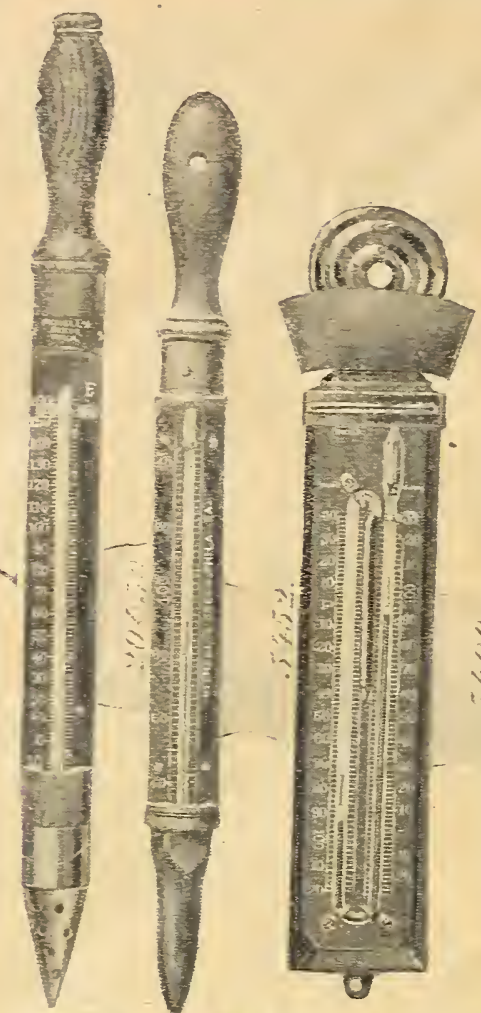

THERMOMETERS

No. 5452. Maximum and Minimum. Registering the coldest and the warmest point during the previous night.

8-inch, each, \$5.00; 10-inch, each, \$๊̃.7j.

TESTED THERMOMETERS

No. 5420 B - \& in., Tin Case....... \$1.00

No. $5420 \mathrm{~B}-10 \mathrm{in} .$, Tin Case....... 1.25

No. $5420 \mathrm{~B}-12$ in., Tin Case........ 1.50

No. 5400- 8 in., Genuine Copper Case 1.75

No. 5100- 8 in., Wood Back, Black

Scale..................... 1.50

No. 5100-10 in., Wood Back, Black

Scale.

1.75

GLASS DAIRY THERMOMETER

No. 5724. For testing milk, etc., also used

for soil purposes. 60c. each.

\section{MUSHROOM OR HOTBED THERMOMETERS}

No.20450. GalianizedIron Point, each . $\$ 2.00$

No. 1. Brass Point, Paper Scale, each 1.50

PUTTY DISTRIBUTOR

For distributing putty, mastica, etc. Price, \$1.50. Parcel Post Weight, 1 lb.
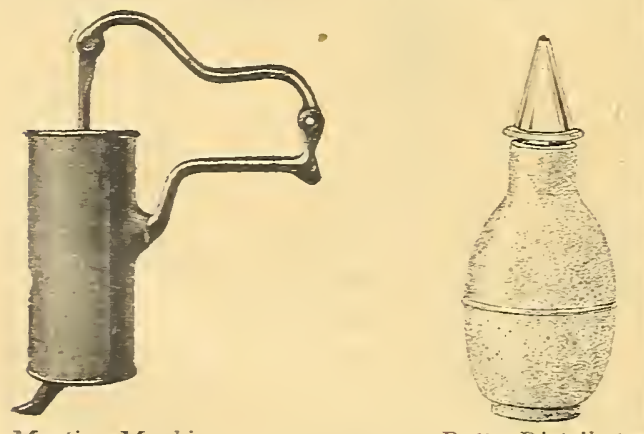

MASTICA MACHINE

For distributing mastica, etc. Made of heary zinc. Price, \$3.00. P. P. Wt., 2 lbs.
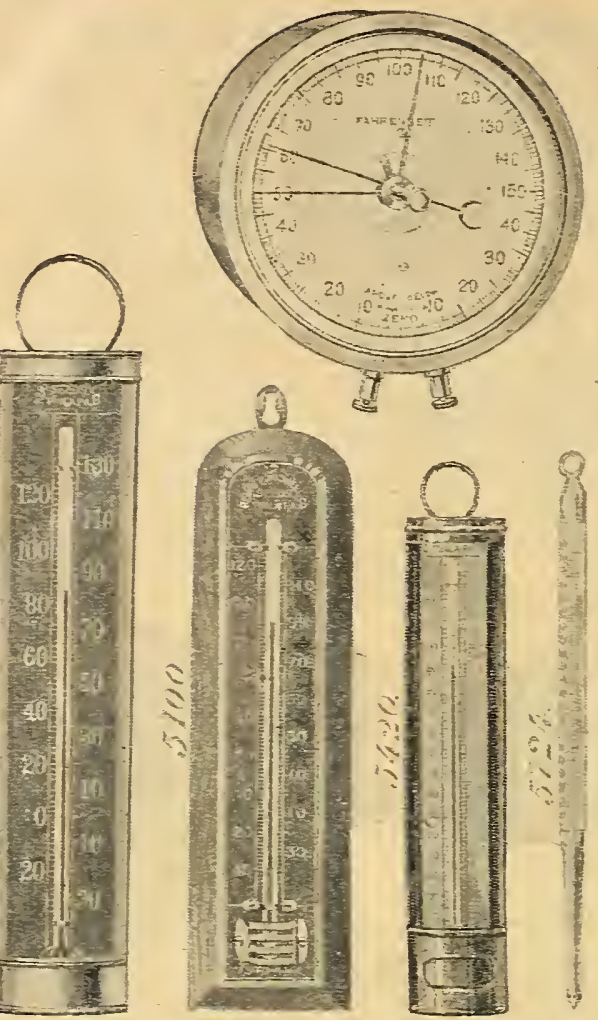

ELECTRIC THERMOSTAT

This device can be set to ring an alarm when the temperature goes above or drops below a desired point. All brass. Not waterproof style, \$11.50; waterproof style, \$17.50. See illustration above.

\section{WEEKLY RECORDING THERMOMETER}

Price .

Please note we do not guarante the.................... arrival of thermometers when sent by parcel post.

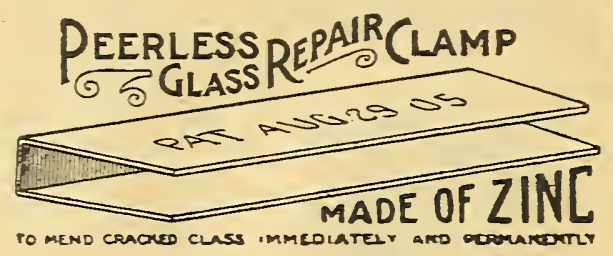

\section{GLASS CLAMPS}

For supporting broken lights of glass. Per box of $100, \$ 1.75$. P. P. Wt., $11 / 1 \mathrm{lbs}$.

\section{TWEMLOW'S PUTTY}

Superior to ordinary putty, more easily applied and lasting. Can be put on with a putty bulb or mastica machine.

16-lb. can (1 gal.) P. P. Wt., 18 lbs....\$2.75 80 lbs. (5 gals.)

160 lbs. (10 gals.)

\section{MASTICA}

13.00

For glazing greenhouses. One gallon will cover about 300 running feet. 1 gallon

\section{HAMMOND'S}

\section{GREENHOUSE WHITE}

A superior white paint for sash bars, sash frames, etc. Per gal., \$1.25.

\section{MASTICOTE GLAZING CEMENT}

Apply with a mastica machine. 1 gal.,
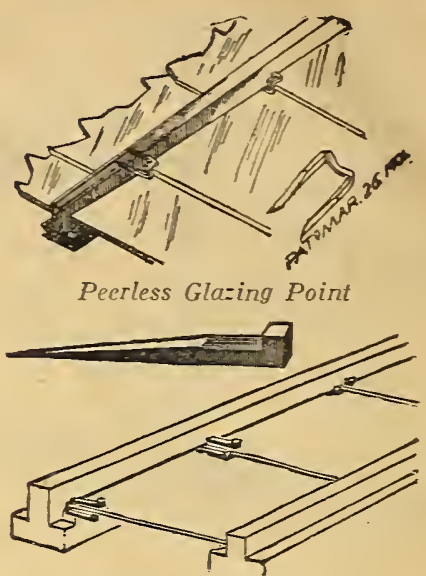

Siebrrt Glazing Point

\section{GLAZING POINTS}

Peerless. Three sizes.

No. 1, for single thick glass.

No. 2, for single thick glass.

No. $21 / 2$, for double thick glass.

Price, 65c. per 1000. By mail, 10c. per 1000 extra.

Pincers. For driving Peerless Points, 60c. By mail, 6ǒc.

Siebert Style. Made with a prominent head; cannot rust; easily driven. $5 / 8,3 / 4$ and $7 / 8$ inches long. Zinc, $60 \mathrm{c}$. per $1 \mathrm{~b}$.; 5 lbs., \$2.75. 1000 to 1200 in a lb.

Zinc Glazing Nails. 50c. per lb.; 5 lbs., $\$ 2.40$.

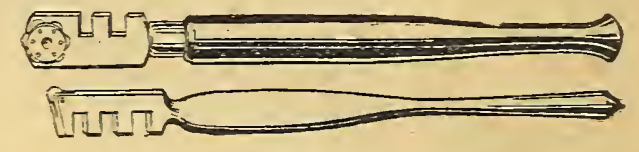

\section{GLASS CUTTERS}

Jingle Wheel, steel, each.........\$0.25 6-Wheel, steel, each............... 60 No.!8 Small Diamond (Ebony handle) 4.50 No. 8A Large Diamond (Mahogany handle)................ 5.75

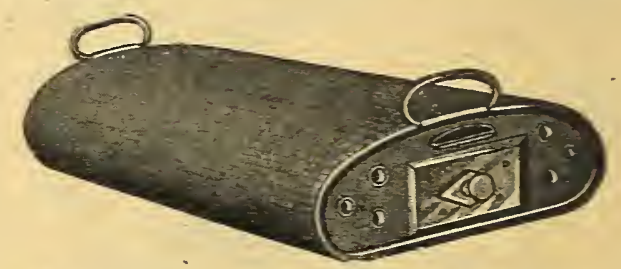

\section{WAGON AND AUTOMO-}

\section{BILE HEATERS}

These will keep the temperature above freezing in most any ordinary closed vehicle during the severest weather.

No. 10. 3 Drawer $\$ 9.00$.

No. 7B. Lehman, covered with green Brussels carpet; 14 -in. long. $\$ 6.00$ each.

No. 6B. Single drawer, 12-in. long, with Brussels carpet, $\$ 3.75$.

Coal for auto nobile heaters. $\$ 1.25$ per doz. bricks; per $100, \$ 8.50$.

Tongs for handling hot coal, $40 \mathrm{c}$. per pair. Please Note.-Wagon heaters burn prepared coal bricks only and no other kind of fuel.

Parcel Post Shipments
Where goods can be shipped in this
manner, we have affixed the packed
weight opposite. Where remittance ac-
companies order please include sufficient
to cover mailing charges. Consult your
post office for proper amounts.




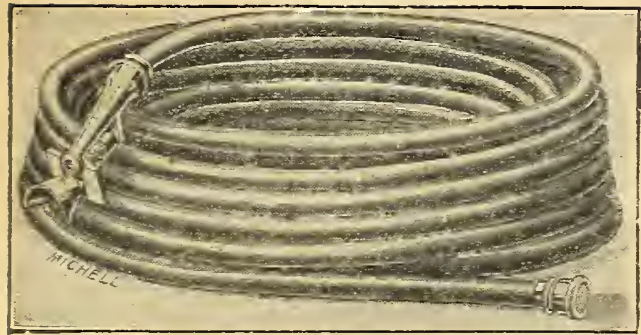

RUBBER HOSE

Special attention is called to "Michell's Akron" Hose, a new brand, which, having been thoroughly tried out, has made good.

Per Foot.

*Michell's Special, 1/2 in.

$\$ 0.14$

*Michell's Special, $3 / 4$ in.

* Michell's Magic. A splendid smooth finish, red hose; $3 / 4$ inch .

*Michell's Akron. Flexible, durable, unkinkable, $3 / 4$ inch .

*Electric, $3 / 4$ inch

*Electric, $1 / 2$ inch.

Spray Pump Hose, $3 / 8$ inch

P. S.-Brands marked * come in reels of 500 feet and sections in any length to that number of feet may be had.

25- and 50-foot sections of hose coupled free. Smaller sections coupled at the rate of 35 c. per pair for couplings.

Hose Washers. 8c. per doz.; 1/4 lb., 30c.; $\$ 1.00$ per lb.

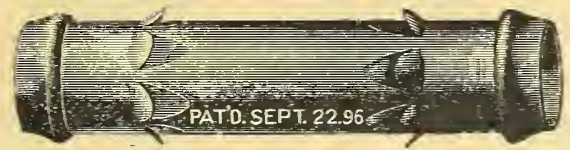

Cooper Hose Hender

\section{HOSE MENDERS P.P.Weight Doz. Each}

Doz.

Cooper's $3 / 4$-inch....11/4 lbs. $\$ 0.12 \quad \$ 1.25$ Cooper's $5 / 8$-inch.... 1 lb. $\quad .12 \quad 1.25$ Cooper's $1 / 2$-inch....1 lb. $.12 \quad 1.20$ Iron, $3 / 1$-inch......21/4 lbs. $\quad .10$

\section{THE PERFECT HOSE MENDER}

Made entirely of brass, with swivel motion- No $\mathrm{b}$ and $\mathrm{re}$ quired.

For $3 / 4$-inch hose, $15 \mathrm{c}$ each ; doz. $\$ 1.50$.

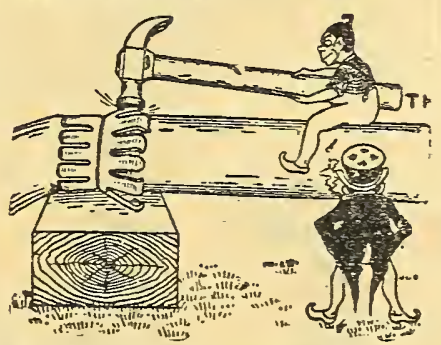

Parcel Post Weight, per doz., 13/4 lbs.

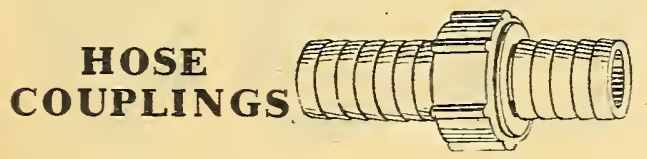

P.P.Wt. Doz. Pair

Plain Brass, $1 / 2$ inch. $31 / 4$ lbs. $\$ 0.25 \$ 2.50$ Plain Brass, $3 / 4$ inch. 4 lbs. $\quad .25 \quad 2.50$

Perfect. Equipped with a clamp on the male and female part for securing to the hose; no band required; for $1 / 2$ - and $3 / 4$ inch hose; mention which is wanted when ordering. 30c. per pair; doz., \$3.00.

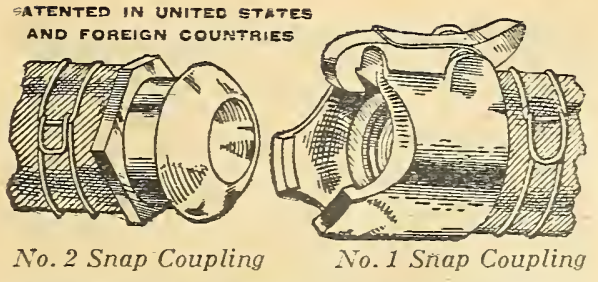

\section{SNAP HOSE COUPLINGS}

Snap Couplings are entirely new and novel. They couple hose instantly, work on a spring, and are water-tight. 35c. per pair; doz. pairs, \$3.75. Washers, 20c. per doz.

Parcel Post Weight, per doz., $21 / 2$ lbs.

SNAP COUPLING PARTS

No. 2. Male. 15c. each; per doz., $\$ 1.50$ Parcel Post Weight, per doz., 11/4 lbs. No. 1. Female. 25c. each; per doz., \$2.50. Parcel Post Weight, per doz., 11/4 lbs.

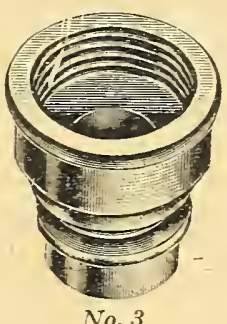

No. 3

\section{ACME HOSE COUPLINGS}

For quickly connecting and detaching hose. No. 3 part, for attaching to spigot, 30c. each; doz., \$3.00. Weight, per doz., 3 lbs. No. 4 part, for attaching to hose, 50c. each; doz., \$5.00. Weight, doz., 3 lbs.

Couplings complete, consisting of one No. 3 and-one No. 4 part, 80c. each; per doz., \$8.00. Weight, per doz., 6 lbs.

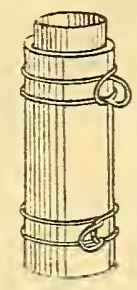

Caldwell Band as applied
to Hose

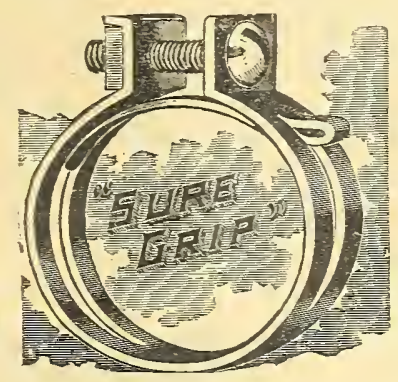

\section{HOSE BANDS}

For fastening couplings and menders.

\section{CALDWELL'S}

8. For 3-ply hose.

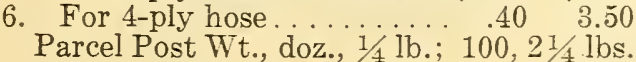

Doz. Gross

\section{SURE GRIP}

$3 / 4$-inch, 6c. each; per doz., 50c.

Parcel Post Wt., doz., 1 lb.; 100, $91 / 2$ lbs.

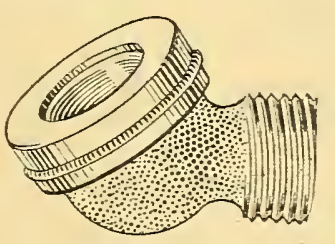

HYDRANT ATTACH= MENTS

To be used for attaching hose to smooth faucets.

No. 2. For sma spigot, $60 \mathrm{c}$.

No. 3. For large or standard spigot, $60 \mathrm{c}$. Parcel Post Weight, 1/2 lb. each.

\section{No. 68 SIAMESE HOSE CONNECTION}

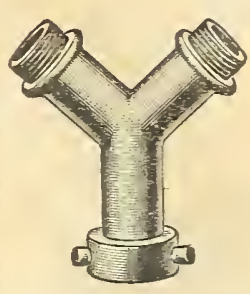

This permits one lead of hose to be diverted in two directions. Additional' three-way nection according pressure. ly adapted sprinkling. each.

Parcel Post Weight,

\section{HOSE REDUCERS}

For reducing 1 -in. pipe to fit regular $3 / 4$-in. hose.

Each

Parcel Post Weight, $11 / 2$

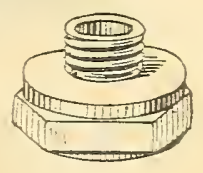

HOSE REELS

Reels are not mailable.

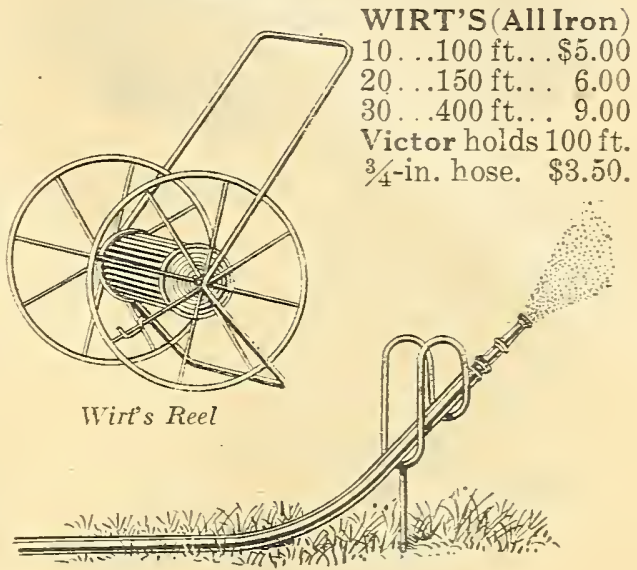

NOZZLE HOLDER

For sticking in the ground while one continues with other work. Made of galvanized heavy wire. Price, 25c, each.

Parcel Post Weight, 8 ozs.

\section{BINKS NOZZLE}

Made of aluminum, with brass face equipped with interchangeable sprays, coarse and fine. It makes watering possible without wetting

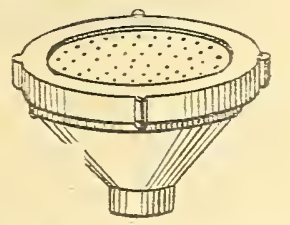
the hands. Positively the best and most indestructible nozzle made. $\$ 3.00$ each; worth twice the price. P. P. Wt., 11/4 lbs,

\section{PERFECTION HOSE NOZZLE}

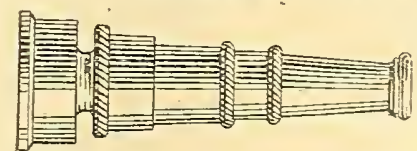

streams. Price, 7 óc. Weight, $1 / 2 \mathrm{lb}$

MIS CELLANEOUS NOZZLES

Boston, Light Copper

Boston, Heavy Brass

Champion.

easily adjusted. P P.

Allen. Similar to the Perfecti

Parcel Post Weight, $1 / 2$ la

Parcel Post Weight 


\section{LAWN SPRINKLERS}

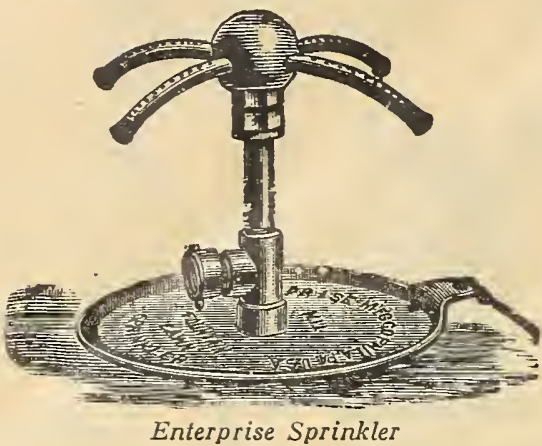

Weight Price

Enterprise. No. 1, $91 / 2$ in. high, 10 lbs. $\$ 5.00$

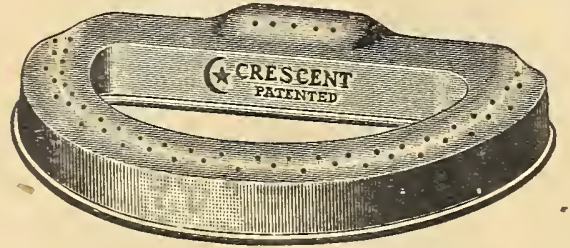

\section{CRESCENT SPRINKLER}

All brass; suitable for watering confined areas, such as side yards, etc. Sprays only a half circle at a time. Price, 75c. P. P. Wt., 2 lbs.

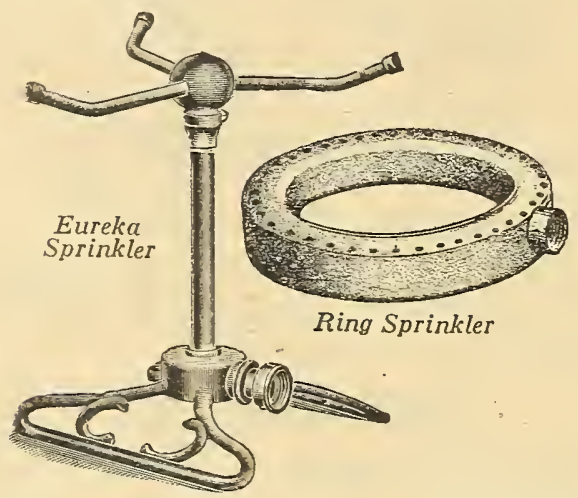

Weight Price

Eureka. No. 55. $10 \mathrm{in.} \mathrm{high}$

Ring or Fountain. Large

4 lbs. $\$ 2.50$

Ring or Fountain. Small....1 lb.

\section{DOUBLE ROTARY SPRINKLER}

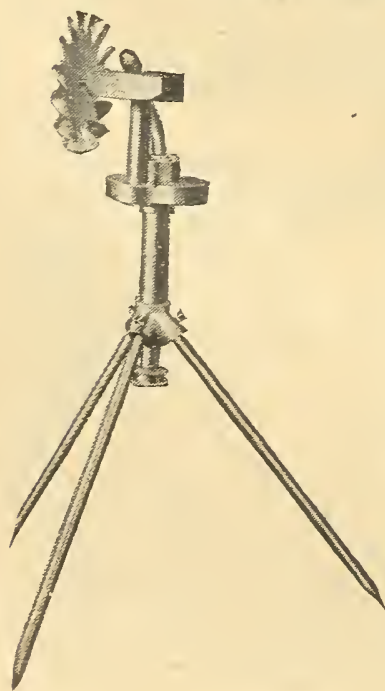

This operates on a new and improved principle; sprinkles evenly, covering a radius of 15 to 80 feet according to the water pressure. Simply attach the hose and turn on the water, the machine does the rest. Water pressure causes thewheel to revolve, cutting the water into drops like rain. Price, $\$ 12.50$.

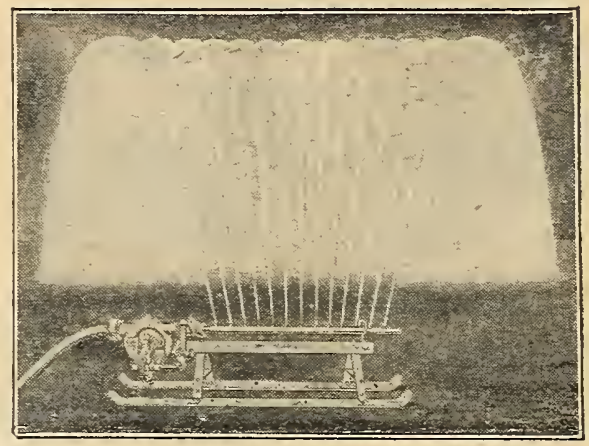

\section{CICO}

OSCILLATING IRRIGATOR

Operates under a reasonable pressure, as there is nothing to revolve, except the water motor, which is a part thereof. This is one of the most recent important improvements in the way of lawn sprinklers. Price, large size, 5 feet long, $\$ 25.00$; small size, 21 in. long, $\$ 15.00$.

\section{PEACOCK SPRINKLERS}

A pipe arrangement, equipped with nozzles set at various distances.

$8 \mathrm{ft}$. Junior $\$ 10.00 \mid 12 \mathrm{ft}$. Peacock. $\$ 17.50$

\section{TURBO SPRINKLERS}

Fspecially designed for putting greens and for golf course fairways. Price, with stand, $\$ 25.00$; without stand, $\$ 18.00$.

\section{CICO}

\section{AUTOMATIC SPRINKLER}

This device is tapped to screw on $3 / 4$ inch pipe. When properly regulated and operated, will water a circular area 50 to 60 feet in diameter. Can also be installed for permanent irrigation purposes. Price, heads only, $\$ 3.50$; with 18 inch standpipe, $\$ 5.00$.

\section{RAINING SPRINKLERS}

For golf courses and putting greens. No. A. 42 in. high, on stand.....\$13.00 No. B. 66 in. high, on tripod...... 18.00 No. C. 36 in. high, on stand ....... 12.00 No. D. 18 in. high, on tripod ..... 8.00

\section{RAINBOW SPRINKLERS}

Standpipe style, for golf courses. Price, $\$ 1.50$.

Sled style, for regular lawns. Price, $\$ 3.00$.

\section{PENNA. RAINMAKER SPRINKLER}

This sprinkler will operate satisfactorily with a pressure of not less than $40 \mathrm{lbs}$.; covers an area of 60 to 75 feet in diameter; 29 in. high; weight 52.lbs. Price, $\$ 22.50$.

\section{MISCELLANEOUS SPRINKLERS}

Aetna. $24 \mathrm{in.} \mathrm{high......6.61/4} \mathrm{lbs.} \$ 2.75$

C. B. G. For golf links....2 lbs. $\quad .50$ Empire. 24 in. high ......7 lbs. 6.50 8-arm Peck. 48 in. high...14 lbs. 5.00 Mayflower. 12 in. high....3 lbs. 1.75 Pluvius. $11 \mathrm{in}$. high ......31/2 lbs. 1.75 Preston. $61 \frac{1}{2}$ in. high.......3 $31 / 2$ lbs. 2.00 Universal. No. 65.10 in. high. $41 / 4$ lbs. 3.00 Waterwitch. 6 in. high .... lb.

\section{RUBBER APRONS}

For protecting the clothing while watering or doing any work in the garden where your clothes could become soiled. $\$ 2.25$.

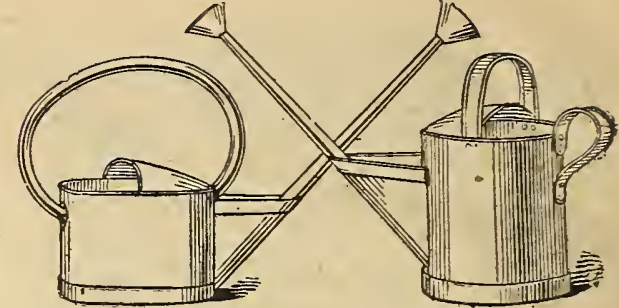

WATER CANS (Wotherspoon's)

Extra Heavy-With Long Spout-Will Last for Years

Each Wotherspoon can comes equipped with two roses, one coarse and one fine These cans not mailable.

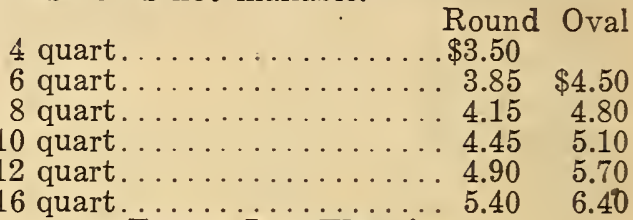

4 quart Fern or Low Watering

Can ................. 2.75

EXTRA ROSES OR SPRAYS

For Wotherspoon Watering Can, either coarse or fine, 50c. each.

Parcel Post Weight on roses, 8 ozs.

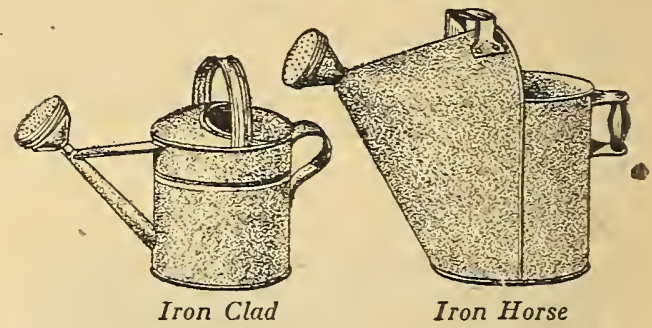

\section{IRON HORSE WATER CANS}

Fine for cemetery purposes and other places where a can desired to last is wanted. This is very heavy and substantially made and is quite easily worth more than the regular galvanized or tin affair. (Not mailable.)

4 quart.......\$1.15 | 10 quart..... \$1.65

\begin{tabular}{l|l}
6 quart........ $1.25 \quad 12$ quart...... 1.90 \\
8 quart.....
\end{tabular}

8 quart........ 1.50 16 quart...... 2.50

IRON CLAD WATER CANS

Made of a lighter gauge iron than the "Iron Horse" style, and from the illustrations it will be seen that the spout and handle is different.

4 quart...... \$1.00 | 10 quart..... \$1.55 6 quart ........ $1.15 \quad 12$ quart...... 1.65

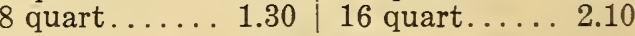

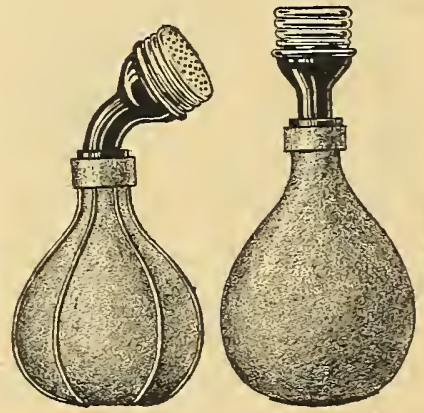

Spraywell

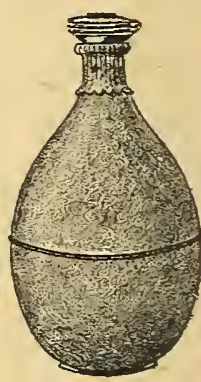

Scollay
RUBBER SPRINKLERS

Either Straight Neck or Crook Neck. Spraywell, 6-oz. cap. Wt. 8 ozs.... \$0.85 “6 8-oz. cap. Wt. 1 lb..... 1.00 “ 10-oz cap Wt. $1 \mathrm{lb} \ldots \ldots . .25$ Scollay No. 1. Wt. $1 \mathrm{lb} \ldots \ldots \ldots \ldots, 1.50$ 


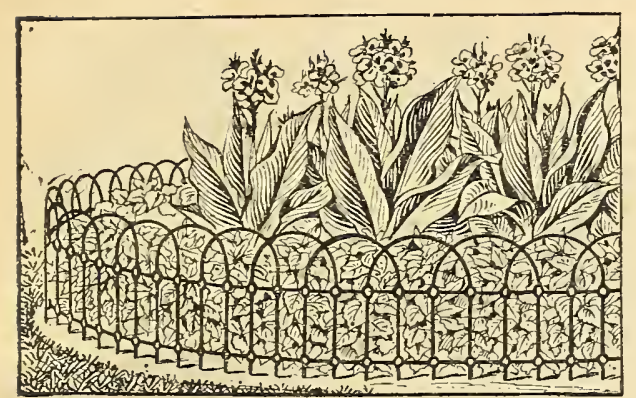

FLOWER BED FENCING

For putting around beds, lawns, etc. Any length desired up to 165 running feet. $18 \mathrm{in}$. Less than $165 \mathrm{ft}$. roll, 15c. per ft.

$18 \mathrm{in.}$ In roll lots, $165 \mathrm{ft}$., $12 \mathrm{c}$. per $\mathrm{ft}$.

$24 \mathrm{in}$. Less than $165 \mathrm{ft}$. roll, $17 \mathrm{c}$. per $\mathrm{ft}$.

$24 \mathrm{in.} \mathrm{In} \mathrm{roll} \mathrm{lots,} 165 \mathrm{ft} ., 15 \mathrm{c}$. per $\mathrm{ft}$.

\section{CONTINUOUS WIRE TRELLIS}

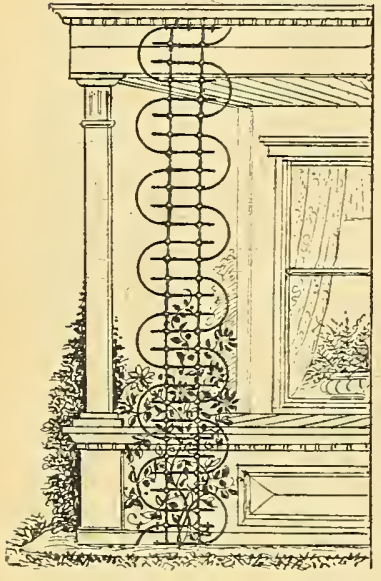

Excellent for training vines of all kinds up porch verandas, pergolas, etc. Thoroughly galvanized and well made.

Any length desired up to 165 running feet.

16 in. wide, less than $165 \mathrm{ft}$. roll, 14c. per ft. 16 in. wide, in roll lots, $165 \mathrm{ft} ., 11 \mathrm{c}$ per ft.

22 in. wide, less than $165 \mathrm{ft}$ roll, 16c. per ft. 22 in. wide, in roll lots, $165 \mathrm{ft} ., 14 \mathrm{c}$. per ft.

\section{WIRE \\ NET - \\ TING}

Price is constantly changing and is subject to change.

No. 19. Galvanized, twoinch mesh, 150 running feet per bale.

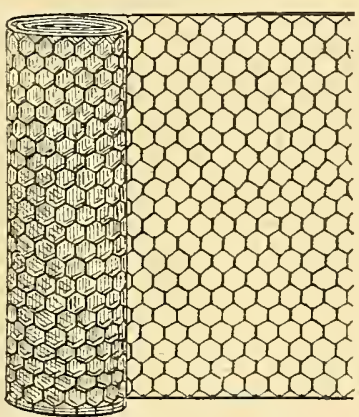

Width

12 inches.

Per Bale | Width

Per Bale

18 inches

$\$ 1.68$

2.40

42 inches.

.... $\$ 4.88$

24 inches

3.00

3.68

36 inches. 4.19 running feet per bale.

Width Per Bale | width Per Bale

12 inches .....\$3.36 42 inches . . . \$9.75

18 inches. . . . 4.80 48 inches . . . . . 11.15

24 inches. . . . 6.00 60 inches . . . . 13.00

30 inches.... $7.32 \quad 72$ inches..... 15.60
No. 20, galvanized, one-inch mesh, 150

36 inches.
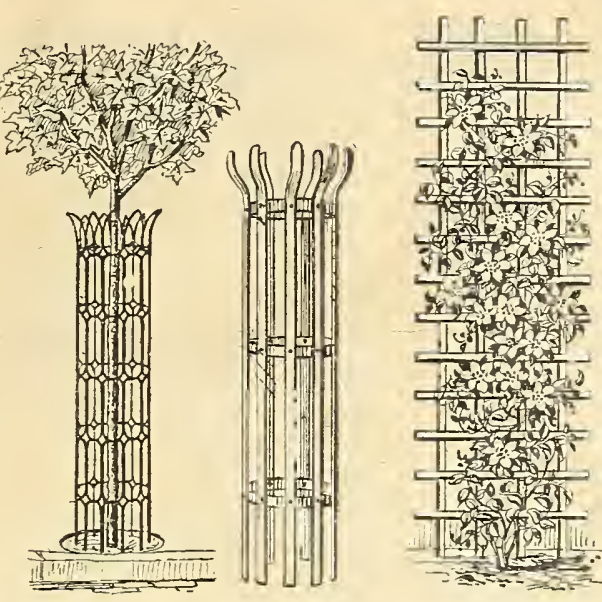

Wire Guard Iron Guard

\section{TREE GUARDS}

Galvanized Wire. Carefully made of heavy material and finished in a neat and substantial manner. 12 in. diam., $\$ 3.75$ 9 in. diam., $\$ 3.00$ each.

No. 4 Iron. Made of flat iron, finished black; will last indefinitely with an occasional painting. $\$ 3.75$ each.

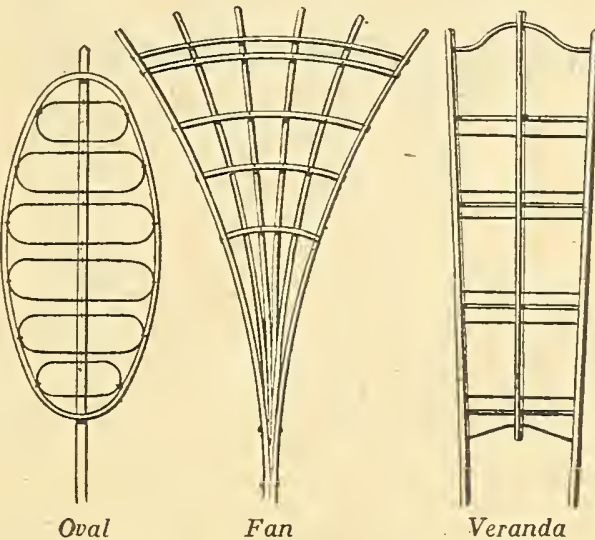

VERANDA TRELLIS

Made of wood and painted green.

2 feet........\$0.90 6 feet, heavy . $\$ 2.50$ 3 feet........ $1.35 \quad 8$ feet, heavy. 3.25 4 feet....... 1.50 10 feet, heavy. 3.75 5 feet, heavy. . 2.25 12 feet, heavy. 4.50 OVAL TRELLIS

Made of wood and painted green. 24 inch

\section{FAN TRELLIS}

Made of wood and painted green. 18 inch......\$0.40 36 inch.

24 inch...... $.50 \quad 42$ inch.

\section{LATTICE TRELLIS}

Made of wood and painted green.

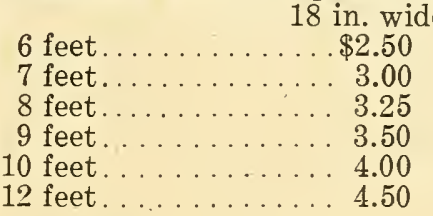

WALL NAILS

STAPLES

$3 / 4$ inch, for fastening netting, 15c. per Ib.

\section{CUT WIRE NETTING}

We can furnish this in both 1 - and 2 -inch mesh, in units of 25 -ft., $50-\mathrm{ft} ., 75-\mathrm{ft} ., 100-\mathrm{ft}$. and 125 -ft. lengths. 1-inch mesh at $4 \mathrm{c}$. per

For fastening climbing vines; equipped with a soft metal clasp which holds the vine against the wall.

Doz. 100

$11 / 2$ inch....... $\quad .60 \quad 3.75$

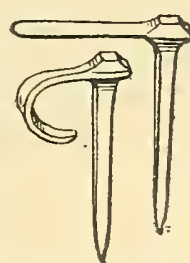

GALVANIZED WIRE WORK

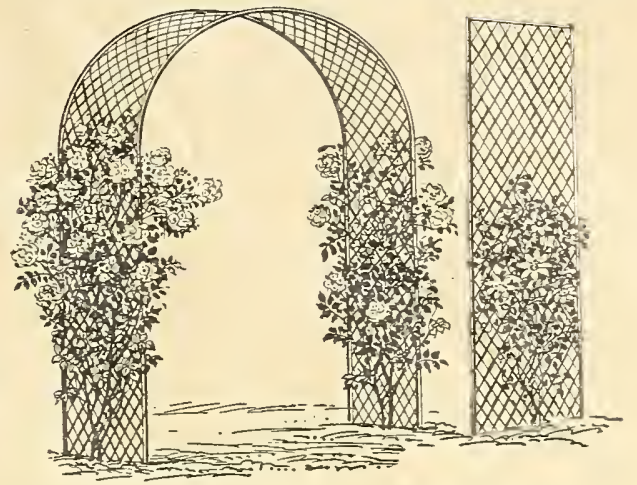

This can be furnished on short notice, any height or any width, in either trellises or arches. Made of heavy diamond mesh wire with strong frames. It requires usually several weeks in which to complete orders for this. 45c. per sq. ft. on pieces aggregating $10 \mathrm{sq}$. ft. or over; less than 10 sq. ft. pieces, 50c. per sq. $\mathrm{ft}$.

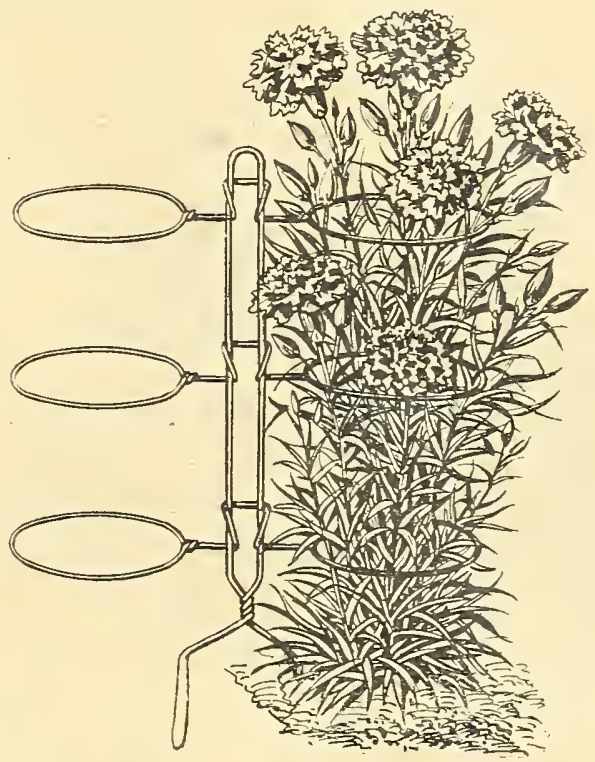

\section{CARNATION SUPPORTS}

The Richmond shown is the most popular support on the market. Can be put together in a minute and is always satisfac$\$ 0.60$ tory; 24 inches high.

$\begin{array}{lll}\text { inch } \ldots \ldots \ldots & .75 & .7 .50\end{array}$
Richmond, double

Doz. $\quad 100 \quad 1000$

$\$ 1.50 \quad \$ 7.50 \quad \$ 60.00$

Richmond, single

Doz. $\quad 100 \quad 1000$

$\$ 1.25 \$ 6.50 \quad \$ 55.00$ Model, 2-ring

Doz. $\quad 100 \quad 1000$

$\$ 1.00 \quad \$ 6.50 \quad \$ 55.00$ Model, 3-ring

Doz. $\quad 100 \quad 1000$

$\$ 1.25 \$ 7.00 \quad \$ 65.00$

\section{HAN GIN G}

BASKETS

Galvanized Wire

For greenhouse, porch and conservator

Each

8 inch

10 inch

12 inch

14 inch 


\section{HOT BED} SASH

Philadelphia Style. Made of best quality cypress. Size, 3 feet $1 \frac{1}{2}$ inches wide, 6 feet long, $1 \frac{3}{4}$ inches thick. Plain, not glazed or painted. Each, \$3.25.

Glazed including painting and puttying. Each, $\$ 7.50$.

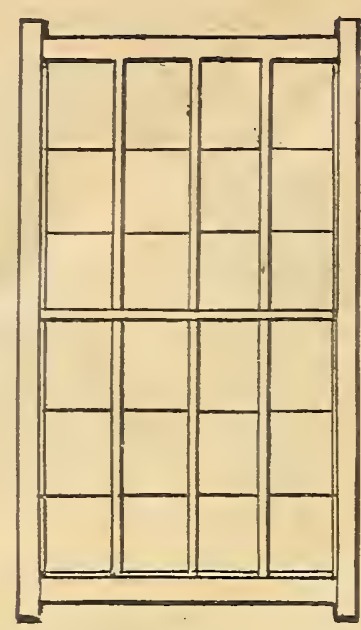

Sunlight Style. Plain, unglazed. Each, $\$ 5.50$. Glazed and painted. Each, $\$ 11.00$

Packing Charges on all Glazed Sash, 50c. per sash additional.

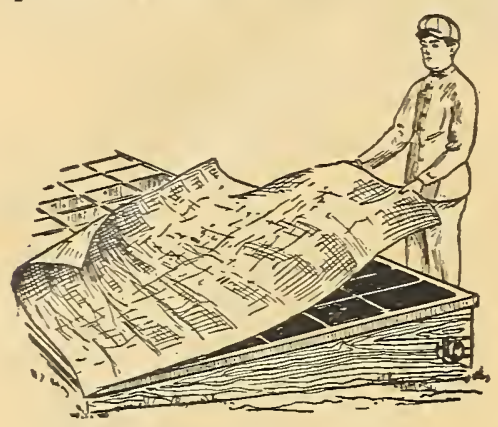

\section{HOTBED MATS}

Hotbed mats keep frost and severe cold out of frames. They mean earlier and bigger crops. The Burlap style are the best mats that it is possible to procure. They are padded with shoddy and are practically indestructible.

Burlap, Non-Waterproof. $72 \times 72$ inches, covering two regular size sash. Each, $\$ 3.00 ; \$ 32.50$ per doz.

Burlap, Non-Waterproof. $40 \times 72$ inches, for one sash. Each, $\$ 2.00 ; \$ 20.00$ per doz.

Burlap one side, Waterproof Drill one side. $72 \times 72$ inches. $\$ 4.25$ each; doz., $\$ 45.00$

Burlap one side, Waterproof Drill one side, $40 \times 72$ inches. \$2.75 each; doz., $\$ 30.00$.

Straw Mats. $3 \times 6$ feet......... $\$ 2.00$

Straw Mats. $6 \times 6$ feet......... 3.50

Special size Hotbed Mats to order; any length, but only in 72-inch widths. Straw Mats made to order any length, $6 \mathrm{ft}$. wide. Under 100 sq. ft., 15 c. per sq. ft.; 100 to 150 sq. ft., $131 / 2$ c. per sq. ft.: 150 sq. ft., and

\section{SHADING OR \\ PROTECTING CLOTH}

Largely used as a substitute for glass where protection is desired. It is admirable for summer use, protecting plants, etc., from the sun and at the same time allowing ventilation. Made of brown cloth.

$\begin{array}{ccc}\text { Yards } & \text { Price } & \text { Price } \\ \text { Per Piece } & \text { Per Yard } & \text { Per Piece }\end{array}$

$\begin{array}{llcl}\text { Light.... } & 60 & \$ 0.151 / 2 & \$ 8.40 \\ \text { Medium. . } & 60 & .22 & 12.00 \\ \text { Heavy . . . } & 40 & .30 & 10.80\end{array}$

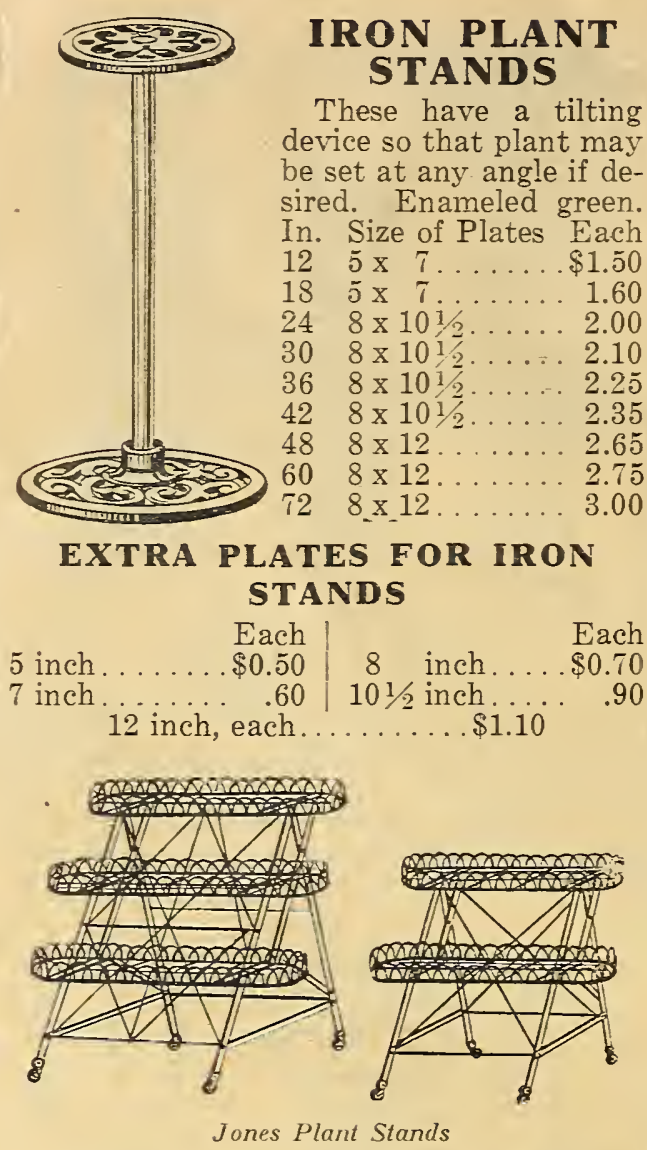

WIRE PLANT STANDS

Painted dark green and finished in bronze. Very substantial and will carry most any weight that can be placed on them. We recommend the Jones style, as it is collapsible and takes up very little space when
not in use. Jones, 2 shelf . $\$ 5.00$ | Jones, 3 shelf . $\$ 6.00$ When wire plant stands require packing for shipment by express and freight, there is a charge of $50 \mathrm{c}$. made for packing.

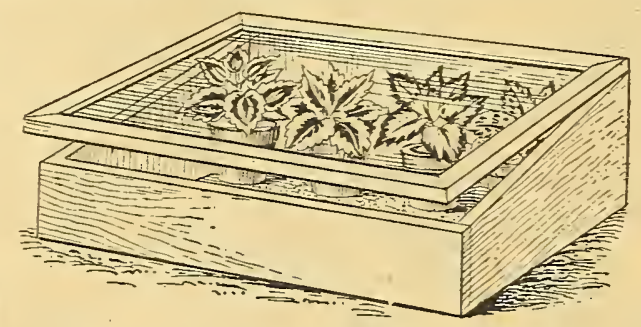

\section{MINIATURE HOTBEDS}

These are very handy to use in connection with window gardening. Suitable for raising seedlings or for rooting cuttings. Seeds started in these will moan an early flower or
vegetable garden. $12 \times 20$ in., $\$ 3.50$ each. Complete with glass. Not mailable.

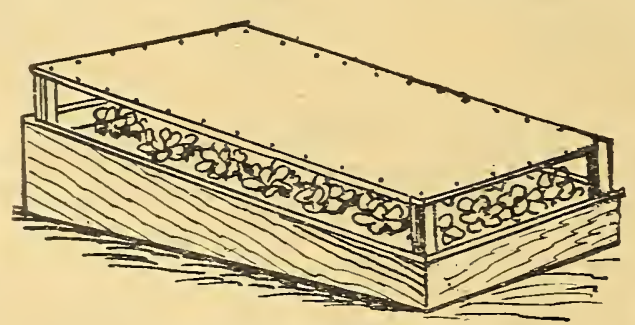

Shading or Protecting Cloth

For prices, see left hand column.

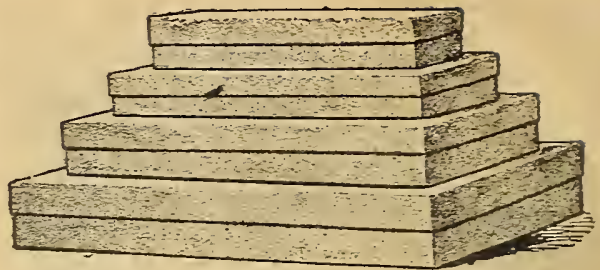

CUT FLOWER BOXES CORRUGATED PAPER

These are desirable for shipping cut flowers from country estates to city residences, very durable.

$48 \times 14 \times 8$ inch $\begin{array}{ll}\text { Each } & \text { Doz. } \\ \$ 0.70 & \$ 7.00\end{array}$

$42 \times 14 \times 8$ inch

$36 \times 14 \times 6$ inch

$30 \times 12 \times 6$ inch.

$.60 \quad 6.00$

$.50 \quad 5.00$

$.40 \quad 4.00$

\section{LIGHT WEIGHT PAPER}

Mist green, lined white inside. The sizes offered in this finish are carried in stock, other sizes in this finish, also in manila, mist tan and oxford gray can be supplied on short notice.

L. W. D. Doz. 100

$18 \times 5 \times 3$ inch..........\$0.60 $\$ 4.40$

$24 \times 5 \times 31 / 2$ inch......... $1.00 \quad 6.85$

$24 \times 8 \times 4$ inch............ $1.15 \quad 8.50$

$28 \times 8 \times 5$ inch ............ 1.7512 .00

$30 \times 10 \times 6$ inch ..........2.10 16.00

$30 \times 12 \times 7$ inch............. 2.7520 .00

$36 \times 8 \times 5$ inch. .............. 2015.00

We can also supply other sizes and styles of boxes.

\section{PAPER FOR WRAPPING BOXES AND FLOWERS}

Lb. $1 / 2 \mathrm{Rm} . \mathrm{Rm}$

Manila. For wrapping. . . $\$ 0.20 \$ 2.25 \$ 4.00$

Manila. Tissue.......... $.20 \quad 1.00 \quad 1.75$

Wax. White, $24 \times 36$ in... $.35 \quad 1.653 .00$

Wax. Green, 24 x 36 in... .50 2.254 .00

ROOFING PAPER, ETC.

Sq. ft. Per roll

Celery Paper..............500 Price on

Marley Rubber Roofing, 1-ply. $108 \$ \$ 3.00$

Marley Rubber Roofing, 2-ply.108 $\quad 3.50$

Marley Rubber Roofing, 3-ply.108 4.00

Tar or Pitch, 2-ply ..........100 2.00

Tar or Pitch, 3-ply ............ $100 \quad 2.50$

Caps for tar paper. $1 \mathrm{lb}, 12 \mathrm{c}$; $5 \mathrm{lbs}$., $55 \mathrm{c}$.

Nails for tar paper. $1 \mathrm{lb}, 12 \mathrm{c}$; 5 lbs., $55 \mathrm{c}$.

\section{TREE LABELS}

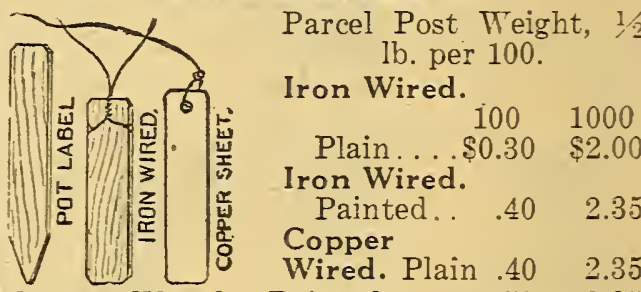

Copper Wired. Painted.... $.50 \quad 2.95$

Copper Sheet, wired. $30 \mathrm{c}$. doz. 1.70

Zinc Sheet, wired. 30c. doz.. 1.75

Indelible Marking Pencils. Each.. .15

\section{PAINTED POT LABELS}

P.P.Wt per $100 \quad 100 \quad 1000$

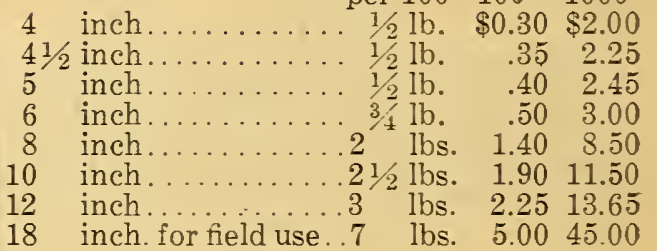




\section{MICHELL'S PLANT STAKES, WIRE, ETC.}

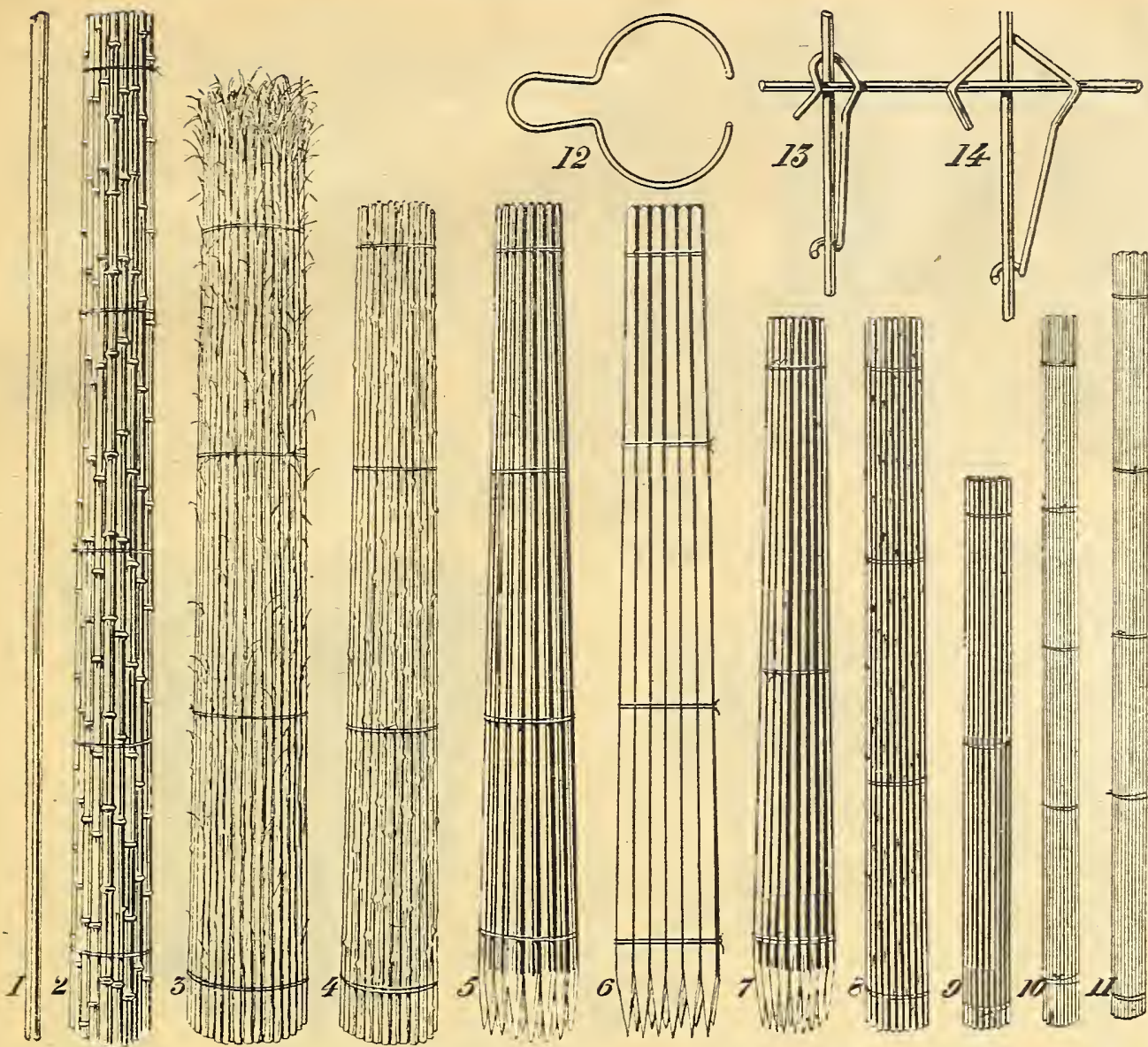

KEY TO ABOVE ILLUSTRATION: No. 1, Pole for Pruners; No. 2, Bamboo Poles, STAKES; No. 3, Southern Cane; No. 4, Japanese Cane, natural; No. 5, Dahlia; No. 6, Square; No. 7, Tapering; No. 8, Japanese Cane, green; No. 9, Hyacinth; No. 10, Galvanized Wire, No. 10, wire; No. 11, Galvanized Wire; No. 8, wire; No. 12, Wire Plant Tie; No. 13 , Eureka Stake Fastener; No. 14, Everlasting Stake Fastener.

TAPERING PLANT STAKES PAINTED GREEN

Weight $\begin{array}{llll}1 / 2 \text { feet } \ldots . . .1 / 2 \mathrm{lb}, & \$ 0.03 & \$ 0.25 & \$ 1.88\end{array}$

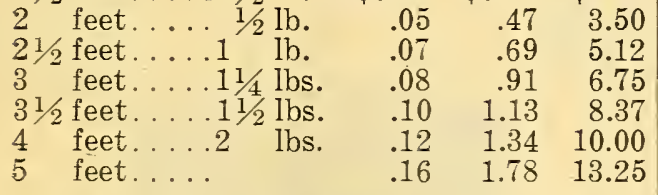

\section{ROSE OR DAHLIA STAKES}

Round tapering style; painted green.

$$
\text { Weight }
$$

3 feet....21/2 Ibs. $\$ 0.13 \quad \$ 1.44 \$ 10.75$

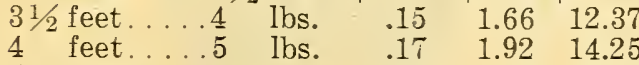

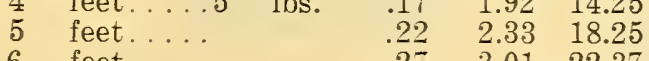

\section{SQUARE PLANT'STAKES}

These are painted green and nicely tapered and finished. Weight per Doz. Each Doz. 100 4 per Doz. Each Doz. 100

per Doz. Each Doz. 100

\section{HYACINTH STAKES}

Used for staking hyacinths, tulips and slender plants; dyed green. $\begin{array}{cccc}\text { per } 100 & \text { Doz. } & 100 & 1000 \\ 5 \text { inch .....11/2 lbs. } & \$ 0.05 & \$ 0.20 & \$ 1.50\end{array}$

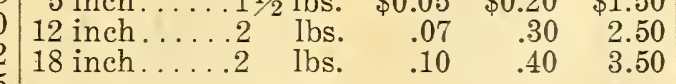

\section{GALVANIZED WIRE}

No. 10 WIRE, LIGHT

No. 8 WIRE, HEAVY $\$ 0.30-\$ 1.85 \quad 21 / 2$ feet

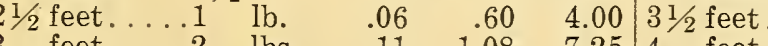
$\begin{array}{lllll}11 / 2 \text { feet.....2 } 1 / 2 \text { lbs. } & .11 & 1.08 & 7.25 & 4 \text { feet } \\ 12 & 1.15 & 8.25 & 41 / 2 \text { feet }\end{array}$ feet. . . . 4 lbs.

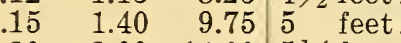
\begin{tabular}{lll|l}
20 & 2.00 & 14.00 & $51 / 2$ feet
\end{tabular} $\begin{array}{llll}.25 & 2.50 & 16.50 & 6 \\ \end{array}$

\section{CANE STAKES}

$\begin{array}{lllll}\text { Southern Doz. } & 100 & 250 & 1000\end{array}$ $\begin{array}{lllll}6 \text { to } 7 \text { feet. . . } \$ 0.35 & \$ 2.00 & \$ 3.75 & \$ 14.00\end{array}$ JAPANESE GREEN CANE STAKES

These are very attractive for all purposes of plant staking; thin and very strong.

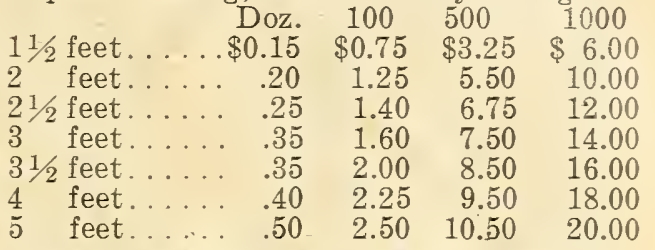

JAPANESE NATURAL CANE STAKES

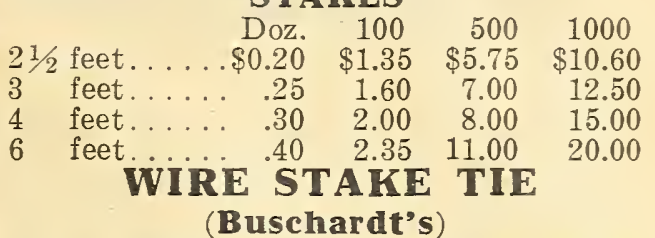

For fastening plants to stakes, either wire or wood; can be used many times.

\section{STAKE FASTENERS}

These take the place of string entirely, lasting several seasons; used for fastening cross wires to galvanized stakes.

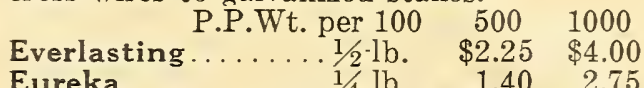
P.P.Wt. STAKES P.P.Wt.

Doz. Doz. $100 \quad 1000$

$11 / 2$ lbs. $\quad \$ 0.20 \quad \$ 1.00 \quad \$ 8.00$ $\begin{array}{llll}11 / 2 & \text { Ibs. } \quad .25 & 1.25 & 10.00\end{array}$

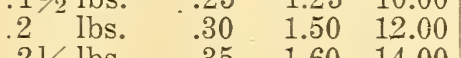
$21 / 1$ lbs. $\quad .35 \quad 1.60 \quad 14.00$ $21 / 2 \mathrm{lbs} . \quad .40 \quad 1.80 \quad 16.00$ 3 lbs. $\quad .45 \quad 2.00 \quad 18.00$ $\begin{array}{lll}50 & 2.25 & 20.00\end{array}$ $\begin{array}{lll}.55 & 2.50 & 22.00 \\ 60 & 2.75 & 24.00\end{array}$ P.P.Wt. Doz. Doz. $100 \quad 1000$ .2 lbs. $\$ 0.30 \quad \$ 1.50 \$ 12.00$ $\begin{array}{rrr}.30 & \$ 1.50 & \$ 12.00 \\ .35 & 1.75 & 15.00\end{array}$ off Putting Greens, also for staking

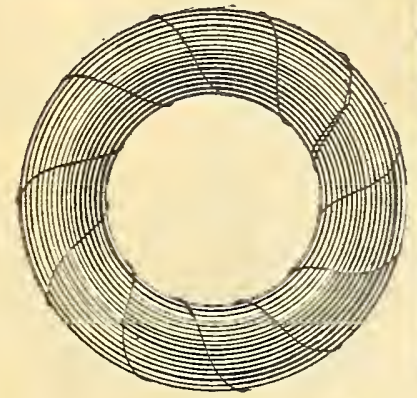

WIRE

Allow for postage if wanted by mail. 12-lb.

No. 16. Galvanized

No. 18. Galvanized.

No. 19. Galvanized

No. 20. Galvanized

No. 22. Galvanized.

No. 16. Annealed.

No. 18. Annealed

No. 20. Annealed

No. 22. Annealed

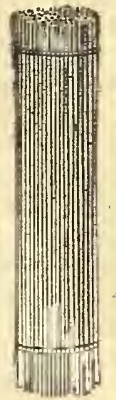

2.75

No. 24. Annealed in 10-1b boxes, cut $81 / 2$ inches, 30 c.

CUT BOUQUET WIRE

For Stemming Flowers

Cut 9,12 or 18 inches in length. No. 20, 25c. per lb.; per box, 12 Ibs. No. 22, 30c. per lb.; per box, 12 lbs.

\section{No. 24, 3 כ. per lb.; per box, 12 lbs}

Used extensively for brushing wor $21 / 2 \mathrm{lbs}$ $.33 / 4 \mathrm{lbs}$. .3 Ibs.

\begin{tabular}{lll|l}
.40 & 2.00 & 17.00 & trees. \\
.45 & 2.50 & 21.00 & 16 feet
\end{tabular}

$50-2.75 \quad 23.0018$ feet.

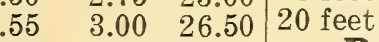

$\begin{array}{lll}.60 & 3.75 & 29.00\end{array}$

$\begin{array}{lll}70 & 4.00 & 32.00\end{array}$

$\begin{array}{llll}75 & 4.25 & 35.00 & 14 \text { feet long }\end{array}$ 


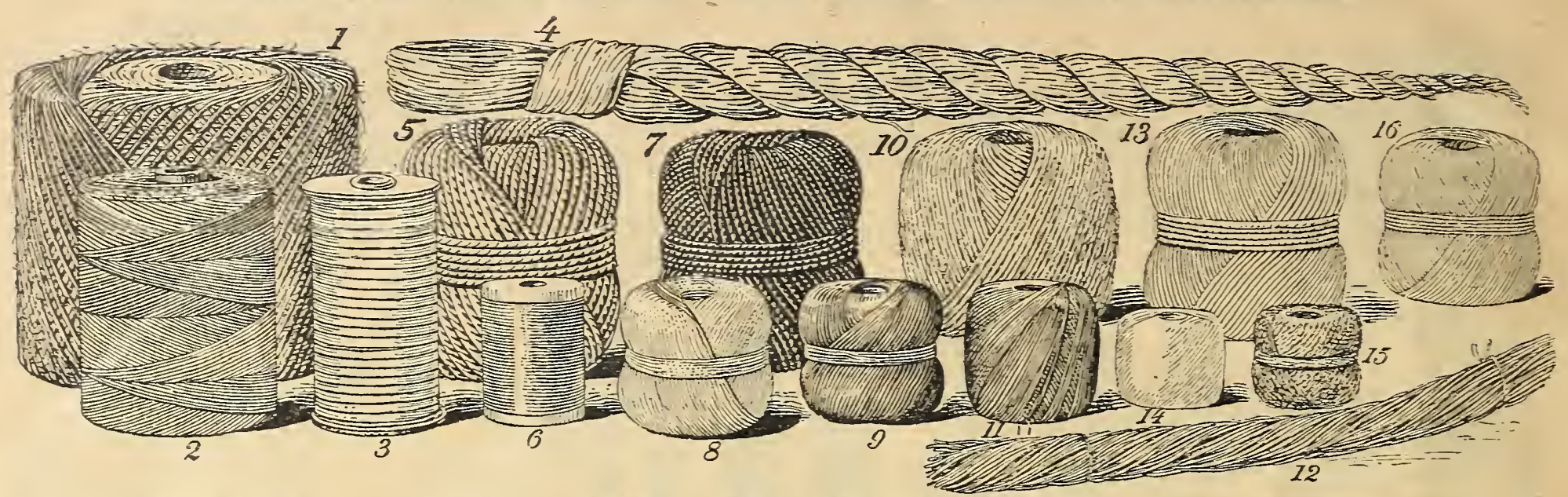

Key to above illustrations. No. 1, Binder; No. 2, Peerless; No. 3, Raffiatape; No. 4 , Raffia; No. 5, Express; No. 6, Silkaline; No. 7, Tarred Marlin; No. 8, Cayuga, Medium; No. 9, Smilax; No. 10, Jute; No. 11, Green Sea Island; No. 12, Tarred Sisal; No. 13, Japanese; No. 14, Special White Cotton; No. 15, Linen Bouquet; No. 16, Cayuga, heavy.

\section{TWINES, ETC.}

No. 108. White Cayuga,

No. 208. White Cayuga,

Heavy.

Jute, 2 -ply and 3 -ply

Linen Bouquet.

Green Sea Island.

No. $41 / 2$ Japanese Twine

Medium heavy

Jefferson White Cotton, 3-ply

Peerless. Color, Nile green.

Tarred. For mat making.

Tarred Sisal. For fodder

Binder.

Express. Very heavy

For stringing Smil

Asparagus, etc. $F$, fine; FF, medium;

FFF, coarse.

Price, per spool, 40c.

Price, per lb. (8 spools).

Smilax Twine (Silkaline Substitute).

Very similar to the above; fast color. Price, 25c. per spool; per lb., $\$ 1.50$.

\section{RAFFIA}

For tying, basket making and fancy work; very long and fibrous.

Natural Color, 25c. per lb.; 5 lbs., \$1.10. Green, $\$ 1.00$ per lb.; 5 lbs., $\$ 4.75$.

\section{RAFFIATAPE}

This article is made of a composition of paper and linen and is tremendously strong; it is about $1 / 8$ inch wide and is put up in 250-yard bolts or hanks. This is very desirable for tying bouquets, flower boxes or for any other purpose where attractive tying material is desired. Color, Nile green. Parcel Post Weight, per bolt, $1 / 2 \mathrm{lb}$.

Per bolt of 250 yards, $\$ 1.00 ; 6$ bolts, $\$ 5.75$.

\section{PARCEL POST SHIPMENTS}

Where goods can be shipped in this manner, we have affixed the packed weight opposite. Where remittance accompanies order please include sufficient to cover mailing charges. Consult your post office for proper amounts.

\section{JONES' POT BRACKET}

No. 1. Holds 5inch pot. Each, $55 \mathrm{c}$; $\$ 6.00$ per doz. Parcel Post Weight, each, 1 $1 \mathrm{~b}$.

No. 2. Holds 6inch pot. Each, $60 \mathrm{c}$; $\$ 6.50$ per doz. Parcel Post Weight, each, 2 lbs.

No. 3. Holds 7 inch pot. Each, 60 70c.; $\$ 7.50$ per 85 doz. Parcel Post .70 Weight, each $21 / 2$ lbs.
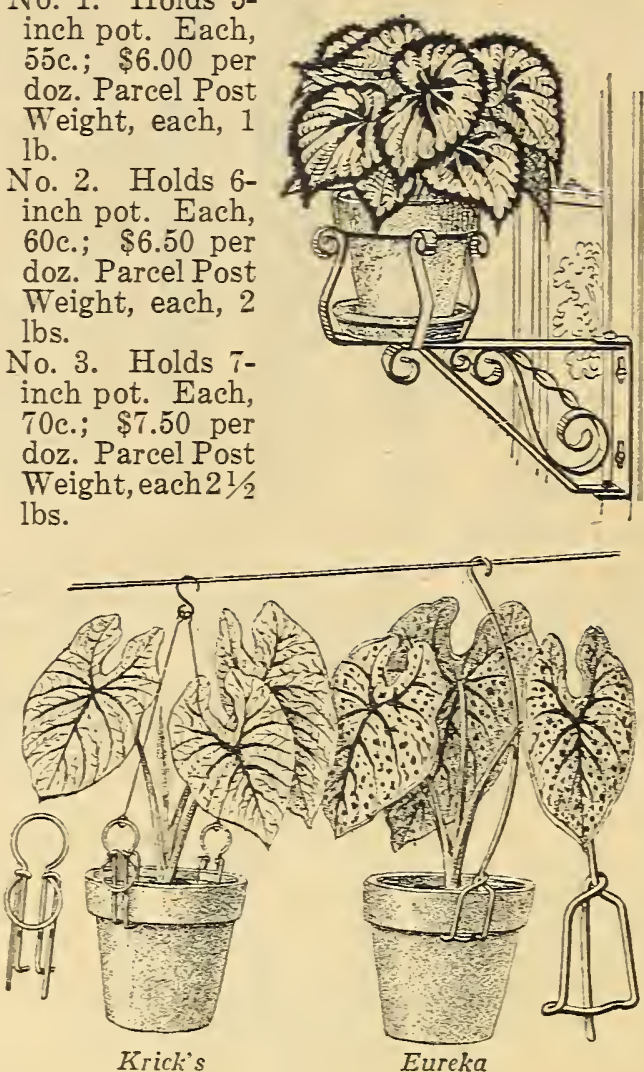

POT HANGERS

\section{Wt. per}

Doz. Each Doz.

Krick's No. 1. For 3 to 1 lb. $\$ 0.06 \$ 0.60$ Krick's No. 2. For 6 and

7 -in. pots.......... $1 \mathrm{lb}, \quad .07 \quad .70$

Krick's No. 3. For 8 to

10 -in. pots. $1 \mathrm{lb} ., 08$

Eureka. Suitable for any size pot up to 8 inches. Made of galvanized wire, 15 inches long. 15c. each; $\$ 1.50$ per doz. Parcel Post Weight, each, 8 ozs.

Our Garden Tool and Sundries Department we believe to be the most fully equipped of any seed store in the United States. Most every article of real merit for horticultural work will be found here, and of the best quality. For complete list see our General Catalog.

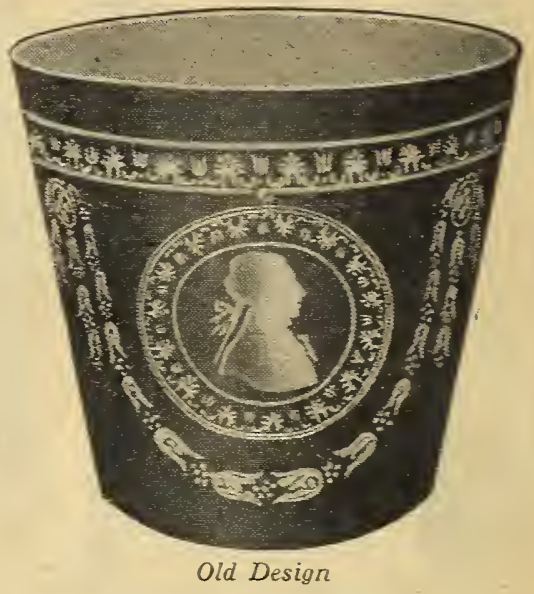

\section{WED GEWOOD}

JARDINIERES

Made of heavy cardboard, water-proofed, substantial and durable; decorated in many designs and printed in several wedgewood colors. Tery attractive for table, conservatory or window decoration effects.

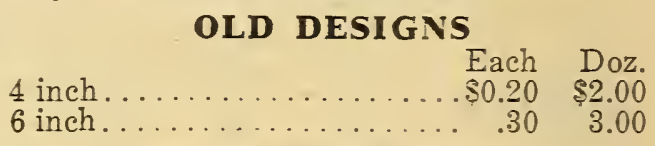

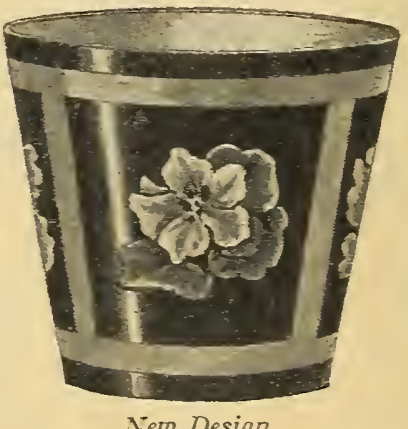

NEW DESIGNS OF ABOVE

An entirely new line which is unusually attractive.

4 inch. Each Doz.

5 inch $\$ 0.30 \$ 2.75$

6 inch

7 inch

$.40 \quad 3.75$

8 inch

$\begin{array}{ll}.00 & 5.25 \\ .60 & 6.25 \\ .75 & 8.00\end{array}$

See third cover page, for complete list of Flower Pots, Bulb Pans, Plant Tubs, etc. 


\section{MICHELL'S SPRAYING AND INSECTICIDE APPARATUS, ETC.}

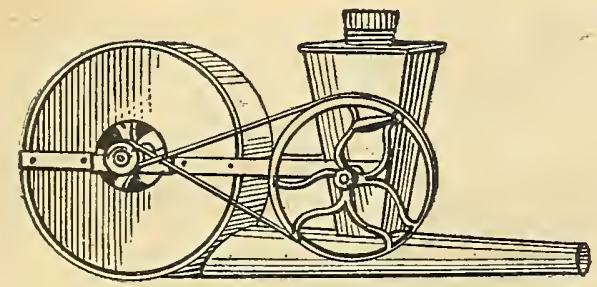

SULPHUR BLOWER

For distributing sulphur and insecticides of various kinds. Made of heavy metal with no wearout to them. A man can dust a very large house in a few minutes, using one of these blowers. Price, $\$ 8.00$.

\section{VAPORIZING LAMP}

Practical and indestructible; all metal; burns kerosene; used for dispensing fumes of Nikoteen and other preparations of this sort: 85c. each.

Parcel Post Weight, $3 / 4 \mathrm{lb}$.

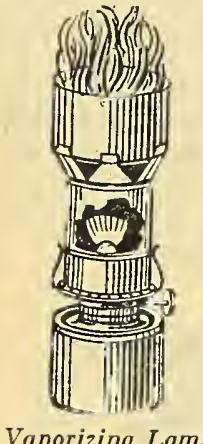

Vaporizing Lamp

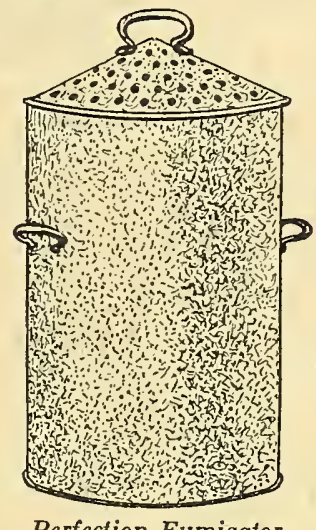

Perfection Fumigator

\section{FUMI GATORS Perfection Make}

Fitted with a water tank to prevent burning out.

No. 1 for house $12 \times 40 \mathrm{ft} . \ldots \ldots \ldots \$ 5.70$

No. 2 for house $14 \times 100 \mathrm{ft}$........... 7.00

No. 3 for house $20 \times 100 \mathrm{ft} \ldots \ldots \ldots . . . .60$

No. 5 for house $20 \times 150 \mathrm{ft} \ldots \ldots \ldots \ldots 10.75$

\section{Eureka Make}

No. 1 for house $10 \times 20 \mathrm{ft}$.

No. 2 for house $12 \times 40 \mathrm{ft}$.

$\$ 3.25$

No. 3 for house $15 \times 100 \mathrm{ft}$. .

No. 4 for house $20 \times 100 \mathrm{ft}$.

5.25

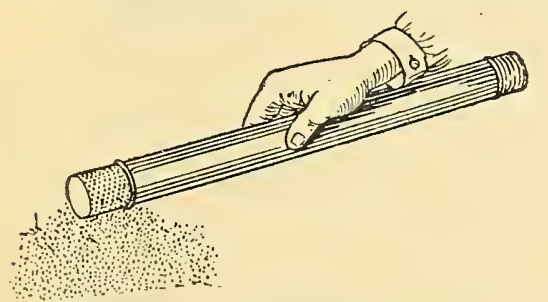

\section{DICKEY DUSTER}

Excellent for distributing Bug Death, Slug Shot, etc. Price, 50c. P. P. weight, $1 \mathrm{lb}$.

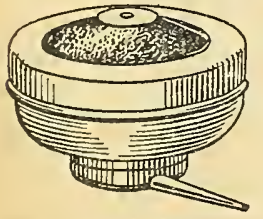

WHIRLWIND POWDER GUN

For distributing dry powder. Price, 35c.

P. P. Weight, 8 oz.

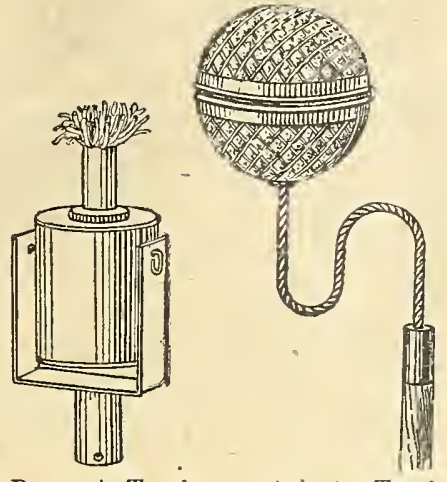

Reservoir Torch

\section{OIL TORCHES}

For burning out worms, caterpillars and other tree pests.

P. P. Wt. Each

Reservoir...1/2 lb. $\$ 0.60$

Asbestos.....1 lb.

.65

\section{POLES FOR}

TORCHES, Etc.

Hardwood, 12 feet, $\$ 2.00$; 14 feet, heavy, $\$ 2.25$. Poles are not mailale.

\section{WOODASON HAND} BELLOWS

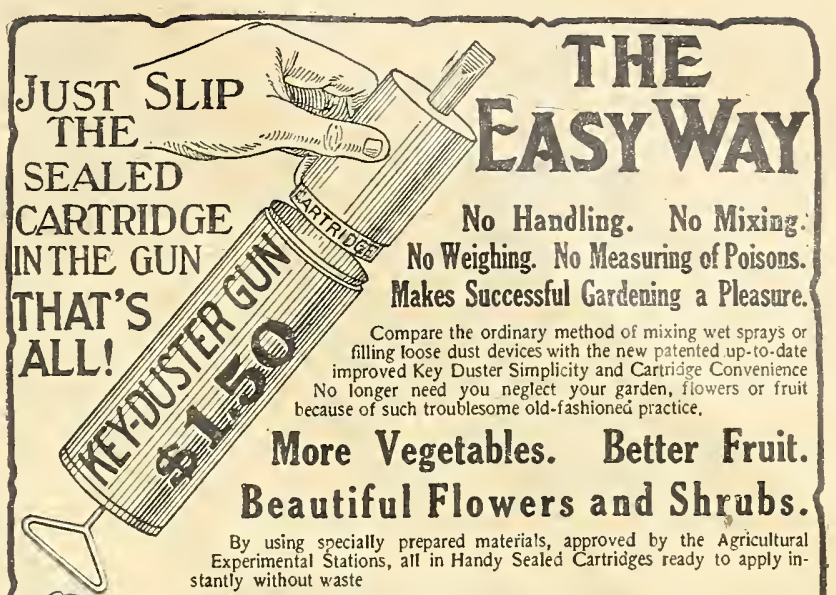

All Handy Sealed Cartridges, $15 \mathrm{c}$ each.

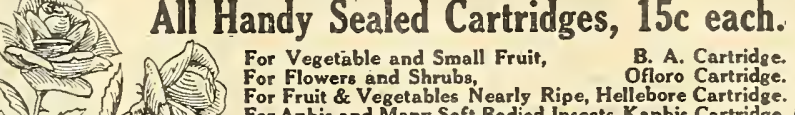

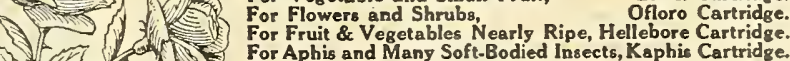
CARTRIDCD O Key Duster Gun $\$ 1.50$ EONTAINFA

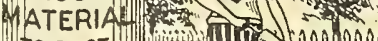
To oust 1 . ABOUT 109 $=(0,0$ (O)

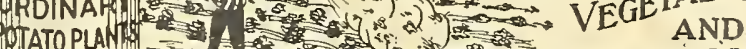
MTATOPLA 15 CENTE

No. 3. Large double cone...5 lbs. Large single cone. . . . . . . . 3 lbs.

No. 1. Small single cone...2 lbs.

No. 2. Sulphur bellows.... 3 lbs.

No. 1

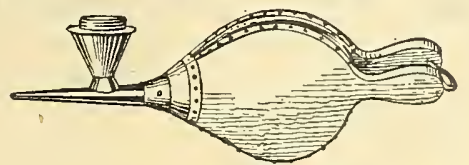

No. 2

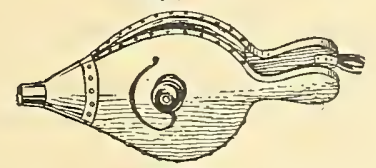

No. 3

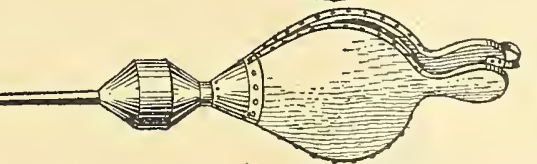

\section{PARIS GREEN} SHAKERS

Tin. For dusting vegetables, potatoes, small fruits and shrubbery, 65c. each. P. P. Weight, 2 lbs.

Farmers'

Favorite.

(See cut.)

Large dou-

ble action

affair, $\$ 3.50$

weight, 4

los.

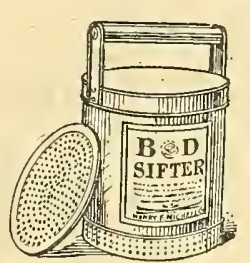
P. P. Wt.
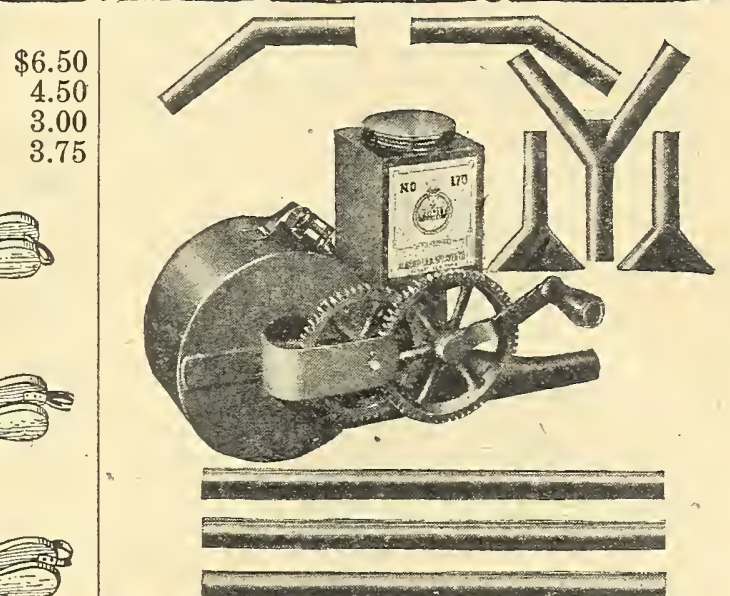

UTILITY DUSTER

Used for the application, in dry form, of Arsenate of Lead, Paris Green, etc. Made of heavy tin, enameled red; iron and brass machined cut gears. Provided with tubes, connections and nozzles as illustrated; also an adjustable carrying strap. Price, $\$ 12.50$.

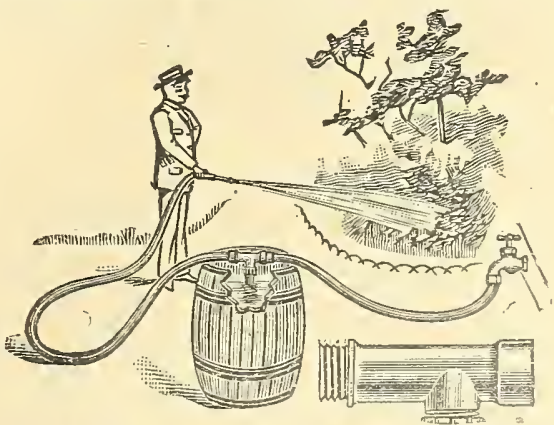

B. D. SHAKER

For applying dry insecticides, such as Bug Death, Slug Shot, Paris Green, etc.; made of tin; practical and durable, P. P. Weight, 3 lbs., $85 \mathrm{c}$.
LIOUID MANURE DISTRIBUTOR This can be attached to hose with which you are watering and, connected barrel of liquid manure, the suction will draw a quantity of manure with it. $\$ 2.50$ each 


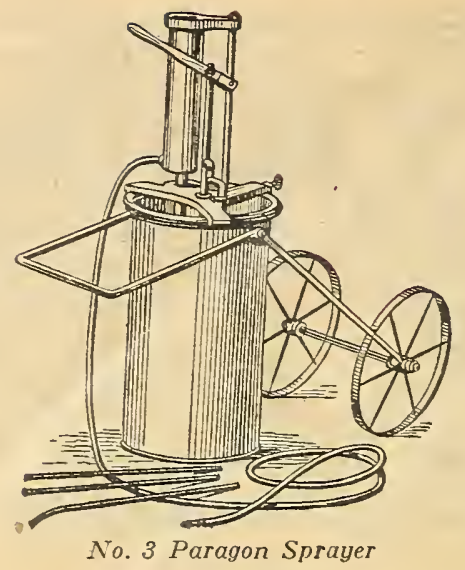

THE PARAGON SPRAYER

Especially desirable for the reason that it is not necessary to strain the material before pouring it into the reservoir, although we recommend that this be done; guaranteed to give absolute satisfaction. Excellent for applying whitewash or paint.

No. 0. Capacity, 3 gallons; equipped with $4 \mathrm{ft}$. of hose, one 3 -ft. extension pipe and 2 spray nozzles. Price, $\$ 12.50$.

No. 1. With a 5-gal. reservoir, $5 \mathrm{ft}$. of hose and 2 extension pipes, $\$ 17.50$.

No. 3. Equipped with a 12-gal. tank mounted on a truck, three $21 / 2 \mathrm{ft}$. extension pipes, 2 nozzles and $10 \mathrm{ft}$. of hose, $\$ 25.00$. Without truck, $\$ 21.50$. We can also supply this sprayer with single wheel at same price.

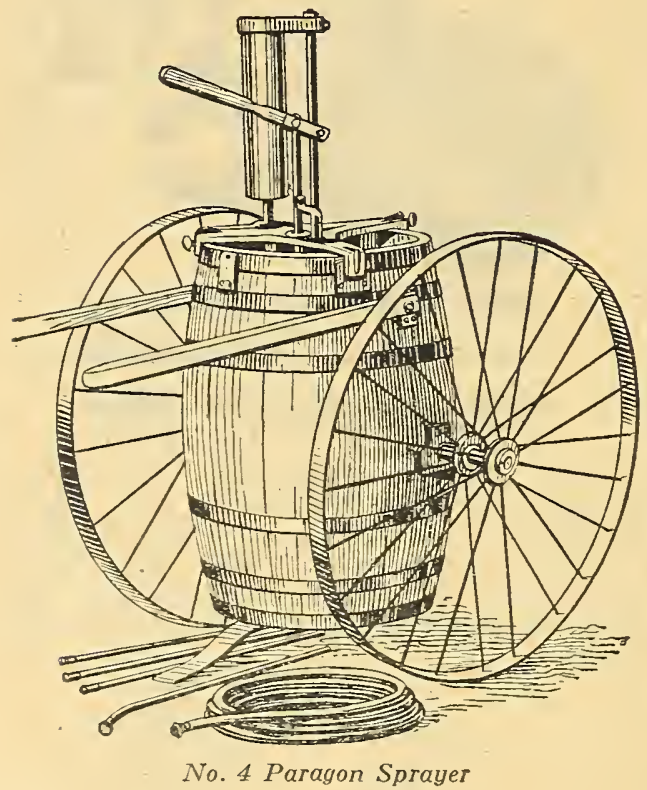

. 4. Mounted on a two-wheel truck; equipped with $10 \mathrm{ft}$. of extension pipe, $20 \mathrm{ft}$. of hose and 2 nozzles. 25-gal. barrel, complete, $\$ 39.50$. Without truck, $\$ 29.50$.

No. 5. Capacity of barrel 50 gallons, equipped with $25 \mathrm{ft}$. 6-ply hose, 110 -ft. iron extension pipe, 13 -way spray nozzle and 1 single spray nozzle, no truck, $\$ 45.00$.

Bucket Washers for Paragon Sprayers, 30c. each.

We can also supply parts for Paragon Sprayers; price list on application.

\section{GOULD'S FRUITALL BAR- \\ REL PUMP No. 1188}

A high-grade pump at an attractive price within the reach of every one who has need for such a pump. 2 in. diameter cylinder. Bronze wearing parts. Plain pump, no hose, nozzle or barrel, $\$ 12.00$.

Outfit C.-With agitator, one $15 \mathrm{ft}$. lead of $1 / 2$ in. spray hose and one Mistry Jr. nozzle (no barrel), $\$ 18.00$.

Outfit D.-With agitator, two $15 \mathrm{ft}$. leads of $1 / 2$ in. spray hose and two Mistry Jr. nozzles (no barrel), $\$ 24.50$.

Barrels for holding spray solution, 50 gal. capacity, $\$ 6.50$.

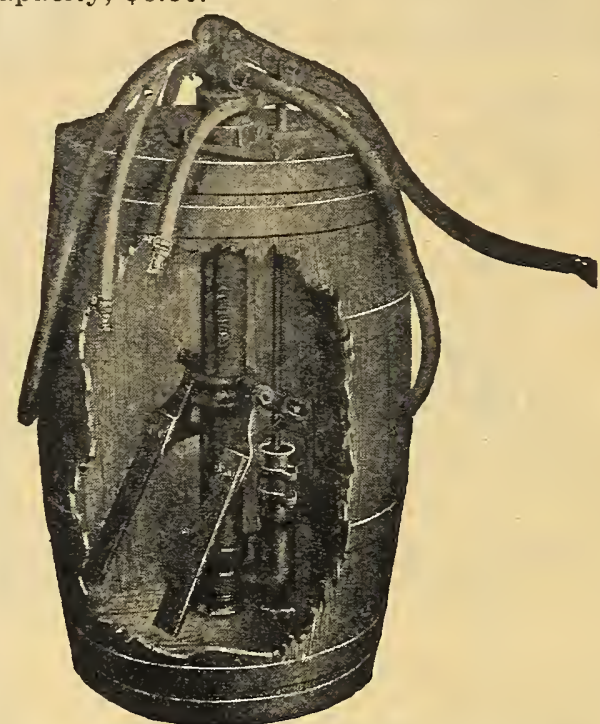

GOULD'S POMONA BARREL SPRAY PUMP, Fig. 1100

Can be used for feeding one or two leads of hose; all working parts are bronze, with lasting qualities. Plain pump, $21 / 2$ in. diam. cylinder only, $\$ 22.00$

Outfit C.-With one $15 \mathrm{ft}$. section $1 / 2 \mathrm{in}$. spray hose and one Mistry Jr. nozzle (no barrel), $\$ 27.50$.

Outfit D. - With two $15 \mathrm{ft}$. sections $1 / 2$ in. spray hose and two Mistry Jr. nozzles, $\$ 33.50$.

Barrels for holding spray solution, 50 gal. capacity, $\$ 6.50$ each.

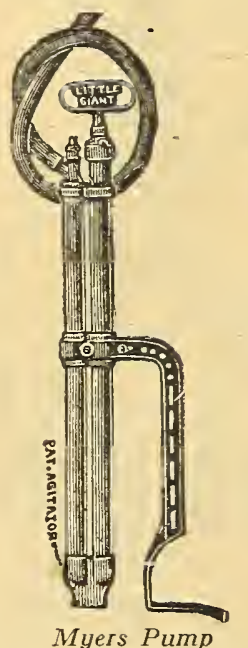

No.

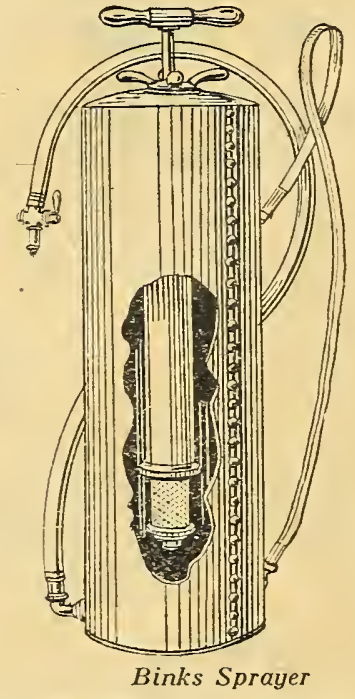

MYERS' BUCKET PUMP

This is a double brass chamber arrangement, and fills the want of those desiring a medium-priced sprayer. Price, $\$ 6.50$.

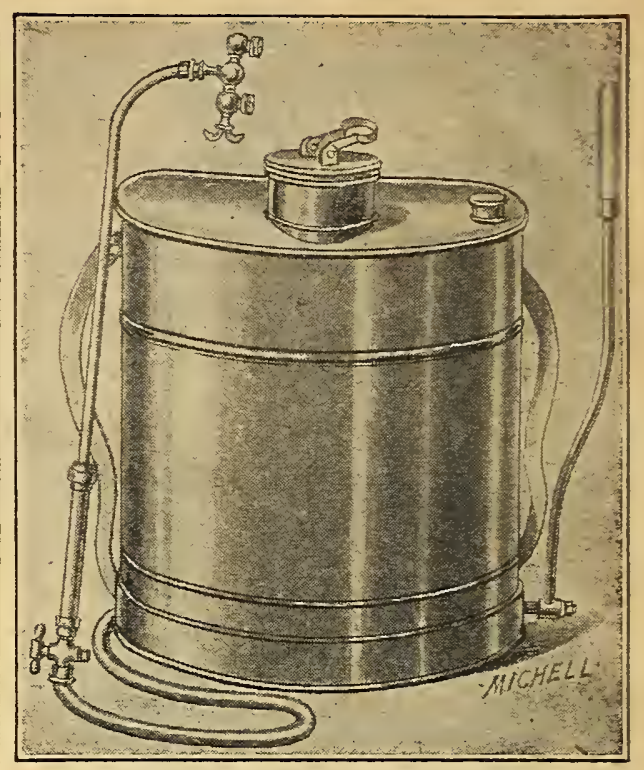

No. 1 MYSTO KNAPSACK SPRAYER

A new French knapsack sprayer which works on a compressed air principle. Compact in construction and light in weight, so that it can be easily carried around. We will sell this sprayer under the condition that if it is not the best purchase in this line you may return it at our expense and your account will be credited in full after you have given it a thorough trial. Price, $\$ 25.00$.

\section{AUTO SPRAY}

This operates by compressed air; safe and efficient; liquid capacity, four gallons; pressure capacity, 40 lbs. No sprayer is sold under broader guarantee for efficiency and durability. They will successfully spray bushes, shrubbery and trees, the latter with the use of extension pipes. The brass tank sprayer is the best as corrosive solutions can be used in it with-

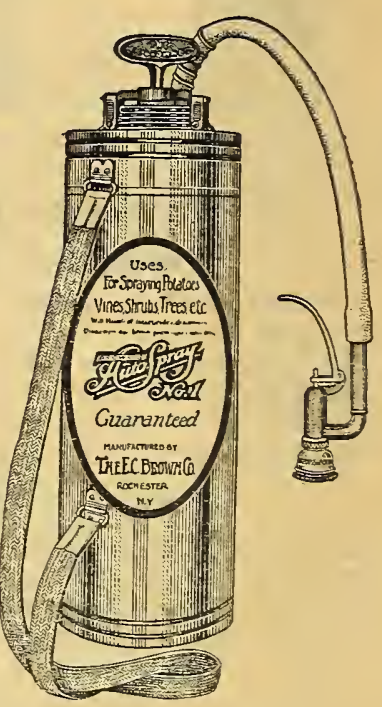
out injuring the same. Auto-Sprayers are not mailable.

No.1-B.-Brass; equipped with hose and Auto-Pop Attachment, $\$ 9.50$.

No. 1-D.-Galvanized Iron; equipped with hose and Auto-Pop, $\$ 6.50$.

Auto-Pop Nozzle Attachment; controls the flow instantly by a pressure of the hand. When Auto-Pop Attachment is purchased separately: Plain, $\$ 2.00$ each. $\$ 2.50$ complete with hose. P. P. Weight, $1 \mathrm{lb}$.

No. 22 BINKS COMPRESSED AIR SPRAYER

Galvanized steel tank, 5 gals. capacity. Brass pump with a patent clamping device, equipped with 3 feet of hose, spray nozzle shut-off cock and shoulder strap. See illustration opposite.

P. P. Wt., 15 lbs. Price, $\$ 8.50$. 


\section{BUCKET SPRAY PUMP}

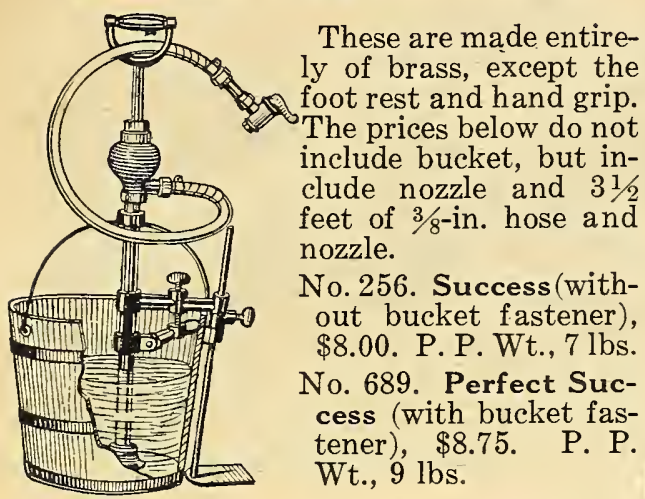

\section{DEMING KNAPSACK SPRAYERS}

These are elegant for carrying around the garden, among shrubbery and tree work, etc.

Fig. 675. Copper tank, holding about 5 gals., complete with pump, nozzle and hose

Fig. 654. Galvanized tank, holding about 5 gals., complete with pump, nozzle and hose. able.

Deming Knapsack Sprayers are not mail-

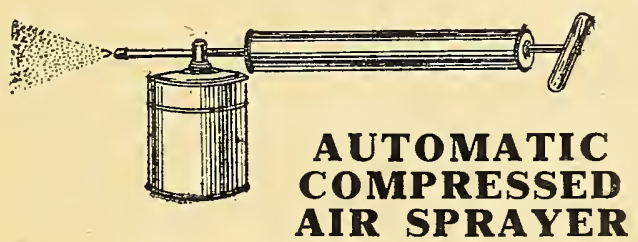

Parcel Post Weight, 2 lbs.

This is the grandest hand sprayer ever offered, very easily operated, especially desirable for ladies' use.

Tin. Each....\$1.00 | Brass. Each. .\$2.00

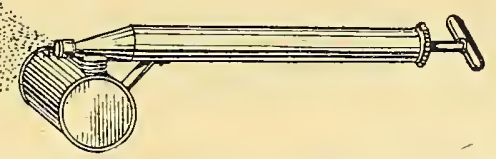

CYCLONE HAND SPRAYER

Similar to the above, except they do not have the automatic air reservoir attachment. P. P. Weight, $11 / 2$ lbs.

No. 112 , Tin, large, 50c. No. 114, Brass, $\$ 1.00$.

\section{JIM DANDY HAND SPRAYER}

Adapted for spraying vegetables and flowers, small fruits, etc.; also valuable for spraying disinfectants in buildings. Heavy seamless brass pump; brass nozzle, noncloggable; throws long distance fine mist or coarse spray. Price, $\$ 3.50$.

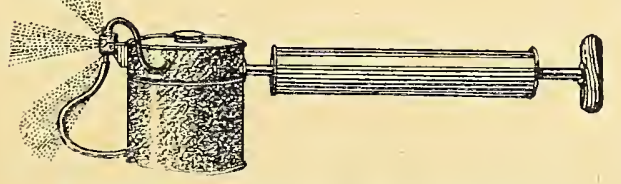

\section{ROBERTSON POTATO SPRAYER}

Distributes the spray solution on the top and underneath the foliage of potato vines and other plants. Made of galvanized iron, in a substantial manner. Price, $\$ 1.75$.

\section{THE KIRKE FEEDER}

Made to accommodate car$\approx \quad$ tridges of various kinds, containing fertilizer and insecticide ingredients, each separate as below. The illustration shows how the Kirke Fertilizer and Insecticide Cartridge Holder is attached to spigot.

Nickeled Cartridge

Holder...... \$3.25

Angle Worm Cartridges.

THE MISTO SPRAYER

The greatest invention ever offered for applying water to cut flowers, or any design work; makes a wonderfully fine mist, avoiding all drip; so simple in design it will last forever; nothing to get out of order; made of metal, nicely nickeled; can be used in connection with most any or dinary bottle. Guaranteed in every respect or money back. Price, without bottle, \$1.25.

\section{SUNDRIES}

Nicotine Cartridges $.80 \$ 9.00$ Salt Cartridges... $.20 \quad 1.50$ Arsenate of Lead Cartridges.

Fertilizer Cartridges.

Bordeaux Cartridges.

556.00

$\begin{array}{ll}.55 & 6.00\end{array}$

$.25 \quad 2.25$

.40

4.00

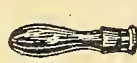

\section{HEAVY BRASS}

\section{SYRIN GES \\ Parcel Post}

No. Diam. Length

99. $11 / 2$ in. $18 \mathrm{in} .1$ spray .... $13 / 4$ lbs. $\$ 4.25$

101. $11 / 4$ in. 14 in. 2 sprays ...2 lbs. . 4.75

101A. $1 \frac{1}{2}$ in. 16 in. 2 sprays . . $21 / 4$ lbs. . 5.00

110. $13 / 4$ in. 20 in. 2 sprays . . $41 / 2$ lbs. .10 .75

120. $13 / 4$ in. 20 in. Adjustable 5 lbs. 12.50

\section{COPPER STRAINER}

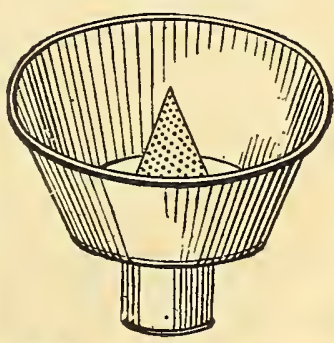

For straining whitewash, spraying material, etc. The neck is of the correct size to fit into the reservoir of an auto-spray, which allows both hands to be free when using it. $\$ 1.40$ each.

P. P. Weight, $3 / 4$ lb.

\section{EXTENSION PIPES, ETC.}

For reaching into trees; $3 / 8$ inch threads. Bamboo, with brass tube; 8 feet. . . . $\$ 4.00$ Bamboo, with brass tube; 10 feet. Bamboo, with brass tube; 12 feet. Galv. Iron, 2 ft., P. P. Weight, 6 ozs.

Brass, 2 ft., P. P. Weight, 8 ozs.. Pet Cock, for extension pipes.

Paragon Extensions, 21/3 ft. $55 \mathrm{c} 1.25$ Parcel Post Weight, 12 ozs.

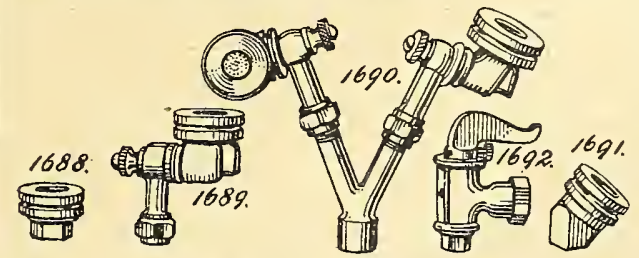

SPRAY NOZZLES ( $3 / 8$-in. Thread) Mistry, Jr., Fig. 1688, Straight style. $\$ 0.85$ Mistry, Jr., Fig. 1691, Elbow style.

Mistry, Fig. 1689, Single nozzle, adjustable angle $169 \ldots \ldots \ldots . . . \ldots . .$.

Mistry, Fig. 16

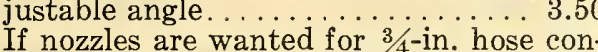
nections, add $65 \mathrm{c}$. to above prices for Fig. 966 combination

Bordeaux Nozzle, Fig. 1692, P. P. Weight, 8 oz., each, $\$ 1.35$.
Bulb Fibre. Qt., 20c.; 45c. per $1 / 2$ pk.; pk., 75 c.; $\$ 1.25$ per $1 / 2$ bu.; bu., $\$ 2.00$.

Bull Dog Clips. For fastening packages, etc., $\$ 1.00$ per box.

Carnation Bands (Rubber). For mending bursted calyx. 30c. per oz.; 1/4 lb., $\$ 1.00$.

Carnation Clips (Baurs). For mending carnations. $\$ 1.00$ per 1000 .

Carnation Staples (Wire). 50c. per 1000.

Celery Tape. Fast red, in 1000-yard spools, $\$ 4.25$.

Charcoal (Lump). For use in potting. Pk., 60 c.; $\$ 2.00$ per bu.; bbl. sack, $\$ 3.00$.

Charcoal (Ground). Coarse, fiñe and powdered. Per lb., 8c.; 35c. per 5 lbs.; 10 lbs., 60 c.; $\$ 1.25$ per 25 lbs.; 100 lbs., $\$ 4.00$.

Cork for Orchids. 50c. per lb.; 10 lbs., $\$ 4.00$.

Glass Cleaner. $\$ 2.50$ gal.; 5 gals., $\$ 10.00$.

Grafting Wax. 1/4 lb., 15c.; 25c. per $1 / 2 \mathrm{lb}$.; lb., $45 \mathrm{c}$.

Moss (Green Lump). Pk., 60c.; $\$ 1.50$ per bu.; bbl. bag, $\$ 3.00$.

Moss (Green Sheet). 1/2 pk., 40c.; 70c. per pk.; bu., $\$ 2.00$; $\$ 3.50$ per sack.

Moss (Sphagnum, dry). Bbl. bags, $\$ 1.50$; $\$ 3.00$ per large bale.

Moss (Sphagnum, live). Pk., 50c.; $\$ 1.50$ per bu.; bbl., \$3.25.

Peat or Leaf Mould. Pk., 50c.; $\$ 1.50$ per bu.; bbl., $\$ 3.25$.

Peat (Orchid.) Pk., 65c.; $\$ 1.60$ per bu.; bbl. bag, $\$ 3.00$.

Pebbles. Qt., 10c.; 75c. per pk.; bu., $\$ 2.00$; $\$ 4.00$ per bbl.

Pruning Compound. Per qt., $85 \mathrm{c} . ; \$ 2.50$ per gal.

Sand. For propagating. Per qt., 10c.; 40c. per pk.; bu., $\$ 1.40 ; \$ 3.00$ per bbl.

Shaderine. For shading greenhouse glass. 5 lbs., $\$ 1.50 ; \$ 3.00$ per $10 \mathrm{lb}$. can.

Soil. For potting. Qt., 10c.; 25c. per $1 / 2$ pk.; pk., 40c.; $\$ 1.40$ per bu.; bbl., $\$ 3.00$.

Tin Foil (Plain). In 5 and 6 -inch widths. 1-lb. pkgs., 20c.; 5 lbs. for 90c.; 5 -inch width in 5 -lb. rolls, $\$ 1.25$. Green or violet in 1-lb. pkgs., 60c. per lb.

Toothpicks. Plain, box, 12c.; 65c. for 6 .

Toothpicks. Wired. 45c. per 1000 $10,000, \$ 3.50$.

Toothpicks. 4-inch, wired, green; per $1000, \$ 1.00 ; \$ 3.75$ per 4500 .

Toothpicks. 6-inch, wired, green $1000, \$ 1.20 ; \$ 3.30$ per 3000 .

Tree Paint (Target Brand). $\$ 2.50$ per gal.

Weed Killer. Qt., 55c.; 90c. gal., $\$ 1.75 ; \$ 6.75$ per 5 gals. $\$ 33.00 ; \$ 50.00$ for 50 gals.

Zementine. For whitewashing ing. 2 lbs., $40 \mathrm{c}$. 


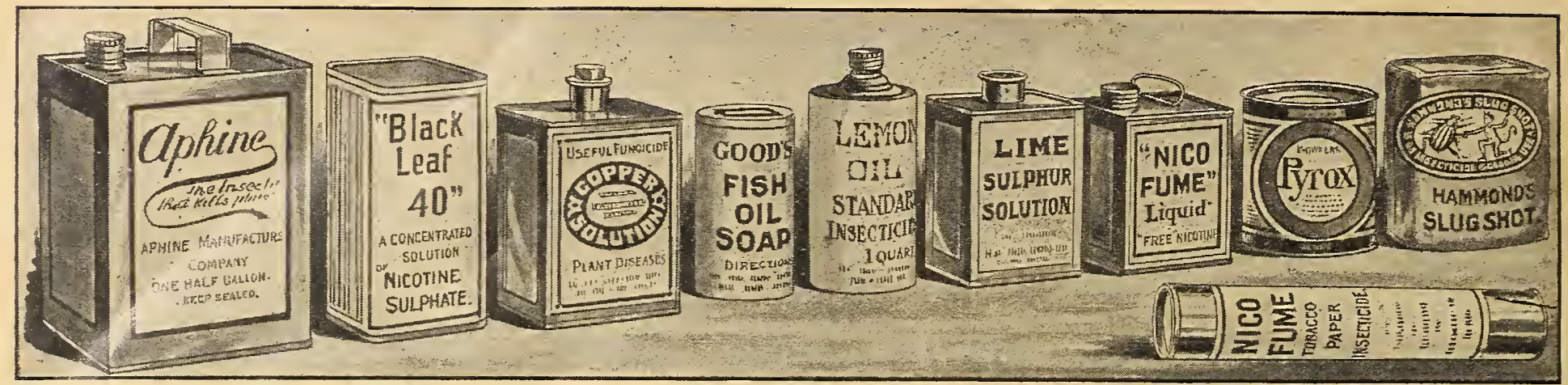

Ant Exterminator (Magic). A powder that is used for distributing around buildings, on greenhouse benches, on lawns, gardens, and any other places infested by ants. Per $1 / 4 \mathrm{lb}$., 30 c.; 50 c. per $1 / 2 \mathrm{lb}$; lb., $80 \mathrm{c}$.; $\$ 3.25$ per $5 \mathrm{lbs}$.

Aphine. For destroying aphis, green fly, thrip, red spider and other greenhouse and outdoor insects. It dilutes readily in water about 1 part to 40 of the latter. Per $1 / 4$ pt., $25 \mathrm{c}$.; $40 \mathrm{c}$. per $1 / 2$ pt.; pt., 65 c.; $\$ 1.15$ per qt.; per gal., $\$ 3.25$.

Aphis Punk. A paper that has been thoroughly saturated with nicotine. Used for fumigating, giving off dense fumes of nicotine. Excellent for aphis, thrip, white and green fly, also red spider. Contains $221 / 2 \%$ of nicotine. Guaranteed effective if used within 6 months of the date on the container; each package contains 12 sheets, $33 \times 6$ inches or $161 / 2 \mathrm{sq}$. ft.; this is in excess of competitive products, so the Aphis Punk is the most economical product of its kind to use. (For use in greenhouses only.) Per pkg. of 12 sheets, $\$ 1.00$; $\$ 10.00$ per case of 12 pkgs.

Arsenate of Lead (Paste). For spraying trees and shrubs against the attacks of leaf-biting insects of all kinds; especially valuable for spraying to prevent the codling moth; dilutes $1 \mathrm{lb}$. to 25 gals. water. Per lb., $40 \mathrm{c}$.; $\$ 1.65$ per 5 lbs.; 10 lbs., $\$ 3.00$; $\$ 5.25$ per 25 lbs.; 50 lbs., $\$ 8.50 ; \$ 15.00$ per 100 lbs.

Arsenate of Lead (Powdered). $1 \mathrm{lb}$. to $11 / 2 \mathrm{lbs}$. dilutes to 50 gals. of water, or may be used dry, like Paris Green. Per lb., 55 c.; $\$ 2.25$ per 5 lbs.; 10 lbs., $\$ 4.00$; $\$ 8.00$ per 25 lbs.; 50 lbs., $\$ 15.00 ; \$ 26.00$ per $100 \mathrm{lbs}$.

Black Leaf 40 . Per 1 oz. bottle, 35c.; $\$ 1.25$ per I/2 lb.; 2 lbs., $\$ 3.50 ; \$ 13.50$ per 10 lbs.

Bordeaux Arsenate. A combined fungicide and insecticide, for fruit trees, potatoes, melons, cucumbers, etc.; also for mildew, black spots, etc., on roses. Per lb., 40 c.; $\$ 1.50$ per 5 lbs.; 10 lbs., $\$ 2.40$; $\$ 5.50$ per 25 lbs.; 50 lbs., $\$ 9.75 ; \$ 17.50$ per 100 lbs.

Bordeaux Mixture (Paste). Used principally for mildew, blight and fungus diseases that affect potatoes and fruit trees; by adding water it is ready for use. In 5-gal. kegs only, price $\$ 8.00$.

Bordea ux Mixture (Dry Form). For dusting plants affected with mildew and all fungous diseases. Per lb., 30c.; $\$ 1.25$ per $5 \mathrm{lbs}$; 10 lbs., $\$ 2.00$; $\$ 4.25$ per 25 lbs.; 50 lbs., $\$ 7.50$; $\$ 14.00$ per 100 lbs.

Boro Wax. For painting trees to destroy and keep away borers. Per qt., 55c.; $\$ 1.85$ per gal.; 6 gals., $\$ 10.00$.

Bug Death. Largely used instead of Paris Green. It is claimed to have the same effect. The manufacturers say that it acts as a fertilizer as well as an insecticide. It comes in powder form, and is applied pure. Not poisonous to persons. Per lb., 18c.; $45 \mathrm{c}$. per 3 lbs.; 5 lbs., $75 \mathrm{c} . ;$

Carbolineum (Arvenarius). A germicide and disinfectant for purifying poultry houses, stables, etc.; also an excellent wood preserver when used as a paint. Per gal., $\$ 1.50$; $\$ 7.00$ per 5 gals. Copper Solution. Made of sulphate of copper and other materials. Excellent spray for carnation rust and diseases of the grape, pear, apple, and other fruits. A good thing to use for leaf blight and mildew. It is diluted in water. Per qt., $\$ 1.50 ; \$ 3.75$ per gal.

Cyanegg. For generating Hydrocyanic Acid Gas. Claimed to be the best remedy for killing white fly. Per lb., $\$ 1.00$. Cannot be mailed.

Dalmatian or Persian Powder. For ridding buildings of all kinds of insect pests, particularly roaches, ants, moths and fleas. Per $1 / 4$ lb., 35c.; 60c. per $1 / 2$ lb.; lb., $\$ 1.10 ; \$ 5.00$ per 5 lbs.

Fish Oil Soap (Good's Caustic). Used extensively as a tree spray and as a summer remedy for San Jose Scale; it comes in a soft soap form and is easily dissolved, $1 \mathrm{lb}$. to 10 gals. water. Per lb., 20 c.; 90c. per 5 lbs.; 10 lbs., \$1.40; $\$ 3.00$ per 25 lbs.; 50 lbs., $\$ 5.75 ; \$ 10.50$ per $100 \mathrm{lbs}$.
Fish Oil Soap. An excellent summer spray, when something stronger cannot be used, where San Jose Scale exists. It is nice for washing off lemon trees, oleanders, and almost anything that would be infested with soft-shelled or in fact most any kind of insect. Dissolved in water according to various purposes. Per 1/2 lb., 12c.; 20c. per lb.; 5 lbs., 70c.; $\$ 1.25$ per $10 \mathrm{lbs}$; 25 lbs., $\$ 2.50 ; \$ 4.50$ per 50 lbs.; $\$ 8.75$ per 100 lbs.

Fish Oil Soap (Rosin). Especially recommended for the destruction of boxwood maggot, bag worm and caterpillars. Per 5 lbs., $\$ 1.50$; $\$ 2.75$ per 10 lbs.; 25 lbs., $\$ 4.50$; $\$ 7.50$ per 50 lbs.; 100 lbs., $\$ 12.50$.

Flyosan. Quickly kills flies and other insect pests; applied with a sprayer. Per pt., 75 c.; $\$ 1.25$ per qt.; $1 / 2$ gal., $\$ 2.25 ; \$ 4.00$ per gal.

Getz There Soap. Ideal for washing palms and spraying in place of Whale Oil Soap. 2 lbs., $60 \mathrm{c}$; $\$ 1.75$ for 8 lbs.; 25 lbs., $\$ 3.75 ; 50$ lbs., $\$ 7.00$.

Grape Dust. A powder preparation used for mildew, aphis, black fly, and other insects and fungous diseases, principally in greenhouse. Per 5 lbs., $\$ 1.00 ; \$ 1.85$ per 10 lbs.

Hellebore. The ideal material for destroying rose bugs, currant worms, and other soft-shelled insects that infest the garden. It can be applied dry or in liquid form. 1/4 lb., 20c.; 35c. per $1 / 2 \mathrm{lb}$; lb., $60 \mathrm{c}$.; $\$ 2.75$ per 5 lbs.

Imp. Soap Spray. An all around outdoor and greenhouse insecticide. Per pt., $65 c$.; $\$ 1.00$ per qt.; gal., $\$ 3.00 ; \$ 12.00$ per 5 gals.; 10 gals., $\$ 22.50$.

Insecticide (Zenke's). A powerful liquid contact Insecticide, embodying the most effective elements which destroy most of the class of sucking insects lying on the leaf surface so as to be in reach of actual contact. Per 8 oz., 30c.; $\$ 2.50$ per gal.

I X L Compound. An English preparation for spraying; harmless to very delicate plants. Kills mealy bug, red spider and all insect pests. Per gal., $\$ 6.50$.

Kaylox. A powder that may be used as a wet or dry spray, for codling moth, potato bugs, . most caterpillars and many leaf eating insects; as a general spray dilute $1 \mathrm{lb}$. to 5 gals. water; for specific use, dilute $1 \mathrm{lb}$. to $71 / 2$ gals. water. Per $1 / 2 \mathrm{lb}$., $35 \mathrm{c}$.; 65 c. per lb.; 5 lbs., $\$ 2.75 ; \$ 5.00$ per 10 lbs.; 25 lbs., $\$ 11.00$; $\$ 21.00$ per 50 lbs.; 100 lbs. $\$ 40.00$.

Kerosene Emulsion (Liquid) (Miscible Oil). Diluted in water this makes an excellent spray for all mild forms of scale, and soft lice of any kind such as infest rose and fruit bushes, vegetables and trees. Dilutes 1 part to 20 parts of water. Per pt., $50 \mathrm{c}$.; 85c. per qt.; gal., $\$ 2.50$.

Lemon OiI Insecticide. The best and cheapest insecticide in the market. Used by nearly all the leading growers. It effectually destroys mealy bug, scale, thrip and red spider. Per $1 / 2$ pt., 35c.; 60c. per pt.; qt., $\$ 1.00 ; \$ 1.75$ per 1/2 gal.; gal., $\$ 3.00$; $\$ 12.00$ per 5-gal. keg.

Lime Sulphur. For scale insects on trees and shrubs, and such fungous diseases as can be treated in winter or early spring; also for leaf curl of peaches. Per qt., 50c.; 75c. per $1 / 2$ gal.; gal., $\$ 1.15 ; \$ 4.00$ per 5 gals.; $1 / 2$ bbl. (30 gals.), $\$ 12.00 ; \$ 15.00$ per bbl. (50 gals.).

Lime Sulphur (Dry Powder Form). Dilute 1 lb. to 6 gals. of hot or cold water. Per lb., 35c.; $\$ 1.40$ per 5 lbs.; 10 lbs., $\$ 2.25$; $\$ 4.50$ per 25 lbs.; 50 lbs., $\$ 7.75 ; \$ 15.00$ per 100 lbs.

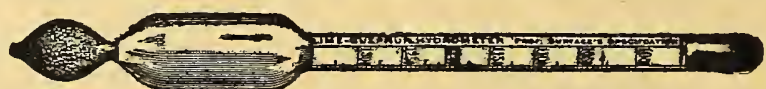

\section{CARBONDALE HYDROMETERS}

For testing the gravity of Lime-Sulphur solution; one should be in the hands of every man who uses this material. Price, $\$ 1.25$. (Postpaid, \$1.35.) 


\section{DIRECTIONS FOR USING ANY OF THE FOLLOWING WILL BE FOUND ON EACH PACKAGE}

Mag-O-Tite. Protects crops against the ravages of the root maggot and other garden pests; also eradicates earth worms from lawns and putting greens. Not injurious in any way to plant life, but is a valuable stimulant and fertilizer. In powder form, ready for use. Per 2 lbs., 40c.; 65c. per 4 lbs.; 8 lbs.; $\$ 1.10 ; \$ 2.75$ per 25 lbs.; 100 lbs., $\$ 9.00$.

Melrosine. An efficient Rose Bug remedy. A powerful and highly concentrated insecticide, used as a spray when diluted with from 20 to 25 times its bulk of water. Per $1 / 2$ pt., $50 \mathrm{c}$. $\$ 1.00$ per pt.; qt., $\$ 1.75 ; \$ 3.25$ per $1 / 2$ gal.; per gal., $\$ 6.00$; $\$ 25.00$ for 5 gals.

Mo-Lo. A preparation for destroying and driving away moles. Per pkg., 25c.

Nico Fume (Liquid): Per 1/4 lb., 75̃c.; $\$ 2.25$ per lb.; 4 lbs., $\$ 8.00$; $\$ 15.00$ per 8 lbs.

Nico Fume Paper. Per box of 24 sheets, $\$ 1.35$; $\$ 5.50$ for 144 sheets; 288 sheets, $\$ 10.00$.

Nicotine (Hall's) (40\%). An efficient preparation of purified free nicotine for the control of plant lice and similar soft bodied insects, in greenhouse and garden, per $8 \mathrm{lb}$. can, $\$ 15.00$.

Nicotine Fumigator (Hall's) $121 / 2 \%$ ). For fumigating greenhouses; takes the place of fumigating paper and tobacco dust; complete with directions. $1 \mathrm{lb}$. size, $\$ 1.25 ; \$ 2.50$ per $21 / 2 \mathrm{lb}$. size; $10 \mathrm{lb}$. size, $\$ 8.50$.

Nicotine Sulphate $(40 \%)$. For outdoor spraying only; excellent for melon lice and aphis that infest garden plants. $\$ 1.25$ per $1 / 2 \mathrm{lb}, ; 2 \mathrm{lbs}$., $\$ 3.50 ; \$ 13.50$ per $10 \mathrm{lb}$. can.

Nikoteen $(30 \%)$. One of the very best forms of tobacco or nicotine preparations; usually diluted in water; makes a most satisfactory spray as well as vapor. Per $1 \mathrm{oz}$. bottle, 25c.; 40c per $13 / 4$ oz. bottle; $1 / 2$ lb. bottle, $\$ 1.25 ; \$ 2.00$ per lb.; 4 lbs., $\$ 7.50 ; \$ 13.50$ per 8 lbs.

Paris Green. A poisonous powder for potato bugs, worms, caterpillars, slugs, etc. It may be used in liquid form 1 pound in 50 gallons of water, or with Land Plaster at the rate of 1 pound Paris Green to 100 pounds Land Plaster. Per 1/4 lb., 18c.; 30c. per $1 / 2 \mathrm{lb}$; 1b., 50c.; $\$ 2.25$ per $5 \mathrm{lbs}$; $\$ 5.50$ per $14 \mathrm{lbs}$

P. T. B. (Para-Dichlorobenzine). For peach tree borers; full directions on each package. Can be used successfully only during August and September, the makers claim it is not effective if used at other seasons. Do not use on very young trees. Ask for descriptive circular. Per $1 \mathrm{lb}$. can, 60c.; $\$ 2.50$ per $5 \mathrm{lb}$. can; $10 \mathrm{lb}$ can, $\$ 4.00$; $\$ 8.00$ per $25 \mathrm{lb}$. keg; $50 \mathrm{lb}$. keg, $\$ 15.50$; $\$ 29.00$ per $100 \mathrm{lb}$. keg.

Pyrox (Bowker's). A combined insecticide and fungicide for all leaf eating insects, blights and fungus troubles; it is a pasty substance, and needs only to be mixed with cold water. Per lb., 40c.; $\$ 1.50$ per 5 lbs.; 10 lbs., $\$ 2.50$; $\$ 5.75$ per 25 lbs.; 50 lbs., $\$ 10.00$; $\$ 18.00$ per 100 lbs.; 300 lbs., $\$ 51.00$.

Rat Corn. For destroying rats and mice in greenhouses, hotbeds, etc.; not poisonous to other animals, $25 \mathrm{c} ., 50 \mathrm{c}$. and $\$ 1.00$ per box.

Readeana Rose Bug Exterminator. Used for destroying rose bugs, green fly, mealy bug, blight, mildew, etc. Harmless to the most delicate plant. Per trial can, 25c.; 50c. per 8 oz.; 24 oz., $\$ 1.00$; $\$ 4.00$ per gal.

Scalecide. Used for the destruction of the San Jose Scale. Dilute at the rate of one gallon Scalecide to 20 gallons water. Scalecide does not clog nozzles, hose or pump, and is pleasant to use. Spray during the winter or early spring when the trees are dormant. Per qt., 60c.; $\$ 1.45$ per gal.; 5 gals., $\$ 6.45 ; \$ 11.00$ per 10 gals.; 30 gals., $\$ 27.00$; $\$ 39.50$ per 50 gals.

Scale Destroyer (Soluble Oil). For San Jose Scale; 1 gal. dilutes to 20 gals. water. Per qt., 65 c.; $\$ 1.60$ per gal.; 5 gals., $\$ 7.00$.

Shoo Fly. For keeping flies off cattle and horses; used with a spray or a sponge; the cattle and horses are either sprayed or rubbed with the preparation in the morning before being put in the field or out to their day's work. Per qt., 50c.; $\$ 1.35$ per gal.

Slug Shot. The standard remedy for currant worms, rose slugs, cabbage worms, and almost any soft-shelled insects that infest the vegetable or flower garden. Per $1-\mathrm{lb}$. canister, $18 \mathrm{c}$.; $60 \mathrm{c}$. per 5 lbs.; 10 lbs., $\$ 1.15$; $\$ 2.75$ per 25 lbs.; 100 lbs., $\$ 10.50$; full barrel lots (about $250 \mathrm{lbs}$.), $91 / 2 \mathrm{c}$. per lb.
Sodium Cyanide. (See Cyanegg.)

Sulco V. B. Will control San Jose and other scale insects, and many species of plant lice and fungus diseases. Pt., 35c.; 60c. per qt.; 1/2 gal., $\$ 1.10 ; \$ 2.00$ per gal.; 5 gal., $\$ 7.00$.

Sulphate of Copper. For destroying fungus diseases of all kinds; also used in making Bordeaux mixture, and for spraying potato vines in connection with Paris Green. Where used as a Bordeaux mixture it requires four pounds sulphate of copper to 6 pounds lime, which is diluted in 50 gallons of water. Per lb., 15c.; 65c. per 5 lbs.; 10 lbs., $\$ 1.20$; $\$ 2.50$ per 25 lbs.; 100 lbs., $\$ 9.00$.

Sulphur. Used principally in greenhouses for checking mildew. It is also used as a preventive and cure for San Jose Scale, when it is used in connection with lime and salt. Per lb., 10c.; 45c. per 5 lbs.; 10 lbs., 85c.; $\$ 2.00$ per 25 lbs.; 100 lbs., $\$ 7.50$.

Sulphur Candles. For fumigating in sick-rooms, also in conservatories and greenhouses. Large, 30c. each; per doz., \$3.00; small, 20c. each; per doz., $\$ 2.00$.

Thrip Juice (Hammond's No. 2). This preparation is very effective against aphis, red spider, mealy bugs and sucking insects generally. Per pt., 85c.; $\$ 1.40$ per qt.; gal., $\$ 4.25$.

Tobacco Dust (for dusting only). Excellent for lettuce and other plants to destroy soft, creeping insects. Per lb., 10c.; 40c. per 5 lbs.; 10 lbs., 60c.; $\$ 1.35$ per 25 lbs.; 50 lbs., $\$ 2.50 ; \$ 4.75$ per $100 \mathrm{lbs}$.

Tobacco Dust (special dusting or fumigating). A specially prepared article. Per lb., 10c.; $45 \mathrm{c}$. per 5 lbs.; 10 lbs., 85c.; $\$ 1.70$ per 25 lbs.; 50 lbs., \$3.25; $\$ 6.00$ per 100 lbs. :

Tobacco Soap (Sulpho). A combination of tobacco extract and sulphur; fine for washing and spraying plants; dissolve in warm water. Per 3 oz., $15 \mathrm{c}$.; $25 \mathrm{c}$. per 6 oz.; 10 lbs., \$3.50.

Tobacco Stems (Fresh). Used principally for fumigating and under benches in greenhouse. They may also be steeped in hot water and used as a spray. Per lb., 10c.; 40c. per 5 lbs.; bushel, $\$ 1.00 ; \$ 1.75$ per bbl. sack; large bales at $21 / 2 \mathrm{c}$. per lb.; $1 / 2$ ton, $\$ 17.00 ; \$ 32.00$ per ton.

Tobacco Stems (Shredded). For mulching flower beds, top dressing lawns, etc.; acts as a fertilizer as well as an insecticide. Per 5 lbs., 25c.; 45c. per 10 lbs.; 25 lbs., $\$ 1.00$; $\$ 1.75$ per 50 lbs.; 100 lbs., $\$ 3.00$; $\$ 13.00$ per 500 lbs.; 1000 lbs., $\$ 25.50$; $\$ 50.00$ per ton.

Tree Bands (Standard). Made of heavy waterproof paper, with a sticky, repellant material under the canopy. Protects trees and large shrubbery against worms, caterpillars, etc.; easily applied. Per 25 foot roll, $\$ 1.75 ; \$ 6.75$ per 100 foot roll.

Tree Tanglefoot. A paste preparation for painting around the trunks of trees, in the form of a band. Caterpillars and other crawling pests cannot get over it. Per lb., 50c.; $\$ 2.40$ per 5 lbs.; 10 lbs., $\$ 4.50$; $\$ 8.75$ per 20 lbs.; 25 lbs., $\$ 10.50$.

Wilson's O. K. Plant Spray. A powerful yet harmless and efficient insecticide for aphis, red spider, mildew, scale, etc., for inside and outside spraying. Per gal., $\$ 3.25$.

Worm Killer (Michell's) (for earth uorms). This is a powder and is distributed over a given surface and soaked with water, which causes the worms to come to the surface, where they may be scooped up readily and further destroyed. It acts as a fertilizer as well as worm destroyer. Per $112 \mathrm{lb}$. bag, $\$ 8.50 ; \$ 39.00$ per 560 lbs.; 1120 lbs., $\$ 72.00$; $\$ 135.00$ per 2240 lbs.

Worm Eradictor (Reade's Electric). This has been found to effectually destroy worms in greenhouse benches and in potted plants, or for outdoor use in the flower and vegetable garden, or among trees. $\$ 1.00$ per 24 oz.; gal., $\$ 4.00$.

Worm Killer (Reade's). For earth worms, to use on lawns, and putting greens. In 100 -lb. bags only. Price upon application

Zenke's Insecticide. (See insecticide.)

Zenoleum. A germicide and disinfectant. Endorsed by forty four State Experiment Stations and Agricultural Colleges, and the leading live stock men of America. Zenoleum is trated solution of coal tar. It mixes with hot or cold wates will penetrate deeper and more rapidly- than any other infectant. Per $1 / 2$ pt., 35c.; 75 c. per qt.; $1 / 2$ gal., $\$ 1.25$; per gal.; 5 gal. can, $\$ 9.50$. 
PLEASE NOTE.-No smaller quantity of Fertilizer than here offered can be supplied.

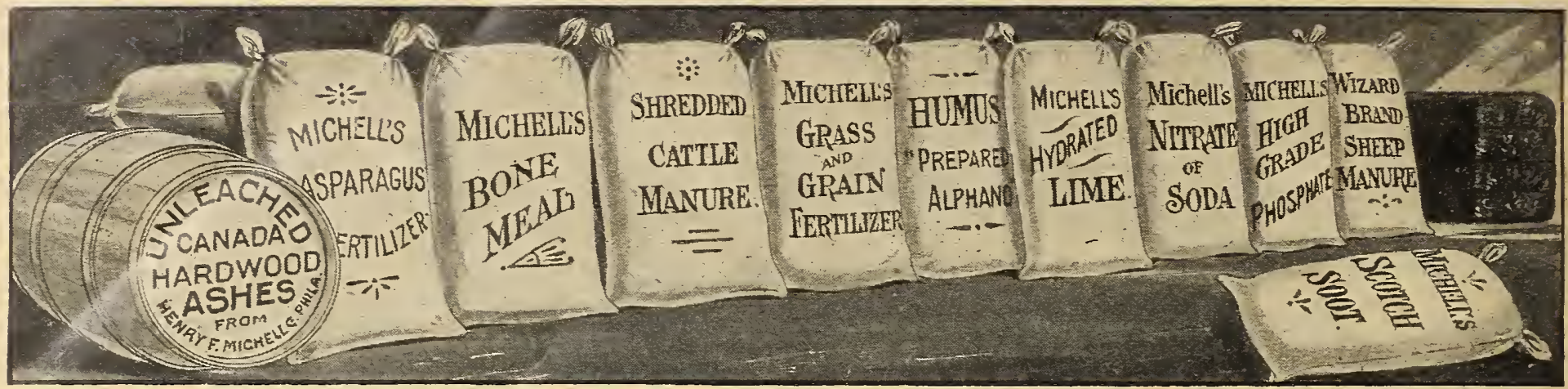

All prices on Fertilizers subject to market changes.

Acid or Rock Phosphate (14\%). Apply 1000 lbs. per acre. Used for mixing with other fertilizers to increase the phosphoric acid analysis. In $200 \mathrm{lb}$. sacks only. $\$ 3.25$ per $200 \mathrm{lbs}$; $1 / 2$ ton, $\$ 12.50 ; \$ 22.50$ per ton.

Alphano Inoculant. A soil bacteria used in growing legumes, thereby increasing the crop and enriching the soil. It comes in a finely powdered form, making it easy to use. 1-acre size (2 lbs.), $\$ 1.00$; per 10 -acre size (20 lbs.), $\$ 8.00$.

Anti-Clover Fertilizer (Michell's). The use of this on golf courses and putting greens is highly recommended as it prevents the growth of white clover which is very unessential on golf courses. Analysis: Ammonia, 8\%; phosphoric acid, 2\%; potash, $1 \%$. $200 \mathrm{lb}$. bags only. $\$ 7.50$ per $200 \mathrm{lbs}$; $1000 \mathrm{lbs}$., $\$ 37.00 ; \$ 72.00$ per ton.

Ashes, Hard Wood. Apply 1000 lbs. per acre. Indispensable for all crops requiring potash; excellent for mixing with potting soil. For top dressing lawns and grass fields it is applied to best advantage either in very early spring or late fall. Per 25 lbs., 85 c.; $\$ 1.50$ per 50 lbs.; 100 lbs., $\$ 2.50$; $\$ 4.25$ per $200-\mathrm{lb}$. bbl.; 1000 lbs., $\$ 18.00$; per ton, $\$ 35.00$.

Asparagus Fertilizer. A mixture that promotes the root and top growth. Apply 800 lbs. per acre. 25 lbs., $\$ 1.00$; $\$ 1.75$ per 50 lbs.; 100 lbs., $\$ 3.00$; $\$ 5.00$ per 200 lbs.; 1000 lbs., $\$ 24.00$; ton, $\$ 42.50$.

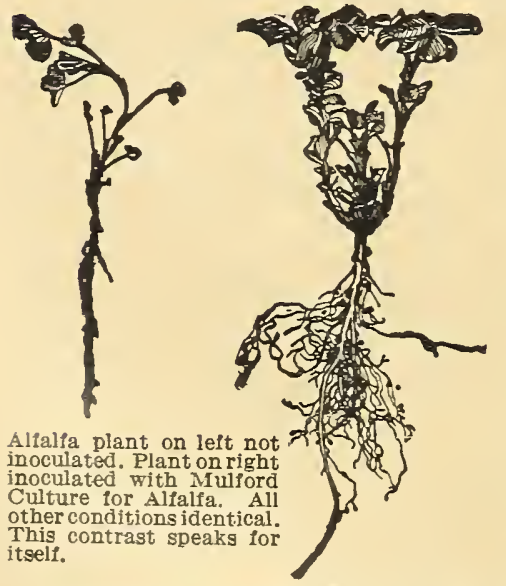

Bacteria, Farmogerm. An extensively advertised preparation for inoculating legumes prior to sowing or planting. Be sure and state crop the Farmogerm is desired for when ordering. Price, trial size (for Beans, Peas and Sweet Peas), 50c.; 1 -acre size, $\$ 1.00$; 3 -acre size, $\$ 2.50 ; 12$-acre size, $\$ 9.00$.

Bacteria, MuIford CuIture. For inoculating clovers and other legumes, such as beans, peas and such other plants that have blossoms similar in shape and form to the above named. When ordering, please state for what crop you desire to use it. 35c. per trial bottle; $1 / 4$ acre size, $75 \mathrm{c}$.; $\$ 1.50$ per acre size; 5 acre size, $\$ 5.00$.

Bacteria, Standard Inoculating. For all legumes; increases the yield; enriches the soil; hastens maturity; improves feeding value. Please specify on your order for what crop you desire to use it, as there is a different strain for each legume. Trial size (supplied only for Garden Beans, Garden Peas and Sweet Peas), 25c.; 50c. per garden size; one acre size, $75 \mathrm{c}$.

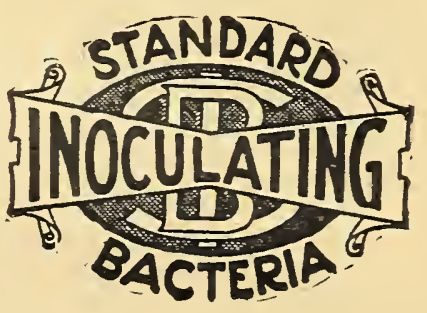

Blood (Dried). For indoor culture of flowering plants, like roses, carnations, etc., its chief element being nitrogen. One of the quickest acting fertilizers. 5 lbs., $60 \mathrm{c}$; $\$ 1.00$ per $10 \mathrm{lbs}$; 25 lbs., $\$ 2.00$; $\$ 3.50$ per 50 lbs.; 100 lbs., $\$ 6.75$; $\$ 13.00$ per $200 \mathrm{lbs}$.

Bon Arbor. A concentrated chemical fertilizer to be used in liquid or powder form, according to directions on package. Dilute $1 \mathrm{lb}$. to 30 gals. water. Per $8 \mathrm{oz}$., 30c.; 60c. per lb.; 5 lbs., $\$ 2.75$.

Bone (Coarse Ground). Apply 800 to 1000 lbs. per acre. Prepared from raw bone, exactly like bone meal, except that it is not so. fine or quick in action; it is used for the same purpose. $200 \mathrm{lb}$. bags only. $\$ 7.50$ per 200 lbs.; 1000 lbs., $\$ 35.00 ; \$ 65.00$ per ton.

Bone Flour. Finely pulverized and bolted. Effective immediately. For rose growing this cannot be excelled. Rich in phosphoric acid and ammonia. Apply $600 \mathrm{lbs}$. per acre. $5 \mathrm{lbs}$., 50c.; $85 \mathrm{c}$. per 10 lbs.; 25 lbs., $\$ 1.50$; $\$ 2.75$ per 50 lbs.; 100 lbs., $\$ 5.00$; $\$ 8.50$ per 200 lbs.; 1000 lbs., $\$ 37.50 ; \$ 70.00$ per ton.

Bone Meal (Michell's Special Grade). Unusually rich in nitrogen and phosphoric acid, the two principal plant foods. We recommend this especially for lawns, gardens and greenhouses, or any purpose where a high-class fertilizer counts. Apply 800 to 1000 lbs. per acre. 3 lbs., $25 \mathrm{c}$.; $35 \mathrm{c}$. for 5 lbs.; $10 \mathrm{lbs}$., $60 \mathrm{c}$.; $\$ 1.40$ for 25 lbs.; 50 lbs., $\$ 2.50 ; \$ 4.00$ per 100 lbs.; 200 lbs., $\$ 6.75 ; \$ 31.00$ per $1 / 2$ ton; ton, $\$ 60.00$.

Chrysanthemum Manure (Thomson's Special). Especially recommended and used by the leading private gardeners of England and America. Very highly concentrated. Per 28-Ib. sack, $\$ 4.00 ; \$ 7.00$ per 56 -lb. sack.

Clay's Fertilizer. An English chemical fertilizer, for forcing greenhouse plants and vegetables. It can be used in either dry or liquid form. $28 \mathrm{lbs}$., $\$ 3.75 ; \$ 6.25$ per $56 \mathrm{lbs}$.; $112 \mathrm{lbs}$., $\$ 11.00$.

Climax Lawn Sand. (See Lawn Sand, Page 79.)

Cotton Seed Meal. Apply 800 lbs. per acre. Exceedingly rich in potash and ammonia, making it excellent for use as a grass and grain fertilizer; for putting greens it is invaluable. 5 lbs., 35 c.; 60 c. for 10 lbs.; 25 lbs., $\$ 1.00$; $\$ 1.75$ for 50 lbs.; 100 lbs., $\$ 3.25 ; \$ 29.50$ per 1000 lbs.; ton, $\$ 57.50$.

Cow or Cattle Manure (Shredded). One sack of this is equal to one cartload of cow manure in regular form. Convenient to handle, making it possible for everyone to get this usually scarce article at all times. Especially suited for soil mixing, mulching and liquid manuring. Apply $1000 \mathrm{lbs}$. per acre. $\$ 3.50$ per 100 lbs.; 500 lbs., $\$ 16.25$; $\$ 30.00$ per 1000 lbs.; ton, $\$ 55.00$.

Cow or Cattle Manure (Pulverized). Thoroughly sterilized and weedless. Quick in action and especially desirable for pot plants, etc. $\$ 3.50$ per 100 lbs.; 500 lbs., $\$ 16.25 ; \$ 30.00$ per 1000 lbs.; ton, $\$ 55.00$.

Grass and Grain Fertilizer (Michell's). A splendid mixture for top dressing wheat, rye, timothy and grass fields. Apply 800 to 1000 lbs. per acre. 200 lbs. for $\$ 4.50$; $\$ 22.00$ per 1000 lbs.; per ton, $\$ 40.00$. 
PLEASE NOTE.-No smaller quantity of Fertilizer than here offered can be supplied.

\section{All prices on Fertilizers subject to market changes.}

Grass Grower (Michell's). This is a complete balanced fertilizer for fairways and putting greens and it is highly desirable, for it avoids putting on fertilizers some parts of which are only suitable for grass growing purposes. This fertilizer is complete in every way and will produce wonderful results. Analysis: Ammonia, $7 \%$; phosphoric acid, $8 \%$; potash, $1 \%$. $200 \mathrm{lb}$. bags only. $\$ 7.50$ per 200 lbs.; 1000 lbs., $\$ 37.00 ; \$ 72.00$ per ton.

Hog Manure (Puiverized). Put up and sold in 100-lb. bags only; splendid for forcing vegetables and flowering plants, increasing size and yield. Per $100 \mathrm{lbs} ., \$ 3.75 ; \$ 16.50$ for $500 \mathrm{lbs}$.

Horn Shavings. Used principally for mixing in potting soil; is rich in ammonia; especially valuable in chrysanthemum growing. 5 lbs., 60 c.; $\$ 1.00$ for 10 lbs.; 25 lbs., $\$ 2.00$; $\$ 3.50$ for 50 lbs.; 100 lbs., $\$ 6.75$.

Humus (Alphano Prepared). An excellent article to incorporate with poor soil in the garden, greenhouse or in potting plants. When used in garden work, the ground should be covered with $1 / 2$ to 2 inches of Humus and spaded in. Price, f. o. b. Philadelphia, 5 lbs., 35c.; 60c. for 10 lbs.; 25 lbs. for 90c.; $\$ 2.75$ per 100 lbs.; 500 lbs. $\$ 12.00 ; \$ 18.00$ per 1000 lbs.; 2000 lbs., $\$ 32.50$. F. o. b. Alphano, N. J., per ton in bags less carload lots, $\$ 20.00$ per ton; per ton in bags in carload lots (20 tons), $\$ 16.00$ per ton; per ton in bulk in carload lots about 30 tons, $\$ 10.00$ per ton.

Humus (Natural). Not a prepared or chemical fertilizer but pure vegetable Humus, that has been decayed. Excellent for top dressing lawns; especially adapted to golf course construction and compost for golf greens; also valuable for the garden and for pot plants. Price, in car lots only, $\$ 6.00$ per ton, f. o. b. Alphano, N. J.

Kainit (Potash Salts). Apply 800 to 1000 lbs. per acre. Excellent for potatoes, corn and other grains; also for top dressing asparagus beds, etc. 5 lbs., 30c.; 45c. per 10 lbs.; 25 lbs., $85 c$.; $\$ 1.50$ per 100 lbs.; 200 lbs., $\$ 2.75 ; \$ 12.00$ per 1000 lbs.; ton, $\$ 22.00$.

Land Plaster. Used for top dressing newly plowed land prior to harrowing and for sweetening the soil on lawns and fields; also used for mixing with Paris Green. Apply 1500 to $2000 \mathrm{lbs}$. per acre. 40c. for 10 lbs.; 25 lbs., $75 \mathrm{c}$.; $\$ 1.10$ for 50 lbs.; 100 lbs., $\$ 1.90$; $\$ 3.50$ for 200 lbs.; $1 / 2$ ton, $\$ 16.00$; $\$ 30.00$ per ton.

Lawn Sand (Climax). A weed destroyer as well as a fertilizer; contains a large percentage of nitrogen. Will be found very valuable for lawn use. For best results follow the directions on the package. $31 / 2 \mathrm{lb}$. tin, $75 \mathrm{c}$.; $\$ 1.35$ for $7 \mathrm{lbs}$; $14 \mathrm{lbs} ., \$ 2.50$; $\$ 4.00$ per 28 lbs.; 56 lbs., $\$ 6.50 ; \$ 12.50$ per $112 \mathrm{lbs}$.

Lime (Hydrated or Powdered). This is a very fine article for distributing on grass. Promotes growth, gives the grass a rich color and has a tendency to prevent the growth of weeds. Apply one ton per acre. Per $125 \mathrm{lb}$. sack, $\$ 2.15$; $\$ 7.50$ per 500 lbs.; 1000 lbs., $\$ 13.50 ; \$ 25.00$ per ton.

Limestone (Pulverized). For applying on sour or wornout soils at the rate of 1 ton per acre. Put up in 100-lb. bags. $\$ 1.50$ per bag; 500 lbs., $\$ 6.00 ; \$ 10.00$ per 1000 lbs.; ton, $\$ 17.50$.

Lime. (Powdered) Made from pure lump lime, thoroughly hydrated. 10-lb. pkg., 45c.

Manure (Fresh Horse, Stockyard and Cow). At short notice we can usually supply first-class horse, cow and stockyard manure in carload lots only. Prices on request.

Muriate of Potash. Apply 100 to $150 \mathrm{lbs}$. per acre, usually with other fertilizers. Excellent for potatoes, corn, grains, etc. Analysis, equal to 50 per cent. actual potash. 5 lbs., $40 \mathrm{c}$; $70 \mathrm{c}$. per 10 lbs.; 25 lbs., $\$ 1.35$; $\$ 2.25$ for 50 lbs.; 100 lbs., $\$ 4.25$; $\$ 8.00$ for $200 \mathrm{lbs}$

Nitrate of Soda. Apply 100 to 150 lbs. per acre, mixing with land plaster or other fertilizers to render application more easy. Use only after plants are above ground. If used in liquid form dilute 2 ozs. to 1 gal. of water and do not apply oftener than twice a week. 5 lbs., $45 \mathrm{c}$.; 85c. per $10 \mathrm{lbs}$.; 25 lbs., $\$ 1.50 ; \$ 2.75$ per 50 lbs.; 100 lbs., $\$ 4.75 ; \$ 9.00$ per 200 lbs.

Phosphate (Michell's High-Grade). For all vegetable crops, grains, grass, etc. Apply 800 to 1000 lbs. per acre broadcast. 5 lbs., 30c.; 50c. per 10 lbs.; 25 lbs., $\$ 1.25$; $\$ 1.75$ per 50 lbs.; 100 lbs., $\$ 3.00 ; \$ 5.50$ per 200 lbs.; $1 / 2$ ton, $\$ 25.00 ; \$ 42.50$ per ton.

Phosphate for Corn (Michell's). Apply $800 \mathrm{lbs}$. per acre. This contains the necessary ingredients to produce a bumper crop of either field or sugar corn. $\$ 5.00$ for $200 \mathrm{lbs}$; ; per $1 / 2$ ton, $\$ 21.00 ; \$ 38.00$ per ton.
Plant Food (Michell's). A highly concentrated chemical fertilizer for house, garden or conservatory. Clean, odorless and producing early and abundant blossoms of rich and brilliant color, and healthy, luxuriant plants. Analysis: Nitrogen, 21/2\%; available phosphoric acid, $7 \%$; potash, $2 \%$. Per 5 oz. pkg. 20c.; 30c. per $12 \mathrm{oz}$. pkg. Allow for postage if wanted by mail.

Plant Eife (Zenke's). A liquid plant food, tonic and fertilizer. It contains in concentrated form the elements of plant food in proper proportion for absorption by the plant. Per $8 \mathrm{oz} ., 25 \mathrm{c}$. $\$ 3.25$ per gal.

Potato Fertilizer (Michell's). Apply at the rate of from 800 to 1000 lbs. per acre. The principal fertilizer for potatoes in this section, being especially compounded for this purpose. $25 \mathrm{lbs}$., $\$ 1.25 ; \$ 2.00$ per 50 lbs.; per 100 lbs., $\$ 3.00$; $\$ 5.50$ per 200 lbs. per $1 / 2$ ton, $\$ 25.00 ; \$ 45.00$ per ton.

Poultry Manure (Pulverized). A splendid fertilizer rich in ammonia and nitrogen, very quick in action, but should be used cautiously; in 100-lb. bags only, $\$ 3.50$.

Salt. For asparagus beds and putting on walks and roads to kill weeds. Apply $800 \mathrm{lbs}$. per acre in early spring. $25 \mathrm{lbs}$. for 75c. $\$ 1.25$ for 50 lbs.; $\$ 1.75$ per 100 lbs.; 200 lbs., $\$ 2.75 ; \$ 12.00$ per 1000 lbs.; ton, $\$ 21.00$.

Sheep Manure (Wizard Brand). Apply 1000 lbs. per acre. One of the most extensively used of animal manures. The analysis shows it to be a perfectly balanced plant food. For garden, lawn or greenhouse use, nothing surpasses sheep manure; it is clean and easily handled, besides giving immediate results. 2 lbs., 25c.; 40c. per 5 lbs.; 10 lbs., $65 \mathrm{c}$; $\$ 1.10$ per 25 lbs.; 50 lbs., $\$ 2.00$; $\$ 3.50$ per 100 lbs.; 500 lbs., $\$ 16.25$; $\$ 30.00$ per 1000 lbs.; per ton, $\$ 55.00$.

Soot (Imported Scotch). This is used principally for bringing a good healthy color into the foliage of chrysanthemum and other greenhouse plants. Also destroys insects and grubs that work on top of and underneath the surface. 5 lbs., $75 \mathrm{c}$; $\$ 1.25$ per 10 lbs.; 25 lbs., $\$ 2.00 ; \$ 7.50$ per $112 \mathrm{lbs}$.

Stim-U-Plant. A plant food in tablet form; contains highly concentrated, immediately available forms of plant food for use in stimulating all fruit, flower, vegetable and ornamental plants, and may be used in tablet or in liquid form. Per pkg. of 30 tablets; $25 \mathrm{c}$.; $75 \mathrm{c}$. per pkg. of 100 tablets; 1000 tablets, $\$ 3.50$.

Sulphate of Ammonia. Apply 75 to $100 \mathrm{lbs}$. per acre only with other fertilizers deficient in nitrogen. A valuable fertilizer for all plants in which a large leaf development or rapid growth is desired; will stimulate growth almost immediately. Analysis equal to $25 \%$ of ammonia. 5 lbs., 40c.; 75 c. per $10 \mathrm{lbs}$; 25 lbs., $\$ 1.50 ; \$ 2.75$ per 50 lbs.; 100 lbs., $\$ 5.25 ; \$ 10.00$ per 200 lbs.

Sulphate of Ammonia (Arcadian). A concentrated nitrogenous top dressing fertilizer, entirely soluble and immediate in action. Analysis: $251 / 4 \%$ ammonia or $203 / 4 \%$ nitrogen. Price upon application.

Sulphate of Potash. Apply 100 to 125 lbs. per acre, usually with other fertilizers. On account of its great strength it must be used judiciously. Valuable for root and grain crops. Analysis equal to $50 \%$ of actual potash. 5 lbs., 40c.; 65c. per $10 \mathrm{lbs}$.; 25 lbs., $\$ 1.40 ; \$ 2.50$ per 50 lbs.; 100 lbs., $\$ 4.50 ; \$ 8.50$ per 200 lbs.

Tankage. This is usually applied to plants such as roses, etc. under glass. It is similar to dried blood. 5 lbs., $35 \mathrm{c}$; $60 \mathrm{c}$. per 10 lbs.; 25 lbs., $\$ 1.25 ; \$ 2.00$ per 50 lbs.; 100 lbs., $\$ 3.75 ; \$ 6.00$ per $200 \mathrm{lbs}$.

Thomson's Special Flower, Vegetable and Vine Manure Imported from England, this excellent chemical fertilizer is reliable food and stimulant for every fruit-bearing plant, also foliage and flowering plants and vegetables of all descriptions. So compounded as to combine stimulating with lasting effect 28 lbs. bag, $\$ 3.00$; $\$ 5.75$ per 56 lbs.; 112 lbs., $\$ 9.50$.

Tobacco Stems. For fumigating, mulching and fertilizing, the are invaluable. The chief fertilizing element in them potash. 40c. for 5 lbs.; per bu., $\$ 1.00 ; \$ 1.75$ per bbl. large bales at $21 / 2$ c. per lb.; per $1 / 2$ ton, $\$ 17.00 ; \$ 32.50$

Tobacco Stems (Shredded). For mulching flower bed benches, top dressing, lawns, etc.; acts as an insecticide as a fertilizer. 5 lbs., 25c.; 45c. per $10 \mathrm{lbs}$.; $25 \mathrm{lbs}$. $\$ 1.75$ per 50 lbs.; 100 lbs., $\$ 3.00 ; \$ 13.00$ per 500 lbs $\$ 25.50 ; \$ 50.00$ per ton.

Wheat Fertilizer. For grass and grain crops. Appl per acre. $\$ 5.00$ per 200 lbs.; $1 / 2$ ton, $\$ 22.50 ; \$ 42.50$

Wood Ashes. See ashes at top of opposite page. 


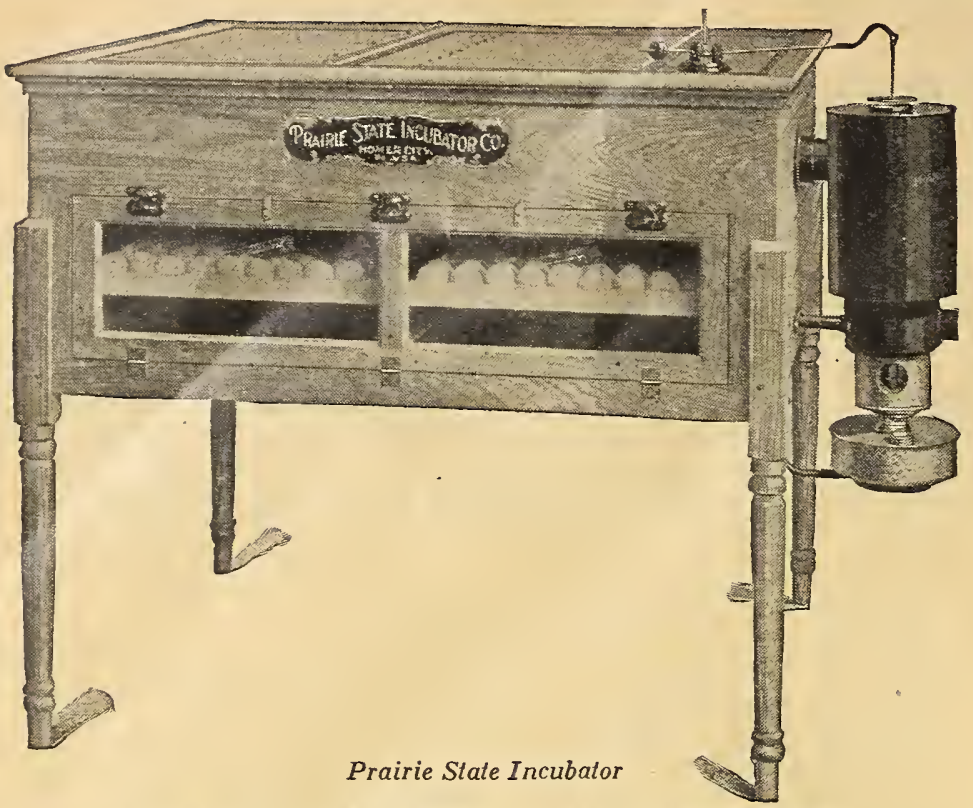

PRAIRIE STATE INCUBATORS

In the building, design and construction of the Prairie State Incubator every known factor to the present time has been taken into consideration. All Prairie State Incubators are equipped with nurseries.

There are many improvements in the Prairie State Incubator that a study of the Prairie State Catalog and a close inspection of the machine itself, if possible, will best reveal.

Every heater is made with extreme care to insure it being as near perfect and fireproof as it can possibly be, which fact, in combination with the construction of the incubator, makes the machine reasonably safe to operate in most any locality.

The Prairie State has the diffusive air circulation system and sand tray moisture feature, and is as faultless as it is possible to make incubators.

\section{Oil Consumption per $24 \mathrm{hrs}$.}

No. 0. Diffusive style. . $3 / 4 \mathrm{pt}$.

No.

No. 1.

No. 3 .

Complete Catalog of Prairie State Incubators and Brooders free on request.

\section{PRAIRIE STATE JR. COAL STOVE BROODER NO. 1}

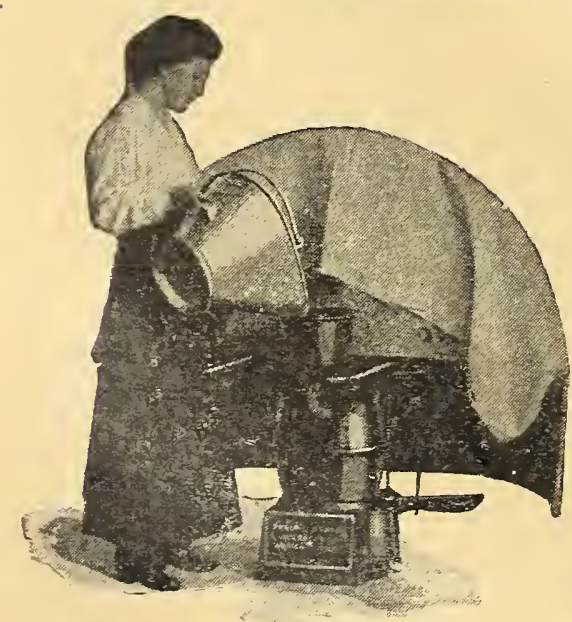

Prairie State Jr. Coal Stove Brooder

The stove is solid cast iron, resting directly on its base without legs, there being no hot place under the stove possible for the chicks to reach. Designed for hard coal, but will burn soft coal also. The canopy is flat, and fitted with an 18-inch hover curtain, wired fast at the edges. Is of galvanized sheet steel, hinged in center, giving ready access to stove when coaling. Regulator is powerful, sensitive, triple control, of wafer type, regulating temperature to a fraction of a degree, with all working parts under canopy and so protected. This size handles flocks of 250 to 1000 or more safely and is adaptable to permanent or portable brood houses. Price, complete with equipment, $\$ 25.00$.

\section{PRAIRIE STATE JR. NO. O COAL STOVE}

\section{BROODER}

The construction of this is similar to the Junior Coal Stove Brooder No. 1, excepting that it has a new design double control regulator instead of the triple control type. Capacity, 200 to 700 chicks. Price, $\$ 20.00$.

\section{PEEPY GEM HOT WATER INCUBATOR}

This is especially designed for the amateur or beginner. It is a wonderful value for the price charged. Very carefully made. Equipped with galvanized water heater and a sensitive thermostat. We can supply this in one size only, 50-Egg capacity, $\$ 10.00$.

\section{PRAIRIE STATE COLONY HOUSE}

The Colony Brooder, with its dry, roomy quarters, level floors, overhead heat, graduated temperature, thorough ventilation and sun parlor for exercise, offers a happy solution to chick raising.

When the soil becomes worn out or if the location has become infected with disease or vermin, the removal of a portable colony brooder is an easy matter, and the birds can be given new quarters on fresh soil and amid new surroundings.

To transform the Combination Brooder into a Colony House, slip out the middle partition, remove the hover and lamp, and you have one of the neatest colony houses that could be built.

3 feet wide, 6 feet long, 3 feet high in front, 2 feet high in back (without heat regulator) .................. $\$ 35.00$

Heat Regulator for the Above $\$ 2.00$, if Bought with Colony House

\section{PRAIRIE STATE JR. PORTABLE HOVER}

Combines all the essentials of the larger brooders in a style and size suited to the small producer or the fancier who wishes to raise small lots separately. While its size and capacity are equal to any other lamp brooder, yet it is light in weight and may be instantly moved from place to place. Heat is furnished by the Standard Prairie State Lamp set in the center of the hover, the warm, fresh air being diffused by the radiator under the galvanized steel hover top, down upon the chicks.

Heat is controlled by the

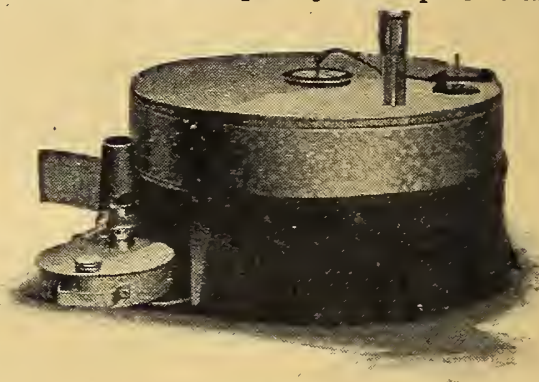
accurate regulator, and ventilation is assured by a perfect system of air flues. Curtain is of cotton duck; top of hover is insulated with mineral wool. Provides ample nursery space for 50 chicks. Price, $\$ 10.00$.

\section{PRAIRIE STATE UNIVERSAL HOVER}

As the name of this hover implies, it has a wide or universal sphere of usefulness. In fact, there is practically no limit to its adaptability. It may be used or attached to any form of outdoor brooder that is two feet or more in height; to any size or form of colony house, mushroom house, small portable building, drygoods box, shed, coop, organ or piano box.

Where regular colony houses are used the Universal Hover can be attached to it until the chicks have been given a good start, and then removed to another for a new brood. It has proven to be thoroughly practical in actual service, giving perfect satisfaction during the coldest winter weather, changeable conditions of spring and the heat of summer.

Complete for outdoor use, with Lamp Case . . . . . . . . . . . \$9.00 Complete for outdoor use, with Regulator. . . . . . . . . . . . . 10.50

Complete for indoor use, no Lamp Case . . . . . . . . . . . 8.00

Complete for indoor use, with Regulator ............. 9.50

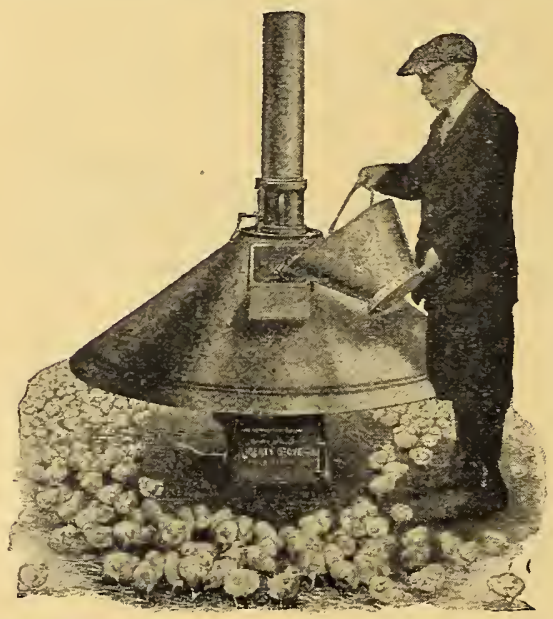

\section{MARVEL Coal Burning Colony Brooder}

Adapted for the expert or novice. The heater, is built of heavy iron castings and is $27 \mathrm{in}$. high, has super-automatic check control. Hover is made of heavy gauge

No. 10, with 41 in. Hover, $\$ 21.50$.

No. 20, with 52 in. Hover, $\$ 26.00$.

No. 30 , with 60 in. Hover, $\$ 32.00$. galvanized iron. 


\section{MICHELL'S POULTRY SUPPLIES, ETC. \\ NORWICH AUTOMATIC POULTRY}

FEEDER

In operating the Norwich Automatic Exerciser and Feeder, it is but necessary to fill the hopper with such grain as may be desired, straight or mixed, filling the feed bar with either cracked corn or wheat, and adjust the valve at the bottom of the hopper to feed in such quantities as desired. Set the machine anywhere in the yard, pen or house, give the feed bar a turn or two, and, surprising as it may seem, in ten to fifteen minutes every hen in the flock will take in the situation and work it.

Another valuable feature is that the hopper, being rainproof, keeps the feed dry and fresh. The hopper is also dust proof, and not a particle of dust can get on the feed.

No. 1.-8-quart hopper. Weight, 15 lbs., $\$ 5.00$

No. 2.-14-quart hopper. Weight, 18 lbs., $\$ 5.50$

No. 3.-20-quart hopper. Weight, 22 lbs., $\$ 6.50$.

No. 4.-32-quart hopper. Weight, 25 lbs., $\$ 7.50$.

\section{MICHELL'S \\ Carbola. An improvement on white wash, combining the features}

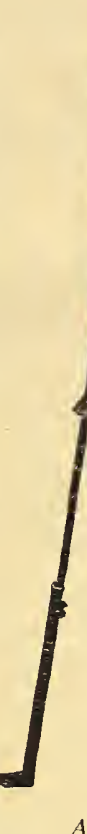

PARCEL POST EGG BOXES

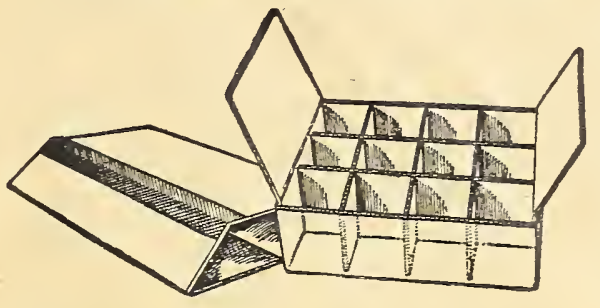

So constructed that each egg is separated by a thickness of corrugated board and the contents are surrounded by a double wall of air-cushioned board. Absolute protection is assured; possesses strength and durability to stand rough handling in transit.

\begin{tabular}{|c|c|c|c|c|}
\hline ity & Each & Doz. & Capacity & Each \\
\hline & 2 & $\begin{array}{r}41.00 \\
2.25\end{array}$ & 5 doz. & $\begin{array}{r}. \$ 0.30 \\
40\end{array}$ \\
\hline
\end{tabular}

\section{SALT BRICKS}

For dairy cows, horses and other animals. This is an essential to general good health in stables among horses and cattle; fastened on the wall it is accessible at all times and remains clean. Per brick, 25c.; $\$ 2.75$ per dozen. P. P. Weight, each, 5 lbs.

Norwich Automatic Feeder
Salt Brick Holders, 50c. each; doz., $\$ 5.00$. P. P. Weight, 3 lbs

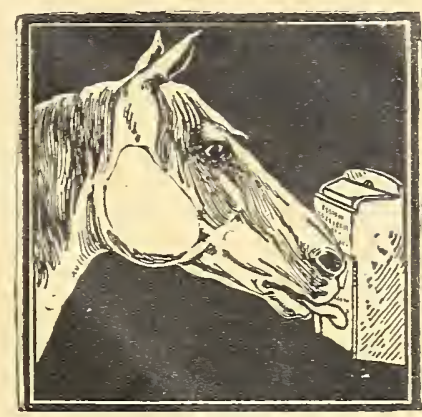

DIES, LICE DESTROYERS, DISINFECTANTS, ETC. of a cold water paint and disinfectant; will not rub or chop; not. a lime product. 30c. per 2 lbs.; 10 lbs., $\$ 1.25$; $\$ 5.00$ for 50 lbs.

Carboletta. A carbolic solution for painting roosts, spraying, etc. 40 c. per qt.; 1/2 gal., 65c.; $\$ 1.00$ per gal.

Carbolineum (Genuine S.P.F.). A poultry house disinfectant, louse and mite destroyer; excellent wood preservative; in gallon cans only. $\$ 1.50$ per gal.; 5 gals. for $\$ 7.00$.

Condition Tablets (Pratt's). 25c. and 50c. per pkg.

Conkey's Canker Special. A wonderful and effective remedy. $50 \mathrm{c}$. per pkg.

Conkey's Cholera Cure. 25c. and 50c. per pkg.

Conkey's Chicken Pox Remedy. 25c. and $50 \mathrm{c}$. per pkg.

Conkey's Gape Cure. For young chicks. 50c. per pkg.

Conkey's Lice Fix. For destroying mites, lice, etc., 50c.

Conkey's Lice Killer (Liquid). For painting roosts, poultry houses, spraying nests and general vermin cleaning, etc. Qt., 60 c.; 90 c. per $1 / 2$ gal.; 1 gal., $\$ 1.50$.

Conkey's Lice Powder. A sure destroyer. 25c., 50c. and $\$ 1.40$ per pkg

Conkey's Noxi-cide. A germ destroyer, which will keep the poultry house in a pure, sanitary condition, destroy all germs and drive out the lice and mites. $45 \mathrm{c}$. per pt.; qt., 70c.; $\$ 1.15$ for 2 qts.; gal., $\$ 1.80$.

Conkey's Roup Cure. The most widely used of the roup remedies; administered in the drinking water. $25 \mathrm{c} ., 50 \mathrm{c}$. and $\$ 1.00$ per box.

Conkey's Scaly Leg Remedy. A sure cure. 25c. per pkg.

Conkey's White Diarrhoea Cure. For little chicks; results always satisfactory. 25c. and 50c. per package.

Death to Lice (Lambert's). For dusting fowls and nests. The most effective chicken lice exterminator in existence. 5-oz. size, 10c.; 25c. for 15 ozs.; 48 ozs., 50 c.; $\$ 1.00$ per 100 -oz. pkg.

Death to Lice Ointment. A salve or ointment used on the heads of newly-hatched chicks. It drives away lice instantly. Easily applied; no mess; no trouble. $10 \mathrm{c}$. and $25 \mathrm{c}$. per box.

Gape Worm Extractors. Two styles: Hallowell, made of German silver and horse hair, 10c. each. Pilling, made entirely of German silver, $25 \mathrm{c}$. each

Germozone (Lee's). The standard remedy for the prevention and cure of most every ill that affects poultry, such as roup, cholera, bowel complaint, diarrhoea, sore head, gapes, etc. Germozone's greatest value is in preventing sickness. In tablet form, $75 \mathrm{c}$.

Lice Expelling Nest Eggs. These are made of naphthaline and are an ideal substitute for the natural egg, which they closely resemble. 6c. each; per doz., 65c.; $\$ 4.50$ per 100 .
Oculum. For cholera, roup and diarrhoea. May be used on chicks and grown fowls with equal success. $50 \mathrm{c}$. and $\$ 1.00$ per bottle.

Persian Insect Powder. This is probably the oldest lice expelling powder in existence. $1 / 4 \mathrm{lb}$., 35c.; 60c. per $1 / 2 \mathrm{lb}$; $1 \mathrm{lb} ., \$ 1.10$.

Pratt's Disinfectant. For spraying poultry houses, stables, etc. It gets rid of lice and mites and keeps poultry houses clean and healthy. 60c. per qt.; $1 / 2$ gal., $\$ 1.05 ; \$ 1.70$ per gal.

Pratt's Lice Powder. For dusting nests, fowls, chicks, etc.; quickly kills the lice. 15c., 30c. and 60c. per box.

Pratt's Roup Remedy (Pills). Four roup, canker, catarrh and diphtheria. As a preventative it is unsurpassed. 25c. and $50 \mathrm{c}$. per box.

Pratt's Sore Head Remedy. A sure, rapid cure for the disease known as sore head or chicken pox. 35c. and 70c. per box.

Pratt's White Diarrhoea Remedy. For baby chicks; keep the germs of the disease from becoming active by using this remedy. $25 \mathrm{c}$. and $50 \mathrm{c}$.

Rat Corn. Kills and mummifies rats and mice. 25c., 50c. and $\$ 1.00$ per box.

Roup Syringe. For administering liquid roup remedies in the nostrils or throat. Price, $15 \mathrm{c}$. each.

Spratt's Dog Soap. Free from poison, and at the same time most effective in the destruction of lice and fleas. 25c. per cake.

Sulphur Candles. Large size, 30c. each; per doz., \$3.00. Small size, 20c. each; per doz., $\$ 2.00$.

Tobacco Dust. For dusting on roosts, nests, etc., to keep away vermin. 10c. per lb.; 5 lbs. for 40c.; 60c. for $10 \mathrm{lbs}$; $25 \mathrm{lbs}$ $\$ 1.35 ; \$ 2.50$ per 50 bs.; 100 lbs., $\$ 4.75$.

Tobacco Stems. For making nests, etc. 10c. per lb.; 5 lbs, $40 \mathrm{c}$ $\$ 1.00$ per bushel; per bbl. bag, $\$ 1.75$; in large bales of about 250 lbs., at $21 / 2$ c. lb.; per $1 / 2$ ton, $\$ 17.00 ; \$ 32.00$ per ton.

Whiting's Roupene. An infallible preventive and sure cure for all cases of roup, canker, diphtheria, chicken pox or sore hea gapes, colds and all diseases of the respiratory organs of or pigeons. Will cure dogs of the sniffles. Price, 50 $\$ 1.00$ per bottle.

Whiting's White Diarrhoea Remedy. 50c. and $\$ 1.00$ pe

Zenoleum Lice Powder. For dusting hens and nests; brooding hens. 35c. per 16-oz. pkg.

Zenoleum Liquid. Dilute one part Zenoleum to one parts water. It is non-poisonous and is not irritating mable. Should be used freely around barns and poult Zenoleum is a concentrated solution of coal tar. I no boiling or stilling. $8 \mathrm{ozs} .35 \mathrm{c} . ; 75 \mathrm{c}$. per at. $\$ 2.00$ per gal.; 5-gal. can, $\$ 9.50$ 
Prices of Poultry Food fluctuate constantly and will be quoted on application where prices are not mentioned.

For Bird Seeds and Supplies see Page 84.

Alfalfa Hay. Used as a scalded feed during the winter months.

Alfalfa Meal. Rich in protein and especially desirable for young birds. Splendid for feeding as a mash or for mixing.

Animál Regulator (Pratt's). For keeping farm animals in prime health and condition. 30c. and 60c. per pkg.; $12 \mathrm{lbs}$., $\$ 2.50$.

Barley. Principally fed for making feathers and bone.

Bone (Coarse Ground). For feeding grown fowls. For muscle making, producing eggs and as a digester.

Bone (Firie Grade). For feeding chicks and pullets and using in the mash.

Bran (Wheat). For mash, etc. An excellent egg maker and very nutritious. Can be fed alone or used in a mixture.

Broken Rice. For small chicks and for conditioning stock which has been allowed to become in a run down condition.

Buckwheat. Fed very largely as a change of diet. Especially good for winter feeding.

Cake Meal. For mixing in the mash. Splendid for use during the moulting season.

Calf Meal (Blatchford's). For weaning calves from cows and taking the place of milk. Fed in liquid form.

Canada Peas. Principally fed to pigeons, when it acts as a bowel regulator. Should not be fed continuously.

Cat Food (Spratt's). Saves the necessity of especially preparing food for tabby. Per large carton, 35c.

Catnip Balls. A plaything and tonic for pussy. 15c. each.

Charcoal. Two grades, fine and coarse. Disinfects the bowels and tones up the whole system. Usually fed from a hopper alone or used in dry or wet mash.

Chicgrain (Spratt's). Can be used as the staple food from the very day the chick is hatched. Claimed to be the most scientifically balanced chick ration.

Chick Food (Michell's). Made from clean, wholesome grains. Properly balanced and proportioned.

Chick Food (Park and Pollard).

Chick Food (Pratt's). For newly-hatched chicks.

Chick Manna.

Chick Meal (Spratt's No. 5 and No.3). For show or prize stock; develops strong, husky specimens.

Condition Powder (Sheridan's). A natural stimulant and persuader for the hen.

Condition Tablets (Pratt's). For keeping poultry in prime health. 25c. and 50c. per pkg.

Conkey's Laying Tonic. To be mixed with the mash. 25c. pkg.

Conkey's Starting Food for Baby Chicks. Contains bone and muscle making properties in the highest degree. Can be used in dry or wet mash form.

Corn Meal (Special Process). Suitable for either mash or feeding little chicks. Carefully ground and sifted.

Cracked Corn. Carefully sifted; fine or coarse. All coarse and dirty particles removed.

Cut Clover Hay. Excellent for using in mashes, taking the place of green food.

Developing Food (Michell's). A mixture of grain that is fed from the time chicks are 3 weeks old till they are 3 months old. Desirable also as a scratching litter for young chicks.

Dog Cakes (Spratt's). Dog cakes are made so that they supply every requirement of the dog's need for sustenance. No cooking or mess.

Dog Cakes (Maltoid Milkbone). Shaped like a bone, which seems to appeal to most dogs.

Fish, Dried Ground. Splendid for egg production. Desirable to feed alone or in a mash.

Gluten Meal. For feeding to both poultry and cows.

Grit. Fine, medium and coarse. This is necessary and aids digestion in fowls of all kinds.

Price Notice. Where we have not quoted prices please ask for them, the many constant changes, make it more practical to omit them.
ANIMAL FO0DS AND TONICS

Grit (Red Cross Health). For pigeons. Contains a variety of materials including seeds of some aromatic herbs.

Ground Oats. This makes an excellent dry food when combined with other similar ration.

Growing Food (Park and Pollard). Feed when chicks are developing. Park and Pollard foods are regarded as the best of their respective kinds.

Hemp Seed. Fed largely to pigeons, also to poultry during winter months; should not be fed continuously.

Hulled Oats. A splendid food for young chicks, as a change of diet or after they have been hatched a few days.

Kaffir Corn. Makes a fine food for pigeons, also used for poultry; very good for feeding during winter months.

Linseed Meal. For feeding with the regular ration during the moulting period; splendid for conditioning birds in preparing to exhibit them.

Mash Food (Michell's Buttermilk). Rich in bone, muscle and feather making elements; makes chicks and fowls thrive.

Mash Food (Park and Pollard). (Lay or bust.) Reputed to be the best mash food on the market.

Mash Food (Buttermilk). For chicks. A specially prepared mash to develop quick growth in young stock.

Meat (Prepared). Very rich in protein. If you want eggs in winter, poultry meat will get them for you, if placed before the fowls where they can eat it at will.

Middlings. An excellent change in combination of a mash.

Millet (For Feeding). Highly nutritious and used extensively for pigeons and young chickens.

Oat Meal (Pin Head). An excellent food for young chicks after they are a few days old and may be continued until they are several weeks old.

Oyster Shells. Fine and coarse. State which is wanted when ordering. Oyster shells contain shell making properties.

Panacea (Poultry Tonic). Made by Drs. Hess and Clark, who have a splendid reputation for making reputable poultry supplies. $21 / 2$ lbs., 30c.; 60c. per 5 lbs.; $12 \frac{1}{2} / \mathrm{lbs}$., $\$ 1.25$.

Pheasant Meal (Spratt's). No. 12 Fine; No. 5 Coarse. State which is wanted when ordering. Especially combined to furnish the peculiar feed requirements of pheasants.

Poultry Food (Spratt's No. 3). A splendid egg producer.

Poultry or Scratch Food (Michell's). An evenly balanced grain ration for feeding growing and adult fowls.

Poultry or Scratch Food (Park and Pollard). A carefully prepared food.

Pratt's Poultry Regulator. A general conditioning tonic to be fed in the mash. Price, 8 oz. package, 12c.; 24-oz., 25c.; 50 c. per 4 lbs.; $12-1 b$. bag, $\$ 1.40$; $\$ 1.65$ per $12-$ lb. pail; 25 lbs., $\$ 3.00 ; \$ 10.00$ per $100 \mathrm{lbs}$.

Prepared Pigeon Food. An excellent mixture of grain. Pigeons thrive better on specially prepared feed.

Puppy Cakes (Spratt's).

Puppy Cakes (Maltoid Milkbone). A pup requires feed that will meet its needs for body, muscle and bone building. Requires no cooking and makes no dirt.

Salt Cat. A tonic for pigeons. Combined with aromatic herb seeds. 25c. per brick; per doz., $\$ 2.75$.

Sunflower Seed. For poultry, parrots, etc. Per lb., 15c.; 40c. per 3 lbs.; 5 lbs., 65c.; $\$ 1.20$ per 10 lbs.; bus. (25 lbs.), $\$ 2.75$.

Vetches or Tares. For pigeon feeding. Ask for quotations.

SPECIAL NOTE

We publish a complete Catalogue on Poultry Supplies which is free on application. 


\section{MICHELL'S BOOKS}

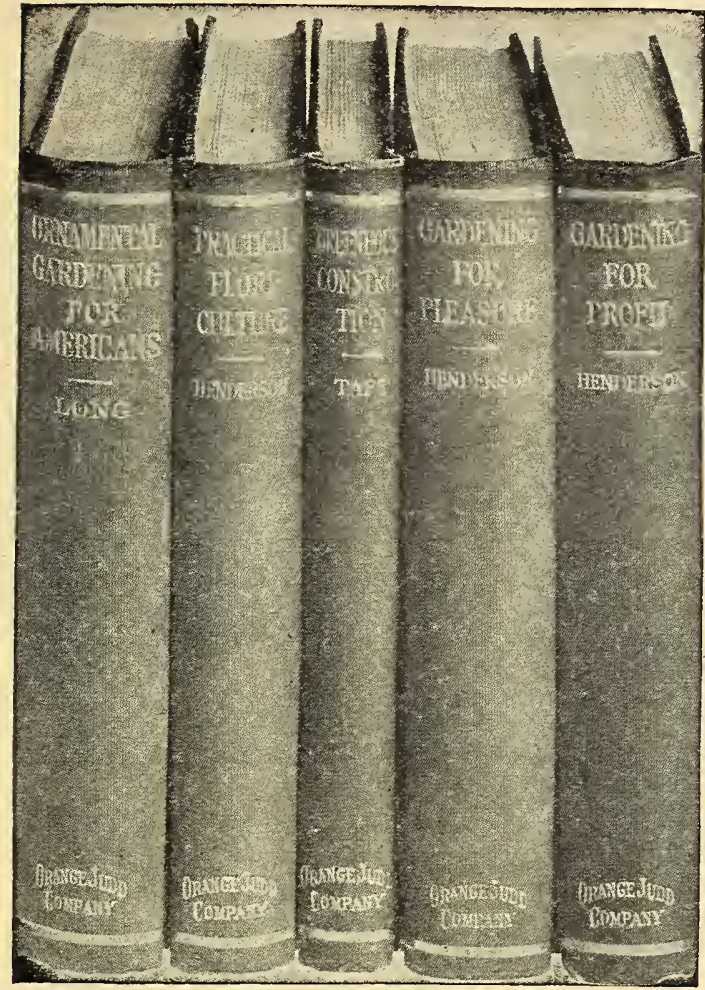

\section{STANDARD CYCLOPEDIA OF HORTICULTURE}

By L. H. B A I LEY

Freshly written in the light of the most recent research and experience, largely by experts in their various specialties. Six large volumes; more than 3600 pages; 24 full page color plates; 96 full page sepia half tones; more than 4000 text engravings. Sold only in complete sets, price $\$ 40.00$.

\section{BOOKS ON FLOWERS, VEGETABLES, Etc.}

\section{Alfalfa (F. D. Coburn).}

$\$ 0.90$

Agriculture, The Principles of (Bailey). A text-book . . 1.80

Asparagus (Hexamer). Its culture for home; for market.. $\quad .90$

Bean Culture (Sevey) ...................... .90

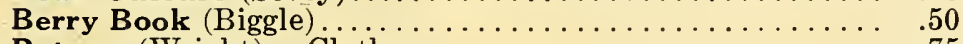

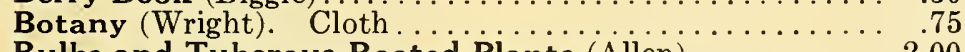

Bulbs and Tuberous Rooted Plants (Allen) . . . . . . . 2.00

Cabbage, Cauliflower and Allied Vegetables (Allen) . . . . .90

Canning and Preserving. Mrs. S. S. Rorer.......... 1.00

Celery Culture (Beattie) .................... .90

Chrysanthemum Manual (Smith). A complete guide.... .60

Clovers and How to Grow Them (Shaw) .......... 2.00

Commercial Carnation Culture. An up-to-date book. . . 1.75

Farm and Garden Rule Book (Bailey) ............... 3.00

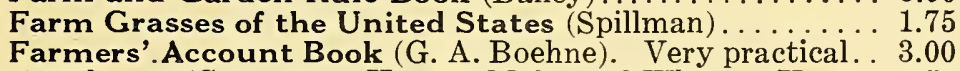

Farmers'. Account Book (G. A. Boehne). Very practical. . 3.00
Fertilizers (Gregory). How to Make and When to Use...

Flowers, How to Grow Them (Rexford) . . . . . . . . . 1.00

Forcing Book (Bailey) . . . . . . . . . . . . . . . . 2.00

Four Seasons in the Garden (Rexford). Profusely illus... 1.75

Fruit Culturist, American (Thomas) ............ 3.50

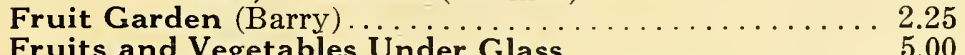

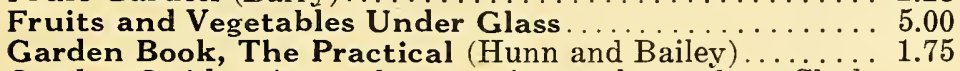

Garden Guide. A complete treatise on the garden. Cloth, $\$ 1.65$; Paper, $\$ 1.10$.

Gardening for Pleasure. A guide to the amateur in the

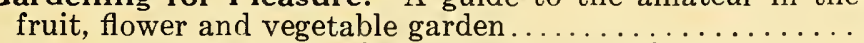

Gardening for Profit. On vegetable gardening .......... 2.00

Garden-Making (Bailey). Tells how to utilize grounds... 2.25

Grape Culturist (Fuller). Best work on the hardy grape. . . 2.00

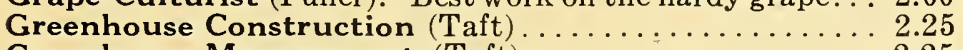

Greenhouse Management (Taft).

Handbook of Plants (Henderson). A dictionary on plants.

Hardy Garden Book, A Woman's (Ely).

Home Floriculture (Rexford). A guide for the amateur.

Home Fruit Grower. Cloth, $\$ 1.65$; Paper.............

How to Grow Roses (Robert Pyle).

3.50

2.00

1.75

1.10
ON AGRICULTURE, HORTICULTURE, POULTRY, ETC., AND MATTERS PERTAINING THERETO

BOOKS ON FLOWERS, VEGETABLES, Etc. (Continued)

How to Grow Vegetables. A practical hand-book and plant-

ing table for the home garden (Allen French) .......... $\$ 2.00$

How to Plan the Home Grounds (Parsons) . . . . . . . . 1.25

Johnson's Gardeners' Dictionary

Landscape Gardening, Practical (Robt. B. Cridland)

Landscape Gardening (Maynard)

Melon Culture (Troop).

Milady's House Plants. Cloth, $\$ 1.10$; Paper

Mushroom Culture (Duggar).

Mushrooms, How to Grow (Falconer)

Onion Culture, The New (Greiner)

Onions, How to Raise Them Profitably

Orchard Book (Biggle).

Ornamental Gardening (Long)

Peanut Culture (Jones)

Peas and Pea Culture (Sevey)

Plant Culture (Oliver and Hottes)

Plant Propagation, Practical (Hottes)

Practical Book of Outdoor Rose Growing (Thomas)

Practical Floriculture (Henderson)

Principles and Practice of Pruning (Kains) .

Principles of Fruit Growing (Bailey)

Potato, The (Fraser).

Pruning Manual (Bailey)

Rhubarb Culture, The New (Morse and Fiske)

Right Use of Lime in Soil Improvement (Agee)

Rose Culture (Ellwanger). A standard book on Roses

Small Fruit Culturist (Fuller)

Soils (Burkett)

Spraying Crops (Weed)

Strawberry Culture (Fuller). Contains all information.

Study of Corn, The (Shoesmith)

Sweet Corn Culture (Wilkinson)

Sweet Pea Culture (Michell). Free with orders.

Sweet Peas for Profit.

Sweet Potato Culture (Fitz)

The Small Country Place (Maynard). Well illustrated

The Spraying of Plants. Gives the principles and practice of the application of liquids and powders to plants for destroying insects and fungi. By Lodeman.

Tomato Culture (Tracy)

Vegetable Forcing (Watt's)

Vegetable Gardening, Principles of (Bailey).

Vegetable Gardening (Watts)

Violet Culture (Galloway)

Violet Culture (Saltford)

Water Gardening, Book of (Bisset)

Wheat Culture (Curtiss) ..............................
Wild Flower Book for Young People (Lounsberry).

\section{BOOKS ON POULTRY AND ANIMALS}

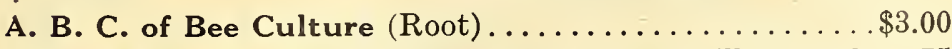

Artificial Incubating and Brooding. 96 pages, illustrated

Asiatics, Brahmas, Cochins and Langshans. 100 pages . $\quad .75$

Chick Book, The. Tells how to obtain good hatches.

Chickens, All About (Johnson). Cloth, 60c.; paper.

Diseases of Poultry (Salmon)

Dog, The (Maxtee). Cloth, 60c.; paper.

Ducks and Geese. Give all details. 104 pages.

Egg Record and Account Book. 32 pages

200 Eggs per Year per Hen

Leghorns. The best mating schemes clearly described.

Minorcas (Northrup)

Orpingtons, The

Plymouth Rocks, The. Barred, Buff and White. Special-

ists describe mating and breeding methods. 160 pages.

Poultry Houses and Fixtures, 96 pages.

Poultry Production (Lippincott).

Profits in Poultry

Rhode Island Reds (Hale)

Standard of Perfection. Explains all the scoring points

Turkeys. Every detail of the business explained. 96 pages

Wyandottes, The (Grevenstedt). All strains, 160 pages 
Comparatively few of us recognize the great economic value of birds. Particularly the bluebirds, house wrens and martins are very easily domesticated. Their favorite nesting sites are bird houses made for their use which may be placed about in the garden and farm or in orchards. As rent, these grateful birds pay amply, destroying millions of insects annually. If you put up bird houses in the autumn or before the birds arrive in the spring you may be able to keep some birds with you all winter if you provide them with shelter and food.

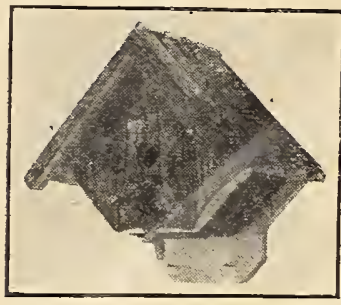

No. 11. Wren House. Price, $\$ 1.75$. Wt., 3 lbs. No. 12. Wren House. Similar to No. 14.

Price, $\$ 1.75$. Wt., 3 lbs.

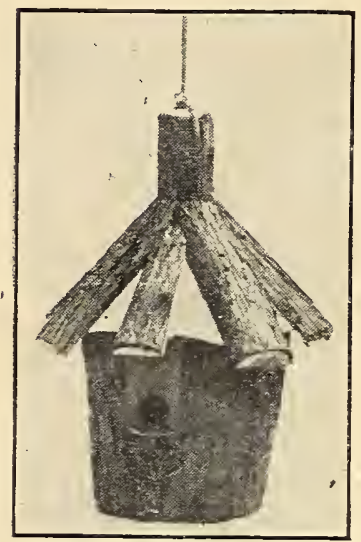

No, 14. Wren or Bluebird House. Swinging.

Price, $\$ 1.75$. Wt., 3 lbs.

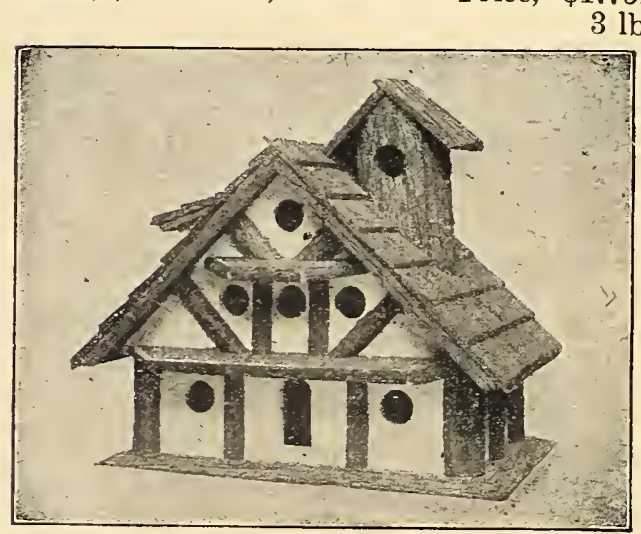

No. 8. 14-Room Martin House. Price, $\$ 20.00$ Not mailable.

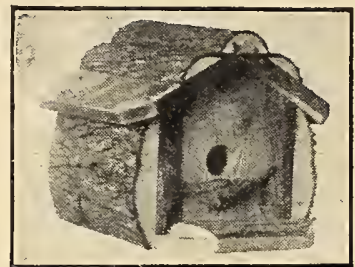

No. 13. Wren House. Price, $\$ 1.75$. Wt., $3 \mathrm{lbs}$.

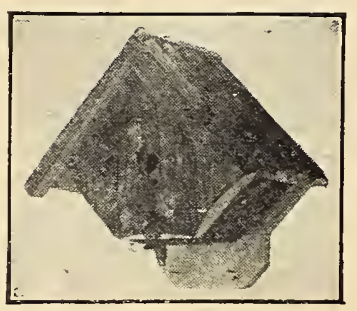

No. 17. Wren House. Price, $\$ 1.50$. Wt., 3 lbs.

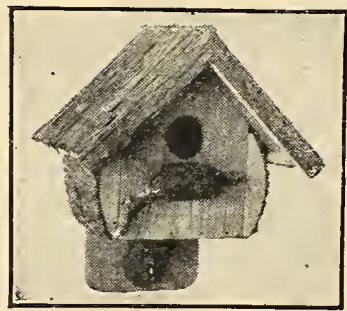

No. 62. Bluebird House. 1.75. Weight, 3 lbs.

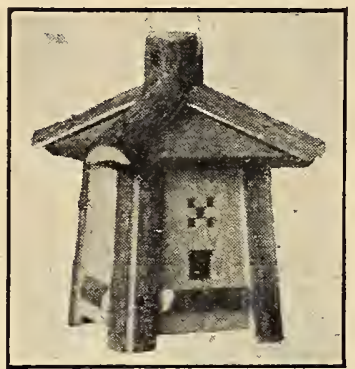

No. 61. Wren House. Swinging.

Price, \$1.75. Wt., 3 lbs.

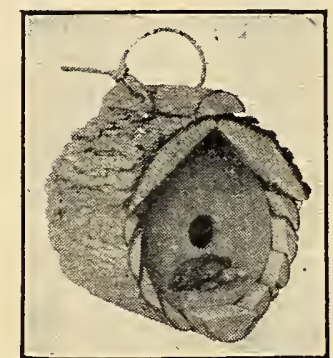

No. 50. Wren House. Swinging. Price, $\$ 1.50$ Weight, 3 lbs.

No. 21. Bluebird House. Price, $\$ 1.75$ Weight, 3 lbs.

No. 63. Wren and Robin House. Price, $\$ 1.75$ Weight, 3 lbs.

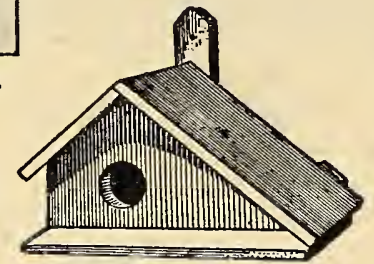

Maryland Wren Box. Natural color, stained. 40c. each. P. P. Wt., $1 \mathrm{lb}$.

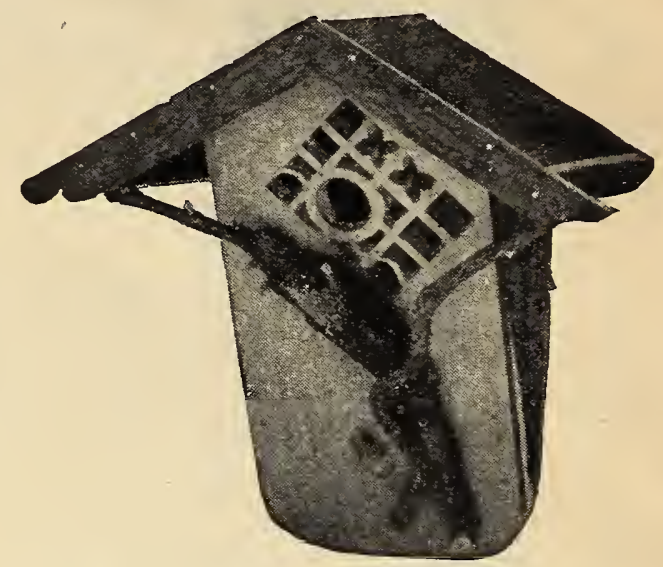

No. 23. The Wren "House Beautiful." Price, $\$ 2.00$. P. P. Weight, 4 lbs.
No. 25. For Woodpeckers, Chickadees, Nuthatches, etc.

Price, $\$ 1.75$

Weight, 3 lbs.

WIRE SPARROW TRAP

We have tried this out and found it to be the best trap made. Scatter a little cracked corn and set trap right over it. You'll be surprised at the catch. $\$ 6.00$ each.

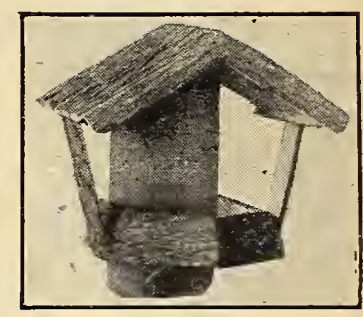

No. 60. Robin House. Price, $\$ 1.75$. Wt., 3 lbs.
No. 78. 4-Room Martin House.

Price, $\$ 5.00$.

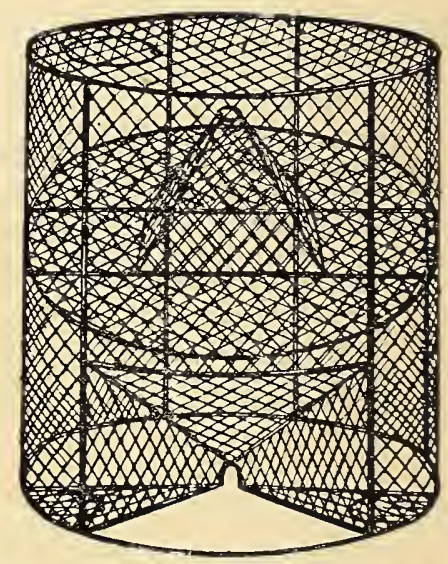

\section{MICHELL'S RECLEANED BIRD SEEDS, PET SUPPLIES, ETC.}

Our bird seeds are of the highest quality, fresh and recleaned. line from us.

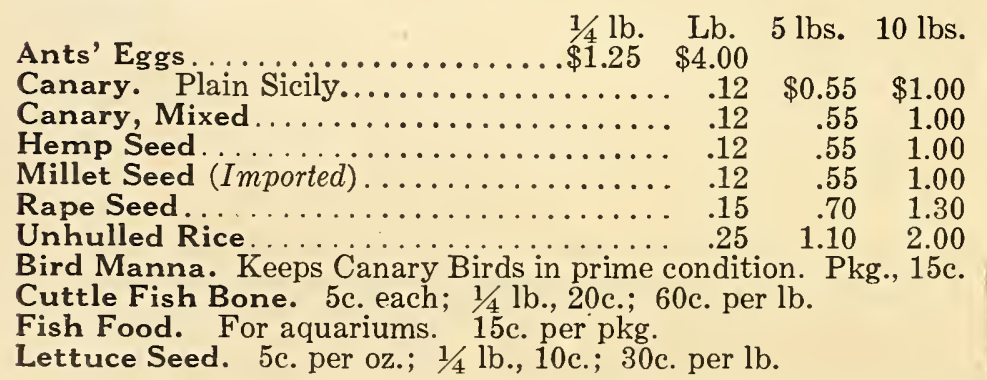

Your feathered pets will thrive if you get your supplies in this

Maw Seed. 1/4 lb., 10c.; 30c. per lb.; 5 lbs., $\$ 1.40$.

Parrot Food (Spratt's). 20c. per pkg.; doz. pkgs., $\$ 1.65$.

Sand for Bird Cages. Fine, red or silver, 10c. per pkg.; doz. pkgs., $\$ 1.00$. Silver (coarse), 10c. per pkg.; doz. pkgs., $\$ 1.00$.

Song Restorer for Canaries, revives the desire to be lively and sing more lustily. Price, 15c. per bottle; per doz., $\$ 1.50$.

Prices on Bird Seeds Subject to Market Changes. SUNFLOWER SEED

We are very large handlers of this important food for parrots. Our customers may depend upon getting a very choice article. 15c. per lb.; 3 lbs., 40c.; 65c. per 5 lbs.; 10 lbs., $\$ 1.20$. 


\section{CATALOG
ORDER SHEET For MICHELL'S SEEDS, BULBS, PLANTS, Etc.}

Date

HENRY F. MICHELL CO., 518-516 Market St., PHILADELPHIA, PA.

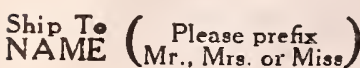
c/o

Street

P. O. Box

Post Office

R. F. D. No.

Freight or

Express Address

County

State

Charge to

Charge Address

Please DO KOT Write in Spuce sbove

Gardener's or Superintendent's Name

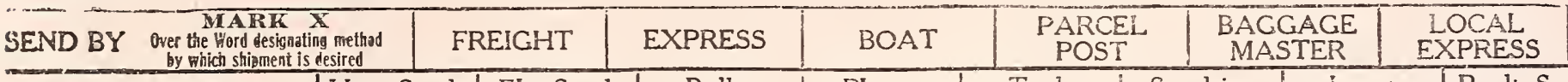

PRICED BY

ORBER

FILLED BY

DATE

FILLED

DOUBLE

CHECKED BY

Shipped Via and Date

\begin{tabular}{|l|l|l|}
\hline & Beg. Seeds & Flo. Seeds \\
\hline & & \\
\hline &
\end{tabular}

\begin{tabular}{|c|c|c|}
\hline Tools & Sundries & Insect. \\
\hline & & \\
\hline & & \\
\hline
\end{tabular}

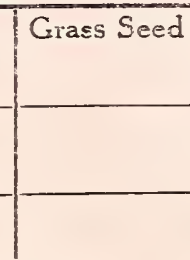

Fertil.

Quantity

ARTICLES WANTED

IF OUT OF VARIETY ORDERED HAVE WE YOUR PERMISSION TO SUBSTITUTE EQUAL OR BETTER IN NEAREST WE CAN SUPPLY?

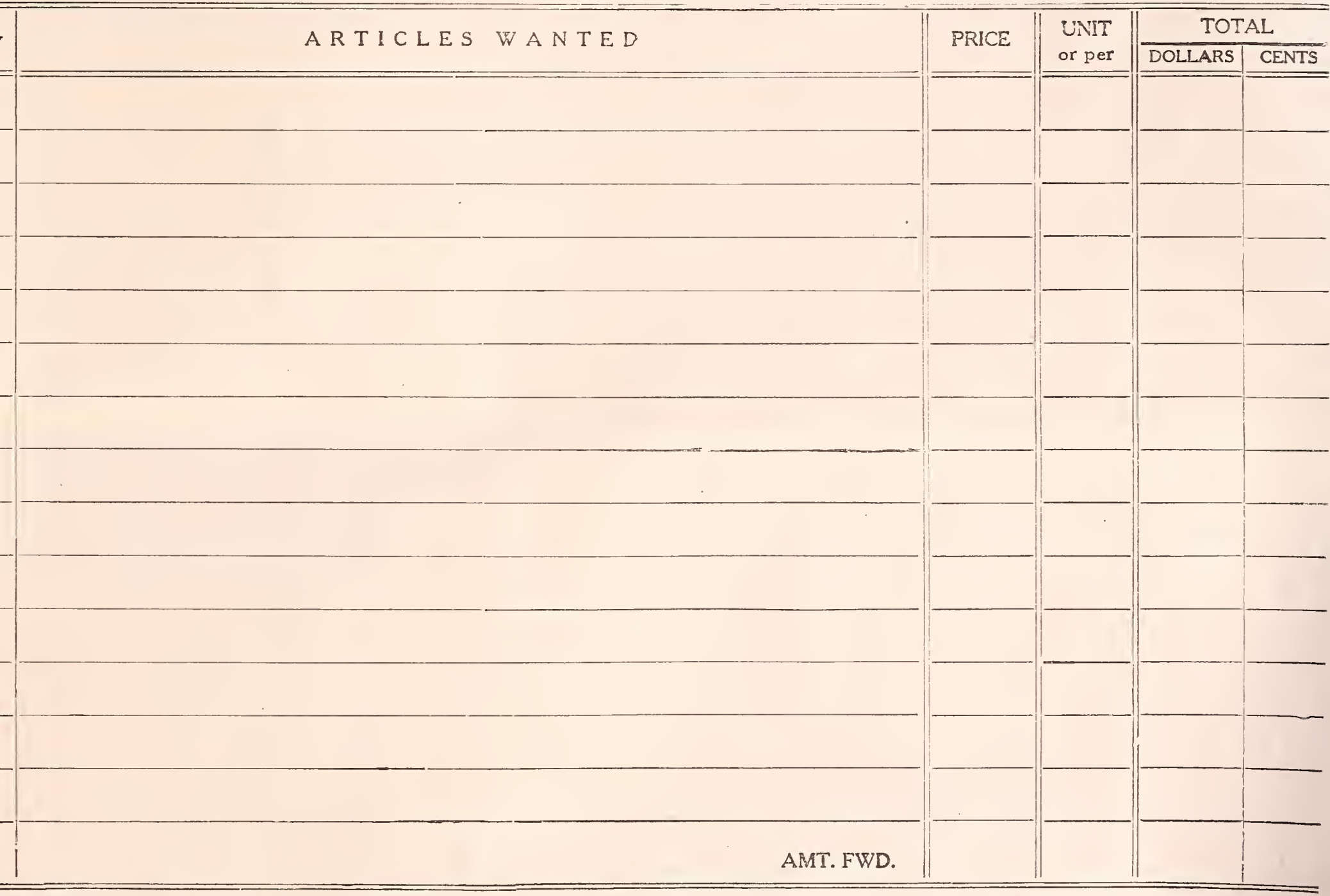

HENRY F. MICHELL CO. give no warranty, expressed or implied, as to the description, purity or productiveness of any seeds, plants or bulb they send out and they cannot be in any way responsibie for the crop. If the customer does not accept the goods on these terms, they can be returned at once. 
AMOUNT FORWARD
From

Post Office

State
PRICE UNIT $\frac{\text { TOTAL }}{\text { DOLLARS } \mid \text { CENTS }}$

\section{MICHELL'S SEED HOUSE} 518-516 MARKET STREET 


\section{MICHELL'S FLOWER POTS, TUBS, ETC. \\ Orchid Pan \\ Earthen \\ Fern Dish \\ Seed Pan \\ Wood Fibre \\ Flower Vase}

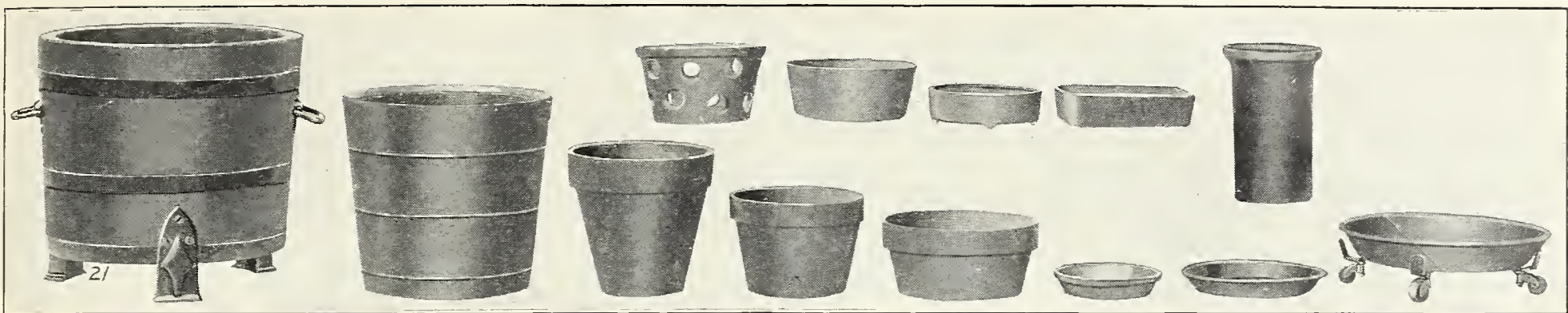

Cedar Tub

Keystone Tub

Earthen
Flower Pot

Azalea

Earthen

Earthenwar

Wood Fibre

Rolling Stand

\section{CEDAR TUBS}

Equipped with Strong Iron Handles These are made by hand, of the very best white cedar painted

$\begin{array}{lr}\text { iron hoops. } \quad \text { Inside Diam. } & \text { Each } \\ \text { No. } 0 \ldots \ldots \ldots \ldots 243 / 4 \mathrm{in.} & \$ 11.15\end{array}$

No. 1

No. 2

No. 3

No. 4

No. 5

No. 6

No. 7

No. 8

\section{MICHELL'S KEYSTONE} PLANT TUBS

Made of white cedar, painted green and bound with strong electric welded wire hoops, which do not rust. Handles are sold 12 separately at 30c. per pair, not attached to 1 Inside Diam. Depth Each

$\begin{array}{rrr}6 & \text { in. } & 6 \\ 7 & \text { in } \\ 8 & \text { “ } & 8 \\ 9 & \text { “ } & 9 \\ 10 & \text { “ } & 9 \\ 11 & \text { “ } & 10 \\ 12 & \text { “ } & 11 \\ 13 & \text { “ } & 12 \\ 14 & \text { “ } & 13 \\ 15 & \text { “ } & 14 \\ 16 & \text { “ } & 15 \\ 17 & \text { “ } & 16 \\ 18 & \text { “ } & 17 \\ 19 & \text { “ } & 18\end{array}$

$\$ 0.70$

No. Diam. Depth Weight

No. 1

No. 3

No. 4

No. 5

No. 6

No. 7

No. 8

No. 9

No. 10

No. 11

No. 12

19

18

ROLLING STANDS for Tubs, Pots, etc. Ins. Diam. Weight Pot

$1421 \%$ lbs. 12 in. No. 8. $1.25 r .00$ $18 \quad 3 \frac{1}{2}$ lbs. 16 in. No. $7-6.2 .10 \quad 24.00$ 22

\section{PAPER FLOWER POTS}

Ins. Parcel Post Weight

Diam. per doz. per 100 Doz. $100 \quad 1000$

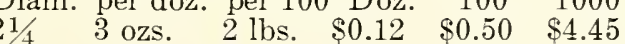

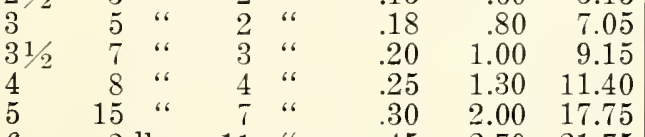

$$
\begin{aligned}
& 62 \text { lbs. } 11 \text { “ } \quad .45 \quad 2.70 \quad 21.75
\end{aligned}
$$$$
\text { 3 }
$$

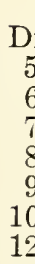

\section{AZALEA POTS}

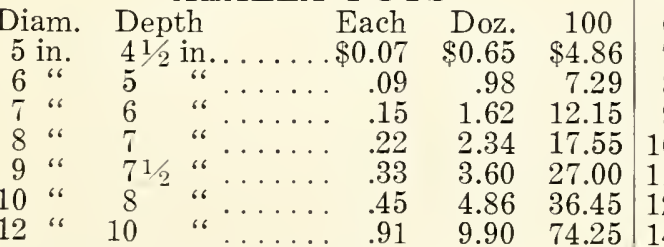
$17 / 8$ in. SEED PANS 6 inches $\operatorname{diam}_{6} \ldots \ldots$. Each $\quad$ Doz.

1.254

1.90

$2.20 \quad 33$

2.70

3.75

etc.

oz. 6

\begin{tabular}{l|l}
68 \\
69
\end{tabular}

.00

\section{Height and}

Width inside Each

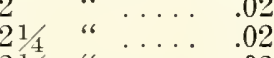

31

$4^{31}$

$41 / 2$

$51 /$

6

$6^{1}$

(1)

“"

FERN DISH LINERS

Very shallow, for inside of fancy silver or

Each Doz. 100 $\$ 0.22 \$ 2.16 \$ 14.40$ Earthenware Each $\$ 0.83$

1.11 1.38 1.65

EARTHEN BULB PANS

$$
\begin{array}{ll}
.22 & 2.34 \\
.33 & 3.60 \\
.45 & 4.86
\end{array}
$$$$
.91 \quad 9.90
$$$$
1.48 \quad 16.20
$$

\section{WOOD FIBRE FLOWER VASES}

8000 in. 13 in. 4 lbs. $\$ 1.65 \$ 18.604$ in.

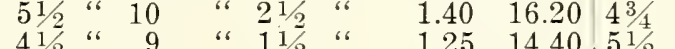

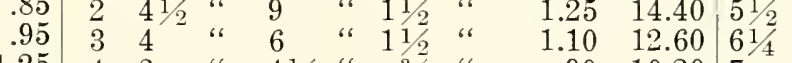

\section{EARTHEN FLOWER POTS}

\section{CUT FLOWER VASES \\ Galvanized Iron}

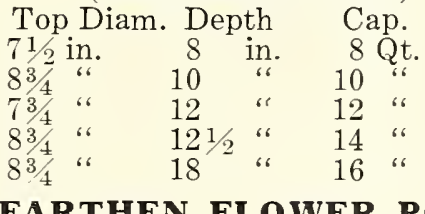

Doz.

$\$ 0.17 \quad \$ 1.22$

$.18 \quad 1.02$

$.18 \quad 1.16$

$18 \quad 1.35$

$.24 \quad 1.76$

$.29 \quad 2.16$

$.36 \quad 2.70$

$.49 \quad 3.65$

$.65 \quad 4.86$

$\begin{array}{rr}.81 & 6.08 \\ 98 & 7.29\end{array}$

$1.30 \quad 9.72$

$\begin{array}{ll}1.62 & 12.15\end{array}$

$2.34 \quad 17.55$

$3.60 \quad 27.00$

$4.86 \quad 36.45$

$7.20 \quad 54.00$

$9.90 \quad 74.25$
EUREKA POT HANGERS

15c. each; doz., $\$ 1.50 ; \$ 11.00$ per 100 . KRICK POT HANGERS

No. 1 $\begin{array}{ll}\text { Each } & \text { Doz } \\ \$ 0.06 & \$ 0.60\end{array}$ Doz. No. 3............... . .08 $\quad .80$

WOODEN ORCHID BASKETS (Square)

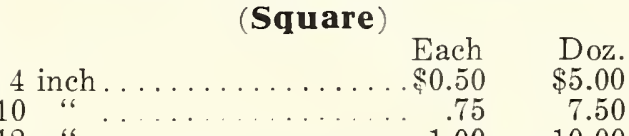

$\$ 7.29$ ORCHID PANS (Round) (Earthen) 12.15 Each Doz 17.554 inches diam........ $\$ 0.35 \quad \$ 3.50$

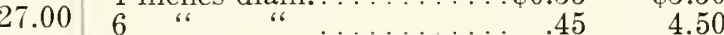

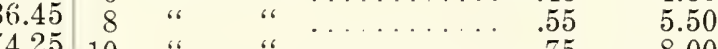

4.2510

" " $" \ldots \ldots \ldots \ldots 1.25 \quad 12.00$

EARTHEN FERN PANS

Height Each Doz. 100 $\begin{array}{llll}17 / 8 & \text { in. } \quad \$ 0.06 & \$ 0.54 & \$ 4.05\end{array}$ $\begin{array}{llll}21 \% 8 & .07 & .72 & 5.40\end{array}$

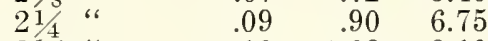

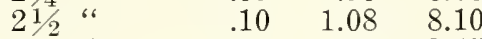
$25 \%$ “ $\quad .12 \quad 1.26 \quad 9.45$

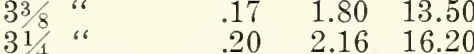

EARTHENWARE SAUCERS

Each Doz. 100

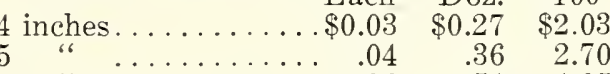

\begin{tabular}{l|llllll} 
Each & 6 & “ & $\ldots \ldots \ldots \ldots \ldots$ & .06 & .54 & 4.05 \\
& 7 & $\ldots$ & $\ldots \ldots \ldots \ldots \ldots$ & .07 & .72 & 5.40
\end{tabular}

$\$ 0.50$
8

$\begin{array}{lll}14 & 1.35 & 10.13\end{array}$

$\begin{array}{lll}.15 & 1.62 & 12.15\end{array}$

$\begin{array}{lll}.19 & 1.98 & 14.85\end{array}$

$\begin{array}{lll}.23 & 2.43 & 18.23\end{array}$

WOOD FIBRE SAUCERS

Extremely desirable on account of being $1000 \quad \begin{gathered}\text { Extremely desirable } \\ \text { absolutely waterproof }\end{gathered}$

9.56 Parcel Post

10.84 Weight Each Each Doz.

12.755 inches.......1/4 lb. $\$ 0.32 \$ 3.60$

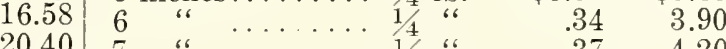

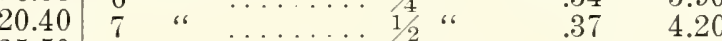

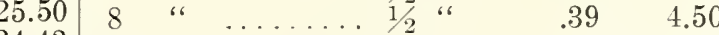

$34.43 \quad 90$ " $9 . \ldots \ldots \ldots .3 / 4$ “ $\quad .43 \quad 4.90$

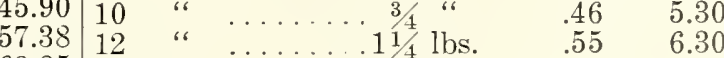

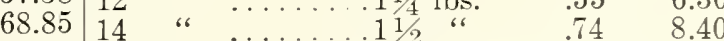

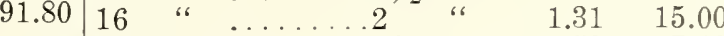

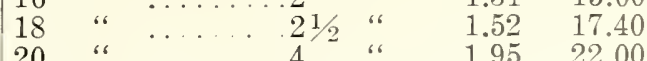

Larger sizes can be furnished as complete rolling stands only. 


\section{MICHELL'S} GRASS SEEDS for Every Purpose
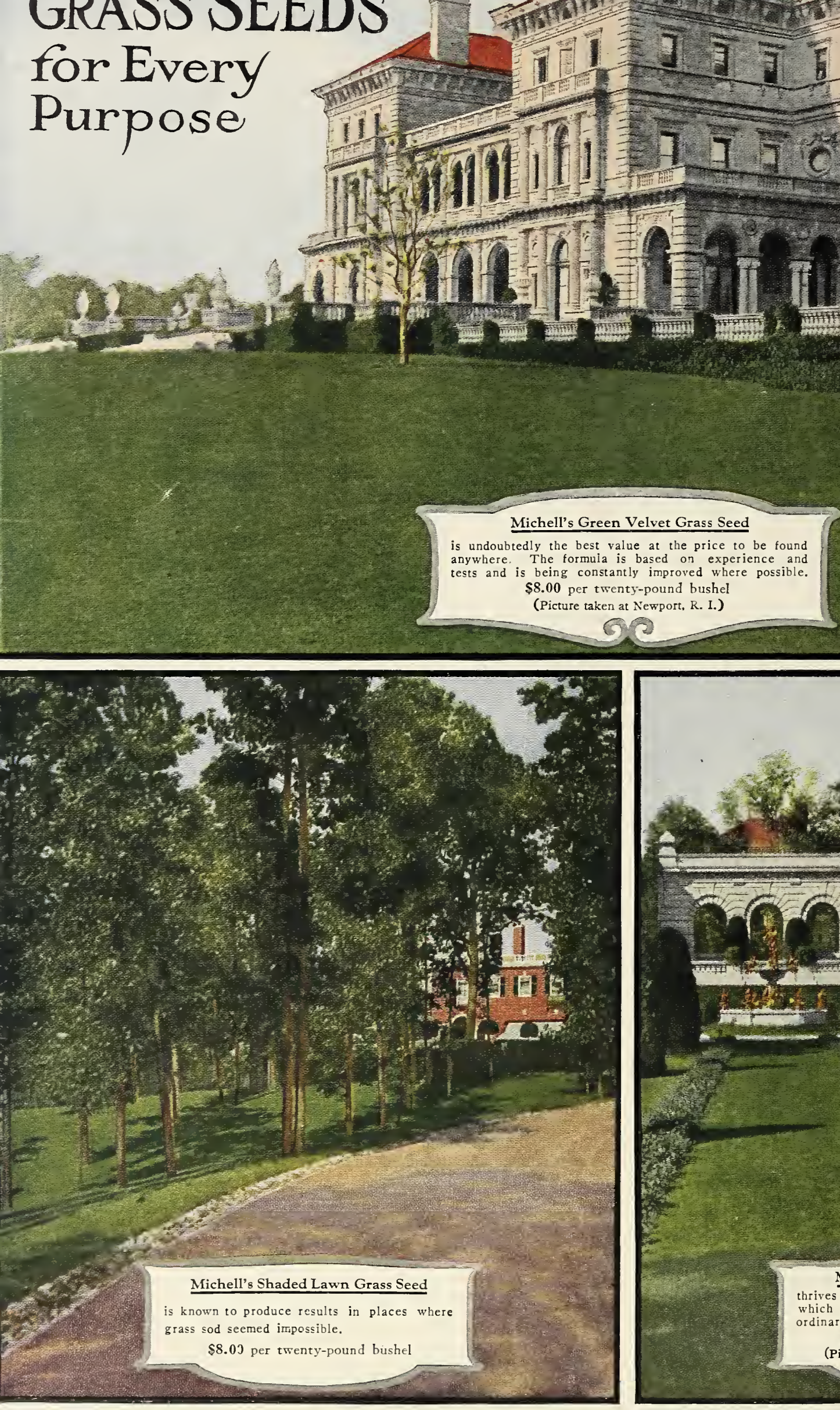

a

HENRY F. MICHELL CO.

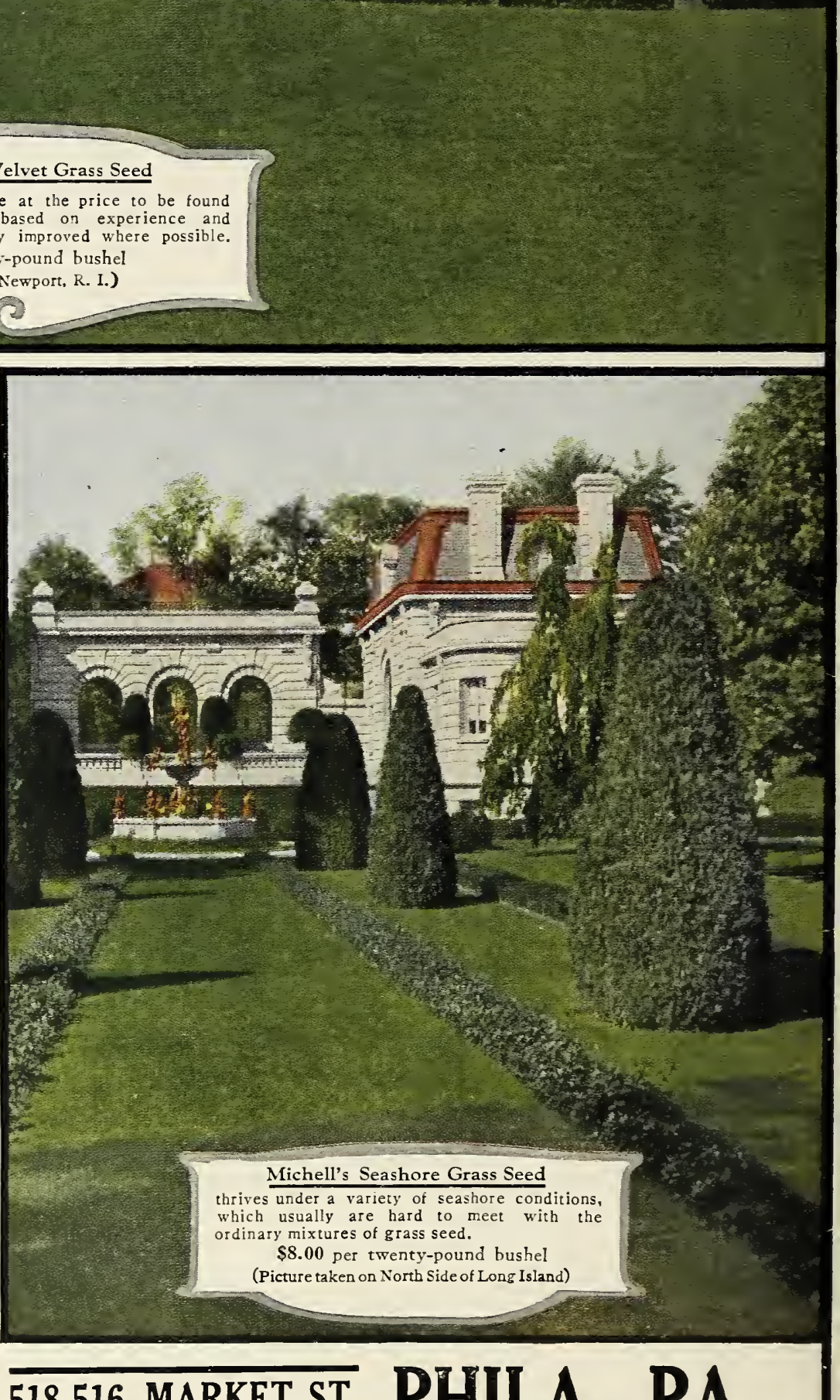

518-516 MARKET ST. PHILA., PA. 